Rik Hoekstra

Two Worlds Merging

The Transformation of Society in the Valley of Puebla, 1570-1640

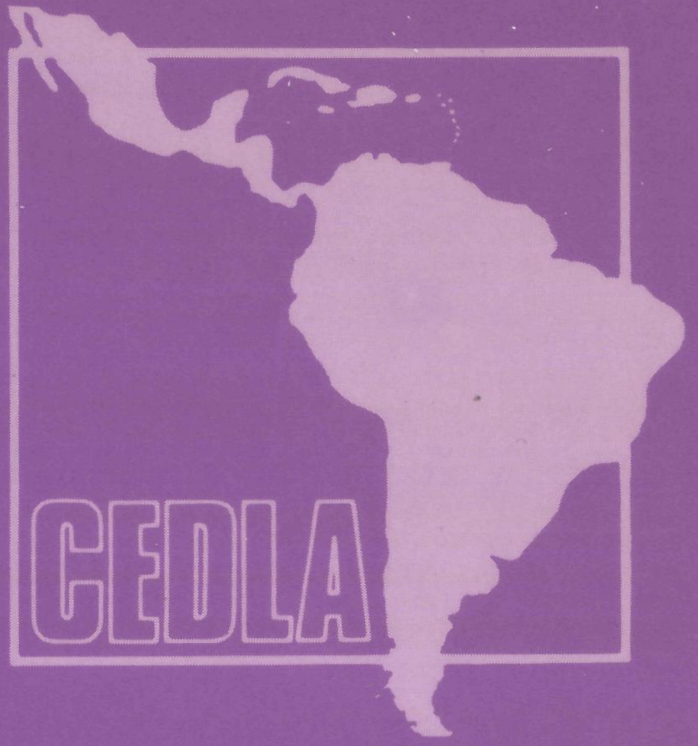

ra

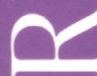

(T)
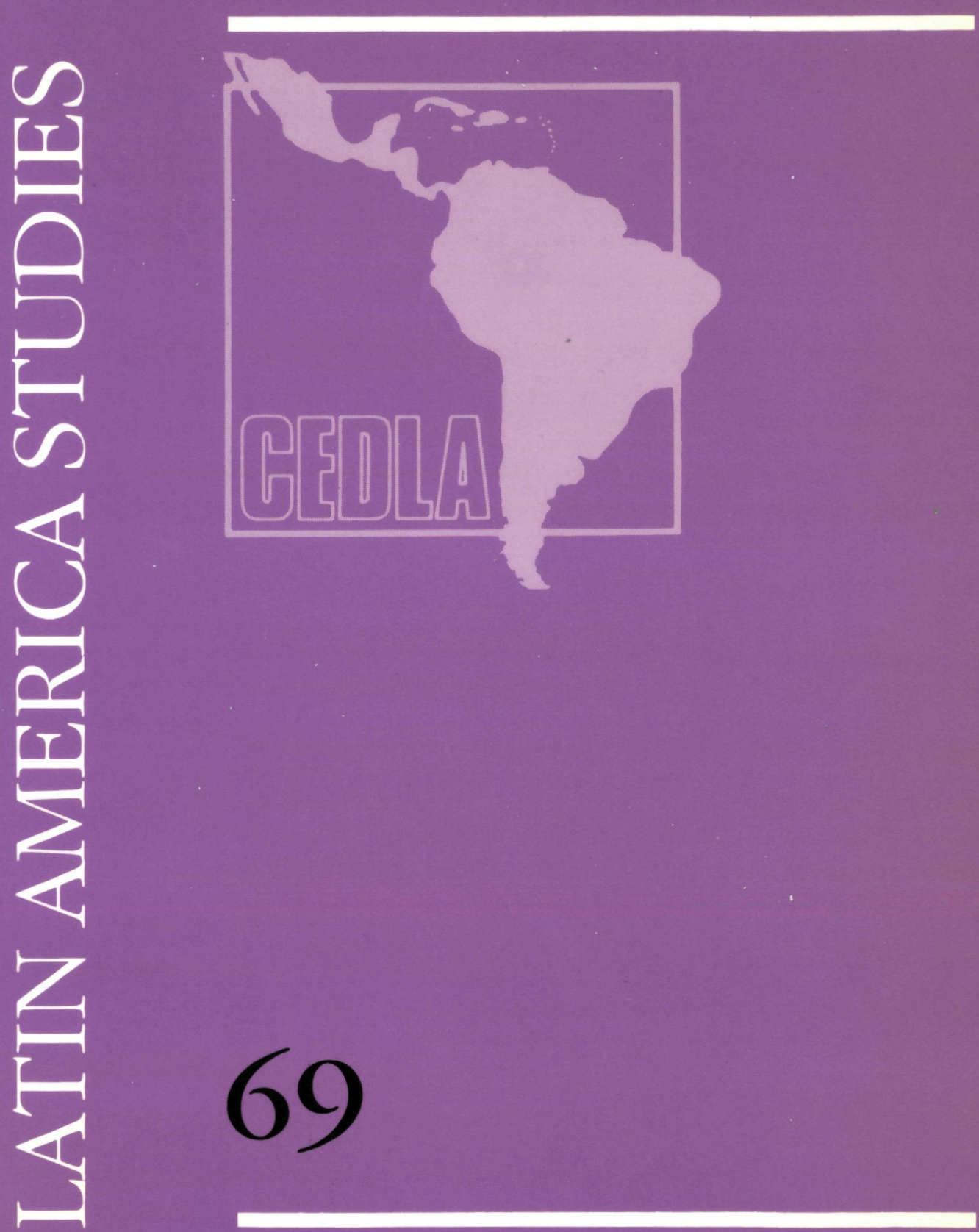

TWO WORLDS MERGING

The Transformation of Society

in the Valley of Puebla

1570-1640 



\section{TWO WORLDS MERGING}

\section{The Transformation of Society}

in the Valley of Puebla

\section{0-1640}

Een wetenschappelijke proeve op het gebied van de Letteren

\section{Proefschrift}

ter verkrijging van de graad van doctor aan de Katholieke Universiteit Nijmegen, volgens besluit van het College van Decanen in het openbaar te verdedigen op dinsdag 11 mei 1993 des namiddags te 3.30 uur precies

door

Frederik Galenus Hoekstra

geboren op 28 januari 1961

le Delf 


\section{Table of Contents}

\section{Preface}

Introduction 1

Periodization 5

$\begin{array}{lr}\text { Summary of contents } & 10\end{array}$

Chapter 1:

Cem Andhuac: the World of the Indians

Ecology and economy 15

Settlement pattems $\quad 20$

Arrangements of authority $\quad 24$

Authority and tribute $\quad 30$

Rights and obligations in life:

teucyotl, tlahtocayorl, and tequitl

A European model $\quad 40$

The house $\quad 45$

Conclusion $\quad 47$

\section{Chapter 2:}

The Shaken Foundation $\quad 49$

The first changes $\quad 51$

Missionaries in the altepetl 55

Spanish groups and interests $\quad 58$

Institutional revolution and social consequences $\quad 59$

The creation of the pueblos de indios $\quad 65$

Congregations: the first programme $\quad 68$

Demographic development $\quad 70$

$\begin{array}{ll}\text { A new order, new problems } & 80\end{array}$

\section{Chapter 3:}

A New Division of Land $\quad 89$

Ecological complementarity versus socio-juridical dilemma $\quad 92$

The formation of labores $\quad 102$

Congregations: the second programme 108

$\begin{array}{ll}\text { Conclusion } & 118\end{array}$

\section{Chapter 4:}

The Practice of Regional Economy and Administration:

The Repartimiento de Trabajo and the Repartimiento de Comercio

The establishment of the repartimiento de trabajo 126

The structure of the agrarian repartimiento 131

The ganania $\quad 141$

The repartimienso de comercios 148

$\begin{array}{ll}\text { Conclusion } & 157\end{array}$ 
The repartimiento de comercios 148

Conclusion

Chapter 5:

The Lost Paradise of the Franciscans 161

The franciscans under fire $\quad 163$

The position of the Franciscans within the pueblos 166

The Spanish appreciation of Indian Christianity 171

The framework of Christianity in the pueblos 174

Church expenditure and the rise of the cofradias 178

The practice of Christianity in the pueblos 186

$\begin{array}{ll}\text { Conclusion } & 192\end{array}$

Chapter 6:

Shifting Powers in the Pueblos 195

Institutional frameworks and practical implementation 198

Rivalling pueblos and caciques $\quad 205$

Damaged Herrschafi $\quad 216$

$\begin{array}{ll}\text { Conclusion } & 224\end{array}$

$\begin{array}{ll}\text { Conclusion } & 227\end{array}$

The aftermath of conquest 227

The real transformation: the genesis of the colony 232

$\begin{array}{ll}\text { Notes } & 241\end{array}$

$\begin{array}{ll}\text { Abbreviations } & 262\end{array}$

$\begin{array}{ll}\text { Bibliography } & 263\end{array}$

$\begin{array}{ll}\text { Glossary } & 280\end{array}$

$\begin{array}{ll}\text { Samenvatting } & 283\end{array}$ 


\section{Tables, Maps, Graphs and Figures}

\section{Tables}

1.1 Tribute obligations in Tepeaca

2.1 Number of tributarios in the valley of Puebla, 1570-1640 73

2.2 Indices of the number of tributarios in the valley of Puebla, 1570-1640 73

\section{Maps}

1 The Valley of Puebla 7

2 Sixteenth-Century Political Division in the Valley of Puebla 63

4 Contracted Indian Workers in Cholula (1590-1599) 77

3 Hacienda Formation in the Valley of Puebla (1575-1620) 101

4 Destination of Repartimiento Labourers

in the Valley of Puebla (ca.1600) 136

\section{Graphs}

2 Demographic Development

2.a $1570-1620$

2.b $1620-1643$

3.a Number of landsales in the Valley of Puebla (1575-1610)

3.b Number of Mercedes in the Valley of Puebla (1572-1620)

Figures

2.1 Administrative Organization in New Spain (from ca. 1570) 



\section{Preface}

This study originates in the surprise about the scarcity of modern historiography of late sixteenth and early seventeenth-century Mexican history. As with many historians and social scientists my interest sprang from the question how a society evolves, which for me is to say, how the several 'sectors' of society interrelate. In the case of early Mexican history the question was how two different cultures influenced each other.

Naturally, questions of such a general nature can not be answered in one study; in the course of the investigations and the elaboration of the material it has become ever more clear to me, as before to many others, that one element of society is not determining for the whole of society nor that the evolution society follows one steady course. Therefore, I think that historical and social science research would gain much if society and its evolution would be considered and studied more as an whole than is usually the case. This is what I have attempted to do and I hope my efforts will contribute make this insight clear.

It is not easy to point at the exact starting point of this study, it lay somewhere at the final period of my study of History in Leiden, where my interest in Latin America was inspired by Dr. Adriaan van Oss, and after his sudden death in 1984 by Professor Slicher van Bath. With him I kept close contact throughout the writing of this book, and his influence is visible in many places.

The project itself was made possible by research grants in 1987-1988, 1989 and 1990-1991 of the Netherlands Organisation for the Advancement of Pure Research (NWO) and the Netherlands Foundation for the Advancement of Tropical Research (WOTRO). The Unger van Brero Fund financed a correction of the translation, which was carried out by Drs. Marie-Anne van der Veer. In the course of the research I received a lot of support of CEDLA, which gave me the institutional backing, without which the project would have been a lot more difficult to accomplish.

Mtro. Ricardo Rendón and Dr. Bernardo García Martínez were my cordial hosts during my stays in Mexico.

Parts of the text were read by the members of the discussion group OLA. I had discussed many of the ideas expressed in this book with Dr. Arij Ouweneel. As in many cases, those who contributed most to the efforts put into a project like this are mentioned last. My parents supported me without relenting. They even visited me while I was doing archival work in Mexico and my father read all of the manuscript, usually even the first, very rough version. Last of all I dedicate this book to Nellie, for all help, support and trust. 
Algunos dirin [...] que los indion son simples y humildes, que no reinn malicin ni soberbia en ellos, y que no tienen codicin; otros al contrario que cotun muy ricos y que son vagabundos y que no quieren sembrar. No crea a los unow ni a los otros, sino trattese con ellos como con cualquiera otre neción sin hacer reglas especiales, teniendo respecto a los medios de terceros, porque pocos hay en eates partes se muevan sin algín interta, or sea de bienes temporales o espirituales, o pasión o ambición, ore sen vicio o virnd. Pocas vecen he visto tratarse las materian con libertad evangélica, y donde nacen muchan murmureciones y proposiciones que i 2 entendieaen en particular no serí causa de tento desasoniego como algunas veces se rigue.

Don Antonio de Mendaze, fire viceroy of New Spain, ca.1550

\section{For Nellie}




\section{Introduction}

The traditional way of looking at the social developments of the first century after the conquest is strongly marked by the idea that Indian society had to give way to Spanish social and economic pressure, especially as far as landownership was concerned. In this way, the evolution of society in the early colonial period was determining for relations between Spaniards and Indians later on. However, recent research has made it clear that in the eighteenth century the Indians usually had enough land to subsist; therefore we may raise the question whether they lost most and best of their land in the sixteenth and seventeenth centuries. In this light it is important to reconsider this formative period of colonial society, not only considering the recent literature, but also and principally by consulting published sources and the rich, unpublished archival material. This is the aim of this study.'

Mexican society had an agrarian nature, both before and after the Spanish invasion. It goes without saying that rights to land were of great importance to both prehispanic and colonial society. However, in his book on the agrarian history of Western Europe, the historian Slicher van Bath explains that there are several types of agrarian societies which have different characteristics. Therefore, the statement that a society is agrarian, can have no more than a very general significance and although the rights to land are indeed of great importance to the social organization, they by no means exclusively determine its structure. Both the current theories on the organization of the Indian societies and the traditional interpretation of the changes after the conquest by the Spaniards are based on the distribution of landownership. Without meaning to doubt the importance of the claims on land, in my opinion a treatment of the social organization on the basis of ownership rights is problematic. If we consider the concept of ownership, it will become evident to what extent this holds good. ${ }^{2}$

Ownership is pre-eminently a legal concept, which in modern western relations expresses the right to dispose of a good or an object. The concept of ownership is derived from Roman Law, and as such it had much influence throughout the Middle Ages. Nonetheless, it is not possible, though not unusual, to use this interpretation in the context of the past without considerable restrictions. In European -especially German- historiography, the question of the distribution of landownership has led to a debate of over a century. Some decades ago, it was settled with the conclusion that neither legal ownership nor even the distribution of ownership rights could be 
considered to have determined medieval social relations. In medieval agrarian society there were often many people and institutions that could claim a right to land, especially to its fruits. In some cases, the rights to usufruct and yields were fragmented between peasants, clergy and various lords in such a way that the actual owner, often the Church or a lord, hardly enjoyed any income from his property at all. In such a case, ownership was neither absolute nor exclusive, and was consequently far removed from our modern concepts. Rights to the land and its fruits were too multiple and too complex, and the social relations of this agrarian society could certainly not be understood on the basis of simple ownership relations only.'

Such was the situation in Europe. Prehispanic Mexico, of course, did not know Roman Law; the concept of ownership was introduced by the Spaniards. This was a strange concept for the Indians. If the distribution of claims to ownership was not decisive in the European medieval situation, it can hardly be expected to have been so in the context of the prehispanic society. Recently an increasing number of authors have argued that on the basis of the sixteenth-century Spanish and Indian sources, it is not possible to demonstrate that the distribution of landownership was the basis of Indian society.

A similar objection can be made to the concept of state, which is used without further qualifications for both the prehispanic and the colonial period. In his monograph, Pietschmann treats the painstaking introduction of the Spanish idea of a territorial state in Spanish America and its evolution. This introduction signified an important change for the Indian world. If we are to understand this, we should not succumb to the usual misconception that the social constellation of Indian society before the arrival of the Spaniards could be couched in the concept of the territorial nation state, in the modem sense of the word. If we want to understand Mexican Indian society of the sixteenth century and the changes that took place in it, we ought to look for other assumptions."

In designing an interpretative framework for post-conquest Mexican history, comparisons are best taken from European historiography. There are two reasons for doing so. In the first place, Mexican society was under the rule of a European power from the time of the conquest. It is not a new assumption that knowledge of the European background, especially the Spanish one, may throw light on the development of colonial society in Mexico and especially on the changes the Spaniards introduced. In the second place, European historiography has a long tradition and, consequently, much is known of European history. Of course, a particular society should always be seen as an entity of its own, with its own autonomy, own specific features and characteristics. Comparing non-European societies with the European situation, there is the immanent danger of a projection of concepts or explanations taken from a specific European context. It could be alleged that these dangers are best evaded by a comparison of the sixteenth-century situation with that of the rural areas of modem Mexico, a method called 'upstreaming' in anthropology. However, a comparison with pre-industrial European history 
prevents a reprojection to colonial times of modemistic elements that have not been introduced until long after Mexican independence was achieved in the nineteenth century. Moreover, a comparison with the present would soon obscure which elements of the colonial society were imported from Europe.

Unfortunately, Latin American and European historians bave little knowledge of each other's results. Here, I shall particularly be concerned with the importance of European historiography for the Latin American, especially Mexican history. To a large extent, Mexican historical writing has its roots in the European tradition, but, especially during the last decades, it has become a scientific tradition with its own dynamics. This is sometimes influenced by, but certainly never dependent on, the developments in the Old World. European historical writing is neither homogeneous nor coherent as a result of the many different traditions that have played a part in it. It is enlightening to consider the differences within European historiography, even though this is not the place to treat them at any length.

In modern European historiography the tradition of the French Annales has long been of dominant importance. This 'French dominance' was preceded by a German one. German historiographical tradition emphasized the political and institutional aspects rather than the social and economic processes. The Annales School, with Braudel as its greatest representative, reacted against these emphases. Broadly stated, Braudel argued that it was the structure of society that determined the course of developments instead of political occurrences. For those who occupied themselves with the functioning of society, institutional history was directed too much towards the external form, expressing too little the internal processes and the social and economic forces. In the practice of European historical writing, the two traditions were never strictly separated. Social and economic history always leaned strongly on a foundation of political and institutional history.6

Historical writing on colonial Mexico began to flourish at the same time when the Annales-tradition dominated European historiography, and was greatly influenced by it. As a result, much attention was paid to social and economic history, and a lot of important work was done in the field of serial history. The economic functioning of haciendas was also studied relatively extensively. The social history of Latin America bas always had strong ties with anthropology. The field of ethno-history is consequently seen as a mix of anthropology and history, and every now and then there is a call for further integration of the two scientific fields. Recently, European historiography has also known an upsurge in the interest in anthropology. The objective seems to be the study of the internal functioning of persant societies and of peasants values and standards. Whereas previously the community was seen as a whole and looked upon from the outside, the new historiography principally directed itself to the intemal processes of the community. In this respect, there is a clear parallel between European and Mexican historiography, even though influences are not very strong at the moment.

Because of its roots in the Annales tradition, Mexican history lacks to a large part the institutional and political background which European history has got as a 
result of the German tradition. Notwithstanding some initiatives, there has been no political history of the colonial era so far. More research has been conducted into institutional history, although in this field there are still important lacunae as well. Often, the development of the Indian communities has been regarded as a derivation of the economic and social situation, without taking the both political and institutional background into consideration. This is regrettable, as at least one significant example can show. Until recently, it was acknowledged that the Crown decreed laws for the protection of the Indians, but it was assumed that these laws had been neglected in the colonial practice. However, in his study of the functioning of the Indian section of the supreme court of Mexico -the Juzgado General de Indios of the Audiencia of New Spain-, Borah argued that the Indians defended their rights skilfully and that the court decided many times in favour of the Indians. In 1985, the historian Stern remarked that "legal tactics mushroomed into a major strategic of Indian life".?

In the light of these developments, the institutional aspects of Mexican history deserve more attention than they have received until now. In the first place, the Spanish state exercised much of its influence through institutions. Especially for the authorities in Spain, formal regulations were the only way of pursuing a political line with some effectiveness in the long term. Both Spaniards and Indians had to accept the rights, as expressed in the Law, as their point of departure, if they wanted to get support from the authorities. The Spaniards introduced important institutional changes, which they thought indispensable for a proper functioning of society or of the legal system. These changes often sprang from the Spanish written and unwritten legal traditions. As a matter of course, Spanish regulations were principally directed at the fiscal, stately and public matters. Being the new authorities, the Spaniards had to ensure that public order was organized according to Spanish concepts and also that fiscal income benefitted the Crown. On the whole, they did not change Indian customs and laws to an important degree. This does not mean that the Spanish regulations did not often imply a radical change for the Indians, and their everyday lives, because the changes in public order did affect them. However, it is by no means clear yet, how the legal position of the Indians, the pueblos de indios or the Indians' property of land evolved. In due course, Spanish Law and institutions became the realities to which they had to adapt themselves in everyday life. Those who appeared in court had to write down their petitions and declarations in accordance with the formal regulations. Even though many of the legal concepts of the Spaniards were initially strange to the Indians, they had to adjust to them. In this regard, sixteenth-century Mexico did not essentially differ from Europe. The historian Sabean remarked on early modern Germany that:"

"the logic of the state's intervention may well have proceeded from fiscal concerns, but from the point of view of villagers, many arrangements and procedures became internalized and were regarded as essential services to be 
expected from the state. A particular [...] regulation may have violated the old custom of a particular village, but once in place for a generation or so would become part of the observed rule structure [...]. Individual villagers used statesupplied institutions to assert their rights, develop strategies of aggrandizement, or maintain defensive alliances".

In studying the political and institutional aspects of colonial Mexican history, it is best to follow the German tradition. In Germany itself these ideas have always remained important, but they have recently also been adopted by a number of NorthAmerican historians. In their attempt to understand the internal functioning of the village communities, they realized that this could not be done by just studying the socio-economic aspects, but that often the political and formal-institutional elements were of great importance.'

One of the most salient features of the German historiography has always been the idea that in early modern times, political power did not just come from the state, but that there were many other sources of power, political but also social and economic. To a large extent, the sources of power were closely related to the agrarian conditions of society. This is not just the case in the European, but also in the prehispanic Mexican situation.

The introduction of the institutions of the Spanish state after the conquest brought about many changes in indigenous society. Indian society became part of the Spanish Empire and had to fit in the political patterns of the Spanish state. This implied a profound reform of the prerogatives of the Indian nobility in the political, social and economic spheres. Of course they also had an effect on the position of the common Indians and their relation to the nobility. Nobles and commoners were frequently opposed, and their disputes often endedd in lawsuits. Due to the institutional changes both the relations between the Spaniards and the Indians, and the relations within the Indian world had to be profoundly revised.

All this does not mean that the social and economic development was of no importance. It goes without saying that the enormous decrease in the number of Indians, mainly due to epidemics, had a far-reaching influence on the evolution of the society of New Spain. In effect, institutional and demographic and related socioeconomic developments exerted a combined influence on society and caused a social transformation in the late sixteenth and early seventeenth centuries. Once this transformation had got its momentum, neither the Indians nor the Spaniards could keep control of it.

\section{Periodisation}

From the view of representativeness, the valley of Puebla is one of the most justifiable choices. As I remarked above, together with the valleys of Mexico and Toluca, it forms the Central-Mexican highland, the whole of which was called 
Anahuac in colonial times. The area is situated in the Sierra Madre, on the neovolcanic axis which crosses Mexico from east to west. The three valleys are all at a height of some 2000 meters. They are separated by volcanoes. The Nevado de Toluca and the adjoining ridge separate the valleys of Mexico and Toluca; the Ixtaccihuatl $(5286 \mathrm{~m})$ and Popocatepetl $(5442 \mathrm{~m})$ are the border between the valleys of Puebla and Mexico. They are the second and third largest volcanoes in the country. The highest volcano of Mexico, the Citlaltepetl of Pico de Orizaba (5650m) is located a little east of the valley of Puebla. To the north the valley of Puebla is bordered by the fourth volcano of Mexico, the Malinche or Matlalcueye (4461m). In the east, south and west, the central valleys of Anáhuac are surrounded by lower, mountainous areas, the so-called faldas. In the north they border on a semi-arid area (Map 1).

In comparison to the valleys of Mexico $(60 \times 120 \mathrm{~km})$ and Puebla $(75 \times 100 \mathrm{~km})$, the valley of Toluca $(50 \times 80 \mathrm{~km})$ was much smaller. In the period under consideration the valley of Puebla had an average of $\mathbf{3 7}$ percent of the total number of inhabitants of the valleys, versus 42 percent in the valley of Mexico and only 21 in the valley of Toluca. ${ }^{10}$ The valleys of Mexico and Puebla differed little in size of population. Being the setting of the capital of Mexico-Tenochtitlan, the valley of Mexico was politically and economically the most important one of the Central Highland. This also made it a rather exceptional area. This was emphasized even more by the fact that the valley had been completely under the power of the Aztecs in the period before the conquest. The valley of Puebla had been much more heterogeneous in prehispanic times. The colonial provinces of Tochimilco and Tepeaca bad been part of the Aztec Empire, but Tlaxcala, Huejotzingo and Cholula had never been subject to Aztec rule. In addition, these political entities had continuously been in a state of war with each other, while the valley of Mexico had entirely come under the 'pax azteca', a unique situation in prehispanic Mexico. Soon after the Spanish invasion, in 1531, the city of Puebla was founded in an uninhabited part of the valley. This was similar to the situation in other areas, for example in the case of Antequera in the valley of Oaxaca and Valladolid in Michoacan, and just like these Puebla was to become the centre of its economic region. An element of concentrated, urbanized Spanish influence thus was introduced into a previously completely Indian socioeconomic environment. In this respect, the valley of Mexico was a somewhat more complicated case, because the Spanish influence in the capital was more or less a continuation of the prehispanic period when Aztec rule had been based in Tenochtitlan. Even though the valley of Puebla had its own distinctive characteristics, all in all, its size, its number of inhabitants and its diversity make it an obvious candidate for a regional study, which has the pretention that it can be used for generalization exceeding the region itself.

The historiographic situation makes the valley attractive as well. In 1952, Gibson already wrote a study on the history of sixteenth-century Tlaxcala. Another big step forward, was the interdisciplinary research project in the valley of Puebla by the Deutsche Forschungsgemeinschaft, which called the valley the area of Puebla- 


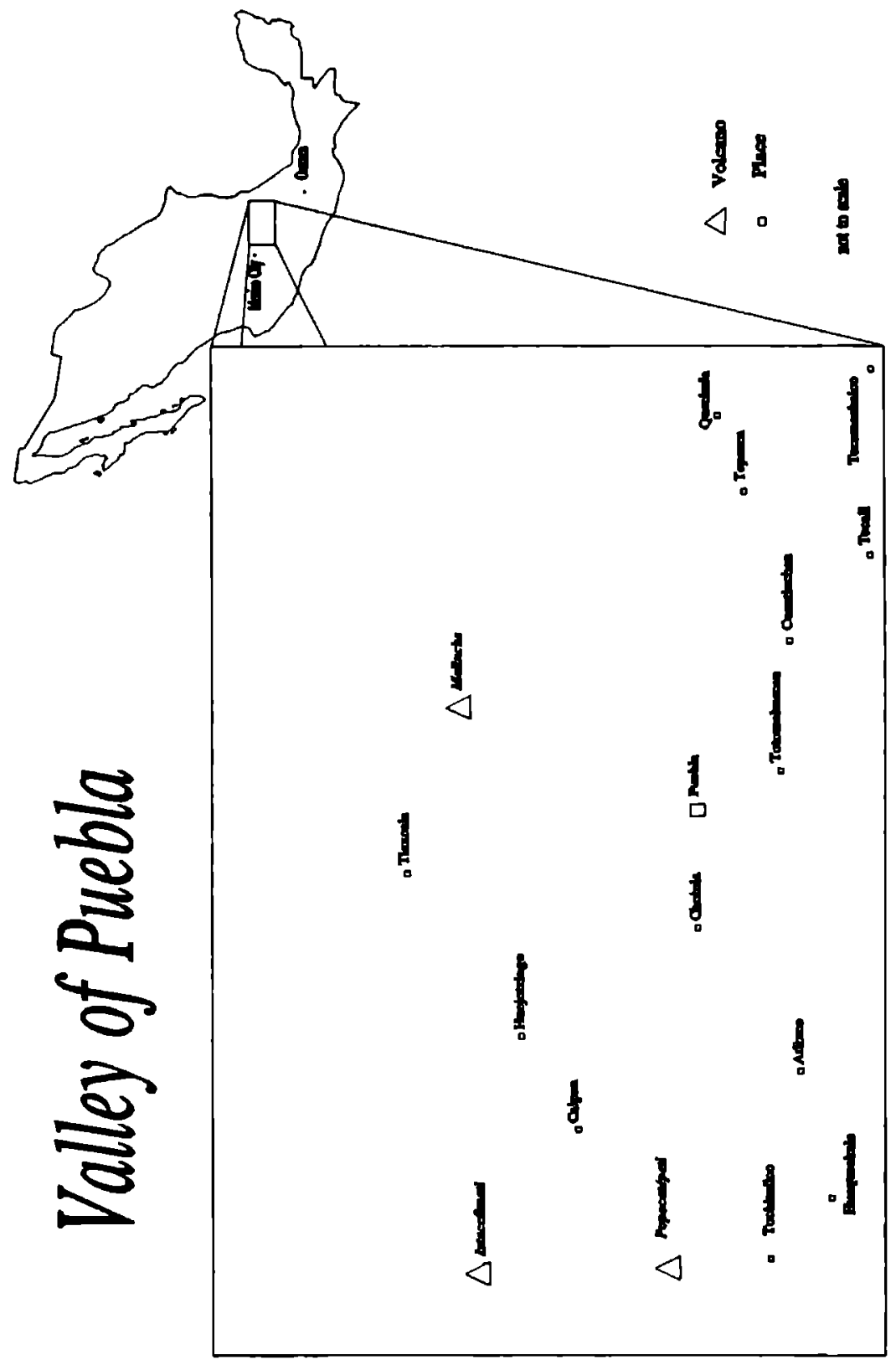


Tlaxcala. This project has resulted in a number of studies, which deal with topics that will be discussed here as well. Prem treated the changing relations of landownership in the province of Huejotzingo in the sixteenth and seventeenth centuries, Nickel and Ewald studied a number of haciendas, predominantly from the eighteenth and nineteenth centuries, and Trautmann wrote a monograph on the historical geography of Tlaxcala. A research group, consisting predominantly of anthropologists, under the leadership of initially Kirchhoff and later Carrasco and Reyes Garcia, has investigated the prehispanic social relations in the area."

A good opportunity for comparison are available for the valley of Mexico for which the work of Gibson has been the standard since 1964 and the valley of Toluca, which has received rather intensive attention from, amongst others, Wood, Lockhart and Jarquín during the last decades. In addition there is a very useful recent study by García Martínez about the Sierra Norte de Puebla, which borders on the valley of Puebla. ${ }^{12}$

An important question of my research bas been when colonial society took shape. It has often been assumed that most changes took place in the period directly following the conquest, which is to say the years 1521-1570. Even though the loss of sovereignty must have been a great shock for the Indians, this assumption is not entirely justified. Initially, the contacts between Spaniards and Indians were too fresh, and the number of Spaniards was too small for them to be able to exert an active influence on the ordering of society. The Crown in Spain was taken by surprise by the sudden necessity of ruling over an enormous empire and a large number of strange new subjects, without being able to fall back upon experience or ready administrative models. Only after the power of the king and the Spanish state had been properly established, it could start with a systematic institutionalization of the conquest.

In addition, in the first decades after the conquest, the Crown's struggle for power with locally organized pressure groups of Spaniards, especially Cortés and the encomenderos, demanded a lot of attention and made it necessary for the Crown to manoeuvre carefully. The Leyes Nuevas of 1542-'43 were a turning point in the developments, albeit that in many instances they were only a codification of many developments. With regard to the Leyes, the literature has predominantly been focused on the most salient features, the effects on the encomenderos and the abolition of Indian slavery. The effects on the indigenous population have not been studied much until now. This is unfortunate, because the Leyes Nuevas initiated a lot of changes in the Indian world, of which the reform of the indigenous tribute system was the most important.

This was a very complex operation, the implementation of which took about a quarter of a century. In about 1570, the effects of the tribute reforms made themselves fully felt and contributed much to the beginning of may be characterized as a social transformation. 1570 is therefore the starting date of this study. Traditionally, this year is also seen as the end of what is called the conquest society. 
The archival material on which this study is based, is mainly from the decades after 1570. However, this starting date is by no means absolute; in order to be able to explain the nature and the dimensions of the transformation, I shall have to pay relatively much attention to the prehispanic period and to the conquest society.

The end of the period of this study is 1640 . This date is somewhat more arbitrary than 1570. Even though Hoberman in her recent monograph on the elite of Mexico City, takes 1660 as the end of her book and Lockhart sees a turning point at around 1650 , there is one event that gives us reason for taking 1640 as a final date: in 1643 the Spanish and Indian ownership rights to land were recorded in a socalled composicion, which is a sign that the new relations of the colonial society were now consolidated. ${ }^{3}$

Another reason to study this period in Mexican history is closely connected with the socio-economic developments pointed out above. Prehispanic society consisted of a number of separate and contending political entities, which also were largely isolated in an economic sense. As the historians Slicher van Bath and Van Oss have pointed out, in the eighteenth century there were four economic regions in Mexico. In their typology the regions have a characteristic structure which rather closely follow the description of an economic region of the nineteenth century German economist von Thünen: they had cores, intermediate zones and peripherical zones. The four economic regions were Central Mexico, South Mexico, Western Mexico and Northern Mexico. Three of them were situated in areas that had a large population in prehispanic times. Just like Michoacan to the West and Oaxaca to the South of Mexico, the central Mexican highlands of Anáhuac -consisting of the valleys of Mexico, Puebla and Toluca and the surrounding areas- constituted a densely populated area within a largely uninhabited Mexico. The fourth region, around Guadalajara, was the only one to have developed completely after the conquest. Both in prehispanic and colonial times the central valleys of Anáhuac were by far the most important centre of population.

In colonial Mexico the valleys of Anáhuac were to become the central areas of the colonial Central Mexican economic region. In the caseof the Central region the valley of Toluca completely belonged to the intermediate zone, while the valleys of Mexico and Puebla had their cores in the cities of Puebla and Mexico. The historian Ouweneel has remarked that the falda-areas were always the peripheries. Because the economic regions developed in areas which already had an important indigenous population at the time of the Spanish conquest, this meant that the existing socioeconomic situation underwent profound changes, which took place for a large part in the period under study. ${ }^{\text {" }}$ 


\section{Summary of contents}

The treatment of a subject such as the transformation of society is impossible without a characterization of the original situation. In chapter 1, "Cem Anáhuac: The World of the Indians", I shall present a picture of indigenous society in the valley of Puebla before the arrival of the Spaniards. My research departs from the demands which agrarian society imposed on the Indians. This chapter is written from the awareness that the social constellation at the time of the Spanish invasion, was the product of a political, economic, social, cultural and ecological evolution of $\mathbf{3 5 0 0}$ years of agrarian development. All the interrelations and influences had resulted in a very multifarious society. It is obvious that it is impossible to treat all intricacies within the confinements of one chapter. In chapter 1, I particularly aim at showing the diversity and complexity of this indigenous society and will deal with some basic principles which exerted a large influence on the social evolution of the early colonial era.

Chapter 2, "The Shaken Foundation" has as its subject the various influences which undermined society as the Indians had known it. As I have indicated above, in the first few decades after the conquest there were a number of important changes in society, but generally speaking the indigenous world was not disrupted, and the Spanish and the Indian worlds remained largely separated. As a result of a constellation of political, institutional, demographic and economic factors, the social relations began to break down. From the middle decades of the sixteenth century the uneasy equilibrium of the conquest society was irrevocably disturbed and a social crisis rapidly developed.

Towards the end of the period of the conquest society a number of Spanish and Indian groups with often contradictory influences may be distinguished, which had to come to terms with the social transformation after 1570 . They all responded to the crisis in their own manner. In chapters 3 to 6 , attention is paid to the way in which the problems were gradually solved. The solution to these problems led to a merging of the previously separate Indian and Spanish worlds into one new, colonial, agrarian society, which was neither Spanish nor Indian, but in which Spanish and Indian influences together created a Mexican society.

Although it was a highly complex evolution, in which the various developments cannot been seen apart from each other, I have chosen for a thematic approach. In this I shall take the existing literature as a point of departure, whenever possible, and re-examine its assumptions on the basis of fundamental archival research. In view of the importance of the institutional changes and their influence on the amount and nature of the documents in the archives, I have chosen to treat the themes as it were 'going in from the outside'. The Spaniards had recently arrived in Mexico; they had to win a place in society for themselves. The Indians had always been part of the agrarian society in the valley of Puebla. Even though society rapidly changed, the changes took place against the background of agrarian continuity. Therefore, an approach of 'going in from the outside' means that I shall first pay attention to the 
questions which concern the relationship between Spaniards and Indians, and afterwards make an attempt at 'penetrating' more deeply into the Indian society.

When Spanish agriculture was introduced in Mexico, huge problems about land arose between Spaniards and Indians. In view of recent research on especially the eighteenth century, it is not possible to maintain that the Indians had to give up most of their land to the Spaniards. Nonetheless, in the sixteenth century there were many conflicts about land between Spaniards and Indians. In chapter 3, "A New Division of Land", I shall argue that these problems can only be understood against the background of the ecological demands of the Spanish and Indian agricultural systems in the valley of Puebla, in combination with the institutional changes. A settlement of these problems was the principal condition for the solution of the disputes between Spaniards and Indians. The Spanish Crown realized the importance of a solution of the question and played an active part in it.

The contacts between Indians and Spaniards were regular and of great importance for the functioning of society. This is treated in chapter 4, "The Practice of Regional Economy and Administration: The Repartimiento de Trabajo and the Repartimiento de Comercios". Based on the development of the two forms of repartimiento, I shall here discuss the way in which Spanish and Indian influences contributed to a settlement of the daily relations between the two groups of the population and to the formation of a regional society.

The clergy, in the valley of Puebla especially the members of the Franciscan order, were closer to the Indians than any other group of Spaniards, if only because their economic position pre-eminently depended on the Indians. Besides, the Franciscan friars also occupied an important place within Spanish political circles. In the first decades of the colonial era, the Franciscans had visions of a Paradise on Earth, in which the Indians would be the Chosen People with the Franciscans as their spiritual guides. From the middle of the sixteenth century they were under severe pressure to give up their pastoral care of the doctrinas to the local bishop, to which they were ultimately forced in 1640. In chapter 5, "The Lost Paradise of the Franciscans," I shall pay attention to the changing position of the Franciscans in the fragile and shifting political balance between the Indian and the Spanish worlds. The argument of this chapter is, that with the disappearance of the two separated worlds as a consequence of the inception of a colonial society, the position of the Franciscans became increasingly untenable, first in the Spanish political realm, but later also in their doctrinas. The changes in the position of the Franciscans had influence on the appreciation of Indian Christianity, which in the eyes of many Spaniards was seen as the product of the friars. Therefore, in the second part of the chapter it will be discussed in what way the Church contributed to the evolution of local Indian society.

In its treatment of the Christianity of the Indians, chapter 5 preludes to chapter 6, titled "Shifting Powers in the Pueblos". This discusses in what way the pueblos de indios, as such introduced by the Spanish state, became institutions in which the various Indian groups acquired a new position. I shall argue that the indigenous 
nobility often managed to use the institutional means which the pueblos offered, for reshaping their old positions, notwithstanding the severe crisis of legitimacy in which many nobles found themselves in the late sixteenth century.

In a "Conclusion" the thrust and the argument of this study will be summarized. 


\section{Chapter 1}

\section{Cem Anáhuac:}

\section{The World of the Indians}

The altepetl was the most important cultural, social and political entity of prehispanic indigenous society; it was a central concept in socio-political philosophy. The Nahuatl word altepetl means 'water and mountain', or 'mountain surrounded by water'. The famous sixteenth-century Franciscan Fray Bernardino de Sahagin, who wrote an extensive General History of the Things of New Spain (Historia General de las Cosas de la Nueva Espana) with the help of high-placed Indian informants from Tlatelolco, recorded the following on the alteperl. The informants directly associated the meaning of altepetl with the one of river, 'atoyatl'. They said:'

"Its name comes from 'arl' (water) and 'totoca' (it runs); as if to say 'running water'. The people here in New Spain, the people of old, said: -These rivers come -they flow- there from Tlalocan [the underworld]; they are the property of, they issue from the goddess named Chalchiuhctli icue [who was the goddess of Tlalocan]. And they said that the mountains were magic places with their surfaces covered with soil and rock; that they were just like ollas (vessels) or houses; they were filled with water which was (in) there. If necessary, the mountains would dissolve at times, flooding the whole world. And hence, the people called their settlements altepetl. They said, ethis mountain of water, with this river springing from its womb. For it is from there that Chalchiuictlicue sends it -offers it [...]»".

Thus, the altepel was a metaphor for 'a place where people can live' and as such, embodied or symbolized much of the Indian standards and values. Water and mountain were the two complementary elements which made life possible for the Indians. The temple -placed on a pyramid which was called coatepetl or snake mountain- stood as a man-made mountain at the symbolic centre of the altepetl and symbolized the tamed forces of nature. ${ }^{2}$ In the temple, the cosmic order was symbolized by a multitude of intricate numerical divisions, as Van Zantwijk has shown. To take one obvious example, the four sides of the pyramids symbolize the four directions of the wind.' 
Man was supposed to do something in retum for the favours he received from the gods. Like the gods, who offered their own blood, water, for the fertilization of the mountain, which in itself was just a barren rock, the inhabitants of the altepetl had to offer human blood, as if it were fertilizing water, to feed the hungry earth and support the gods. In the same way, the gods offered their heart, the sun, every day and man, in return, had to sacrifice human hearts. This is the background to the many human sacrifices on the pyramids.

The inhabitants of an altepetl were led by its most important god. In the legendary traditions of the Aztecs, which they claimed to be dating from the time when they were still nomads -Chichimecs-, the god Tezcatlipoca was said to have promised the equally legendary Mexican king Huitzilopochtli -who was later to become an important Mexican god- that he would make the Mexicans win all their wars if they became his servants:

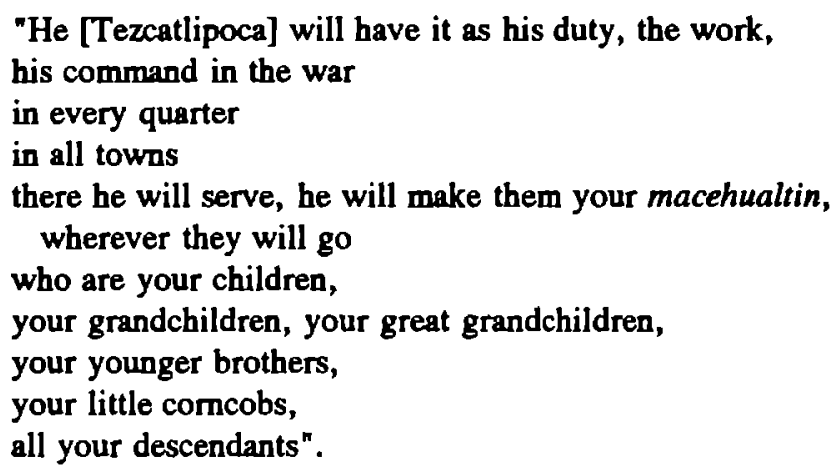

Everyone had his place on earth and within the cosmic order. An astrologer determined the day sign (tonalli) of newborn children. The tonalli determined the child's fate, on the basis of which it was decided what would become of him. Everyone had his duty (in Nahuatl: tequitl; in Spanish: cargo) within the cosmic order. There was a fundamental difference in position between nobles, pipiltin, and commoners, macehualtin. The earthly task of the nobles consisted in leading a noble life, piltequitl, and in ruling, tlahtotequitl. The macehualtin's duty consisted in obedience and servility to the lords during the wars, both in their occupations and on the land.

Every man was a servant, macehualli, of the gods and as such, liable to give them tribute. As has been explained above, tribute consisted of blood sacrifices made on the pyramids or on the battlefields. In exchange, the gods granted man the opportunity to live in an altepetl. The ruler, thahtoani, was a substitute of the gods. When the Aztec tlahtoani ascended the throne, he would pray to Tezcatlipoca: "Verily, now, how hath thy [macehualli], the stupid one, N., looked to thee- he who briefly, for yet a little while, will bear afflictions for thee on thy reed mat, thy reed seat [=throne]". Tezcatlipoca, "the lord of the near, lord of the nigh", "commissioned [the new ruler], for it is his charge, [his] duty, [his] 
obligation to make public to the altepetl the spirit, the words of your ruler [god]".'

It was pointed out to the new ruler, that he had undertaken an arduous task; he had "undertaken to shoulder a bundle of people, to carry a load of people. For thou wilt find tiring the common folk, for great is the burden which thou hast underiaken [...]". The ruler was expected to give 'shelter and protection' to his macehualtin: "Rulers are esteemed like cypresses, like silk cotton trees. Beneath them, there is the seeking of shade, beneath them is the seeking of shadows". "The good ruler is a protector; one who carries [his subjects] in his arms, who unites them, who brings them together. He rules, takes responsibilities, carries burdens. He carries his subjects in his mantle; he bears them in his arms. He governs, he is obeyed [...]". It was the duty of every lord to be to his macehualtin "like their ramparts, their refuge [...] he provided a rampart, for whatever might befall the macehualtin would first befall the ruler or the nobleman"."

In this chapter, I shall treat some aspects of life in the altepetl, which for the Indians symbolized the world. Of course, the prehispanic Indians realized that their life was determined by many elements (nature, the gods, the ruler), but for them these were symbolized in the altepetl. Many of their notions were connected with agriculture, which, after all, was the main occupation of most people. When dealing with a society of people that depended on agriculture to such a large degree, it is necessary to pay attention to ecological circumstances first, in order to understand the ecological constraints and possibilities.

\section{Ecology and economy}

The food supply of the indigenous population largely depended on maize, which was cultivated on so-called milpas together with a number of other crops. Milpas were fields of a rather modest size, on which maize beans and vegetables grew on different vertical levels. The maize stalks served as climbing aids for the beans. Below the maize plants, vegetables, such as squash, were cultivated, as well as all sorts of chilies and tomatoes. The system of milpa-cultivation did not exhaust the soil and made the rotation of crops or the use of fallow superfluous. After the Spanish Invasion, the milpa system remained in use, and in large parts of Mexico it is still used today. Compared with wheat, Europe's most important crop, maize yielded ten to twenty times as much.'

The possibilities for agriculture were closely related to the natural environment. Like the entire Central Mexican highlands, the valley of Puebla offered reasonable farming conditions, but its possibilities were limited. In Mexico, climate is determined by altitude rather than latitude as is the case in Europe. Tierra caliente -hot land- is all land up to $600 \mathrm{~m}$ of altitude, tierra templada moderate land-is situated between 600 and $2,800 \mathrm{~m}$, and above this altitude the 
land is called tierra fría -cold land-. The valley of Puebla is situated at an altitude of 2,000-2,600 m. In Mexico, the entire valley is classified as tierra templada, and only the upper slopes of the volcanoes are tierra fria. This may be so, remarked the Spanish official who wrote a description of sixteenth-century Tepeaca, but "concerning climate [it is to be remarked], that at any time of year in the sun it is summer and in the shade it is winter"." The central highlands were surrounded by tierra caliente: to the east, the land sloped down to Veracruz on the Gulf of Mexico. To the south-west, the valley descended into the lower valleys of Atlixco and to the south-east into the valley of Tehuacan.

At an average temperature of $14^{\circ} \mathrm{C}$, the climate was moderate, although night frost often occurred at the change of seasons at the end of October and the beginning of November and in January and February. According to the sixteenthcentury author Muñoz Camargo, who had had a Spanish education:"

'From October till the end of February -[from] when the sundescends to the antarctic until it has reached the equator again- there is great cold, ice and snow. It is not so bad that one would not be able to inhabit the [Tlaxcaltec] land [or] to live and to move on it, but this does apply for higher regions, where it snows quite a lot. But we are treating the inhabitable parts, [where] it is sometimes cold, but moderately and bearably so. However, there is one exception in the extreme, which is in November and December, when those who are in the sun burn themselves, and those who go into the shade almost freeze and can hardly bear the cold [...]'.

All important crops that were cultivated in Mexico were very sensitive to frost. The greatest danger of frost occurred at a height of $2,800 \mathrm{~m}$ and above, which made the cultivation of maize very precarious there.

Precipitation was a second crucial factor for agriculture. Mexico had only two seasons: the dry season and the rainy one. The dry season lasted from October until May. At the end of February and the beginning of March there were some showers, but it remained dry throughout the other months of the dry season. The rainy season lasted from the end of May till October. While the rainy season started off slowly, during these months, it would sometimes be pouring down on end for days, with a yearly average precipitation of about $800 \mathrm{~mm}$, which was not spectacular. Moreover, the rainy season was not very reliable, and amounts of rain greatly varied per year. Most rain (1,000-2,000 mm) fell on the upper slopes of the Malinche, and on the slopes of the Popocatépetl and Ixtaccihuatl. The east and north of the valley had little rain, with a yearly average of ca. 600 $\mathrm{mm}$. Even dryer was the area east of the Malinche, where the yearly average did not rise above $400 \mathrm{~mm}^{12}$ According to Muñoz Camargo, the problem was aggravated by the condition of the soil there. He remarked on the town of Nopalucan situated there, that 'although it sometimes rains there for days on end, it is stone dry when the rain stops, as if it had not rained at all [...] because of the sandy soil'." 
The hydraulic situation in Anahuac widely varied, because of the large differences in season. During the heavy showers of the summer months, floods were no exception and roads were often washed away or tumed into impassable mud tracks. In wintertime, the land gradually dried out. During the short period of intermittent showers of early spring, nature would revive a little, but the actual growing season would not begin until the rainy season had started."

There were few permanent rivers. Only the Atoyac and Zahuapan, situated at the lower parts of the valley, received sufficient water to prevent them from falling dry. There were no other permanent river, but just arroyos, which contained water in the rainy season, only. The water would stream down from the slopes and gather in the valley. This flood of rainwater was less problematic in the valley of Puebla than in the valleys of Mexico or Toluca. The basin of Mexico had no natural drainage and in prehispanic times large lakes had formed here. These lakes were rather shallow and marshy and extended quickly in times of rains. The valley of Puebla had a better drainage, because it sloped down into the valleys of Tehuacan and Atlixco; nonetheless, in the rainy season, large marshes were also formed on the lower banks of the rivers Atoyac and Zahuapan. According to the agronomist Wilken, the main problem for agriculture in the low parts of the valley was, and still is, the high level of ground water. ${ }^{15}$ As a result, not only the high slopes of the volcanoes and the arid areas in the east and north-east were hardly suitable for agrarian purposes, but agriculture took great efforts on the low riverbanks, too.

In these low parts, land frequently flooded in the rainy season, which was also the growing season. Consequently, the plants ran the risk of drowning if they were not protected. In order to secure the crop, it was necessary to raise the land. To that end, a field was marked out by channels. The earth from the ditches was dumped onto the fields. In this way, a ridge and a drainage system were created at the same time. These so-called camellones were similar to the chinampas, the artificial islands in the lakes of the valley of Mexico, which consisted of alternate layers of reed mats and mud from the bottom of the lake and were divided by channels. Of course, both the chinampas and the camellones were quite labour-intensive agricultural systems. This was not just true of their construction, but also of their maintenance, as the channels had to be cleaned regularly to prevent them from silting up. Another problem was that the ridges of land ran the risk of becoming salty. ${ }^{16}$ Apart from the risk of flooding, the banks of the river had the disadvantage of being overgrown with stiff scrub. As a result of the ecological problems on the upper slopes and on the low riverbanks, the most obvious solution was to cultivate maize and other crops on the lower parts of the slopes.

The topsoil of the volcanoes was a very thin layer. Milpa-cultivation did preserve it, but as the natural covering of the soil had disappeared with clearing the land for cultivation, this stabilization was easily disrupted. If a field was left fallow, the topsoil was washed away with the heavy summer rains, and too 
intensive cultivation drained the soil, causing erosion." Eroded agricultural land soon changed into white boulder clay, called tepetate, which was then no longer of agricultural use. To prevent erosion on the slopes, milpa cultivation was practised on slightly sloping terraces. In the course of time, the rural population constructed these and fortified them by planting a large sort of agave, called metl in the Indian Nahuatl language. During the time of the Spaniards, it became known by its Antillian name of maguey. The advantage of the cultivation on terraces was that the water did not wash down the fields, but could instead be led through channels overland and be retained by dikes. As the milpas were situated on the slopes, the water was drained by piercing the dikes."

Indian agricultural implements were usually uncomplicated, as the indigenous population employed neither iron nor the wheel, thus excluding the use of wind or waterpower. The most important agricultural tool was a digging stick with a sharpened end, which was hardened by burning. However, these huictli, or coas as they became known in the Spanish period, were well suited for the thin topsoil. Other agricultural tools and also arms, were made of wood and stone, as well.

More intensive agriculture had been developed in some places around the regional centres where food was needed most. In the valley of Puebla, in the altepetl of Cholula and Tlaxcala, gardening was practised on the camellones on the marshy banks of the rivers Atoyac and Zahuapan. There were gardens on chinampas in the valley of Mexico. Only a small part of the agricultural production was obtained in this way. The anthropologist Sanders and his team, who have thoroughly investigated the ecological and agricultural developments in the valley of Mexico from the earliest times onwards, have estimated the extension of chinampas at 12,000 hectares against 30,000 hectares of de temporal-cultivated land at the time just prior to the arrival of the Spaniards, although much more maize was produced on the chinampas. In the present state of Tlaxcala, gardening on camellones only occupies 2.5 percent of the total agricultural lands in the 1970s and 1980s, and we may wonder whether a much larger part of the area of cultivated land would have been dedicated to agriculture on camelllones in prehispanic times." Because of this, de temporal (rainy season) milpa cultivation on the terraces created on the lower slopes, was much more important than gardening, even though the irrigated fields yielded much more.

Unlike the inhabitants of the Old World or the Andes, the Indians of Mexico had no domestic animals of importance, such as cattle, donkeys, sheep, goats or even lama. Consequently, they had no need for pasture. The Indians' diet was largely vegetable. Animal protein was provided by the only domesticated animals, dogs and turkeys, complemented by game and fish. The Spanish official who wrote the Relación de Cholula in the 1580 s, remarked with some disgust on the habit of eating dogs, that the animals were eaten 'when they are still pups and fat [and] they say it is good meat'. The Indians bunted birds, rabbits, deer, and snakes in 
the woods and ravines. The lakes in the valley of Mexico provided fish and fowl. Apart from this, the Indians used to eat some, to us unusual, animals, such as locusts and some sorts of cold-blooded aquatic animals like larvae and frogs. ${ }^{21}$

On the slopes of the volcanoes, the Indians cut firewood and gathered many sorts of roots and fruits. However, the Indians' daily food mainly consisted of maize and beans. Maize was processed into food in many ways. The most common way of eating maize was the flat maize bread which was baked on a stone baking slab (comal). The maize dough was prepared by cooking the kernels with lime, followed by grinding them on a special grinding stone called metate. The Spaniards called the bread tortillas. They were eaten with a filling of mainly beans, vegetables and a sauce of herbs, spices, especially chilies, of which there were many different varieties. ${ }^{2}$

Above, I have already mentioned the use of magueyes for the fortification of the terraces, but the plants were also used for many other purposes. The dried, fibrous leaves were used as fuel, roofing-material and were processed into rough textiles, cord, and sandals, whereas the sharp ends were used as needles. Most important, however, was probably the juice that was collected from the plants. This could only be done once at the end of the maguey's life, after a maturing period of several years. ${ }^{23}$ The ovary was removed from the maguey's heart as soon as it began to shape. For some time, a sweet juice would well from the wound, which was called aguamiel in the Spanish period. Then the juice was left to ferment. Within a few days it changed into a slightly alcoholic drink, called octli or pulque. The end product was called white pulque when it was left as it was, and yellow pulgue when it was cooked with a special kind of root. The white sort was less intoxicating than the yellow one. Pulque was the alcoholic drink of prehispanic Mexico. Magueyes were not only planted on the edges of terraces as fortifications, but also on special fields (magueyales) which had rows of magueyes of all different ages to secure a continuous supply of pulque.

Besides magueyes, there were other plants used for purposes other than food. Although coarse textiles were made of maguey leaves, it was more common to wear cotton clothes. That is, as far as clothing was worn at all, because the Indians' clothing was usually quite simple. Cotton mantles, however, were an important item to designate rank. Cotton did not grow in the valley of Puebla, but had to be imported from the drier and wetter areas in the south. The nopal cactuses, that were growing in the wild all over the dry areas, were planted in the entire valley from Thaxcala and Huejotzingo to Tecamachalco. In this case, the edible leaves and fruits (tunas) were not very important, as they could also be gathered in the wild. The main purpose for cultivating nopales were the cochineal insects living on the leaves. They were 'picked' after they had become mature, and were then dried in the sun. The dried insects were ground and used as raw material for red paint. The production of cochineal was a difficult, intricate and time-consuming activity, requiring specialized skills. 
Above, I have restricted myself to an outline of the ecological foundation of the prehispanic social system. A second important, non-ecologically determined restriction on the arrangement of society was the absence of money. In the trade of luxury products, which was conducted over long distances, easily transportable gold dust, silver or quetzal feathers were used as means of exchange, but these products were too valuable for everyday trade. Cocon-beans were used as a means of exchange until well in the colonial period, but they were of too little value to serve as proper money. Cotton cloaks bad more value, but they actually occupied an intermediate position between means of exchange and commodity, especially as cloaks also served to designate rank among the Indians. The Spanish writer of the Relacion de Tepeaca remarked that the use of cloaks as a means of exchange was a locally-grown custom, which was not checked by the rulers. Moreover, cotton could not be easily transported in large quantities, when depending on carriers (tameme). Consequently, trade remained confined to either the local barter of daily products or the long-distance trade of luxury products. Exceptions were commodities, such as salt and raw cotton, which were not indigenous to the valley of Puebla, but had to be imported from other areas, mainly from the south. ${ }^{24}$

\section{Settlement patterns}

The Indian places of settlement depended on the possibilities for agriculture. Settlements could always be found near water; the arid areas east of Tepeaca, the northem parts of the present state of Tlaxcala and the area east of the Malinche were largely uninhabited. The low banks of the rivers were too wet and the danger of inundation was too great. After the Spanish conquest and the following pacification, these banks were colonized in part. Muñoz Camargo describes how, one day in May of the year during which he wrote his report (1581 or 1582), the river Zahuapan burst its banks and washed away five hundred houses. As it was still early in the evening, the inhabitants could rescue themselves. The same writer noticed that on top of all this, down in the valley, the ground was more susceptible to frost. ${ }^{2 s}$ On the high slopes it was too cold for agriculture, so the Indians lived on the lower and less steep slopes of the volcanoes and the hills of the valley.

The valley of Puebla had no population centre that matched Tenochtitlan in the valley of Mexico. On the eve of the Spanish conquest, this centre may have had as many as 300,000 inhabitants. There were only a few cities in the modern sense of the word before the Spaniards arrived. In the valley of Puebla only Cholula seems to have been a real city. Tlaxcala, Tepeaca and Huejotzingo, which were also to become provincial towns in colonial times, were religious and administrative centres. As compact towns they were Spanish creations. Puebla 
and Atlixco were not founded by the Spaniards on uninhabited land until late in the sixteenth century. Muñoz Camargo wrote: ${ }^{2 x}$

'One has to keep in mind that [...] an Indian's house has its fields and orchard of fruit trees and magueyes, which they call metles, maize plantings and cochineal nopales [surrounding them], as a result of which such settlements occupy much space, although not to such a degree that it is not easy to see which of them is a ward, hamlet or village, as there are least a few scattered villages and [some even] very close together, where you may recognize large and medium-sized villages'.

Viceroy Monterrey (1595-1603), however, saw less variation. He wrote that the Indians generally lived 'disorderly scattered over the countryside in separate houses, or in hamlets and wards like the farmsteads and little villages in the mountains of Castile'."

Temples were built on central spots in the altepetl and the area was divided among them. They were surrounded by the palaces of the rulers and some houses of the subjects. As for the pattern of settlement, we can state that both for cosmological and strategic purposes, the temples and palaces were situated high on the mountain slopes and on the hilltops, which made them difficult to approach. The population density around these centres was higher than elsewhere in the principalities. Many people living there were no peasants, but mostly artisans or merchants, who depended on the rulers and nobles for a living.

The temples were made of stone, plastered in many colours and richly decorated with omaments. Possibly, the palaces were made of stone, too, but most common houses were rather humble. They were mostly built of adobe and then called jacales, or made of maize straw fixed to wooden frames, in which case they were called chinamirl. They were thatched with little slats and zacate, which is a kind of rough grass. ${ }^{20}$ According to the Relación de Tepeaca, the doorways of the houses were turned away from the street as much as possible, and screened with maize reed, as the Indians 'did not like being seen in their homes'. ${ }^{29}$ The Tlaxcaltecs did not use proper doors either, but preferred 'moveable reed mats [...] on which a few bells of copper or gold, or other metals, [or of] seashells were attached which sounded or made noise [...] when the door was moved, opened or closed' ${ }^{*}$ At the rear of the yard, wooden shacks (zencales) or adobe troughs (cuescomates) were placed, which served as stores for maize."

The unequal distribution of the population over the valley of Puebla was not only caused by the natural environment, but also by the migrations and wars throughout the centuries prior to the arrival of the Spaniards. There had been permanent habitation in the valley of Puebla for some 5,000 years before the Spaniards arrived. Demography history, however, was anything but static. There had been continuous migrations of peoples, wars, conquests and subjections. As a result, at the time of the Spanish invasion, the valley was inhabited by a variety of people, 
who predominantly differed from one another in their use of different languages. According to the Nahuatl historical traditions from the twelfth to the fourteenth centuries, the Nahuatl-speaking, so-called Chichimec, tribes bad migrated into the valley and conquered it. They did not form a homogeneous society. It is more likely that the groups adopted the language of the conquerors or the other way round, with the result that at the time of the coming of the Spaniards the central parts of the valley were inhabited almost exclusively by Nahuatl-speaking groups.

At the beginning of the sixteenth century, Nahuatl was the most common language on the central highlands and, being the language of the powerful Aztecs, it served as a lingua franca in the whole of Mexico. In the remoter parts of the valley of Puebla, however, lived other groups of people which spoke different languages. In the east and north-east, this was predominantly Otomr and in the south, Chocho or Popoluca. Non-Nahuatl-speaking people were regarded with contempt by Nahuatl-speaking people. In more than one sixteenth-century source, we come across disparaging remarks on Otomíes. For example, Muñoz Camargo wrote that while the Otomíes were valiant warriors and skilled in hunting and agriculture, they 'were only born to work, and for nothing else [...] They had a very bad disposition, [were filthy] and as far as human order is concerned, they were great barbarians, who were hard to convert [...]'. As many as ten or fifteen lived together in one house, and due to jealousy, they regularly beat each other to death. Concluding, Muñoz Camargo states that they were 'slow witted, [had] few qualities and even less talents'.

The discord among the Indian peoples found expression in the division of the land in principalities, which were called altepetl in Nahuatl and later on sentorio in Spanish. At the time of the conquest, the valley of Puebla was subdivided into eight altepetl: Tlaxcsla, Huejotzingo, Totomehuacan, Cuauhtinchan/Amozoc, Tecalco (later to be called Tecali), Tecamachalco, Quecholac (later: Quechula) and Tepeyacac (later: Tepeaca). According to the historical traditions of Cuautinchan, the last five altepetl had been part of the vast altepetl of Cuauhtinchan until the fifteenth century, when it fell apart as a result of internal strife." A similar development had occurred in the altepetl of Huejotzingo. Its southem half did not come under Huejotzinca rule until the fifteenth century. It had previously been part of the territory of the altepetl of Quauhquechollan (later to be called Huaquechula), but after repeated wars with Huejotzingo, the Quauhquecholca had been dispelled to the south and the population of the surrounding areas of the former Quauhquechollan had largely been driven out. This shows that the subdivision of the valley into alsepetl was not a static situation."

Most of the altepetl of the valley of Puebla had -forcibly or voluntarily-allied with the Aztec empire. They were in a continuous state of war with non-allied altepetl, Tlaxcala and Huejotzingo. Between the altepetl of Tlaxcala, Huejotzingo and Cholula, and between Cholula and Cuauhtinchan, the swampy banks of the Atoyac constituted a natural barrier. Because of their low situation, the riverbanks were very vulnerable to attacks. Apart from this, they were only of a 
very limited use from an agricultural point of view. The sixteenth-century Franciscan Motolinia wrote about the banks of the Atoyac:"

"In former times, a large part of these lowlands remained unimproved on account of the wars. In all sections, the valley has large towns and these, before the Spaniards came, were always at war with one another. Here were the fields where they gathered to give battle and where they fought. It was the general custom in all these towns and provinces that on the boundaries of each section they left a large portion of the land uncultivated and, instead of tilling it, used it as a battlefield. If perchance the field was sometimes sown, which was rarely the case, those who sowed it never derived enjoyment therefrom, because the enemies devastated and destroyed the crops".

The subdivision into altepetl makes it clear that the spatial restrictions which the natural environment imposed on the indigenous population, were enforced by military and political factors. This accounts for the fact that the altepetl only occupied rather small areas in prehispanic times. Settlements were confined to the central areas of the principalities. The dry northern and eastern regions, the higher slopes of the volcanoes and the low banks of the rivers largely remained uninhabited. This pattern of scattered centres of habitation was not restricted to the valley of Puebla, but occurred throughout the whole of prehispanic Mexico, with the exception of the valley of Mexico. There was such a high population density here, and the Aztecs and their predecessors had managed to pacify the area to such a degree in the fourteenth and fifteenth centuries, that there were no more buffer zones between the various altepetl. These were situated on the generally narrow banks of the lakes in a continuous zone of habitation, although in previous times all altepetl had been separated by some two kilometres of uninhabited area.*

The Indian way of living was for an important part determined by natural ecological restrictions. Man could only influence these up to a very limited extent. It is important to realize the consequences of these ecological constraints: the lack of major domestic animals made it impossible to use animal working power. The application of mechanical power in the form of wind or waterpower was not under consideration, because the Indians did not use the wheel, notwithstanding the archaeological evidence of toy carts. All labour had to be performed by man. The only exception was transportation on the great lakes in the valley of Mexico, which took place in canoes. Opposed to the constraints was the high yield of maize. Consequently, far from all labour was needed for subsistence agriculture. Comparatively many people could dedicate at least part of their time to commerce, craft, and religion. As a result, the Indians produced a variety of craft products, which they traded on local markets or tianguez. While there was a rather elaborate local market system, in prehispanic times, Indian society had not developed a labour market in which labour could be contracted on a free basis; 
consequently, labour had to be acquired in another way. Because of the importance of manpower, the way in which this control was organized was vital to the social structure of prehispanic Mexico. This implies that the division of authority in society was very important. Authority over groups of people was, after all, the foundation of economic, political as well as social power.

\section{Arrangements of authority}

In the last two decades, the concept of the Asiatic mode of production has become the point of departure for the description and analysis of prehispanic Mexican landownership. The pivot in the concept of the Asiatic mode of production is the control by the ruling classes of the means of production, in Mexico mainly land and labour. Control was exerted through social structure (claass division) and political institutions (state, tribute, landownership), by which the ruling classes extracted the economic surplus consisting of labour and products. According to the idea of the Asiatic mode of production, the commoners were exploited by a ruling upper class, that used the arrangement of society as an instrument. Transposed to prehispanic Mexico this meant that, for this purpose, the already existing organization of commoners in calpulli was used. Although not all authors explicitly support this concept, they all seem to have based their work on it.

In the literature, a distinction is made between pillalli, private lands of Indian nobles, which were attached to offices or which were obtained by grant, and calpullalli, lands which were corporately owned by the calpulli; the calpulli are seen as the 'fundamental social organizations' of Mesoamerica, in which the macehualtin were corporately united. Per region, there was a considerable difference in names given to the various forms of landownership.

In this view the commoners were divided into two groups. On the one hand, there were the commoners who depended on the nobles (called terrazgueros and mayeques) and on the other hand, there were the calpuleque (members of a calpulli). This distinction was connected with the kind of land they were working. Terrazgueros or mayeques worked the lands of nobles (pillalli) or the land given in reward by the tlahtoani to those who had made themselves useful, or who occupied a position. Calpuleque worked the common lands of the calpulli (calpullalli). There is no consensus on the difference in social status between the two groups. In the literature, the differences between regions have been pointed out time after time. This already starts in the treatise by Alonso de Zorita (1580), one of the most important sources used for the investigations of prehispanic landownership. Zorita's account was based on many years of experience as an oidor, i.e. judge and administrator in the Audiencias of Mexico and Guatemala. The Audiencias were the supreme courts in the American colonies which also had administrative authority." 
This short characterization gives an impression of the assumptions of the various authors, but suggests more unity than there actually is. In the first place, if one studies the literature, it is impossible to get a clear picture of the various forms of landownership, because of the many different names and forms of ownership that appear in the sources. There is just as little clarity on the legal status of landownership. Writing on the landholdings of the indigenous nobility, Haskett remarked that they were not yet private possessions." The historian Borah wrote on the Indian view of landownership:"

"For the Indians, land was essentially a means of production, held by the community or clan and allocated to support certain offices or functions. Tenure was fundamentally conditional and subject always to the requirement of use. Indian conceptions of the nature of landholding most closely approximated those of the feudal linkage of land to service or office. It is unlikely that aboriginal Indian society had any conception of the owning of land in the sense of Roman Law, that a man could be the master of land which was his to allow to remain idle, destroy, or till as he chose, subject only to the right of the sovereign to tax or to take for public use on due compensation".

In the sources, the question of the landownership of the calpulli is only described by Zorita and many modern interpretations are actually based on his text. A lot of source material from the sixteenth century has been lost, yet many indigenous and Spanish accounts have remained. Therefore, it is remarkable that landownership is only treated extensively by Zorita. The absence of the question from other sources makes us suspect that it was a less crucial matter than is assumed nowadays. Summarizing the evidence on landownership in the valley of Mexico, the anthropologist Hicks wrote that Zorita's information has been based on information by the Franciscan Fray Francisco de las Navas whose investigations were predominantly carried out in the valley of Puebla, especially in the area of Cuautinchan. He continued: ${ }^{\infty}$

"It is most probable, therefore, that this part [i.e. the section treating the calpulli] of Zorita's work [...] refers to the Cuaubtinchan region and not to the Valley of Mexico. [In Cuauhtinchan] the term calpolli was evidently restricted to a type of unit [...] that held lands in common, was internally ranked on the basis of kinship, was headed by an elder of the lineage, and did not give tribute to specific nobles. This fits well with Zorita's account; but by the sixteenth century there appear to have been no such entities in the Valley of Mexico".

It is worth examining to what extent this calpulli was important in the valley of Puebla. To be able to appreciate its role, we have to turn to the relations of hierarchy and power in the valley of Puebla first. 
Many sixteenth-century sources pay attention to the hierarchical framework of indigenous society. One of the most extensive and systematic is the report of Zorita, which was already mentioned above. His description may serve as a general summary of the situation in prehispanic Mexico.

According to Zorita, there were four sorts of lords (señores): thahtoque (sing.tlahtoani); tecuhtin (sing.tecuhtli) or teteuctin (teuhctli); calpulliheads and pipiltin (sing.pilli). Each altepetl had three and sometimes four rulers (tlahtoque), whose position was hereditary. One of whom was the chosen leader (sentor supremo). The supreme lord had no jurisdiction or authority in the territories of the other tlahtoque.

A number of lesser lords, tecuhtin in the valley of Puebla, and teteuctin in the valley of Mexico, ruled a teccalli or a tecpan. Their position depended on the tlahtoque, who appointed them for life. It was not hereditary in principle. The tlahtoque tended to favour members of the ruling family whenever succession was at stake. The available documentation suggests, however, that there was regional variation concerning the hereditariness of the function.

A third type of lords mentioned by Zorita were the pipiltin. Pilli was a general term for nobleman. The pipiltin were dependent on a higher noble, a tecuhtli or a tlahtoani. There were many names for different kinds of pipiltin, as they fulfilled all sorts of positions at the administrative and military level.

The lowest indigenous leaders in the description of Zorita were the calpuleque, the leaders of a calpulli, which Zorita regards as a community. The calpulli were also subordinated to the tecuhtli. The leadership of the calpulli was hereditary, but the community had to confirm the new leader after he had succeeded." A broad stratum of common Indians was subject to these various lords.

Zorita's description gives an impression of the many kinds of lords and leaders in Indian society. In fact, there were various possibilities for a lord to establish his lordship over an area or over people. Colonization of uninhabited regions was the easiest way, but on the central highlands this had hardly or not been possible for a long time before the Spaniards arrived, as the inhabitable land had largely been occupied already or had at least come under the influence of an existing altepetl. The different ways to establish dominance and lordship can be illustrated by the large hierarchical framework of the Aztec empire.

Van Zantwijk convincingly argues that the Mexica -who later became known as Axtecs- had not immigrated from the far north of Mexico, as their own tradition would have it, but from the northern part of the valley of Mexico itself. Initially the Mexica were a rather insignificant group of mercenaries. In the course of the fourteenth and fifteenth centuries they managed to gradually increase their power. Although growth of their power was not without setbacks, the Mexica became the most important allies of the Tepanecs, at the time the most powerful group in the valley of Mexico.

At the beginning of the fifteenth century, the Mexica and the Tepanecs conquered most of the altepetl in the southern part of the valley of Mexico. After 
troubles in the Tepanec-Mexica alliance in 1428, the Mexica revolted against the Tepanecs, whom they defeated. In their revolt, they were supported by the altepetl of Tlacopan and Texcoco. The three victorious altepetl allied in the Aztec Triple Alliance, in which Tenochtitlan got the lead. In the course of the fifteenth century, the Triple Alliance conquered an area that ranged from beyond the valley of Toluca in the west to the coastal areas in the east -with the exception of Tlaxcala and Huejotzingo- and from north of the valley of Mexico to beyond the valley of Oaxace in the south. ${ }^{42}$

In the rise of the Aztec power, there were different ways in which they established their dominance. An alliance formed a political co-operation between two altepetl on a more or less equal basis. At the time of the Spanish Invasion, the Mexica were allied to Tlacopan and Texcoco in the Aztec Triple Alliance. This was not an alliance of equals, however, because the Mexica clearly dominated. The Aztec emperor was a Mexica king and the kings of the other two alteperl were subordinate to him. Each one of the three allies made his contribution to the joint army in times of war. They received their share in the gains of their conquests or in the rulership over a conquered area, in accordance with their efforts. The relations within the alliance changed in the course of time. For example, Tenochtitlan gradually got the upper hand of its twin city of Tlatalolco, which was situated on a neighbouring isle. In 1473, the king of Tenochtitlan sent an expedition army to Tlatelolco, which he thought pursued too independent a course, and brought it under direct Tenochca rule."

Voluntary submission to the Aztec emperor went one step further than alliance. Those who submitted themselves, could maintain that it was an alliance, in which they did not have to give up their own rulership. This was, for example, the case in Tepeyacac and in Ocopetlayuca (later called Tochimilco), which was situated on the upper slopes of the Popocatépetl. In the sixteenth century, the Tepeyacactlaca, -i.e. the people of Tepeyacac- declared that they "did not recognize the superiority of Moctezuma, the ruler of Mexico [at the time of the conquest] but considered him a friend and ally in the wars that those of Mexico were waging against those of the neighbouring [altepetl] of Tlaxcala and Huejotzingo with whom they had continuous wars"." The Aztecs, however, had stationed a garrison in Tepeyacac and levied tribute on the altepetl. We may assume that the Mexica actually saw this area as subjected to them. Ocopetlayuca, on the other hand, did not pay any tribute to the Aztecs and its task within the empire was just to guard the pass between the Popocatépetl and the Ixtaccthuatl. Consequently, the position of Ocopetlayuca was that of a more equal ally of the Aztecs than Tepeyacac.

A more strict form of submission was established when an altepell was conquered during a war and the ruler of the defeated party had to surrender. The Aztecs usually let the incumbent ruler stay on and merely imposed a tribute. Thus, the ruler of the defeated altepetl came to depend on the Aztec emperor. To 
prevent revolts, it was made clear that after an insurrection, tribute would be increased considerably, and this threat was actually enforced.

Another possibility was to dispel the incumbent ruler with or without his followers. The altepetl was then placed under the direct lordship of one of the Aztec allies. An Aztec magistrate was put in the place of the dispelled ruler, which gave the Aztec lord direct power over the altepetl and all revenues of the former ruler then fell to him. However, this also meant that an intensive direct lordship had to be exerted over the conquered altepetl and that extensive control as in other places would not suffice. This form of control was only applied to altepetl which occupied a military or economic position that was crucial to the Aztecs."

The Aztec empire consisted of a hierarchic pyramid of altepell, which were more or less directly subjected to Aztec rule. Most of these had retained an important part of their independence and only a small number bad been placed under a more direct control. This distinction is also visible within the smaller units of the altepetl in the valley of Puebla.

The kingdom of Cholula took a separate position among the alrepetl of Central Mexico. It was particularly important as a religious- and trade centre. According to the Spanish official who wrote a description of Cholula in the 1580s, in prehispanic times, it used to be 'a metropolis, which [was] venerated [by the Indians] as much as Rome in Christianity and Mecca with the Moors'. Being the centre of an important cult, it was able to maintain a large degree of independence, even though it was subject to Aztec authority. The altepetl was led by the two high priests, the Aquiach or Quiach, who was the eagle priest and the Tlalquiach, the jaguar priest. The area of Cholula had been divided in six principalities, each of which consequently dominated part of the altepetl of Cholula. Besides priests, merchants, that is non-nobles, were very important and could even become tecuhtli. However, this only occurred in Cholula and perhaps Tenochtitlan. Unfortunately, too little is known about the situation in Cholula to be able to present a more profound treatment."

In the altepetl of Tepeyacac, the situation was different. As has been mentioned above, the rulers of the altepetl were subject to the authority of the Aztec emperor, but within their altepetl, they had a position which was independent from him. At the time of the Spanish invasion, the rule over the altepetl of Tepeyacac had been divided among three lords, who were called Don Luis de Guzmín, Don Hernando de la Cruz en Don Juan Tlaylotlac after the conquest. Apart from this, there were three subordinated altepetl, Tecalco, Tecamachalco and Quecholac, whose position in relation to Tepeyacac was similar to the relation between the lords of Tepeyacac and the Aztec emperor. The subordination of Acatzingo to Tepeyacac made the situation even more complicated. Although Acatzingo had some degree of autonomy, it did not constitute a separate altepetl."

In earlier times -from the twelfth to the fourteenth century- all these altepetl had been part of the larger kingdom of Cuauhtinchan, which according to its own 
traditions had once been founded from Cholula. In the fifteenth century, this kingdom had fallen apart as a result of internal dissensions. From then onwards, Cuauhtinchan had constituted a separate altepetl which had also depended on the Aztecs. At the end of the fifteenth and the beginning of the sixteenth centuries, the situation in the area of Tepeyacac was still quite turbulent. As early as in 1467, Axayacatl, the ruling Aztec emperor at the time, had had to settle a border conflict between Cuauhtinchan and Tepeyacac." In the sixteenth century, the alteperl of both Tecamachalco and Quecholac had only been in existence for a short time. Shortly after the conquest, the principality of tlahtoani Aquecaluca had fallen apart into two separate altepetl which had different lords. Thus, we see that even within one altepetl of this area, the leading lords were part of a threetiered hierarchy. From numerous sixteenth-century sources it appears, that apart from this, in Tepeyacac as well as in the subordinate altepetl, there was a division of power between several important and less important noble houses. ${ }^{\text {o }}$

An illustration of the principle of organization can be found in Huejotzingo, where in the course of a lawsuit in 1560, the so-called Matricula de Huexotzinco was drawn up. This was a pictorial writing in the indigenous tradition, containing a census of the colonial province of Huejotzingo of the time, which extended from the actual areas of Texmelucan in the north to Atlixco in the south. At the time the Matricula was drawn up, the province was divided in four Spanish cabeceras the centres of which -San Juan Huexotzinco, Santiago Xaltepetlaya, Santa Marfa Almoyahuacan and San Pablo Ocotepec- in the town of Huejotzingo. In the time before the conquest, the altepetl of Huejotzingo had been under the authority of only two tlahtoque. They had been involved in a conflict with the nobles of the two principalities. The disputes were not settled until colonial times, which then led to the establishment of the cabeceras. As the lords of the later cabeceras were already important in the altepetl in prehispanic times, and as the Spaniards took over all supreme power after the Invasion, the creation of four cabeceras involved no fundamental change for the relations within the altepetl."

There were several possibilities of hierarchic stratification between the lords. The sixteenth-century Tlaxcaltec historian Muñoz Camargo, gives a fairly clear picture of the situation in Tlaxcala. Muñoz Camargo's description of the Tlaxcaltec situation is rather schematic. Possibly its clarity is artificial, inspired by his desire to draw a clear picture for Spanish readers and expressing the view of the Tlaxcaltec elite. In practice, division of authority was more complex, and less centralized. However, if we realize its limitation, the description is very illustrative, precisely because of its simplification.

The author describes how Chichimec tribes took the altepetl of Tlaxcala from the resident population, the Otomies. When these had been expelled to far-off regions and the entire area came securely in Chichimec hands, in due course, they founded four principalities, each of which took up part of the area. As mentioned above, these were situated in the northern part of the area, on the upper slopes of the Malinche and its bordering mountains. Three of them, 
Ocotelulco, Quiahuiztlan and Tepeticpac, were situated on the mountain of Tepeticpac. Muñoz Camargo explains that in Nahuatl, Tepeticpac means 'on the top of the mountain', a natural fortress. The centre of the fourth principality Tizatlan- lay at some distance, on another, equally inaccessible, ridge. The rulers of these four principalities were the thahtogue and the most prominent lords of Tlaxcala. However, they were not the only ones, according to Muñoz Camargo, because they gave rise to many other noble houses, by giving areas to the Chichimec nobles who had helped them in war as 'generals, captains and other officers'. Some of these noble houses which Muñoz Camargo -using a Spanish and a Nahuatl term together-called tecuhtli mayorazgos, got independent positions, while others, the pilcales, which is to say 'bound houses (casas solariegos) of the prominent', remained directly dependent on the 'great houses' of the tlahtoque. They all had to recognize the lordship of the tlahtoani, who had given them power. Following the same principle, these lower leaders distributed land and usufruct rights among their subjects."

The description of the prehispanic division of power in the Aztec empire in general, and more specifically in the various altepetl in the valley of Puebla, gives an idea of the complexity of the hierarchic structure of society as a result of the historical development which varied from place to place. At the same time, Zorita's more generalized distinction of different kinds of lords appears to be an essentially correct sketch of the system, according to which positions of power were ordered. The position of the calpuleque has been left aside up to now, because the calpulli were organizations of Indian commoners within the altepetl.

\section{Authority and tribute}

Subordination and authority took shape in the levy and supply of tribute. Tribute was an exaction in the form of goods or services, implying a recognition of a higher lord. Again, this is most clearly illustrated by the example of the Aztec empire. The Mexica had founded the supply of their city of Tenochtitlan on the supply of tribute. This system, which had already existed in a less developed form before the rise of the Mexica, was consolidated in the second half of the fifteenth century. The Aztecs especially exacted tribute in food from the areas immediately surrounding the lakes. Tribute from remoter areas consisted of more easily transportable, usually costly luxury products. As Tenochtitlan was that dependent on the altepetl around the lakes for its food supply, the altepetl had been thoroughly pacified by the Aztecs. In the empire, travelling calpixque were responsible for the collection of tribute. These dreaded tribute collectors were led by thirty-eight high calpixque, the hueicalpixque. The entire tribute system was commanded by one high-ranking noble, the petlalcalcatl."

The direct connection between lordship and tribute was indicated by the declaration which, according to Muñoz Camargo, the Tlaxcaltecs made, when 
they leamed of the conditions which the Aztecs wanted to impose on them in exchange for a peace treaty. Muñoz Camargo who, being a Tlaxcaltec, was hostile to Tenochtitlan, wrote that the Tlaxcaltecs sent a messenger (embajador) to the Aztec emperor to inquire about the conditions, because they were tired of the lasting wars with the Aztecs and their allies, and because they had gradually become isolated. The Aztec emperor answered that he 'was the only lord of the entire world, and all who were born were his vassals'. and had to recognize him as their lord. The Tlaxcaltec had to submit to him and to pay him tribute, just like the inhabitants of the other areas under his rule. If not, he would subject them. The Tlaxcaltec messenger answered:"

'Most powerful lords, Tlaxcala does not owe vassalage to you, nor have they [i.e. the Tlaxcaltecs], from the beginning of history recognized any overlord or ruler of the world with neither tribute nor tax, because they have always conserved its [i.e. Tlaxcala's] freedom. And as they [i.e. the Tlaxcaltecs] are not used to this, they shall not want to obey you, because they would rather die than to consent to such a thing. Rather we [the delegation] understand that what you ask from them, they will seek to ask from you, [and] they will shed more blood over this than they shed in the war of Poyauhtlan, which your ancestors fought with the Chichimecs of Poyauhtlan, who were the ones from whom the Tlaxcaltecs descend. Thus, we shall return with the answer you have given us'.

Within the smaller areas of the altepetl, tribute also played a key role. Here, the relations between rulers and dependent nobles mattered less than those between nobles and commoners. In the hierarchical relations between higher and lesser nobles, the ties between persons mattered most: the supreme lord delegated power to a lower lord, who had to pay tribute in exchange, with which he also recognized the higher power.

In my opinion, within the altepetl, the principles of the relation between nobles and commoners were comparable with those between lords. Here, the relation between the nobles of Tecamachalco and Quechula is illuminating. As has been mentioned above, these two colonial pueblos had been under one tlahtoani before the conquest, whose principality had been divided in the colonial era. The exact division of territorial rights between them was not entirely clear in the sixteenth century. The Spanish official who wrote the Relacion de Tepeaca remarked:

"Many of the [subject] hamlets of these two pueblos of Tecamachalco and Cachula [or Quechula] belong to both the mentioned pueblos by more or less balf, because the areas of these two pueblos are undivided and common of both these pueblos. They [actually] have two churches and each pueblo recognizes its inhabitants [vecinos] and levies tribute from them and makes them attend to the other public works to which they are obliged; and this division is very clear among them as they never have a difference of opinion and the 
cause of this unity is that in times of their heathendom these two pueblos were of one lord who was called Aquecaluca and they were [only] divided after the Spaniards came'.

Once again, Muñoz Camargo gives a clear picture of the principle. He continues his above cited account on the relation between the different kinds of lords as follows:*

'Any tecuhtle who founded a teccalli, which is an independent house ('casa de mayorazgo'), or a pilcalli, which is a dependent house ('casa solariega') took all the lands that fell to him because of the division [by the tlahtoani], with mountains (montes), springs, rivers or lakes. For the main house [he took] the largest and best fields or terrain, and then, he divided the remains among his soldiers, friends and kin alike, and all of these were obliged to recognize the higher house, and to come to it with acknowledgements of bundles of firewood and game and flowers and bouquets for the maintenance of the main house. And he who is [tecuhtli], is obliged to maintain them and to consider them kindly as the friends and kinsmen of the house. And, thus, they are called teixhuihuas, which is to say the grandchildren, of that particular house. And in these divisions of land they also divided [land] among serfs [terrazgueros] and founded settlements on it, and these were vassals who, as such, paid them [i.e. the tecuhtin] tributes of the things they cultivated and gathered and in this way they [i.e. the tecuhtin] came to be caciques and lords of many people and vassals who recognized them and paid vassalage; with these vassals they founded important towns and settlements with which they sustained themselves. And they governed their repúblicas in a good way and [in good] harmony, according to their barbarous and rustic talents'.

This quotation of the Tlaxcaltec author implies that in prehispanic times all land was in the hands of the nobles. Once again, we have to realize that Muñoz Camargo was trying to forward the interests of the Tlaxcalan elite for Spanish readers, but his assertion is not an isolated remark. In an attempt to keep their old prerogatives, the nobles of Huejotzingo declared in a petition to the king in 1554, that they had held all land from time immemorial (de tiempo inmemorial hemos tenido las heredades todas). They claimed the macehualtin of Huejotzingo had never held any land before, but had worked the lands of the nobles for their own benefit and in exchange they had supplied the nobles with firewood, water, turkeys, chilies and everything else needed for their sustenance."

As for the area around Tepeaca, a group of investigators led by Carrasco and Reyes Garcia, concluded that in prehispanic times, all land had been in the hands of caciques and principales. In a document of $\mathbf{1 5 5 3}$ from the municipal archives of Cuautinchan, a witness declared on the subject 'The first thing I say and declare, is that here in Cuautinchan, in Tecalco, in Tepeyacac, in Tecamachalco and in Quecholac the calpultin do not possess land [...] Only the tlatoque own lands on which they serve as tlatoque'." 
From these examples, we may conclude that in post-conquest years indigenous ownership of land in the valley of Puebla, one of the most densely populated and important areas of Mexico, was disputed and that in many areas nobles claimed to have the exclusive right to landownership. However, the necessity to forward the question of landownership was a peculiarity springing from the need to translate old indigenous rights and prerogatives into Spanish terminology and as such the preoccupation with ownership was a colonial development. This is quite obvious in the case of the indigenous nobles, who claimed land and tribute, but was also true for many Spanish authors.

Spanish reports on the Indian society treat often the division of the authority. Usually, the authors' interests reflected in their descriptions. Some were hostile towards the Indian social structure, as it impeded them from getting power, as in the case of the party of encomenderos, or from reforming society, as in the case of royal agents such as visitador Valderrama. On the other hand, there were the friars of the mendicant orders who wanted to protect the Indian social order, since this suited them best. All these parties meant to influence the viceregal lawyers of the Audiencia. These tried to comprehend and change the Indian world, but often they collided with the Indian views." Zorita was one of these lawyers. By his experience of some ten years as an oidor, by the intensive contacts with his informants and by his interest, he had come to understand a great deal of the indigenous system. He was mainly influenced by experienced Franciscans, as he himself asserts in the first pages of his treatise. ${ }^{\infty}$ His representation has clearly been marked by this influence.

Despite all their information on indigenous society, neither Zorita nor the Franciscans were able to set aside their own way of thinking or their own concepts of landownership. Moreover, it was with sorrow that they all looked upon the loss of the indigenous society in the second half of the sixteenth century. The idyllic haze with which the Franciscan descriptions of the indigenous world had already been shrouded due to the apostolic context of the conversion, was only strengthened by these conditions. The calpulli were compared with the Old Tribes of Israel, and in the Franciscans' views, they led a nearly paradisiacal existence under the severe but just guidance of their natural lords. The communal supervision of their lands took place in absolute harmony. The religious cruelties and the intensive use of labour services -in Europe a sign of slavery-were the only major dissonants in the communities. But these were the products of the ignorance of paganism into which the essentially good souls of the Indians had strayed. By the light of Christianity and the guiding hand of the friars they could be led away from these errors, and thus reach paradise on earth. In some places the Franciscans persuaded Indian nobles to abolish or moderate personal services and grant written land titles to the macehualtin. ${ }^{61}$

They were impeded in their reforms by Spanish colonists and governmental politics, about which they complained bitterly. Zorita joined the Franciscan position in his treatise, and elaborated on the destruction of the old indigenous 
order and the consequent harm to society. In my opinion, we should see his assertions on the communally owned lands of the calpulli as a romantic distortion of reality. He expressed reality more accurately, when he described the situation of the mayeque. They lived on someone else's lands, he wrote, but "[...] considered and called this land their own, because they had the useful dominion thereof, and the owners the direct domination". "The same was true of the calpulli-lands.

Without questioning the great problems of the material and the great regional varieties in the prehispanic social system, I think the structure of prehispanic society cannot be understood, if we take the division of landownership as its only point of departure.

\section{Rights and obligations in life: teucyotl, tlatocayotl and tequitl}

The prehispanic lords needed a number of executives, who were dependent on them, to form an army and to govern on behalf of them. They had to remunerate their faithful in kind, because they lacked means of exchange. Whenever more services were demanded and the rewards increased, the remuneration in kind turned out to be insufficient. Instead, the lords gave usufruct of land, with which the vassals were able to support themselves while serving their lord. The same sort of relationship appeared lower down the social scale: the right to work land was given in exchange for working the lands of the lord. It appears that land itself was no guarantee for wealth: above all, the right to have land worked, was preponderant. In other words, not the control of land by ownership, but the control of people and a work force was crucial to this society. This system was determined by personal bonds between lords and vassals. A person's place in society depended on birth.

The lords had domains in which they held authority over the people attached to them. As a reward, a lord could assign a number of subjects to particularly meritorious vassals. The people assigned to a dependent lord could live in one area, but this was not necessary. In the long run, such an assignment might become a new domain, by becoming hereditary and thus independent of the lord. Yet, the ties between lords and vassals were not necessarily dissolved when a domain became independent, which was by no means the lord's intention, since it affected his authority. Society in prehispanic Mexico developed under the influence of the political and military upheavals of the time and, all the time, old domains disappeared and new ones came into being.

The idea of mutuality was the basis of this system. The lord had rights, but also duties. The subjects had duties, but also rights. The position of the lords is clear. So are the duties of the subjects, but their rights are less evident. A subject had the right to a plot of land of sufficient size to support himself and his family. He had the right to be protected from attacks on his lands and from looting by 
foreign powers. As an economic right, we can possibly count the provision of sustenance in difficult times, like assistance in case of illness or poverty.

The bonds between higher and lesser lords were maintained and strengthened by the exchange of gifts. The size of gifts was a sign of the wealth and power of the giver. Whenever a lord failed to fulfil his duties as a protector, he either offered himself as a vassal to a higher lord -often a former rival- or he was subjected and deposed by an assailant. In Nahus social philosophy, the position of human beings was prescribed by and linked with a general world view, based on the inequality and hierarchy of society. Social and political philosophy was closely linked with religion and therefore it was normative; as such, it was less an expression of society and existing social relations, than of the way they ought to be.

The position of the lords had a jurisdictional, military and spiritual side. Thahtoque only got their position after elaborate initiation rituals, which have been described by Zorita for the valley of Puebla. During the initiation, they had to prove that they were worthy of the rank of tlahtoani by showing perseverance and a stoic, humble attitude. Following the initiation, their duties were summarized in a short speech by the high priest, which was most illustrative of the three aspects of the position of the leader. Accorddingto Zorita the speech ran as follows:"s

"My Lord: consider the honor your vassals have done you. Now that you are confirmed as a ruler you must take care of them and regard them as your sons; you must see to it that they be not offended and that the greater do not mistreat the lesser. You see that the lords of your country, your vassals, are all here with their people. You are their father and mother, and as such you must protect and defend them and treat them justly; for the eyes of all are upon you, and you are the one who must govern them and keep order among them. You must be very diligent in affairs of war. You must watch over and punish the wicked, lords as well as commoners, and correct and reform the disobedient. You must give special care to the services of God and his temples, so that there will be no lack of what is needed for the sacrifices. Thus all your affairs will flourish and God will watch over you".

In Nahuatl, this complex of obligations, rights and duties of a tlahtoani, but also of tecuhtin and all other lords, were comprised in the two terms teucyotl and tlatocayotl (lordship, rulership), often appearing together in the sources."

The most important right of the teucyotl and tlahtocayotl was that noblemen, pipiltin, of whatever rank did not pay tribute but were entitled to tribute on account of their status as noblemen. However, they fulfilled services to their overlord. These services could, for example, consist in being a judge, a tribute collector (calpixqui), or an officer in the army. The priests occupied a special place, as they had a direct responsibility towards the gods. Up to a certain extend, they depended on the rulers, but sometimes they could be a 
counterweight to lordly powers. They did not fulfil services for the lords, nor did they pay any tributes. The degree to which they could be autonomous, depended on their influence on the ruler and the people. It also depended on the political circumstances, which varied per area and on the attitude adopted by both rulers and priests.

The macehualtin were supposed to fulfil a task in life - their tequitl. Each of them had to pay tribute to his lord. The tribute of the macehualtin, like the tribute man paid to the gods, consisted of a part of the things that had been given to them in life. By means of sacrifices, man enabled the gods to exert their rulership or tlahtocayotl, and by paying tribute, the macehualtin enabled their lord to exert his teucyotl and tlatocayotl. The lord gave his macehualtin the possibility to support themselves by giving them land in usufruct and a right to a share in the products of the altepetl, of which water (atl) and firewood (growing on the mountain - tepetl) were most important. The macehualtin gave part of the fruits of their labour as tribute: hens, firewood, chilies, cacao and personal service. The latter consisted of one or two weeks per year of service in the lord's house, for which they had to supply water and firewood. The wives of the macehualtin also had a task in the supply of tribute and services. Their specific contribution to the tribute consisted in the spinning of cotton. During the weeks of house services, they prepared the food. The tribute was assessed per -what the Spaniards were to call- suerte, land that had been assigned to the macehualli. A suerte was a standard unit which varied per area, depending on the fertility of the land and the natural circumstances. ${ }^{.5}$

The way in which the macehualtin had to behave in life, according to Indian norms, is explained to us in an indigenous moral speech, or huehuetlatolli. The Franciscan Torquemada, who was writing at the beginning of the seventeenth century, recorded the following speech of a peasant father to his son: ${ }^{: 6}$

'Work you have in this altepetl of yours day and night; [...] you will not sleep quietly, because you are a peasant, and you live in service; live like this: keep your sandals, your staff and your digging stick [huictli] and all the rest that belongs to your office in order, because being a peasant you need them, to go to your work in which the gods have put you. And this is your fate, and fortune, and nothing more or of more vanity. You are bom to serve another, to lift mud and to make adobe, besides the cultivation that you do in the fields; do not sorrow, because with this life and work you serve the altepetl and the lord; and with this work you will get what you and your wife and children need; undertake what belongs to your office, work and sow and harvest, and eat of your work'.

In this quote, the duties of a macehualli have been summarized in a nutshell. It was his duty to serve his lord and to work, so that he would be able to support his family, because, as the father continues: 
'If you are unruly in the altepetl, you will not be able to live and you will become detached from everyone [...]. You will do much evil and damage to your wife and children. And you will find neither a bouse, nor a place where they will want to give you shelter, sooner great indignation and disgust will befall you and much bad luck will follow you. You will bave no property and it will be your [own] fault. You will live in misery and poverty, as a result of your disobedience $[\ldots]$ '.

Artisans supplied less products from the Xlandbut instead contributed from their occupations. Carpenters and masons supplied extre services to their lords. Merchants had to give products of their trade and an extra tribute in cacao. Whoever wanted to become a merchant had to ask his lord's permission, and was exempted from the ordinary macehualli-status. Because of this, the merchants were a privileged group. Mostly, they worked directly for the lord, just like some artisans, such as silver workers and weavers of feather cloaks. Consequently, 'artisans of all trades paid their tribute of [the trade] they knew and with which they occupied themselves [...]'. As an example, the obligations of the macehualtin to the four most important lords of sixteenth-century Tepeaca have been included in table 1.1. One can see that in all four cases, tribute burdens were roughly equal, but that the exact content of the duties changed per lord. Once again, the personal character of the lord-macehualli agreement is apparent. The obligations of the vassals of one lord are equal -probably to prevent conflicts between two macehualtin of one lord-, but the obligations of the macehualtin of different lords varied. ${ }^{m}$ Apart from the personal services, there were also general labour services, called coatequitl, which were demanded in times of need or war and, for example, in case temples had be built. All macehualtin of an alrepetl were supposed to take part in the coatequitl. There was no fundamental distinction between the supply of goods and the supply of labour services in the levy of tribute."

The collection of tribute and the division of labour services were carried out by calpulli. It appears from documents that the calpulli were mainly an instrument for the organization of the tribute collection. Such an interpretation is supported by the exclusion of widows and elderly people from the calpulli-organization in the Matricula de Huexorzinco. They were exempted from tribute obligations. This also explains the use of the name of calpulli for various social groups, as Carrasco has noted. Calpulli were subdivided into groups of twenty and larger ones of one hundred men (=households). The duty of the leaders of groups within the calpulli was to collect tribute goods and divide labour obligations. The calpulli were led by tribute collectors, who were called censecpanpixqui, in case they led twenty households, and macuiltecpanpixqui, if they led one hundred households. Thus, the macuiltecpanpixque were the leaders of five calpulli. They could be pipiltin but that was not necessary. The title for those who divided the labour duties was tequitlato. It is not clear, whether these were different people from the centecpanpixque. From the protocols of lawsuits, one gets the impres- 
Table 1.1: Tribute obligations in Tepeaca

\begin{tabular}{|c|c|c|c|c|}
\hline $\begin{array}{l}\text { Name of } \\
\text { Cacigue }\end{array}$ & $\begin{array}{l}\text { Don Dionisio de } \\
\text { Mendoza }\end{array}$ & $\begin{array}{l}\text { Gabriel de los } \\
\text { Angeles }\end{array}$ & $\begin{array}{l}\text { Don Melchior } \\
\text { Rodriguez }\end{array}$ & $\begin{array}{l}\text { Doña Francisca de } \\
\text { la Cruz }\end{array}$ \\
\hline $\begin{array}{l}\text { Number of } \\
\text { macelantes }\end{array}$ & $\begin{array}{l}160 \text { boused of mocehnales } \\
\text { (andias revieros) }\end{array}$ & Number untonown & 2009 bounes of macehundes & 520 macehuales \\
\hline Oenend earvicen & 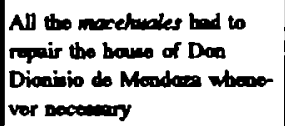 & & & 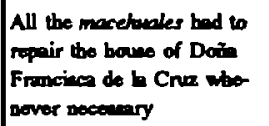 \\
\hline 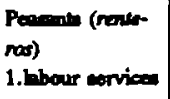 & $\begin{array}{l}\text { each 'rentero' cultivited a } \\
\text { plat of } 6 \times 100 \text { broeses for } \\
\text { Dicaisio de Mendaen }\end{array}$ & $\begin{array}{l}\text { each 'rentero' aultivated a } \\
\text { plot of } 6 \times 100 \text { brazes for } \\
\text { Cabriel de lo Angelea }\end{array}$ & $\begin{array}{l}\text { each inacehar cultiveled a } \\
\text { plat of } 6 \times 100 \text { brezar for } \\
\text { den Melchior Rodriguea }\end{array}$ & 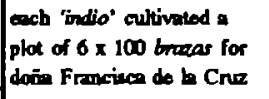 \\
\hline $\begin{array}{l}\text { 2Additional } \\
\text { anplien }\end{array}$ & $\begin{array}{l}4 \text { timedyour (Chritum, Bar- } \\
\text { bor, Corpu Chriti and Sen } \\
\text { Francieco) a turtey ben, and } \\
100 \text { encoo bean }\end{array}$ & $\begin{array}{l}4 \text { timea/yoar a turtey ben } \\
\text { and } 100 \text { cacao bean }\end{array}$ & $\begin{array}{l}4 \text { timea/year } 5 \text { turkey hent } \\
\text { and } 400 \text { cacoso beane }\end{array}$ & \\
\hline $\begin{array}{l}\text { 3. Obligatione of } \\
\text { wives of mace- } \\
\text { houles }\end{array}$ & $\begin{array}{l}\text { the wives of the 'renternos' } \\
\text { apen } 40 \text { reole (ecpullas) of } \\
\text { ection per year each }\end{array}$ & $\begin{array}{l}\text { the wivee of the 'renteras' } \\
\text { spem } 40 \text { ecpolllas of eotion } \\
\text { per year each }\end{array}$ & $\begin{array}{l}\text { the wiven of the 'revieres' } \\
\text { open } 40 \text { copollias of cotion } \\
\text { per year ach }\end{array}$ & 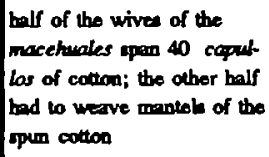 \\
\hline Marons: & $\begin{array}{l}4 \text { moson } 4 \text { times a year } 50 \\
\text { coos bem sind cultivation } \\
\text { of a plot of } 2 \times 100 \text { brasen }\end{array}$ & & & $\begin{array}{l}20 \text { madons } 4 \text { timea/year } 50 \\
\text { acao beane }\end{array}$ \\
\hline Captenter & $\begin{array}{l}2 \text { arpenten } 4 \text { timed/year } 100 \\
\text { cono bean cach }\end{array}$ & & $\begin{array}{l}9 \text { cappenters } 2 \text { times/yoar } 9 \\
\text { digging sticke (coas) and } 40 \\
\text { alicle to cultivate band }\end{array}$ & \\
\hline $\begin{array}{l}\text { Mat (petme) ma- } \\
\text { ker }\end{array}$ & $\begin{array}{l}2 \text { petrite maker } 4 \text { timeaf your } \\
3 \text { petales (mate) }\end{array}$ & $\begin{array}{l}3 \text { pelole makor } 4 \text { timea/y. } \\
\text { ear } 4 \text { petortes }\end{array}$ & $\begin{array}{l}2 \text { petase moker } 4 \text { timea/year } \\
3 \text { mate (esteras) }\end{array}$ & $\begin{array}{l}14 \text { petaie maker } 4 \mathrm{tim}- \\
\text { elyear } 1 \text { petate }\end{array}$ \\
\hline Potien & & $\begin{array}{l}3 \text { potien } 3 \text { timen/year } 4 \\
\text { pots } \\
4 \text { pble maken } 4 \text { timed yo- } \\
\text { ar } 20 \text { phices }\end{array}$ & $\begin{array}{l}4 \text { potten } 4 \text { timea/year } 20 \\
\text { platen }\end{array}$ & $\begin{array}{l}7 \text { potien } 4 \text { timed/year } 19 \\
\text { plales }\end{array}$ \\
\hline $\begin{array}{l}\text { Church ingers } \\
\text { (conteras) }\end{array}$ & & & & $\begin{array}{l}12 \text { canterces } 4 \text { timed/year } 50 \\
\text { como beans }\end{array}$ \\
\hline $\begin{array}{l}\text { Perfumens (acoy- } \\
\text { ete maters) }\end{array}$ & $\begin{array}{l}1 \text { aecolete mater } 4 \text { timea/year } \\
100 \text { acoyetes }\end{array}$ & & $\begin{array}{l}5 \text { acayete maken } 4 \text { timealyo } \\
\text { ar } 100 \text { acoyetes }\end{array}$ & $\begin{array}{l}15 \text { accyese maker } 4 \text { timen } \\
\text { /yoar } 100 \text { acayeks }\end{array}$ \\
\hline Balket maken & & $\begin{array}{l}4 \text { baket makers } 4 \text { ti- } \\
\text { mea/year } 12 \text { bouket }\end{array}$ & $\begin{array}{l}\text { The Indiane who made bas- } \\
\text { keth } 4 \text { timealyear } 10 \text { balkete }\end{array}$ & $\begin{array}{l}2 \text { backet makern } 4 \text { ti- } \\
\text { mee/year } 10 \text { baikets }\end{array}$ \\
\hline Sandal maken & $\begin{array}{l}4 \text { malal maker } 4 \text { timed/your } \\
3 \text { pir }\end{array}$ & & $\begin{array}{l}5 \text { endal makers } 4 \text { timealyear } \\
3 \text { pairs }\end{array}$ & $\begin{array}{l}\text { mandal molen (which are } \\
\text { shoes of the hod) } 4 \text { timea } \\
\text { lyour } 1 \text { pair }\end{array}$ \\
\hline Painters & & & & $\begin{array}{l}20 \text { pinter } 4 \text { times/year } \\
100 \text { coneo beans }\end{array}$ \\
\hline $\begin{array}{l}\text { Feather Clonk } \\
\text { matens }\end{array}$ & & & & $\begin{array}{l}5 \text { indion who made feather } \\
\text { cloale every year } 1 \text { foot- } \\
\text { length }\end{array}$ \\
\hline
\end{tabular}


sion that the calpulli-leaders represented their people in litigations. It is not clear whether they were chosen by the members of the calpulli or appointed by the lords. In colonial times, in any case, there were heads of calpulli for whom land was worked, and who were consequently entitled to tribute. Their prehispanic remuneration by the lords they represented, may also have been an exemption from liability to tribute. They had extensive records of the macehualtin entrusted to them. Sometimes, they had maps of the plots assigned to the macehualtin, too. On these maps, the plots reserved for the lord and the temples were represented. The calpulli-leaders took care of the tribute collection of both the supreme and private lords' macehualtin. In the Matricula, the macehualtin of private lords have been designated with a red spot above their heads. The division into calpulli was not static. According to the Matricula, in Huejotzingo, contrary to other calpules -or according to the accompanying Spanish text, the barrios-, the barrio (elsewhere called calpul) of Aculhuacan had 138 macehualtin, 124 of whom the Spanish commentator called terrazgueros of private persons (de personas particulares). This difference was a result of the recent settlement in Huejotzingo (por ser advenedizos) of the macehualtin, who had submitted to the lord of the barrio. They had already been absorbed by the tribute system, but had not yet formed a separate calpul."

According to the Tlaxcalan list of nobles of Ocotelolco which was drawn up in the 1550 s, there were 37 seccalli dependent on Maxixcatzin, the tlahtoani of Ocotelolco. Apart from that, there were a number of houses of lower standing, the pilcalli, the yaorequihuacalli and the huehuecalli. Per noble house, the names of the nobles belonging to it have been given; in the list it was indicated after the name of each noble, how many dependent nobles (teixhueihuan) and macehualtin (tlalmaitl) he had. As there are not enough data, it is impossible to say which teixhueihuan and tlalmaitl fell under the authority of which noble. However, it is remarkable that there were considerable differences in the number of teixhueihuan and slalmaitl per noble. For example, Don Francisco Otozcuauhtzin had 328 teixhueihuan and 12 tlalmaitl, Don Domingo de Angula had 815 teixhueihuan and 24 tlalmaitl and Don Juan Maxixcatzin himself had 322 teixhueihuan and 327 tlalmaitl. Moreover, he had 216 merchants (pochteca) under his authority, a number of whom were possibly seixhueihuan. There is no fundamental difference in the numbers per type of noble house. "From other sources, it is also known that the number of macehualtin who were subject to the rule or tlahtocayotl and teucyotl of the nobles, could greatly vary.

Summarizing, we can state that the Indian lords had a noble house -teccalli, pilcalli- with dependent nobles, who could be the lords of a house themselves. The lords had macehualtin who supported them and who belonged to their house. The lord exerted his teucyotl over all of his dependents. Each noble and macehualli could expect his lord to take care of him. The lord could fulfil this expectation by allocating land to his macehualtin. The dependent nobles were 
regarded as members of his household or were assigned macehualtin of their own.

\section{A European model}

The social situation in prehispanic Mexico has striking parallels to medieval Europe. First and foremost, both societies were agricultural. In the second place, there was a turbulent political and military situation, which limited possibilities for trade. Thirdly, political powers of the tlahtoque and lords strongly depended on locally and regionally determined alliances. Speaking of the European Middle Ages, society is usually immediately characterized as 'feudal'. However, feudalism was a complex phenomenon, with many regional variations, to which the term was not applied until the seventeenth century. It is important to be aware of the variety in social alliances in the European situation, in order to be able to compare the medieval situation with prehispanic Mexico. Some examples may serve to illustrate this variety. ${ }^{14}$

In medieval Europe, not all lords were rich or held extensive manors. The manorial system, which many social scientist consider to be the essence of 'feudal' society, had its centre between Rhine and Loire. Elsewhere, it was often introduced to a lesser degree or in a much later period. Consequently, there was a lot of regional variety. The following two examples give an impression of this variety. In de region of De Veluwe, in the eastem part of the Netherlands, the manorial system only flourished for a short period, from the ninth to the twelfth century, and it was followed by a long period of 'degeneration and decay'. In the thirteenth century, there appeared manors that did no longer serve as the centre of management and exploitation of manorial ownership, and consequently were not much more than large farmsteads. At the end of the thirteenth and the beginning of the fourteenth centuries, there were manors without function and serfs without manorial ties. There was a large variety in the number of serfs per lord. By far the largest number -966- belonged to the count of Gelre. The provost of Deventer and the count of Kleve followed him with, respectively, thirty and twenty-seven serfs. The other twenty-seven lords had an average of four serfs, and a number of them only had one. The serfs of a manor did not necessarily live on a domain, but were often scattered over the countryside."

The medievalist Wickham has shown that the 'feudalisation' of some NorthItalian valleys, which resulted in the concentration of land under the influence of a few monasteries, was a product of the power relations within those local societies. The former owners of the land came to depend on the monasteries, but consolidated their position in local society, especially towards rival groups, as they now came under the protection of the monasteries. ${ }^{\text {" }}$

The other example is ninth-century Brittany, which had a variety of ties and bonds between people:" 
-[There] seems to have been social distinctions between vassals, vassalage without fiefs, a hint of use of vassalage for administrative as well as military purposes, and by contrast properties held for rent, as a result of negotiated contract, with an obligation of personal loyalty ('fidelity') but not of service. There was certainly no 'union' of benefice and vassalage and not the slightest suggestion of holding property for military service. The classic picture does not fit".

The relations between people in medieval Europe were not based on equality; it was more a matter of a variety of rights, duties and agreements between people. In European, especially German, historiography, the ties between a lord and his subject were designated by the term Herrschaft (lordship). Nowadays, this word has got a negative ring as a result of developments in social and political philosophy from the sixteenth to the nineteenth century, as it gradually got the connotation of oppression. The fate of the word 'feudalism' was a similar one. Feudalism and Herrschaft came to stand for the dominance and oppression of commoners by the lords and overlords of the ancien régime. If we take earlier connotations of the word Herrschaft into consideration, this was by no means the case."

In the first place, it should be remarked that Herrschaft in its older sense expressed no abstract, but always a concrete idea. In an attempt to prevent "conceptual and terminological problems". Robisheaux writes in his book on early modern Germany:"

"One should not confuse the [lords] personalized and concrete relationships of authority in [a] territory with the more abstract and impersonal structures of domination in a modern state. The German term Herrschafi can convey more precisely the meaning of these relationships. Herrschaft always referred to specific relationships of power, all of them rooted in law and entailing personal relationships with reciprocal obligations. One can understand the term abstractly, of course, but [in medieval and early modern times] the term was always understood concretely, that is inseparable from the exercise of specific types of power over villagers: Herrschaft over the land (Grundherrschaft), serfs (Leibherrschafi), or the courts (Gerichtsherrschaft), to name only a few examples. With each of these authorities came the right to extract certain surpluses (rents, dues, labor services, and so forth) or the right to command obedience and loyalty from those under a jurisdiction. But lords had always to provide protection (Schutz und Schirm) in exchange for these rights, or their authority could be called into question".

However, it may be observed that the power that was supposed to give Schutz und Schirm could just as well act violently and arbitrarily towards its subjects. On the other hand, the promise of faith was not always complied with on the side of the subjects. The Herrschafi agreement of mutual faith was thus an ideal of the vertical ties from person to person, which not only implied the fulfilment of 
mutual rights and duties, but also the legitimacy and rightfulness of the lord. The lords of Aragon expressed this conditionality of the monarch's rule in their oath of allegiance to the king: "We who are as good as you and together are more powerful than you, make you king and lord, provided that you observe our fueros [i.e.privileges] and liberties, and if not, not"."

In feudal society there was never a state in the modern sense of the word, as 'the ties of Herrschaft of the nobility apparently had an independent source, at least in principle, [and] did not derive from a central authority, which is to say that every or none authority in the middle ages was 'stately'; in any case not only royal authority". "Actually, the centrifugal tendencies of changing alliances were the most important threat to the power of the medieval European kings, as their kingdoms tended to fall apart when regional nobility gained strength and tied themselves to rivalling kings. The political and military situation constantly changed as a result of wars and varying alliances. All positions of power were supported by social and economic relations which were (largely) the outcome of some 3,500 years of agrarian development. Consequently, all social positions and power relations were highly complex and varied regionally, according to local historical development. Nowadays, historians are aware that 'the old Herrschaft structure, which is so often regarded as the typification of feudalism' was not just a product of 'conquest, violence and injustice', but just as much of voluntary ties and alliances."

As stressed before, feudal Europe was anything but uniform. In late medieval times, within the ranges of influence of the lords, cities and village communities developed, which constituted autonomous corporations. The communities had never been totally absent, but after the thirteenth century, as population had increased, ever more peasants had united in communities of interest, like those who regulated the use of common fields (Dutch: markgenootschappen). Yet, these were not independent of the lords' Herrschaft, because the community members took part in the exertion of Herrschaft, as they fulfilled offices in their communities in commission of the lord. Frequently, the "communitary, [...] corporative elements in the village, city and countryside [...] are opposed as antipole to Herrschaft, while in reality in older times both were intimately intertwined, the one could not be imagined without the other"." The dependence on the lord lay in his power to appoint local officials. Robisheaux writes on early modern times, that "villagers shared in the fruits of their own domination. Power was widely and diffusely spread within the village, its exercise very often tentative and conditional. For villagers knew where the power lay in their communities, and they understood how to lay their hands on a share of it"." For the powerful overlords, kings, princes and counts, consenting to the delegation of some of their power to these communities was a way of restricting the power of all sorts of local lords and thus of increasing their own grip on the territory. Both the communities and the overlords had an interest in strengthening the position of the 
corporative organizations. In the long run, it came to be more important to which community people belonged, than under whose Herrschaft they fell."

Communities were particularly important in Spain, where they had been crucial in the repopulation of the countryside after the Reconquista on the Moors. Spain had by no means been as fully feudalised as, for example, the area between Rhine and Loire and in the early sixteenth century, the comunidades even had a far reaching form of self-government."

Because of the importance of personal ties, the feudal system has been called a Personenverband (system based on personal ties). In the personal relations of Herrschaft, the position of the lords served a jurisdictional, military, and religious purpose. The jurisdictional position of the lord enabled him to extract revenues from legal procedures, fines and from acting as a judge. It was a guarantee to his subjects that the internal order was maintained and that their rights were more or less observed. The military position gave the lord prestige and important means to maintain and even extend his authority, as well as the possibility to raise revenues by looting and plundering after a military campaign. For his subjects, the military side of the position of the lord meant they were protected against attacks from the outside. The religious position gave the lord prestige and a certain link to the supernatural. Many of the lords were thought to possess supernatural powers. In this respect, however, the lords had to share their powers with priests. The religious side of their position made it easier for the lords to legitimize their power. For the subjects it meant a direct link with the supernatural, which was a prerequisite for survival in an uncertain world. It is impossible to say which of the three aspects of the position of the lord predominated.

In a sociological sense, the term Herrschafi has been used by Max Weber and his followers. Weber distinguishes three 'reine Typen' ('proper types') in which Herrschafi could be legitimized: the modern Herrschaft resting on the rational belief in the legality of the established order; the traditional Herrschaft rooted in the belief in the sacredness of the current tradition and the charismatic Herrschafi of which the basis is the sacredness, the heroism or the exemplary conduct of one person." From a sociological point of view, these types have proved most useful, but the historian Brunner has pointed out that, being a sociologist, Weber was predominantly directed at the present. He wanted to explain why rationality had risen in the West." The legitimacy of traditional Herrschaft was to him contrary to the other rational, bureaucratic Herrschaft, and, therefore, irrational. Brunner emphasizes that this view has been determined by too modern assumptions, as far as the old term Herrschafi is concerned, which after all was always understood in a concrete sense with all its inseparable virtues of wisdom and justice. A society only appears 'traditional' from a certain distance in time or space, as is the case with a past social order or a different culture:" 
'These differentiations can only be made after the breakthrough to the 'modern world'. In it the phenomenon of Herrschaft has experienced a fundamental change. Only from the beginning of the nineteenth century the problem of legitimacy appears, there is being spoken of the tradition, of the "historically constituted', the superseded [...] Older centuries never knew 'tradition' or 'history' as the only foundation for legitimation. [People then] lived in an order which seemed 'old' to them, because in their conviction it was good, right, and therefore had been as valid in history as it was in the present'.

In this view, justice and legitimacy both have a natural and divine origin hence, divine and natural law- and were superior to both lord and subject. Herrschaft ultimately had a religious background: 'Herrschaft in its full sense mediated the subjects towards a superior power'.90 Consequently, a lord got his rights from the supernatural, to which he owed fealty. With its religious connotations, Herrschafi strongly corresponded to the idea of a 'God given order.' In this world view, everyone had his place and had to know his place. Who fulfilled his duties towards the supernatural and his fellow human beings, could count on protection and the guarantee of his place. Who did not fulfil his duties forfeited his rights. This applied to both the subject and the lord. Because of the strongly personalized view on social position, there was a multiplicity of rights, privileges and statuses, resulting in an intricate society.

There was a long European tradition, starting with Aristotle and had been carried on by such distinguished and influential philosophers and theologists as Saint Augustine and Thomas Aquinas and virtually every other medieval writer, in which society was compared to an organism, or more specifically, a body. This organistic idea comprised the image of both the vertical and the horizontal ties in society. The king or lord was the head or the heart and the members of the body were the different social groups. As with any organism, one part could not exist without the other, and the organism was only alive with all its elements working together in harmony."

In medieval writings, the term community generally included both the lord and his subjects. There were several kinds of human communities, which since Aristotle had been schematically divided into three types. These types were the three ways of ruling according to reason, law and wisdom (prudentia). There was a distinction between one's life, one's household and society or republic. The republic, however, was a less abstract and legally defined concept than in its original, classic Roman sense." Although the 'political', lawful rule of the republic was considered to correspond to the highest degree of reason and wisdom, it was not essentially different from the wisdom that was needed to rule oneself or one's household. Using a modern terminology, we might say that all power was thought to be patrimonial. As has been expressed above, this did not exclude, but on the contrary necessarily included, the horizontal organization of human life. Thus, in the European world view, the inequality and difference between people was God given, but they were all equal before God and they 
were brothers in the House of God. The historian Southern remarks that, although a lower noble's place in hierarchy was determined by the bonds of vassalage by which he was subjected to lords, his knighthood made him a brother-in-arms of the king."

Another English historian, John Bossy, points out, that in this line of thought, there were two normative and ritual ways of approaching human relations in medieval Europe: on the one hand, there was the parent-child approach which symbolized the vertical ties in society -like those between lords and subjects- and implied matching rights and duties. On the other hand, there was the brotherhood approach which symbolized the horizontal ties between people with the implication of matching rights and duties. The normative idea of brotherhood in Europe was expressed in the religious orders and to a lesser degree in the civil communities and corporations, which in principle had a character of corporation instead of Herrschaft, although the communities were not separated from lordly ties."

\section{The house}

This strongly personalized way of theorization on society, implies that in medieval Europe many terms had a meaning different from the modem one. There was no strict theoretical division between politics, ethics and economics. 'Political' or 'policy' originally referred to the way in which a republic -in the sense of a political body- had to be ruled, that is according to the highest degree of reason and lawfulness; by extension, 'political' came to mean orderly. Thus, political life meant lawful, orderly life, and notwithstanding the many developments of political theory in the fifteenth century, it was still used in this way by Spaniards in sixteenth-century Mexico. We can see more reflections of this medieval 'paradigm' in early Mexico. The well-known sixteenth-century Spanish debate on the 'humanity' of the Indians concentrated on the Aristotelian criteria of a human life 'according to reason', appearing, as mentioned above, this was shown by the prudentia with which man rules himself, his house(hold) and society. Fray Bartolomé de las Casas, the famous defender of the Indians, dedicated many pages of his apology on the Indians to demonstrate that they lived according to reason and followed the "Aristotelian scheme of the three kinds of prudence [...]. They sustained and governed themselves, or they had the government of themselves, in what is called monastical [rule], [which is] almost government of one, and in the domestic or paternal or economic [rule], in which the understanding and use of reason is concerned, and [...] they had and sustained themselves, before we Spaniards came, in that [i.e. the government] of the city or the political'."

Economics thus encompassed all care of the house, not just its economic activities, as it has come to mean nowadays. "The housebold in this sense mainly referred to the peasant household, which predominantly aimed at sustaining itself. As such, it depended on the unpaid, but not free, labour of the peasant family. 
This implied that the leader of this household was not only an economic leader, but also had to be able to dispose of the people living in the household.

In a nice analogy, Brunner characterizes this peasant household as a 'simple centrally planned economy', in which the leader of the household decided on the use of the means of production, the purchase and consumption of goods and laid these decisions down in an economic plan. However, this implicated that this leader of the household was more than an economic leader in the modern sense. The Austrian historian Brunner expresses his position as follows:"

'He must be a 'householder', lord of the house, caretaker [...] who disposes of the people, means of production and consumption goods [in his house], who manages production, the labour effort and consumption at the same time. The peasant bousehold was unthinkable without the unpaid labour of the family members; it existed necessarily in the social construct of the 'total house'. It always was a household in the old sense of the word, which not only concerned the economic, but in which housekeeping also included the human relations'.

Even though in many cases a household included more people than just a family, it was natural to use the figure of the father, that everyone was familiar with, for explaining the rights and duties of this head of the household. As has been mentioned above, there was no fundamental division between the rule of a household, and that of the larger entity of the republic. Consequently, in moral treatises the position of a ruler or lord was often compared to that of a father. The comparison was even extended to the supematural, as God was called the Father of man.

In the Indian social order, a large part of social theory centred on the position of the lord. The house played a very important role here, which, as in Europe, was reflected in the world view. As I have emphasized above, in both societies, the lord's power was bound to the person of the lord and the rights he had inherited from his ancestors. Obviously, the position of a dynasty changed over time; the starting point being a simple peasants household. The bouseholds of many lesser lords were probably hard to distinguish from those of richer commoners. As the wealth and power of the household grew, its basic functions remained the same. Even though in the course of time the personal position of the lord received ever more public aspects, this was not reflected in social theory, where the ruler was compared to a father and his position as the caretaker of a household was emphasized. According to the informants of Sahaguin priest spoke to the nobles of Tenochtitlan about the newly ascended tlahtoani:*

"Who dost thou think thou art that he dealeth personally with thee, with thy altepetl even though thou art a responsibility, a burden? [...] And now it is true that truly thou troublest his beart over the city. It is true that he is thy real mother, thy real father. Thy mother is not thy mother; thy father is not thy father. Truly this is thy mother, this is thy father". 
These words were supposed to be true of all the nobles who exerted teucyotl and tlasocayorl within their domain. The description which in Sahagin's work is given of the good lond is almost the same as the description of the good father. This responsibility for a house recurs down the social scale. The farmer instills in his son the responsibility for the welfare of his house. On the other hand, in a similar speech, the young woman is reminded by her mother of obeying her husband, although she shares the responsibility for the household. If the future husband will appear to be too stupid to take proper care of his house, the mother tells her daughter, she will have to undertake the responsibility for the house and family herself."

Considering all this, in my opinion, the concept of Herrschaft is also useful in the approach of prehispanic society. For, even though, of course, there is no exact parallel with the European Middle Ages, as all historical comparison falls short in one way or another, in the whole normative treatment of lordship and its context, the Nahuatl teucyotl and tlahtocayotl seem to be rather close equivalents of the German word Herrschaft. The complex and heterogeneous Indian system of concrete personal obligations and relations of Herrschafi may be characterized as a Personenverband. ${ }^{100}$

\section{Conclusion}

The Indians lived in a Personenverband, in which the concrete personalized relations between lords and subjects were of central importance. The possibility to have land worked and, hence, hold influence over land and control over people was far more important than divisions of landownership. The division of rights to land was most complex and the various claims overlapped; there was no exclusive and absolute right of landownership. The rights to land were always connected with rights to tribute, jurisdiction and religious and military leadership. According to the ethics of Herrschaft, these rights were counterbalanced by the duty to protect the subjects. The relations of the Personenverband could be very complicated. Each individual had his own place in the web of social relations. As human power could never be absolute, the power of the lord ultimately had to be sanctioned by the supernatural. The gods exerted their lordship over man, like the lord exerted his lordship over his subjects. These relations were also fixed and determined by fate. Society was pervaded by this connection between the earthly and the supernatural and made the Indians of Central Mexico realize that they lived in a world that was strongly determined by hierarchic ties. This consciousness was reinforced by the 'moral philosophy', as Sahaguin called the whole of huehuetlatolli or wise speeches.

Whatever corporate tendencies there may have been in Mexican society, they never became 'official', as this moral philosophy strongly reflected the interests of the tlahtoque and the elite at large. In this philosophy, only the vertical ties 
between people are mentioned. When Sahagin's informants treated the family, they elaborately talked about the relations of parents and grandparents to their children, but not of brotherhood. The metaphor of the father figure recurs in their descriptions, but a metaphor of brotherhood is not used. This is a striking difference from medieval European social theory as outlined above. We may wonder why a corporative idea is virtually absent in Mexican philosophy. Of course, we have to realize that this was a theoretical way of looking at society, which was not meant as a description, but rather as a standard of behaviour. In this light, it is not surprising that the lords' concerns to consolidate their power were strongly present, because their position depended entirely on the obedience of their subjects.

In both prehispanic Mexico and medieval Europe, those with important religious positions were the most important social theorists. However, there was one important difference as in principle, if not always in practice, the Church occupied a position that stood apart from the temporal powers and, as such, had room to develop and express some ideas on society that benefited its independent power, but did not always support kings and other lords. ${ }^{101}$ In contrast with this, in Mexico, the connection between priests and the powers of the world was much more direct, as the religious were not an independent body, but depended strongly on the tlahtoque. Therefore it can be assumed, that Mexican social theory also reflected more directly the interests of the lords than in Europe. Yet, although in Mexican moral philosophy all social positions were placed in the light of lordsubject relations, this does not exclude the possibility that in practice the calpulli -or similar local social organizations- were not just instruments for the tribute collection, but actually had internal coherence, based on mutual services and neighbourly assistance or a certain ethnic identity. Here, the figure of a local leader, mostly a tribute collector, may have played an important role. In colonial times at least, there were a number of communities which under the leadership of such local leaders soon developed an identity of their own.

Prehispanic Indian social relations differed from the contemporary situation in Spain. This was true of the common Spaniards, but even more so of the Crown and its advisors who had spent centuries in fighting the particularism of the privileges of the lords and the cities. The aim of the Spanish Crown was to concentrate administrative power in its own hands as much as possible, using all means at its disposal, whether they were military, political or cultural. These differing Indian and Spanish traditions could not co-exist in the newly conquered areas. Hence, the first century following the conquest, was characterized by the conflicts and the interactions between the Spanish and Indian traditions. 


\section{Chapter 2}

\section{The Shaken Foundation}

After the conquest the world the Indians had known vanished. However, although the Spaniards did of course impose their rule, initially they did not try to introduce profound changes into the existing society. In the period just after the invasion a conquest society came into being, in which Spaniards and Indians coexisted and the indigenous social order was not immediately disrupted. After a few decades, however, this conquest society was undermined by a number of factors, which initiated the social transformation in which the Indian and Spanish worlds would merge. In this chapter, I shall describe these factors. Furthermore, attention will be paid to the social groups that existed at the end of the conquest society, of which the changing position during the course of the social transformation of the late sixteenth and early seventeenth centuries will be analysed in the rest of this study.

In 1519, Hernán Cortés and his small army set foot on Mexican shore near modern Veracruz, burning his ships behind him. This was the start of the Spanish invasion. Two years later, the Spaniards controlled the whole of Central Mexico. However, military victory was only the beginning: the organization of the administration of the new territories required at least as much effort. In a formal declaration to the tlahtoque, Cortés made it instantly clear that they were now subordinated to him. Henceforth, supremacy lay in his hands, even though Cortés stressed that, being a capitán general, he was just acting in the name of the king of Spain. This way of subjection and submission was nothing new to the Mexican tlahtoque. Obviously, Spanish rule was to bring profound changes for the Indians, but many of these only took effect at a later stage. This had two reasons: in the first place it took the Spanish authorities some time to decide which policy to follow vis a vis the Indian world and in the second place it was not simple to supplant the social relations that came into being immediately after the conquest with a system as desired by the authorities in Spain.'

This conquest society developed rapidly after the invasion. When the military victory had been consolidated, Cortés proceeded to distribute the Indians among the most prominent of his men in so-called encomiendas. This was a continuation of a custom that had been developed in the Spanish Reconquista and had earlier been transferred to the Antilles. Simpson wrote: ${ }^{2}$ 
"As developed in the Antilles, the encomienda was [...] the delegation of the royal power to collect the tribute from and to use the personal services of the Kings vassals [i.e. the Indians]. The encomendero undertook to look after the welfare of his charges and to educate them in proper [Spanish] norms of conduct, as well as to discharge the usual feudal obligation of bearing arms in the King's defence".

The Spanish Crown was opposed to the granting of encomiendas, because in the Antilles the encomenderos had already shown that they could become dangerously autonomous. Theoretically, they were subject to the Crown, but in practice they were very independent. They not only had authority over considerable groups of Indians, but the encomiendas also provided them with an autonomous source of income. The threat of the encomenderos increased when they petitioned to have the encomiendas made hereditary. The granting of encomiendas was well under way in Mexico when in 1523, a royal order came into force that the newly acquired territory was not to be divided in encomiendas: ${ }^{3}$

"Because it is a just and reasonable thing that the natives of the said land serve us [i.e. the king] and give us tribute in acknowledgement of our sovereignty and of the service that they owe to us as our subjects and vassals. [And because] we have been informed that among themselves they used to give a certain tribute to their tecles and prominent lords".

Cortés promptly replied, that a repartimiento of encomiendas was the only way to govern the country. He proposed to reserve a number of 'provinces or pueblos, which appear to be the most profitable and of most quality' for royal income." According to Cortés, the rest of the tribute yields were too small to be of much use to the king; moreover, most tributes were in kind. The greatest opponent of Cortés was Rodrigo de Albomoz, the royal contador, who wrote to the Crown that the encomiendas would certainly be very profitable to the king, because the Indians 'in these parts are very reasonable and orderly and they are used to pay tribute to Moctezuma and to their lords, just like the peasants in Spain'.' The letters of Cortés and Albornoz were the start of a long series of advices to the Crown about the collection of tribute, the use of Indian labour services and, in general, on the way of governing the colony. All groups of Spaniards who were involved in the reorganization of the Mexican territories, took part in the debate on the proper approach and time, and again the Crown asked for new advices. The Franciscan Motolinfa observed that the king was like a blind man, because he could not see anything of what was happening so far away and could merely trust his ability of listening well to reliable sources. At a meeting in 1526 in which most of the parties concerned participated, it was provisionally decided that the repartimiento of encomiendas would be maintained. A number of altepetl were reserved for the Crown, like Tenochtitlan and Texcoco in the valley of 
Mexico and Tlaxcala in the valley of Puebla, as well as all the places that had been or were to be populated by Spaniards."

The Spanish Crown was most dissatisfied with the situation and was intent on the submission of the encomenderos. Even though the Crown constantly aimed at centralizing its power, its policy was crossed by a number of other objectives. From the outset, the authorities in Spain stressed the necessity of protecting the Indians and reducing their tribute obligations. The propagation of the Christian faith among the heathens was to be given priority. Soon it proved impossible to reconcile these aims in practice, and the first decades of Spanish rule were characterized by a stream of often contradictory measures, in which the centralist tendency predominated. The centralist measures were codified in the Leyes Nuevas (New Laws) of 1542-1543, which were consequently both a consolidation of the preceding policies, and also served as a new point of departure for future policy. In the literature on this period, most attention has been paid to the abolition of Indian slavery and the reduction of the power of the encomenderos. With the Leyes Nuevas, the encomenderos retained the right to revenues from the encomiendas, but jurisdiction over the encomienda Indians was irrevocably consolidated in royal hands, since provinces were formed under corregidores and alcaldes mayores. In due course, the encomiendas ceased to exist, because hereditariness was restricted to two generations and new encomiendas were no longer granted. In the American colonies, the laws caused much turmoil among the Spaniards who saw their privileges curtailed. In several places they revolted.

In addition to the changes in the Spanish part of New Spain's society, the Leyes were also to have a profound effect on indigenous society. They thus initiated a radical reform of the conquest society which had come into being in the early years after the Spanish invasion.'

\section{The first changes}

Even before the Leyes Nuevas were promulgated, a lot had changed in the government of the Indians. The most distinct and not unimportant change was, that after the conquest, most references to Indian society were couched Spanish terminology. Frequently, the Spaniards did not simply translate indigenous words, but, either consciously or unconsciously, influenced the conceptuality in the vocabulary by the use of Spanish terms. The general term used for any Indian noble, regardless of his rank, was principal (dignitary, prominent). In this case hidalgo, the closest Spanish equivalent to the Nahuatl word pilli, was not used, because of its immanent legal claims. After the conquest the highest Indian lords were of course deprived of their sovereignty, as far as any had been left under Aztec rule. An indigenous supreme lord, in Spanish señor universal or señor supremo, no longer existed and all Indians were declared subjects to and vassals of the king. Initially, tlahtoque and tecuhtin were called sefiores naturales 
(natural lords) but this use was soon abandoned, because the Indian nobles could derive from this designation legal claims under Spanish Law.' Viceroy Don Antonio de Mendoza proposed to create a separate noble order for prominent Indian nobles, but this idea found no mercy in the eyes of the authorities in Spain. As all Indians now fell under royal authority, the Spaniards no longer distinguished between tlahtoque and important but lesser lords like tecuhtin. They treated all important nobles equally and designated them as caciques. Even though the caciques were not admitted to a noble order, they were the only Indians who were entitled to use the Spanish honorific Don. The lands and other patrimonial rights of a cacique were in Spanish summed up by the term cacicazgo, equivalent to the Spanish mayorazgo, which designated an entailed estate of the eldest son (mayor).'

The Nahuatl word macehualtin was usually preserved in the hispanized word macehuales, but in due course, the general terms indio and natural became more and more current during the Spanish period, although macehual never completely disappeared. There was a slightly different meaning to all these words: macehual was mostly used to describe an Indian commoner of the prehispanic period, in order to distinguish him from caciques and principales. Indio was used to indicate an Indian in the most general sense of the word, although in the course of time, indios were legally defined as those belonging to the republica de indios, the republic of Indians (see below). Natural meant that someone had been bom in a certain area or town, and as such was fully equivalent to the English 'native'. In this sense, the word was also used for Spaniards to indicate their domicile, in order to make clear that someone was an inhabitant (vecino, with Indians also tributario), or a resident (morador) of a certain town or area, but had been born (natural) elsewhere. An example of the terminology is provided by Don Tomás de Rojas, who would have been a tecuhtli and possibly even a tlahtoani of Cuautinchan in prehispanic times. In a document, he was once called "Don Tomás de Rojas indio, cacique y principal, natural del pueblo de Cuautinchan"."

Spaniards translated lord-subject relations into Spanish equivalents. A macehualli could be called indio rentero, or solariego in relation to his lord, although terrazguero was most common throughout the colonial era. From the time of the important tribute reform, that started in the 1550s, Indian commoners were often called tributarios in the documents. Throughout the colonial period, a tributario was a legal term for an Indian who was liable for tribute.

The altepetl were called senorios (lordships) by the Spaniards. An encomienda usually comprised the indios of one señorio. Another possibility was to assign half of the proceeds of their tributes to an encomendero, and the other half either to another encomendero or to the king. In this way, the encomendero, or in areas that were not assigned to an encomienda- the representative of the king (generally an alcalde mayor or corregidor), could assume the supreme administrative position, and hence, in fact, the position of the former tlahtoani. However, from the start, the king managed to preserve most prerogatives of authority 
for himself, so that the encomiendas never truly became domains in the European sense. Frequently, the encomenderos did not reside in their encomienda territories, but only received the tribute revenues which were collected for them by calpixque (often hispanized to calpisques), as had been the case with the former Indian lords. When the Spaniards recorded many tribute obligations in the middle of the sixteenth century, it appeared that the encomenderos received the same tributes as the tlahtoque formerly had.

In this way, we should also look upon the granting of encomiendas to the heirs of the most prominent Aztec nobility by Cortés, because this grant by the Spanish conqueror was actually a recognition of their old rights. An example is the grant of 1526 and 1527 to the daughters of Moctezuma 'because by law it belong[ed] to them as their patrimony and rights.." Doña Maria received the sefiorio of Ecatepec and three estancias (outlying hamlets) going with it. Her sister Doña Isabel received the señorio of Tlacopan (Tacuba) and its inhabitants. This seriorio consisted of the principal town and seven estancias, with a total of 1240 tributary families or houses (casas). ${ }^{12}$

The administration of the newly conquered territories was not confined to the granting of Indians to encomenderos. The conquest was justified by the idea of propagating the Christian religion across the world, just like the motivation of the Reconquista had been to regain the lands that had been lost for Christianity to the Moors. In this matter, the interests of the Church and the Spanish Crown coincided; the 'Spanish' kings Ferdinand of Aragon and Isabella of Castile were even called the Catholic Kings. With the promulgation of the papal bull "Universalis Ecclesiaen in 1508, the king received important prerogatives over the Church in his territories, provided that he would take care of the conversion of the indigenous American population. These ecclesiastical privileges were called the patronato real. In Europe the regular clergy (those bound by a religious order or regula), were not allowed either to fulfil parochial tasks, or to administer most of the sacraments. However, under the regulations of the patronato real, the king put the mendicant orders, being the Franciscans, the Dominicans and the Augustines, in charge of the missionary task. They had autonomy within their orders, and had served in Europe as travelling preachers living from alms from ancient times onwards. Therefore, they were better prepared for the missionary work, which demanded a lot of their improvising abilities, than the secular clergy (those working in the World or seculum) who were part of a strict hierarchy and lacked the flexibility of the mendicants. Moreover, the use of mendicants enabled the king to safeguard a greater independence from the Pope, as the friars were not subjected to his direct control.

In 1524, the first three Franciscans arrived in Mexico; two of them soon died, the third -the famous Flemish lay friar Pedro de Gante- diligently began the immense task of conversing millions of Indian souls. In the following years, with each fleet from Spain, new delegations of Franciscans came to assist him in his 
efforts, of which the 'apostolic' twelve of 1524 have become the most famous ones. In 1526 and 1533, the Franciscans were followed by Dominican and Augustinian friars, respectively. Other orders, among which the Jesuits were most prominent, did not arrive until much later in the sixteenth century; they did not take part in the missionary activity. Soon, a secular hierarchy was installed in Mexico as well, but hardly any secular priests participated in the conversion of the Indians. ${ }^{\text {s }}$

Each order enjoyed a large degree of independence, which is evident from the rather large intervals in time between the first arrivals of the orders and their followers. In the missionary activity among the Indians, this autonomy was maintained. Without any coordination whatsoever, the orders plunged into a competition for securing the most promising territories. A number of historians has occupied itself with the course of the conversion of the Indians." Ricard's comparison -derived from sixteenth-century authors- of the mission with a 'Spiritual Conquest', as a consolidation of the military conquest, has found much support and, indeed, the conversion looked like a military campaign. At first, it was directed at strategic parts, generally the centres of the altepetl and the tlahtoque, as the friars held the view that if the rulers had been won, the rest of the population would follow. In this, according to Van Oss, 'expansive phase' the missionaries penetrated into the country as far as possibly. This phase was completed in fifteen years. It was followed by an 'intensification' phase, during which the new religion was consolidated. Van Oss argued, that the mendicant orders allowed themselves to be guided above all by demographic considerations, which means that at first, they directed their activities at those areas where the Indian-population density was highest. This is hardly surprising, considering that a handful of friars had set itself the task of converting millions of Indians."

The Franciscans themselves were also convinced of the greatness of their work. They regarded themselves as the apostles of the New World, an idea that was strengthened by the fact that in 1524 one of the earliest delegations had consisted of twelve men. Brading writes that: ${ }^{15}$

"It would be an unpardonable injustice not to emphasize the exemplary dedication of so many of the first evangelists in the Indies, with the Franciscans in Mexico taking the lead in preaching the gospel as much by example as through instruction. Their provincial, Martín de Valencia, was an ascetic more liable to scourge his own mortified flesh than to whip dissident Indians".

Notwithstanding this just qualification, when reading the Franciscan chronicles and testimonies, we may observe that the authors were sometimes rather pleased with the achievements of their order. ${ }^{7}$ However, we should consider that this somewhat self-satisfied tone was inspired by the order's necessity to assure itself of the ongoing support of the Crown, in view of the pressure of the attacks on the Franciscans by the rivalling orders and the secular branch of the Church. 
Because of the troubled relations between the mendicant orders, they stayed out of each other's territories as much as possible. In 1556, they even agreed upon an official policy to that end.

The Franciscans were the first ecclesiastics to arrive in Mexico and the whole country lay open to their missionary efforts. First, they directed themselves at the areas with the highest population densities: the valleys of Mexico and Puebla on the central highlands, and Michoacan in Western Mexico. In the valley of Mexico they were soon followed by representatives of the other mendicant orders. In the valley of Puebla, however, the Franciscans kept their missionary monopoly among the Indians for a long time. The other orders also concentrated on specific areas. The Dominicans went to the south to the population centres in Oaxaca and Chiapas, and the Augustines had to content themselves with the area of the actual state of Hidalgo, which came nearest to a fourth largest population centre, but where far less people lived than in the areas that had been claimed by the Franciscans and the Dominicans. Otherwise, the Augustines and all other orders that arrived after them, had to squeeze their missionary posts in between the territories of others."

\section{Missionaries in the altepetl}

The mission centres formed by the mendicants in the Spiritual conquest were called doctrinas. In accordance with their 'tactic of conversion', a doctrina often coincided with an altepetl. As I have already mentioned, the friars had initially concentrated their efforts on the caciques, assuming that as soon as they had been converted, their subjects would follow as a matter of course. Van Oss wrote that:"

"most caciques surely understood that sooner or later they would have to reach an accommodation with the Spanish if they were to conserve their communities intact. We may imagine that the friars took advantage of this implied threat, and insinuated themselves by playing on the caciques' vulnerability".

The Franciscans got the 'best territories' of New Spain, as the colony was now called, and in the sixteenth century they were the most powerful in religious matters.

As soon as a temporary missionary post had been established, the friars would convert or expel the indigenous priests, whom they regarded as servants of the devil, and they would not hesitate, if necessary, to eliminate them. They had the indigenous temples broken down, demolished and replaced with churches and monasteries. The Christian buildings arose on the remains of the old sanctuaries and were built from the same stones. This conversion tactic was nothing new: it had proved its usefulness in the Christianization of Europe, where many churches 
bad replaced sanctuaries, as well. In the same way as the churches replaced pagan buildings, the regular clergy literally replaced the former priests. ${ }^{20}$ In this process, the friars showed respect for the position of the cacigues. Van Oss writes:"1

"The initial conversion to Christianity as practised by Guatemala's [and Mexico's] friar-missionaries thus depended as much on shrewd human calculation -tying the fate of the cacique to the cause of religious colonization, and by extension to the acceptance of Spanish rule- as on Christian doctrine. The introduction of Christianity and the colonial system of administration proceeded relatively peacefully by these means, respecting the social hierarchy, and perhaps even strengthening it. Through the agency of the religious orders even the most remote highland communities were thus marched one by one into the church and, therefore, into the Spanish empire".

The doctrinas were the centres from where surrounding places were visited. Even when, at a later stage, improvised churches were replaced by more permanent constructions, these would in general still remain the principal towns or cabeceras of what then bad become provinces. As the cabeceras were usually founded in places where the tlahtogue lived and where the main temple was situated, there was a clear continuity with prehispanic times in this respect. The friars did not construct big churches or monasteries in the villages and hamlets surrounding the cabeceras, which were under the influence of the alrepetl's ruler. Here, at most, chapels were constructed. ${ }^{n}$

The social position of the Franciscans and the other mendicants was closely associated with the fate of the Indian society and especially that of the caciques. The friars depended on the Indians for their subsistence. This was in accordance with their mendicant ethic, which laid down that the friars should only live on what the people were willing to give them. In Europe, the mendicants were supposed to live from alms and, according to Motolinia and Mendieta, the first Franciscan missionaries in Mexico were also very poor. As was to be expected, the friars' way of living became less adventurous after they had settled. Van Oss remarks that this shift was reflected in the description of the lives of the Guatemaltec missionaries: "If the first missionaries had distinguished themselves as daring and militant soldiers of Christ, the role of the doctrineros was more domestic: they had to be builders and architects, consolidators and constructors of the Christian republic".2 From many documents it appears that the doctrineros received personal services and tributes in kind from the Indians. We may assume that they not only took over the position of the indigenous priests in a religious sense, but were also supplied with tribute products by the Indians, who had formerly maintained their own priests. In line with the indigenous tradition, the caciques assigned to the friars the tribute proceeds of groups of macehuales within their señorios. ${ }^{24}$ 
During the first decades, the encomenderos had become the new rulers over the Indians. As such, they received tributes and were adopted into the Indian system of Herrschafi, even though their authority was almost immediately curtailed by the Crown. This takeover of the position of the indigenous rulers was something the Indians could have expected in the light of earlier conquests and submissions. Yet, the encomenderos did not become an integral part of Indian society. They usually did not live within the territories of their encomiendas and had no direct command over the Indians 'commissioned' to them. Consequently, their position within the Indian world remained just formal and the encomenderos hardly ever came into direct contact with their Indians. This does not mean that the indigenous population accepted their position just like that: whenever the encomenderos imposed too heavy or unjust a tribute or labour obligations, the Indians would protest to the colonial authorities or resist the measures in another way. ${ }^{\text {" }}$

Similar to the way the encomenderos had assumed the position of rulers, the clergy became the new mediators in matters of the supernatural. As such, they rather easily fitted into the indigenous Herrschaft and tribute system. Due to this, and because of the mendicants' missionary victories, they soon became the Spaniards who were most closely involved with the Indians. They participated in both Indian and Spanish society. This close relation to the Indians made the Franciscans their most important spokesmen, apart from the Dominican bishop Las Casas. The Franciscan writers strongly identified with the Indians, especially the caciques. They regarded the common Indians as children in need of their fatherly protection. Provided that they would remain in charge -a condition that was guaranteed by the Spanish rule- they were willing to share this task with the caciques, whom they regarded as senores naturales and thus destined for Herrschaft and, hence, fatherly and leading tasks. The friars were fascinated and often even elated by the way the Indians exerted their sefiorio. The only blemish on the Indian reputation was heathendom and the friars had come to save them from it.

In this way, the rural friars came to hold a very strong position. Due to their influence on the Indians, they were a very important social group, which also enjoyed a lot of influence in political and social matters. Political support from the Franciscans was indispensable for the Spanish authorities, especially in the valley of Puebla.* According to the sixteenth-century Franciscan chronicler Mendieta, the close relation between the Franciscans and the Indians enabled the friars to prevent a revolt. Mendieta says that he got his information from the well-known missionary and chronicler Motolinia, whom he had known well and who always spoke the truth. Mendieta goes on saying that during the first period following the conquest, only a handful of Spaniards remained in Mexico. They felt more and more uncomfortable, as they knew themselves surrounded by millions of Indians who had been subjected to violence and bore the Spaniards ill feelings. These locked themselves up with spears, lances and cannons (espadas, 
Lanzas $y$ artilleria), and only the Franciscans continued to live among the Indians. In the meantime, the Indians, who had formerly continuously waged war, conspired and planned an armed insurrection, and only the alertness and information of the Franciscans could prevent these vicious plans. ${ }^{n}$

\section{Spanish groups and interests}

A few decades after the conquest, there were various Spanish groups in New Spain with in many ways contradictory interests. The encomenderos and the missionaries were interested in by and large maintaining the situation that had come into existence directly after the conquest, since their own position had come to depend strongly on it. The encomenderos and those claiming to be entitled to that position, especially wanted to consolidate the encomiendas, and preferably effectuate a general distribution of the transatlantic territories into encomiendas, a so-called repartimiento general. It was important for them that the indigenous society and particularly the tribute system remained intact, as their position was based on this foundation. However, they were not interested in maintaining the position of the caciques, because strong caciques weakened their position, since they undermined the argument that a repartimiento general was indispensable for a solid govemment of the colony.

Unlike the encomenderos, the mendicants had a strong interest in maintaining the old indigenous order, as they strongly depended on the caciques. They also realized that profound changes in the indigenous social fabric would not only hurt the caciques, but also themselves. Thus, the Indian cause soon became the cause of the missionaries; the indigenous nobility and the friars closed ranks.

Opposed to these two interest groups were the Spaniards, who would benefit most from a change in the situation as it had come into being during the conquest period and directly afterwards. First, there was the Crown, which held the view that all encomiendas should be abolished as soon as possible and all Indians be brought under the direct rule of the king, as the authorities in Spain had wished from the beginning. Moreover, tribute should principally benefit the Crown instead of the encomenderos or caciques. On the other hand, the king regarded it his responsibility to take care of the well-being of his subjects. The old European ideal of Herrschaft still played a part in these matters, notwithstanding the changing, 'more modem' political views that also existed in sixteenth-century Spain. The king continuously stressed that the Indians were to be converted to Christianity, which he regarded as his duty, and that tribute ought to be 'moderated'.

The secular clergy also favoured a change in the relations of the conquest society. It argued that the conversion of the Indians had been carried out deficiently and that the Indians, like the New Christians in Spain (Jewish and Moorish converts), returned to their paganism. It is hardly surprising that in the 
eyes of the seculars the regulars were not the most appropriate group to correct the Indians, because of their close association with the Indians and their lack of discipline. The secular clergy was also largely the advocate of a growing number of Spaniards in the Spanish population centres, that had no hope of ever getting an encomienda. Initially, this group could hardly make its voice heard and could only bope to gain respect in case the current situation would change. If we take into consideration these varied interests, it is hardly surprising that the king received widely varying answers to his requests for advice about the way in which his new territories should be governed."

The Crown decided to assume a pragmatic attitude and to adopt of all parties, those suggestions which sounded most reasonable, in order to avoid administrative obstacles. The transatlantic situation was hard to judge for the king and his advisors, and therefore difficult to govern. In 1540, the Franciscan Motolinía even asked for a crown prince to be sent to Mexico, who should establish a kingdom of his own there. ${ }^{7}$ Of course, this did not happen, but farreaching authorities were bestowed upon the representatives of the king in the transatlantic territories. Initially, a collegiate council, the Audiencia, was founded -in New Spain in 1527-, much like the collegiate councils in Spain's European territories, but it did not have enough authority to keep an adequate administration. Therefore, the first viceroy, Don Antonio de Mendoza was sent to New Spain in 1535 . He was invested with royal dignity and prerogatives. Viceroy Mendoza proved an able and wise man. The two most acute problems he was confronted with, were the way in which the colony should be governed and how the Indian world had to be fitted into the new order. As I have mentioned above, the Leyes Nuevas were an important step in the direction of a new organization of the administration..$^{\infty}$

The laws not only increased the Crown's grip on the Spanish part of the colony, but also had a profound influence on the Indian administration. Of course, the measures against the encomiendas affected the Indians, but from the laws also resulted a number of measures that were more specifically directed at the Indian world. The execution of the policy was left to the Spanish authorities in the colonies."

\section{Institutional revolution and social consequences}

During viceroy Mendoza's term of office, two changes were introduced with the establishment of provinces and the foundation of pueblos de indios, which deeply influenced society as it had become during the first decades after the conquest. In both ceses, the Leyes Nuevas were the consolidation and codification of an important institutional change, which had already been prepared by royal ordinances and the policy of the viceregal administration. In its attempts to curtail the encomenderos, the Crown had created so-called corregimientos from the 
1530s onwards. The corregimientos were administrated by a royal official, the corregidor, whose task consisted in taking care of the royal privileges, and to protect the Indians from ill treatment. In practice this meant enforcing the law, taking care of civil administration and see to it that the encomenderos did not abuse their position. In the course of time, the Indians who were not subject to an encomienda but directly to the king, were placed under an alcalde mayor. The alcalde mayor was another royal official, always a Spaniard, whose office initially implied a somewhat higher authority than that of a corregidor, but soon the positions of both officials became practically alike and a change in names had no major consequences. When an encomienda was abolished, the corresponding corregidor was subsequently often replaced by an alcalde mayor. ${ }^{2}$

As mentioned above, the Leyes Nuevas implied a substantial weakening of the encomenderos. The promulgation of the laws caused so much unrest among the Spanish population, that viceroy Mendoza did not want to implement them too energetically. However, the encomiendas were gradually abolished. The position of the encomenderos had always remained limited in the valley of Puebla, and from the start, the Crown's policy had been aimed at reducing it. With the introduction of the Leyes Nuevas, the encomenderos only retained a right to tribute, but lost whatever other authority they still enjoyed. At the end of the century, the power of the encomenderos had almost completely disappeared and in the seventeenth century their numbers further decreased. As a result of the lack of documents, it is hard to get insight into their actual position. In the archives I have come across just one document that gives an impression of the financial position of one of them. It is difficult to form an opinion of the representativeness of this single example, but at least it shows that not all encomenderos were wealthy.

Don Francisco de Artiaga was the son and minor heir of Don Diego Pérez de Artiaga, in life encomendero of half of the pueblo of Cuautinchan. From 1582 to 1600. Don Francisco de Artiaga received each year a fixed amount of maize from the encomienda he had inherited. At first, this was 330 fanegas $(18,150$ litres), but when the number of tributarios had been re-assessed, the amount was reduced to 228 fanegas (12,540 litres). This amount of maize was worth a few hundred pesos, depending on the current price in the city of Puebla, where it was sold. He was obliged to contribute 100 fanegas (5,500 litres) and 200 pesos of the proceedings to the Franciscan monastery in Amozoc, in agreement with the obligations of the encomenderos to take care of the spiritual care of the Indians that had been 'entrusted' (encomendado) to them. All in all, the child cannot have retained more than 200 pesos a year of the earnings from his encomienda, less than the annual salary of the administrator (mayordomo) of the hacienda of San Bernardino in the 1620 s, which amounted to 190 pesos and a foal."

With the Leyes Nuevas, the position of the corregidores and alcaldes mayores had been reinforced. These royal officials were placed at the head of newly 
created provinces. The careful implementation of the Leyes Nuevas by the administration of Mendoza, made their immediate result look like a mere formal one. However, this was not the case. At first, the former relations of authority between encomenderos and corregidores remained virtually unchanged, but the foundation of the position of the royal officials changed. Formerly, they had been royal agents who enforced law and order among the people who came under the authority of an encomendero or the king, whereas they now became heads of a province." The provinces were the regional entities in an administrative system, which had gradually been established on a territorial basis in the sixteenth century. In an advice to the king in 1533, ten years before the Leyes Nuevas, the Council of the Indies, the royal goveming body for the Americas, expressed the principle as follows:"

'It is convenient that the Indians be ruled and governed in such a way that they receive some satisfaction from such government, so that they multiply and their number does not decrease as it has up to now, because they are ruled by and subject to persons [the Council means encomenderos] who look after thheirown interests more than the health of the Indians or a good rule over them. And in this way, it seems that the jurisdiction [authority] over the entire country ought to reside with his majesty now and that those who exert it in civil and criminal matters be appointed by his [the king's] hand or that of his governor and that his jurisdiction be distributed over provinces'.

For that purpose the alcaldias mayores and corregimientos should consist of clear-cut territorial dimensions, because the entire country had to be divided and there should not be any areas of which it was not evident under whose authority (jurisdiction) they came. Henceforth, the alcalde mayor or corregidor of a province had all Spaniards directly under his care and had the supervision of the Indians in his territory.

The point of departure in the administrative organisation of society was the legal distinction between Spaniards and Indians, which had been created under the influence of the ideas of the regular clergy in particular. Spaniards belonged to what was called the república de espanoles, while the Indians belonged to the republica de indios. Administration of the two groups was separate in principle, although the alcalde mayor had jurisdiction over both Spaniards and Indians in his province. Initially, it was the intention that Indians and Spaniards should live separately, but in actual practice this measure appeared not to be realistic.

The advice of the Council of the Indies, cited above, also mentioned the Indian participation in the administration and the position of the caciques:*

'[...] It seems [to us] that the caciques, by whom the Indians used to be reigned, should not be entirely deprived of the superiority that they had over them [the Indians], [but] rather that they should be permitted to be able to compel the Indians to work their [i.e. the Indians'] holdings and not to live 
idly, and they ought to be given some jurisdiction and governing power over the said Indians, because if their caciques are being informed and instructed about what they are to do, they will certainly rule well [...]'.

As a result, the caciques retained the government of the Indians, but the altepetl was transformed into one or several so-called pueblos de indios within the new administration founded on a territorial basis. Apart from being lower ranked administratively, the pueblos de indios usually comprised smaller areas than a province, and most alcaldias mayores contained several pueblos. In principle, however, it was possible for an alcaldía mayor to enclose the territory of a single former altepetl, now pueblo de indios. In such a case, the jurisdiction of an alcalde mayor was still more extensive than that of the pueblo, because the caciques or Indian officials in the pueblos held no authority whatsoever over the Spaniards in the area and only a restricted jurisdiction over the Indians in their pueblo.

With the measures resulting from the Leyes Nuevas, all inhabitants of New Spain -and the other American territories- were permanently placed under royal authority. Following the administrative order which already existed or was brought into force everywhere in western Europe at the time, the administration was divided into territorial units.

The institutional changes had an important influence on the society of New Spain. From 1545, the borders of the provinces were demarcated. The valley of Puebla was divided into the provinces of Tlaxcala, Puebla de los Angeles, Cholula, Tepeaca and Huejotzingo. The borders between the provinces had been determined by Spanish officials in consultation with the caciques. The demarcation of the no-man's-lands on the banks of the river Atoyac, presented no problems: between Tlaxcala and Tlaxcala and Huejotzingo the river became the border. The border between Huejotzingo and Tlaxcala lay in a largely uninhabited area and remained of little importance. Consequently, it was only sketchily recorded (Map 2).*

Elsewhere, demarcation caused more problems. The status of the alcaldia mayor of Atlixco remained obscure for a long time, an indication that the reform could not be carried out in all areas at once. Moreover, the example shows how complex the changes could be in some cases. The province of Atlixco, as it eventually came to be, comprised, among others, the territory which came under the influence of the former señorio of Calpan, a matter which had been disputed between the caciques of Cholula, Huejotzingo and Calpan itself for a long time. By virtue of prehispanic conquests, the area surrounding Huaquechula belonged to Huejotzingo, but in the second half of the sixteenth century it was separated from Huejotzingo by a corridor that consisted of the territory of Calpan and the area around Acapetlahuacan. In the Acapetlahuacan area lay a fertile agricultural region, which came under the influence of the city of Puebla. In the early 1530s, it had been given to the inhabitants of Puebla by the caciques of Huejotzingo. 


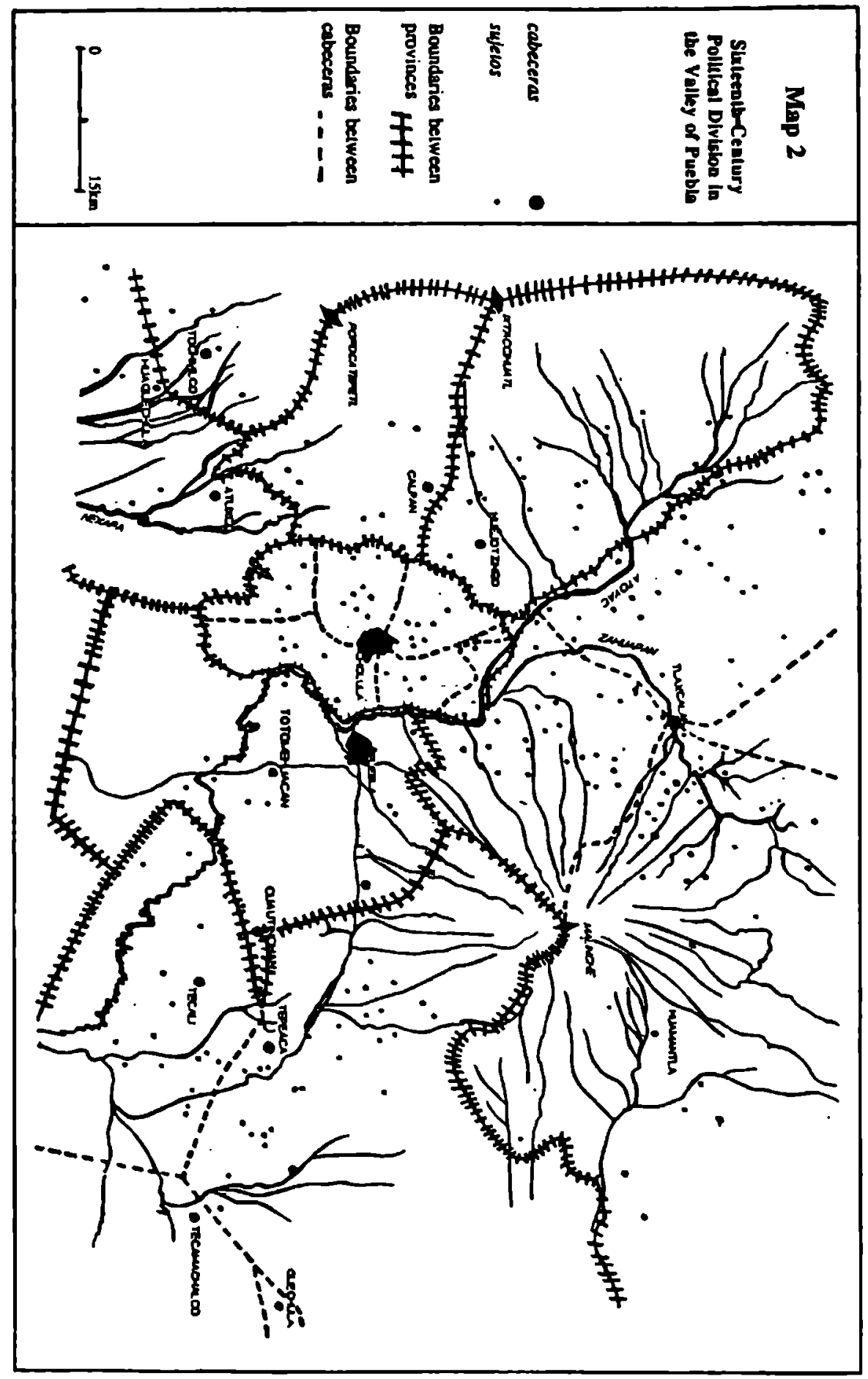


This act was connected with the foundation of the city of Puebla itself. In order to be able to establish it, the Spaniards had been obliged to reach an agreement with the surrounding seflorios. The foundation had been led by the Franciscan Motolinia; we may assume that the Franciscans used their influence to convince the caciques of the need to donate no-man's-land for a good cause. The donation of agricultural land was in line with the Crown's objective of making Puebla de los Angeles a city of self-sufficient Spanish farmers. As such, it was a social experiment that was inspired and organized to a large degree by the Franciscans in the valley of Puebla, who were the advocators of a separation of the Spanish and the Indian world, because they expected little good from Spanish influence on the Indians. The objective of the experiment was to see whether the Spaniards were able to subsist without the tribute and labour of the Indians. After a few years, the experiment proved a failure, but the Atlixco area remained under Puebla's influence for half a century, until the town (villa) of Atlixco was established in 1579-1580. At that time, both the anger and protests of the city's administrators could do little to influence the decision of the Crown."

It is hardly surprising that the caciques of Huejotzingo were enraged about their loss of influence over both Calpan and the Atlixco area. Consequently, there were a number of conflicts about the southern border of Huejotzingo. From 1538 to 1552 , both Huejotzingo and the neighbouring pueblo of Tochimilco, claimed water rights from one of the small streams on the northern slopes of the Popocatépetl. In 1551, Huejotzingo was in conflict with Spaniards about the use of firewood on the monte and with Calpan and Huaquechula about claims to land." - It is remarkable that in these three conflicts all traditional rights of Herrschaft (water, monte and land) were disputed, with the exception of services. We may assume that in all three cases the actual issue at stake was the Herrschaft, which was disputed and made concrete by way of a claim to each one of the rights.

The Huejotzinca were not the only group that regretted the donation of the Atlixco land to the city of Puebla. In 1551, the caciques of Cholula protested to the alcalde mayor of Puebla, because the land that the Huejotzinca had donated to Puebla, also comprised some Cholultec land. The Cholultecs demanded satisfaction from the city of Puebla itself, because some Cholultec macehuales had been driven from their land by Poblanos (citizens of Puebla) and their houses had been bumt."

Using one specific argument in order to attain a higher objective, was a tactic often employed by the Indians. The new division of the teritory was also used to settle old conflicts, especially those concerning borders. A lengthy process between Tepeaca and Cuautinchan -lasting throughout 1546-1547concerned the rightfulness of a border between the two pueblos. The disputed border had been demarcated by a judge of the Aztec emperor Axayacatl after an armed conflict in 1467. In the course of the process, a large number of witnesses from both provinces and their large neighbourhood were heard. In the final phase of the lawsuit, Cuautinchan feared to lose, as at that time, Tepeaca was in 
possession of the land. In a last attempt to decide the case in its favour, Cuautinchan accused Tepeaca of having bribed the Indian witnesses with mantles and cacao. After some time, Tepeaca challenged Cuautinchan's witnesses, because it said they were prejudiced and enemies (enemigos) of Tepeaca. In the end, the case was decided in favour of Tepeaca."

As I have shown above, the demarcation of provinces could lead to severe difficulties between the Indians and Spaniards. Nevertheless, the establishment of provinces had less influence on the Indian world as a whole than the establishment of the pueblos de indios had. This was a second step in the introduction of an administration founded on a territorial basis.

\section{The creation of the pueblos de indios}

The creation of the pueblos de indios was a complicated operation, which was inseparably linked to the reform of the tribute system. In this case, the Leyes Nuevas were no more the start of the reforms than in the case of the division in provinces. For example, already in $\mathbf{1 5 3 0}$ the king ordered that some administrative functions should be created among the Indians, in order to have them begin to understand our way of living, both in their governance and in the orderly way of living (policía) and the affairs of the common wealth (república)'." Initially, this ordinance found little response and was therefore repeated in 1552. With the administrative reforms, resulting in the Leyes Nuevas, it became more and more urgent for the Spanish authorities to obtain insight in and control of the administrative functioning of the Indian world. Until the 1540s, it had enjoyed considerable autonomy, but the Spanish Crown was of the opinion that this autonomy should not get out of hand, since, in due course, the Indians were to become part of the territorially-based administration under the king. Above all, the authorities in both Spain and Mexico wanted a survey of the way in which tributes were actually collected and distributed among the Indians, in order to be able to control it. Within the new administrative and tributary system of the Spaniards, there was no room for the myriad of rights and duties of the old altepetl."

In prehispanic Central Mexico no political structure had existed that could be compared to the colonial pueblo de indios, even though in most cases, the pueblo was clearly the inheritor of an altepetl. It is important to note here, that in due course, in New Spain -and even in the whole of Spanish America- an administrative structure was introduced that was uniform, at least in its external and formal aspects. The pueblo was the unit in which the Indian self-governance took place. As a matter of course, the viceregal administration followed the missionaries' division in cabeceras and visitas in its reform of the altepetl. This parochial structure became the point of departure for the organization of the pueblos. The centre was situated in the cabecera; the visitas, called sujetos in this context, 
were administratively subordinate to it. As an administrative unit, the pueblo de indios consisted of a cabecera with its sujetos."

Especially after the Leyes Nuevas had been promulgated, viceroy Mendoza systematically introduced an administrative structure modelled after the corporate bodies of Spain. With this, the altepetl changed into pueblos de indios. A hierarchy of Indian officials was created within the pueblos. The gobernador de indios was the highest official; he was the head of a so-called cabildo, consisting of alcaldes, regidores and alguaciles, who govemed the internal affairs of the pueblo. Another important position in the pueblos was that of fiscal, the churchwarden. All these positions had to be filled by Indian nobles. According to the law, thehigh-ranking officials had to be elected by all the Indians of the pueblo, but in practice the electors only consisted of the principales, the nobles of the pueblo.*

The Spanish authorities had several objectives in mind by introducing the pueblos as a unit in an administration on a territorial basis. As mentioned above, one of the most important objectives was to effectuate the increase in tribute income, which the Crown had desired ever since the early days of the colony. Sixteenth-century Spanish officials remarked that this desire was in contradiction with the decrease of the tribute burden of the Indians, also advocated by the king. This contradiction was easier solved in theory than it was in reality. ${ }^{77}$ For a long time, the Crown had been of the opinion that, apart from the tribute received by the encomenderos, the existing indigenous tribute system basically yielded too little, because all Indian nobles were exempted from tribute payment to the king and enjoyed the right to tribute themselves. Due to this, a significant share of the yield went to the indigenous nobility, who in the eyes of the Crown had lost all claims on it with the conquest. In this respect, they were in a position comparable to that of the lords of Spain, whom the Crown tried to deprive of their feudal levies and services. But this was mere theory and practice was quite different.

One practical problem in increasing the tribute yields of the king, was the fact that practically all tributes were in kind. The central government had no use for all the tribute goods and insisted on their conversion into money. ${ }^{48}$ However, when the tribute was converted in 1550, the supply system of the city of Mexico fell apart, as the Aztecs had founded it on tribute supplies in kind. Quite alarmed, the Crown decided to compromise: henceforth, the Indians only had to supply goods originating in the tribute-supplying pueblos themselves. However, this solution by no means solved all problems. Mantles were a common tribute item on the central highlands. As they were usually made of cotton which was imported from other areas, the Indians saw the new regulations as an excuse to stop supplying mantles. This illustrates that a reform of the tribute system was a most complicated matter, and by no means as simple as the authorities in Spain had imagined." 
Sometimes Mendoza got tired with the experiments that accompanied the introduction of the new administration. In 1550, he wrote to his successor Don Luis de Velasco:*

'Truly, if I had to do everything the [Spaniards here] advise me, these territories would have been turned upside down twenty times already [...]. In Indian affairs there have been so many changes, that I have said several times that we are bound to make them crazy with so many experiments. Twenty years have passed since I came to these territories and all this time I have spent watching and trying to understand them, and I would swear that I am more upstart and Xconfusechow in the administration of them than I was in the beginning, because now problems appear that I had neither seen nor understood before'.

To get a firmer grip on the tribute question, the Crown instructed its viceroy Mendoza to register which tributes the Indians supplied to their caciques and principales. At the same time, he had to see to it that the burden of levies enforced by the caciques was moderated, because, according to official reports to Spain, these were outrageous. However, viceroy Mendoza hesitated to intervene drastically in the tribute system. In an elaborate report to the king on the state of affairs in New Spain, he wrote that intervention in the local ways of levying tribute was only useful in situations where there already existed a conflict among the Indians of one pueblo. Spanish meddling would otherwise only cause problems."

The Crown was not satisfied with Mendoza's careful adaptations, and constantly pressed her representatives in New Spain to implement more radical reforms. The ultimate objective was, that all Indians would henceforth supply tribute to the king. As had already become clear to all those concerned, this objective could only be attained by gradual change. The Mexican historian Miranda, who has extensively studied the sixteenth-century changes in the tribute system, perceives three phases in the process of change: from the time of the conquest to circa 1550, from circa 1550 to 1577 and from 1577 onwards. ${ }^{2}$

As I have outlined above, in the first phase, until 1550, there were only rather marginal adjustments of the indigenous tribute plus some experiments. The second phase was a much more radical period. It started with the formal separation of tribute and labour services in 1549. As I have discussed in chapter 1, labour services were an integral part of the indigenous tribute system. Because the encomenderos fitted in this system, they received both goods and services from the Indians in their encomienda. The Spanish Crown regarded the unpaid services as a kind of slavery and had urged for their abolition even before the Leyes Nuevas. Notwithstanding the reports of the authorities in Mexico, which stated that abolition would induce severe trouble, the labour services to the encomenderos were abolished in the ordinance of 1549. For the time being, 
however, tribute in kind was maintained, although for the first time a formal separation was made between tribute and labour services."

In addition to an indigenous administration so-called cajas de comunidad were introduced into the altepetl, now called pueblos de indios. All tribute income had to be put into it. The indigenous officials, the gobernador, alcaldes and regidores, in time, lost the right to direct tribute income which was related to their offices. These rights were replaced by salaries that were paid from the tribute income of the pueblo (sobras de tributos). This second phase was painful and radical and lasted for more than a quarter of a century. Not until in 1576 a number of important, institutional changes and, as important but largely uncontrolled, social and economic changes had come into being, could the Crown attain its objective. In that year, the Audiencia promulgated an ordinance that each Indian would have to pay a fixed annual tribute to the king. Henceforth, the tribute was a tax of one peso and half a fanega of maize (1 fanega = ca. 55 litres) per tribute-paying Indian (tributario). After 1576, the annual tribute for the Crown was consolidated. ${ }^{*}$ This second phase in the change of the tribute system was only attained with great difficulty.

\section{Congregations: the first programme}

In my opinion, the so-called congregations of the period 1550-1564 were one of the most important instruments in the execution of the reforms. The missionaries urged the authorities to concentrate the Indians, who were living disorderly and inconveniently scattered all over the land, in settlements based on a Spanish model. They wrote to the king, saying that measures to congregate them, would have a salutary effect on the spiritual care of the indigenous population. As a result, not only the 'empire of Jesus Christ' would be served, but, as they wisely added, the authority of the king would also benefit." Viceroy Don Luis de Velasco, who ruled from 1550 to 1564 , was instructed by the king to co-operate with the friars in congregating the Indians into proper villages. This congregation policy focused on the cabeceras. These were generally moved from their poorly accessible, but strategically favourable, sites on the mountain slopes, to the more approachable plains. In the literature it has repeatedly been pointed out that in this respect, the congregations had a 'military goal' and were a means to introduce a 'pax hispanica'. In my opinion, however, the most important objective was to attain more general political goals for the Crown. As I have argued above, the Spanish policy was intended to establish an administrative system which was based on territorial divisions. As such, the congregations were a result of the Leyes Nuevas, and connected with measures like the tribute reforms and the repression of the encomiendas. ${ }^{\$}$

Before the actual period of the congregations started in 1550 , the city of Tlaxcala had already been created from three or four centres of the prehispanic 
altepetl. These were moved from the slopes of the volcano Malinche to the valley of the river Zahuapan. In the rainy season, the city regularly inundated, because of its situation on the low banks of the river. The same problem occurred in the city of Puebla de los Angeles, which the Spaniards had founded in 1531 on the strip of no-man's-land on the banks of the river Atoyac between the altepetl of Tlarcala, Cholula and Tepeaca. As a result, the authorities were attentive to the risk of flooding in the congregations of the $1550 \mathrm{~s}$. Most cabeceras, such as Huejotzingo, could be moved without any risk of inundation. There was no need to move Tecali and Cuautinchan, as they were situated on accessible sites. Tepeaca was moved from the top of a mountain to a lower spot in the mountains, but not as far as the valley of the river Atoyac. There were plans to move Tecamachalco, but the authorities abandoned the iden, because the only alternative was to shift the cabecera to the banks of the Atoyac, which would create an unacceptable risk of flooding."

There were many congregations in the valley of Puebla, but at this time there were also congregations elsewhere in New Spain. In Michoacán, the indigenous settlements around lake Patzcuaro were included in a congregation, and also in the valley of Oaxaca, the Spanish authorities moved cabeceras from the hilltops to more accessible locations. The valley of Mexico with its population concentrated around the lakes, was largely exempted from the congregations, with the exception of the area around Tlalnepantla which was situated at some distance from the lakes."

Most of the Indian reactions to the congregations have not survived; more detailed information is only available from Acatzingo and Tlaxcala. In Acatzingo seven barrios were consolidated into one town. As a result of the resettlement and the expansion of the town, houses were built in an area which was under the Tepeacan range of influence. After consulting the local Franciscan friar, the authorities compensated the Tepeacan caciques involved.

The Indian cabildo of Tlaxcala was concemed about the economic consequences for the Indian commoners, when, coming from the barrios, they would be congregated into the newly founded city. It reluctantly accepted a decision to this effect, but suggested to start with the resettlement of the richer, and thus economically less vulnerable, macehuales, to shat effect this move would have on them." This proved to be no foolish advice. In the early 1560 s, viceroy Velasco decided to call a halt to the congregations, because they had tumed out to be a much greater burden on the Indians than he had assumed at first. He had already been wamed by his predecessor Don Antonio de Mendoza, who wrote that congregations would prove to be less beneficial on the administrative and ecclesiastical level, than many Spaniards thought. Moreover, they would inflict great harm upon the Indians..$^{\infty}$

In this first period of congregations, only the population living in the centre of the altepetl was congregated into cabeceras, while most sujetos remained where they were. If the congregations of the 1550 s and 1560 s had been no more 
than attempts to concentrate the Indian population into well-ordered settlements, their success was very limited. Nonetheless, they had been a powerful instrument in the introduction of a new administrative and tribute system. In this respect, the objective of the congregations had been to assign all Indians to the administrative authority of a pueblo de indios, which is to say the new territorial unit, rather than to that of a cacique, or the old personal ties. Therefore, taking an analogy from European history, we may characterize this change in socio-political structure as a replacement of the old indigenous Personenverband by a Spanish Territorialverband."

With the introduction of both Spanish provinces and pueblos de indios, the administrative reorganization of society in New Spain had progressed a great deal. This does not mean that all problems connected with the introduction of this Territorialverband had been solved now. For decades, the tribute reforms were still to cause unrest in the pueblos de indios: Indian commoners would protest to nobles who still demanded tribute for themselves in addition to the tribute paid to the king. Moreover, there were nobles who had lost their old tribute rights, and who would employ any legal and, sometimes, illegal means to retain their old position and way of living. The disturbed relations within the pueblos de indios were of great importance to the formation of society in New Spain; they will be discussed extensively below. Nonetheless, to understand these changes properly, we first have to tum to the demographic and related socio-economic developments. These further increased the pressure on New Spain's social relations, which were already tense as a result of the introduction of the administration based on a Territorialverband, and which also created many of the conditions that were important in the changing society.

\section{Demographic development}

The depopulation of Latin America in the first century after the conquest, has been much debated, and the number of studies on the decrease in the number of Indians is large. Data on the period prior to 1570 are scarce and not very reliable, hence estimates of the number of Indians vary considerably. The estimates by Cook and Borah have been most influential for Mexico. They registered a total of 25 million Indians in Mexico just before the arrival of the Spaniards. Notwithstanding the debate, these figures by Cook and Borah have found wide acceptance, not so much due to the result of their sound calculations, as to the lack of data from the time prior to 1570 . Their results have more or less been uncontested for the period after 1570, which interests us here. More information is available on that period, and the various studies on the development of the population after 1570 do not vary too much. However, this period does not supply any sources explicitly compiled for demographic purposes, either. The most accurate data on the number of Indians have been based on the 
fiscal and ecclesiastical reports of the number of Indian tribute payers or tributarias. ${ }^{2}$

The number of tribusarios was important for both Spaniards and Indians, because it determined the amount of the imposed tribute. Even before the arrival of the Spaniards, the Indians had elaborate tribute registers, and this tradition was continued after the conquest. In the registers, the Indian rulers, and in colonial times the local administrators, recorded how many tributarios, widows, disabled, elderly people and so forth, were dependent on them. Only a few of these lists have survived, but it is evident from the sources that all rulers, and later pueblo administrations, had such lists. This is not surprising in view of the interest which the Indian nobility, the later caciques, had always had in keeping an adequate administration and collection of tribute.

Tribute lists were only related to the number of Indians who were liable for tribute. The total population number may be derived from this by multiplying the number of tributarios with the average family size. Since there are no adequate sources available about the period under discussion, it is extremely difficult to determine the average family size. However, this is not important when measuring the fluctuation in the size of the population, because the definition of who was or was not a tributario, did not change in the sixteenth and seventeenth centuries."

Be that as it may, the sources on the number of tributarios are certainly not without any problems, either. The tribute which the various pueblos de indios had to pay, had been fixed on the basis of the number of tributarios. In order to reduce the risk of fraud, the Spanish authorities always demanded access to the tribute registers, for the sake of fixing the tribute sum and other official purposes. Furthermore, the data were often submitted to a personal inspection by a Spanish official. This did not rule out fraud, but by and large we may assume that the Indian administrators, though stating the lowest possible aumbers of tribute payers, did not violate the law.

The data used both here and in other studies, have not only been taken from official reports, but, to a large extent, also from sources compiled by the Franciscans for other purposes. They were meant to be a description of their province (1570), or a report to the Crown, on the basis of which the authorities determined how many Franciscans were needed for an adequate spiritual care in the pueblos (Moderación de dóctrinas from 1588 and 1623). As we may recall, the Crown provided for their support by paying the Franciscans out of the tribute revenues. Hence, we may assume that the Franciscans would state the highest possible number, for example by including the rributarios who were working for Spaniards, and for whom the employer paid tribute, but who were under their spiritual care. After all, high numbers of tributarios were a reason for appointing more friars in the doctrinas."

Summarizing, it may be said that deducing population numbers and fluctuations from the numbers of tributarios, is the only way for obtaining reasonably 
correct figures, since they are based on actual counts rather than mere estimates. However, they do not show the full picture. Generally speaking, they only show the tributarios that came under the authority of the pueblos. This was sufficient for fixing the tribute sum, but for historians it should be a reason to be careful when using these sources for demographic purposes.

To indicate the importance of the decline in the Indian population during the late sixteenth and early seventeenth centuries, I have included tables 2.1 and 2.2. Table 2.1 shows the development of the numbers of tributarios in the provinces of the valley of Puebla, and table 2.2 shows the index numbers of the development. Graph $2 . a$ is based on these data. The numbers of tributarios have been represented by a block. Each one of the five-year periods of which data are known $(1570,1588,1600,1623,1643)$, has been shaded differently. The tribute counts lead to the predominant, hardly surprising, conclusion, that the Indian population had sharply dropped in 1640 , in comparison with 1570 . The graph shows a real implosion. The low point in the development occurred between 1620 and 1630 . In general, numbers had slightly risen in 1643 , compared to the data of 1623; the situation was most favourable in the alcaldia mayor of Puebla. The exceptions to this rule are Cholula and Tochimilco, where the number of tributarios continued to drop. In the case of the marginal province of Tochimilco, high on the slopes of the Popocatepetl, it is likely that a migration to more central areas took place. In Cholula, the continuous decline in the number of tributarios may be explained by the migration to nearby Puebla. This city took over the role of Cholula as a centre of commerce, as a result of an increasingly growing number of Spaniards and the economic stimulation politics by the Crown.

In my opinion, migration also occurred in the other areas of the valley. At first sight, this may not seem very logical since the population in all provinces of the valley dropped to the same extent. This is, however, a weak point in the source material used. I have explained above that the data come from the tribute registers that were kept in the pueblos de indios, and that the number of tributarios can therefore only inform us of the number of Indians living within the pueblos. From the early colonial years onwards, there had been complaints about the large number of people wandering about the country. These people were Spaniards, mestizos and mulattoes. In the literature, much attention has been paid to these Spaniards, mestizos and mulattoes, who are supposed to have given the Indians in the rural areas a hard time, with their thirst for wealth and undisciplined behaviour."s

On the other hand, many authors have pointed out that many Indians migrated as well, as they withdrew from the congregations, in order to return to their former settlements. In the society of the sixteenth and seventeenth centuries, Indian migration became a serious problem. When the city of Puebla was established in 1531, the Indians were allowed to settle there without being liable for tribute, provided they would be willing to execute paid labour for the Spaniardds. The Crown even saw itself repeatedly obliged to revoke ordinances 
Table 2.1: Number of tributarios in the valley of Puebla, 1570-1640

\begin{tabular}{lcccccc}
\hline Piaces/Years & 1570 & 1588 & 1600 & 1623 & $1630 / 9$ & $1640 / 9$ \\
\hline A.Aulixco & 9612 & 4908.5 & 5230 & 2500 & \\
B.Cholula & 12000 & 8114 & & 3644 & 2873 \\
C.Hueiotzingo & 6270 & 5543 & & 2167 & 2259 \\
D.Tecali & 6000 & 3412 & 3282 & 1518 & 2287 \\
E.Tepeaca & 25300 & 17067 & 11500 & 6632.5 & 7766 \\
F.Tlaxcala & 40000 & 24000 & 16000 & 10099 & 12692 & \\
G.Tochimilco & 3000 & 1206 & & 474 & 342 \\
H.Puebla (jur) & 4570 & 3760 & 3275 & 2622 & 3143 \\
\hline Total & 106752 & 68010.5 & & 34341.5 & \\
\hline \hline
\end{tabular}

Table 2.2: Indices of the number of tributarios in the valley of Puebla, 1570-1640

\begin{tabular}{lcccccc}
\hline Places/Years & 1570 & 1588 & 1600 & 1623 & $1630 / 9$ & $1640 / 9$ \\
\hline A.Allixco & 100 & 51.1 & 54.4 & 26.0 & & \\
B.Cholula & 100 & 67.6 & & 30.4 & & 23.9 \\
C. Huejolzingo & 100 & & & 35.2 & & 36.0 \\
D.Tecali & 100 & 57.0 & 54.7 & 25.3 & & 38.1 \\
E.Tepeaca & 100 & 68.3 & 45.5 & 26.2 & & 30.7 \\
F.Tlaxcala & 100 & 60.0 & 40.0 & 25.2 & 30.7 & \\
G.Tochimilco & 100 & 40.2 & & 15.8 & & 11.4 \\
H.Puebla & 100 & 82.3 & 71.7 & 57.4 & & 68.8 \\
\hline Total & 100 & 46.0 & & 32.2 & & \\
\hline
\end{tabular}

Talic numbers are extimates. Underlined names of provinces indicate that the tigures for those provinces consist of data for several cabeceras.

Sources: Biblioteca Nacional de México-Archivo Franciscano-Caja 89-exp.1376; Archivo General de la Nación (México)-Tierras-Vol.27-flv; "Memoriales del obispo de Tlaxcale, Fray Alonso de la Mota y Escobar," Anales del Insrinuto Nacional de Antropologia e Historia, I (1939-1940) (Mexico City, 1945), 192-304; "Relación particular y descripción de loda la provincia del Santo Evangelio...," in J.García Icazbalteca, Nueva colección de documenros para la historia de Mérico. Siglos XVI y XVII, (Mexico City, 1892), Vol. II, 1-28; Gabriel de Rojas, "Descripeión de Cholula," Relaciones Geogricas del Siglo XVI: Thaxcala, 2 Tomos., René Acuña, ed., (Mexico City, 1984-1985), 123-148; Moderación de doctrinas de la Real Corona, administradas por las órdenes mendicantes (1623) F.V.Scholes and E.B.Adams, eds (Mexico City, 1959); P.Gerhard, A Guide to the Historical Geography of New Spain (Cambridge, 1972); W.Trautmann, Der Kolonialzeitliche Wandel der Kulturlandschaft in Maxcala. Ein Beitrag zur historischen Landeskunde Mexikos unter besonderer Berilcksichtigung wirtschafts- und sozialgeographischer Aspeke (Paderborn, 1983), 404-405 


\section{Graph 2}

\section{Demographic Development}

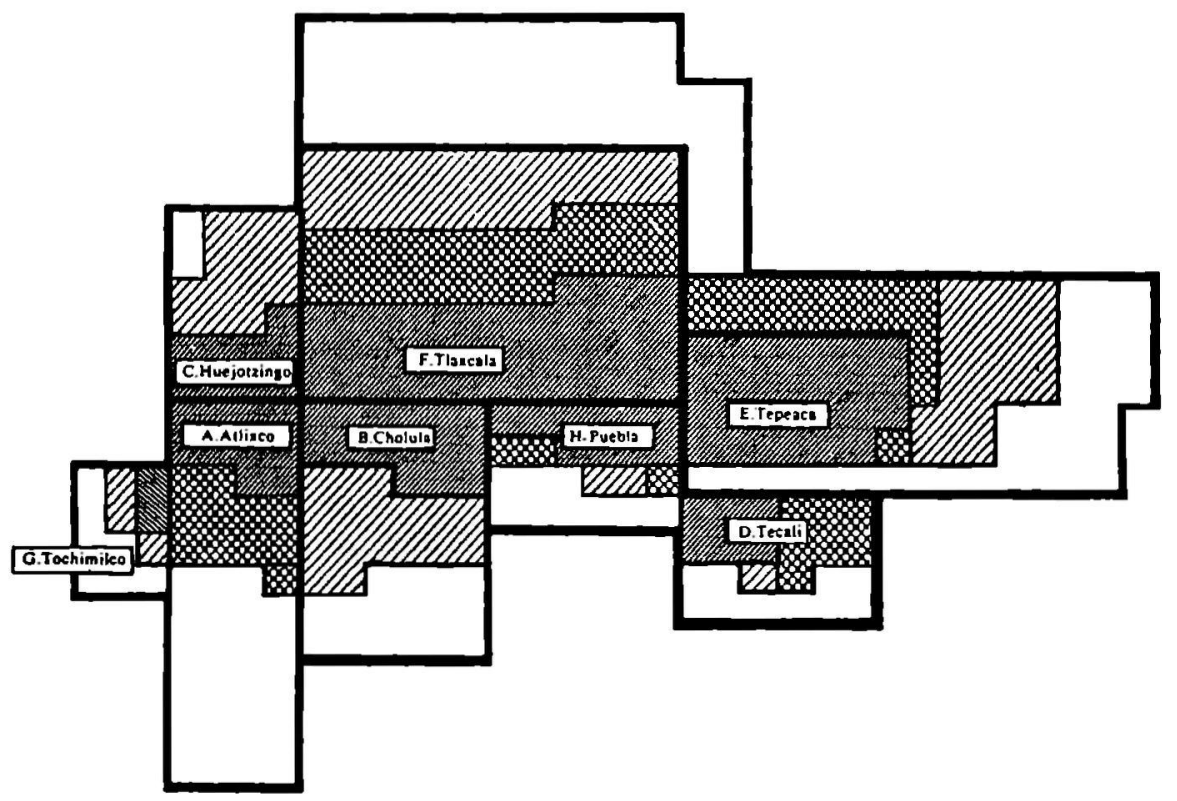

Graph 2.a 1570-1623

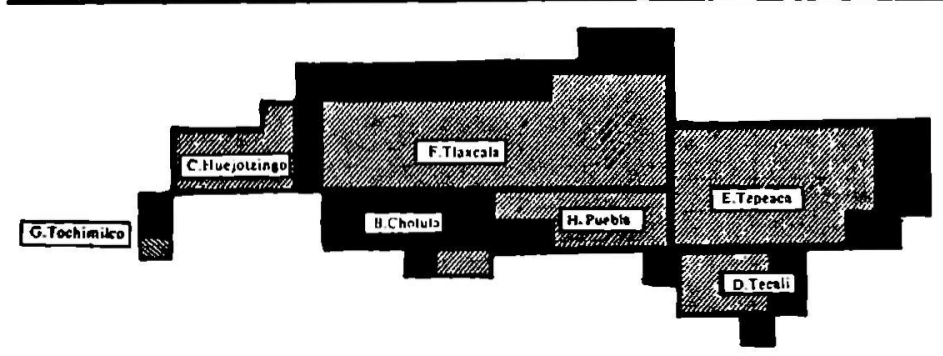

Graph 2.b 1623-1643

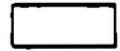

1600
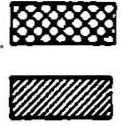
which allowed the Indians to go wherever they wanted. In the city of Mexico, viceroy Luis de Velasco promulgated an ordinance, aimed at banishing 'vagabondism' of whatever kind:"

'In this city of Mexico there are many vagabond Indians, both of those bom here and of those from other parts, who appear in and come to this city, who do not have work nor want to serve anyone and wander about idly and [who] commit some excesses to which idleness gives them occasion. And because it is convenient to the common wealth of the republic that the foresaid stops and other inconveniences that might come to pass [as well], and in order that such Indians put themselves with masters, there should be a father for them, who would take care to put them with masters'.

Following this ordinance, two Indian officials were appointed for this purpose. The Spanish cities were not the only official bodies to express concern over the roaming Indians: the Spaniard López de Velasco, who wrote a description of Spanish America in 1570, noted that many Indians came to Tlaxcala from neighbouring provinces, because the Tlaxcaltecs had been exempted from tribute payments to the Crown, as a result of their assistance in the conquest.

The lack of sources makes it impossible to determine the accurate quantitative size of the Indian migration and it is even hard to give some idea of its size. Nonetheless, there are some sources that allow a little insight. In the documents belonging to the Matricula de Huexotzinco, which was a census of tributarios in Huejotzingo, the caciques of the town complained that many of their subjects had migrated to Tlaxcala. In the light of the personal ties between lord and vassal, these migrants who withdrew from the power of their cacique, were referred to by the term huidos, 'fled'. In 1560, five percent of the macehuales in the Matricula were huidos, compared to a census of two years before. Yet, Indians were not only leaving Huejotzingo. There were also groups of macehuales in Huejotzingo referred to as 'just arrived'. Huidos are not only mentioned in the tribute lists of Huejotzingo, but also nearly always in the records on gananes, the permanent Indian workers on haciendas. As both the data from the haciendas and the Matricula are isolated data, it is not possible to estimate the number of these indios vagamundos, as they were called in official documents. On grounds not further specified, the historian Miranda estimates their number to have increased to as much as forty percent of the total tributary population in the second half of the seventeenth century. The Indians migrating from the pueblos de indios where they were tributarios, fell outside any form of official record, so that their number will remain unknown forever."

Upon closer examination, however, the sources used above to determine the number of tributarios, show a little of this 'invisible part' of the population. In the case of Cholula and Huejotzingo, there are counts for 1623 and 1626. In both provinces the number of tributarios was twice as high in 1623 as in 1626. The data for 1623 have been taken from the Moderación de Doctrinas, which, as I 
have explained above, was used to determine the number of Franciscans needed for proper spiritual care. The figures of 1626 are connected with the determination of the tribute sums for the provinces. There is no way one can prove the correctness of the figures in this comparison, but they do make it very likely that, at least in the early part of the seventeenth century, there was a considerable number of Indians either in Spanish service, living in the Spanish cities, or wandering about in the rural areas.

The Indian administrators of Cholula stated in 1589 that in this province there had been: ${ }^{\text {T }}$

'For more than seven years many Indians who bave fled from other parts, who are only absent from their places of birth in order not to pay the tributes they owe to his majesty [...]. [And because they] have not been recorded in tribute lists until now and have not been registered anywhere they [i.e. the Indian administrators] asked to decree that they [i.e. the migrants] should be obliged to pay tribute just like the other Indians of the said city [of Cholula]'.

The problem of the indios vagamundos was not confined to the central parts of New Spain. Similar reports came from the newly established city of Oaxaca, several hundreds of kilometres to the south of Mexico City, which gives an indication of the distances covered by the migrating part of the indigenous population:"

'Every day several Indians from Tlaxcala, Guaxocingo [Huejotzingo], Teguantepec and other parts come to settle in the said pueblo of Guajaca [Oaxaca] and have their houses, wives children and lands in it. And [...] even though they benefit from them [i.e. their lands and houses], they do not want to pay the tribute they owe, which harms the pueblo'.

The distances which the migrants travelled were often remarkable, as is clear from the example above. The so-called asientos de trabajo, the notarial records containing labour agreements between Spaniards and Indians, allow us to go into some detail. On Map 3, I have indicated from what parts of the country the 344 Indians came, who made labour contracts with Spaniards in Cholula between 1590 and 1599. The Spanish employers were mainly owners of textile plants (obrajeros) and to a lesser degree farmers (labradores, now usually called hacendados). As can be expected, the majority of the Indians came from the province of Cholula itself (50.1 percent). Among the areas outside of Cholula, the neighbouring provinces of Tlaxcala (21.9 percent), Puebla and Huejotzingo (both 8.9 percent) and Tepeaca (5.3 percent) were the most important ones. Other areas in the valley (23 peercent) and the valley of Mexico also supplied many migrant labourers (15.4 percent). The most striking aspect is, however, that there were also Indians who came from much farther away (16.6 percent), all the way from Yucatan, Tehuacan and Guatemala in the south and Michoacan in the west. 

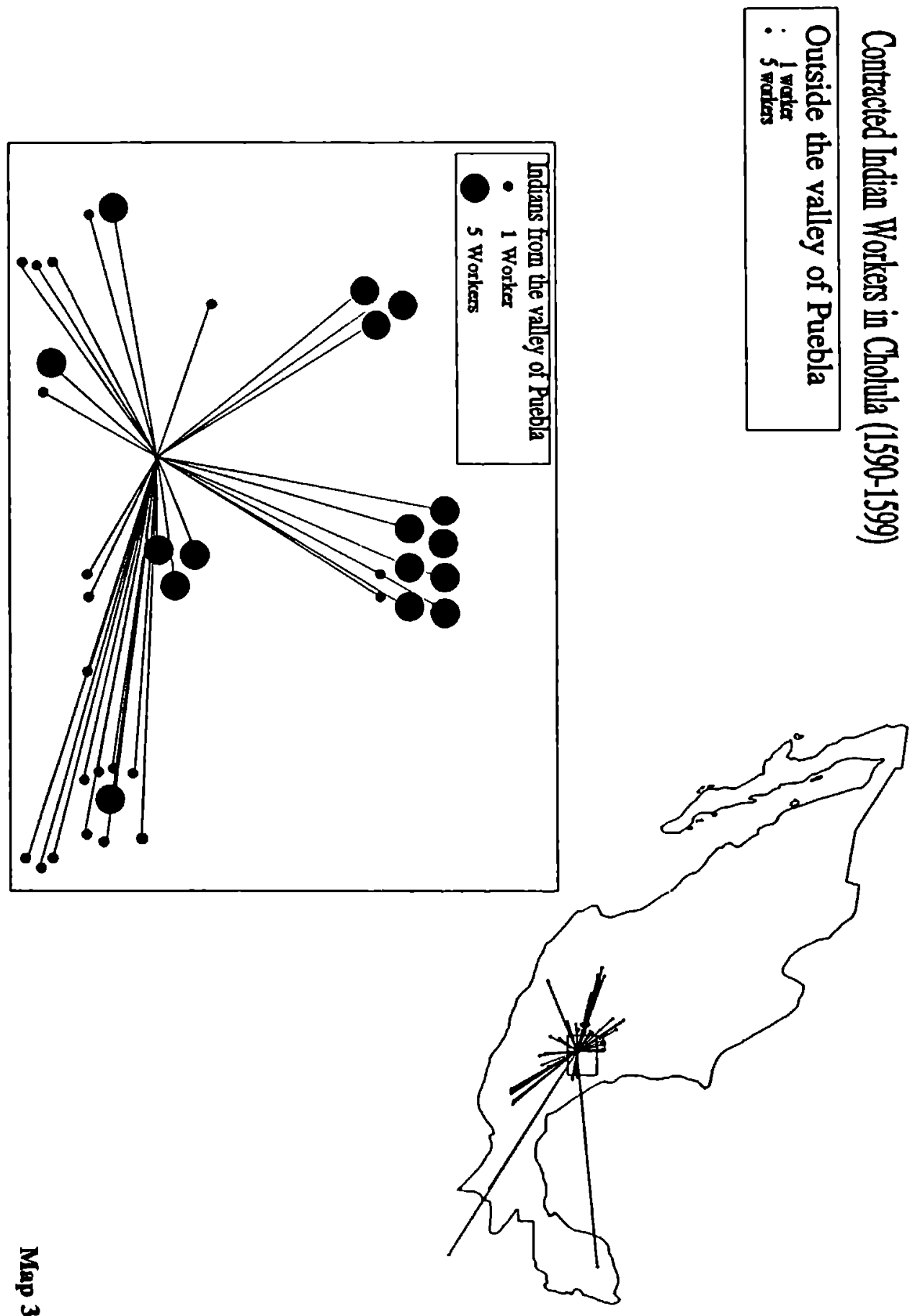
Summarizing, we may state that contrary to what has generally been assumed, the indigenous population was not static but rather very mobile. In this respect, the Indians resembled the European rural population of the time. ${ }^{n}$

The reasons for migration were the flight for epidemics, the heavy tribute burdens and the labour services, and the increase in possibilities outside the home towns in the late sixteenth and early seventeenth centuries. Studying migration has made it clear, that a significant part of the population in the sixteenth and seventeenth centuries is beyond our scope. These people fell outside the category of tributarios within the jurisdiction of a pueblo de indios, and only ended up in the sources by accident. Further detailed -and painstaking- investigations of the available sources, could possibly bring to light more and more coherent data on the scale of the migration in the early colonial era."

Apart from the individual migration, relocation of groups of the indigenous population also occurred, for which migration may not be the appropriate word, even though they were of demographic importance. The most important examples were the congregations of the population. As indicated above, there were two periods of congregations. A first one took place in the years 1550-1564, under the authority of viceroy Don Luis de Velasco. It has already been discussed above. The second period of congregations, the only ones with a proper programme, lasted from 1598 to 1607 . It was a more ambitious undertaking than the previous ones of half a century before. In the central parts of the valley of Puebla and also in those of Mexico and Toluca, the congregations concerned relatively few Indians, so that their demographic consequences were limited. This does not mean that they were not important, but their importance lay in the way of a further arrangement and institutionalization of the Spanish-Indian relations, as will be elaborated in chapter $3 .^{14}$

The Crown also moved Indians for other reasons than to accomplish the congregations. The Tlaxcaltecs, the former allies of the Spaniards, were regularly used to colonize the largely uninhabited northern borderlands of New Spain. With the decrease in population, resistance to these replacements was growing, and in the course of the sixteenth century they became increasingly rare. ${ }^{79}$

The most important impulse for colonization originated with the Indians rather than the Spaniards. Indian colonization became possible when the old buffer zones between the different altepetl had disappeared. After the Leyes Nuevas of the 1540s, the borders between the altepetl were changed into province borders. The caciques considered it their right to exert Herrschaft on these former no-man's-lands, which had now come under the sphere of influence of their altepetl, or rather pueblo de indios. An example is the province of Huejotzingo, of which viceroy Mendoza wrote to his successor Don Luis de Velasco, that the nobles distributed all wastelands among themselves: ${ }^{\text {}}$

'When Fray Antonio de Ciudad Rodrigo was guardián of Guaxocingo [Huejotzingo], the Indian nobles (indios principales) of that pueblo divided almost 
all vacant lands among themselves. I, having just arrived [and] being anxious to do something for the Indians, without further consideration approved and confirmed this division. [But now] I have understood that this was most harmful to the republic. Your Lordship [i.e. Don Luis de Velasco] has to look upon it and, even though it is most inconvenient with these people to return to past matters, this matter is of the kind that cannot bear to be left as it is'.

The division of the no-man's-land among the Indian nobles, may also have occurred in the surrounding provinces. These areas remained vacant, but some attempts at colonization were undertaken from the over-populated province of Tlaxcala. The procedure of colonization was by the prehispanic tradition: a cacique would give land to a small group of Indians under the leadership of a low-ranking noble. In this way, some parts of the banks of the rivers Atoyac and Zahuapan were colonized, but also an area east of the volcano Malinche which had formerly been uninhabited. Here, Huamantla and Nopalucan were founded. In both cases, the colonists had to continue paying tribute to the caciques under whose sphere of influence they fell. They may have been exempted from tribute for the first few years, in order to enable them to settle and prepare the land for cultivation. This kind of exemption was at least common in a later period when Spaniards started renting wastes.

There was also colonization in other provinces. In Cholula, the banks of the Atoyac were colonized as well, especially in the area around Tultzingo, albeit on a much smaller scale than in neighbouring Tlaxcala. Perhaps the congregation of Huejotzingo from the higher slopes of the volcano Ixtaccihuatl to the banks of the river Atoyac, initiated by the Indians, should be regarded as part of the process of colonization of lower-situated areas, too. There are fewer data on the provinces situated to the east of the city of Puebla, of which it is only known that Santo Tomás, a sujeto of Tepeaca, was founded in the 1540s." Indigenous colonization ceased to continue as the population density dropped due to depopulation. Moreover, the caciques soon noticed that, even though colonization meant an extension of their influence over newly incorporated areas and a growth of their wealth, it was difficult to maintain and impose their traditional Herrschaft on the Indian colonists, especially as the tribute reforms changed the relations between the Indian lords and macehuales. Above all, however, the Indians increasingly had to reckon with the Spanish presence in the valley of Puebla. The number of Spaniards has not been well documented. It is not surprising though, that in less than a century, between 1570 and 1662, their number appears to have grown from a few hundred to about five thousand Spanish vecinos -family headsin the entire valley of Puebla. The latter mostly settled in the few urban centres, of which the cities of Puebla, Tlaxcala, Cholula, Huejotzingo and Tepeaca in the valley of Puebla and the town of Atlixco in the valley of Atlixco, were the most important ones. During this period they never accounted for more than fifteen or twenty percent of the entire population, yet the rate of Spaniards compared to 
that of Indians doubled. Most of them lived in the cities and seldom came into contact with Indians in the countryside, even though there always were Spaniards occupying themselves with business outside the urban areas. ${ }^{70}$

In the New Spain of the second balf of the sixteenth and the first half of the seventeenth centuries, there was the remarkable phenomenon of both a dramatically decreasing Indian population and, in addition, a large number of Indians withdrawing from the influence of the pueblos de indios, while on the other hand the number of Spaniards increased. The demographic changes showed a shifting balance of population numbers towards the urban areas. Together with the institutional changes of the middle of the sixteenth century, the demographic changes put an increasing pressure on rural society and especially the pueblos de indios. Traditional ways of supplying food began to fall short and in the middle decades of the sixteenth century the social relations of the conquest society could not remain intact.

\section{A new order, new problems}

The introduction of Spanish rule brought important changes for the Indian population of Central Mexico. The upper ranks of the Indian nobility lost their supremacy to the Spanish Crown. The most radical change was caused by the new administrative division based on a Territorialverband. It sprang from the Crown's wish to get a firmer grip on its new territories. This wish was frequently expressed during the first decade of Spanish rule and found its final expression in the Leyes Nuevas of 1542-1543. The Territorialverband got its Mexican form through the demarcation of the provincial borders and the foundation within each province of one or more pueblos de indios; these were the elaborations, on a regional level, of the fundamental division of the state into two 'republics', a Spanish and an Indian one, which basically were the projection of a state divided into estates. The new provincial division coincided by and large with the former independent altepetl. The provinces became the most important regional units and they were placed under corregidores and later under alcaldes mayores. All Spaniards in a province fell under the jurisdiction of these regional magistrates.

The Leyes Nuevas did not just affect the power of the encomenderos, who had been the first Spanish authorities for the Indians, but were also directed at the autonomy of the indigenous caciques. The latter were especially affected by the reforms of the 1550 s, as they lost most of their rights to tribute. The tribute was transformed into a tax based on the number of tributarios and was levied per pueblo de indios. The ecclesiastical system of cabeceras and sujetos -already established by the missionaries-, was used during the congregations to form the pueblos de indios. These were placed under Indian leadership, and became the most important local administrative instrument. As a result of the new tribute system, in the congregations of the 1550s the Spaniards authorities assigned all 
Indians to pueblos de indios. With this measure, all inhabitants had been formally divided according to the administrative division of the Territorialverband. The hierarchic lines may be summarized as follows: the king was the undisputed head. He was advised by the Council of the Indies. Far away from the colonies, the government in Spain could only outline the political framework. In the colony of New Spain, the viceroy was the head of the administration. He was assisted in this task by an Audiencia. The inhabitants of Mexico -as was the case in the other Spanish colonies- were all subjected to his authority, at least as far as temporal matters were concerned. The country was divided in provinces, alcaldias mayores. An alcalde mayor had jurisdiction over all inhabitants of his province, both Spaniards and Indians. However, there was a legal difference between the position of Spaniards and Indians, because they were members of different republicas. The Spaniards were put directly under the authority of the alcalde mayor, whereas the Indians in first instance fell under the jurisdiction of a pueblo de indios. These official divisions are summarised in figure 2.1.

Officially, Spaniards and Indians were supposed to live separately, but in practice this rule proved to be ineffective. These different legal positions also involved different rights and duties. Two examples may illustrate this. To take the most obvious, Spaniards and Indians had different fiscal duties: Indians paid tributes, but were largely exempted from the Spanish sales tax (alcabala). The second example is more complicated, but an expression of the same principle. The Indians were regarded as legal minors and 'miserables' of the king, who needed his protection and a continuous guidance and education in religious matters by the clergy and Spanish officials. Besides these two basic estates, there were groups, which were not at all, or only partly, subjected to these jurisdictions, like the clergy, and later the children of parents of mixed racial backgrounds, of whom the mestizos were the most important group.

The fiscal system was structured in accordance with this territorial organization. For the república de indios this meant that, officially, no Indian noble had a right to tribute any longer, and that only the caciques and their eldest sons were exempted from tribute rights. All those formerly entitled to tribute, should now be paid from the tributes that were centrally collected per pueblo de indios.

As the Indian population decreased and more and more Indians migrated from the pueblos de indios, less and less food was produced in the rural areas. The migrating Indians no longer produced food, but still had to be fed. The growing Spanish population in the cities also needed more food than ever. In the demographic development there was a contradictory tendency, of which the economic results reinforced one other: as the supply of food decreased, the demand increased.

The decrease in the supply was strengthened by the effects of the reform of the tribute system after 1550. This reform had two sides: in the first place, between 1548 and 1570 , the tribute of the pueblos de indios was gradually 


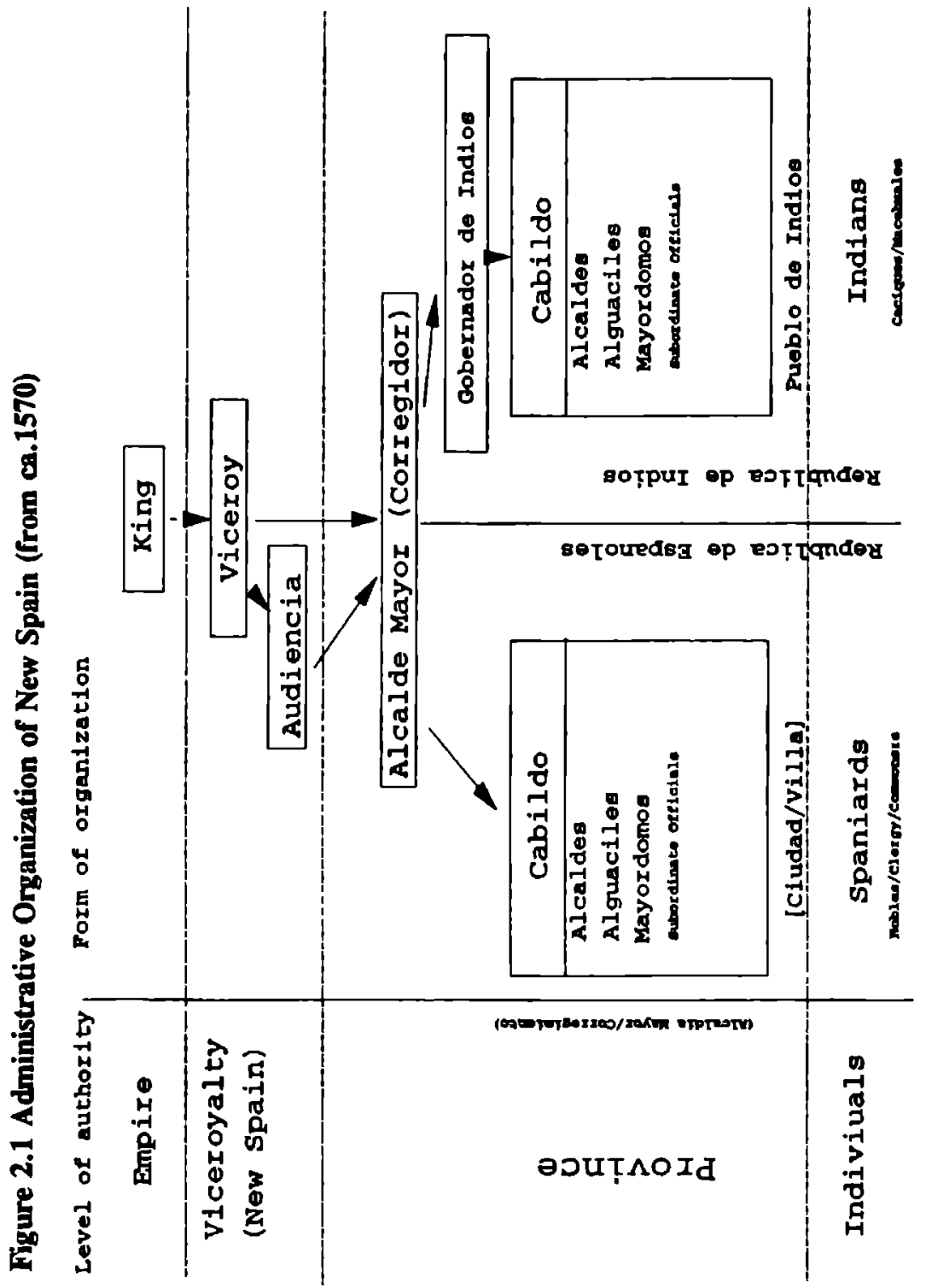


changed into a fixed tribute sum in money plus a limited amount of maize per head. As this was a gradual change, adaptation to the new tribute system could be gradual as well. The abrupt abolition of the Indian personal services in 1549 was far more radical. This largely paralysed the supply system of MexicoTenochtitlan which depended on Indian carriers. As I have mentioned in chapter 1, this supply was based on tribute supplies from the alkepetl, of which transportation was an integral part. Viceroy Luis de Velasco did not know how to cope with the severe decrease in the supplies to the capital. In 1553 he wrote:"

"The Spaniards are very resentful because the New Laws touch them all. The Council [of the Indies] has declared that it is personal service for the Indians to bring royal and private tributes to this city. Since the greater part of such tribute is in foodstuffs [...] there is much want in the city [of Mexico], and I find no means of provisioning it, because, if the Indians do not do it, no disposition which I or the Spaniards will make will suffice to provide the city even with bread and water and fodder for the horses, which are the strength of the country [...]. There are usually 200,000 mouths [to feed in Mexico City]. Consider, your Majesty, how they are to be fed, for there are not among them a thousand farmers, and the city is surrounded by a lagoon, unless [food] be brought in from without [...]. The provisioning of this city with wheat and maize -as well as all the other cities in the country- cannot be done unless it be done with Indians [...]. As personal services are removed, the necessity becomes as great as that of a city besieged".

The most pressing situation existed in the city of Mexico, but the effects of the measure were also felt in other cities with a growing population of Spaniards and Indians. The cities, and to a lesser degree the mining centres, were the only places with a considerable population that did not produce food, but had to buy it on a market that was supplied from the outside. As a result, a serious scarcity was imminent, which could not be solved easily. Notwithstanding all these problems, the Crown in Spain categorically refused to reinstate the personal services, because it regarded it as a kind of slavery, which was contrary to the royal duty of protecting the Indians.

The problem also had another dimension. As a result of the depopulation of the pueblos de indios and the tribute reforms, the food supply of the Spanish population centres strongly decreased. At the same time, the number of inhabitants of these centres increased and with it the demand for food, especially wheat. Even though from early colonial times on, the authorities in New Spain had attempted to make the Indians cultivate wheat, Indian agriculture remained focused on maize. This had several practical reasons. The Indian milpa system was quite different from the agricultural system the Spaniards had introduced from Europe. The milpas were susceptible to erosion and, consequently, not well suited for tilling with ploughs and extensive wheat cultivation. Moreover, wheat did not fit in the mixed cultivation of crops that was practised on the milpas and 
would have greatly disturbed it. The clayey soil of the riverbanks was more suitable for the cultivation of wheat, but cultivating these wastelands was a rather arduous task. On top of all these agricultural problems, the Indians were used to maize products. If enterprising Indians had been wanting to start cultivating wheat despite all objections, they would not have been able to take the wheat to the urban markets, because there was no infrastructure. All in all, the structural problems for the Indians to start cultivating the Spanish staple crop, were almost insuperable in early colonial times. Thus, it is not at all surprising that in 1550 , some three decades after the conquest, viceroy Mendoza complained that, notwithstanding all his efforts to stimulate the Indians, the Spaniards still were the only ones who cultivated wheat." Even in the following decades, the situation only changed very slowly. As explained above, in the second half of the sixteenth century, the urban population grew and the countryside depopulated. The effects as far as food supply was concerned, became particularly pressing after the dramatic cocoliztli epidemic which took a heavy toll of the Indians in New Spain. The late 1560 s and early 1570 s, the enforced tribute reforms became stricter all the time, with all concomitant effects on the food supply. All these developments resulted in a growing urban demand for food and an increasingly favourable climate for Spaniards who were willing to try their luck in agriculture."

Many of the Spanish colonists had few economic occupations or possibilities. Their hopes of an encomienda had disappeared after the containment of the encomenderos by the Leyes Nuevas. As a result, they started to cultivate wheat even though production increased at too slow a pace in the eyes of the authorities. At first, the cultivation of the European crops remained confined to the direct surroundings of the Spanish population centres. In 1561, the oidor (member of the Audiencia) Ceynos declared that Tenochtitlan which formerly had only had a small fringe of agricultural land, was now surrounded by:

'Pastures, gardens and estates of our people [i.e. Spaniards]. In a circle of two miles around this city, Don Antonio de Mendoza in his time and Don Luis de Velasco in his, granted land to our people in order to sow wheat on lands that were found not to be tilled by the Indians, which [now] yield 50 or 60,000 fanegas $[\ldots]$. If this were not the case, one would not be able to live here [in Mexico-Tenochtitlan], as there would be no means to subsist on'.

The city of Puebla de los Angeles was founded in 1531 for the very purpose of constituting a community of Spanish farmers. To this end, its citizens were granted land in the valley of Atlixco. The farms in the valley of Atlixco were to supply the necessary goods for the city of Puebla. The plots of land granted to its vecinos, however, were small and not suited for wheat cultivation on a large scale. Even when the demand for food started to increase in the middle of the sixteenth century, wheat haciendas were not immediately founded. Except for the immediate vicinity of the cities, few Spanish agricultural enterprises developed. Before the great changes of the last decades of the sixteenth century it was 
sufficient that a Spanish system of transportation came into being to take over the role of the carriers and to transport food from the pueblos de indios to the still small urban markets. Spaniards with a sense of enterprise started breeding horses, cattle and mules along the major roads and around the cities. Amelioration of the road system was given priority. Previously it had only been used by human carriers, but now it had to be largely adapted to transportation with carts. This process was not entirely without problems. Usually, Indians in a certain area were ordered to build and maintain bridges, to improve roads and so on." In Mixtepec, to the south of the valley of Puebla, the Indians were ordered to stop digging game traps in the road, because these were so well hidden, that horsemen had fallen into them several times already, which had proved fatal to the horses."

The valley of Puebla was crossed by two important roads: the main road (camino real) from Mexico City to Veracruz on the Atlantic coast, and the road to Oaxaca in the south through Puebla and Tehuacan. The road to the south dated from prehispanic times, when it had connected Cholula with Oaxaca. The camino real from Mexico to Veracruz, however, was a new element in the geography of the valley. In prehispanic times there had been a road from Tenochtitlan to the Atlantic coast, but it had been of little importance, because there had been no important concentrations of population there, and the Indians of the central highlands had had no connections over sea like the Spaniards. Besides, the road had passed through the Sierra Norte de Puebla, where carriers could regularly be refreshed without being threatened by hostile attacks. Both the barren territory north of the altepetl of Huejotzingo and Tlaxcala and the Llanos de Ozumba, had been absolutely unfit for indigenous transportation, because there had been no road stops, the area had been too dry for carriers and it had bordered on the territory of the altepetl of Tlaxcala and Huejotzingo, the enemies of Tenochtitlan."

This changed after the invasion. Veracruz was the only Mexican harbour for fleets to and from Spain during the entire colonial period. Consequently, a proper connection between the cities of Mexico and Puebla and Veracruz was indispensable. It was natural to construct a road through the northern parts of the provinces of Huejotzingo and Tlaxcala, because the area was flat and provided the shortest connection with the valley of Mexico. When the central valleys had been pacified, hostile attacks were no longer a threat to provisioning the road, as there was enough room for both extensive stock breeding and resting places for the animals. Therefore, in about 1550, many livestock haciendas came into being in the northem areas of Huejotzingo and Tlaxcala on the periphery of the valley of Puebla, in the Llanos de Ozumba and in Texcoco in the valley of Mexico. Here horses, cattle and mules were bred."

Along the roads through the valley of Puebla proper, the Spaniards also started livestock baciendas, but this had another reason. During the sixteenth century, many textile factories (obrajes) were founded in places like Puebla, Tlaxcala and Tepeaca. These predominantly produced woollen fabrics and were 
supplied by the small livestock haciendas in the valley. Neither the Spanish authorities nor the Indians were very pleased with the breeding of sheep on the riverbanks in Tlaxcala and in the more populous parts of Tepeaca. At first, the sheep were badly guarded and often found their way into Indian milpas where they served themselves of the maize and badly damaged the crop. The cattle that was kept too close to Indian settlements also harmed the crops. Because of this, the authorities took measures to contain the breeding of cattle by banning it to the extensive uninhabited areas north of the densely populated central highlands. From then on, livestock haciendas only remained in the dry and barren areas north of Tlaxcala and Huejotzingo, directly along the camino real. The cattle that remained in the valley after about 1560 , were used for ploughing and as draught animals.

From about 1570, a number of wheat-producing centres rapidly developed, especially in the valley of Puebla. In the Atlixco-area the small farms of the early days proved to be not profitable enough, particularly after the ban on the cultivation of cash crops such as vines and silk. Towards the end of the sixteenth century, there was a distinct concentration of Spanish landownership in Atlixco, and the inefficient small plots were replaced by larger wheat haciendas, or labores as they were usually called. A second wheat area of importance came into being in the plains of San Pablo, east of Tepeaca. These two centres were geographically connected by an almost continuous strip of labores which were founded in the late sixteenth century on the banks of the rivers Atoyac and Zahuapan. At the turn of the century, the valley of Puebla had become a very important centre of wheat production, which supplied both the city of Puebla and the greater part of the camino real to Veracruz and the fleets to Spain. In addition, the Spanish garrison in Havana on the island of Cuba, was supplied with grain from Atlixco during the entire colonial era. In this way, Atlixco took over the role of Andalucia, where, according to the historian Vassberg, agriculture flourished from about 1540 to 1570 , due to the growth of the Atlantic markets. After this period, the Spanish producers lost a significant part of these markets, as the overseas territories became increasingly more autonomous."

As a result of these developments, more and more Spaniards in the valley of Puebla became involved in agriculture towards the end of the century. The formation of Spanish landownership was a painful episode in the history of New Spain. Whereas until about 1570 , the Indians had been the only ones at work in agriculture, the participation of the Spaniards caused a rivalry among the two population groups in the countryside, which further complicated the already existing problems. The Indian nobility started to resist the growth of the number of Spanish labores, while an increasing number of Spaniards tried to set up agricultural enterprises. As tensions increased in the countryside, it became clear that the agricultural problems had to be solved, if society was to continue to function. After several decades, a solution could be reached, but the authorities 
had to put in many efforts. This solution inevitably led to changes in the structure of both the economy and of society at large. 



\section{Chapter 3}

\section{A New Division of Land}

The formation of Spanish agricultural enterprises during the sixteenth and seventeenth centuries is a much-discussed episode in Mexican history. Even though a lot has changed in the view on Spanish haciendas in late colonial times, up until now, little research has been conducted into the actual formation of the labores (now mostly indicated by the more general term haciendas) during the early colonial period, the sixteenth and seventeenth centuries. Therefore, the picture is still based on older literature which states that the evolution of rural Mexican society consisted of a number of developments which succeeded each other according to a social logic. Although interpretations vary somewhat, most authors assume that Spanish landownership came into being at the expense of the Indians. They suggest a causal connection between such late sixteenth and early seventeenth centuries' phenomena as the mercedes -traditionally regarded exclusively of grants of land by the Spanish authorities-, the second programme of congregations at the turn of the century, sales of land on the part of the Indians and the formation of haciendas. The overall result has been expressed most characteristically by the Mexican historian Florescano:'

"The appropriation of the best lands by the Spaniards, and sometimes their mere presence, obliged the Indians to install themselves in regions of retreat [...]. Thus, the irrigated lands and the main valleys (Mexico, Toluca, Puebla) were incorporated little by little into the new agriculture while the Indians withdrew to the mountainous and least accessible regions".

In this view, there were three main ways for the Spaniards to obtain Indian land: through outright force, through (sometimes forced) sales, and through mercedes. Gibson describes how a hacendado who wanted a merced, conspired with officials against the indigenous population. The Spaniard claimed that the land he wanted was not used by the Indians. Wastelands were royal property under Spanish law, so the authorities could grant someone a merced, if the claimant could prove that the land lay waste. According to Gibson, it was generally pointless for the Indian towns to protest. ${ }^{2}$ From this point of view, the congregations of the turn of the century were used to remove the Indians from their settlements on fertile land to villages that were situated on much poorer soil, in order to vacate land for Spanish agriculture. 
The connections assumed in the formation of labores, imply that cause and effect would have succeeded each other in time. To get a firmer grip on the chronology of the phenomena in the late sixteenth and early seventeenth centuries, I have quantified as many of the data as possible. The general trend in the formation of baciendas in the valley of Puebla may be observed in an analysis of the quantified data on grants of mercedes and sales of land in the provinces of Cholula, Huejotzingo, Tepeaca and Tlaxcala. In the case of congregations, quantification is useless, as they were not a spontaneous phenomenon, but the result of planned actions by the authorities, all taking place during a single period.

Graph 3.a shows the number of sales of land in the various provinces, and in graph 3.b, the number of mercedes is shown. It appears that the granting of mercedes did not occur simultaneously with the sales of land. Mercedes were granted until 1615, long after the Indians had stopped selling land to the Spaniards at the beginning of the seventeenth century. ${ }^{3}$ In the case of Cholula, only data on the period between 1590 and 1599 have survived, which makes a comparison difficult. There were many sales of land in Cholula then. In the late 1570 s and the early 1580 s, there were years when quite a number of sales of land occurred in both Tlaxcala and Huejotzingo. These peaks may be attributed to the effects of the great epidemics in the years 1576-1580. In Tlaxcala, as in the neighbouring provinces, most sales of land occurred during the last years of the sixteenth century. The number of sales in Tlaxcala was still rather high after 1600 , but at that time there were mainly sales among Spaniards. After 1600, Indians only occasionally sold land. The data on Huejotzingo and Tepeaca reinforce this view, although in Tepeaca the sales continued over a longer period of time. Considerably fewer sales of land have been recorded for the province of Tepeaca than for the other provinces. In general, the Indians living there would sell land sized several caballerias (one caballerla being ca. 43 ha.), whereas in Cholula, Tlaxcala and Huejotzingo, the Indians usually sold tracts of land of less than one caballeria.

Most sales were recorded in the last few years of the sixteenth century; this was shortly prior to the second period of congregations, which, after all, occurred from 1604-1606. As a result, a causal connection between these congregations and sales of land is not supported by the data, and depopulation only seems to have had an indirect effect on the sales of land. Indeed, mercedes were not directly related to any of the other phenomena: they have been granted during the entire period, with an evident peak well into the seventeenth century. Thus, many mercedes do not appear to be connected with sales of land in a straightforward way. The continuous growth in the Spanish production of wheat in the second half of the sixteenth century can also be seen in another source, the data on tithe, even though the data are at times rather deficient." This is not only true of the Puebla-controlled valley of Atlixco, where Spanish agriculture 

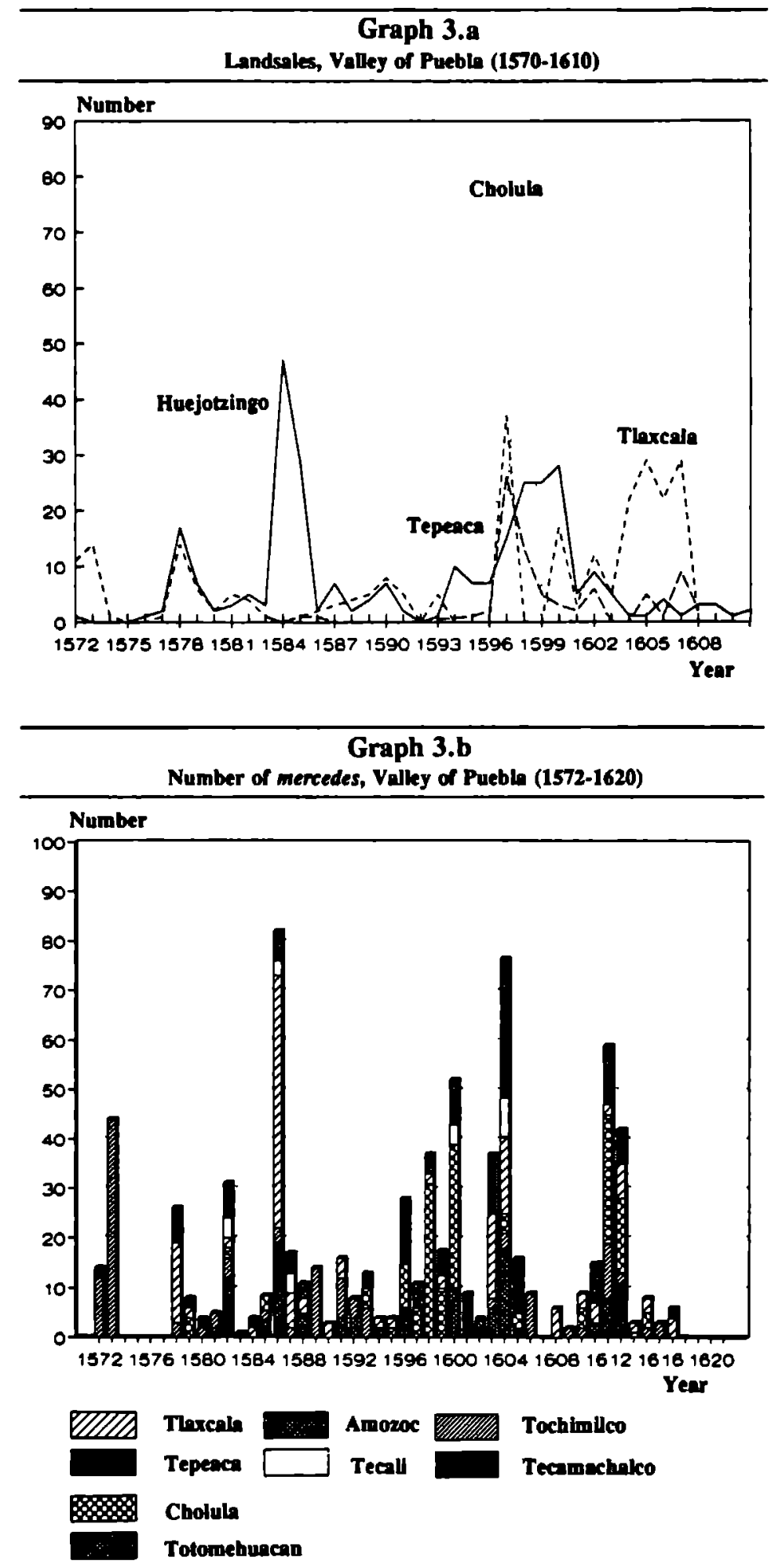
developed early, but also of the valley of San Pablo in the province of Tepeaca. The large amount of wheat produced by Spaniards, is also mentioned in the relación geográfica of Tepeaca (1580). We would expect Spaniards to have consolidated their important and productive wheat haciendas by means of a merced at an early stage. Mercedes were granted during the entire period, but this does not confirm the rapid consolidation of landholdings in wheat-producing areas. The large number of mercedes in the seventeenth century seems not to bear any relation to the consolidation of landholdings. This seventeenth-century peak did follow the period of congregations, but the lapse of time was too long to allow for a direct causal relationship to exist. From the archival material, it is clear that from 1570 to 1590 there were many lawsuits about land between Indians and Spaniards, whereas the number dropped significantly after the turn of the century.

Summarizing, we may state that the various developments in the period 1570-1620, did neither coincide nor show any coherent relationship. Even though I have not been able to quantify the data on the Indians renting out land to Spaniards, it is striking, in this context, that after 1595 the Indians almost stopped doing this, whereas it seems to have been quite normal before that time. ${ }^{3}$

This reconsideration of the phenomena which were traditionally seen as directly related to the formation of haciendas, makes it clear that the relations were not simple and straightforward. This does not mean that these socioeconomic developments had nothing to do with the formation of labores. It cannot be denied that the increasing activities of the Spaniards in the countryside, and particularly their occupation of agricultural lands, caused a profound crisis in the society of the valley of Puebla.

\section{Ecological complementarity versus socio-juridical dilemma}

The analysis as outlined above, largely ignores the role of the authorities in the period between 1570 and 1620 . Still, it is evident that they played an important part in all this. The congregations were a political instrument, which cost a lot of material and immaterial effort. The mercedes were granted by the viceregal authorities, who also supervised the procedure leading to the grant. The many conflicts between Spaniards and Indians took up a lot of the time and energy of both the Audiencia and of the local officials. Above all, the authorities were extremely worried by the unrest in the rural areas and were willing to put in a lot of effort to restore order.

The central dilemma of the Crown was how to realize a number of contradictory objectives. On the one hand, it wanted to promote Spanish agriculture to the extent that the latter could meet the demand of the increasingly growing urban food market. On the other hand, it felt obliged to protect the pueblos de indios 
and to guarantee the Indians a proper subsistence. The solution to this dilemma became especially urgent in the second half of the 1580 s, when the contradictory interests of Spaniards and Indians had already led to many conflicts and the formation of Spanish agriculture stagnated.

For a clear understanding of the rural crisis, we have to distinguish between two different aspects. The first one is the ecological side, which, of course, established many of the conditions for the development of Spanish agriculture. Notwithstanding its importance, ecology was no obstacle for the development of Spanish agriculture. The difficulties were mainly caused by the socio-political side of the formation of Spanish labores. In fact, the contrasting Spanish and Indian social and legal systems gave rise to many of the difficulties in the rural areas.

In contrast to the livestock haciendas which the Spaniards had founded before 1570 , the land used for the cultivation of wheat, and consequently for the founding of labores, was largely situated in the areas that were densely populated by Indians. This did not mean that the Spaniards actually drove the Indians off their land. In prehispanic times, the Indians had hardly ever used the lowlysituated land of the valleys; these were actually often the no-man's-lands between the altepetl. With the introduction of the pueblos de indios as local units in the territorially-based administration, the rather vague borders of the altepetl had been replaced by well-defined pueblo borders, leaving no no-man's-land. The Indian nobles had no clear idea of what to do with the newly granted areas and, consequently, these usually remained uncultivated lands on the peripheries of the pueblos.

In fact, these lands were often used as pastures, since the 'irrigation land' inundated every now and then, both exposing the crops to flooding and of catching illnesses, and making the soil become brackish. These dangers are illustrated by the example of the eighteenth-century Jesuit hacienda of Xaltipan on the banks of the river Zahuapan in Tlaxcala, which the Company had to convert from agriculture to pasture, because time and again, the wheat was ruined by chahuistle, a kind of grain rust, caused by excessive bumidity. Another example is the cultivation of the valley of Atlixco, that was not without problems either. Shortly after the farmers of the area had started its exploitation, they had to come to an agreement with the Indians of nearby Calpan about digging drainage canals for them.'

Notwithstanding the problems with the low-lying lands, the Spanish farmers were in a better position than the Indians. They did not have to fear attacks from hostile neighbours, because the entire area had been pacified after the conquest. But there were also some ecological and technological advantages. Compared to maize, wheat was more resistant to the night frost, which particularly afflicted the flat and low-lying parts of the Central-Mexican valleys. The Spaniards repeatedly expressed their surprise at the fact that the low riverbanks, which in their view were very suitable for irrigation, were not used for agriculture by the 
Indians. Spaniards and their ploughs and draught animals could till the tough, wet and rather densely grown soils of the low-lying riverbanks better than the Indians, who only had wooden digging sticks at their disposal. Wheat was broadly sown on vast and flat fields, while maize was cultivated in rows on the milpas, in combination with other crops. In short, the Spanish agricultural system was much more suitable for the low-lying lands of the valleys than the Indian system, because it could better adjust to its stiff demands of cultivation and maintenance. On the other hand, as argued above, the Indian agricultural system was pre-eminently suitable for milpa cultivation on the vulnerable lands of the lower slopes."

The cultivation of wheat by the Spaniards only developed properly after some time. 'By nature' the Spanish and Indian systems of agriculture were thus oriented towards different ecological areas. Because of this, it was possible that Spaniards and Indians engaged in ecologically complementary agricultural activities. Notwithstanding the ecological complementarity of Spanish and Indian agricultural systems, Spanish landownership could not freely expand into the wastelands, because a socio-political barrier hampered hacienda formation until the late sixteenth century. On the subject of landrights, Spanish law differed considerably from Indian custom. New Spain was an agrarian society; so, obviously, land was an important item, not just for the production of food, but also for the acquisition of wealth and status. The social systems of both Spaniards and Indians were, consequently, closely intertwined with rights over land. In the last decades of the sixteenth century, it became more and more obvious that the Indian and Spanish views on rights to land were irreconcilable. It was not just a matter of conflicting interests between Spaniards and Indians, but the legal basis on which the claims of both parties was based, was different. They were not easily brought into line as they originated in the different Indian and Spanish socio-juridical complexes which I have characterized above as Personenverband and Territorialverband. The Crown soon realized that solving these problems was crucial to the well-being of New Spain. The dilemma was largely of a legal nature, and, consequently, had to be predominantly solved by legal instruments. To understand the dilemma, we have to look at the difference in Spanish and Indian views.

The Indian caciques, who held power over the pueblos, said that their rights to land also extended to the sparsely populated and uncultivated areas now falling within the jurisdiction of their newly created pueblo. Consequently, the caciques wanted the Spaniards, who settled on this land, to pay tribute. The Spaniards, however, were of the opinion that they were in their right whenever they took possession of wasteland and cultivated it. According to Spanish tradition, they had the right to do so and they often refused to pay rent to the caciques. This was a complex legaalmatter, as the Crown had ordered that the indigenous laws would remain valid as long as they did not conflict with 'divine' or 'natural' law and did not undermine Spanish authority. For the Spaniards it was difficult to 
acknowledge indigenous views, whereas the Indians understood little of the Spanish opinions. It is obvious that this confusing situation gave rise to many conflicts when the Spaniards started to found labores in the central parts of the valleys of the central highlands.

As I have explained in chapter 1, the indigenous view of rights to land concentrated on the influence over territories. A lord had rights to a certain area, but his rights were not absolute. Whenever he was a vassal to a higher-ranked lord, he was liable for tribute, but the higher-ranked lord could never claim more than these tribute rights. On the other hand, macehuales who lived on the land, were under the obligation of paying tribute, but in return they were entitled to usefruct of the land. As I have stressed above a European, modem, absolute and exclusive definition of landownership did not apply to this distribution of rights, as it ignores the essence of the indigenous views on rights to land.

Sixteenth-century Spaniards, on the other hand, had a view on landownership that was much closer to the modem idea, although there were still some important differences. According to the Spanish view, all land which did not explicitly belong to someone, belonged to the king. As a result, all uninhabited and uncultivated or vacant lands, tierras baldias, were royal property, tierras realengas. However, there was a number of other important Spanish traditions which made the sixteenth-century view differ from the modern one. To a large extent, these traditions bad come into existence during the Reconquista, when a vast and largely empty land had to be repopulated. In this period, it had become a custom that anyone could take possession of uncultivated land and work it or use it as graze land. In occupying and cultivating this land, the person in question received the de facto right of ownership. This custom was called presura and was of great importance for the ownership relations in the Spanish countryside in the sixteenth century and long afterwards."

The importance of the community, or comunidad, had also increased during the Reconquista in Spain. A comunidad was entitled to pastures (ejidos), agricultural lands and access to other necessary natural resources, like water and wasteland, or monte. Different from prehispanic Mexico, the late medieval and sixteenth-century comunidades in Spain often owned important tracts of land. The land was property of the comun (all members of the comunidad), which granted the tax-paying inhabitants the usufruct of a plot, and the right of access to pastures and to monte. This grant was in principle not linked with the private properties of a person, as it resulted from the membership of the comun. These traditions were of such importance in Spain, that the historian Vassberg, who studied them at length, wondered what their fate would be in the American colonies. $^{10}$

In their approach of the rights to land in America, the Spaniards based themselves on these traditions. By law, all Mexican comunidades were granted the right to ejidos, monte and sufficient land for its members. Legally, it made no difference whether the comunidades were Spanish (mostly cities) or Indian 
(pueblos de indios) settlements. The law did not imply that all land should be immediately demarcated for the various comunidades, but it did firmly establish the principle that a comunidad either Spanish or Indian- could and even should own land; throughout the colonial period, this principle was to exert an influence which can hardly be overestimated."

Apart from this law, there were other measures that evolved from the Spanish tradition. Therefore it is expedient to give some more details about the various land titles. In the first place, there were the so-called mercedes de tierra. Legally, a merced was nothing more than a royal grant of rights or privileges bestowed on a person. Actually, all mercedes that were granted by the viceroy of Mexico, had to be confirmed by the king in Spain, because it a concerned a Crown grant; in view of the long communication lines and the lack of expertise in Spain in dealing with the overseas territories, the king never claimed this right. The person favoured could be anyone: a Spaniard, an Indian and also legal bodies such as a Spanish city or a pueblo de indios. Land on which a merced was issued did not necessarily have to be tierra baldia, or wasteland, since people who had had cultivated land for some time, could also apply for a merced. Initially, however, mercedes were usually issued to Spaniards on tierras baldias. There were several standard sizes of land, depending on its use. For the breeding of stock, sitios for cattle (ganado mayor, ca.1756 ha) or small stock (ganado menor, ca.439 ha) could be granted. The mercedes for sitios were usually circular, because they concemed land for the extensive breeding of stock and not all land was used either all at the same time or continuously. For agricultural purposes, caballerias (ca.43 ha) were granted. Caballerlas could have any form, because in this case, the entire lot was used.

According to Spanish tradition, a merced was no conditio sine qua non for the legitimate foundation of an agricultural enterprise, as the presura was legitimate as well. A merced was only granted, provided that the land concerned was actually used. From the beginning, mercedes de tierra were instruments for the recognition of rights to land on any basis. This did not entirely coincide with the royal wish to control the tierras realengas, but in Spanish custom (uso y costumbre) the principle of presura was so strong that the Crown could not prevent it. In due course, the mercedes became a means to show rights to land, and with it, of consolidating de facto landownership.

Before a merced was granted, one had to prove that the land on which there was an option, was used by the applicant himself and by no one else, especially not by Indians. A standard procedure had to be followed here, in which all possibly interested parties, among whom all neighbouring usufructuaries, were consulted. In this so-called citacion, anyone could dispute the merced, if he could give a plausible reason that he had rights to the land or that granting the merced would be in conflict with his interests. When this procedure had been carried out, the representative of the Crown -usually the alcalde mayor or his deputy- would 
take the applicant by the hand and lead him along the borders of his new property. By way of taking possession, the applicant then had to throw away some stones from the land, pull some weeds and conduct some other symbolic acts. If the procedure was not carried out as prescribed, the merced could be challenged by the duped party. Whenever this party managed to prove that it had older rights to the land, the merced was rendered null and void.

Apart from the merced there was also the amparo, an important legal instrument. The amparo did not include the grant or transfer of rights to a person, but the protection of demonstrable rights, which had officially been recognized before, but were either being actually violated or threatened to be so in the near future. Amparos were a powerful instrument in protecting the rights of Indian individuals and pueblos, but they could also benefit Spaniards. Yet, the amparo was mainly used in favour of the Indians, and as such, it was at least as important a legal instrument as the merced. Land that was protected by an amparo was regarded as the confirmed property of the person or pueblo who had received it. No one could alter this, unless he was able to show that the amparo had been granted unjustly. From the beginning, the Indians had known of the amparos' existence and how to obtain them and they did not hesitate to apply for one. Using these legal instruments, which originated from the Spanish tradition, the authorities had to deal with the conflicts that occurred between the Spaniards and Indians in the rural areas of the late sixteenth century. In order to solve the crisis which developed in the 1580 s and to prevent turmoil, it was obvious that the authorities first had to register Spanish and Indian claims to land, and then bring them into line, so that both parties could refer to similar rights in case of a conflict. But this was not easily accomplished. ${ }^{12}$

Whatever confidence the Indian nobles had ever had in the Spanish authorities in the early colonial period, they had lost with the tribute reforms and the settlement of Spanish labradores, because they considered these to have injured their patrimony." The Indians did anything to preserve their land. Some pueblos, directed by its caciques, went as far as to take possession of a piece of land the night before it was to be inspected by a commissioned magistrate, and built an entire settlement on it. Other caciques claimed that the land had been cultivated by the Indians of their pueblo in former days, but had been deserted after the epidemics. Their opponents, however, showed up with witnesses who testified that the land had never been cultivated by Indians, and an inspection on the spot by the magistrate (vista de ojos) made it clear that this was indeed land that had never been cultivated. This gave the Indians the reputation of taking matters immediately to court, if they were not satisfied with a decision and, besides, of being great liars and frauds. Even the Franciscan Torquemada, who was kindly disposed towards the Indians, had to admit that the Indians often lied. However, he was of the opinion that in prehispanic times they had never failed to tell the truth, and owed their new behaviour solely to the bad example set by the Spaniards." 
In principle, the Indians did not object to Spanish agriculture as such, but just to the cultivation of land without compensation. It was not unusual for the caciques to rent land to Spaniards. Renting was comparable to the indigenous system of supplying tribute in exchange for the right to work land, and even among Indian nobles it was not uncommon to 'rent' land. However, there were Spaniards who, even though they had formerly rented land from a cacique, came to the conclusion that the land was actually tierra baldia and therefore stopped paying rent. This idea was strengthened by the fact that Spaniards in the same area were granted tierras baldias by the Spanish courts. Sale of land was much less attractive to the caciques than renting, as a sale implied that all claims to the land were permanently renounced. Moreover, the sale of land, which was part of their patrimony, did not in any way fit in with the old Indian way of thinking about land and managing it.

This situation was brought the authorities to despair. In each case a Spanish judge would grant land to a Spaniard, even when his decision that lands were tierras baldias had been preceded by careful and elaborate inspections, Indians would reclaim the land

after some time and were often prepared to engage in costly lawsuits. In the beginning of the seventeenth century, viceroy Monterrey complained that he himself had seen that the land along the road from Mexico City to Acapulco -the most important harbour on the Pacific coast- was completely empty and vacant. When the Spaniards started exploiting it, however, the Indians of the city of Mexico protested and claimed that it was theirs. He ironically added that he expected that when the Spaniards would occupy the territory of Florida, there would probably be once again Indians from Mexico City challenging the rights to land of the Spaniards 'as if the lands were next to their houses and they would be able to find friars to help them and they would search witnesses among the Indians, or they would even order them [to testify] without any other intention than to take [the lands] from the Spaniards'. ${ }^{\text {is }}$ The only remedy left to the authorities in order to solve the enormous problems, was to redefine the indigenous rights to land after Spanish concepts.

Several times, the Crown tried to register the actual distribution of landed property. The first documented investigation of this distribution took place in the 1580s in the province of Tepeaca. Oidor Pedro Farfán was commissioned to this area, due to the many processes between the Indians of Tepeaca: ${ }^{16}$

'[...] And so that they [i.e.the Indians] are recompensed and protected, it is convenient and necessary that an oidor of our Audiencia goes to the said city of Tepeaca and the pueblos of Acatzingo [and] Tecamachalco and the plains of San Pablo and the other parts and places where the said lands are situated on which there are the said lawsuits, and [be is to] proceed with them [i.e. the lawsuits] as they are [and] do justice to the parties involved [...]. We order that the original lawsuits be handed to you and that you continue in their 
spirit, and in other lawsuits which are not available in the original or which come and occur before you about the said lands, you shall indicate in which way the parties concemed are to put forward their rights and prove what they think convenient; and when you have heard them on their rights, you shall also decide about the said things in such a way, that if the said indians have been aggravated by the lands that they have sold and rented to the said Spanjards, or if these [Spaniards] have taken them from them on their own authority or acquired them by right of sale or merced to their harm, they are to be restored and [the lands] are to be retumed to them and the damages that their [i.e. the Spaniards'] livestock have done to their fields are to be paid. And if some of the lands that the Spaniards have acquired of these Indian through sale or rent are realengos, or if the said Spaniards occupy more land that they have received by title from our viceroys [...], you shall make particular report of this to our viceroy of New Spain, so that he will determine what is to be done. You shall give order that such people shall not cultivate what is realengo, to which they do not have sufficient title and that they shall observe all necessary measurements and consultancies'.

In the course of this investigation, the caciques formulated their rights in the old terminology of rights to both land and macehuales and not in the Spanish way of meticulously demarcated tracts. They seldom indicated the size of their lands, because they declared that it had never before been measured. To Spanish standards, these specifications were too vague and could not be transformed into manageable legal terms. Thus, the conflicts remained. Even though the records of this investigation on the Indian rights to land were actually used at a later stage in colonial time to demonstrate the rights of a cacique to a cacicazgo (i.e. the properties and rights belonging to a certain cacique-ship), and thus had legal power, the testimonies of the Indians were not the decisive factor in the matter of the division of landownership. Possibly, the fact that now the rights of individual caciques had been recorded, but not the rights of pueblos as a whole, may have played a part here. Above, I have argued that all land lay under the influence of caciques and hence the pueblos as a community owned no property. In Spain, however, communities (comunidades) were very important landowners and Spanish lawyers in New Spain attached much importance to the pueblos as well. By recording the rights of the caciques, only part of the indigenous rights to land had beenrrecorded, in the Spanish view.

In the 1590s, the Crown finally got the situation in the countryside under control, as a result of a complex of causes. In the first place, there was the permanent pressure from Spaniards, who wanted to acquire land in the more populated areas. Secondly, the combined effects of depopulation and tribute reforms made themselves more and more felt within the pueblos de indios and the earnings of the caciques and principales had greatly diminished as a result of them. Especially the epidemics which swept the country in 1576-1580 dealt a sever blow. But at the same time, the authorities introduced a number of measures to allow a more 
effective policy. In 1591, the Crown issued a measure that was aimed at legalising ex post facto all non-official landrights of -particularly- the Spaniards: 'We have thought it useful to decree that those who possess [agricultural] lands and pastures in this New Spain without just and legitimate title, shall compose with his Majesty and with his viceroy in his royal name what is just'."

The way chosen by the Crown for carrying out this composicion, was that the granting of mercedes as a legal title to land, now became compulsory. According to the decree (cédula), the mercedes were now regarded as the new recognition of rights to land. At the same time, the Crown saw the programme of mercedes as a source of additional income. It hoped to find funds for the protection of the fleets from Spain to America which were a much-loved target for privateers. In this respect, the success of the composicion, as that of later composiciones, proved to be very limited." The mercedes were especially granted to Spaniards, but similar measures were directed more specifically at the Indians. In 15901591, many caciques received an official amparo of the land they possessed. It is not clear whether this restored the caciques' trust, or whether they were under such tremendous economic strain, or whether there was too much Spanish pressure for buying land, but from the beginning of the 1590s, they started selling large amounts of land to the rural Spaniards. On Map 4 the areas have been indicated, where the Indian nobles sold land to Spaniards. In light of the ecological conditions of both Spanish and Indian agriculture, it is not surprising that the plots lay mainly on the banks of the rivers Atoyac and Zahuapan and in marginal areas on the periphery of the valley. Only little land was sold in the densely-populated zones of the altepetl, where the Indians farmed themselves. The Indians were not driven off these unproductive lands, because they had never occupied them. It is more likely that the often impoverished indigenous nobles saw a way of turning pieces of land, which were useless to them, into a profit.

The documents of the sales of land generally give some indication of the uselessness of the plot for the indigenous owner. A standard sentence is: "I have no use of the land at all, because it lays waste and I have a lot of other land to work"." Sometimes the documents are more precise. In a Cholultec sale of land, it is stated that the reason for sale was, that the owner did not profit from the land in any way, because it was inundated. In many documents concerning sales of land in Cholula, the lands are said to be situated in the marshes (cienega) or even the deep marshes (cienega honda). Of the cienega it is said that it was impossible to work the land as a result of the water. As I have argued above, the swampiness of the lands sold to the Spaniards was sometimes a problem to them, as well. ${ }^{\text {2o }}$

In the central parts of the valley, the sales of land continued until about 1602-1603. Even though after that, caciques would still sell land in less populous areas of the province of Tepeaca, henceforth, Spaniards mainly sold land among each other. The end of this period of sales of land coincided with the beginning 

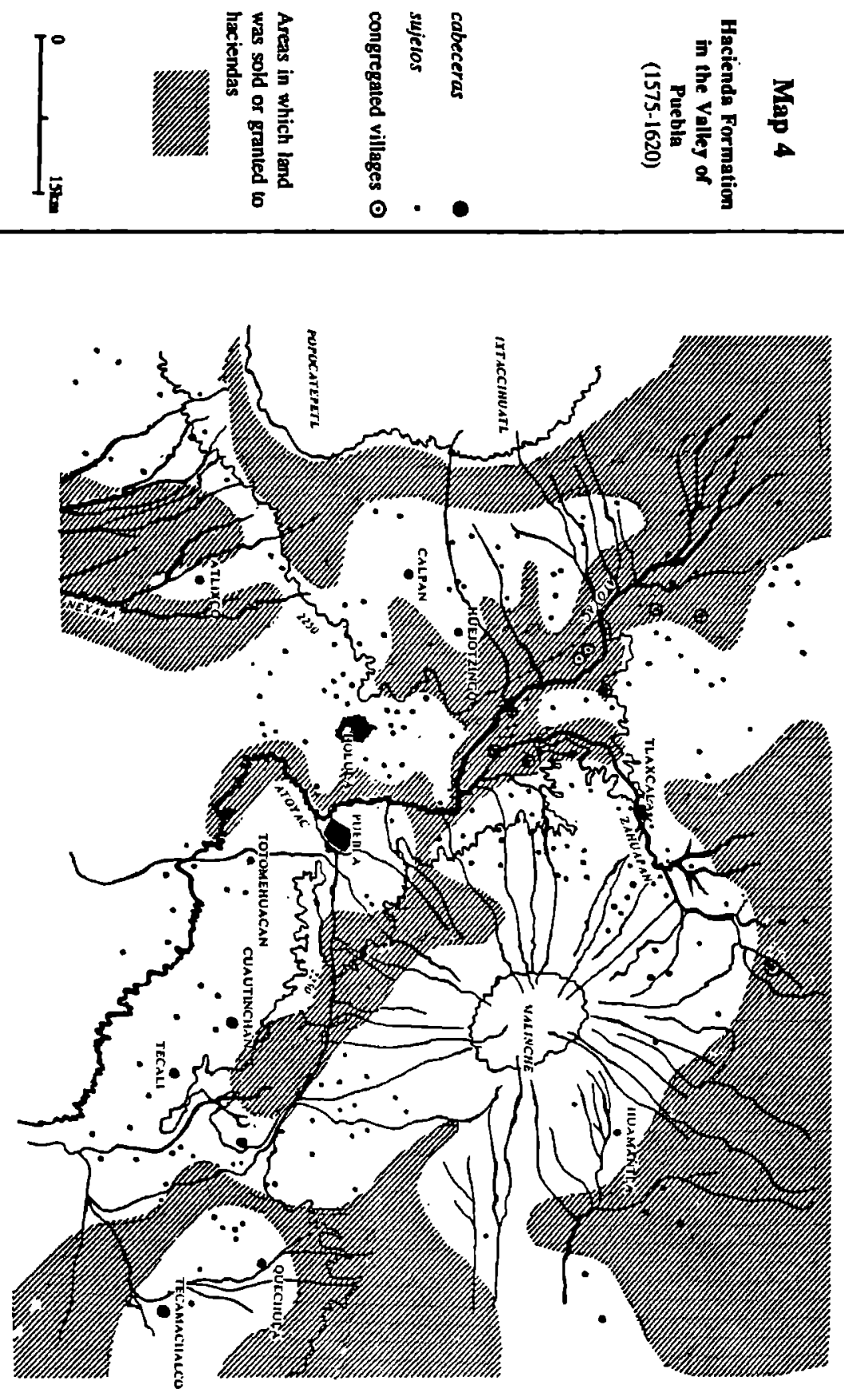
of the period of movement of settlement within the framework of the second programme of congregations, which lasted until 1607 . When the congregation programme was completed in 1607, and the large numbers of sales of land from Indians to Spaniards had come to an end, part of the composicion was already outdated, due to the mercedes that had been granted in the 1590s. In 1611, archbishop Fray García Guerra, at the time ad interim viceroy of New Spain, noticed that the land market had not settled down yet:21

'Experience teaches us that there are many people who have an amount of sowing and pasture land without the [appropriate] justifications [i.e. land titles] and consequently ask from us to grant them a merced on the surplus of land [in addition to already granted mercedes]'.

Therefore, the composición had to be continued, so that at last the division of landownership would be clear: ${ }^{n}$

'I decree that within six months following the day that this decree has been issued, each and every person, of whatever quality or position, who holds and possesses sowing or pasture land without rightful or legitimate title, will appear before me to compose (componerse) with His Majesty what is just and to acquire sufficient titles of it [i.e.the land], as laid down in the royal order'.

The period of six months proved to be insufficient, since the ordinance was followed by a second wave of mercedes, which lasted until 1615 and should be regarded as the second part of the composicion that had started in 1591. The difference was, however, that this time, not just Spaniards but also many pueblos applied for mercedes. This was a result of the second congregations programme. Before we turn our attention to this programme and its role in the efforts to solve the rural crisis of the late sixteenth century, we have to take a closer look at the actual formation of labores in the light of the sales of land of the 1590s.

\section{The formation of labores}

Some examples may clarify the process of the formation of labores. As we have seen above, Spaniards from all of the provinces in the valley of Puebla, bought Indian land in the 1590s. Until the turn of the century, it were mostly Indians who sold land. The Spaniards were in need of land, and after having waited for a long time, a large amount of land suddenly became available to them in the 1590s when the Indians started selling land. Everyone bought as much as he could, and we can almost speak of a run on land. Spaniards joined several lots together, creating larger estates, and often applied for a merced afterwards to consolidate 
their holdings. The mercedes stipulated that the land should be cultivated within three years or the merced would be withdrawn.

Some Spaniards were not really attracted to a farmer's life, and would therefore resell their land. There were also Spaniards and Indians who tried to make fast and easy money through speculation. For instance, in 1602, the Tlaxcaltec Indian Diego Izcoatzin sold the nine dispersed lots be bad bought from other Indians, to Spaniards. In the province of Cholula, Hernando de León, interpreter of the authorities, sold much of the land that he bad bought from a large number of Indians. Generally speaking, however, many Spanish sellers of land were more interested in improving their estates. To this end, they would sell land which was useless to them on the land market and buy more useful plots instead. Thus, we often come across the same names in one province. For example, the most active persons on the Tlaxcaltec land market were Alonso de Nava, Diego López Cano, Francisco Méndez de Palacio, Juan de Carillo and Lope de Salazar. $^{2}$

Even within one province, not all labores were consolidated simultaneously. In 1600, Francisco Martín de Cuenca, labrador in Atlangatepec, Tlaxcala, had a complete hacienda de labor (wheat hacienda) as he called it. He bad put it together out of nineteen different lots (suertes, pedazos, heredades), which he had bought from, in particular, the Spaniards Juan de Soria and Juan Camacho, who had acquired the land from Indians. His labor lay in the areas (pagos) of Santa Clara Atlangatepec, San Francisco Zocoquiloyoca and Santa Clara Ozumba. Most of his land was situated in the marsh of Santa Clara. In 1601, in the southern part of the province of Tlaxcala, Manuel Sanchez Vermejo and his wife sold a hacienda de tierra y labor in the area of Santa Ana and Santa Cecilia to Juan Guerrero. It consisted of 21 separate tracts which had been purchased from the Indians. In that seme year, a group of people consisting of Hernan García, Melchior de los Reyes and his wife, his son Diego de Montilla and his daughter and her husband Bernardo de Ávila, sold a hacienda in Santa María Nativitas to Hemán de Yañez from the city of Puebla. It consisted of ten lots and contained some houses. ${ }^{24}$

In this same period of time, there were also many haciendas which had not yet been consolidated. In 1602, Alonso de Cárdenas and his wife sold a heredad de pan llevar (wheat farm) in the pago of Xalatlaco to Francisco Méndez. The heredad consisted of sixteen lots, which Cárdenas and his wife bad bought themselves, partly from various Indians and partly from Spaniards. Some weeks later, Lope de Salazar sold six pieces of land in the same pago to Diego Lopez Cano. On that same day, Diego Lopez bought a heredad de pan llevar from Francisco Méndez de Plasencia and his wife. They had composed it out of purchases from Lope de Salazar and Alonso Cárdenas only a few weeks before. In Atlangatepec (Tlaxcala), the division of landownership had not stabilized either. In 1601, Alonso Rodriguez sold two plots in the pago of Cetoluca to Juan López Orronez. 
Alonso Rodriguez had bought the land from the cacique Don Diego de los Angeles. ${ }^{2 s}$

A few years later, the average size of the estates had increased, but still not all of the Spanish rural estates had been consolidated. In 1607, Francisco de Espinola sold seven lots in different pagos to Miguel Ximénez. In that same year, Diego Muñoz Camargo sold a scattered collection of six plots in the pagos Tenjac and Quatequetlan to Blas Hernández de Santa Marra. The ten lots in the pagos Santa Maria Magdalena Yautelopan and Magdalena Jaltican, which Francisco de Herrera sold to Diego Díaz in 1608, were no complete hacienda, either. In the remoter areas of Tlaxcala, haciendas were mostly founded on the basis of a merced. Notwithstanding this, at times, sales of land here were the basis for Spanish landownership, too, as in the case of Nuestra Señora del Rosario, which later was to become a pulque-hacienda in the uninhabited north of Tlaxcala. Its creation started when Bartolomé López de Morales purchased a piece of land from the Indian Juan del Castillo. ${ }^{25}$

This pattem of landsales was not confined to Tlaxcala, as already appeared from the quantitative data presented above. In Cholula, the formation of labores was comparable to that of neighbouring Tlaxcala, even though the sales of land, which were on a large scale, seem to have started a little later, with less land available. Between 1598 and 1604, the Spaniard Diego de Coca Rendón composed the Cholultec bacienda Santa Maria Zacatepec from purchases of land from several Indians and the Spaniard Francisco López de Castro. In 1604, he sold his labor to Diego Fránquez, who applied for a medida (demarcation) of his land, which was contested by Juan Catalán, labrador in neighbouring Huejotzingo. $\mathrm{He}$ alleged that the border between Cholula and Huejotzingo, which had been demarcated with palmtrees and maguey cactuses some fifty years before, had been moved by Diego de Coca and Cholultec Indians. However, Juan Catalán was unable to produce better titles of land than Diego Franquez and lost the case before the corregidor of Cholula, who led the investigations. In 1605, the hacienda was sold to Francisco de Chávez for the amount of 4097 pesos, including buildings and stock. At that time, the hacienda comprised 13 caballertas (559 hectares), a large part of which was situated in the marshlands between the provinces of Cholula and Huejotzingo."

The hacienda de labor San Juan Buenavista, also in Cholula, was founded in a similar way. In 1711 the time of the composicion from which the data have been taken- it comprised 26 caballerias. At that time, it was composed of 44 lots which Pedro Alvárez Botello and Francisco had bought from both Indians and Spaniards between 1594 and 1613. The majority of the sales took place in 1598. In 1711, the hacienda Buenavista consisted of the original hacienda of that name and of the rancho Cacalotepec, which had changed hands seventeen times in the seventeenth century. The rancho San Antonio Tenamastla (Cholula) comprised eight caballerias in 1711. The foundation of the rancho was based on nine sales 
from Indians to Hernando de León and a merced for water in 1598. In 1610, some mercedes were granted on the land of the hacienda, as it was called at the time. Francisco Rodriguez contributed most to the formation of the estate. A sale in 1614 was followed by another eight in the seventeenth century. The final case from Cholula is the hacienda San Diego Chipilo, which comprised ten caballerias in 1711 . It was founded in the period from 1596 to 1600 , by way of thirty sales of land from Indians to Hernando de Leon. Apparently, Hernando de Leon sold it again at the very beginning of the seventeenth century, because he was not one of the Spaniards who received a merced on parts of the land in 1603, 1612 (both 3 caballerias) and 1617 (4 caballerias). In the seventeenth century, the estate was sold three times. ${ }^{20}$

In the alcaldia mayor of Tepeaca, Indians would more often sell larger plots of some caballerias to Spaniards than they would in the other provinces in the valley of Puebla. Here, many wheat haciendas had been founded earlier, as the plains of San Pablo had been one of the first areas to attract Spanish farmers. In 1606, the labrador Diego de Paz received a merced on tierra baldia in the pago of Amozoc, in the presence of the Indian cabildo of the town, consisting of a gobernador and some alcaldes. It had been investigated beforehand whether the Indians were not cultivating the land now or had cultivated it before the congregations. This same procedure was followed in the case of Juan de Carrillo, when he wanted to sow his land, notwithstanding the fact that he already held a merced for a piece of land surrounding his inn (sitio de venta) which was probably used for grazing mules of passing mule trains. The inspection was carried out by the alcalde mayor of Tepeaca, Juan de Heredia, by order of viceroy Montesclaros..

According to the German sociologist Nickel, haciendas in the remote plains of Ozumba, to the east of Tepeaca, were founded by means of mercedes in the sixteenth and seventeenth centuries. There was plenty of land in Ozumba and the haciendas kept the original circular forms of the merced for an estancia de ganado menor (sheep ranch) until the end of the sixteenth century. In more populous areas, the form of such grants was usually changed under pressure of the formation of haciendas in the area."

Even though the Jesuits were a most exceptional group in colonial society, the process as described above is confirmed by the formation of the Jesuit haciendas in the valley of Puebla, which has been analysed by Ewald. Their hacienda Los Reyes in Santa Maria Nativitas (Tlaxcala) was composed by a number of Spaniards who bought land from Indians in the period between 1588 and 1604 . It was extended by some additional purchases in 1610, 1612, 1615 and 1616 . Operations on the hacienda were hampered by its marshy situation throughout the colonial period. The hacienda Amalucan near Amozoc (Tepeaca) was founded between 1583 and 1596. The estate was extended and consolidated while it was sold and resold by Spaniards in the seventeenth century until it was donated to the Jesuits in 1620. The hacienda San Pablo in the plains of that same name 
between Tepeaca and Tecamachalco, was composed by Jesuits from several Spanish donations, which took place until 1618."

After the first years of the seventeenth century, hardly any land remained vacant in the marshy central areas. The authorities offered the labradores an opportunity to consolidate the accumulated plots into a bacienda by means of a survey (medición) of the land and a merced. The mercedes were thus a means for the authorities to finally rocord the division of landownership in the Spanish, legal way (composición). To settle this division was particularly important in areas where conflicts were likely to develop. Hence, the majority of mercedes were granted in the densely-populated agricultural region in the centre of the economic complex. Fewer mercedes were granted in marginal areas. After the composicion, the labradores bought little land from the Indians. The few sales that still took place, usually concerned haciendas or parts of haciendas, which often changed bands among Spaniards."

In his monograph Milpa y Hacienda Prem has analysed the geographic distribution of mercedes, granted per decade in the former altepetl of Huejotzingo. From his analysis, it appears that the first mercedes were granted around the camino real passing through the north of Huejotzingo. Initially, only pastures (estancias) were granted. In the valley of Atlixco, many mercedes were granted in the 1570s. In my opinion, this should be seen as a measure by the Crown to deprive the town of Puebla of its control over the area, and to place it under the jurisdiction of the Crown, in exactly the same fashion as these matters were being dealt with in Spain at that time. In the course of the 1580 s and after, ever fewer pastures were granted, and attention was directed towards the agricultural land in the central areas of Huejotzingo, especially the land on the banks of the Atoyac. After 1615, the composición was completed and only mercedes of marginal pastures (montes) high on the slopes of the volcanoes lxtaccibuatl and Popocatepetl were granted."

The data for Huejotzingo have been confirmed by those from the other provinces in the valley of Puebla. The development in the granting of mercedes, reflects the economic development of what was to become the Central-Mexican economic complex. Until 1570 , especially sheep and mule ranches were established, meant to provision the camino real especially in the uninhabited parts of the provinces of Huejotzingo and Tlaxcala. The production of wheat also developed quickly, although initially only in the valley of Atlixco and to a lesser degree in the valley of San Pablo near Tepeaca. From the 1580s, the number of haciendas greatly increased. The haciendas were first established in the river valleys between the densely-populated mountain slopes. Haciendas were formed from the separate plots which the labradores had bought from the Indian nobles. Subsequently, the property of land was consolidated by a merced. From 1590 onwards, only agricultural land was granted in mercedes; many former estancias switched to the cultivation of wheat. By ca.1615, all land in the central areas had 
been divided, and the division of landownership between Spaniards and Indians had been established for a long time. The nearer an area was situated to the city of Puebla, the core of the evolving economic complex, the more important it was for a labrador -or an Indian village- to have mercedes with which rights of possession could be demonstrated.

The contradictory interests of Spaniards and Indians did not always mean that the two groups were opposed to one another. Especially in matters of sales of land, Spaniards and Indians cooperated at times. This is shown in the example of the prices of land. In 1590, a decree was issued, stating that in transactions of land surpassing a total value of thirty pesos, the intended sale had to be announced in the marketplace (pregón) for a period of thirty days. The Indian sellers as well as the Spanish buyers benefited from circumventing this elaborate and costly decree, because the town crier had to be paid by all parties concerned. Consequently, many of the prices paid for the plots by the Spaniards, were remarkably uniform. Prices are known for 627 (59 percent) of the 1062 cases of sales of land from the provinces Tlaxcala, Huejotzingo, Cholula and Tepeaca, collected in the course of my research. Nearly half of the sales yielded a price between twenty and thirty pesos, regardless of the size of the plot that was up for sale. Under twenty pesos were paid for very small plots; very large pieces of land yielded over forty pesos. This disproportionate division of prices is due to a reaction to this measure introduced by the authorities. It is usually impossible to retrieve the prices that were actually paid.

In a few cases, however, the prices do appear in documents. This occurred, for example, in the case of a sale in Cholula, where the labrador Diego de Coca Rendón appealed on behalf of the Indian woman Marra Martha against the price which had been paid for her land. He declared that the contract stated that twenty-eight pesos had been paid for the land, but in reality it had been fiftyeight pesos. All the same, Marra Martha had lost badly by the sale. Diego de Coca succeeded in having the contract rendered null and void, and a new procedure was started, and this time the pregones laid down by the Crown were obeyed. A further indication of private sales is, that when the elaborate procedure with pregones was followed, the Indians would receive prices well over thirty pesos for their land. 


\section{Congregations: the second programme}

Besides the amparos for the caciques and the mercedes for the Spaniards, the congregations at the turn of the century, were also an instrument which should establish the division of landownership between Spaniards and Indians. Thus, the congregations and the programme of mercedes both formed complementary parts of a large composición. In the mercedes, Spanish landownership was recorded; in the course of the congregations, Indian rights to land were often newly recorded and expressed in Spanish terms. A more detailed description of the period of congregations shows how they fit in the political objectives of the viceregal authorities.

Although the actual second congregations programme did not officially start until 1598, it had a long bistory. In Mexico and Spain, the congregations which had been carried out in Peru under viceroy Toledo, had a good reputation, even though in the eyes of modem historians, their success was by no means overwhelming. The authorities were of the opinion that Mexico was to follow the example set by Peru. In 1588, the alcalde mayor of Tlaxcala was commissioned to carry out a congregation in that province. There is no other documentation on this congregation than just the instruction, but apparently it was very successful."

From 1590 onwards, Don Luis de Velasco the younger, who was viceroy at the time, had a number of congregations carried out. He was one of the most energetic promoters of the programme. His preference for congregations can partly be explained by the fact that his father, during his term of office (15501564), had also carried out congregations, but had been obliged to stop them prematurely. The programme of the late sixteenth century first started at the beginning of the 1590s, when viceroy Don Luis de Velasco the younger carried out some congregations on his own initiative. However, he had little means to pay for this policy and got no further than a few well-meant attempts. A more structured approach was not possible until 1598, when the Crown actively started to support the programme, and part of the tributes were reserved as a fund for the congregations. The new viceroy, the Count of Monterrey, assumed the general direction the congregations. In 1604, after the close of his term of office, he wrote an extensive report on the course of the entire congregations programme up until that moment. In this report, we recognize the three phases of this second programme of congregations which Cline distinguishes in his article on the congregations. In 1598-1599 there was a survey, followed by a phase of planning from 1600 to 1603 . From 1603, the plans were executed. Cline wrote, that from 1607, the Indians were officially allowed to return to their previous settlements, but this was after Monterrey's term of office."

In his report, the viceroy complained that it was much more difficult to carry out the congregations in Central Mexico than in remoter areas. In effect, much larger and less problematic congregations took place in Michoacan, Oaxaca and 
the Sierra Norte de Puebla than around the cities of Mexico and Puebla de los Angeles. According to the viceroy, the problems in the central highlands were due to the resistance of the friars of the mendicant orders against the congregations. Elsewhere, they saw ecclesiastical advantage in concentrating the Indian population and therefore cooperated. However, in the central highlands the friars had no problems with the accessibility of the Indians and therefore they had little reason to promote congregations there. According to Monterrey, the congregations were also obstructed by the Indians around Mexico City and Puebla. They were more hispanized (mas ladino) than elsewhere, and hence more inclined to opposition, if they thought that they might profit from it. Most congregations in the valley of Puebla were of a modest scale and were confined to the concentration of, at the most, a few dozens of Indians in barrios. The resettlement was executed in close cooperation with local Indian leaders. ${ }^{*}$

The reports on the congregations in the valley of Puebla and the litigations connected with them, enable us to consider the implementation of the viceregal politics in some detail. It appears that every time a congregation would cause any problems, the plaintiff took the case to court at once; many of these lawsuits have survived. There were Spanish as well as Indian complaints. Sometimes, both Spaniards and Indians tried to use the congregations to their own advantage. Of most congregations no reports or legal documents have survived. There are no data on the congregations in the western part of the valley of Puebla, the provinces of Atlixco, Cholula and Huejotzingo. The cabeceras of Tochimilco and Huaquechula, both situated high on the slopes of the volcano Popocatepetl and sparsely inhabited, are the only exceptions here.

In the province of Tlaxcala, the congregation just affected some small settlements which had been founded on the strips of former no-man's-land in the 1530 s and 1540 s. In the larger part of the alcaldia mayor of Tepeaca, congregations also remained confined to a limited number of Indians. The most extensive congregations were founded in the remoter area of the valley of Puebla: in the district of Tecali and in Santo Tomás, a sujeto of Tepeaca. In both cases reports were written. Even though the congregations sometimes greatly affected the lives of the Indians, the Indians only resisted to them if it concerned large-scale ones."

The congregations did not really start until the viceroy bad appointed a number of commissioned judges (jueces de comisión) who had to investigate which pueblos de indios were to be congregated and in which place the concentration was to take place. They were commissioned to describe elaborately the area under their care. They had to account for their proposals for congregation. For Tlaxcala and Tecali there are even detailed instructions."

In the spring and summer of 1599, Don Juan Maldonado de Montejo, juez comisario of the province of Tepeaca, accompanied by a clerk and an interpreter, took his first measures. In both Tecali and Santo Tomis he followed the same procedure. He summoned the officials of the pueblo on a Sunday after Mass and instructed them to draw a map of the cabecera and all sujetos subordinated to it. 
The map was checked by the padre guardion, the priest responsible for the doctrina -a Franciscan friar- who knew the pueblo best. On the same day, Maldonado started his 'visisa y demarcacion', a survey of all settlements on the basis of the map. In accordance with his instructions, he recorded the condition of each hamlet: how many tributarios were living there, whether there was a church or a chapel, and what climate prevailed." He noted what occupations the Indians had, and whether there was sufficient agricultural land. Furthermore, the judge inquired about the supply of water, the presence of sufficient pastures for livestock and the condition of the 'montes' which were used for the cutting of firewood."

After some days of reflection, Don Juan Maldonado decided in both cases on the places of congregation. In the case of Santo Tomás his decision was undisputed. Santo Tomás and its sujetos were situated in an area without an adequate supply of either water or monte. None of the settlements there was suitable as a centre of congregation. The church and monastery in Santo Tomis were about to collapse and the padre guardian had no proper housing. All consulted authorities -the alcalde mayor of Tepeaca and the responsible Franciscans- agreed with Maldonado that Santo Tomás was in a miserable condition. Everyone thought it best to resettle the population in the village of Santa Isabel. In Santa Isabel, there was sufficient land and water to take care of the inhabitants of Santo Tomás. The only problem was that Santa Isabel was a sujeto of Tepeaca, while only 85 of the 325 tributarios of Santo Tomás were liable for tribute to Tepeaca. The other 240 were tributarios of Acatzingo. If they were moved to land under the influence of Tepeaca, trouble was imminent, because either the caciques of Tepeaca would demand tribute from them, because they were now living on their land and Acatzingo would otherwise be offended, or the caciques of Acatzingo would continue demanding tribute, because the macehuales were theirs and Tepeaca would be offended as they were living on their land. However, a solution was easily found, as in Acatzingo there was room enough to harbour 240 extra Otomi-Indians in the Otomi barrio. It was therefore decided to move the 85 tributarios of Tepeaca to Santa Isabel and the other 240 tributarios and their families to Acatzingo. On the further course of the congregation no records have survived."

The case of Tecali was more complicated. Maldonado assigned five centres, in which the other seventeen sujetos of Tecali were to be congregated. On the very day that he made his decision known, the Indian administrators submitted a petition to have it withdrawn. They objected to the congregations on two points: for a start, there was no ecclesiastical need of them, as all Indians attended mass observantly, and the Franciscan village-priests could provide them with all sacraments, if necessary. From an ecclesiastical point of view, they said, congregations would only be harmful, since in every sujeto there was now a 
church or chapel with retables, paintings and gold ornaments and all attributes necessary for mass, which would be lost if the places were abandoned."

In the second place, the Indian administrators argued that the congregations would be economically harmful to Tecali and its sujetos. The macehuales, who were already poor, would have to make costs to build new homes, which would be unbearably high for them. On top of this, they would have to leave their fertile land. This would result in a loss of their fruit trees, magueyes and nopales. Hunting would largely disappear, as it depended on dispersed settlement. As the Indians did not come forward with an alternative for the proposed centres of congregation, the Franciscan guardian of Tecali joined his proposal and Maldonado went ahead with it."

The course of this congregation of Tecali is unknown to us until January 1605, when the newly appointed juez congregador, Diego de Inestrosa Vargas, had a preliminary meeting with Fray Pedro de Zárate, at that time padre guardian in Tecali, who was a declared opponent of the congregations. The submission by Inestrosa of a letter of recommendation from the Franciscan Provincial, did not prevent the guardián from lecturing him on the congregations. Fray Pedro knew that he could do little to stop the congregation of Tecali; nonetheless he made a statement to 'ease his conscience', which he had recorded by the clerk of the commission of congregation. He wamed that forced resettlement would inflict great harm upon the Indians. The least the Spanish authorities could do in recompense for the 'affliction and immense labour' which they inflicted upon the Indians by the congregations and the accompanying destruction of the church, was to excavate the bones of the ancestors with due respect and ceremony and to consecrate a new cemetery. Fray Pedro had become so enraged at the policy of congregations, which he considered disastrous, that he had sent a copy of his declaration and a separate letter to the Council of the Indies in Spain. In the letter, he stated, once again, his opinion that the congregations would cause the 'total destruction' of the Indians.

Meanwhile, Inestrosa carried on. In February, he started the congregation of Santa Marfa Asunción, one of the sujetos of Tecali, which had been designated by him as a centre. The first part of the congregation of Santa Maria went smoothly. A traza (a chessboard pattern of streets) was laid out around the church and the Indians of the barrios concemed were successfully involved in the activities connected with the congregation." Only during camival -carnestolendas, the last three days before Ash Wednesday- practically all Indians concerned were celebrating in the cabecera of Santiago Tecali and did not react to the trumpet signal of the early morning. The number of Indians who were later found in a house-to-house search was too small to start work with. On top of this, they got drunk while waiting for the congregation committee that was looking for more workers.

The real problems did not develop until the work of the committee had largely been completed. The traza was laid out, everyone had been granted a plot for his 
house (solar) and the houses just had to be built. In the instruction to the Indians, the juez congregador bad indicated that he wanted the houses to be built of adobe or stone and not of maize straw or wood. The congregation committee continued its work in the next centre of congregation and left responsibility for all further activities to an Indian principal. Every month, the alguacil or escribano, who were part of the committee, carried out an inspection in Santa Marfa, but the construction was not getting on. Only after some inspections and many exhortations, huts of maize straw were built, but the construction of stone houses had not even begun yet. On a tour of inspection on August 8, by no means all Indians of Santa María Asunción lived in the congregated village yet, nor was anyone busy constructing his house at that time and none of the walls had been built of either stone or adobe." Therefore, once again, the committee itself took over the command of the construction activities. This had some effect, because by the end of the year, at least most of the houses were occupied and in some places walls of stone were under construction. In January and February 1606, the old houses in the former places of settlement were destroyed to prevent the Indians from going back there. Obviously, the Indians were rather distressed about this, because most of them could not be found on the day the destruction was to take place. It is not known how the congregation of Santa Maria ended, as the last part of the archival record which contains the account of the congregations has become illegible due to moisture. ${ }^{\text {o }}$

Inestrosa did announce that he would continue the congregation in San Miguel, but $I$ have not been able to locate the documentation of this part of the congregation. ${ }^{31}$ By the end of April 1605, however, the committee arrived in San Francisco Mixtla, another of the five centres designated for congregation in the district of Tecali. Here, the work was hampered from the start. Just like his predecessor in 1599, Inestrosa started by summoning all people concerned, especially the village officials, in the local church, in order to explain his plans. Despite his twice repeated summons, which had been communicated by an Indian alguacil, no one turned up. The responsible alcalde, who was brought from the cabecera of Tecali, apologized by saying that the Indians of Tecali were busy putting together a workforce for the drainage works of Mexico City, the so-called repartimienso de desagile. The viceroy had ordered that absolute priority should be given to this repartimiento. The alcalde was the only one who could do the job, as the gobernador -the leading Indian village official- of Tecali was in the city of Mexico and the other alcalde lay ill. Inestrosa instructed him to summon the Indians all the same. He just wanted to make a short speech, after which the Indians could go on organizing a workforce. At last the information meeting was held, although many Indians were absent, already on their way to Mexico City, or preparing food for the joumey. The juez congregador explained that the congregation was meant to make all Indians live together orderly, so they could 
assist each other in times of trouble, be taught about the christian faith and allow the law to protect them effectively.

The juez congregador ordered lists to be drawn up of the Indians living in the various hamlets. Those who were not going to Mexico, had to gather in front of the church a few days later, carrying their digging sticks and some long ropes in order to measure the lots for the houses. To inspire the Indians with some respect, Inestrosa had a whipping post erected in front of the church, so that every one who did not cooperate would know what was awaiting him. On the first day, everyone started work industriously. On the land that was designated for building, solares of $60 \times 60$ varas (ca.50 by 50 metres) were measured out on the indications of the juez congregador. On that day, 52 Indians measured out 39 solares. The next day at six in the moming, an Indian trumpet player was ordered by Inestrosa to give a signal for gathering. Although he was blowing his trumpet till eight, hardly anyone turned up. The alguacil of the village was one of the few that had come, and was ordered to go by all the houses to find workers. He returned with only eight Indians; the others were untraceable. To inspire both these eight and the other ones with some awe, Inestrosa had three of them given ten lashes with a 'disciplina'. Finally, at nine, there were seventeen Indians, who measured out solares until it started to rain in the aftemoon.

The morning of the next day 25 Indians came after the trumpet player had been blowing his instrument for two hours again. They had to remove thornbushes and wild nopal cactuses from the monte behind the church, before they could go on measuring. And even after that, work did not progress smoothly, because the ropes got stuck in the remaining shrubbery. To make sure the workers would come back on Monday, their digging sticks were kept back at the end of the day. Whoever would not show up to collect his coa, would be punished. Sunday was a day off, but before Mass, with the entire population present as usual, the Indians were, once again, ordered to come to work. To make sure this happened, the Indian alguacil and the clerk of the congregation commission were sent out to find workers before six on Monday moming. These early activities bore fruit, as 58 Indians now appeared. On 10 May, the works of measurement had been completed and the solares were allotted. For those who had gone to Mexico City, solares were given to their wives, children or relatives.

The juez congregador gave elaborate instructions for the organization of the solares. The instruction was inspired on the local use of so-called jacales (Indian house). Each jacal that was built on the allotted solares was to measure thirty by twelve feet. The walls of the huts were to be built of stone and adobe and thatched with zacate (a kind of straw) or palm leaves. Next to the houses, thirty feet of nopal cactuses had to be planted on the solar for the cultivation of cochineal, with four or five nopal leaves per foot. To build jacales, the Indians were divided into groups of eight workers (cuadrillas). The work had to be finished within a month, and those not cooperating were to be punished. In view of the earlier opposition to Inestrosa's plans, it is not surprising that the construc- 
tion of these houses, like in Santa Maria, soon stagnated. This time, the juez congregador ran out of time and had to break off his mission and leave it unaccomplished.

The authorities did not leave it at that. After having read Inestrosa's report, a year later -May 1606- they appointed a juez conservador, who had to see to it that the congregated Indians finished the houses and did not return to their old settlements. The deputy of the alcalde mayor of Tepeaca in Tecali was named to this office. It is not known how he fulfilled his task, as no reports have survived. In a general decree for the whole of New Spain in 1607, the Indians were officially allowed to return to their old homes if they wanted to. In later colonial times, Tecali consisted of 22 sujetos, as in the visita of 1599 , so we may conclude that the attempts of the last congregador were no more successful than those of his predecessor.

Complaints about the congregations did not just come from the Indians. In Tepeaca, the juez congregador lamented that the congregated Indians of San Salvador (east of Tepeaca) could not finish their new homes, as they had to work on nearby labores all the time. More often, the Spaniards were concerned that their Indian labourers would be involved in a congregation. To prevent this, the labrador Don Juan López Mellado petitioned to the Audiencia to exempt his labourers from congregation. ${ }^{\text {. }}$

A few objections concern the illegal occupation of Indian land by Spaniards. For example, the Indians of Santa Maria Nativitas, sujeto of Tepeaca, accused Alvaro Ruiz of usurpating their land and planting fruit trees and magueyes. In the village of Amozoc, in the alcaldia mayor of Puebla, however, an Indian cacique tried to turn the congregation to his advantage. The local Indians, led by their cacique Bartolomé de Luna, charged the Spaniard Antonio Carrillo before the alcalde mayor with having illegally cultivated a plot on their land in Santa Clara Tapalayuca, sujeto of Amozoc. In the litigation it appeared, however, that the Indian cacique had sold the land to Carillo a few years earlier, and used the confusion following the congregation to try to get it back by accusing him of having taken it illegally. This plan failed, as Carrillo was able to show a merced whereas the Indians could not prove any claims to the land."

In Amozoc, which formed a pueblo de indios together with Cuautinchan, there had been trouble during the entire previous decade. The pueblo was divided in a number of irreconcilable factions, the leading caciques of which tried to seize power in the village. No wonder that at the time of the congregations a lot of manipulation took place. The caciques of Amozoc, together with some influential local Spaniards, succeeded in making the juez congregador, Juan Jiménez de Riancho, side with them. Jiménez was easier to influence than his colleagues in Tecali and Tepeaca. One day in 1605, at four in the morning, he entered the hamlet of Santa Maria Nativitas, a sujeto of the city of Puebla -not the same settlement as the sujeto of Tepeaca mentioned above-, with a gang of thirty 
armed Spaniards and set fire to it. According to the Indian leaders and a number of Spanish witnesses, Jiménez and his company burned all jacales, which had been built of wood and straw, without previous warning. It was a miracle that everyone could escape alive. The witnesses thought it even more shocking that the church was destroyed and that, without any consideration, the assailants threw three statues of Christ, a statue of San Pablo and San Jacinto and a large one of San Francisco into the street, as if the inhabitants of Santa Maria Nativitas were 'infidels and Chichimecs'." The village-leaders argued that Santa Maria had been founded with the consent of the viceroy, which had been laid down in official papers. However, Jiménez took these from them, when they were shown to him on that fateful morning. Afterwards, he locked up the Indians of Santa Maria in Amozoc until five in the afternoon, without giving them the opportunity to build new houses. Two Spanish witnesses declared that, in their opinion, the juez congregador had been manipulated by the caciques and the Spanish inhabitants of Amozoc -one of whom was the encomendero-, who wanted the control over the tribute and labour of the thirty or forty Indians from Santa Maria Nativitas. It is not known how the suit ended, because the alcalde mayor only heard the local witnesses and then sent the case for judgment to the Audiencia.

Jiménez was an exception; in general, the jueces congregadores took their task seriously and fulfilled it properly. The majority of the congregations went smoothly. Most problems developed in the larger congregations. Above, I have mentioned two of the most important causes for this, according to viceroy Monterrey: the opposition by the local friars and by the Indians on the central highlands, who were much more hispanized than the indigenous population elsewhere. These factors indeed appear to have been important. As we have seen in Tecali, in 1599, the Indian officials of the pueblo submitted an elaborate petition to have the proposed congregation cancelled and in 1605 the local friar fiercely opposed them. The manipulation of the congregations by the Indians especially the caciques- to their own advantage appeared most clearly in the congregation of Amozoc.

In my opinion, elsewhere the indigenous nobility was more willing to cooperate with the Spanish authorities, because the central highlands differed considerably from the remoter and more secluded areas. One of the most important effects of the congregations was that the collection of tributes had become easier. This not only served the Spanish authorities, but also the local caciques, because they were responsible for the collection of tribute and had rights to tribute themselves. On the central highlands, the Indians generally lived in easily accessible places, but in the remoter, more mountainous areas the population density was lower and the terrain was less accessible. Here, the caciques benefitted from large-scale congregations and were more inclined to cooperate. The success of the congregations depended on local leaders. This does not mean that the common Indians in remote areas were very pleased with the congrega- 
tions. Even there, the congregations only lasted for as long as the Indians were allotted better land there than they had had before, which sometimes happened. ${ }^{\text {s }}$

In the primary sources and in the literature, a number of reasons for congregations are mentioned. In contemporary official documents, the accessibility of the Indians for the clergy is given as the main reason. In view of the protests of the regular clergy, the most important group of village-priests at the time, this reason was of secondary importance, especially for the authorities in New Spain. Considerations of this nature were possibly more important in the mountainous regions on the border of the highland. Above, I have discussed the simplification of the collection of tribute in isolated areas. This was a reason for the indigenous caciques to cooperate. Since the previous period of congregation in the 1550 s, the tributes had been collected per pueblos de indios on the basis of the number of tributarios in the pueblo. The collection of tribute was a responsibility of the Indian officials, and the amount of tribute paid to the Crown did not depend on the accessibility of the tributarios. The Spanish authorities also benefited, but the fiscal advantage remained limited. The congregations had only reduced the risk of fraud.

Above, I have said that, at least on the highlands where the majority of the Indians lived, most congregations only affected a limited number of Indians and resettlements were rather marginal. Although there was more movement of population in the remoter areas, only in a few cases a congregation served more structural objectives for the authorities. This was the case in the Sierra Norte de Puebla, where many Indians were moved from the isolated mountain slopes towards the new camino real in the northern part of Tlaxcala. Because of the attempts of structural adaptation, the Mexican historian Garcia Martínez, who has studied the congregations in the Sierra at length, even calls the Spanish officials designers of geography (disentadores de geografia)."

The rather marginal resettlement of the Indians on the central highlands, the area in which most haciendas were founded, makes it doubtful whether clearing the land for the haciendas was as important a motive for the officials as many have assumed. In this respect, it is significant that haciendas hardly played a part in the discussions and disputes about the congregations at all. There were some conflicts about land, which were concentrated in the area around the city of Puebla. In Amozoc, it was not the Spaniard who appropriated Indian land, but rather a cacique of the village who would attempt to deprive the Spaniard of his land. In the congregation of Tecali, the haciendas were of no importance whatsoever. In the description of the sujetos of Tecali, no haciendas are mentioned and in 1599, apart from the Franciscan padre guardián, there was not a Spaniard to be found in the entire district who could serve as a witness in the case of the congregation. 
Besides the spiritual care, official reports mention two more reasons for congregation, to which little attention has been paid in the literature. The juez congregador of Tecali expressed them most clearly: if the Indians started to live together they could help each other and it would be easier for the law to protect them; they had to form true comunidades. This last point was also often been mentioned in other documents. In my opinion, this was the most important reason for congregation: the congregations at the turn of the century were a means to facilitate the recording of the landownership of the pueblos de indios. The mercedes and earlier amparos of cacique-land were complemented by the congregations. During the initial survey by the jueces de comision of the pueblos de indios, which they had to congregate, they did not only make a visita (visit), but also carried out a demarcacion (demarcation). From the second period of congregations, several amparos of cacique-land have survived. In 1643, the Indians of Cuautinchan and Amozoc testified in a lawsuit on land that the juez congregador had granted them 40 caballerías (some $1720 \mathrm{ha}$ ) of land in the congregation. According to the American historian James Lockhart, a number of village annals, written in Nahuatl, from the valley of Mexico, which he has studied, started precisely in the period of congregations, when the jueces congregadores allotted land to the pueblos in question." Consequently, the most important objective of the congregations was not to resettle the Indian population, but rather to establish the actual landownership. The concentration of Indians was a means to this end. As a result of the dispersed settlement, it was very difficult for the authorities to assess the landrights of Spaniards and Indians. Consequently, most congregations affected only small numbers of Indians, especially on the central highlands. Elsewhere, often more Indians were resettled, but the objective remained the same.

Just like the first congregation period, those of 1590-1607 constituted a phase in the establishment of an administrative division of New Spain on territorial criteria, which had been initiated under Spanish rule. With the complex of measures connected with the composicion of land, the new division of land between Spaniards and Indians had been recorded. The Indians kept their old milpa-lands and also retained an important part of the rights to monte and water. By means of the purchase of land and through mercedes, the Spaniards arrived in many of the areas that had formerly been no-man's-lands between the various altepetl of the valley, where they founded labores. These were added to the livestock haciendas that they bad previously founded in the vast uninhabited tracts of land surrounding the densely-populated areas of the valley of Puebla. The distribution of land as it had been established in the valley of Puebla until about 1620, is depicted on Map 4. In 1620, after the composición had been completed, there was little unused land in the rural regions of the valley and all rights of ownership were settled from that time on.

During the entire colonial era, the distribution of landownership between Indians and Spaniards remained virtually the same. This did not mean that lands, 
especially those in Spanish hands, remained with the same family all the time. Historical research has shown that especially in the eighteenth century, Spanish land often changed ownership. With the land, the official titles to it were also sold. As a result, selling land changed little in the distribution of landownership between Spaniards and Indians. It is hardly surprising that a renewed composición in 1643 met with resistance from the Spanish landowners. In Cholula, Huejotzingo and Tepeaca there had been an elaborate inspection which had only been concluded some 25 years before and they were not at all pleased by the thought of a repetition, which could only cause unrest and would cost a lot of money. The labradores of Atlixco declared that '[...] the lands of their jurisdiction do not need to be surveyed and there are no baldlas nor demasías, because all [lands are] highly esteemed and valued'." In order to meet the royal wish to get revenues from the composicion, without having to go through the trouble of a survey, the labradores of the valley of Puebla paid a sum of redemption.

\section{Conclusion}

Agrarian development was one of the most decisive changes affecting the late sixteenth and early seventeenth centuries' social transformation in the valley of Puebla. For many the rights to land were the basis of existence; after all, colonial society was an agrarian society. The formation of Spanish labores marked a breakthrough in the relation between Spaniards and Indians. As the demand for food serving a Spanish diet grew, number of labores increased, Spaniards started to produce food themselves and came to play a more significant part in rural society.

The Spanish agricultural system required far different ecological conditions than the Indian one. Spanish wheat cultivation prospered best on the flat lands of the riverbanks in the lower parts of the valley where the soil could be ploughed without the risk of erosion and where irrigation was possible. The Indian milpas, on the other hand, were confined to the lower slopes. Apart from ecological considerations, the Indians usually refrained from using the riverbanks from a military point of view as well, since the flat lands were very vulnerable to attacks. Consequently, the lower parts of the valley were generally used as buffer zones between the altepetl. With the pacification under Spanish rule, both agricultural and military objections had been removed. In principle, there was an ecological separation between Spaniards and Indians. The Spaniards, however, could not simply occupy the lower parts of the valley with labores, as this conflicted with the Indian view on their rights to land.

According to the traditional indigenous view, the caciques of the altepetl held the power of decision over all land within their sphere of influence. This right differed from the European right of ownership, founded in Roman Law, in the 
sense that it was neither exclusive nor absolute. According to the Spanish custom of presura, however, anyone was free to cultivate wastelands, after which he was entitled to consider it his property in the sense of Roman Law. Two views on the rights to land clashed here and this gave rise to a large number of conflicts. The problems were hard to solve, as each party thought to be in its right. For the colonial courts it was almost impossible to reach a decision: Spanish law recognized the legitimacy of Indian rights, but these had not been written down. Moreover, the claims of the Indian nobles, especially the caciques, often comprised vast areas of waste land and also parts which were inhabited and worked by macehuales.

The authorities in Mexico City realized that a solution to this dilemma was of the utmost importance for both the development of Spanish agriculture, which was vital to the urban centres, and for the restoration of peace in the pueblos. Consequently, they initiated an elaborate programme that was meant to record the factual distribution of landownership. This programme had two parts. The labores of the Spaniards were recorded in mercedes; the Indian possessions were first recorded in an inquiry, but as this appeared to be insufficient, it was followed by the second programme of congregations. These attempts by the Spanish authorities soon bore fruit: when the Indian nobles saw that their rights had been recorded in Spanish documents, they felt less threatened. At the same time, they impoverished, due to the tribute reforms and the depopulation. They started to sell their unproductive lands, mainly the clayey plots on the riverbanks and land in the uninhabited peripheries of the provinces. There were many Spaniards who wanted to buy the land: in the 1590 s, this led to a real scramble for land. The sales of land by the Indians were concentrated in the last decade of the sixteenth century; after the turn of the century, their number dropped considerably.

The purchases by the Spaniards did not immediately result in fully fledged labores; these were often composed later on, by joining parcels and by a selective sale among Spanish landowners. As a result of the sale of such large amounts of land, the first recordings of landownership were no longer sufficient and in the second decade of the seventeenth century, the authorities started a programme to record the changes, as well. Around 1620, the division of landownership stabilized. By then, nearly all agricultural land in Spanish hands had been transformed into labores. This did not mean that the sale of land had come to a standstill, because Spaniards continued to buy and sell labores during the entire colonial era. From this time, however, it were mainly complete farms that were sold and no more separate fields.

In the pueblos de indios, the situation had already stabilised with the congregations. The recording of the Indian landownership, however, had favoured the caciques, because they were the ones who could actually demonstrate their rights to land. With the recording of the division of landownership, they had received the right of decision of all land that had been under their traditional Herrschaff. 
These rights comprised both the land that was used by the inhabitants of their pueblo and the wastelands, the monte, which were also used by the inhabitants. This implies that, within the pueblos, the Indians held on to the old, indigenous rights to land, whereas in the relation to Spaniards, the new European laws and customs ruled. In the course of time, the European way of thinking gradually entered the pueblos, but this was a very slow process, which took most of the colonial period.

The formation of labores created the necessity of a radical adjustment of the economy in the region as a whole. Before the development of Spanish agriculture, the city of Puebla de los Angeles, the centre of the region, had been dependant on the food production in the pueblos de indios, but after the emergence of Spanish agriculture, it soon came to depend on Spanish production. For a long time, this only held good for wheat, and much less for the supply of maize and the other goods, both agricultural and non-agricultural, that were produced in the pueblos de indios. Adequate supply was only possible, if transportation was adapted to the new demands. The transportation of products was not the only problem in the society of New Spain. Agriculture on the labores did not just depend on the availability of land, but also on an sufficient supply of labour. This last point was most problematic in an area in which the supply of labour was not regulated by the market, but by the rights and duties of Herrschafi. The Spaniards would have preferred these structural adjustments of economy and society to develop naturally, but it soon became clear that, once again, intervention was the only way by which the authorities could prevent the developments from getting out of hand. 


\section{Chapter 4}

\section{The Practice of Regional Economy}

\section{and Administration: the Repartimiento}

\section{de Trabajo and the Repartimiento}

\section{de Comercios}

The formation of haciendas and the introduction of an entirely new system of administration changed the socio-economic relations and also the landscape in the valley of Puebla in such a way, that we may characterize the entire process as a structural social transformation: in 1620 , the valley of Puebla looked completely different from 1570. The changes in the relations of ownership did not take place in a social vacuum. The subject of the present chapter is the way in which the changing balance of power and the evolution of the social and economic structure influenced one another. Attention is mainly focused on the Spanish officials at the regional level: the alcaldes mayores, corregidores, their deputies and their interaction with other social groups.

The transformation took shape particularly in the reactions of the various Spanish groups to the demographic and administrative developments and to the new opportunities which these changes implied or which they created themselves. The future lay open to those who adjusted with flexibility to these new possibilities and opportunities. Whoever could not summon this flexibility, lost his position. This was especially true of the encomenderos and the Franciscans, who had formerly played an important part in the relations between Spaniards and Indians. Their position is discussed elsewhere.

The relation between Indians and Spaniards took on a wide variety of shapes in the late sixteenth and early seventeenth centuries. In general the archival material suggests, that in the course of time they worked out a way of living together, notwithstanding the inevitable conflicts and tensions between the two groups. The Spaniards could not dominate the situation in the rural areas, because the Indians 
defended their rights whenever necessary and the Spaniards were only a small minority. As I have argued in the previous chapter, the Spaniards could bardly put any pressure on the Indians in the formation of haciendas. Besides, there was neither a standing army nor a regular police force to exert pressure. Whenever a rebellion was to be repressed, an expedition force had to be especially formed from ill-trained local Spanish civilians. Although the Spaniards actually used to walk around with muskets (arcabuses) or swords and daggers, a single Spaniard stood no chance against a turmoil. The muskets could only fire one shot, after which reloading was a laborious and rather time-consuming task. In addition, the authorities took action against the possession of arms.

The administrative reforms of the mid-sixteenth century had greatly reinforced the position of the bureaucracy of the Spanish state. The Leyes Nuevas strengthened the formal position of the regional officials, known as corregidores, alcaldes mayores and, in Tlaxcala, governor (gobernador). As a result of the important role in the social life of the valley of Puebla, which their official position gave them, they managed to obtain a lot of power in practice, as well. They executed the political programmes of the authorities in Spain and the city of Mexico, yet had quite an autonomous position.'

Their credibility at a local level depended on their way of running the administration. The Crown had granted them sufficient authority to enable them to give meaning to their position. They had been given jurisdiction in order to "know according to civil and criminal justice all that goes on in their districts among Spaniards, among Indians and among Spaniards and Indians'.' Officially, they had a term of office of no more than three years, but in practice this varied between one and four years. For showing their authority, they received a so-called vara de justicia, a staff without which they were not supposed to appear in public. As stated in the law, the vara de justicia was the 'insignia by which the Jueces are known [and by which it is known] to whom conflicting parties are to go to ask for justice, so that all receive justice in equal measure and everyone is heard benevolently'.3 The Spanish regional officials were the people who exercised the royal power within their districts. As such, they were the agents of the state authority, which had basically been organized as a rationalized bureaucratic Herrschafi in a Weberian sense."

In reality, the administrative authority, which rested on a narrow basis of tax income, restricted the practicality of a rationalized administration in the modern sense of the word. Soon, lack of funds forced the Crown to start farming out a number of lower offices. Initially, these predominantly concerned the offices of clerks, alguacilazgos (constables), in the cities, and several offices connected with the collection of taxes. At times, however, the sale of offices was not confined to administrative functions, but also extended to the sale of the monopoly on the supply of meat for the cities.' In this way, the risk -and most of the profits-connected with the uncertain supply of meat to an always unpredictable market, was taken off the authorities' shoulders and put under a private person's control. The sale was a 
guarantee that the person who had bought the monopoly or administrative post would make an effort to fulfil properly the duties connected with his office, as these would provide him with an income. Notwithstanding the sale, ho was still responsible for his acts to the Crown. With these sales, the Crown acquired a steady source of income, which would have been difficult to secure in any other way.

During the colonial era, offices with a judicial function, like those of the alcaldes mayores and corregidores, were officially not for sale, but when the Crown was short of financial means, this prohibition was frequently forgotten. Parry, Tomás y Valiente, Yali Romín and especially Pietschmann have elaborately studied the evolution of the sale of offices. As the sale of offices of these regional officials was never legitimate, it is difficult to find out when it all started. In 1638, the viceroy was still being corrected by the authorities in Spain for having sold the office of alcalde mayor in Huauchinango in the Sierra Norte de Puebla, but towards the end of the seventeenth century, the sale of offices seems to have become more and more common. This was also the time during which Spain itself was in turmoil as a result of the Spanish Wars of Succession, when the Crown suffered a greater shortage of money than ever before and the overseas colonies were largely left to their own devices."

The regional officials were appointed by the viceroy, who also allowed his own preferences to play a part here. This does not mean that the appointment of officials in the administrative sphere was a careless matter. For example, the alcaldes mayores of Tepeaca were usually high-ranked nobles, often members of the distinguished Spanish military orders. This did not make them excellent civil servants according to modem standards, but to contemporary standards, they were the men most qualified for the offices. Consistent with prevailing views on the estates society (German: Standenstaat), the Crown was of the opinion that the nobility were better suited to fulfil these offices than commoners, as a result of their superior descent and nature. Moreover, nobles were not supposed to be dependent on work for a living, and, consequently, to fulfil an office just for the honour involved and not for any profit. Of course, this was theory rather than practice, as, notwithstanding their nobility, most officials did profit from their office.

At the end of the sixteenth and the beginning of the seventeenth centuries, we can distinguish a growing autonomy of administration in New Spain and other LatinAmerican territories. The Crown saw very well, that the autonomy of its overseas officials could easily lead to all sorts of abuses and therefore imposed several restrictions and means of control. Whoever appointed an official was not only responsible for his own acts, but basically also for those of his subordinates. In this way, a viceroy might be beld responsible for the behaviour of an alcalde mayor. In his turn, an alcalde mayor was responsible for the behaviour of his subordinates and their families. Each official was supposed to bebave according to the abstract principle of 'good government' (buen gobierno) and to put public welfare (bien público, república) before personal interests (particulares intereses). 
The authorities of the various offices and administrative bodies often overlapped, the aim of which was to obtain a balance between the influence of the people who fulfilled an office and corporate organizations. Thus, for example, the viceroy had all power of government, but the Audiencia also had considerable authority in this area. In legislation, the lines between the spheres of influence of both institutions were kept vague on purpose. At a regional level, there was the same relation between the regional officials and the Spanish and Indian cabildos.'

Moreover, besides the regular administrators, special officials were often appointed to supervise one sector of society. At the highest administrative levels, they were the so-called visitadores generales, who received their assignment in Spain and were to evaluate the operations of the Audiencia, the viceroy and the provincial officials, as well as the functioning of the administrative system in general. Some illustrious visitadores generales of sixteenth-century New Spain were Diego Ramírez and Juan de Valderrama, who played an important part in the revision of the tribute system." However, initially, special officials were quite often appointed at lower administrative levels as well. Thus, in the sixteenth-century valley of Puebla, there were jueces comisarios for the cultivation of cochineal (juez de la grana), for the supervision of textile factories (juez de obraje) and for labour services (juez repartidor or juez comisario de los alquileres). The jurisdiction of these jueces comisarios was limited; besides, they could often do no more than react to the existing situation. After the turn of the century, the king in Spain restricted the appointment of these regional officials, as they were too expensive and not effective enough. Their duties remained, though, and were taken over by the alcalde mayor."

It is often stated in the literature that the sale of offices and the lack of control by the Spanish state led to vast corruption. In the modern view of a rational bureaucratic Herrschafi in a Weberian sense this reproach is possibly justified, but in the context of the early-modem state, it is out of place and anachronistic. There were two forms of corruption in the Spanish-American context. The first form was the appointment of friends and relatives to public offices coming under the control of a specific official, and the second one was the use -or abuse- by officials of their position and the power connected with it, assuming implicitly that this automatically gave rise to a dishonest exercise of these positions. However, what we are prone to call corruption was based on a system. It falls outside the scope of this study to make an in-depth investigation into the first forms of alleged corruption, the nepotism and favouritism, but in order to understand the system behind it, it is necessary to make two comments on the subject.

In the first place, granting public offices to friends and relatives, should be seen against the background of an organization of society based on strong family ties. The powerful were expected to be a patron for both relatives and friends, regardless whether they had economic, social or political power. When offices were sold to relatives, it partly prevented inflation, which was likely to occur if a saleable office was sold to competing bidders, who subsequently had to squeeze everything out of the position just to play even. In addition, if an official had to borrow money in 
order to be able to pay for the office, there were no banks to supply it. Only in the case of relatives there was enough confidence that lent money would be returned. ${ }^{10}$ Granting positions to friends and relatives had another advantage: it enabled the highest official involved to increase his control over the administrative territory falling under his influence. He knew the appointee personally and was, consequently, familiar with his strong and weak points. As a result of these relations of blood or friendship, there was also a standard mutual responsibility. In other words, it was considered only natural that a friend or member of the family would not abuse trust nor take his own interest as a point of departure in the exercise of his position. Doing so, he would not only discredit himself, but also his patron. This principle was not only valid at a regional level, but also up at the highest levels: whenever the king wrote to the viceroy, besides his personal and official titles, he would also call him 'my relative' (deudo mio)."

In this way, the administrative organization remained manageable in a society in which control of the activities of subordinates in distant places was very difficult, because of the limited means of communication. In a Weberian sense, we could say that, in practice, the administrative organization predominantly showed traits of a 'patrimoniale Herrschaft' besides the rational bureaucratic intentions. It should be noted that Weber implied that all non-bureaucratic forms of administration were less rational. However, this is a twentieth-century projection which hampers a proper understanding of earlier systems of Herrschafi. Colonial rule was a form of administration which both adjusted to and evolved from the circumstances, and as such it was the most rational under the circumstances for that time.

It would be a mistake to attribute too much influence to the rural officials and their representatives. They often had some thousands or even tens of thousands of Indians in extensive areas under their orders and had to take care of the administration of the Spaniards within their province as well. Besides, within the districts, communications were mostly defective and, consequently, slow. As a result, they could not exert a very direct control on the social life within the territory under their jurisdiction; a problem of all early-modem governments. This does not mean that they did not hold an important position in society, but just that they did not have a firm grip on its functioning. ${ }^{12}$

It is obvious that these considerations only apply to the system in general. In practice, it depended on the individual officials whether the means of control, which the system offered them, indeed followed the standard rules, leading to buen gobierno instead of personal abuse of power or profiteering. The success of the Crown's intentions can be measured by the degree to which the Crown could implement its policy. Based on the development of labour relations, I shall argue below that although the officials usually pursued the Crown's policy, the Crown could not directly impose its will on social processes, because in the course of these processes, the social groups in New Spain and the existing social structure would modify both the policy and the processes themselves. The so-called repartimiento de trabajo -the distribution of labour by regional officials- is the central issue in the 
treatment of labour relations. The degree to which officials at a regional level enriched themselves through comption, will be treated in the analysis of a second form of repartimiento, the notorious repartimiento de comercios, which is usually described as a forced sale or purchase of goods by Spanish officials from the Indians. The general assumption is, that Indians fell victim to the illegal pursuit of profit by Spanish officials. In this last case, it will become clear once again that regional circumstances were of overriding importance for the form of the repartimiento de comercios.

\section{The establishment of the repartimiento de trabajo}

Many authors have been preoccupied with the labour relations, especially the repartimiento de trabajo. The repartimiento de trabajo (literally: redistribution of labour) was a forced employment strategy introduced by the Spanish authorities, which meant that the tributarios of the pueblos de indios were obliged to perform labour services in Spanish enterprises, either labores or mines, or in public works, for example in the city of Mexico. It came into being in the sixteenth century and is thought to have developed from the prehispanic coatequitl. This had been a general labour service for all macehualtin of an altepetl, which was only made use of in times of great need, like wartime or natural disasters, and for building exceptionally large projects, like temples. The repartimiento de trabajo consisted of labour duties of a fixed period of time -usually ranging from one to several weekswhich rotated among the Indian population. It is seen as one of the most oppressive practices of colonial rule. Actually, this view already dates from the sixteenth century, as the repartimiento was one of the most controversial subjects in Spanish America. The repartimiento de trabajo, called mita in the Andes territories, had a different length of life in the various parts of the Spanish colonies. In Central Mexico, the system, with the exception of the repartimiento for the mines, lasted for about three quarters of a century -from ca. 1570 to 1632 -, but, for example, in Central America it lasted for most of the colonial era.

It has been assumed in the literature that in Central Mexico the forced services for agriculture became superfluous in the course of time, because the duties of the Indian repartimiento labourers from the pueblos de indios, were taken over by labourers (gananes) who were recruited by Spanish hacienda-owners from the Indian communities. It has often been discussed whether or not this was accompanied by the rise of the so-called debt peonage, which means that the Spaniards forced such high advances on the Indians, that the meagre wages they earned were insufficient for them to redeem these advances during their employment. Both points deserve attention."

In their handbook on the colonial history of Latin America, Lockhart and Schwartz write that the history of labour relations had two remarkable breaks: one between encomienda and repartimiento and the other between repartimiento and 
peonage. The break between encomienda and repartimiento was not very distinct, but from the beginning, the repartimiento had been designed as an alternative for encomienda. The relation between repartimiento and peonage was more complex and rooted in the agrarian practice of the sixteenth and seventeenth centuries. The broad outlines of this development have been sketched by Chevalier, Zavala and Gibson."

In the course of the sixteenth and seventeenth centuries, in the rural areas -and indeed in the urban areas as well- a labour market came into being, in which demand and supply slowly reached an equilibrium. As is evident from the date of the abolition of the repartimiento, this growth towards an equilibrium more or kept less pace with the consolidation of the Spanish landownership in the second and third decades of the seventeenth century, which has been sketched in the previous chapter. Unfortunately, it is not quite possible to sketch the development of the labour market in quantitative detail, because no figures are available.

It is not immediately obvious to what degree the free labour market replaced the forced labour services. In order to understand the relation between these two forms of labour supply, we must first go more deeply into the characteristics of the agrarian repartimiento and the way in which it took shape in the valley of Puebla. In the background, the policies of both Mexico City and Spain always played a role. These continuously aimed at abolishing the repartimiento duties of the pueblos, and as long as this was impossible, at reducing them as much as possible. The object was to establish a proper labour market in which the laws of demand and supply would rule, instead of the situation of the early period, which had been characterized by government intervention.

The evolution of the labour relations in the period from 1570 to 1640 was most intricate, because it was influenced by a great number of circumstances. Of course, the Spaniards were dominant on the demand side of the labour market that was coming into being. The formation of labores and the foundation of obrajes (textile mills) in the major towns and cities brought about an increase in the demand for labour. On the supply side of the labour market there were two tendencies. On the one hand, supply grew, because an increasing number of Indians escaped the influence of their pueblos. On the other hand, however, supply dropped due to the depopulation as a result of epidemics. Matters were further complicated by the strongly controlled policies of the Spanish authorities, aimed at a regulation of labour relations.

This readiness to intervene was a symptom of the dilemma concerning labour supply, which vexed the viceregal authorities. They realized that an adequate labour supply was of crucial importance to the functioning of Spanish economic activities. From the outset, the viceregal administration had preferred to leave this entirely to the free recruitment of labourers on the labour market. The remarkable growth of the demand for labour on the rapidly evolving Spanish haciendas was not immediately accompanied by an equal growth of labour supply. In prehispanic labour relations, which I have characterized as a Personenverband, there had never been a labour market of any size, although there had always been people who had earned a living 
partly by performing occasional services for others. Before the tribute reforms were established around 1570, most labour had been tied to the personal relations of power which had defined prehispanic society and had continued under the encomienda. As I have remarked above, the Indians regarded the labour services as an inseparable part of tribute. Thus, it was not surprising that often the caciques objected strongly to the introduction of structural and official repartimiento services, because they saw them as further encroachments on their tribute rights.

Because the macehuales were so closely tied to the power structure of their pueblos, it was not likely that they would offer themselves on the labour market, as this would imply that they would withdraw from their pueblos and loose their rights to land. As we have seen above, however, many macehuales did escape in the last decades of the sixteenth and the early decades of the seventeenth centuries, and, consequently, the supply of labour increased rapidly. Only because the labour supply still had to develop from scratch and because the change in mentality of the indigenous population was not accomplished overnight, initially the growth of the supply could not keep pace with the growth of the demand for labour. As macehuales left their pueblos and offered themselves as labourers on the labores towards the end of the sixteenth century, the needs of the labradores were somewhat reduced, but at the same time this increased the economic pressure on the pueblos and especially on the caciques who lost many of their subjects.

The repartimiento caused strong feelings in late sixteenth- and early seventeenthcentury New Spain. Naturally, the labradores were in favour of a repartimiento of labourers to the labores and the prevailing view in official circles was that the maintenance of forced labour services was the only solution to the lack of labour. As could be expected, the most vehement protests to the labour services came from the Indian caciques, the regular clergy, especially the Franciscans, and officials who had been influenced by them, like Alonso de Zorita. The most important spokesman for this group was the Franciscan Mendieta, who had the Indian caciques complain against the new Spanish order in his Historia Eclesiastica Indiana: 'In which good law is it appropriate that, while we are the natural inhabitants of these lands and [the Spaniards] have just arrived, we are to serve them, without having done any wrong to them, but rather they to us'." There were even Indians of noble descent who now had to serve Spaniards.

In this quote, we once again see the protest of the Indian nobles against the effects of the tribute reforms, as a result of which many lower-ranking nobles had lost their tribute rights and privileges. In the eyes of Mendieta and the other Franciscans, the repartimiento services were nothing more than slavery and a means of oppression. Wherever the Indians were treated well, they would come to the Spanish Labores by themselves, he wrote. ${ }^{16}$ The picture of the repartimiento as appalling exploitation and enslavement sketched by the Franciscans, deeply influenced later historians.

Admittedly, there were some elements in the repartimiento which made it one of the most arduous duties for the indigenous population. The primary problem of the 
agrarian repartimiento was the significant difference with the coasequitl from which it had evolved. The coatequitl had usually been confined to the own altepetl, and the macehualtin had taken part in it together with their wives. Labour had been divided in such a way that the women had prepared the food, while the men had performed the work for the altepetl. Repartimiento labour often took place at quite some distance from the own pueblo, so the Indians had to take food for the road. The tortillas they took with them did not keep long and within a few days even became uneatable. The labour services themselves were not so much of a burden to the macehuales, but mostly the fact that they still had to serve their caciques, too, in addition to the repartimiento. After all, these were part of the old tribute obligations and, obviously, the caciques were not willing to give up their old rights. Especially the obligation to submit those groups to the repartimiento that had previously been exempted from the services, the terrazgueros, the artisans and part of the lower nobility, crossed Indian custom to such a degree that it met with enormous resistance. ${ }^{17}$

In 1549, the personal services were detached from the tribute obligation of the Indians to their encomenderos. Gibson quotes the Spaniard Suárez de Peralta, who remarks on his youth in the city of Mexico in the middle of the sixteenth century, saying that before the measure of 1549 "everyone's house was filled with whatever the land provided, [...] but the moment that these rules took effect everything had to be bought, properties began to deteriorate, and people found themselves in need "." The scarcity of labour increased to such an extent that a solution had to be found right away. The Crown in Spain refused to reinstate the personal services that were part of the encomiendas, but agreed to force unemployed Indians to perform wage labour for some crucial sectors of the economy. In the instructions to viceroy Luis de Velasco it was voiced as follows:"

'[...] Because the said Indians are by nature inclined to idleness, which is to their own great disadvantage, you are to see to it that in all provinces of this New Spain, the Indians who are artisans, understand their trade and practise it. Those who are farmers, have to till and cultivate the land and to sow maize and wheat on their fields, to which purpose you have to give them land without inflicting harm upon anyone else. And the traders have to know their trade and merchandise. [...] You are to order the Indians who are not occupied in any of the trades mentioned above, that they hire themselves out to work on the labores in the countryside and in the urban works, so that they do not wander idly, because idleness is cause to many vices. And you are to order the clergy that they persuade them to act in this way, and you on your part have to do so, as well [...]. The oidores who go on inspection have to do likewise, so that the above said is done and takes shape through the hands of our authorities. [But] the Spaniards are not to force [the Indians] to do this, even if they are Indians of their own encomiendas. You shall order that the day's wages for their work be given to the working Indians themselves, and not to their principales or anyone 
else. And they are to be moderately charged with work and one [i.e. the Spanish employers] is to know, that those who commit violations against these matters will be severely punished'.

The labour services under responsibility of the Spanish officials were not entirely new. As Hirschberg has shown, the first precedent was created with the foundation of the city of Puebla de los Angeles in 1531. In the Poblano context, the labour services were, according to her, meant to be "an alternative to encomienda"." Under the leadership of the Franciscans, the Spanish authorities had partly exempted the Indians of Huejotzingo, Cholula, Calpan and Cuautinchan from payment of tribute, in exchange for their labour services to the city. Tlaxcala was exempted from tribute as a result of its alliance with the Spaniards during the conquest, but it was supposed to supply labourers for the foundation of Puebla. The former status of Cholula and Huejotzingo as private encomiendas was even rescinded to allow for the continuation of labour services in the period following the foundation of the city. In the case of the city of Puebla, rotating labour services were used, in which each shift was relieved after a week by the next. As such, the system showed a relation to the labour services to the prehispanic lords, which after all, also lasted a week. To what extent this rotating system of large groups of people was part of the indigenous coatequitl, or whether it was a Spanish innovation, remains unclear. ${ }^{21}$

After the foundation of the city of Puebla, the Poblanos continued to receive labour services for the construction of houses in the city and, increasingly, for their agrarian enterprises in the valley of Atlixco. In 1550, viceroy Mendoza decreed that the indigenous coatequitl should also be used for recruiting people to work on the haciendas surrounding the city of Mexico. In the 1550s, in both Puebla and Mexico the coatequitl remained in use for the supply of labour. According to Gibson, the coatequitl in the valley of Mexico was called llamamiento general (general summon) by the Spaniards. He also argued that the three tiered structure of the Aztec empire could still be distinguished in the structure of the official labour services in the valley of Mexico. Before the 1560 s, this new form of labour services was rather informal, but in due course it was formalized in the repartimiento de trabajo."

The authorities thought to have found a way to make the inevitable labour services as little a burden for the Indians as possible. Until 1575, the repartimiento was hardly applied at all. Until that time, in the valley of Puebla, only religious constructions -especially the cathedral- in Puebla and the farms in the valley of Atlixco were regularly supplied with labourers. In 1575, there came an order that the labour duties were to be extended to the mines. However, this was only the case in areas where there were both mines and Indians, like the area around Teotitlan del Camino south of Puebla, Sultepec, southwest of Toluca, Taxco, in the present state of Guerrero, and Pachuca, north of Mexico City. The repartimiento was never used in the important, but distant silver mines of Zacatecas; there, the Spaniards remained dependant on (black) slaves and especially on labourers who had been hired on the free market. ${ }^{33}$ 
After 1575, the forced labour services of the Indians also remained confined to the agrarian repartimiento and the construction of churches and monasteries in the valley of Puebla. In addition, at times there were occasional duties like the services for the construction of the drainage works in Mexico City, for which Indians from a large part of New Spain were recruited. For example, during the congregation of Tecali in 1606, many Indians wore absent as a result of the desague obligations of the pueblo. ${ }^{24}$ Indians from Tlaxcala were working at the construction of the cathedral of Puebla in the sixteenth and a large part of the seventeenth centuries. In 1616, it was said that, every week, fifty labourers worked on the construction of the church. Still, the cathedral was not finished until 1640, when the energetic bishop Palafox y Mendoza speeded the construction works up. Apart from the cathedral, Indians were frequently released from the agrarian repartimiento to help in the construction or reparation of churches and monasteries. ${ }^{2}$

\section{The structure of the agrarian repartimiento}

By far the most important form of repartimiento in the valley of Puebla was the agrarian repartimiento. Until about 1580 it was confined to the valley of Atlixco, but after that it was introduced in the plains of San Pablo in the alcaldia mayor of Tepeaca as well. At first repartimiento duties were the same all year, but after 1576 it was determined that the year was divided in two periods in which different labour services were required. In the half year from November to April the single (sencilla) repartimiento applied, 'as this is the time in which not so much is needed', while from May to October double (dobla) repartimiento services were demanded. This was the time in which weeding and harvesting was conducted on the labores, the

percent of the number of tributarios of a pueblo. The duties of the sencilla and the dobla taken together this amounted to three weeks of service per macehual per annum."

The agrarian repartimiento was under the administration of a special official, the juez repartidor. Though before 1580 someone had occupied himself with the

appointed for the plains of San Pablo, the nearby agricultural centre, whose detailed instructions have survived. From later documents it appears that this instruction for the greater part remained valid for the entire period in which the agrarian repartimiento existed. Therefore it is worthwhile going into some detail. Information on the position of juez repartidor is scant, but it is clear that this instruction for the juez repartidor of San Pablo was no exception. It seerns to have been more or less the same in other areas where there was an agrarian repartimiento. The decrees as they applied in San Pablo apparently were first developed in the area of Tacuba, near the city of Mexico. The instruction of the juez repartidor of Azcapotzalco in the valley of Mexico (1580) has survived completely and was more or less identical 
to the one of San Pablo. As is to be gathered from a number of documents this also was the case in the valley of Atlixco, and in the area of San Juan Ixtacamaxtitlan, more to the North, where in 1606 the labrador Andres Quixada complained of frequent unwanted and costly visits by the local officials. ${ }^{20}$

The juez repartidor was required to actually reside in the area under his administration. He was to see to it that the Indians were only used in cultivation -especially wheat- and the reparation of houses, corrals and stores on the labores. He was to pey regular visits to all labores that received repartimiento labourers, to consider how many labourers the labradores needed to work the land they had sown and to make sure they treated the Indian labourers well. He had received jurisdiction over all matters concerning the repartimiento and power over both Spaniards and Indians. He was given authority to impose sanctions on those who refused to cooperate to the proper settlement of the repartimiento, no matter whether this concerned Indian officials who refused to supply labourers, or labradores who kept them for too long, treated them badly or employed them in a different way than he had indicated. On Saturday the labradores had to pay the wages of the Indians, to the amount of a half real per working day. Apart from this wage they had to pay a half real per worker to the juez repartidor and another half real per half year for each fanega of wheat sown. ${ }^{29}$ The shifts of labourers each worked a full week from Monday to Monday. They were supposed to gather in the village of San Pablo, as this was situated most favourably on the plains. On Monday aftemoon, when the next gang arrived, the labourers could retum home. The Indians who came from a longer distance than four leguas (some $16.5 \mathrm{~km}$ ) were also paid for the days of travel; they were equally distributed over the labradores, so that one Spaniard would not have to pay more than another. In 1580 the repartimiento of the plains of San Pablo were imposed on the Indians of Tecamachalco, Quechula and Nopaluca. Tecamachalco had to supply 550 labourers in the time of the dobla; Quechula 420 and Nopaluca 10. In the time of weeding (the escarda) the sencilla proper had not yet been introducedTecamachalco had to supply 160 labourers, Quechula 40 and Nopaluca was exempted. ${ }^{\text {o }}$

Not everything conceming the functioning of the juez repartidor had was explained in this instruction. In 1599 it was complemented, because of the frequent problems in the repartimiento, in which the labradores in the words of the Audiencia used to 'serve themselves of them [i.e. the Indians] just for their own profit and not for that of the republic as they ought to'." The most important problems were that the labradores did not pay the Indians or kept them on their labor for too long a period. The viceroy ordered as a remedy that on the day that the week of repartimiento for a gang started, the money that a labrador would come to owe for the week of service ahead, was to be put in a box with three keys, held by the repartidor and his two deputies. The Indians were to be made explained that their money was in the box, so that they would not have to ask for their wages when their week of services was finished. The box was held in custody by the juez repartidor. He also had to see to it that after the period of service as many Indians retumed as 
had gone and that they were not put to work on holidays or art night. According the this same instruction many Indians ran away during the repartimiento, so that the labradores would 'suffer in both services and money'. In these cases the repartidor was to return the excess money for wages which the labradores had trusted to him.

The Audiencia was also prepared to act on request by the labradores. When in 1606 they requested a decree in which it was pronounced that in absence of the repartidor, one of the farmers could not be appointed as a deputy, on the rather obvious reason that this would lead to great trouble 'especially because he was a labrador and would be interested to allocate more Indians to himself than he was entitled to, and he would [assign] more and fewer Indians as would please him'." Considering the wide-spread resistance to the repartimiento and the never abating stream of complaints flooding the offices of the authorities in the city of Mexico and in Spain, it is not surprising that the authorities were soon convinced that the repartimiento was by no means such an ideal solution to the problem of labour supply as they had imagined. Many Spanish officials of the second half of the sixteenth century sighed that it seemed as if all that was in favour of the república de espanoles was harmful to the Indians and the other way round. ${ }^{34}$ Hence, more and more limitations were imposed on the repartimiento. The wage of the Indian labourers was raised and it was decreed that apart from their half real a day, they also had to be given board and lodging. The authorities constantly tried to abolish the repartimiento, especially under pressure of the many complaints by the clergy. From 1590 onwards a number of measures were taken which were to lead to abolishment. In that year viceroy Villamanrique tried to abolish the sencilla. On 17 March he wrote that he had made ' $a$ new and good regulation of the repartimiento of the Indians for the labradores'." He held the opinion that for the cultivation of wheat it was not necessary that the Indians supplied services throughout the year, because, he stated, the labradores did not employ the Indians in quiet times, they sold the services, which then were used for other purposes. He recorded that for the most important agrarian works, the weeding and the harvest, only ten weeks of labour were needed. Therefore he reduced the total of services to two thirds of the old duties which had to be accomplished in ten weeks. His successor Don Luis de Velasco adopted the decree. However, for the time being it was impossible to abolish the duties of the sencilla altogether, because of the lack of labourers who offered themselves voluntarily for work on the labores. In the seventeenth century the duties still existed, even though the labour services outside the period of harvests were reduced to two percent instead of four percent of the tributarios of a pueblo. In the time of the dobla, the duties now amounted to ten percent per week, but in due course these obligations were further cut down.

The abolishment of the entire agrarian repartimiento remained the ultimate goal the authorities were striving for. Viceroy Velasco wrote to the Council of the Indies that ideally the Indians would voluntarily contracted with a Spanish employer, without having to be compelled. The Council was by no means deaf to such suggestions: on the basis of its advice in 1596, in 1601 the king decided to abolish 
the repartimiento. He issued a decree that all repartimientos were to be abolished, except for the mining repartimiento. He did not intend, he wrote, to deprive 'the said estates and estancias of the services they needed for their cultivation and care, but while these [had] all they needed the Indians ought neither to be oppressed nor to be held [on the estates] contrary to their will, as had been the case in the past'. The Crown had in mind that 'the Indians who were needed for work on the said estates and estancias would hire themselves for the necessary jobs from the surrounding pueblos $[\ldots]^{\prime},{ }^{*}$ but among the labradores this gave rise to such impassioned protests, that this measure first had to be postponed and later cancelled. In Atlixco and Huejotzingo the repartimiento was executed in the normal way in 1603 and 1604.

In addition it has to be remarked that the situation in the rural areas had not stabilized yet at this time. As I have argued in the preceding chapter, ownership relations had not been settled in the first decade of the seventeenth century. Many labores were still in the middle of a process of development. Viceroy Velasco's plan to have the Indians tie themselves with one labrador, also the season labourers, at this moment had no chance of success because of the rapidly changing size of the labores and the quickly changing owners. The danger that a labor would pass into other hands within a short time was not at all imaginary, and voluntary ties to a labrador were perforce very temporary character."

After a postponement of eight years in 1609 at last the prohibition of the agrarian repartimiento of 1601 was revoked. The Crown wrote that apparently on that moment it was impossible to keep the labores going without the forced labour services. However, these had to be cut back as much as possible, both at that time and in the future. If the Indians would appear to be more cooperative in the future and would indeed tie themselves to a labrador, the agrarian repartimiento was to be abolished without further delay." In the course of the seventeenth century the importance of the repartimiento steadily decreased. When in the 1620 the rights to repartimiento services were taken from the regidores (aldermen) of the city of Puebla, this decision had to be revoked later, but the eventual formal abolishment of the agrarian labour services in 1632 caused little commotion. After that the repartimiento did continue, however, for the mines and the desagule of Mexico City."

The agrarian repartimiento in the valley of Puebla was focused on the valley of Atlixco and the plains of San Pablo, the two most important agrarian areas. The way in which the various pueblos de indios had to take part in the repartimiento was of course strongly tied to the demands of farming. As I have indicated above the repartimiento evolved from the personal services to the vecinos of Puebla de los Angeles in the 1530s and 1540s. These were increasingly employed on farms of the valley of Atlixco, most of which belonged to the Poblanos. Many of the pueblos of the valley of Puebla had to contribute to the repartimiento in Puebla, as a result few pueblos were initially involved in the repartimiento of San Pablo, where Spaniards 
only settled at a later time. In the instruction of the juez repartidor of San Pablo in 1580 it was decreed that only Tecamachalco, Quechula and during the period of dobla also Nopaluca had to supply labourers. The other surrounding pueblos of Tepeaca, Acatzingo, Tecali, Cuautinchan and Amozoc were obliged to supply labourers to valley of Atlixco. However, with the growth of the number of labores in the plains of San Pablo in the 1580s and 1590s, the demand for labourers grew. At the same time the supply from the repartimiento soon reached its limit, because the repartimiento duties of the pueblos were bound to fixed quota and the authorities strove to decrease rather than to increase these numbers. In addition the number of tributarios decreased as a result of epidemics and migration, and with it the number of repartimiento labourers related to it. The necessity of the labradores of San Pablo was lessened somewhat because the pueblos of Tehuacan and Tepexi, situated some fifty kilometres from the plains of San Pablo to the southwest and the south respectively. After some time labores began developing in the area of Tehuacan as well, and with it a demand for labour, resulting in a decrease of the number of labourers from this area.

On request of the pueblos of Acatzingo and Tepeaca in 1591 the viceregal authorities investigated the services these pueblos had to perform in the valley of Atlixco, because they alleged their men had to walk two days to get there and another two days to return. The investigation showed that for the labourers of the pueblo of Tepexí it made no difference whether they went to San Pablo or to Atlixco, so that it was decided that Acatzingo and Tepeaca were allowed to change places with Tepexf. But Tepexf had far less tributarios that Tepeaca and Acatzingo, so that the exchange could only be temporary. Tepeaca and Acatzingo, however, seized the opportunity and interpreted the measure as a alleviation of their duties. This was much to the disadvantage of the labradores of Atlixco, who brought the case before court in the Audiencia in the city of Mexico. In 1595 therefore, it was emphatically decreed that Acatzingo and Tepeaca were allowed to change with Tepexi, but that they had to keep on sending the difference between their own share and the one of Tepexi to the valley of Atlixco. Of course the pueblos protested again: Atlixco was far away and the labradores kept their labourers for too long and treated them badly. The Audiencia instructed the juez repartidor of Atlixco to see to it that the regulations were accurately followed, but it closed the case. ${ }^{\circ}$

The repartimiento-duties of the pueblos of Cuautinchan and Tecali were also partly transferred from Atlixco to San Pablo. All taken together in the beginning of the seventeenth century the labradores in Atlixco got their supply of repartimiento labourers from the pueblos de indios of Calpan, Cholula, Huejotzingo, Huaquechula, Tochimilco, Cuautinchan, Acatzingo, Tepeaca, Tecali in the valley of Puebla and Tepexi, Chietla and Huatlatlauca that were situated more to the south. The repartimiento labourers from the labores on the plains of San Pablo came from the pueblos of Tecamachalco, Quechula, Nopaluca, Tepeaca, Acatzingo, Cuautinchan, Tecali and Tehuacan. Only the province of Tlaxcala remained completely exempted from the agrarian repartimiento (Map 5). 


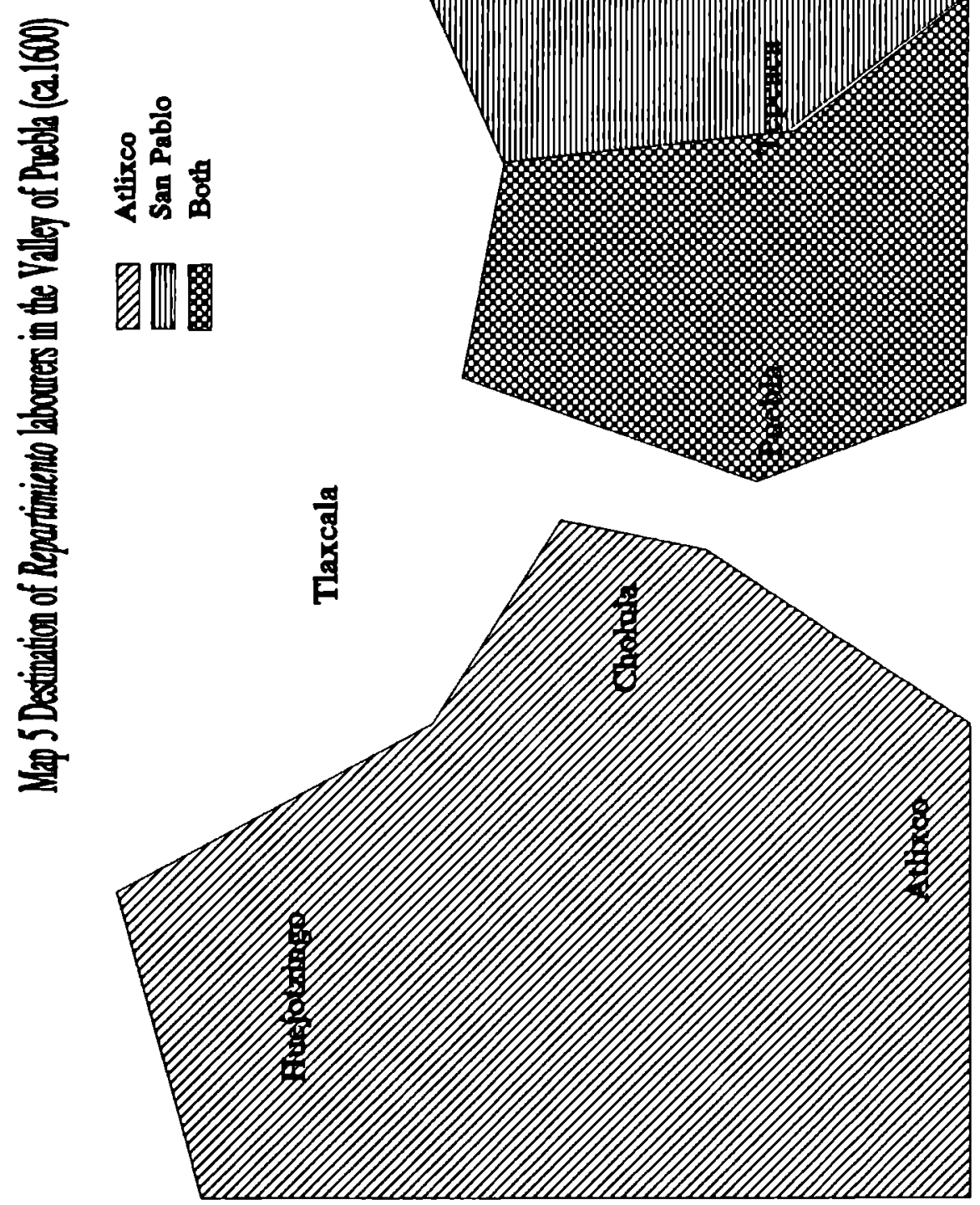


As the repartimiento labourers grew scarce and the number on labores in the central parts of the valley of Puebla became increased, it became ever more difficult for the labradores to get men from the repartimiento. Consequently, after 1590 the number of permanent labourers, mostly called gaflanes, increased in the entire valley. They lived on the labores and were treated differently from the repartimiento workers, who were usually called tlaquehuales in the valley of Puebla from early times on. In the seventeenth century most labores had gananes, indifferently whether they had a right to repartimiento or not. This was a result of the demands of wheat cultivation. Before these had found expression in the repartimiento with the division the authorities had made between the periods of sencilla and dobla. The dobla and sencilla duties of the 1580s, however, were rough divisions of half a year, based on a minimum of spontaneous labour supply outside the repartimiento obligations. As I have indicated above the duties of the repartimiento were energetically cut back by the authorities in Mexico City whenever this was possible. In the seventeenth century the duties of the dobla just occupied one or two months and focused on the harvest; the other jobs were mainly done by gañanes. In the course of time the repartimiento increasingly got the function of seasonal labour supply.

If we take into consideration that the non-urban repartimiento in the valley of Puebla was exclusively granted for the production of wheat, seasonal labour was indeed only necessary for the harvest, as far as the irrigated wheat was concerned. Information is scarce, but as far as can be gathered from the documents, the labores exclusively employed irrigated wheat cultivation in this time." This implies that the harvest took place just before the rainy season. The grain stayed on the land as long as possible to ripen and to dry, but just before the rains started it had to be brought in as soon as possible so that it would not be spoiled. On the milpas of the Indians at the same time the stalks of the maize had to be bound into bundles, which had to be strengthened by a heap of earth, to protect the stalks from being flattened by the driving showers. ${ }^{2}$ In the time just before the rainy season there was a peak in the agricultural operations, both on the labores and on the Indian milpas. For the rest the activities in the cultivation of the different crops were not synchronic. The argumentation of various authors that the repartimiento-duties of the Indians coincided precisely with when the time when their own fields demanded most attention, is just valid for the period from May to June." However, there was a number of factors which made the burden easier to carry. The activities on the milpas stretched over a couple of months, while the repartimiento services remained confined to one week. The Indians had to perform services at tums, as a result of which they could take over the labour of each other; this had been a prehispanic use. On top of this the heaviest duties were those of the young, unmarried men, who had no responsibility for a farm or family of their own."

Only the Spaniards in the oldest hacienda areas had a right to repartimiento labourers and even then just to a minimum. Every new labrador who wanted labourers from the repartimiento, had to request a survey (visita) of his Labor and 
in the seventeenth century he even needed an viceregal order. From the sixteenth century until the abolishment of the repartimiento, there were labradores who applied for such an order." Apart from them a lot of labradores were deprived of repartimiento labourers. An example may illustrate how little room there was leeft in the repartimiento at the beginning of the seventeenth century. In 1603 Hernando de Ortega from Puebla applied for a renewed grant of labourers. Previously he got twelve Indians from Tepeaca and Acatzingo by way of the repartimiento of Atlixco for his labor in Totomehuacan, but because Tepeaca predominantly supplied services to San Pablo in 1603, his supply had stopped. He alleged that his labor and the bridge of the road to the south, which he was obliged to maintain, suffered from the discontinuation of the services and applied for new repartimiento labourers from Tecali or from Huatlatlauca. On advice of the juez repartidor, the viceregal authorities granted him twelve new Indians from Huatlatlauca, some fifty kilometres from the labor, but the next year these did not show up and the pueblo of Huatlatlauca notified the authorities that it did not intend to send any in the future either. The matter was brought before the Audiencia. The pueblo alleged that the granting was unjust and ought to be revoked because it inflicted too much harm on its Indians. In the end Huatlatlauca lost the suit and was after all obliged to continue sending Indians to the repartimiento. Pending the lawsuit the Audiencia preferred to have the services performed by the pueblos of Tecali and Cuautinchan, which were closer to the labor. However, these had to be taken from the services to the city of Puebla, because according to the regulations of the repartimiento Tecali and Cuautinchan could not be obliged to perform more services than they already did."

In the valley of Puebla the repartimiento remained confined to the two agricultural areas mentioned above. Outside these, except for some special cases, no repartimiento labourers were granted. As a consequence the important agricultural areas of Huejotzingo, Tlaxcala and Cholula fell outside the repartimiento. But also many of the labores in the valley of San Pablo that came into being after 1590 remained dependant on voluntary labour. When in the first decade of the seventeenth century the control of the labour of the labores of the valley of San Pablo was intensified, several labradores attempted to stay out of the compulsory inspection of the responsible official, the juez comisario de alquileres. Their reason was that they just had gañanes and no rights to repartimiento and hence the juez comisario had no authority over them."

From the end of the sixteenth century it appeared that there was some sort of informal repartimiento in Tlaxcala, which was entirely in the hands of the caciques and principales of the province. In 1591 the macehuales of the town complained before the Audiencia that each week they provided a repartimiento of 600 labourers. The macehuales who fell under this obligation were greatly harmed by them, as they received no wages at all." Although the Spanish authorities prohibited these practices, the informal repartimiento continued. In periods of a large demand for labour on the labores the labradores recruited groups of labourers in Tlaxcala. For this they needed the cooperation of the Indian officials (regidores) there, who 
demanded ten or twelve pesos of commission. Before the Audiencia the labradores complained of these practices, which were indeed illegal, bearing in mind earlier directions against such interference of Indian nobles with the labour supply. In this case the Audiencia ruled against the charging of commission and decided that the labradores could freely contract labourers on the market. But the labradores could not escape their arrangement with the Indian nobles that easily. The caciques of Tlaxcala also knew jurisprudence and perceived that the Audiencia was fiercely opposed to labradores who forced Indian labourers to work for them. Shortly after the first decision of the Audiencia they appeared before the court to complain of the same labradores whom they accused of dragging Indians forcibly from their pueblos in order to perform labour services on the labores. The labradores in their turn were reprimanded by the Audiencia." Both the nobles and the labradores now had a verdict of the Audiencia against them. In fact the dispute remained undecided and both parties were served best by making peace and resuming the old agreement.

This was an example of the caciques' masterly ability to use Spanish laws and regulations for the protection of their own position; the second point of interest was the informal regulation of labour services between labradores and pueblos de indios, in which the caciques played a mediating role. The necessity of this informal regulation on the part of the caciques and the officials in the pueblos sprang from their responsibility for tribute payment. This notwithstanding the fact that the Crown intended to make tribute a responsibility of the pueblos as a whole when it introduced the cajas de comunidad in the pueblos. Seasonal labour services, were organized by the caciques and pueblo officials to help collecting enough money in the caja de comunidad to pay the tribute.

These interferences of the caciques with the labour supply dated from the sixteenth century. In 1587 the viceroy decreed that neither the 'gobernador, alcaldes, tequitlatos nor principales' of the pueblos de indios in the plains of San Pablo -and numerous areas in the valley of Mexico- were allowed to continue distributing 'indios gananes' from their groups of tlaquehuales among the labradores according to their own discretion, as they had been doing before. In this, the viceroy wrote, they did not appear to be considering the harm done to the other labradores, who could not work their fields at the right time as a result of the lack of labourers. The sanction against the Indian nobles was that they were expelled from their offices and dignities (oficios $y$ cargos). ${ }^{30}$ In the seventeenth century the interference of the caciques with the labour supply simply continued, to the anger of the jueces repartidores and the labradores who were interested in a proper execution of the repartimiento.

It is not surprising that the authorities in the city of Mexico stimulated the local contracting of labour and always supported those labradores who complained about being hampered by other Spaniards in their attempts to contract Indian labourers in the pueblos. In 1631 Martín Alonso de Aradilla was the first of a number of labradores who complained of the alcaldes mayores of the provinces of Tlaxcala and Cholula, who at that time also were the jueces repartidores in those provinces. He 
alleged that he used to contract many indios peones 'for days or weeks' in those provinces for his labores in Huejotzingo. These Indians reached an agreement with him voluntarily and 'after their period of service they used to return home most satisfied' or, at other times, they went on to work on labores in Tlaxcala. According to Alonso de Aradilla these practices were perfectly legal for labradores who got no Indians from the repartimiento and he accused the alcaldes mayores who worked against him, of just acting out of their own interest, wishing that the services were paid to the alcaldes and the gobernador of the pueblos, in stead of to the Indians themselves." When the case of Alonso de Aradilla was supported by the Audiencia within one year five other labradores followed with the same complaint. The case of Aradilla was used as jurisprudence."

On the other hand after the repartimiento had been abolished there were many complaints that tlaquehuales were still distributed in the old way. Accusations like these affected the deputies of the alcaldes mayores (tenientes) but also the clergy and the Indians officials in the pueblos. The levies which the labradores had to pay from the sixteenth century to the juez repartidor also remained. It is striking that a number of the conflicts about the continuation of the repartimiento occurred in Tlaxcala, while this province had never had obligations in the agrarian repartimiento. This once more indicates the degree to which regulation of the local authorities had become part of regional custom. According to the investigations of Zavala, Gibson, Riley, Tutino and Ouweneel seasonal labourers were still contracted in the same way in the seventeenth and eighteenth centuries."

To a large degree, the developments were influenced by the Spanish authorities. They increased fiscal pressure twice in the period under study, in order to get more labour from the pueblos. They did so by forcing the officials of the pueblos to comply with their tribute obligations more strictly, by seizing the tribute income in the cajas de comunidad under control of the Indian cabildos and by restricting the expenditures of the cabildos. This caused large problems in the pueblos and the cabildos were forced to send more men to work on labores in order to obtain additional money. Undoubtedly, these Spanish authorities had not foreseen an extension of the informal labour services when they increased their fiscal pressure on the pueblos. But in my opinion the authorities did intend to get more labour from the pueblos when they put pressure on the cajas de comunidad. The first time was in 1598-99, when the authorities were on the verge of abolishing the agrarian repartimiento. Their overestimation of the effect of the measure appears from the failure of the abolition of 1601 . The second time, the 'tribute screw' -if we may characterize the measure in this way- was put on, was in 1639-1640, some years after the ultimate abolition of the official agrarian repartimiento in 1633. At that time, the authorities were greatly concerned by the informal continuation of the old practices; they wanted a voluntary labour supply from the pueblos, in which local officials had no part. The fiscal measures were a powerful measure in the hands of the authorities, and one they applied with restriction. Usually they were quite lenient in 
exacting tribute from the pueblos, and the requests of cabildos applying for a temporary reduction of the tribute were generally granted."

During the seventeenth century, the repartimiento labour and the informal seasonal labour succeeding it and the gantanta gradually became complementary forms of labour, which existed side by side on the labores. In this complementary labour regime, the gafianes performed the regular jobs throughout the year and the -formal or informal- repartimiento labourers were employed in the seasonal labour. Apart from the demands of agriculture, there were other circumstances which influenced the development of labour relations. In the first place, due to the pressure on the labour market, the demand for labour could not be supplied exclusively by the repartimiento. Moreover, the policies of the Crown were directed at reducing the Spanish dependency on the compelled labour services. When Spanish landownership had stabilized in the second and third decades of the seventeenth century, the importance of the local organization of labour had increased. No doubt, the authorities had rather hoped to see the Indian labourers go to work on labores entirely of their own accord, but within the social relations, which were still largely dominated by caciques, it was inconceivable that macehuales would go and perform seasonal labour on the haciendas on their own authority.

The agrarian repartimiento was an intermediate phase in the development of labour relations in the valley of Puebla. In the second half of the sixteenth century, forced labour services were organized with the objective of meeting the pressing need of labour on the labores. From the very beginning, the authorities made it clear that this was an emergency measure, which was to be replaced as soon as possible by a system of free wage work based on the mechanism of the free market. Thus, their measures were constantly meant to increase the voluntary labour supply from the pueblos. As a result of the explosive growth of the number of labores and the large demand for labour which accompanied it on the one hand, and on the other hand the relapse in the growth of labour supply as a result of the depopulation among the Indians, a balance on the rural labour market only came about in the course of the seventeenth century.

In this new regional equilibrium, not just the labradores and the Indian labourers mattered, as the authorities had foreseen, but the caciques also played an important part. They organized the supply of seasonal labour from the pueblos, to which effect they closed agreements with the labradores. This once again shows the influence which the caciques managed to keep at a regional level.

\section{The gaftanta}

In the late sixteenth and early seventeenth centuries, the permanent labourers, or gafianes, on the labores were of major significance, but in an absolute sense, their numbers remained small throughout the period. Usually, the number of gañanes in 
the areas of Tlaxcala, Totomehuacan and Tepeaca, was not larger than ten to twelve people per labor, according to my archival material. With some forty garianes in the 1620s, the large hacienda of San Bernardino (Tepeaca) was an exception. However, a number of these labourers worked on the summer pastures which the hacienda owned in the Mixteca, hence the number of workers actually residing on the farm must have been smaller."

There were few gantanes, as a result of a number of intertwined reasons. It was difficult to attract labourers; this was the very reason that the labour repartimiento had been introduced. Therefore, gantanes were expensive. It was not so much the direct labour costs, because the monthly wages of two pesos of the permanent labourers were lower than those of the tlaquehuales from the repartimiento, who initially received balf a real and later on a full real per day. ${ }^{* 6}$ The tlaquehuales did not get food rations; not even in the seventeenth century, despite late sixteenthcentury regulations to have this amended. The gafianes, however, got a fixed amount of food per week, the so-called racion, even if they were ill. They were also expensive, because they lived on the haciendas permanently, and had to be paid, whether there was work or not. Furthermore, the labradores paid the ganlanes advances to their wages. These debts had to be paid back by means of their work on the labores.

From the scarce material of the sixteenth and seventeenth centuries which allows us to get an insight in the development of the debts, it seems that labradores were even supposed to pay advances to the gañanes before they entered their service. The notebook in which the labrador Juan López de la Vara recorded the debts and the services of his gananes in 1602, shows that he paid an advance of two to four pesos to the Indians who entered his service, either on the market where they were contracted, or on his labor on their first working day. At the end of the sixteenth century, it was customary in Cholula to pay an advance to all different kinds of contract workers, accompanied by the statement that they had to pay back the debt from their wages during the contract period." It is obvious that in such cases the debts comprised, at most, the wages for the entire contract period. To the labradores the debts of the gananes often meant some hundreds of pesos of investment and this was all the more reason to keep the number of permanent labourers as small as possible.

Even though the gañanes often voluntarily asked for advances, the debts which thus arose, undoubtedly enabled the labradores to force the Indians to fulfil their labour duties. The authorities tried to take action against this exercise of force, but their efforts were often in vain. There were two sides to the labour relations, and the labradores were not the only ones to take advantage of their position, as is illustrated by the following example. In 1602, the Indian Andrés told the teniente of the alcalde mayor of Tepeaca in Quechula that the Labrador Diego de Frias from Tepeaca wanted to take three pesos from him. The teniente issued a probibition, but after a few days the labrador in his tum appeared before him to complain. Supported by Indian witnesses, he put forward that the Indian in question had come 
to his house one day, in order to ask for the pesos as an advance, because he wanted to enter into his service."

It was not always necessary for a labrador to attract labourers by advancing wages. In the administration of the hacienda San Bernardino in Tepeaca, the gafian Pablo de Leon was said to be new on the hacienda and to have no debts. The data which I have at my disposal, do not give an indication whether this changed in the course of time." Historians have long regarded the advance of wages as an indication that the ganania was just as unfree a form of labour as the repartimiento or even the encomienda, with the implication that even though the form of labour changed, this made little difference to the situation of the Indians. They assumed that regardless of the changes, the relations between labrador and ganin continued to be simply of an exploitive nature. In recent times, a number of authors has emphasized that the debts were not really a means by which the haciendas used to attract or retain their gananes. In this view, it is stressed that the gañanes voluntarily served on the haciendas and went away whenever they felt like it, for example when they were badly treated. Some authors have argued that the relation between labrador and gantan was characterized by a 'moral economy', in which the gañanes supplied services in exchange for a guarantee of their subsistence. ${ }^{.0}$ I think this last view is the best expression of the labour relations, as they actually exxistemn the labores. The nature of the relation between labradores and gafianes can be understood if we take a closer look at the development of the status of the gafianes.

Before the Spanish cities and the first haciendas had been founded, all Indians belonged to an altepetl and a cacique to which they had to pay tribute. In the course of the sixteenth century, however, more and more macehuales escaped the influence of the pueblos and migrated to go and work in the cities or on the labores. When they moved to the cities, they were lost to their cacique, who could no longer demand tribute from them." This was different when they went to work on the haciendas as garianes. In that case, they often remained within sight of their pueblo and their cacique and were still supposed to pay tribute to the pueblo. Especially, if they no longer took part in the social life of the pueblo and earned their money in service of a hacienda, it was only logical that the labrador would pay tribute for them to the pueblo. Soon, this seems to have become part of the agreement between labrador and gañan. Of course, this somewhat vague relation between gafianes and their pueblos caused problems. On the one hand, for example, the caciques of Tehuacan complained that the gafianes were hiding behind their employer in order to avoid paying tribute, whereas on the other hand, in 1622, the labrador Nuñez de Mondragón accused the cacique of Tepeaca of having forced him to pay tribute for two Indians who were not from Tepeaca but from Tlaxcala and Mexico."

The question was even more complicated than this, because, as tributarios of the pueblos, the gafianes were obliged to supply labour to the repartimiento labour. This resulted in the somewhat strange situation that gaflanes were taken away from the labor on which they were working, in order to go and work on another labor for one week. The Audiencia and the alcaldes mayores implemented these duties quite 
energetically. In the sixteenth century, it frequently occurred that those who were charged with the organization of the repartimiento (tequitlatos and mandones), would go and fetch the Indians on nearby labores, if they refused to come of their own accord. In 1607, the labrador Alonso de Torre from Amozoc complained that he had no repartimiento labourers, so that he was left without any labourers when his Indians were fulfilling their repartimiento-duties elsewhere. The authorities in Mexico City showed no compassion and upheld the order."

In 1631, the caciques of the Cuautinchan and Amozoc complained that two Indians were in the service of the nearby labor of the Jesuits, and that they also had other tributarios of their pueblo living on other labores. They had been taken from them by constables (alguaciles) of the juez repartidor, in order to have them serve in the repartimiento. The Audiencia prohibited these last practices, and ordered that the gaflanes had to come to Cuautinchan to fulfil their duties and if they did not comply with it in time, they should be punished. To make quite certain, however, the authorities asked, at the same time, the juez repartidor to express his opinion in an account of the situation. ${ }^{4}$

These examples may suffice to show that the ganlanes gradually became part of an inextricable tangle of claims to tribute and labour duties and rights. In the second decade of the seventeenth century, a settlement was reached, according to which the labradores paid the tribute of their ganianes directly to the treasury instead of to the pueblos first. In the 1620 s, this regulation was also introduced elsewhere, after people had heard of the customs in Tepeaca. With this, the ganianes had become tributarios of a hacienda, rather than of a pueblo. In 1623, in several provinces in the valley of Puebla, the Franciscans treated tributarios already as though they belonged to a hacienda. ${ }^{\text {is }}$

The question of the legal status of the gananes arose from the customs in the rural areas. The fact that the labradores had already been paying tribute for their permanent labourers, had been one of the most important reasons for the debts of the labourers on the haciendas. The direct payment of tribute by the gananes or their employers was therefore merely a formal step, which was of little practical consequence. In my view, this formal step originated in the consolidation of the relations between labradores and gananes, which kept pace with the consolidation of the labores in the first decades of the seventeenth century. With the regulation, the viceregal authorities recognized for the first time the right of the labradores to force indebted Indians to pay their debts in services. However, this was only a legal difference of degree, with few practical consequences. Moreover, it was agreed for the time being, that debts could be paid in money, although tribute debts could not be redeemed in theory. ${ }^{\text {In }}$ the late sixteenth and early seventeenth centuries, gantanes were usually in no position to redeem their sometimes substantial debts at once, and redemption by Spaniards, in order to attract Indians to their own enterprises, was explicitly forbidden.

Zavala, Riley and Verlinden attach much value to the measure, as it was used to force Indians to perform agrarian services, but in my view, the measure and its 
subsequent codification should be seen rather as an official sanctioning of common practices. The official recording of tributarios as belonging to haciendas, could greatly simplify the exceptionally intricate claims and rights of the rural areas. The admittance of the gantanes as tributarios to the haciendas, was also a step in the development of the position of the labradores in the rural areas. From the very beginning, it had been part of the labrador's duty as an employer, to take care of the welfare of the Indians. These duties had been separated from the wages be paid them. He had to feed them and to assist them in case of injury or illness. Furthermore, an employer was supposed to give financial assistance, for example in the case of a marriage. He also had to take care of the spiritual well-being of his labourers. This last obligation chiefly meant that he should not only allow them to go to church, but even had to see to it that they regularly attended Mass, observed Christian holidays and went to confession at least once a year. The servant on his part, had to do whatever his employer ordered him to do. These were the mutual obligations, usually couched in the term of 'moral economy'."

All debts and eamings of the gañanes were recorded in a separate notebook. The recording consisted of writing down all expenditures, advances and food rations of a particular ganan and subtracting the debts from their wages. The wages were calculated by indicating the days an Indian had worked with marks and multiplying the number of marks by a day's wages. These notebooks were therefore called libros de rayas (literally: books of marks). The authorities introduced this system in the sixteenth century to facilitate the control of labour; it remained customary throughout the colonial period.

As in the course of the seventeenth century the labradores often came to own labores for a longer period, their ties with gañanes would sometimes last as long and, at times, even become closer. In accordance with the spirit of the times, in the long run, labradores not just acted as employers, but gradually became more like a lord and master to the gananes. In the seventeenth century, the labores increasingly acted as a collective. This is best illustrated, by looking at the conflicts between rural Spaniards or between labradores and the authorities. In the sixteenth century, these conflicts were usually between individuals or between an individual and the authorities. However, from the seventeenth century, a number of conflicts has come down to us through the sources, in which a hacienda as a collective, i.e. the labrador or a mayordomo and his ganianes, resisted the law. In 1638, in the province of Tepeaca, the constable (alguacil) of the alcalde mayor accused Juan Camacho el Sordo, mayordomo of the hacienda de labor of Don Pedro Juárez de la Parra, and all the garianes, blacks and mulattoes of the hacienda of having resisted him. The alguacil had gone to the hacienda with a decree from the alcalde mayor, in order to fetch two Indians who were serving on the hacienda, to lead them before the court of the alcalde mayor. When he arrived, he found all people that lived on the hacienda before him, armed and shouting, and he was unable to carry out his order. Another example is provided by the accusation of the cacique Don Pedro de Luna against Alonso Hernández Buon and his gañanes in 1619. The gaflanes bad 
helped Alonso Hernández when, one night, he had gone out on horseback and had kidnapped two boys from Don Pedro's service, to have them work on his labor. In this case, the labrador and his gañanes also worked as a team outside of the labor."

The mutual rights and duties of both labradores and gafianes had been by and large clear from the start. When the social structure of the valley of Puebla began to take shape, the position of labradores began to resemble that of the caciques more and more. The collection of the gantanes' tribute through the haciendas instead of the pueblos was an important step, although not of overriding importance in this process. It was a measure, however, which made it officially clear, that the labrador had the same sort of position of Herrschaft with the Indians on his labor, as the caciques had with their macehuales in their domains. In the course of time, this position was even strengthened. An important development in this process was the right of the gananes to work a piece of hacienda-land for their own use, as a result of which the position of the gafianes even more came to resemble that of the tributarios in the pueblos.

As in all relations of Herrschaft, the relation between labradores and gafianes had both a positive and a negative side. The positive side were the more or less balanced duties of the moral economy. The negative side consisted of the pressure the labradores could and did exert on their labourers. At times, this ended in beatings, confinement or forced services. As I have remarked above, these were two sides of the same coin; whether the overall balance was positive or negative largely depended on the person of the lord. This was another aspect in which the position of the labradores differed little from that of the caciques. From the point of view of the law, both caciques and labradores had the right to fetch back labourers who still owed them tributes or advances. Not just labradores, but also caciques, could have tribute debts paid in money, instead of having them all paid in kind through service. Thus, in 1597, the Indian Gaspar Suchial from Tochimilco entered the service of an obraje in Cholula. The obrajero forwarded 31 pesos as an advance on his wages, so he could pay his tribute debts to the gobernador of Tochimilco, for which he was at the time imprisoned in the town jail of Cholula.

Legally, it made no difference whether the Indians had prematurely left either a hacienda or a pueblo de indios. In both cases, they were called runaways (huidos). They appear invariably on the tribute lists and on lists of gafianes. The measures of the authorities to discourage these escapes were ambivalent. At a regional level, however, neither the labradores nor the caciques ever doubted whether it was legal to bring back Indians who had escaped from their service. Moreover, they both even cooperated in cases which they considered to be legal, as is apparent from the case of a huido of the hacienda of San Bernardino, who was arrested in the pueblo de indios of Tecali, with the help of a local cacique, and brought back to the hacienda. ${ }^{*}$

All this does not mean, that labradores or caciques never transgressed their authority. There are many examples of labradores who tried to keep their labourers, even after they had paid their debts, or even seized labourers from other labores or from pueblos de indios. Caciques were also charged with fetching Indians from a 
hacienda against their will. This is illustrated by the case of the earlier-mentioned Don Pedro de Lung, cacique from Acatzingo, who seized two gañanes of the labrador Diego Bravo de Cordoba from his Labor, and burnt their houses so that they could not return." In these cases, the authorities, either the Audiencia or the alcaldes mayores, invariably took action against labradores and caciques, even though they were inclined to sanction forced service in cases of debt.

In matters of rural labour relations, the viceregal authorities were in a dilemma, because they wanted to accomplish that Indians would serve with someone only out of their own free will, and to assure that the labores had enough labourers. Moreover, they could neither permit nor accept that indebted Indians left the labores or escaped from the influence of their pueblos, both of which happened. Only in the course of the seventeenth century, regional custom gradually was formally codified in laws. ${ }^{n}$

The labour relations of the labores were not the only ones of importance in the valley of Puebla. Much demand for labour came from the textile industry, the obrajes, which were established in the Spanish cities and towns and which began to prosper in the late sixteenth and early seventeenth centuries. The urban economy is largely beyond the scope of this study; nonetheless it is important to compare the labour relations of the obrajes with those on the haciendas. According to Salvucci, there were over thirty obrajes in the city of Puebla from around 1580 until 1630; apart from these, there was a considerable number of them in Tlaxcala, Atlixco and Cholula." The obrajes had many Indian workers and the authorities often complained of their miserable labour conditions. In 1597, the viceroy wrote that he had often tried to improve them, but that it was impossible to change them all without ruining the entire sector, which was vital to the Spanish urban economy. Therefore, he could do no more than to concentrate the obrajes in some cities, in order to be able to better control the compliance with the regulations. After that, action was indeed taken against obrajes outside of the urban centres, as in the case of Rodrigo de Orea who had looms (telares para tejer sayales) on his hacienda in the plains of San Pablo and had his Indian labourers work far too hard on them."

Usually, the measures against the abuses on the obrajes remained without much effect. "Visitation committees were repeatedly sent to the obrajes to see whether the workers were treated properly, but in many of the factories the owners were informed well in advance by informers about the arrival of the visitation committee, so that they had time to accommodate illegally locked-up workers in cellars and neighbouring buildings." Of course, it is unknown how large this group of illegal workers was, although we have to remember that not all imprisoned workers were locked-up illegally. For the question is complicated by the fact that the obrajes also partly served as an official prison, in which convicts of all kinds served their sentences. Most likely, they worked in a closed section of an obraje, which also had open sections. In the notarial acts of Cholula, there are many employees of, predominantly, obrajes, who had to earn the money to pay for the fines which had been 
imposed on them, by working in an obraje. In such cases, the obrajero would pay the entire sum which the convict owed the authorities, and then this former convict had to serve in exchange for a fixed amount of wages, until he had eamed back his debts. The crimes which were redeemed in this way varied from debts to Spaniards or caciques, to kidnapping a mulatto-woman from an obraje, stealing or even manslaughter." Most workers seem to have entered the obraje service with a contract on a voluntary basis and for a fixed period of time, ranging from some months to several years. In these cases, it was also common to advance at least part of the future wages, which had to be earned back later. This was possible, because the obrajeros also had the obligation to feed, cloth and take care of their workers when they were ill. In order to keep matters under control, they were obliged to keep record of the debts and wages of their workers, although, of course, this did not apply to those who were held against their will."

\section{The repartimiento de comercios}

When the role of officials is treated in the literature on eighteenth-century Mexico, it is automatically related to the commercial contracts which the alcaldes mayores had with the pueblos de indios. These chiefly consisted of the so-called repartimiento de comercios; a practice which had many adversaries in the higher circles of the colonial bureaucracy, and which is supposed to have been very harmful to the Indians. The repartimiento de comercios is usually seen as a forced sale of Spanish products to the Indians, or as a compulsory monopoly of the purchase of the goods which the Indians produced in their pueblos. ${ }^{\text {"I }}$ In this view, the repartimiento was an example par excellence of colonial corruption, because the regional officials abused their authority at the expense of the Indians, in order to enrich themselves.

In recent times, this view has changed and dissident opinions have been expressed by authors like Pietschmann, Dehouve and Ouweneel who have explained that the repartimiento of the eighteenth century was largely a voluntary arrangement between an alcalde mayor and a pueblo de indios, and which was necessary from an economic point of view. According to Lockhart, it did not exist in Toluca in the sixteenth century. ${ }^{*}$ The repartimiento seems to have only fully developed in the seventeenth century, but this has hardly been studied. In general, the repartimiento de comercios by regional officials, seems to have been less extensive in the seventeenth century than in the eighteenth century. Nonetheless, the regional officials were repeatedly forbidden to trade with Indians and in 1641, the well-known visitador Don Juan de Palafox y Mendoza, who was also bishop of Puebla, complained that the alcaldes mayores abused the Indians when doing business with them. In words that were to become a standard for anti-repartimiento spokesmen, he asserted that the alcaldes mayores:" 
'Sell [the Indians] what they do not need and make them accept it by force (por fuerza). The Alcalde Mayor summons a Gobernador de Indios, to have him sell [the Indians] of his district cows, mules and other livestock for twenty pesos apiece, while they have cost him [i.e. the alcalde mayor] no more than six pesos; they do the same thing with wine, by which they inflict great harm upon the Indians [...] as with all other commodities'.

On top of all this, according to Palafox, the alcaldes mayores paid no taxes on the goods they sold to the Indians.

Like the repartimiento de trabajo, the repartimiento de comercios was a colonial phenomenon, with prehispanic antecedents; both were derived from the Herrschaft of the Indian nobility. Without this background, it is hard to understand both forms of repartimiento. As I have argued above, the coatequitl, the predecessor of the repartimiento de trabajo, was an expression of the power of the tlahtoani to summon workers, in case of an emergency or for public works, and as such, it was a right which the Indian rulers rarely used. It was based on the obligation of the macehuales to serve and was connected with tribute. The structure of the repartimiento de comercios was connected with another aspect of the Herrschafi of the Indian nobles: their leading position in economic life. In Chapter 1, I have argued that each macehual paid tribute to his lord from the earnings of his occupation. In the middle decades of the sixteenth century the tlahtoque of Tepeaca received, among other things, a large amount of products from artisans. This implies that a tlahtoani could also direct production by ordering or stimulating his macehuales to produce a certain product. Through tradesmen who came under his Herrschaft, he traded these products on the local tianguis and, in the case of luxury products, also on longdistance markets. In addition, each macehual-woman had to spin a certain amount of rough cotton. In the case of Tepeaca, but also in Tlaxcala and in the valley of Mexico, the rough cotton was imported from other parts falling under the supervision of the tlahtoani, who was therefore the organizer of the production of craft work. After the Spanish invasion, these customs somewhat disappeared when a more intensive trade had developed, but the caciques managed to retain considerable rights to tribute and to these services.

Although the regional Spanish officials took over the political power of the tlahtoque, especially on the local level, they could not directly take over the position of the tlahtoque. They were not part of the pueblos de indios proper and they only had a limited term of office, as a result of which it was not easy for them to actually establish their power over the indigenous population. In the pueblos, the caciques still had most authority. Moreover, the alcaldes mayores had number of subordinate officials, algualciles mayores, and especially tenientes, who were rooted in regional society and could exert considerable power at the local level. These subordinate officials played an important role in economic life. They got involved in all sorts of economic relations from which at a later date the repartimiento developed. In the late sixteenth century, the alcaldes mayores and their subordinates, 
who had been appointed by them, were entitled to a number of Indians who would perform personal services (servicio personal) in their houses and would supply zacate (a kind of rough grass) for their horses. The receipt, or appropriation, of goods and services from the pueblos de indios by Spanish officials is connected with the repartimiento trade. Some examples may enlighten this mixture of formal and informal obligations."

In 1590, the Indians of Tepeaca complained of the new, Spanish alcalde mayor. It was a local custom to give the alcalde mayor four Indians (indios tepisques), an Indian woman who would prepare maize tortillas for a week (india molendera) and, in addition, three cargoes of zacate a day. The new alcalde mayor, however, 'without any cause or reason' demanded ten Indians and two tortilla makers per week and twelve cargoes of zacate per day. From the day he had arrived, he had not paid for the zacate and the Indians who disobeyed his orders were severely punished. The Indians asked the Audiencia to reduce once again the obligations to four Indians and one Indian women 'as was custom'. The Audiencia sent Alonso de Nava, the Spanish governor of Tlaxcala, to settle the case: the alcalde mayor was not allowed to demand more than three cargoes of zacate, which he also had to pay. He had to pay back the surpluses he had received. He only had a right to four Indians and one woman to serve him every week, and he had to pay them daily wages, too."

An interesting case is the following one from Cholula. In 1590, the Indians of the town supplied Don Rodrigo de Vivero, the local corregidor, with two cargoes of zacate, for which he paid one real each. His tenientes, the town clerk and the interpreter, got an equal amount of zacate, but paid no more than half a real per cargo. The Indians put forward that they were not obliged to deliver the zacate. Moreover, the lower officials regarded the supplies as merchandise (grangeria), which they 'sold for four or five reales more than it had cost them'. The Indians did not object to the supply of two cargoes to the corregidor, which they regarded as a moderate thing (cosa moderada), but they were of the opinion that his subordinates had to content themselves with half the amount and should pay just as much as the corregidor. The Audiencia adopted this proposal. Hence, supplies to the various regional officials were allowed by the authorities in Mexico City."

In Cuautinchan, the Audiencia went one step further. In 1590, the Indians of the pueblo asked to be exempted from the supply of zacate to the teniente, as it had trouble enough supplying grass to be used as fodder, to the nearby city of Puebla and to travellers on the camino real. The Audiencia restricted the services to the teniente to two cargoes a day, for which he had to pay two reales, but it would not abolish the services altogether."

Because the viceregal authorities tolerated the services and supplies to the regional officials, they did not disappear in the seventeenth century, notwithstanding repeated prohibitions to this effect by the authorities in Spain." Two examples from 1639 illustrate that the nature of the services remained the same in the sixteenth and seventeenth centuries. In that year, the Indians from San Felipe in the province of 
Tlaxcala complained that the teniente of the place forced them to supply Indian servants and tortilla makers for his own household."

In that same year, a teniente of Tecali demanded from the pueblo an Indian servant and his wife for his household, in addition to the Indians which the pueblo had already given him; moreover, the pueblo had to hire a cook for him for a peso and a half per week. Tecali had to supply seven cargoes of maize-straw and three hundred blocks of firewood, and all this without any payment. Moreover, he took twenty eggs for one real, whereas the Indians were usually paid a real for eight eggs, and 'all other things necessary for the maintenance of his house for less than half the fair price'." Here, again, the Indians did not so much protest against the services themselves, but against what they considered to be unjustly heavy demands. As in the case of the personal services by the Indians, the Audiencia took more and more severe actions against the supplies to individuals. At an early date, these practices had been forbidden by Spain and in the middle of the seventeenth century, the viceregal authorities kept these orders even more firmly in hands. Thus, they prohibited the teniente of Tecali to demand similar services from the Indians in future. If he needed anything, he should purchase it on the market."

As far as we can infer from the archival material, the late sixteenth- and early seventeenth-century officials below the rank of alcalde mayor, the tenientes, alguaciles mayores and the like, seem to have been more tightly integrated in local trade than the alcaldes mayores or corregidores themselves. In 1619, a repartimiento was organized in Huejotzingo by such a subordinate official, the alguacil mayor. In the lawsuit it was stated that he sold calves on credit to the Indians for exorbitant prices. Whoever refused to pay, was thrown in prison; whoever was unable to pay had to earn back his debts on one of his labores. The clerk of the town of Huejotzingo was his brother-in-law, so that the Indians did not dare bring charges against him before the corregidor, because they were threatened with tough measures and had to travel in secrecy to the Audiencia. In this case, the Audiencia ordered the corregidor to take action against his alguacil mayor. Apparently, neither the Audiencia nor the Indians assumed that the corregidor was involved in these practices. ${ }^{\circ}$

Actually, this lack of involvement on the part of the corregidor is not as surprising as it may seem. They were often both tradesman and labrador, and it was essential for their work that they enjoyed a position of some distinction. Usually, the alcaldes mayores could not ignore them, when lower officials had to be appointed." The alcaldes mayores were indeed sometimes involved in these repartimientos, as was the case, for example, in the pueblo of Pahuatlan, in the province of Huauchinango, where the alcalde mayor had the Indians spin rough cotton for him. Here, once again, the Indians protested that these levies were beyond the regular tribute, and now they could not even supply their normal tribute. In this case, as was the case with all the complaints about the repartimientos in the sixteenth and seventeenth centuries which have survived, the protests always concerned the weight of the levies, never the levies themselves. ${ }^{n}$ In the context of the repartimiento de trabajo, 
I have argued that at a regional level, the Spanish labradores started more and more to resemble the caciques. As they were partly the same people as the officials, who were subordinate to the alcaldes mayores, it is obvious that in these public they also used the caciques as an example: in a way, the officials ranked with the caciques. It is quite understandable that the badly paid officials demanded the same prerogatives for themselves as the caciques, above whom they had been placed and to whom they certainly felt far superior. The administrators were able to acquire the same economic position as the caciques, because the repartimiento was economically advantageous for both Spanish officials and Indians. The repartimiento enabled them to demand a position of monopoly in trade in exchange for the exercise of their distributive and controlling power.

The repartimiento de comercios could concern both the purchase and the sale of products. In theory, the repartimiento had two functions. With the sale of their own products, the Indians had the advantage that they could buy products on credit. This was based on the lack of means of payment, as a result of the considerable increase in trade and transportation streams in early colonial times. This greatly hampered the winding up of transactions. A partial solution was found in the growing use of cacao-beans as small currency, rather than as a beverage, but this was insufficient. The lack of currency not only obstructed trade between Indians and Spaniards, but also hampered trade among Spaniards themselves: in the 1590s, many transactions among Spaniards in Cholula were paid in instalments and sometimes even in kind." On the other hand, the pueblos de indios, which had to pay their tribute obligations, could only sell their products, if they were purchased by the alcaldes mayores or their agents. Consequently, payment of tribute frequently consisted of the sale of goods in the repartimiento. It is obvious that this was more often the case in remoter, mountainous areas than in the central districts like the valley of Puebla. Two rather elaborate examples may enlighten both the scope of the repartimiento de comercios under the regional officials in the seventeenth-century valley of Puebla and how it worked.

The first example is the only well-documented case of a repartimiento, organized by an alcalde mayor in the seventeenth-century valley of Puebla, that I have come across in the archives. In this case, the repartimiento was organized by a teniente, Francisco Vello, an obrajero and tradesman from the city of Tlaxcala. The case has survived, because it was part of a large-scale investigation, which the bishop and visitador Palafox initiated against the incumbent viceroy, the Duke of Escalona and those he had appointed. Among these so-called criados was Don Francisco de Pereda Lascano, the Spanish governor of Tlaxcala, on whom the investigators compiled an enormous file.

The repartimiento as it emerges from the documents on seventeenth-century Tlaxcala, is consistent with the picture we know from recent literature. The Spanish official filled the need of livestock in Tlaxcala. The animals had to be brought all the way from the north, and it was too expensive for interested individuals to organize the supply themselves. In addition, as has been remarked above, there was 
a persistent lack of currency in the rural areas, as a result of which few people either Spaniards or Indians- were in a position to pay for the livestock, at once. Paying on credit also meant that the expensive animals could be bought sooner than if money was to be saved first. Calves had to be paid in two instalments, mules in three. Some purchasers paid in maize or other products. Francisco Vello financed the repartimiento; he had probably obtained his capital with his obraje. However, he could not act alone, but needed the consent of the Spanish governor, who appointed him as his teniente. This support from the regional authority gave the repartimiento an official touch and guaranteed legal sanctions should debtors fall short."

The governor traded in livestock and wine. To that end, he had contacts in the port of Veracruz, where he had Poblano merchants buy wine. He owned large herds of goats which he had slaughtered in Ixmiquilpan in the present state of Hidalgo, where they had a slaughterhouse for goats. He sold the yield of meat and fat (cebo $y$ manteca) in the city of Puebla. The hides were stored in a depot (bodega) near his house. Most of this business he had carried out with the help of Francisco Vello. In the course of the trial, this Francisco Vello was accused of having taken a sum of one thousand pesos from the caja de comunidad of Tlaxcala, in order to pay his debts, but this accusation could not be proven. It was rather a strange matter, because no one could get access to the caja without the help of at least the Indian gobernador, at the time, Don Antonio Téllez. Even though Don Antonio maintained that he had been forced to give the money, there was at least one Indian witness who testified that the gobernador had paid the money in order to assure himself of the support of the Spanish governor to ensure the approval of his re-election which was officially forbidden."

Don Francisco de Pereda had sold the wine which he had brought from Veracruz to shop owners, innkeepers and a priest, all of whom Spaniards. These were illegal transactions, and these Spaniards possibly resold the wine to Indians, but in this respect, neither the governor nor his assistants had anything to do with the Indians. There were direct contacts in the repartimiento conceming livestock, consisting of calves, mules, horses and sheep. The Spanish governor did not only use Francisco Vello's assistance, who, according to his own agent Diego López Arronez, was responsible for the growth of the repartimiento under the governorship of Don Francisco. In the various pueblos, the repartimiento of sheep, and of larger livestock, was carried out by the tenientes of the Spanish governor. A mulatto, Pedro de Zurita, took care of the repartimiento of calves and mules to Spaniards west of the volcano Malinche, and ordered a number of his trustees to do the same east of the mountain. ${ }^{\star}$ In 1619, according to an informal note by Don Francisco himself, his various local tenientes and agents had distributed, all together, 56 calves among the Indians in the various pueblos. The Indians had paid 10.5 pesos each, $11 / 2$ pesos less than the Spanish labradores paid for a calve in that repartimiento." The repartimiento did not only concern the Indians, for the majority of the repartimiento's customers were labradores, and, furthermore, owners of mule trains, a priest 
and a blacksmith; of the 155 parties involved in the repartimiento of calves and mules, only five were pueblos de indios. Anyway, the pueblos did not pay more for the livestock; it even seems that they got the cheapest livestock, the quality of which was then, of course, also less good. But when soon afterwards, two of the calves of San Lorenzo Quapiastla, a sujeto of Huamantla, died, the Indians only had to pay for thirteen calves, instead of for the fifteen they had received."

The Indians and Spaniards were supposed to purchase livestock from the repartimiento, because it belonged to the governor and was regarded as his privilege. The Indians in Huamantla told the investigating magistrate that they had been persuaded (persuadido) by the repartidor to buy one mule. Other villages in Huamantla had been obliged to buy sheep and calves. The repartimiento in Huamantla was altogether no gentle business, because a Spanish labrador also complained that he had been forced to buy twenty calves. On another hacienda, a new mayordomo had just arrived, who told the magistrate that there were six calves on the hacienda which were called the calves of the governor'" A more doubtful case of a compulsory purchase concemed the cacique Don Bernardino Vázquez, who, at the time of the repartimiento, was one of the Indian officials in the cabecera of Tepeticpac. He complained that he had been forced to buy four hundred sheep. However, his complaint did not so much concern the repartimiento as such, but rather the state the animals were in. He claimed that they were too weak and too small to his liking, which makes us suspect that he had ordered the sheep in advance and simply was not satisfied with the product he had received. It is understandable that Francisco Vello pressed Don Bernardino to buy the sheep anyway, as he could not resell the ordered sheep anywhere else. At any rate, Don Bemardino resold the sheep to other Indians and had thus become part of the system of reparimiento himself. ${ }^{100}$

In the repartimiento of Don Francisco de Pereda in Tlaxcala, one example of its possible use, consisting of the purchase of Indian tribute products by Spanish officials, was missing. This was not the case in other areas. According to Dehouve and Pastor, in the early seventeenth century, in the remote mountainous areas of the Mixteca and the present state of Guerrero, both situated to the south of the valley of Puebla, a repartimiento of merchandise had come into being. ${ }^{10}$ This may be illustrated by a few examples: in the pueblo of Hueytlalpa in the alcaldia mayor of Zacatlan in the northern part of the present state of Puebla, the clerk of the alcaldia mayor organized a repartimiento of cotton, which be had woven into mantles. In addition, he demanded eggs, turkeys and 'other commodities', which the Indian leaders (tequitlatos) had to collect for him. This clerk was quite unruly, not only because of his involvement in the illegal trade, but also because he upset the Indians by making them pay ten or twelve pesos for the election of their Indian officials; he even influenced the outcome of the elections, which had already led to vehement disputes at an earlier stage. ${ }^{\text {in }}$ 
Not only the local temporal officials were involved in the repartimientos, but also the clergy, as in the pueblos of Chile and Xopala, in the province of Zacatlan. There, the parish priest (cura beneficiado) demanded annually 306 feet of mantles, 154 pesos, six turkey cocks and, in addition, the food he got on holidays. If something was missing, he demanded 15 pesos worth of eggs as a fine, which he had sold on the market. These duties were far too heavy a burden and the Indians protested, although they did not complain about the system of supplies as such.

There was never a repartimiento de comercios for purchases in the valley of Puebla itself. To a great extent, this was the result of the geographical location of the valley. An important factor in the development of a repartimiento was the accessibility of an area and the possibility to sell the products which had been produced in a particular province. The valley of Puebla was a densely-populated, easily accessible area, with markets in Puebla and in cabeceras like Cholula, Tepeaca and Tlaxcala. In these places many traders were active, who mostly eamed a living out of the products that were produced by the indigenous population.

One example of tribute products that were traded in another way than through the repartimiento de comercios was the tribute maize of Tepeaca which supplied the city of Puebla, though not through the repartimiento de comercios. A year's harvest of tribute maize was stored and then sold to a merchant from Puebla. According to Pastor, selling the tribute products to a Spanish merchant assured the Indians of a better price, than either direct sale on the market or sale in a repartimiento could yield. However, this depended on the location of the pueblo and, indeed, on the merchant. In 1591 and 1592, it was at least a risky venture for the pueblo of Tepeaca to do business with the merchant Pedro de Ubina from Puebla. He had the commission to buy that year's tribute maize of Tepeaca, but he kept the harvest in the stores of Tepeaca, from where it was usually collected, as long as possible. According to the Indians, it was his objective to let the maize rot or be eaten away, so that he could make them pay back at 'exorbitant prices' the maize he had paid in advance but never collected. The accounts of the town of 1555 show the seriousness of consequences that could result from this, when 500 out of 700 fanegas maize rotted in the stores of the town and could only be used as pig fodder. The Audiencia ordered the alcalde mayor of Tepeaca to see to it that in future the merchant, who had a commission for the tribute maize of a specific year, would come to collect the grain within two months after it had been stored. If he failed to do so, further storage was on his own risk. ${ }^{105}$ While in the valley of Puebla, the production or purchase of tribute maize was not subjected to the repartimiento, elsewhere this was usual. In the vicinity of Huamantla (Tlaxcala), for example, the purchase of tribute maize for the city of Puebla was prohibited by the authorities, because the maize was meant to supply the inns (ventas) along the camino real from Mexico to Veracruz.

In the valley of Puebla silver, the most important export article of New Spain, was not mined. However, in the sixteenth and seventeenth centuries, the area was an important centre of cochineal, next to silver the most precious article of trade. 
Cochineal was a scarlet dye made of dried and ground insects. At first, the Spaniards were not sure what the cochineal, which they bought from the Indians, was actually made of. Had they been interested to learn the complicated and painstaking production process, the Indians would not have been willing to teach them, as producing and selling cochineal was a most profitable enterprise. For a long time, the dried insects were therefore taken for grains (grana). ${ }^{103}$

As was the case with the sale of maize, the individual traders and the caciques from the pueblos themselves, were more important than the officials. ${ }^{100}$ In 1595 , the caciques of the province of Tlaxcala demanded not just maize and money as a tribute from the common Indians, but also a 'large amount of cochineal' and many other things. ${ }^{107}$ In sixteenth-century Tecamachalco and Tepeaca, Spanish traders were forbidden to buy cochineal in the houses of the Indians, because they used too much violence in their pursuit of what they wanted. As a consequence, the alcalde mayor had to see to it that cochineal was exclusively purchased on the tianguis. ${ }^{100}$

In the second half of the sixteenth century, the cochineal production in the valley of Puebla was declining. The reasons for this decrease are not clear. After the epidemic in Tlaxcala of 1576, the production had dropped so much that the viceroy felt the need to intervene; he ordered the alcalde mayor of Tlaxcala to investigate the problem. ${ }^{100}$ In 1581 , production had gone up a little again, but at that time, the Indians who cultivated cochineal did not pay much attention to the work on their milpas, as a result of which, the production of maize in the province of Tlaxcala threatened to drop. The viceroy declared that the cultivation of cochineal, though labour-intensive, could certainly be carried out besides the milpa cultivation, because the periods of work did not coincide. ${ }^{.10}$ Perhaps these problems occurred, because the Indians regarded the cultivation of the precious cochineal as a matter of prestige, which relieved them of the agrarian obligations of a common macehual. Anyway, cochineal production continued to go down, notwithstanding the considerable eamings from the trade in this dye and the attempts by the authorities to tum the tide.

In the 1590s, cochineal production was already moving more and more towards the Mixteca in the south, where it was concentrated in the eighteenth century. However, during the period under study, the valley of Puebla was the most important region for the cochineal production. Its decline continued to be a source of concem for the authorities in both Mexico City and Spain. In 1618, contrary to its own policy, the Council of the Indies permitted a juez visitador de la grana cochinilla to be appointed in order to remedy the situation. In that same year, it appeared to be impossible to buy the 2,000 arrobas $\left(30,600 \mathrm{~kg}^{\prime \prime \prime}\right)$ of cochineal for the king, who had asked his viceroy in a letter to do so. With combined efforts, the merchants of the valleys of Mexico and Puebla managed to buy 1,105 arrobas. Apart from the limited supply, the main reasons for this were that the merchants had to comply with their contracts and had too little time to gather the amount the king had asked for. ${ }^{112}$ Another indication of the growing scarcity of cochineal was the price of an arroba, which had gone up from 50 to 60 pesos by the end of the 
sixteenth century, and from 85 to 130 pesos in the second decade of the seventeenth century."'s

Apart from their involvement in the production of cochineal, the authorities also tried to get a grip on the trade itself. In 1590, the alcabala (sales tax) office for cochineal was moved from the traditional trade centre of Cholula to the Spanish city of Puebla. For the traders and merchants living in Cholula, it was too much trouble to go to Puebla with their trade every time, where they were continuously hindered by unwilling taxmen and bureaucrats. Their protests against the fact that they were denied a living this way, fell on deaf ears with the Audiencia in Mexico City. The attempt to move the centre of cochineal trade to Puebla was apparently successful, because in 1618, the centre of trade indeed seems to have been in Pueble, rather than in Cholula. The Poblano traders often resold their cochineal to big merchants in the city of Mexico. ${ }^{14}$

\section{Conclusion}

The actions of the Spanish state and its representatives in the sixteenth and seventeenth-century valley of Puebla were closely related to the social and economic situation in the region. In the late sixteenth and early seventeenth centuries, a regional economy gradually came into being in the valley. This was not dominated by one group of people, but developed in a field of influence, consisting of various interdependent power groups. Traders, labradores and local authorities on the one side, and caciques, principales and even Indian commoners on the other, all influenced this evolution. Their actions were restricted by the demographic developments, the demands of agriculture and the possibilities of trade. In addition, the existing socio-economic pattems at a local and regional level and the relations of power and Herrschafi to which the Indians were accostumed, were also of importance for the changes in the social and economic structure of the region and for the position the Spaniards came to occupy in it.

The authorities in Spain, in Mexico and at the regional level, could not influence the formation of the regional economy as much as they had hoped. The repartimiento de trabajo, which had at first seemed to be a decent solution to the pressing problem of labour, turned out to be far from ideal in practice and caused much resistance. Even though the authorities were convinced of the need of abolishing the repartimiento de trabajo, this appeared to be very difficult. The measures that were taken to make abolishment possible, had little effect. When the repartimiento had finally been abolished officially, it continued to exist in an informal form. In the case of voluntary, hired labour, the authorities were so much tied to local customs that, in the long run, they had no other choice but to formalize it in laws.

In the repartimiento de comercios, the regional and local officials followed the example of the caciques, despite the orders from their higher authorities, aiming at constituting a system of civil servants. At first, especially the officials below the 
rank of alcaldes mayores and corregidores embraced aspects of the position of the caciques. Usually they had come to play a crucial part in local and regional society. Officially, they were placed over the caciques, they had many contacts with them and as a matter of course they adopted many of the privileges of these powerful local men. This did not only benefit their personal ambitions, but also their status in regional society, in which they held a position of authority. At a local level, the involvement of Spaniards in the pueblos de indios and the caciques was best developed in the repartimiento de comercios, in which the local and regional officials played a pivotal part.

Both in the repartimiento de trabajo and the repartimiento de comercios, the local and regional officials and also the labradores, embraced elements of the indigenous caciques' position of Herrschaft. For the alcaldes mayores this did not mean that they no longer functioned within the colonial state, because their position and the responsibilities involved, did not change. The organization of the Spanish state as a rational, bureaucratic Herrschafi in a Weberian sense and the administrative division based on territorial criteria, remained valid. At the regional level, however, this bureaucratic Herrschaft was modified in accordance with the demands of the socio-economic and power relations of regional society. As a result, the execution of power at a regional level did not become less 'rational', in accordance with Weber's views, but was adjusted to the specific situation in the valley of Puebla. Undoubtedly, this did not agree with the Crown's intentions, because it limited the possibilities of administrative control of its officials. However, a limited central control did not imply that anyone holding a public position, did so just to enrich himself. What the central authorities took for abuse of power, did not necessarily have to be the case for those who fell under the authority of the regional officials. Those who misbehaved within their region, however, were harmful to the central authorities, because their actions could lead to disorder and loss of control. Of course, there were officials who abused their offices, but all in all they seem to have been exceptions and the Crown and the courts took complaints against its officials seriously and tried to remedy them.

Not just the influence of the authorities was limited, the actions of other Spanish groups were also largely determined by the regional situation. Thus, traders could not impose their will on Indian producers: although cochineal was a profitable product, the production in the valley of Puebla gradually declined. In the repartimiento trade, local officials and traders depended on each other. Besides the tenientes, traders were the creditors for the repartimiento, if, indeed, they did not occupy the official positions themselves. These two groups of local Spaniards organized and paid for the repartimiento of livestock in the valley of Puebla, but because the animals were sold on credit, they depended on the threat of sanction, which only the regional authorities, the alcaldes mayores could offer. The repartimiento de comercios became a vital part of economy and society in New Spain at large. In the late seventeenth and early eighteenth centuries, the repartimiento de comercios was 
to become the most important link between the urban markets of Puebla and Mexico City and the pueblos de indios.

The labradores were limited in their choice of a system of labour. The labour repartimiento was increasingly curtailed by the authorities in Mexico City; gananes could not be contracted for seasonal labour only, and it was too expensive to contract them for a whole year when they only worked during the season. When in 1632 the labour repartimiento was abolished, they remained dependent on seasonal labour from the pueblos de indios, and because of this, they continued to be dependent on those who organized the seasonal labour. These were the caciques, although, at times, the local Spanish authorities and even the priest could be intermediaries. In the course of time, however, the labradores managed to come to occupy a more steady position in rural society. Their relations with the gaflanes gradually became more and more relations of Herrschaft; in this respect, the position of the labradores came to resemble that of the caciques. Their position had two sides. On the one hand, in their relation with their gananes, they were committed to the moral obligations which their position as a lord and master implied. On the other hand, this position also justified a certain pressure on the Indians in their service. These positions of Herrschaft of both the labradores and the caciques largely determined local customs concerning the labour relations, and the right to enforce service.

At first sight, it would seem that the Indians had little influence on socioeconomic developments. It has to be realized that all these socio-economic innovations were a result of the growing involvement of Spaniards in the regional economy, which gave rise to new opportunities for them. This was far less the case with the Indians, especially the powerful ones, who did not have to conquer a position, but rather had to try and preserve one. The more succesful they were in retaining their position, the more influence they could exert on the future of the regional economy. At first, the caciques could not be expected to take the initiative. Yet, from the degree to which both the labradores and the regional and local Spanish officials came to follow the example of the caciques, one can tell how important their position was in the seventeenth century. This does not mean that the caciques did not react to the new developments or seize any opportunity that came their way. The measure to which the repartimiento de comercios came to play a role in the regional economy of the valley of Puebla, and elsewhere, depended on an interplay between the economic chances and possibilities of the regional and local officials, the Spanish traders and also the caciques in the pueblos de indios. The adjustments that took place in the pueblos de indios will be the subject of chapter 6 .

It is obvious that by and large the Indian commoners were affected by the socioeconomic developments. They had to do the work and follow the orders of both the Indian caciques and Spanish labradores. Yet, they were not just victims. In the first place, the macehuales fell under the 'contractual' terms of the Herrschafi. This means that they were not without rights, and that they were even entitled to resistance whenever these rights were violated. The colonial authorities protected these 
rights, as many authors have observed. Secondly, because both the labradores and the caciques depended on their labour, the macehuales had the opportunity to escape from the influence of one lord and go to another. In that case, they would place themselves under his protection and often had him take over their debts. Even though the Indians did not easily take this step and their lords often tried to bring them back, the appearance of huidos on all lists of tributarios and gananes, makes it clear that this was an opportunity which many seized. 


\section{Chapter 5}

\section{The Lost Paradise of the Franciscans}

Much attention has been paid in the literature to the relation between the secular and the regular branches of the Church. On the other hand, particularly in the last decades, investigations have increasingly focused on the reaction of the Indian population to Christianity and Christianization. These two elements of colonial Christianity have usually been studied as if they were separate entities and hardly connected by social developments. The relation between the regular and secular branches of the Church has mainly been seen as a result of the political developments in Spain and in the upper echelons of colonial society. According to many authors, Indian Christianity soon obtained a certain autonomy. On behalf of the official Church, only the rather isolated local clergy could influence it, and even these friars were largely excluded. Yet, it takes little imagination to suppose that Church and society in the sixteenth and seventeenth centuries were closely related and strongly influenced by each other.

In the middle of the sixteenth century, the spiritual care of the Indians in the valley of Puebla was almost exclusively in the hands of the Franciscans. Even the Indian barrios of the Spanish towns of Puebla and Atlixco were under their care. The secular clergy was only in charge of the parishes in the pueblos of Nopalucan, Tlacotepec and San Salvador in the sparsely populated area east of Tepeaca and Tecamachalco. The valley of Puebla was part of the Franciscan province of Santo Evangelio, which comprised the doctrinas in the secular bishoprics of Mexico and Puebla-Tlaxcala and was administered from the city of Mexico. In the seventeenth century, the Franciscans had, in addition, schools in Cholula, Tlaxcala and Puebla and hospitals in the most important cabeceras.'

The doctrinas functioned like parishes. As I have indicated in chapter 2, they consisted of a cabecera de doctrina and one or more visitas. The number of visitas per doctrina widely varied, depending on the size of the doctrina and the structure of the pueblo. In general, the Franciscans maintained the division of pueblos; sometimes the borders of the pueblo and the doctrina differed a little for practical reasons. $^{2}$

The radical social transformation, which I have described in the previous chapters, by no means left the position of the Franciscans untouched. In 1640, however, the incumbent bishop of Puebla, Don Juan de Palafox y Mendoza, forced them to give up their doctrinas to the seculars. This event marks the end of the Franciscan influence, although it had already been going downhill for a 
long time, both in the valley of Puebla and in New Spain in a broader sense of the word. In this chapter, I want to examine how the power of the Franciscans could vanish within three quarters of a century after 1570 and how this relates to the development of society. An important question is, of course, to what extent the developments in the valley of Puebla were an exception within the context of New Spain. The demise of the power of the mendicant orders in general is undisputed in the literature and in this respect the Fransciscans were not exceptional and the valley does not distinguish itself from New Spain in general. I shall argue that there were two factors that made the evolution of the valley of Puebla stand out; together these account for the loss of the Franciscan doctrinas in 1640. The first element, and arguably the most important, was the person of bishop Palafox y Mendoza; this may be regarded as more or less accidental. The second element was more structural and concerns the attitude of the Franciscans concerning the way in which the doctrinas and the local clergy could be maintained. In this they differed somewhat from the other mendicant orders, as a result of which they remained more dependent on income from the pueblos de indios.

The Franciscans had connections with Spaniards as well as with Indians, the clergy were the only Spanish group which occupied a formal position in the pueblos- and in the sixteenth century they also influenced the upper administrative circles. As a result, their position itself was also dependent on developments at all levels of society. On the other hand, especially in the early colonial period their central position allowed to have an important voice in many sectors of society. The fate of the Franciscan friars cannot be well understood without a short outline of the Spanish political controversies concerning the Church, which I shall discuss first. The second point of attention is Christianity in the pueblos de indios as the Franciscans organized it, the aims that they strove after and the degree to which they could attain them. In this context, it is important to look at the Indians' attitude and their influence on the process. The central issue is, in what way the evolution of the position of the Franciscans in both sections of society contributed to the weakening of this very position and how their weakening position in one section of society influenced their position in the other one.

The second part of this chapter is devoted to the question in which way Indian Christianity developed after the time of conversion. During the sixteenth and seventeenth century the Indians became ever more autonomous in religious matters, but the Church as an institution remained influential in the pueblos. On the other hand, many authors have pointed out that the local church, and matters of religion were of great importance to the functioning of the pueblos. The sections on the Christianity of the Indians I will try to illuminate the way in which the Indians could introduce their own elements into the context of the official Church. The appreciation of the Christianity of the Indians in Spanish circles underwent great changes, especially from the middle of the sixteenth century. In my opinion, the changing attitude was related to the political contro- 
versies in Spanish circles, and to the demise of the position of the mendicant orders.

\section{The Franciscans under fire}

Around 1550 the Franciscans were one of the most powerful groups of Spaniards in New Spain. The subsequent growth of the secular Church is seen as symptomatic for the end of the foundation period of the Church and, at the same time, of the end of conquest society. The power of the Franciscans was founded on the positions they had fulfilled in the spiritual conquest. They had carried out a major part of the conversion of the indigenous population, and in this respect, they had only been equalled by the other mendicant orders, the Dominicans and Augustines, who had been active in other areas. The ecclesiastical administration of the valleys of Mexico and Puebla, was initially in Franciscan hands. In the valley of Mexico, they soon had to share their power with other orders, and also with the secular branch of the Church, but for the time being, in the valley of Puebla, their position was unassailable. ${ }^{3}$ When viceroy Velasco the elder wanted to congregate the Indians in the $1550 \mathrm{~s}$, he could only realize his plans with the help of the friars minor. Their counsel was highly esteemed in government circles and no authority, not even the king himself, could easily brush aside their advice.

The Franciscans and, in particular, the Franciscan chronicler Gerónimo de Mendieta were influential advocates of the division of the population into two repúblicas, the república de espanioles and the república de indios. ${ }^{*}$ In the sixteenth century, the Franciscans had visions of an Indian millennium under their shining leadership. They wanted the separation of Spaniards and Indians of the conquest era to become permanent. Each population group would get its own world, or república and its own governance. In this view, the Indians would fall under the repuiblica de indios, which would be ruled by the Indian leaders as far as civil matters were concerned, while spiritual matters would be taken care of by the Franciscans. The doctrinas were to form the basis for this order. Soon, it became clear that the expectations of the Franciscans were too high and that the friars had to accommodate themselves to the reality of relations within the colony. The very size of the Franciscan enterprise soon became a problem. The number of doctrinas, which had reached its peak in about 1560, could only remain unchanged for two decades. Then, the number of friars structurally fell short of being able to man all doctrinas adequately. The Franciscan Provincial repeatedly urged the Crown to send reinforcements, but his pleas fell on deaf ears. Therefore, in 1567, the order felt compelled to give up a number of distant doctrinas and to concentrate on what it considered to be its core areas. The provinces in the valley of Puebla were at the top of the list of priorities.s 
The official position of the Franciscans received a severe blow when, at the Council of Trent (1545-1563), and later enforced in the Third Mexican Council of $\mathbf{1 5 8 3}$ for the Mexican situation, the mendicant orders were officially prohibited from doing any parish work. Although the measures had a long history in Europe and had certainly not been devised for the colonies of Spain, they could well be applied to the situation in Mexico. The conversion of the Americas had been placed in the hands of the Franciscans and the other mendicant orders, because they had been more flexibly organized than the secular Church and due to their lesser degree of organization, they had been a lesser threat to the establishment of the power of the Crown. With the completion of Christianization, the advantages of having the mendicants preach the Faith, had disappeared. From the middle of the sixteenth century, when the Crown, with all its strength, tried to organize a decentralized administration in the overseas territories, the religious organization was, as a matter of course, also reordered more strictly. The necessity to do so became even more apparent to the Crown when the Franciscans, and to a lesser degree their fellow mendicants, turned out to be the most formidable opponents of all administrative reforms concerning the Indians. From about the 1560s, the Crown therefore aimed at strengthening the position of the secular Church. An important champion of this policy was Don Martín Enriquez, the third viceroy of New Spain, who complained of the vast worldly powers of the Franciscans.

From the start, the secular Church had been more focused on the Spanish part of society and was more strongly tied to the cities. Because the seculars acted within the framework of a strictly organized and institutionalized hierarchy under the bishops, they were less autonomous than the mendicants who had fewer hierarchical lines. In the course of the sixteenth century, in contrast to the conquest period when all European power still had to be established, the Crown did not have to fear too much influence of the Pope, as he had granted the king of Spain the right of patronage of the American Church. As a result, the king was entitled to appoint bishops and prelates and, consequently, to control this kind of appointments. If we take these political backgrounds into consideration, it is hardly surprising that after 1570 , the flourishing period of the Franciscans and the other mendicant orders was over, and that from then on they were increasingly pushed on the defensive.

Initially, the consequences of the campaign of the secular Church against the mendicant orders were limited. The decrees of the Third Mexican Council were weakened by the Crown and for the time being, the orders were allowed to stay on in the doctrinas and to exercise their tasks as parish priests. This decision was chiefly taken, because it was impossible in practice to replace the mendicants in the doctrinas with sufficient well-trained and competent secular priests. Moreover, the mendicant orders were still supported by important parts of the viceregal government. The viceroys were generally engaged in a fierce competition for power with the secular prelates, above all, the Archbishop of Mexico.6 
Notwithstanding repeated attempts, the secular Church did not succeed in either driving the Franciscans away from their doctrinas, or in 'secularizing' the parishes, as the replacement of regular clergy by secular clergy was called. This changed with the arrival of the energetic bishop Don Juan de Palafox y Mendoza. His actions were predominantly directed at the Franciscans. Of course there was an enormous protest from both the Franciscans themselves and also the viceroy.'

Some authors have put forward explanations of the secularization of the Franciscan doctrinas in 1640 . Israel argues that it was a result of a political struggle for power in the republica de espanioles between a party of peninsulares (Spaniards bom in Spain) and a party of criollos (Spaniards born in the Americas), which, according to him, was alive throughout seventeenth-century Mexico.' According to Piho, the crucial factor in the secularization was the craving for income by the secular Church.'

In my opinion, an important factor in the secularizations was the person of Palafox, who did not find his match among the bishops of seventeenth-century Mexico. He was a fervent absolutist and believed in regalism and the unity of state and Church, which is to say the hierarchic and institutionalized state. In his way of thinking, there was no room for independent religious orders like that of the Franciscans. He considered their position in the valley of Puebla to be an excess of power.

Palafox was a representative of the dominant political culture, alive in circles at the Spanish court at the middle of the seventeenth century. At the time, the Spanish monarchy was facing a decline of its power, both in Spain and in its territories abroad. Understandably, political theorists who advocated a strengthening of the king's position were welcome in such a situation. Therefore, Palafox was one of the king's confidants, and the king hoped that the bishop would be able to impose some order in the colony which he regarded as being too independent. However, Israel exposes that the political line of the bishop of Puebla, who was later to become viceroy ad interim, as well, was too radical for the delicate political relations of New Spain. ${ }^{10} \mathrm{He}$ tried to force all social sectors under the control of the state and the Church. His actions divided the república de espanoles into two fiercely opposed camps. Especially his attempts to enforce a stricter fiscal legislation, caused much consternation among the important merchants of Mexico. But perhaps his greatest political mistake was to try and force the Jesuits to pay tithes and to bring this group under the control of the secular Church. In the middle of the seventeenth century, the Jesuits were one of the richest and most powerful groups in New Spain, with many contacts with high placed Spaniards. Palafox did not have enough power to infringe upon the position of the Jesuits and this conflict caused his political defeat in New Spain. However, his assaults on the Franciscans were much more successful, because their position had greatly debilitated since the middle of the sixteenth century."

To recapitulate the political situation of the period, the strength of the Franciscans had always been in the doctrinas and their power over large numbers 
of Indians which was related to this. In the middle of the sixteenth century, this was true of all the mendicant orders. In my opinion, the renson for the exclusive secularization of the Franciscans in the valley of Puebla in the middle of the seventeenth century, is the difference in development in the relations between the Franciscans and the Indians and the relations between the Indians and the other mendicant orders as far as the financing of the doctrinas was concerned. Below, I shall argue that the Franciscans had become estranged from the Indians in the pueblos than the other orders because of their attitude in financial matters. To be certain, this should not be seen as the only reason for the secularization, but rather as the background to the political events of the seventeenth century, which were strongly influenced by Palafox. On the other hand, it would be a mistake to assume that the political developments in the Spanish part of society, and more in particular, in the city of Mexico, determined the regional power relations all by themselves. In the rural areas, both relations among Spaniards and between Spaniards (whether lay or ecclesiastical) and Indians influenced the position of certain groups in society. Therefore, we now have to look at the relations between the Franciscans and the Indians in the pueblos, because one of the most remarkable aspects of the secularization is the lack of resistance from the Indians, who, in other cases, were always ready to defend their interests in any area. This is particularly striking, if we take into consideration the extent to which the Indians had identified themselves with the friars in the sixteenth century.

\section{The position of the Franciscans within the pueblos}

In the sixteenth and the seventeenth centuries the relation between the Franciscans and the pueblos underwent great changes. There were two important influences that contributed to this change. On the one hand, there was the evolution of the pueblos whereas on the other hand, the attitude of the Franciscans also played an important part. In the course of time, and especially in the first decades of the seventeenth century, the situation in the rural areas slowly stabilized after the upheavals of the last part of the sixteenth century. The overall result was that from 1560 the heydays of the Franciscans- to 1640, the caciques and the pueblos as a whole gradually became less dependent on the Franciscans. To understand these developments, it is necessary to return to the evolution of society as discussed above.

In chapter 2, I have explained that the organization of the doctrinas in cabeceras and visitas was the first Spanish form of organization that was imposed on the alsepetl. When afterwards it was decided to introduce pueblos de indios, the structure of the doctrinas became the blueprint for the organization of the new Indian administrative units. So, to a substantial degree, the areas of Franciscan jurisdiction coincided with those of the caciques in the former altepetl, now the pueblos de indios. When in 1567 the Franciscans announced that they were 
going to leave some doctrinas because of a lack of friars, the caciques involved showed great distress. Flattered, the Franciscans interpreted this as a sign of devotion to them and to the new religion, but to a large extent, considerations of self-interest obviously must have played a part, as well. If the doctrinas were abandoned, the churches would, in fact, become visitas of neighbouring doctrinas. The caciques certainly understood that the neighbouring pueblos could regard this as a licence to submit them, too. After all, in prehispanic times, the temples had been the centres of the alsepetl, and the pyramid was even seen as the heart of the altepetl (altepeyollotl). When an altepetl had been conquered, the temple was symbolically destroyed. Small wonder, then, that the Indians also applied these views to the churches."

In the same line of thought, one should look upon the resistance of the Indians of Tecamachalco when the Franciscans transferred Tlacotepec and San Salvador, two of its sujetos far to the east, to the seculars in 1567. After the transfer, the sujetos could easily claim to have the right to become autonomous (pueblo por sI) and to escape from the influence of the cabecera. The fear of Tecamachalco was fairly reasonable, as both Tlacotepec and San Salvador were among the first pueblos to separate from their cabecera. ${ }^{13}$

Above, I have argued that in the course of the sixteenth century, the pueblos got their own identity and started to look more and more like well-defined units of Indian administration. The social position of the caciques, which had been undermined by the tribute reforms, consolidated again in the late sixteenth and early seventeenth centuries. As a result of the concurrence of all these developments, the pueblos were settled firmer in the society of New Spain. Even though the churches still remained a most important element in the pueblos of the seventeenth century, the caciques' dependence on the Franciscans steadily diminished.

In large measure, the social evolution as outlined above, also occurred outside of the valley of Puebla, and cannot be seen as an exclusive explanation for the secularization of the Franciscan doctrinas in 1640. However, on this point the Franciscans differed somewhat from the other mendicant orders on the point of finances. The problem was the way in which the clergy of the doctrinas was financed, as a result of which the Franciscans became a heavier burden on the pueblos than the other mendicants.

In Europe, of old, the tithes had been the most important source of income for the Church -although on the other side of the Atlantic Ocean, they by no means always benefited the parish clergy-, but in Mexico their importance was far less. For a long time, the Indians did not pay any tithes at all and when, at last, they had to start paying levies on products of Spanish origin, there were many protests. The church of Tlaxcala had to wage a test case with the pueblo of Tecamachalco, in order to have it arranged that the Indians were no longer completely exempted from tithes." 
The Franciscans and the other mendicants fell outside of the episcopal hierarchy and had no rights whatsoever to tithes. They received an income from the tribute which a pueblo paid to the Crown or an encomendero, but this was supposed to be insufficient for their sustenance. For the rest, the Franciscans were dependent on alms (limosnas) from the faithful, which was, of course, entirely in line with their mendicant ethic. However, these alms soon assumed an institutionalized form, because the friars were being included in the indigenous tribute system; consequently, the alms were in fact tributes and the Franciscans were not at all miserable. In Tepeaca, the cabildo spent about thirty percent of its income, some 325 pesos, on the Franciscans. This included the regular expenses on food and clothes for the friars, but also the often considerable sums that the cabildo spent on visits of bishops and other prelates.

Other pueblos did not always expend so much on the Franciscans. In 1572 and 1573, the cabildo of Tecamachalco disbursed a much smaller part of its income on the local friars, 2 and 7.5 percent, respectively. Neither in the accounts of the pueblo of Tepeaca, nor in those of Tecamachalco, the number of Indians serving in the monasteries has been mentioned, merely the material costs. In the case of Tecamachalco, it is also questionable whether all expenses paid in maize have been counted. Without doubt, the Franciscans often had large numbers of servants, but their number seems to have varied per pueblo. As the financing of the friars by 'alms' was in a way a continuation of the old tribute system, the contributions show the same bewildering local variations as all indigenous tributes. ${ }^{\text {s }}$

Yet, the tribute from the cabildo were not the only source of income to the Franciscans, and, in due course, its importance tended to diminish as a result of both the depopulation of the pueblos and the tribute reforms. Besides the tribute, in the later sixteenth century another important source of income developed for the friars when, in the later sixteenth century, many cofradias were established in the pueblos. Cofradias were lay brotherships with a number of religious and social tasks, of which many Indians were a member. One of their most important tasks was to take care of the souls of their deceased 'brothers', by having masses said for the dead. To be able to do so, the cofradias often had considerable properties at their disposal. Below, I shall return to the cofradias and what they meant to the Indians. Their importance for the Franciscans was that they provided a more or less institutionalized source of income for the Church.

The scarcity of archival material makes it impossible to treat the financial position of the Franciscans in detail. However, the archives do reveal that their relationship with the leading Indians in the pueblos deteriorated towards the end of the sixteenth century. This deterioration was also echoed in the Franciscan literature of the time. The Franciscan writers Motolinía and Mendieta both proudly mentioned the affliction and distress of the Indians after the Franciscans had announced that they were going to abandon some of their doctrinas. Of course, relations between the friars and the pueblos were not always good in the 
early colonial period. To take one example, in $\mathbf{1 5 5 5}$ one of the noble factions in Cuautinchan, where the caciques were involved in fierce conflicts, accused a local friar of being partial. Actually, as I have argued above, the affection the Indians demonstrated in 1567 had strong elements of self-interest. Nonetheless, for whatever reason, the relations between Franciscans and leading Indians were often close in this period.

In the course of the sixteenth century this good relationship rapidly deteriorated. In 1595, for example, the Indians of Tepeace and Acatzingo complained to the Audiencia that the Franciscans demanded too many contributions from them, besides the normal costs of living, in flat contradiction with the king's decrees. In the seventeenth century, the pueblos often complained of the Franciscans' interference in labour services. These complaints particularly increased after the abolition of the repartimiento in 1633, when the Franciscans continued these labour services. These practices were so wide-spread that the viceregal authorities felt compelled to intervene. In the seventeenth century, the Indian complaints about the Franciscans were not restricted to financial matters, but the overall relationship between the friars and the Indians was troubled, as appears from the numerous complaints of Franciscan interference with pueblo administration and elections.

The growing gap between the Franciscans and the caciques did not remain unnoticed to the Franciscans themselves. The seventeenth-century successors of Motolinfa and Mendieta, Torquemada and Vetancurt, had to admit that the love between Indians and Franciscans had considerably cooled. Even if this thought would occasionally have had crossed their minds, it would have been taboo to talk about it. Torquemada and Vetancurt attributed the increasing lack of understanding between caciques and Franciscans to the decline in moral standards of the friars as a result of the laxity and the decadence which had pervaded the order after the first period of conversion. Vetancurt even wrote that "the Indians' early love for the friars [...had] been changed to hatred by their descendants".

Except for Palafox, circumstances were hardly different for the other mendicant orders, but they fell victim to the secularization much later. I think that the person of one bishop, regardless his energy, will not do as an adequate explanation for such a long delay. However, there was yet another factor which distinguished the Franciscans from its fellow mendicant orders. The Franciscans were determined to hold on to their ideal of poverty, while the Dominicans and Augustines had already abandoned their strict vow of poverty in the sixteenth century and had acquired considerable landed property. But the Jesuits were not the only order and they were rather different from the mendicants; the Augustines and Dominicans had also obtained large tracts of land from the 1580s onwards.

As early as 1562, the Dominicans had already said in writing that they could not live on alms alone as the Franciscans could. At first, the accumulation of land by the mendicant orders met with resistance from the authorities, but they 
were presented with a fait accompli and, in due course, had to resign to the facts. According to the historian Taylor, in the eighteenth century, the Dominican order owned up to a third of all agricultural land in the valley of Oaxaca where it enjoyed a monopoly position similar to that of the Franciscans in the valley of Puebla."

The Franciscan order did not possess any land whatsoever, but held on to its vow of poverty. Under the order's doctrine, the friars were not to get involved in financial matters at all. The monasteries in the valley of Puebla had appointed a specific official, the sindico, for all these matters. This was an office of honour for a local, wealthy Spaniard, often a tradesman or a labrador. Whenever the Franciscans received a bequest of land, the sindico had to sell it immediately, and put the money in the monastery's cash box, which he had in trust."

This does not mean that the brothers adopted a passive attitude in financial matters. In 1593, the guardian of the monastery of Santo Tomas complained to the cabildo of Tepeaca that the provisioning of his monastery was insufficient. He felt that the neighbouring pueblos Acatzingo and Tepeaca, under whose authority Santo Tomás fell, should contribute in the costs. The cabildo agreed at its following meeting." Nor did the Franciscans hesitate to take matters to the court of the alcalde mayor if people did not meet their obligations of payment. This was the case with the Indian Bernabé de Silva from Quechula who, in 1614, bequeathed a hacienda to the Spaniard Martín Gonzales de Lanciego, in order to appoint him guardian of his children. There was a censo of forty pesos on the hacienda, which bad been reserved for masses for the souls of Bernabé's father and mother, to be said by the Franciscans of Quechula. When Gonzalo failed to pay the interest to the friars, they demanded the money due before the alcalde mayor, who granted it. ${ }^{20}$

As a result of the depopulation and the tribute reforms in the late sixteenth and early seventeenth centuries, the financial burden of the payments to the Franciscans increasingly troubled the pueblos. The cajas de comunidad and the new tribute income came under an ever closer control of the viceregal administration. The caciques and principales felt compelled to redefine their old tribute rights and many of them subsequently impoverished. In these days of great financial insecurity and rapid, radical changes in the pueblos, the Franciscans refused to change their financial position and to become less dependent on the Indians. They held on to their fundamental principle of leading a life of poverty and were thus the only order with no sources of income apart from those coming from the pueblos. This made them a heavier burden on the expenditures of the pueblos than the parish clergy elsewhere. Notwithstanding the growing importance of the income from the cofradias, the Franciscans still largely depended on the contributions from the cabildo, which were based on the old tribute system. The refusal of the Franciscans to give up their traditional position in the pueblos, increasingly appeared to be a refusal to adapt to a changing society. It was 
inevitable that this would cause an estrangement between the Franciscans and the nobility in the pueblos.

If we take into consideration the disturbed relation between the Franciscans and the caciques, it is not surprising that the pueblos hardly reacted to the secularization of 1640 . As has been saiddbefore, this was not the only factor contributing to the secularization, which could only take place, due to a combination of circumstances: the increasing autonomy of the pueblos, the concentration of Franciscan power in the pueblos in the valley of Puebla and Palafox's resolution to take action against this. All in all, the secularization cannot be seen as to have been caused by one development. Had Palafox not acted against them, the Franciscans would have remained in their doctrinas in the valley of Puebla somewhat longer, but it was clear that the friars had failed to keep pace with the changing society, and that there was no future for them. Of course, the changing position of the friars in the doctrinas did not fail to influence the pueblos. Above, I have already mentioned that the pueblos became less dependent on the friars. Actually, we might even say that the Indians appropriated Christianity in a way that it became part of the identity of the pueblos. Thus, it is to Indians' Christianity that we now have to turn our attention.

\section{The Spanish appreciation of Indian Christianity}

Van Oss has pointed out that the Christianity which the friars brought from Europe was already an extremely complex religion, although it was passed on to the Indians in a uniform and simplified form." At first, the missionaries did not attempt to pass Christianity on to the Mexican society in all its complexity, but just tried to convey what they believed to be the essence of their faith. They could hardly be expected to do more in a situation in which they had set themselves the task of converting thousands and thousands of Indians within the shortest possible period of time. The Franciscans and the other mendicants held the view that conversion and the conveyance of the first principles of Christianity were most important. Meanwhile, the missionaries tried to join in the Indian way of living as well as possible.

Especially the Franciscans were convinced that it was important to bring Christianity to the Indians in their own language, so that they would be able to understand it. Thus, they leamed Nahuatl as soon as possible and, subsequently, started translating many religious texts. Gibson mentions the example of one of the first missionaries, the Franciscan Pedro de Gante.?

"[He] described the way in which be deliberately fostered [the] fusion [between Christianity and the rituals of the native religions]. Having observed the singing and dancing of the Indians in pagan worship, he composed a Christian song and drew new patterns for the mantles to be 
used in a Christian dance. In this way, he said, athe Indians first started to show obedience to the Church" ".

There were several handbooks for confessions and the well-known Franciscan Fray Bernardino de Sahagin wrote a psalm-book, in which he used indigenous verse forms as a point of departure. Soon, there were also religious plays in Nahuatl, which responded to the Franciscan desire to indoctrinate the Indians with visual aids. The Indians enthusiastically participated in staging these plays.

In translating these Christian works, with their rather specific terminology, the friars were soon confronted with the problem as to what extent they should translate the texts, and in which cases they were to hold on to the original terminology. In terms of language being the vehicle of thought, the Franciscans rejected the possibility to use the Nahuatl word teotl (god) for their own God. Their consideration was that they preached that the indigenous gods were devilish, and they wanted to prevent the Indians from getting the idea that God had something of the Devil about him.

In general, this applied to all concepts which the friars regarded as the core of Christianity, like the saints and the sacraments. Terms like church or priest (teocalli, teopixqui) were far less crucial to them, and could therefore be translated. In this way, the friars consciously directed what has been called the Nahuatlisation of Christianity. They were convinced that in this way it would have the greatest effect on the Indians. They very well realized that pushing through an orthodox Christianity would alienate the Indians and possibly even repel them. In the 1530s, the Franciscan author Motolinía was convinced that this method had been very successful and that there were hardly any better Christians than the Indians of New Spain. ${ }^{3}$

As in the course of the sixteenth century, resistance to the power of the mendicants was growing, ever more protests were heard against the successes they claimed to have reached in conversion. It is remarkable that as the power of the mendicants declined, the Indians were increasingly accused of falling back on paganism or of returning to a paganism with Christian elements. In due course, even within the Franciscan order a movement developed, which tried to make a virtue of the necessity, by claiming that the deficiencies of indigenous Christianity were precisely the reason to have the Franciscans keep the doctrinas. ${ }^{20}$ The Indians should be seen as children who needed a helping hand to stay on the right track and who were more fit to lend this hand than the Franciscans who had behaved fatherly towards the Indians?

These Franciscans argued that it was necessary to have a thorough knowledge of the old religious practices, if one was to understand the Indians' errors. If these were not known, according to, among others, Fray Bernardino de Sahagin, the Indians could continue their idolatry right under the noses of the friars, without them even knowing it. This argument made so much sense that Sahagin got the opportunity to start off his project of investigation into the 
customs and traditions of the Aztecs. In the course of the sixteenth century, the 'anti-Indian' current radicalized and managed to denounce Sahagún's approach as a trip to the Devil's empire, which might keep alive indigenous recollections of former rites. Although everyone recognized Sahagin's good intentions, he was only able to finish his project with intervals and with the support of some powerful patrons in Spain. Sahaguin did not live to see his work published, as this did not happen until the Spanish era was over. ${ }^{25}$

In this way, the issue of the success of conversion was politicised along the lines of the ecclesiastical conflict between regulars and seculars. As mentioned above, the early colonial Mexican Church was a bundle of contradictions. Orthodoxy was a subject of heated disputes in Spain itself and in Europe at large, and the Spanish ecclesiastical establishment was alert to anything they regarded as non-orthodox, which meant unlike Spanish Christianity as they knew it or rather thought it should be. Everyone was well aware that suppressing heterodoxy was the principal aim of any Christian and certainly of the clergy. In discussions at the time, accusations of heterodoxy were just about the worst charges that could be brought against a group of people and in the sixteenth-century political disputes between the mendicants and the secular clergy, the last party of course raised the issue of the imperfections of Indian Christianity. The mendicants could hardly defend themselves to the imputations, because of course the Indians were not orthodox Christians in the Spanish sense.*

From the beginning, the Franciscans, and the other mendicants, did not regard the Indian world as being wicked only. They were delighted with the degree of social order or policia they saw in Indian society. ${ }^{27}$ By joining in the Indian way of living, they tried to intertwine Christianity with the indigenous traditions. They tried to use what they saw as the good and orderly sides of Indian society for their own ends. Thus, they used the Indian way of rule for the Church. Indian functionaries were appointed who were to take care of the churches in the pueblos. The cabildos were not only instructed to take care of the civil administration, but they were also to see to it that idolatry was banished. To ensure that everyone attended Mass on Sunday, the local leaders were to accompany the Indians to church. If they did not fulfil these duties, they could be punished or be discharged from office. From the beginning, the Franciscans made sure that the Indian leaders had a personal interest in maintaining Christianity, but they did not try to eradicate all indigenous elements. ${ }^{20}$ Therefore, Christianity in the pueblos had merged with Indian traditions, we may discern an official side and a side which was determined by custom. As with many institutional innovations, the Indians adopted the parts that were useful to them and used it to attain their own aims. 


\section{The framework of Christianity in the pueblos}

The church buildings themselves and their interiors were the most visible proof of the presence of Christianity in the pueblos de indios, and were indeed the places where many of the pueblo's Christian celebrations took place. Of course, they were only the outward signs of Christianity, but nonetheless important to the Indians, and often they played a central part in the life of the pueblos. The largest churches were the monasteries and monumental churches in the cabeceras de doctrina. However, these were not the only religious buildings in the pueblos: there were usually also hermitas, chapels which were devoted to a specific saint, and smaller churches in the visitas. In the main church of the cabecera de doctrina, a Mass was celebrated every Sunday and every holiday. The visitas had to content themselves with less. In the twenty-five visitas of Tepeaca, Mass was celebrated each Sunday, but in nearby Tecali they were served in terms, but each was at any rate attended on the name-day of its patron saint. ${ }^{x}$

Every church, big and small alike, had a patron saint, who also gave his name to the cabecera or sujeto in which the church was situated. The identity of the sujetos seems to have been connected with the visita church. This did not mean that a sujeto had to comprise a group of people living in one settlement. For example, around 1600, the sujeto (hermita y pueblo sujeto) of San Francisco Coatepec, which was subordinate to the cabecera of Tecali, consisted of five thaxilacalli (Mistla, Tlatlauquitepec, Caltitlan, Tlacpac and Quauhtlan), which were all named San Francisco. ${ }^{*}$ It is obvious to assume that this was a continuation of older, prehispanic ties of tlaxilacalli to a temple, but there is no documentation on this matter in the case of Tecali. As far as I know, the exact continuity of prehispanic and colonial religious organization has not been documented in any case, although it does not take a lot of imagination to assume a relationship of form and structure.

The example of Tecali gives us an impression of these visita churches. In 1599, the juez congregador recorded the condition of all 22 sujetos. Apart from the cabecera of Santiago Tecali, which had a monastery and a large church, only the settlement of San Martin Esmezuca had a church which the Spanish civil servant described as being of a passable construction (mediana lucida). In the other visitas there were no more than chapels. Some were large, but most were small, and the juez congregador judged the church in San Salvador Temiztlan as just a very small (mury pequefia) chapel. The chapel in San Buenaventura Tlacpac was dilapidated (mal reparada) and the one in San Lorenzo Tecartzingo had not been finished yet."

The constructions were of stone, a combination of stone and wood, adobe or a combination of wood and adobe. According to the Indian administrators of Tecali, all these chapels also had cloisters and some rooms for visiting friars. The interior of the churches cannot have been very special. It was one room with a tamped earthen floor, with no benches and just an altar at one end. 
Even though all visitas had a church or a chapel of their own, the inhabitants usually attended Mass in the cabecera de doctrina, where also the font for baptismal water was situated. In this case the criteria were, whether the visitas were within reach of the sound of the church bell (al sonido de la campana). On the saint's days of the patron saints of the visitas, a delegation of the cabecera usually attended Mass in the visita."

The visitas did not need a proper church, but the cabeceras did. In all cabeceras de doctrina the friars did not only have a church, but also a monastery, some of which were very important. These monastery churches rather differed from the small churches and chapels of the visitas. They were huge buildings, a source of pride for both the Franciscans and the Indians of the pueblos. Many of the churches had a so-called open-air chapel (capilla abierta) outside of the main building, in which services could be celebrated before the mass of people that had gathered in the atrium of the churches." In the cases of the neighbouring pueblos of Huejotzingo and Calpan, small chapels had been built in the atrium, which were used for the four parts (parcialidades) of the pueblos. ${ }^{*}$ The atriums served as the cemeteries for the dead of the cabecera, but not of the entire pueblo. In the sujetos, the dead were buried in the atriums of the visitas. This was one of the most important reasons why in 1604, the Franciscan guardian of Tecali protested against the congregation of the pueblo. If the Indians were forced to leave their places of residence, he argued to the juez comisario of the congregation, they would also be separated from their dead and ancestors, as a result of which they would be greatly distressed."s

The monasteries and churches of the cabeceras were often built on the spot of a prehispanic pyramid and temple, which they replaced. The same stones were used for the new buildings. As one example out of many, we mention the present church of Huaquechula, where there is still a stone in the lower part of one of the walls on which unmistakably a prehispanic warrior has been depicted. Elsewhere, the churches and monasteries were the centres of congregated pueblos, which had been built around the church and the central square in front. Together with the tianguis Sunday Mass was one of the few occasions on which a majority of the pueblo was present. Consequently, this was an appropriate moment to make public announcements which concerned all inhabitants. Hence, the church was not just the religious centre of the pueblos, but quite often also fulfilled an important role in social life. When there was no separate building (casas de cabildo) for the Indian administration of the pueblo or of a sujeto, the church would serve as such. ${ }^{\star}$

The construction of the monumental churches and monasteries particularly took place after the period in which the Indians had been converted, but prior to 1590." This is hardly surprising, because this was the period in which the pueblos de indios were founded and Christianity moved from a disconnected and rather improvised stage to a more institutionalized and stricter form. Probably, most of the large constructions were preceded by a smaller emergency church. 
An example comes from Cuautinchan, where in 1542, the Franciscan Fray Antonio Santo was supposed to say Mass in a construction which was covered with zacate straw and in which a bell was hanging from the branch of a tree."

According to Kubler's investigations, the churches were designed by the friars and built by the Indians. We have to note, however, that the Franciscans could make use of the skills of the Indian carpenters and constructors. The Franciscans were inexperienced as building masters when they arrived in New Spain, but the construction of the churches usually went miraculously well. Nonetheless, later in the sixteenth century, more and more separate master builders were appointed. The churches seem to have been quite strong constructions and many of them have stood the test of time. A less successful product was the church of the pueblo of Santo Tomás, which was subordinate to Tepeaca. At the time of the juez congregador's visit of inspection in 1599, it was about to collapse."

Gabriel de Rojas, the author of the Relación geografica de Cholula, was not very enthusiastic about the technical skills of the Franciscan master builders on the spot. In ca.1580, the monastery there had been extended by a chapel which was to hold the many Indians that attended the services. The chapel was built on a large number of arches. One day, the vault above the arches was ready, but it was still being supported. In order to be able to celebrate an important feast, the props were removed from under the vault, supposing that the construction would be strong enough. That night, when the feast was over, the entire roof fell down and only the walls remained standing upright. According to Gabriel de Rojas, the hand of God was responsible for keeping the roof from falling at daytime, when there were four or five thousand people in the chapel, but he expressed his surprise at so much human foolishness."

Elsewhere, the churches needed reconstruction after some time, which does not mean that faulty constructions caused the problems. For example, in 1628, the large monastery (convento principal) of Tlaxcala, which at the time was nearly a century old, suffered from rot in the wooden roof. As a result, a hole had developed, which had been provisionally repaired by placing a wooden hut (jacal) over the bad spot. This prevented the roof from falling down for a while, but everyone was convinced that if the roof was not replaced altogether, the church would collapse during the rainy season. As it was now necessary to repair the church, the Indians asked the Audiencia for a licence to extend it, because it had just 'a small capacity, and there were many Spaniards and Indians' who had to attend service there."

The interior of the cabecera churches was rather different from the modest hermitas and chapels in the visitas. The differences were more in the quantity than in the kind of objects. Moreover, one should remember that the cabeceras had different functions from the hermitas. In the hermitas of the visitas, services were only occasionally celebrated and were usually of a simple nature. In the churches of the cabeceras, the most important religious activities of the pueblos 
took place; as a consequence, these had to live up to certain expectations. Besides, the monasteries of the cabeceras were the Franciscans' daily residences, so they had to contain all that was needed in a material and spiritual sense.

The interiors of the churches had of course mainly been determined by the directions of the Spanish friars. The Indians had no experience with the demands of Christianity and did not know which conventions and instructions they had to follow. The cabecera churches were important elements within the pueblos and by furnishing their churches 'in the proper way', the Indians of the pueblos were able to gain prestige. As a result, soon the churches were filled with images of saints, altars, retables and other altar pieces, etcetera. This involved large sums of money, which the administrators of the pueblos, but also wealthy Indian individuals were only too pleased to provide. Especially, if by gifts or efforts they could connect their name to a prestigious religious object like a retable, they spared no trouble or expense.

The only concrete example of an Indian sponsoring a specific object in a church that I know of, is Doña María de la Cruz, cacica of Tepeaca, who, in ber testament of 1602 , bequeathed thirty pesos for a frontal (altar cloth) for the main altar in the church of Tepeaca. Much more is known about the things which the pueblo de indios as a whole purchased for their churches, and of the costs involved. ${ }^{2}$

Each cabecera church had a main altar and some side altars, devoted to different saints. The main altar was adorned with a large, often richly decorated altar piece, the retable, which had pictures of the good works and the life of the patron saint of the pueblo, and usually some additional images of saints. For poor pueblos it was sufficient to have a painted retable, but all self-respecting pueblos had it gilded, if possible. The side altars were less decorated. The larger churches normally had some chapels, devoted to a specific saint. Here, too, were images of saints and there were often paintings on the walls. Many churches even were decorated with frescoes on all walls. The Franciscan churches bore the Franciscan mark, consisting of the cord of the order's habit, painted at the top of paintings.

Besides the paintings, the retables and the images of the saints, the cabecera churches also had many possessions which were connected with worship, and which were normally locked away in the sacristy. There were silver chalices and plates for the sacramental wine and the hosts. The altars had to be covered with a cloth. In an ordinary service, a simple woven cloth sufficed, with occasionally an embroidered border or some simple decorations. For the various seasons of the Church, however, cloths of different colours were needed. In addition, on feast days, richly decorated or worked cloths of damask or brocade were used, with embroideries in gold and silver. There were cassocks for all occasions. The colour of these also varied in accordance with the season of the Church and there were richly worked cassocks for feasts. The clothes of the acolytes and the members of the choir were also stored in the churches. In Tepeaca, the cabildo 
even bought a suit for the perrero, the man who had to chase dogs out of the church."

In processions, palanquins were used, on which images of saints were carried around, and which preferably had golden or silver handles. On these occasions, the doorposts of the church were sometimes adomed with a decorated cloth. In the services, during the processions and at other occasions, all kinds of musical instruments were needed, ranging from trumpets, flutes and shawms (chirimfas), to organs. Initially, the Spanish authorities had encouraged the purchase of musical instruments, but soon, restrictions had to be imposed, because of the great number of Indians making music during Mass. Together, they produced so much noise, that attention was being distracted from Mass a little too much; moreover the musicians were reputed for their unruly behaviour."

Finally, the large churches and monasteries also had a number of books, which had been purchased by the religious community. In 1628, there were thirty-eight books in the monastery of Atlixco, most of them of a religious nature: a Bible, some concordances, books of prayers and sermons, hagiographies and several comments on the Gospels and other parts of the Holy Scripture. The only non-religious books were a Nahuatl grammar by Fray Francisco de Asuncion and a Nahuatl dictionary, the author of which has not been mentioned. Apart from a number of non-specified books, in 1557 the cabildo of Tepeaca bought four precious choir books for two hundred pesos all together and a book for canto llano (Gregorian chant) for ten pesos."

\section{Church expenditure and the rise of the cofradias}

The above illustrates that expenditure on the Franciscans was only part of the money the pueblos spent on the Church and on religion at large. Therefore, the matters of Church finance were of great importance in the pueblos. According to the accounts of Tepeaca that have been mentioned above, apart from the thirty percent of its earnings spent on the Franciscans in 1550-1559, the pueblo spent another twenty-three percent on the Church. These costs were partly this high as a result of the recent foundation of the large church of the cabecera, and the many items for the interior which still had to be purchased. However, about a third of the expenditures were for feasts which were celebrated in the town of Tepeaca. At the time when the accounts of Tepeaca were compiled, the cajas de comunidad had only recently been introduced. In a test case before the Audiencia and later even before the king's court, Tepeaca was presented as an example of the state of disorder of the cajas in the pueblos. The Fiscal blamed the high expenditures on the Franciscans, but they protested and alleged that the Indians spent such a large amount of money on the Church out of their own free will, and that only a small part benefited the friars, to which the Audiencia agreed. As 
a result of the detailed report, the Fiscal of the Audiencia drew up a number of measures in order to regulate the expenditures of the pueblos with the principal aim to restrict the expenditures on the Church and to increase the tribute income of the king. The king agreed to the measures."

The result was that the pueblos could only build churches in future with the Audiencia's consent and with a previous elaborate calculation of the costs involved. The Indians were also prohibited from spending a lot of money on feasts. The regulations of the Fiscal were adopted as a general measure. Especially the prohibition to build churches without previous consent of the Crown had considerable effect, as is clear from the large amount of sixteenth- and seventeenth-century applications for licenses to construct a church or a chapel."

An example of such an application and its treatment by the Audiencia is the well documented Indian chapel (capilla de los naturales) of the Franciscan monastery in Cholula. In 1580, the roof of the construction fell down. In 1591, the Cholultecs wanted to have the chapel roofed, because 'as it was not covered, one suffered harm and danger from water, wind and cold during Mass and the sermon'." The Audiencia established a procedure. Luis de Arciniega, master builder of the cathedral of Puebla had to make an estimate of the costs. The Audiencia consented to it that the cabildo of Cholula would use the five hundred pesos of income that it had received from the lease of the town's slaughterhouse. This was by no means sufficient and the Cholultecs had to indicate how they intended to cover the rest of the costs, without imposing extra levies on the macehuales (sin echar derramas). For the time being, the corregidor was ordered to sort matters out. At the same time, the Audiencia already granted the cutting of two thousand planks and beams (tablas $y$ vigas) on the Malinche in the province of Tlaxcala."

Cholula suggested to use the income of fifteen thousand pesos which it had in loans on its possessions (quince mil pesos de censo en posesiones de su comunidad) in Puebla, Atlixco and Cholula itself. This was granted, provided that none of these censos was sold. Meanwhile, Luis de Arciniega had consulted the local Franciscans and the corregidor, and everyone was convinced of the necessity of the operation. Arciniega thought that roofing the chapel would mean a lot of work, but that it would be neither very difficult nor costly. He estimated the total costs at some nine or ten thousand pesos, which could be paid in the way Cholula had suggested, plus a contribution of one thousand pesos from the tribute income that had been reserved for the king. The Audiencia did not issue a licence until these elaborate investigations were over. ${ }^{* 0}$

The restrictions on the costs of feasts in the pueblos were imposed with more difficulty. Even before the administration of the caja de comunidad was investigated in 1560, the high expenditures on feasts had been a source of concem for the authorities, as appears from the ordinances of the cabildo of Cuautinchan, in which in 1559 , before the lawsuit against Tepeaca, it was already stated that the costs of the local feasts were not to exceed the amount of fifteen 
pesos. Only in the case of the feast of the pueblo's patron saint, the cabildo was allowed to spend twenty pesos." At first, the decrees had a most limited effect. The 1572-1573 accounts of Tecamachalco show that disbursements on the Church constituted twenty percent of total expenditure. Most feasts cost ten to fifteen pesos, but the feast of the patron saint Santa Maria de Asunción of 1572 cost eighty pesos. The alcalde mayor did accept the accounts, but wamed the cabildo to keep down expenditures on feasts. ${ }^{2}$

According to the tribute accounts of Tlaxcala of 1641, in principle, no feast whatsoever was paid out of the tribute income of the caja de comunidad any longer. Tlaxcala had some extra sources of income, though, especially censos and leases on community goods (bienes de comunidad), but these generally failed to provide sufficient means to pay religious celebrations with. The town used to pay the celebration of the feast of Corpus Cristi out of this income. In 1641 this was made impossible, because Tlaxcala had a tribute debt and all income of the pueblo had been confiscated by the juez contador who had to collect tributes. However, these bienes de comunidad were a vulnerable source of income, as they could be easily controlled by the authorities, which could confiscate it in case of tribute debts. In 1599 and 1640, this happened in many of the pueblos in the valley of Puebla. To make sure that they could celebrate the feast anyway, the necessary funds were 'borrowed' from the caja for once, with the consent of the Spanish governor of Tlaxcala. The sum concerned was not twenty pesos, but the considerable amount of 224.5 pesos. ${ }^{33}$ According to both Gibson and Ouweneel, in the seventeenth and eighteenth centuries a substantial part of the income of the cajas de comunidad was spent on feasts."

With the establishment of sodalities (cofradias) the Indians got the opportunity to hide the income of the pueblos from the view and influence of the fiscal authorities. The cofradias were a religious institution which had been introduced from Spain. In Mexico, both Spaniards and Indians were usually organized in these lay confraternities. The intentions of the cofradias of Mexico, which have recently been elaborately discussed in literature, did not differ much from those in Spain. In the Spanish cities, the cofradias were mainly important as a means to organize fellow craftsmen and, as such, they were often strongly tied to the guilds. In the rural areas, however, they were a coherent factor within the comunidades."

First and foremost, the cofradias, in Spain, in the rest of Catholic Europe and also in America, aimed at honouring a specific saint or celebrating a religious feast and to encourage its devotion. The idea behind the cofradias was furthermore, that the members were brothers before the Church and in the eyes of God, and had to behave accordingly. Moreover, the confraternities fulfilled an important social role, albeit that this was not the same in all instances. In sixteenth-century Cáceres -but not in New Castile- and in France from the sixteenth to the eighteenth century, the cofradias usually fell outside the influence of the parish clergy; they only needed the priests for celebrating masses and for 
some other ceremonies. The confraternities were often associations of flagellants and in the eyes of the prelates, breeding places of heterodoxy. The decrees of the Council of Trent aimed at keeping multiformity out of Christianity and to place all manifestations of religion entirely within the area of the parish clergy's authority. This was often an arduous task, as in many cases the parish clergy came from the parishes themselves and were not able to distance themselves from local beliefs and practices. ${ }^{*}$ In comparison to large parts of Europe, the Mexican clergy of the rural areas were in this way much closer to the counter-reformatory ideal and up to the most modern standards of its time. The Franciscans in the valley of Puebla, as well as the other orders elsewhere, took up a very detached position from their parishioners and they were most critical towards the Christianity the Indians practised.

Cofradias have already been documented in the valley of Puebla for the period prior to $1550 .^{7}$ In 1542 , in Cuautinchan, the caciques founded the cofradía of Nuestra Señora de Asunción, the patron saint of Amozoc, which fell under the jurisdiction of Cuautinchan. In Tlaxcala, a cofradía was already mentioned in the 1540s. In Tecamachalco and Quechula, cofradias were founded in the last quarter of the sixteenth century. As in Tlaxcala, the first cofradias were founded to support hospitals, and possibly dedicated to Nuestra Señora de Concepción, as in seventeenth-century Jalisco, from which Chance and Taylor's examples have been taken." According to the Franciscan Mendieta, they were founded at the same time as the monasteries. In about 1570 he wrote:"

'In order that these hospitals would have facilities for attending to the invalids and for the payment of normal costs, [the friars] decreed that these said hospitals would have some livestock farm or maize plot of their own or some other source of income for their subsistence'.

In due course, however, these hospitals no longer responded to their objectives, because: ${ }^{60}$

'This institution was eagerly accepted by the principales and the leaders of the pueblos, just like all [institutions] which are in some way involved in collecting goods from the macehuales, because they expect that they will have to administrate and manage themselves whatever they will have to pay them. [...] It is certainly not surprising that they profit as much as possible from all this, and from all other things that they collect from the peasants, because they are being dispossessed and deprived of the absolute authority and income that they formerly had, which consisted of all that they wished to demand from them [i.e. the peasants], doing as they pleased. And they have no other estate nor any other way left to provide for a living'.

All this resulted in such a decline of either the livestock or the fields which had been reserved for the hospitals, that there was little left. Mendieta wrote: ${ }^{61}$ 
'In this way, the hospitals have neither served in the past, nor serve now but for three lame or paralysed patients at the most, and at times, just for one, who serves as a pretext (cabeza de lobo) so that the principales can have their way'.

Gradually, things had got out of the Franciscans' control, and the principales had made common course with the local administrators. Taking this into account, Mendieta thought it wise to abolish the hospitals and to use the buildings which had been constructed for them as 'meeting places for the cofrades (members) of the cofradia del Santtssimo Sacramento or of Nuestra Seftora'.

In several places, these cofradias had been founded by Franciscans who wanted to impart the Indians with more Christian civilization (policla cristiana). In some areas, they were devoted to the Most Holy Sacrament of the Communion (Santlssimo Sacramento) to get the Indians more involved in Holy Communion, and elsewhere they were devoted to 'some feast of Our Lady', to induce the Indians to concentrate more on the Mother of God. There were also places with cofradias of both devotions and on top of that of the True Cross (Vera Cruz), to strengthen discipline on Maundy Thursday. Mendieta had to acknowledge that these cofradias also met with resistance from Spaniards, who suspected that the Indian nobles would use them for their own advantage. Mendieta wrote that he knew that the 'Devil used any means to destroy whatever he could of the building of God', but, nevertheless, he held the view that 'the cofradías [were] most beneficial to the Indians of New Spain and a great help in converting them to good Christianity (buena cristianidad)'. Thus, the Franciscans should found cofradlas in places which were still without them."s

From the start, the cofradias contained all the elements that were to characterize them later on. They were lay confraternities attached to one church or chapel, with their own sources of income and devoted to one specific feast or saint. The members took care of each other and, according to Mendieta, in their care of the sick, they were even more important than the hospitals." Furthermore, as in Europe, the cofradias had an important task during the burials of its members, by keeping an night vigil by a corpse and by having Requiem Masses said or sung. To this effect, the cofradias had some singers in their service, who took the bodies to the burial. ${ }^{\text {.s }}$ The cofradias were also expected to have Memorial Masses celebrated at set intervals after the funeral, in accordance with the stipulations that had been laid down in the testament of the deceased, so that a soul would 'not stay in purgatory for too long' ${ }^{66}$

Some specified in their testament that masses should be celebrated for their own souls only, whereas others also wanted masses read for a deceased husband, wife, children or parents. To this effect, the cofradias received sometimes small and at times considerable bequests, depending on the wealth of the deceased and the number of masses he or she thought necessary. This number varied from merely a few masses for their own soul to a few dozen for the entire family. 
Doĩa Ana Sánchez beat everyone else when, in 1605, she bequeathed the small fortune of 1272 pesos to celebrate masses for the souls of herself, her deceased husband and his first wife."

The cofradias did not depend on bequests of money only. In some cases, gifts of land or macehuales have been documented, as in the case of the foundation of the cofradia of Nuestra Señora de Asunción in Cuautinchan, where four solares and fifteen macehuales were donated. Later on, this cofradia received more land from bequests by caciques. If we take into consideration that the cofradias of the eighteenth century have been known as wealthy organizations with, at times, very considerable material sources, we may suppose that they invested the bequests of money.

This aspect was most attractive to the pueblos and especially to the caciques and principales. Above, I have already quoted Mendieta, who held the view that the hospitals were a fiasco, because they were used by the principales as a source of personal profit. The growing control of the Spanish authorities over the cajas de comunidad meant, that in due course, the cabildo members in the pueblos were more often personally held responsible for missing income or too large expenditures. As in all public organizations, the cacigues and principales also played a major part within the cofradias in the pueblos. Thus, the administrators of the cofradias belonged to the same group of people as the leaders of the cabildos. By transferring land and income from the jurisdiction of the comunidad and, consequently, from the caja de comunidad to that of the cofradias, the administrators withdrew it from the influence and control of the authorities. Although the Franciscans did initiate the cofradías, as did the other clergy elsewhere, they could but raise little protest against the cofrades' right to take their own decisions where the affairs of the institution were concerned, as long as it remained within reason from a Christian point of view. ${ }^{\text {ss }}$

The cofradias were important within the pueblos, because an entire pueblo or part of it, was united in a confraternity. This had several advantages over a dependence on the caja de comunidad. The cofradias were institutions within the pueblo and only responsible to its cabildo and not to the Spanish authorities. As the membership of a cofradia was voluntary, at least officially, the administrators could get away with imposing special levies on the macehuales on top of the regular tribute (derramas) in case of failing funds or large festivities. The cabildo officials did not have this authority, except when the Crown gave them permission in a particular situation. ${ }^{\pi}$

The cofradia only had to pay for the feasts of its own church or chapel, usually the church of one barrio, whereas the cajas had to cover the expenses of several churches and chapels. The inevitable result was that some of the churches were favoured above others, depending on the officials who controlled the cabildo and, with it, the caja de comunidad. This happened in the pueblo of Quechula, where a great turmoil developed in the 1570 s. Here, the officials of one part (parcialidad) of the pueblo were in charge of the cabildo. They had used 
the money of the caja to build a magnificent clock tower next to the church of the parcialidad. The Indians of the other parcialidad paid heavily, but did not benefit from the clock tower in any way. The cofradias made it possible to tie funds to specific parts of the pueblos. For example, the pueblo of Cuautinchan consisted of two large parts, under different caciques, the partidas of Cuautinchan and Amozoc, which both had a cofradia of their own. The Indians of Amozoc had been united in the cofradía of Nuestra Señora de Asunción and those of Cuautinchan in the cofradia of Santissimo Sacramento. Only caciques like Don Pedro de Luna (1597) or Don Joseph Sánchez (1606)- who rose above the interests of one partida, because they were important within the pueblo at large, were members of both confraternities."

This does not mean that the cofradias did not respond to the above-mentioned intention of Mendieta to further Christianity among the Indians. There is no reason to suppose that the cofradias failed to do so; at the same time, however, they were fitted in the social structure of the pueblo, thus combining Spanish and Indian purposes. The ties between a cofradia and an ecclesiastical community were so strong, that Doña Maria de la Cruz from Tepeaca, who married a Spaniard when she remarried for the second time, is the only Indian I have found, who bequeathed a sum of thirty pesos to the Spanish cofradia of Santíssimo Sacramento of Tepeaca in her testament of 1602. Apparently, Doña Maria was supposed to have certain ties with the community of Spaniards in Tepeaca, because of her marriage to a Spaniard. On the other hand, in 1586, encomendero Don Rodrigo de Vivero, his wife Doña Melchiora and their seven children were admitted to the Indian cofradia of San Francisco in Tecamachalco; they were apparently supposed to be part of the community of Tecamachalco. ${ }^{n}$

In the middle of the sixteenth century, there were cofradias in all pueblos in the valley of Puebla that were under Franciscan administration. Most of them were of the devotion advised by Mendieta. In the countryside there were not only Indian cofradias, but according to the seventeenth-century Franciscan author Vetancurt, Spanish confraternities were also attached to all Franciscan monasteries in the valley; these often had the same devotions as the Indian ones. In the larger cities there were Spanish cofradias as well, some of which were extremely wealthy and had men from the highest circles of colonial society among its members. ${ }^{\text {" }}$

In the Anales de Tecamachalco, it is stated that the Spaniards in that pueblo founded a cofradia of their own, because they did not want to fall under Indian administration. In general, it was not forbidden for Spaniards and Indians to be members of the same cofradia, but in practice this was rare. Contrary to Indian use, Spaniards sometimes paid feasts out of their own pockets. An example is Francisco Martín Cortés, who paid some 69 pesos to the patron-saint feast of San Pablo when he was mayordomo of the cofradia in the plains of San Pablo in 1625. 
The Indian administrators of the cofradias, mainly mayordomos, escribanos, and cantores, came from the ranks of the caciques and principales, but the Indians, with their strong sense of status, could not have conceived otherwise. It is not clear how these administrators below the level of cabildo were appointed. If the Indians followed the Spanish example, they were elected each year. The only data on this matter are from Tlaxcala, where, in 1550, the cabildo decided that henceforth the so-called diputados of the hospital, which after all was the predecessor of the cofradlas, the mayordomo and the escribano, had to be elected, just like the cabildo officials were elected. As far as can be derived from the somewhat confusing documents, the election was carried out by the lords of the cabildo, and not by the members of the cofradia, as used to be the case in Spain. ${ }^{74}$

The cofradias had consciously been established by the Church, with the intention to increase the devotion and community spirit of the Indians. The institutions partly responded to this purpose, but their success among the Indians is accounted for by the position they fulfilled within the pueblos. Since the caciques and principales had been able to bring the cofradias under their control, these gradually came to be part of the social life within the pueblos. Sodalities enabled the Indians to spend funds on feasts and hide these from the view of the Spanish authorities, and at the same time, they imposed extra levies on the Indians for the festivities. To what extent the Indians accomplished their purpose will be clear, if we consider that at the end of the eighteenth century, the authorities tried to get a grip on the cofradias. They did so by means of a decree, by which it was forbidden to impose derramas, and, at the same time, by trying to declare the alcabala applicable to the properties of the cofradias. However, both attempts had little success."

The ritual counterpart of the cofradias was the system of compadrazgo, in which on various ritual occasions the members of the pueblo received the ritual co-parenthood of each other's children. The basic idea was that the compadres would share the responsibility of a child's education and take care of a child, should anything happen to the parents. Because the compadres were parents before God, it was forbidden for a godparent and a godchild to get married. The compadrazgo relations were also connected with the religious community, but they were not institutionalized in an organization which was associated with the Church, like the cofradias. Compadrazgo-relations were individual 'contracts', while cofradias were a matter of collective concern. ${ }^{*}$

Even though the original idea of compadrazgo relations as a kind of 'insurance' for the godchild was complied with, the contracts were usually between people with mutual interests, mostly of an economic nature. In this way, they were an extension of marital alliances which were of great importance throughout society. The compadrazgo relations of early colonial Mexico have been badly documented. The only concrete indications that economic interests played a part in compadrazgo relations are from Tlaxcala, where the cabildo made allusions to 
them in relation with cochineal cultivators and traders that seem to suggest that the compadragzo relations were factor of importance in their relations of trade."

The cofradias were part of a whole system of ritual kinship relations, which became as important in the pueblos de indios as in Europe. The cofradía organization expressed the idea of community spirit and a common subordination. As such, the cofradias were an element of the organization Herrschaft of the pueblos, which was subordinate to both the caciques and to the padre, as the priest of the pueblo was called. The solidarity of the brothers in the Lord was celebrated with communal meals, which, according to the pueblo accounts of Tepeaca and Tlaxcala, were always part of the religious feasts in the pueblos."

\section{The practice of Christianity in the pueblos}

Apart from the weekly masses, church life in the pueblos also consisted of feasts. Fireworks and processions would add lustre to them. They invariably ended in heavy drinking, which greatly dissatisfied and deeply concerned the authorities, who tried to stop the use of pulque with a never abating stream of ordinances and measures. Many have explained the Indians' alcohol consumption as a result of the trauma of conquest. However, the North-American historian Taylor has remarked that the drinking was a continuation of a prehispanic tradition." Even though Indian drinking may have been somewhat more extreme than in Europe, village feasts could sometimes get out of hand there, too. Tackett writes on village feasts in eighteenth-century France: "the secular festivities accompanying the longer processions sometimes fell entirely out of hand. A holiday armosphere reigned with drinking and dancing and stragglers of different sexes disappearing into the bush". We need little imagination to assume that the same was the case in colonial Mexico, where ecclesiastical feasts were the only diversion in a monotonous peasant existence.

The feasts were an important part of Christianity in the pueblos. In his Confesionario Mayor the Franciscan Fray Alonso de Molina specified the four most important feasts of the year: Christmas, Easter, Corpus Christi and San Francisco. All Indians were supposed to observe these, although in doctrinas of another order they probably observed the day of another patron saint. An important part of the feasts in the pueblos were the processions, which consisted of a walk around the atrium of the church with some images of saints, crosses and sometimes also the Holy Sacrament. The whole church and the path of the procession were decorated with flowers. According to a description of Torquemada, there were three paths, separated by arches which were also adomed with flowers. The procession itself followed the middle path: the crosses, the palanquins with the images and the priests and their assistants. The men and women separately of the congregation followed the two other paths." As early as the middle of the sixteenth century, Spaniards participated in the pueblo feasts, and 
even in weekly Mass. Because the Indians formed by far the majority of the participants, the feasts had a strong indigenous character, but they were not exclusively Indian. The Indians of Tepeaca were even flattered by the presence of Spaniards at the pueblo feasts. The Spaniards just had to refrain from arrogant behaviour, because this would lead to conflicts with the Indians, as in Tlaxcala in 1576."

Processions were not confined to pueblo feasts and they did not always take place within the enclosure of the atrium of the pueblo church. In the case of the feasts of Corpus Christi and of the patron saints, the sujetos brought their images of saints to the church of the cabecera, to participate in a large procession there." At times, processions were also held to ask a saint -mostly Mary- for protection from crop failure, epidemics and other disasters. This frequently happened in the cities of Puebla and Mexico, but also, for example, in Tecamachalco when the vast epidemic of 1576 broke out."

As in Europe, processions were not just an expression of the devotion of the pueblo as a whole, but also an important social affair. In a procession, everyone could show off his prestige, status and wealth, but the Indians could also derive these qualities from it. Therefore, everyone had to appear dressed-up, in order to represent his position within the pueblo society with dignity." The Indians were very fond of ceremonies of this kind; according to Torquemada, they were even ceremoniáticos. In this light should been seen the importance which the Indian cabildo of Tlaxcala, in 1549, attached to the right attire of the cofrades of the cofradia of the town's hospital. For the procession of Corpus Christi -the most important one of the year- they needed red mantles and the cabildo was responsible for it."

The important place of religious activities in the pueblos is apparent in some conflicts over ceremonies which developed in the pueblos. In 1603, in the pueblo of Atlihuetzian (Tlaxcala), the local Franciscan friar Fray Alonso de Rivas was inspired by 'Lutheran' thoughts. He refused to lead the local cofradia in processions and in services for the Virgin Mary to whom this brotherhood was devoted. He held the view that the Indians should not ask favours from the Mother of God, because 'she was a woman of flesh and blood, like all others'. As a result, the Indians had not been able to perform the ceremonies which were necessary for a proper functioning of the cofradia for quite some time, and as I have argued above, this was an important part of social life in the sixteenth century. To remedy this lack of religious assistance, the Indians lodged a complaint against the Franciscan with the court of the Inquisition when it had a sitting in Tlexcala in 1603. As the file is incomplete, only the accusation is known, and the end of the case is, unfortunately, missing. Nonetheless, the attitude of the Indians is clear."

A rather different case, which evidently was connected with a dispute between two villages, was the conflict between the Indians of the barrios of Guacalomolico and San Juan Aquiahuac of the pueblo of Cholula about the 
celebration of the feasts of San Andrés. Before the Audiencia, both barrios demanded the right to dance and play during the celebrations. The Audiencia ordered that in that year the inhabitants of San Juan Aquiahuac could play, but that the corregidor of Cholula was to see to it that in future the equality (igualdad) between the two barrios was guarded and that the conflicts would disappear."

This last example makes it clear that processions were only part of the feasts in the pueblos. During the procession, by way of diversion, dances were performed by children, accompanied by devout music and singing. At the beginning of the evening, the real dances would begin in the atriums of the churches. According to Torquemada these dances were 'the most important ceremony of their feasts', which were performed 'in the ancient way'." These dances were subject to severe attacks from critics of the conversion of the Indians, precisely because they had been derived from indigenous dances. Confronted with this criticism, the Indians of Tlaxcala petitioned to the Audiencia in 1592 for 'permission to celebrate their feasts with the dances and mitotes [Indian dances] in the churches as they are used to. This notwithstanding the fact that it is forbidden, because people say that they use old rites and ceremonies.' The Audiencia acknowledged the reasonability of this petition, but in view of the accusations of the continuation of idolatry, remained careful. Therefore, the Audiencia agreed to the petition, provided 'these dances [were performed] in the presence of Franciscans who know the language and know what they are singing, so that every opposition disappears'. If the Indians complied with these conditions, they were allowed to resume their way of celebrating the feasts. ${ }^{20}$ This reaction of the Audiencia indicates the tendency towards tolerance vis $d$ vis the Indians, which continued to exist among many Spaniards, notwithstanding all criticism on Indian Christianity and the large-scale investigations into idolatry that took place in the seventeenth century. ${ }^{\text {"1 }}$ Thus, Tackett's remark about eighteenthcentury France also applied to Central Mexico:"27

"Doubtless many curés were willing to tolerate the modes of religious expression of the villagers at least in their more innocuous manifestations. They were well aware of the danger of losing the confidence of their flocks if they tampered too much with the traditional local beliefs and practices".

The Dominican Fray Diego Duran, who was convinced of the need to investigate the old 'rites and feasts', pointed at the parallels between the Indians and the Spanish peasants in his treatise on the idolatries of New Spain:"3

"[...] We consider that in Spain also live people who are as course and dull as they [i.e. the Indians] are, or a little less, as in many parts of Castile [...] there are people with a primitive and course nature and above all with little knowledge of the Faith, even less than the Indians here. Because [at least] here on every Sunday and feast-day, they are taught the doctrines and one 
teaches them the law of the Gospel, whereas it happens to [the peasants] in many parts [of Spain] that they do not hear a sermon in their entire life. But notwithstanding all this, it may happen that [in Spain] one meets someone, who is dulled by a life on the land, who lacks sufficient judgment to be able to tell how big a star is, but says that it is as big as a nut, and the moon [no bigger] than a cheese, but who with all his coarseness would sooner have himself beaten to death than to doubt one of the articles of faith. If he is asked why God is one and trine, he answers because it is, and if he is asked why it are three persons and not four, he answers because it is not. And with these two reasons, because it is and because it is not, these people answer to all doubts and questions of faith. They firmly believe in what their parents have taught them and in what the Holy Mother Church teaches and believes".

According to Durán, as far as this was concerned, there was not so much difference with the Indians, but the Indians needed more education because they lacked the foundation of the tradition."

The Spanish tolerance towards Indian Christianity can also be illustrated by the expressions of art in the pueblo churches of Central Mexico. The Indians had a long tradition of art in the service of religion, which has been saved a little in sculptures and in pictorial manuscripts. The Spaniards demolished most sculptures because they were idols. The skills of the Indians partly remained. The administrations of the pueblos were intent on adapting the interior of their churches to the standards of Christianity as much as possible. Ideally, they were decorated by European artists like the Flemish Simon Pireyns (in Spanish Simón Pirines), who, in the sixteenth century, painted the retables of Tepeaca and Huejotzingo, amongst others. There were, however, very few European artists available in the sixteenth century, and most of their commissions were located in the Spanish churches of Puebla or Mexico."s

In most cases, the churches were decorated by Indian artists, who imitated the standard European style as well as they could. From the 1520s, missionaries like Fray Pedro de Gante and Motolinfa were delighted with the craftsmanship of the Indian artisans and their ability to learn European skills and techniques. When the Indian artists were working, they would use the skills they knew best. The fresco techniques which the Spaniards often used in the churches, they had known of old, just like the arts of sculpture and painting in polychrome. Apart from these, there were some ways in the application of materials, with which the Spaniards were not familiar. For example, the Indian artist Juan Gerson painted religious images on indigenous amate-paper, made of the bark of a specific tree, on the vault of the church of Tecamachalco. In the churches in the neighbourhood of Tecamachalco, like Acatzingo and Tepeaca, this method of painting was probably also applied, considering the many times the cabildo of Tepeaca bought paper and paint for the churches. However, only the paintings of Juan Gerson have survived. . 
Even stranger to the Spaniards was the technique of feather work, which had flourished in prehispanic times. Every pueblo had its own feather workers, but the most prestigious objects were still produced in Mexico-Tenochtitlan. Thus, in 1550-1559, the cabildo of Tepeaca bought large amounts of expensive feathers, but also specially purchased an image of a saint in feather work in the city of Mexico.

In the early colonial period, Indian artists had been trained by indigenous masters, and had only received some additional instruction from Spanish artisans. For most of their works they depended on instructions by local friars, or on their own observation. No wonder, that sometimes Indian influences entered into the images in the churches, notwithstanding their clearly Christian examples and theme. In Juan Gerson's paintings in Tecamachalco, Indian cosmological signs can be recognized in images which have otherwise been strongly inspired by Christian motives. In 1550s, in Tepeaca and its neighbourhood, images of saints were still made of feathers. In the church of Tepeaca, two feather eagles were placed. Eagles were symbols of the Indian worldview par excellence. ${ }^{n}$ The Franciscans did not hamper the Indians in their expressions of art as long as they thought their intentions were good.

The tolerance of the clergy did not prevent the Spanish population as a whole from being deeply suspicious and even frightened of the Indians. The two sections of the population did attend Mass together, and the images of saints which worked miracles attracted the devotion of both Spaniards and Indians. But in general, the Spaniards were a little frightened of the Indians and in the city of Puebla, where they were surrounded by many Indians, they clung to the Spanish traditions. Soon, Puebla came to be known as the most devout city of New Spain."

The Spaniards' fear of Indian magic is apparent in a case before the Inquisition against the Spaniard Francisco de Castillo Maldonado, a labrador and a regidor of Atlixco, who had a hacienda on the slopes of the volcano Popocatepetl. The Indians were seen as a source of witchcraft and of all sorts of frightening magic. During the sitting, Francisco appeared to be a strange man, who, according to the testimonies of several witnesses, in the course of time, had repeatedly shown to possess magic powers. Together with friends, he would organize strange and wild drinking parties and they said that he could predict a day in advance whether it was going to rain or if an earthquake was coming. He had put a spell on some cows of the Indian Juan Jiménez, which caused them to die, because Jiménez had been unwilling to lend them to him. One day, he had scared Francisca de las Nievas, who was staying on a labor near his own. He had shown her a piece of wood that superficially had looked like cinnamon and had said that he could bewitch every woman he wanted, 'but he did not say to what end'. To everyone who wanted to hear it, Francisco de Castillo had declared that be had learned everything he knew from an Indian sorcerer from the nearby pueblo of Tochimilco, who had held him in a cuescomate (indigenous 
grain store) for some time and had taught him everything about magic herbs. According to witnesses, time and again, he would go and brush up his knowledge in the pueblos around Atlixco, where he was involved in all sorts of obscure practices and drank creepy drinks, made of peyote (a mushroom with hallucinatory qualities)."

The Franciscans themselves were not completely free from fear of the old gods, or devils, as they preferred to call them. Gabriel de Rojas, who was no friend of the Franciscans, wrote in his Relacion de Cholula that number of friars had been frightened by the large number of bolts of lightning that had struck the old pyramid of Cholula. A cross had been placed on the pyramid, which had already been destroyed twice by the lightning. In order to investigate whether a 'mystery' was hidden inside the pyramid which attracted the lightning, the friars initiated some excavations, during which they dug up many large seashells, which the Indians had formerly used as wind instruments. Of course, Rojas said, the excavations were superfluous, because 'who seriously considers the nature of the thunderbolts, and [knows] that they occur a lot in this area, will find it hardly surprising [...] that the cross was demolished twice already, as it has been placed forty varas higher than the highest buildings in town. ${ }^{100}$

Considering bow much the Indians were devoted to the ceremonies and how much the caciques and principales had been involved in practising Christianity in the right way from early times on, it is most unlikely that the elite of the pueblos contributed much to upholding the cult of the ancient gods. In Indian pueblo culture, displaying status and grandeur by way of outward show was much more important than serving the 'being' of the old gods and following a personal conviction, as in twentieth-century Christianity. Even if old ceremonies continued to be performed just after the conquest, they contributed little to the status of their leaders, at any rate, much less than taking part in, or even leading, new Christian rites, or in contributions to the furmishing of the churches.

The bistorian Clendinnen has recently reconsidered a famous case of idolatry in sixteenth-century Yucatan. According to the accounts of the rigorous investigations by the Inquisition, which were carried out under the leadership of bishop Diego de Landa, the Indians were even supposed to have continued sacrificing men. After rereading the testimonies Clendinnen concludes, however, that, under the threat of torture, the Indians probably gave the bishop the answers he wanted to hear. Actually this was no exception during investigations by the Inquisition. ${ }^{101}$ In one famous case of idolatry in Central Mexico against Andrés Mixcoalt, noble from Texcoco, it appears that his resentments against the Christian faith were mainly a result of his anger about the loss of old aristocratic values. Andrés Mixcoatl connected this loss with the introduction of Christianity. This was a complaint of more Indian nobles. Few of them did come to the same extreme conclusion as Andrés Mixcoatl, who hoped to restore the old glory by falling back on the old religion, the old rites and practices. On the contrary, most of the nobles, hoped that by devoting themselves to the cause of the new religion 
they would be able to retain as much of their old dignity as possible. In retrospect, this last attitude proved to be justified, as Andres Mixcoatl was condemned by the Inquisition, whereas many other nobles acquired status through Christianity. ${ }^{\text {100 }}$

\section{Conclusion}

Christianity in Central Mexico had many sides and elements, but they were never apart from each other, nor from society as a whole. As a result of the Franciscans' zeal, the Church soon managed to obtain a firm position in the valley of Puebla. The Franciscans involved the Indians in the rites of Christianity by joining their own world and giving the caciques and principales a leading role in the pueblo churches. Because the Church was able to contribute to the Indian desire for ceremonies and thus fulfilled an important part in social structure of the pueblos, the Indians were ready to accept the new religion, even though they did not renounce all their old customs at once. The clergy took a tolerant attitude towards these old customs, as long as they thought they did no harm. In this way, Christianity took root in the pueblos and the Indians gradually came to become less dependent on the Franciscans. With the formation of the cofradias, an important step was set in the direction of the consolidation of the pueblos in colonial society, because the cofradias gave a more autonomous financial basis to the pueblo organization, which could exist besides the cajas de comunidad.

The Franciscans remained dependent on the churches in the pueblos, because they refused to look for autonomous sources of finance, as the other mendicant orders did. As a result of this, and of the stabilization of the place of the pueblos in colonial society, Franciscans and caciques in the pueblos estranged from each other. At the same time, there was a growing resistance of the secular clergy against the power of the Franciscans in the valley of Puebla. They particularly attacked the order with their fierce criticism on the success of the conversion and by accusing the Indians of idolatry, which they said had subsisted under a Christian cover. However, during the conversion, the Franciscans had tried to adapt to the Indian traditions, because they thought it might help Christianity to take root. They thought that continuous education would diminish the degree of superstition. What the Franciscans regarded as rather harmless superstition, their adversaries saw as idolatry. The Franciscans could hardly defend themselves against these accusations, because it was undeniable that Indian Christianity bad elements of syncretism.

This concurrence of local and country-wide political circumstances shook the 'Franciscan imperium' and during the seventeenth century, the friars were pushed increasingly on the defensive. They only got some support from the viceroy, who saw them as an ally against a too powerful archbishop. Yet, when the energetic bishop of Puebla, Don Juan de Palafox y Mendoza, removed the 
Franciscans from their doctrinas in 1640 , the viceroy only weakly protested, and the pueblos de indios involved were rather indifferent, as well. They did not look upon the arrival of the secular clergy as a big change. Even though the Franciscans still held some doctrinas in the diocese of Mexico, the secularisation of 1640 marked the final end of the earthly paradise, which sixteenth-century Franciscan authors like Motolinfa and Mendieta had wanted so badly to found. 



\section{Chapter 6}

\section{Shifting Powers in the Pueblos}

At the end of the sixteenth and the beginning of the seventeenth centuries, Spanish influence in the countryside increased with the tribute reforms and the foundation of the haciendas. In chapters 4 and 5, I have argued that this process, quite logically, did not take place in a social vacuum, but that particularly the interaction with the existing indigenous society was of importance. This was not only true of the economy, but also of culture and religion. The result of all these intertwined developments was a complex social and economic situation, in which Spanish and Indian elements were not opposed to one another, but often merged into a new entity, which was neither clearly Spanish nor clearly Indian. Spanish innovations were frequently integrated into an existing social framework, although they were usually modified during the process. Without profoundly changing the initial intentions, there were shifts of accents, due to the way in which they were adopted by society. Of course, the introduction of new elements could often only be accomplished at the cost of a lot of trouble and pain; outright unusable measures were simply resisted, under the well-known adagium of 'I obey but do not comply' (obedezco pero no cumplo).

I have repeatedly remarked that the Spanish political and economic reforms created new opportunities and challenges in Spanish-Mexican society. If we consider society in New Spain as a whole, there is no denying that the Spaniards constituted the upper stratum of society. In the previous chapters, I have particularly paid attention to the question in what way Spanish groups reacted to the changes. To them they were very significant, because they did not yet have a fixed place in the society of New Spain and under the circumstances the fate of an entire social group was often decided within the span of one single generation.

It is obvious that the Indians were also confronted with rapid and radical changes, though the social processes often had different implications for Spaniards and Indians. Contrary to the Spaniards' situation, the changes implied less new opportunities for the indigenous population, but rather pointed out the necessity to adjust themselves.

In these cases, it was already apparent that the caciques, and to a lesser degree the principales, as the most powerful people within the villages, used their influence to protect and reinforce their own positions by adapting these within the social environment of the rapidly developing colonial society. However, the macehuales did not remain passive either, although they had far less power and, 
consequently, fewer possibilities to use changes to ameliorate their position. The most powerful means they had was to withdraw from the influence of the pueblos and with it from that of the caciques. In such cases, they could hire themselves out to Spaniards. It was only one step further, to start wearing mestizo clothes and thus leaving tribute duties behind. In the middle of the seventeenth century, the Indian officials of both Cholula and Tlaxcala complained about this practice.'

Because of their important position within the pueblos, the caciques, and partly the principales as well, were pre-eminently the Indians who got into contact with Spaniards. They held considerable tracts of land and occupied the leading positions in the pueblos. It was their responsibility to represent and defend the interests of the pueblos as a whole. Under Spanish rule, the pueblos were defined as part of the colonial political order, meaning the basic administrative entity of the republica de indios, and this especially influenced the Indian structures of administration and Herrschaft. The caciques and principales protested, because their position was disputed both in society as a whole and within the pueblos themselves. In the pueblos, the tribute reforms caused a crisis of Herrschaft, which could only be mastered with great difficulties.

In chapter 1, I have described the intricacy of Indian society before the arrival of the Spaniards. After the conquest, a new and uniform administrative division was imposed, which does not mean that all internal differences between the pueblos were then wiped out. The conflicts which frequently developed in the pueblos, were often alike, because they struck at the roots of indigenous sacial organization. However, the Indian reactions varied, depending on the historical background and also on the characters of the caciques involved. The Crown's objective in founding the pueblos, was to constitute the Indians as a public body. This was quite a change for the indigenous population and they often regarded the new regulations as strange but in the end unavoidable.

Even though the comunidad has often been seen as a continuation of the altepetl and the lands of the comunidad as a continuation of the landed property of the calpulli in prehispanic times, the comunidad was an alien concept for the Indians, which they treated as such in writing -comunidad is a much-used loan word in sixteenth-century Nahuatl documents and is used besides altepetl. It is difficult to make a strict distinction between private law and public law, and although both the altepetl and the prehispanic tlahtoani contained many public elements, the Indians evidently considered authority to be a personal and often patrimonial matter.

Some examples can illustrate this. Indian witnesses declared about Don Juan de Mendoza, one of the early sixteenth-century caciques of Tecamachalco, that before the cabildo had been established in the pueblo, a comparable administrative council had gathered in Don Juan's house under his leadership. ${ }^{2}$ In 1591, in Cuautinchan, Don Diego de Rojas and Don Pedro de Luna suggested to hand over the tribute lists of the pueblo from the gobernador to the cacique, who had held them in his possession in former days, as well. The alcalde mayor, whom 
the viceroy bad commissioned to investigate this matter, considered the proposal to be most undesirable, because this would 'make patrimonial what belongs to the administration [gobierno, i.e. public domain]'.'

For the Spaniards, the introduction of the pueblo de indios was first and foremost a political decision. For the Indians it involved coping with a number of new positions which were not so much based on traditional personal claims and privileges, but had to respond to the formal demands of the Spanish authorities. Thus, leadership was no longer granted for life, as political positions bad to be filled every year. Controlling them was therefore much more difficult. However, for the Indian nobility, political power constituted just one side of its position. Their hold on tribute and land was at least as important to their Herrschaft. Above, I have shown bow difficult it was to define rights to land within Spanish concepts. The problems which such a transitional situation were bound to cause in the pueblos, were intensified by the demographic and economic situation that became more pressing with the dramatic mortality among the Indians in the course of the sixteenth century. Apart from the compulsory payment of tribute to the king, the demographic decline made income from tribute increasingly meagre. This led to conflicts both between nobles and macehuales and among nobles themselves.

There simply did not remain enough income to accommodate the entire group of indigenous nobles, which usually constituted some ten percent of the Indian population. Slicher van Bath has exposed that one of the results of a considerable decrease in population is that the social scale becomes more simplified. Agricultural surpluses are not sufficient to support the same number of non-producers as before the decline, and craftsmen cannot find enough customers to buy their products. On the other hand, agricultural producers tend to get a better price for their products and agricultural land becomes less scarce. Generally speaking, this implicates that in places where agricultural land had been scarce before, a decrease in the number of privileged people caused a growth in wealth for the poor. 4

These tendencies could also be observed in the pueblos the indios of the late sixteenth and early seventeenth centuries. As a result of the changes in the social organization, often long-standing and, at times, most disagreeable conflicts between the various nobles of a pueblo would develop. In their struggle for power, the Indians used any means at their disposal to weaken the position of their rivals and seized any opportunity to strengthen their own. The conflicts concerned complex relations of Herrschaft, which had many sides and could assume a bewildering variety of forms, in which local backgrounds were often more important than new juridical frameworks. For the Spaniards these conflicts were difficult to understand. In the light of the persistence and vitality of existing organizational social patterns, which I have repeatedly stated above, and because of the continuing influence of many caciques and, to a lesser degree, principales, the aim of this chapter is to analyse to what degree the old relations of Herrschaft 
were weakened by the social transformation, to what extent they changed with it, and what eventually remained of them.

\section{Institutional frameworks and practical implementation}

In the early colonial period, the Indian nobility was fitted into the colonial order by means of new institutions. The provinces (corregimientos/alcaldias mayores) and the pueblos de indios constituted the framework of colonial administration as a whole. The institutional framework did not only shape the colonial environment, but the administrative structure of the pueblos was also changed by the tribute reforms. In chapter 2, I have already paid attention to the introduction into the pueblos of a large number of institutions and officials with Spanish names and titles and often with a Spanish background. A quarter of a century after the conquest, local Indian society had caciques, principales, gobernadores, alcaldes, regidores, alguaciles, fiscales and mayordomos, who had to come to terms with institutions such as the cabildo, the comunidad and the cajas the comunidad. These offices and institutions had a clearly defined contents, which called for a profound adjustment of the organization of society and Herrschafi, but which did not necessarily have a disruptive effect on them. As such, they contrasted sharply with the tribute reforms.

The evaluation of the performances of the local administrators lay in the hands of the local Spanish authorities, the corregidor or alcalde mayor. Some of the officials were subjected to so-called residencias which took place at the end of their term of office, when their acts were checked and witnesses from the pueblos were heard. However, most officials were never subjected to a residencia and an annual evaluation was only compulsory for the mayordomos of the comunidades who were responsible for the administration of the cajas de comunidad. A residencia for the other officials had to be applied for. ${ }^{5}$ Whenever an evaluation was carried out, the perspectives of both the Indians and the Spanish authorities were taken into account, but during the term of office these usually remained separated, as most of the daily actions of the local administrators affected either the Indians in their pueblos or the Spanish authorities. As a result, an official's behaviour in daily life mattered most and this was, quite understandably, less adapted to the letter of the law than to the customs of the pueblo.

A general survey of the various positions within the pueblos can be derived from sixteenth-century ordinances of several cabildos." The ordinances were not always dictated by the Spanish authorities, as is clear from the introduction to the Ordenanzas de Tepeaca, in which it is stated that they were the result of a request by the town's cabildo. The cabildo consisted of a number of Indian caciques and other nobles, who proposed a number of regulations:? 
'So that the matters and questions which occur in relation with the exercise of justice and the administration of [the cabildo] were regulated, they had gathered various times in their cabildo and ayuntamiento. They had talked and tried to device an order which was convenient to the welfare of the republica (bien de república). [When] they had considered it well, they had made certain rules which they presented to me [viceroy Don Luis de Velasco] and they asked me -because what was contained in them was good and beneficial for the good governance of the pueblo- to decree to approve and confirm them'.

It is unknown whether there were specific models for the ordinances of the pueblos. In Tlaxcala and Tepeaca the rights and duties of the escribanos and alguaciles almost match exactly. Tlaxcala and Tepeaca were neighbouring pueblos and in this case, it is possible that the cabildo of Tepeaca adopted in its proposal the ordinances of the corregidor of Tlaxcala, which had been decreed earlier.'

The Spanish authorities introduced the administrative reforms as a coherent set of measures, with the ultimate objective to make the entire Indian tributary and administrative system uniform. At times, the Indians were able to use some of the administrative reforms for coping with the effects of the tribute reforms. Haskett remarks that although the administrative organization of the pueblos bad been derived from Spanish examples, many of the new offices came to have clearly Indian characteristics.' This was understandable, because although the authorities were quite specific in their instructions for the Indian administrators, they did not record more than their formal duties and authorities.

The number of appointed officials varied per pueblo and especially depended on the number of inhabitants. The Spaniards introduced a limited number of eligible offices. The elected offices were the most important of the pueblos: the gobernador, the alcaldes and the regidores. Together these chosen people constituted the cabildo, the meetings of which were exclusively accessible to them, some administrative assistants and the Spanish alcalde mayor. Other people were only admitted if they had a special license. Per pueblo de indios there was only one gobernador; the number of alcaldes varied from two to four. There were usually far more regidores elected, but fifteen is the largest number I have come across. In Tepeaca, the gobernador and alcaldes were elected by an election committee of electores, consisting of four tequitlatos from each of the eight parts (parcialidades) in which the pueblo had been divided. In 1550, in Tlaxcala, there were 220 electores from the various parts of the pueblo; according to a statement in the Actas de Cabildo, they were the assembled principales from Tlaxcala. It is not known how they were split up over the various cabeceras and sujetos. ${ }^{10}$

In all of New Spain, the most important administrators were elected, but the elective procedure had not been organized in a uniform way. Perhaps this was the result of the differences in prehispanic background and the size of the pueblos. However, most of the territorial subdivisions of the pueblo were usually 
represented in the cabildo. In cases in which a pueblo had more than one cabecera, these all had a representative in the cabildo and in other cases the various parcialidades or barrios were represented."

The appointments of the other officials took place without the intervention of electores. In Tepeaca, the regidores were elected by the actual cabildo, to prevent sitting officials from being re-elected. In Thaxcala, the appointment of regidores was carried out by the incumbent gobernador and the four 'tlahtogue' as they were still called by the Indians- of the pueblo.'2 The cabildo also appointed lower officials such as alguaciles (who were usually called by their Nabuatl name topiles), mayordomos and escribanos. Their number depended on local circumstances. By way of this formalization, lower and higher positions in the pueblos were organized into a coherent hierarchical system of rights and duties. In the new administrative order, these indigenous officials were all civil servants of the king. This meant they were no longer expected to demand tributes, which had always meant a recognition of their lordship to the Indians. The change was symbolised by the establishment (tasación) of the salaries they were to receive for the fulfilment of their offices. These officials were to be paid out of the tribute income of the pueblos.

The duties of the officials within the administration of the pueblos were described well. The gobernador was supposed to engage exclusively in matters of governance (gobernar y mandar; regir)." At first, it was decided in both Tepeaca and Tlaxcala that he would serve a two-year term. The reason for this was that if he was elected every year:"

'The year would have passed, before he could have become familiar with the matters of the pueblo and could not govern as he should, but if be was elected for two years, he would have the opportunity to know and understand the matters and [also] how to govern'.

Apparently, either a two-year term of office was not a very fortunate choice, or the ordinances were overruled by the Crown, because in the course of the sixteenth century, it was reduced to one year. In Tlaxcala, the cabildo protested vehemently, but the authorities did not relent.

The alcaldes were in charge of the second task of the cabildo, which consisted of the treatment of the lawsuits to the extent that they came under the jurisdiction of the pueblo. These were usually cases of no great importance. In Tepeaca, where the regulations were most clear, the alcaldes had to have audience sittings twice a day: for two hours in the morning after the High Mass (misa mayor) and for three hours in the afternoon after the Evening Mass."

From the sixteenth and seventeenth centuries not many cases have survived which were treated by the alcaldes. They will mostly have involved petty theft, drunkenness, small fights and similar offenses. Two somewhat more elaborately documented cases are about a girl who got pregnant. In 1565 in Tlaxcala, the girl 
was of a lower social station than the boy. Her father had thought it a desirable match for his daughter. However, the boy denied everything and said he had not got her pregnant. The girl was left disenchanted. In 1599 in Quechula, the daughter of a local regidor got pregnant. The regidor suspected Pedro del Castillo. He was infuriated by his daughter's loss of virtue and had thrown the young man into a storeroom in his house. The boy had been there for a while, but had kept on denying that he had been involved with the girl. His father asked the alcaldes to investigate the matter and the boy was acquitted. ${ }^{15}$

Other cases involved matters of rights to land and gifts from one principal to another. In cases of disputes about land, or of sizeable transactions, cases were soon taken to the Spanish court of the alcalde mayor, because, generally, one or more nobles were involved in such cases, as a result of which, alcaldes, being friends or relatives of the contesting parties, had an interest of some kind in the case and were therefore partial, so that they could not decide it. Besides the gobernador and the alcaldes, the regidores were the third group of officials who were members of the cabildos. Theirs was chiefly an executive task, but they did have a vote in the cabildo. Most of their tasks remain unspecified; it is clear however, that they had to see to it that the local market was functioning properly.

The cabildos had a whole range of officials below them, ranging from mayordomos, who were responsible for the daily administration of the cajas de comunidad, to alguaciles or topiles, who carried out all sorts of police tasks, and tequitlatos and macuiltecpanpisque. The latter were also called merinos or mandones in Spanish, indicating that they were leaders of groups within the pueblos. They took care of the collection of tribute and the distribution of labour duties. The alguaciles were led by a head-alguacil (alguacil mayor).

Besides these civil servants there was also a number of officials who fulfilled ecclesiastical duties. Apart from the administrators of the cofradias, this group comprised the mayordomo de iglesia or the fiscal, who was the person who bad the sacristy in custody. Furthermore, there were cantores who sang in the choir in masses, and alguaciles or topiles de iglesia, whose main task seems to bave consisted in assisting the friars and seeing to it that all Indians would attend Mass. This last responsibility rested on all indigenous officials, who, on top of this, were supposed to set a good example and to be present at all masses of some importance, unless they were seriously ill.

Such was the official division of the offices of the pueblos; it appears from the documentation that to a large degree, the ordinances were carried out in practice. Of course, most of the decrees were no problem to the Indians, as they did not conflict with Indian custom. Filling the positions with people, was the main problem.

In the sixteenth and seventeenth centuries, the pueblos usually comprised a large number of scattered settlements, divided among two or more 'parts' (parcialidades), and coinciding with the former domains of tlahtoque." In the colonjal 
era, all tlahtoque and recuhtin had become caciques, which implied that the various ranks of the higher indigenous nobility were now all included in the category of cacique. As in prehispanic days the domains of the tlahroque had contained several smaller domains of tecuhtin, this meant that the largest cacicargos, those of the size of a parcialidad, mostly contained smaller cacicargos, as well. These divisions soon became rather obscure, as a result of the congregations and tribute reforms of the middle of the sixteenth century, in combination with the introduction of Spanish institutions into the pueblos besides the Indian forms of organization according to the relations of Herrschaft. In the sixteenth and early seventeenth centuries, a sujeto could be identified by the fact that its inhabitants fell under the influence of one cacique -or even a lower noble, a principal-, or were associated with one sujeto church, rather than because they were actually physically concentrated in one village or hamlet. After all, sujetos were often very scattered settlements and prehispanic indigenous society had known no clear territorial demarcations of jurisdiction within an altepetl.

It is obvious that factions of Indian nobles (caciques and principales) under the leadership of one high-ranked cacique were attracted to the new institutions and offices. From the start, the Spaniards understood that the leadership in the pueblos had to be distributed among these factions. The Spanish authorities, who had formulated the regulations for the administration of the pueblos, were well aware of the need of an equilibrium among the forces within the pueblos. Otherwise, the pueblos would come to suffer from oppression, turmoil and disorder, which was a most undesirable matter, from their point of view. In this respect, the Spanish regulations were not much different from the prehispanic system of the distribution of power, because the forces from the various factions within the altepetl had been kept in balance as well as possible by each newly arrived power and the nobles had checked each other.

Above, I have already mentioned that the electoral colleges for the positions in the cabildo consisted of representatives from the various subdivisions of a pueblo. It had usually also been laid down that the members of the cabildo were to come from different parts of the pueblo. For example, Gibson argued that in sixteenthcentury Tlaxcala, the offices of the cabildo rotated among the four cabeceras, as had been prescribed. But in Tepeaca, the distribution of offices was also properly regulated. The gobernador was to come from the cabecera, but he should also be elected by the representatives of the sujetos. Two out of three alcaldes came from the cabecera of Tepeaca and the third had to be elected 'beginning with the pueblo of Acatzingo, [then] in turn from the other pueblos of the [...] province of Tepeaca'." Three of the regidores of the cabildo of Tepeaca came from Tepeaca itself, two from Acatzingo, two from the sujeto of Oztoticpac and another two from the remaining sujetos."

The principle was expressed most clearly in the ordenanzas that were compiled for the pueblo of Quechula. Apparently, the powers were not as well 
balanced here, as they were in neighbouring Tepeaca, and all officials came from one parcialidad: ${ }^{20}$

'From now on during the elections which are held every year in this pueblo, the alcaldes, regidores, mayordomos and other officials have to be elected from all parcialidades of this pueblo, in order to banish the dissentions and strife which develop when all officials are from one parcialidad. And when elections are held for [the office of] gobernador, he also has to come from each parcialidad in turn [...]. The gobernador and the alcaldes must not come from one [single] parcialidad; from where the gobernador comes, the alcaldes should not come and the same is true of the other officials who are chosen every year besides the gobernador and the alcaldes [...]'.

The problem was, that on the one hand, many pueblos consisted of a large number of subdivisions, which all bad their own leaders or mandones, but on the other hand, there was only a limited number of seats available in the cabildo. For example, in 1550 there were 220 caciques, principales and mandones in the pueblo of Tlaxcala." Obviously, they could not all get a seat in the cabildo. Consequently, it were mainly the higher nobility, the most important principales and the caciques, who would claim the offices in the cabildo. For the mandones on a lower lever only the lower offices remained, like alguacil or fiscal and they could, at most, reach the position of regidor or mayordomo. Still, competition was important. After all, the pueblo notables derived prestige from an office within the administrative structure of a pueblo; moreover, it also gave them some political influence and even some extra income.

The positions within a pueblo rotated annually, at least officially, and it was prohibited for officials to have themselves re-elected to the same office within a few years. Therefore, a cacique could not consolidate his position by continuously occupying the office of alcalde or gobernador. If a cacicazgo had come to dependent on a cacique occupying these key positions in the administrative hierarchy of the pueblo, then, in case of a complaint from an adversary in the pueblo before the alcalde mayor or Audiencia on the basis of the official regulations on a limited term of office, a cacique would run the risk of losing not only the key position in the administrative hierarchy, but an important part of his entire cacicazgo, as well. Thus, the caciques had to find other ways of securing their power through the new administration.

Moreover, both the Indians and the Spanish authorities very well perceived the danger of powerful caciques, who would come to dominate the cabildos if they occupied the offices of gobernador or alcalde. On account of this danger, in the 1552 Ordenanzas of Tepeaca, the two supreme caciques and 'powerful men' (hombres poderozos) of the pueblo, Don Hernando de la Cruz, and Don Luis de Guzmán were even denied access to the posts of gobernador or alcalde, to prevent them from abusing their power and thus causing unrest. The ordenanzas stipulated that they could partake in the assemblies of the cabildo, 'so that they 
do not complain that they have no part in public life (república)'." In Tlaxcala, the supreme caciques were not supposed to be elected gobernador either, although they could join the gobernador in appointing lower officials. ${ }^{\text {w }}$

We may doubt whether the regulations against the appointment of such 'powerful men' were very effective. At any rate, according to Gibson, Don Leonardo Xicotencatl -one of the four tlahtoque of Tlaxcala- held the office of gobernador in 1590 . In the pueblo of Cuautinchan, it was custom that the position of gobernador was taken up by one of the caciques of the pueblo. Because all levels of the pueblos were represented in their administration, this soon came to play an important role in pueblo life. In most pueblos de indios the formal rules usually seem to have been followed.

As I have remarked above, for the Spanish authorities, the introduction of a new administrative system meant that all pueblo administrations were made uniform and that pueblo officials could be held responsible for certain established duties and positions. Within the pueblos, however, the hierarchic system of officials was not just part of the official regulations of the new administrative system, but also a way to have local men of power occupy public positions of a certain prestige. And the offices did have status. In the ordenanzas of Tepeaca, it was decreed that when the alcaldes and alguaciles encountered the gobernador in the streets of the pueblo, they had to 'accompany him to where he was going', because the gobernador was a dignitary (justicia) of the king and as such should be honoured and respected (honrado y acatado). When the corregidor came to the pueblo, all indigenous officials, including the gobernador, had to honour him in the same way. After all, he was a civil servant of higher rank..$^{24}$

Seen in this light, it is obvious that for the factions of the caciques of a pueblo it was of utmost importance to take part in the fulfilment of official positions and in the cabildo. Therefore, cabildos usually consisted of members of the caciquefactions of a pueblo only, which all were under the influence of one of the caciques. In fact, much of the power embodied in the cabildos was directed by the caciques. Yet, it would be a mistake to assume that the offices in the pueblo administration were actually hollow, because all local power lay with the caciques, which is to say, outside of the public sphere of the cabildos; the cabildos did have 'real' power. This is illustrated by the petition of some of the principales of the pueblo of Cuautinchan, who, in 1590, requested the Audiencia to appoint a gobernador from outside the pueblo: ${ }^{2}$

'As in the said pueblo [of Cuautinchan] there are many unquiet and rebellious Indians, who are divided in parties and parcialidades, and some of them are supported by the friars and others seek other supporters for their pretensions, [but] always that party dominates, which is able to acquire the office of gobernador [...]. Then the adverse party is beaten and is persecuted, and all this results in great harm to the macehuales and the pueblo [as a whole], and royal tribute income is significantly decreasing [as well]'. 
The distribution of the main offices among the principales within a pueblo sometimes implied that a specific office got more weight than it officially had. For example, in 1591, the mandón of Santo Tomás Xochtlan in the province of Tlaxcala held the office of fiscal, which, in principle, was an ecclesiastical office. However, in this capacity, he represented the interests of Santo Tomás before the Spanish authorities. ${ }^{*}$ In both Huamantla (Tlaxcala) and Santa Maria Nativitas (Tepeaca), the most important mandon held the rank of alguacil. Notwithstanding the importance of the offices in the pueblos and the public power they implied, their importance should not be exaggerated. Powerful nobles needed to hold a high public position to exert their power; so many people were dependent on them, that they could control an important part of social life through the informal relations of the pueblo."

\section{Rivalling pueblos and caciques}

As we have seen the introduction of the cabildos did not mean the end of the power of the caciques at all, as Gibson and many others have suggested, though in the course of the sixteenth century, the caciques became less prominent actors in pueblo politics, but still influenced it by faction politics. This did not mean that the power of the caciques was not affected by the changes of colonial society. The late sixteenth-century pueblos de indios had a far simpler structure than prehispanic society. This was partly a result of the administrative changes, but the simplification was not just formal. Above, I have repeatedly remarked that the combination of tribute reform and demographic decline put an enormous pressure on the pueblos. The tribute reforms, the epidemics and the emigration of macehuales resulted in a decrease in the number of Indians who paid tribute to the indigenous nobles. Because of this, the nobles' position of Herrschaft came under such pressure, that we can speak of a society in crisis. Not just the exercise of power was disputed, but also the attitude of pueblos towards one other was not clear. Naturally, not all of these conflicts were new; in many cases, old enmities affected the relations and what to historians may appear to be new conflicts actually were old ones in disguise. Therefore, it is often hard to tell whether in these cases, old disputes were now being fought, or whether the conflicts just involved questions which had arisen in colonial times. We may also wonder whether this made any difference to the Indians; they used any means, both to get what they regarded as their right and to incriminate their adversaries.

In chapter 2, I have already treated some conflicts between pueblos about borders, which were important just after the foundation of the pueblos. Such conflicts were by no means scarce. According to the Libro de Asientos of the early 1550s, merely in the months from March up to and including May of 1551, twenty-seven cases of conflicts between caciques of several pueblos of New Spain came up before the new viceroy Don Luis de Velasco in the Audiencia of 
Mexico. Not included here, are those conflicts in which Spaniards were involved, or which were decided by regional officials without the interference of the Audiencia. The Spaniards tried to adopt and adapt the local traditions as much as possible. In many cases, for example, in lawsuits, they asked caciques, whether they had inherited their rights to sentoria $y$ cacicazgo (lordship and cacique-ship) from their ancestors and whether these ancestors had been 'lawfully married according to the rites and customs of their paganism [i.e. before the Spaniards came]'."

A few examples may illustrate the importance of local tradition in the settlement of disputes. In a lawsuit of 1553 in Cuautinchan, the witnesses of the various parties raked up the entire history of the pueblo to indicate whether a party did or did not have a right to a piece of land and whether the members of a certain calpulli were obliged to pay tribute to a cacique. Tlaxcala and Cholula had been enemies of old and were keen on anything that could be explained as an intrusion on their authority. In 1549, some Tlaxcaltecs who lived on land that the Cholultecs considered theirs, were obliged to pay tribute to Cholula. Apparently, Tlaxcala could not prevent this, but took counter measures by prohibiting Cholultecs from cutting wood in Tlaxcaltec areas. The province of Cholula did not have any woods and depended entirely on Tlaxcala for its supply of wood. As a second measure, there was a close check on whether Cholultecs who were staying in Tlaxcala -and with the growth of migrations there numbers were increasing- had paid tribute in Cholula. If not, they were supposed to pay tribute in Tlarcala. The segulations against the cutting of wood by Cholultecs were not sufficient, because in 1560, the cabildo of Tlaxcala complained that there were many Cholultecs who cut wood in the southern parts of Tlaxcala. It was customary to burn wood in order to obtain lime and for charcoal. The lime was cooked with maize, which was necessary to process the maize kernels into the dough used for tortillas, the daily bread of the Indians. The Cholultecs sold the lime to the macehuales of Tlaxcala, an injustice in the eyes of the Tlaxcaltec cabildo, because it held the view that their macehuales had a right to use the wood themselves. After all, they paid tribute for this right. The prohibition of the Tlaxcaltec cabildo was adopted by the Spanish authorities."

The Tlaxcaltec wood was not only in demand among the Cholultecs, but also among Spaniards like Juan Ochoa, who needed it for his cart company. He was exempted from the general prohibition for outsiders, and could cut wood in Tlaxcala, but also in Totomehuacan and Tepeaca. He was allowed to use the wood for his own enterprise only, which the Audiencia considered to be of great benefit to the república, but had to consult the Indian authorities. Maintaining the prohibition was not easy and a matter of ongoing concern for the Indian administration of Tlaxcala. Apart from the Indians of Cholula, Spaniards also continued to cut wood in Tlaxcala. In 1603, the cabildo complained before the Audiencia that there were still Spaniards who either cut wood illegally, or bought it from Indians, in order to resell it on the market. 
The sixteenth-century Tlaxcaltec author Muñoz Camargo describes another interesting conflict between Tlaxcala and Tepeaca. According to his account, the foundation of the pueblo of Nopaluca led to an intricate confusion of claims. Nopaluca was founded in the plains of Ozumba, east of the Malinche, by Otomispeaking Indians from the estancias of Quauhtelulco and Pachocan, which were subordinated to Tepeaca. However, the Otomis had not taken the initiative themselves. The area of the plains of Ozumba was semi-arid and had been uninhabited in prehispanic times. Alonso de Andrada, an important Spaniard in New Spain in the first period after the conquest, had donated an estancia de ganado mayor in the plains to his slave, or servant, a black named Juan. This Juan had made friends with the Indian Don Domingo, a tequitlato from Xilotepec, an area north of the city of Mexico which was predominantly inhabited by Otomf-speaking Indians. Together with some of its people, Don Domingo moved to the plains of Ozumba. He made friends with the Indians of the Tepeacan estancias of Quauhtelulco and Pachocan, mentioned above. With 'friendship and good treatment', he persuaded them to come from the hills to the plains of Ozumba. This led to the foundation of Ozumba. According to Muñoz Camargo, the town had as many as one thousand inhabitants who all 'regarded the black Juan as their lord and master and obeyed him as such [...] until he died [in 1533]'.

After that time, Gonzalo Carrero from Puebla held Nopaluca in encomienda, until it was taken from him by Don Sebastián Ramírez, who was visitador general of New Spain in the middle of the 1530s. At that time, it had to be decided whether Nopaluca fell under the jurisdiction of the pueblos of Tepeaca or of Tlaxcala. Both pueblos claimed the right to tribute from the Indians of Nopaluca and went to the Audiencia in Mexico 'to claim this pueblo and to say that it belonged to its territory and to its sujetos'. Tepeaca tried to prove its claims by alleging that Tepeacan macehuales (vasallos in Muñoz Camargo's terminology), people from Tepeacan territories, were involved. On the other hand, Tlaxcala alleged that they had settled on areas which lay under the influence of Tlaxcala. Finally, Nopaluca said that it was not subordinate to either one of the pueblos. After all, these Indians argued, its inhabitants partly came from Xilotepec and they had never been subordinate to either Tlaxcala or to Tepeaca. On the contrary, all Nopaluqueños had settled on uninhabited territory, without ever having recognized the caciques of Tepeaca as their lords. Therefore, they argued, they had a right to autonomy (jurisdicción de por st).

Viceroy Antonio de Mendoza was thus confronted with a multiplicity of mutually exclusive claims, in which Tlaxcala started from the sphere of influence over territories, whereas Tepeaca based itself on personal dependency. Nopaluca referred to the Spanish right to populate uninhabited land and said it had never felt subordinate to either one of the parties. As a result, the viceroy had to pass a judgment of Solomon. He was well aware that if he wanted to keep peace between Tepeaca and Tlaxcala, Nopaluca could not be assigned to either one of 
them. Therefore, he first gave Nopaluca in encomienda to the Spaniard Gonzalo Carrasco and later to Diego Muñoz Camargo (the father of the author), an important man from Mexico City who, at the time, did not have an encomienda. Under viceroy Don Luis de Velasco, however, Nopaluca was taken from the encomienda-system and made liable to pay tribute to the Crown. Tepeaca and Tlaxcala accepted the decision."

Besides a conflict between two old enemies about the authority of territory, macehuales and tribute, this was also a case which concerned a sujeto. Sujetos usually had their own leaders, who, at times, were caciques themselves, but were mainly ambitious principales or mandones. Because the identity of a sujero used to be defined by a lord or a church common to the inhabitants, it was an obvious crystallization point of frustrated ambition of lesser nobles, or smouldering dissatisfaction among part of the macehuales. Some examples can illustrate this.

The precise prehispanic situation is not clear, but at least from the time of the conquest, Acatzingo had been subordinated to Tepeaca, which had hurt the pride of the Acatzinca. Moreover, the caciques who had influence over Acatzingo lived in Tepeaca. From the 1560 s, there were many lawsuits between the cabecera and its sujeto. It is not easy to interpret the causes of these conflicts. The problem started in 1568, when Acatzingo complained before the Audiencia about the election of the officials of the pueblo, the oficiales de la república. Acatzingo maintained that principales were always elected and that macehuales never were, and that the principales all lived in Tepeaca. The Indians of Acatzingo were involved in a lawsuit with the principales of Tepeaca about the tributes. Therefore, Acatzingo alleged, the principales had conceived a hatred for the tributarios of Acatzingo, and because the nobles 'had authority in the pueblo', they vexed and harassed the Indians of Acatzingo, none of whom was able to assume the task of protection or defence. In the light of this complaint, the Audiencia decided that the macehuales would be allowed to be elected to half of the offices. In practice, this meant that one out of three alcaldes in Tepeaca was to be a macehual from Acatzingo. In 1571, it appeared that the cabildo would not have this, and chose alcaldes from 'those who are called principales [...] and had not approved of electing a macehual or any other official as alcalde'. According to the cabildo this conflicted with an old custom and, consequently, it refused to comply with the decree of the Audiencia. However, the Audiencia held on to its point of view and urged the alcalde mayor of Tepeaca to carry out the order. ${ }^{2}$

The case was continued when Acatzingo pretended before the court of the king to be a cabecera in its own right (cabecera de por $s$ ) and requested to be granted the title of 'ciudad' -at the time still granted to Indian comunidades, which later could only be pueblos de indios-, which it obtained on the basis of a false account (siniestra relacion). It thus imitated Tepeaca, which had obtained the title in 1559. Tepeaca took action against the pretensions of Acatzingo and, in 1573, managed to convince the king that Acatzingo was a sujeto." It got a decree from the king, which obliged Acatzingo to cooperate in an interrogation by Tepeaca. 
This happened in 1575, under the leadership of the alcalde mayor. Tepeaca had formulated denigrating questions on purpose, in order to make Acatzingo sense its inferiority. The interrogated people were selected from among the most prominent men of Acatzingo. Although the inquiry (interrogatorio) has not survived, it appears that, among other questions, they had to answer the question whether Acatzingo had always been a sujeto of Tepeaca and its gobernadores, caciques and justicia and had supplied services and tributes to it 'like sujetos are obliged $10^{\circ}$. Furthermore, it was asked whether or not Acatzingo had always fought side by side with Tepeaca in the wars of prehispanic times and if it did not consist of just two small barrios, with a very small number of people. The representatives of Acatzingo could not deny all this, but each one of them insisted that although Acatzingo had always been subject to Tepeaca, it did have principales of its own, who actually were served by macehuales and that Acatzingo had had its own leaders during wars."

If we consider the two cases side by side, the problem does not quite seem to have been the fact that the macehuales were oppressed, but rather that the principales of Acatzingo wanted to liberate their pueblo from its submission to Tepeaca, while Tepeaca wanted to degrade the Acatzinca principales to the status of macehual. In order to reach their objectives, both groups tried to manipulate the Spanish courts, by appealing to principles that were known to the judges. The conflict did not end with the two cases, mentioned above. As I have shown, in 1568-1571, Acatzingo almost succeeded in freeing itself from the influence of Tepeaca, by requesting the right to elect its own administrators, while Tepeaca managed to prevent this by raising a well-based protest before the viceroy. Of course, the representatives of Acatzingo indignantly rejected the attempt to degrade all Acatzinca to macehuales on the basis of their subjection. For the time being, this submission was continued, but Acatzingo's aspiration to become independent had not yet broken.

In the seventeenth century, this aspiration surged again. In 1613, the traders of Acatzingo made an agreement with the cabildo of Tepeaca, that they did not have to take part in personal services in exchange for extra payment. The Audiencia had approved of this agreement, but apparently it was not sufficiently enforced, because in 1620, Acatzingo applied for a confirmation." The conflict became more acute when, in 1627, Acatzingo refused to take part in the cabildo elections in Tepeaca and organized its own. When, in 1629, Acatzingo did not comply with the summons for the elections for the third year in succession, Tepeaca called upon the alcalde mayor. Acatzingo resisted in every possible way. First, it brought forward that in 1625, viceroy Cerralvo had exempted the place from the obligation to go to the election, and that for the past three years, Acatzingo had organized its own elections. Tepeaca argued against this that the elections had always been organized in Tepeaca and that Acatzingo had never submitted an exemption. Apparently, these were convincing arguments, as the rebellious officials of Acatzingo were put into jail; a normal means of exerting pressure. 
After that, Acatzingo argued that it was a nuisance to have to travel two miles (leguas) to Tepeaca for the elections every year. Moreover, it expressed the view that it had a right to autonomy, as it had had a Franciscan monastery of its own for eighty years, suggesting that it was practically a cabecera. After some more sessions, in the course of which no new facts came to light, although Acatzingo did produce the exemption of 1625 , the alcalde mayor decided that this was not sufficient to invalidate the old claims of Tepeaca, and restored Acatzingo's obligation to come to Tepeaca for the elections.*

In the course of the seventeenth century, Acatzingo nevertheless managed to separate itself from Tepeaca, like many other sujetos. This was a result of the general tendency of a weakening of the bonds between cabeceras and sujetos, and the fading importance attached to these bonds. In the period prior to its separation, Acatzingo was not just subordinated itself, but had subordinate settlements of its own, with which it did not always maintain very good relations either. For example, in 1640, the Indians of the barrio of San Salvador complained that they had to pay tribute to Acatzingo according to the tribute assessment of fifty years earlier, when there had been forty full tributarios. Now, no more than four were left, who were 'very sad', because they did not know where to get the tribute of the deceased. Moreover, Acatzingo demanded too many services from them. The Audiencia ordered a reassessment to be carried out, and charged the alcalde mayor to protect the four remaining tribute families of the barrio."

The dispute between Acatzingo and Tepeaca about the matter of submission, provides an example of the time span such conflicts could enclose. It was no exception, as many of the problems between cabeceras and sujetos had a longstanding existence, in which they would be smouldering for some time, and then suddenly reappear under another pretext or in reaction to new laws. Another example of such a conflict is the cabecera of Tecali, which came into conflict with its sujeto Toxtepec. In Toxtepec, a Popoluca-speaking minority lived in a pueblo, which was dominated by people who spoke Nahuatl. The ethnic difference may have been a source of identification for the inhabitants of the sujeto, or perhaps the Popoluca-speakers were simply oppressed by the Nahuatl population. Anyhow, in 1545, the unusual situation occurred that Toxtepec and some other related barrios and estancias petitioned for a merced for land to viceroy Don Antonio de Mendoza, because they said they feared that 'certain persons wanted to take the land from them [...], which would greatly harm them'.:

This application was unusual, because it radically went against the Indian custom that only caciques held influence over land. It is also remarkable that the sujetos used specific Spanish legal terminology. They applied for a merced for what they called their comunidad, measuring 2.5-3 caballerias in ejidos for cultivation and for grazing their livestock. They thus present one of the earliest examples of Indians outside the cacique-group who used the possibilities open to 
them under Spanish Law. As was to be expected, they soon came into conflict with the caciques from the cabecera of Santiago Tecali, who disputed their possession of land. At first, the caciques could make few effective objections to the claims of the sujetos, which were based on usufruct. Spanish Law allowed many possibilities for ownership of the comunidad, and attached the right of decision to the right of usufnuct of the comunidad. On the other hand, with the Indians the right of decision had always been a prerogative of the nobility."

The ecological situation of Tecali and its sujetos can clarify the origins of the conflict. Tecali itself was -and is- situated on a barren ridge, mainly consisting of eroded, highly infertile boulder clay, called tepetate. For agriculture and supplies the Indians, including the nobles, of the cabecera depended on the sujetos, which were situated in more fertile areas along the river Atoyac. This was no problem as long as the caciques could exercise claims to the land in the sujetos. When in 1599, the juez congregador made a survey of the entire pueblo of Tecali because of his plans for congregation, it was established that the macehuales of the cabecera cultivated land at a considerable distance from the cabecera, on the banks of the riveerAtoyac. Small wonder, the inhabitants of the sujetos saw this as an infringement on their rights to land, which they had held since 'time immemorial'. It is equally plain that the mercedes made caciques of Tecali fear for their positions. In 1547,1560, 1562 and 1567, they invaded the lands of the comunidad of Toxtepec. The most severe were the encroachments of 1562, when the caciques set their livestock free on the milpas of the sujeto, which were severely damaged as a result of this.

Notwithstanding the encroachments, at first, the situation was to the advantage of the sujetos, and, time and again, they were protected by the Audiencia and the viceroy. This changed when in 1587, Don Jusepe de Celi and in 1591, Don Diego Melendes Flores, both Spanish civil servants and jueces comisarios of the Audiencia, conducted investigations in Tecali. They only paid attention to the landownership of the caciques and principales. Especially the cacique Don Francisco Flores had many claims to land and he presented many witnesses to prove that he and his ancestors had exerted these rights of old. After all, he and his family had long exerted Herrschaft (sentorio) over the sujetos.

As little as the caciques and principales of Tecali had been able to object effectively to the mercedes of the sujetos, the sujetos were able to put forward few convincing objections to the claims of Don Francisco Flores. Still, in 1592, they appeared in the Audiencia before Don Luis de Velasco, whom they told that they had cultivated land in their sujetos since time immemorial and that they had merely disposed of what they designated as the lands of the comunidad. The 'surrounding area was so dry and infertile'," that agriculture was impossible. Yet, they said, a few years earlier, Don Jusepe de Celi had come, who had wanted to take the land from them, only to resell it to the cacique of Tecali (which was not true). They said that Don Jusepe had used as an excuse the fact that not every single one of the inhabitants of Toxtepec had individual titles to 
land, but this 'had never been custom' among them. The inhabitants of Toxtepec pathetically alleged that they knew 'nothing of lawsuits' and that the land had been taken from them of which they 'were the real, miserable and defenceless inheritors'. Even though they had 'no one to protect them', they had come to dispute the possession the caciques had taken of the land."

In the eighteenth century, the long-standing conflict ended in a real revolt of the inhabitants of Toxtepec against the caciques of Tecali, in particular against Don Francisco Domingo López de Castillo. In fits and starts, the dispute continued well into the nineteenth century, but these late colonial developments fall outside the scope of this study. In Tecali, the caciques had a dispute with the macehuales of a sujeto subject to them. As I have remarked, the sujetos of Tecali were exceptional in their application for mercedes. In the sixteenth century, it was more common that several families of caciques were opposed to each other. Notwithstanding these unusual aspects, even in the case of Toxtepec it were not the macehuales themselves, but rather the principales who represented the interests of the sujetos involved."

The usual sixteenth-century conflicts between caciques, involved the rights to land, tribute and macehuales, and the nobles hardly ever shrunk from using any means with which they could appropriate the prerogatives of Herrschaft. The first example of such a conflict is from Tecamachalco, where Don Juan de Mendoza and his son Don Francisco de Mendoza had to litigate more than thirty years about their cacicazgo.

The case started in the 1550s. At the time, Don Juan de Mendoza was already an old man. He was the son of Ilquicaxoxoque Acuechetzin (whose name was spelled differently by every Spanish clerk), who in his turn came from an old noble family which had been prominent in Tecamachalco from time immemorial. Initially, Don Juan had been married with Doña Marla Tozpetlatzin, who had died. According to several witnesses, he had grown demented as he got older and remarried a Spanish wife, whose name is not mentioned. The witnesses all agreed that Don Francisco had been born from the first marriage. However, the principales of the cabildo of Tecamachalco took offence at Don Juan's marriage to a Spanish woman and they removed him from his cacicazgo, and put it in the name of the comunidad of Tecamachalco. The witnesses did not agree on the reason of Don Juan's dismissal. All Spaniards who were interrogated declared that the marriage to the Spanish woman was the reason for the 'anger' of the principales of the cabildo. However, some elderly Indian witnesses declared that the principales rebelled against their cacique and that this was the real reason that he lost his land and macehuales. In my opinion, this last version is more likely to be correct, not just because the Indian witnesses was more intimately acquainted of the situation in Tecamachalco, but also because the actions of the principales more or less coincided with the radical congregation and concomitant tribute reforms which took place in Tecamachalco and Quechula the 1550s, and involved 
many of Tecamachalco's sujetos. Be that as it may, Don Juan took actions against what he perceived as unjust behaviour of the principales and an encroachment on his patrimony. He went to the city of Mexico, where he died pending the lawsuit. After his death, the suit was decided in his favour, a verdict which was afterwards even confirmed by the Council of the Indies in Spain."

Don Juan's son Don Francisco was at the time still too young to succeed his father as a cacique. Both before and after he had come of age, however, the principales refused to return his cacicazgo. Consequently, Don Francisco ended up in bitter poverty, which prevented him from engaging in a lawsuit. He did live in Tecamachalco, where he was one of the subordinate members of the cabildo. One of the witnesses testified that the other principales always chose a gobernador among themselves, to prevent Don Francisco from getting enough power to demand his rights." No one could make any reasonable objections to Don Francisco's claims, as he was bom from an Indian father and mother who both came from Tecamachalco. In the meantime, according to all witnesses, the principales showed off with the cacicazgo, and they and their families benefited from the tribute income. They even had distributed some of the lands of the cacicazgo among themselves. With the help of his brother-in-law, the Spaniard Francisco López, in 1580, Don Francisco at last managed to bring charges against the principales before the Audiencia. The Audiencia declared Don Francisco to be in his right and ordered the cabildo of Tecamachalco to return his cacicazgo. However, this did not happen until 1591, after renewed interventions by the viceroy. Then the transfer was final, because the Mendoza family held the cacicazgo until at least well into the seventeenth century."

The second example of a conflict between cacique families comes from Cuautinchan, which has been mentioned several times above. According to the Cuautinchan tradition, the tlahtoani of the entire area belonging to the colonial province of Tepeaca, had resided in Cuautinchan. It is difficult to judge how much truth this tradition contained, but, at any rate, the alleged empire of this tlahtoani had fallen apart long before the Spaniards had arrived and during the Invasion, the centre of power had been located in Tepeaca."

In the first decades after the conquest in Cuautinchan there had been several cacique-factions that had claims to the leadership of the pueblo. There were also calpultin which were not at all satisfied with the fact that their leaders had been degraded to macehuales and which hoped that their former rights of Herrschaft would be restored under Spanish rule. They demanded this in a lawsuit they waged before the Cholultec Indian judge Don Simón de Buenaventura in 1553. Controversies concentrated on parts of the cacicazgo of Don Diego de Rojas, who, in due course, was succeeded by his son Don Tomás. It appears that as little as his predecessor Don Juan de Osorio, an Indian judge from Huejotzingo, Don Simón could solve the problems to the satisfaction of all parties concerned, because in 1560, a conflict flared up about land in the cabecera of Amozoc, which was subordinated to Cuautinchan. Especially the estancia of Chachapa- 
tzingo was a source of dispute. In prehispanic times, all land in Amozoc had been no-man's-land (tierra de guerra) between Cuautinchan and Tlaxcala, but at the time of the congregations, between 1555 and 1560 , macehuales had settled on the land, who now cultivated it. Don Diego de Rojas asserted that they had done so without his permission and, together with some principales who were subject to him, he harassed the macehuales in all possible ways. Of course, they complained about this before the Audiencia and the viceroy, on whose authority they had settled on the land.

The Spanish authorities were embarrassed. After all, in carrying out the congregation and conducting the accompanying distribution of land, the Cholultec judge had acted on their authority. Don Simón returned to try and solve the problems, but he did not succeed in bringing the parties together. There were more people who tried to find a solution. In 1564, the macehuales protested against the solution reached by Fray Diego de Estremera, the Franciscan guardián of Cuautinchan. According to them, the friar had made an agreement with Don Diego de Rojas, which would benefit Don Diego only. They said Don Diego tried to drive them away from the land and to replace them with terrazgueros who were trustees of his. This conflict about land in Amozoc was not solved until the various parties involved reached an agreement in 1616, and distributed the land among themselves."

the meantime, the pueblo of Cuautinchan was deeply tom apart by disputes about land and about the old rights of Herrschaft. In the late sixteenth century, there were two contesting cacique-factions, one under the leadership of Don Tomás de Rojas, Don Pedro de Luna and Don Joseph Sánchez and the other one under the leadership of Don Pedro de Torres and Don Francisco de Moscosso. These two factions conceived a deep hatred of each other and used any pretence to harass one another, and the faction that managed to obtain the office of gobernador in the elections for the cabildo, could tip the scales in its own favour for as long as the term of office lasted.

The authorities did not know very well how to handle the situation in Cuautinchan and tried to reach several solutions. The Franciscans had divided the pueblo into two parts, most likely to prevent the conflicts from ending up in actual armed fights. They were generally in favour of the Rojas faction, appointed one Zacarfas de San Juan as gobernador. Zacarías was a macehual, whom they thought to be humble (manso). But when Zacarlas had been gobernador and alcalde a few times, the principales came to complain before the Spanish authorities that the office had gone to his head. He was 'insolent to a degree that it was unbearable. He requested that in all estancias and sujetos visited by him, he would be received with trumpets and be given abundant food and drink'. He made a habit of drinking wine till he was loaded and would then start ill-treating the common Indians." It is hard to determine whether the grievances were real, or merely slanders of the principales, who thought it was a disgrace when macehuales were appointed to such high offices within the pueblo 
'because to them as principales belonged the use of such offices'," and not to what the viceroy once described as the 'estate of the macehuales' (estado de los macehuales) -in contrast to 'the estase of the principales' (estado de los principales)." Within the disturbed relations of Cuautinchan, the best solution was to find a gobernador from outside the pueblo. This would calm down the parties and provide some rest to the tormented pueblo. This solution was put into practice for some years, especially in 1590-1591, when the crisis reached its apogee."

As some people of the pueblo had already observed, the conflict situation in Cuautinchan made the gobernadores make unbridled abuse of their power once they had obtained their office. A party in power oppressed its opponents and the macehuales of the pueblo in general. This resulted in a wide variety of problems. The caciques of one parcialidad refused to put macehuales at the disposal of the repartimiento de trabajo when the other party was in power, or hid macehuales in order to bring the administrators into trouble with the Spanish authorities. The other faction, in its tum, imposed far too heavy burdens of tribute or service and withheld tribute money which was destined for the king or the encomendero. Principales who held an office refused to hand over the keys of the caja de comunidad when there was a change of oficiales de republica at the end of their term of office, and they refused to pay the salary of the gobernador who was from outside the pueblo." There were also gobernadores who took land from the inhabitants of Cuautinchan." The cabildo officials of the enemy parcialidad requested the income from the meson (inn) in Amozoc for themselves, even though the inhabitants had built it 'out of their own pockets'. "Even when in 1580 the cabildo petitioned to buy lambs from surrounding haciendas for the invalids of the pueblo, this tumed out to be far less innocent and charitable than it seemed to be. Ten years after the petition, in 1590 , the macehuales complained before the Audiencia that the members of the cabildo regarded it as their acquired right, as a 'privilege of their office', to sell meat on the market. To this effect, they bought 'sheep on the nearby haciendas, who were ill because they had eaten harmful plants or something similar to that', thus inflicting barm upon the macehuales who bought the meat. These practices were of course forbidden by the Audiencia."

As has been said before, the problems reached an all-time low in 1590-1591, when a genuine flood of mutual denunciations was made before the Audiencia. The temporary banishment of some people who were seen as the instigators of trouble (Don Tomís de Rojas, Zacarías Velásquez and Zacarias de San Juan) in 1590, and again of Don Tomás de Rojas in 1591, brought some relief of the turmoil, but for a long time, the situation in Cuautinchan remained tumultuous and everyone had to struggle to get any right at all. For example, in order to get service of two Indians in 1595 -a very normal privilege for a cacique- Don Tomás de Rojas had to prove before the alcalde mayor that he was actually a cacique. All in all, it is hardly surprising that the congregations of the early 
seventeenth century in Cuautinchan degenerated into intrigues and into abuse of the situation. The problems seem to have abated only in the second decade of the seventeenth century, when the land in Chachapatzingo, which had been disputed for such a long time, was finally distributed among the contesting parties."

Such serious conflicts as the one in Cuautinchan were scarce and dreaded by the colonial officials, who tried to solve such feuds in any possible way. Within the valley of Puebla, Cuautinchan was the only pueblo de indios where things got out of hand to such a degree. In the case of Cuautinchan, the problems started off with a conflict about land, but elsewhere the income which the caciques and principales received from their macehuales was an important reason for disputes. An example of such a case is Topoyango in the province of Tlaxcala. Although Tlaxcala had a strongly centralized administration, which seemed to have an exceptional control on tributes, even there in the 1580 s, the principales of Topoyango demanded the right to levy their own tributes and tried to wriggle out of the influence of the cacique of the parcialidad of Ocotelulco. These efforts failed, but the principales did not give up, and made another attempt in the seventeenth century."

\section{Damaged Herrschaft}

Apart from conflicts between pueblos and caciques and their factions, there were also frequent and major crises in the relations between the indigenous nobles and the macehuales. In contrast to the conflicts between the nobles, which were often based on local circumstances, these were general problems which were not confined to the valley of Puebla, but occurred throughout the Central Highlands and even throughout New Spain. The reason for the problems were the tribute reforms, which undermined the position of the nobles and implied trouble for all traditionally privileged groups in the republica de indios. The principales and the caciques soon became conscious of the erosion of the old standards and values and with it, of the loss of status. As early as the 1560s, the cabildo of Tlaxcala complained about the macehuales who had made a fortune with the cultivation and sale of cochineal. At a 1553 meeting of the cabildo, the Tlaxcaltec officials complained that since no one would cultivate anything else but cochineal, all food products had become scarce and expensive. In addition, those who cultivated cochineal were lazy and bought food, mantles and cacao in abundance from the money they earned with the dye. Furthermore, they did not observe Sundays, but traded goods and got drunk on pulque, or even on expensive wine from Castile. They squandered what they had acquired with God's grace. The members of the cabildo accused the cultivators of cochineal of not appreciating what had been given to them, but to be drinking chocolate which was too stiff, with lots of cacao:" 
"When they find the chocolate just a little too watery, then it is not to their liking and they do not want to drink it. Some pour it on the ground whereby whoever has given his very good cacao to someone is affronted, but they imagine themselves very grand because of it".

Those among them who had been a subject before:

"No longer respected whoever was his lord and master, because [they are] seen to have gold and cacao. That makes them proud and swells them up, whereby it is fully evident that they esteem themselves only through wealth".

According to the cabildo their arrogant behaviour was in marked contrast to earlier days, when "not everyone cultivated cochineal, but maize, chilies and beans instead". The cabildo officials held the view that this situation ought to be restored: ${ }^{61}$

"Because if our Lord God should wish that famine come, and if there are in people's possessions more money, cacao and cloth, will those things be eaten? Will there be salvation through them? It cannot be. Money, cacao and cloth do not fill one. But if people have much food, through it they will save themselves, since no one will starve; no one will die being wealthy".

And therefore, in conference with the Spanish authorities, the cabildo decreed that the maximum number of cochineal plants per household had to be reduced to ten and that women could no longer buy or sell cochineal on the market. ${ }^{2}$

At this same time, the cabildo expressed its concern about the crumbling away of the landed property of the teccalli, the grand nobility of the province. It worried them that many nobles had sold their lands and now started to look more like macehuales, rather than nobles. If things continued this way, the cabildo officials feared, the teccalli would be ruined within the next decade and "perhaps those who are in the lordly houses will become ordinary commoners, and the commoners who are buying the fields will be noblemen". To prevent this from happening, the sale of land in the domains of the teccalli was restricted, but these measures had little effect. Later on in the sixteenth century, the Tlaxcaltec author Muñoz Camargo said in his history of Tlaxcala, that there were many poor nobles in the province, but that they owed their poverty mainly to themselves and their 'foolish pride' (locura virtuosa). According to him, as in prehispanic times, the sixteenth-century nobles prided themselves on their descent and refused to conduct any work with their hands. Even more strongly than previously they felt above putting a digging stick into the soil, because 'they said they were nobles and they could not dedicate themselves to such dirty business'. This had become rather worse than better after the conversion, because the nobles said that now they 'were better, because they had been converted and become Christians and had submitted to the Emperor Don Carlos, King of Castile'." 
This concern about lost values was by no means confined to Tlaxcala. The resentment of the loss of privilege and the stubborn adherence to old aristocratic values also pervaded the well-known letter of the cabildo of Huejotzingo, which, in the old courteous Nahuatl formulations, supplicated the king of Spain not to carry through any tribute reforms. The Huejotzinca nobility had been obliged to reach a compromise with regard to their privileges before, when in 1550 the Franciscans of the provinces had persuaded the nobles to carry through a limited land reform. To this effect, the nobles had written a petition to the king in which they stated that they had had all lands since time immemorial. They explained that the macehuales had enjoyed the usufruct of the land and had been obliged to give them tribute and services, in exchange. These 'tyrannical customs' had been handed down by their ancestors, who had not realized that they had been acting tyrannically, because they had been pagans (como eran infieles no conocieron este ser tiránica cosa). After long consideration, the principales of Huejotzingo had decided to give land in property (donación perpetual) to the macehuales. Spiteful, the nobles observed that all Indians were now Christians, which implied that there was a 'great equality' (muy gran igualdad) among them. Taking this into consideration, the principales were ready to moderate the tributes, but not to abolish them altogether. The macehuales would still be obliged to work a piece of land of 20x20 brazas for the lord of the land (sentor de la tierra) for each $80 \times 20$ brazas which was allotted to a macehual, which is to say twenty percent. Obviously, the concession of the land reform was intended to prevent loss of tribute, but it did not, nor did the letter of supplication of 1560 , because Huejotzingo was not exempted from the general tribute reform. ss $^{\text {s }}$

Although the pueblos had known tensions about tribute and land for quite some time already, it was especially the implementation of the tribute reforms by the royal visitador Valderrama that caused great consternation. Valderrama visited New Spain in 1564 and dedicated himself to the introduction of the capitation of tribute, which was to be maintained throughout the colonial period. In the years following his visita, his work was finished by other officials. In 1573, Doña Ana Bárbara, cacica of the pueblo of Tepexi, south of the valley of Puebla, worded the general feeling of the indigenous nobles when she complained before the Audiencia that 'the person who had lasely counted and assessed [the] pueblo [of Tepexi], had ordered not to give her any [tribute], as a result of which she was poor and needy'. She asked the viceroy to 'order that she be supplied with the tribute (terrazgo), which [her macehuales] used to give her and that she should be given from the tribute income of the pueblo what would be convenient for her sustenance'."

In the late 1560s, there were disputes in the pueblos about tribute rights and tribute obligations. On the one hand, it was about which rights the nobles could retain and, on the other hand, to whom the macehuales were to pay tribute: to the king, the indigenous caciques and principales, or to both parties. From 1567 to 1571, the caciques and macehuales of Tepeaca were involved in a lawsuit 
before the Audiencia of Mexico. The case was about the 'land, tribute and services' the macehuales owed to the caciques. Through Alvaro Ruiz their procurador (attorney)- the caciques claimed that the macehuales from times immemorial supplied their ancestors and themselves with terrazgo and services, because they were living on their lands. The procurador of the macehuales Agustin Pinto-, on the other hand, pleaded that this had indeed been the case before the Spaniards had arrived, but now the caciques had lost the right to tribute, because of the conquest. The caciques answered that the land was 'leased' (arrendado) to the macehuales, who, consequently, had to pay the rent (renta; terrazgo), or vacate their lands. The Audiencia decided in favour of the caciques in 1568 . This judgement was upheld on appeal by the macehuales in 1571, but even after this date, not all macehuales submitted to the decision and the case dragged on for a long time."

This case was no exception: in 1571, in Tlaxcala, the viceroy ordered the indios terrazgueros of some barrios to submit to their terrazgo obligations. The 'four or five' rebellious Indians (indios revoltosos) were to be thrown out of their barrios." Another Tlaxcalan case, lasting from 1570 to 1589, involved the terrazgueros of Huamantla (Tlaxcala) and the cabildo of Tlaxcala. It appears from the documents that the parties had litigated on the terrazgo duties before. Considering the costs of these litigations, the Huamantleca agreed on an assessment (tasacion) of the terrazgo, because 'they lived on the land of the principales of Thaxcala and Atlihuetzian and worked it'. the burden of the terrazgo developed after the assessment by the Audiencia. It especially intensified in 1589, when part of the Huamantleca succeeded in persuading their principal to reduce the obligations. The other principales refused to follow this example and were supported by the Audiencia. The terrazgueros who still persisted and did not want to leave the building of the Audiencia were sent home on pain of a whipping. ${ }^{\text {" }}$

A third case from Tlaxcala is the lawsuit of Diego Sánchez and Juan de Paz versus some terrazgueros who lived on five dispersed pieces of land in San Pablo Quauhtotoatlan sized $400 \times 80$ to $400 \times 120$ brazas. The terrazgueros asserted they had no tribute obligations because the land was theirs. As their witnesses the principales called some of their fellow principales from Tepeaca, Cuautinchan, Calpan, Puebla, Cholula and from Tlaxcala. Only from one neighbouring pueblo, Huejotzingo, there was no representative. Of course, the witnesses all declared that Diego Sánchez did have a right to the terrazgo and that the terrazgueros unjustly claimed the land. The result of the litigation is unknown to us, as the documentation is incomplete. It seems highly unlikely that the nobles from the neighbouring pueblos could be considered experts on the intricate situation of landownership in Tlaxcala, but their testimonies were used rather to prove the privileges of Diego Sanchez and Juan de Paz and the fact that macehuales had no land of their own." 
In these cases, the tribute reforms had clearly led to a crisis as to the legitimacy of the caciques and principales, which the procurador of the macehuales worded as follows: ${ }^{72}$

'Because the law of peoples permitted [...] legitimate wars, like the one that had been conducted [...] in this land [i.e. Mexico] by Don Hernando Cortés [...], who reduced it entirely to the service of God our Lord and [that of the king of Spain], and because of that, the Indians were vassals [of the king], [...] without distinction, whether they were principales or not'.

For this reason, their lands, like the people, had been submitted to the king, too. Such being the case, the other party, which was that of the principales, alleged that:

'They had levied the tributes [which were the subject of the suit] by way of terrazgo and were entitled to levy [tribute] from [the macehuales, because they were] renteros, had ceased in this present suit, as all of the land was [the king's], and the other party [the principales] could not give what was not theirs, nor rent it out and the lands were of his party [the macehuales]'.

Many principales and caciques impoverished in the later sixteenth century. They often had only a limited tribute income which they owed to their membership of a teccalli. This meant that their position depended entirely on their 'vassalage' to the cacique who was the head of the teccalli. Consequently, their position was derived from the Herrschaft of the cacique, who had given them rights to tribute income in return for their services; this meant that these rights could not continue to exist, detached from the context of the teccalli. Therefore, these principales could hardly ever show their rights to tribute before a colonial court, and would usually lose them. Their situation was pitied by many people in the late sixteenth century, among whom the Franciscan authors, who were very influential. Alonso de Zorita wrote his Breve relación de las cosas de la Nueva España especially in defence of the indigenous nobility. He was mainly inspired by the Franciscans Motolinía, Francisco de las Navas and Andrés de Olmos. Zorita said that the Indian nobles, or lords as he called them, had to appeal to Spanish courts to be exempted from tribute obligations, but:"

"Since the lords do not know how to appeal, nor to whom an appeal should be directed, or before whom it should be made, and since they do not have the money needed for litigation, they lose their liberty [of tributes], and their mayeques (i.e.personal dependents) and lands as well. For the mayeques rise up against their lords and seize their land, declaring that it belonged to their forebears and now belongs to them. Since Spanish officials do not understand how this land was held, the mayeques have their way". 
As I have repeatedly remarked, the tribute reforms were not the only blow for the principales; the undermining of their positions was especially reinforced by the severe depopulation among the Indians. This was not just true for the lower but also for the higher ranks of the indigenous nobility, the caciques. The remaining macehuales could not take over the tribute burden of the dead. Where the burden became too heavy, they emigrated from the pueblos. As one example out of many, I can mention the pueblo of Tochimilco, where in 1591, the cacique Don Juan de Tovar had the macehuales pay too much tribute. According to the account of a number of officials of Tochimilco before the Audiencia, 'for this reason many Indians had moved away from the pueblo'."

In the pueblo of Huaquechula, the officials used to replace the tributes of tributarios who had died, by levying them on their children and widows. These practices were forbidden by the Audiencia, because the categories of women and children were not liable to pay tribute. Even though this transfer of tribute burden from a deceased unto his heirs seems a rather obvious solution, but both Spaniards and Indians regarded it as immoral. ${ }^{75}$ As such, measures like this could also tum against the responsible caciques or cabildo, because Indian moral philosophy prescribed that a legitimate exercise of power ought to be honourable and just. The adversaries of a particular cacique could easily accuse him of being a tyrant, according to the old norms that had been worded most elegantly by the informants of Sahagín:?

"The bad ruler is a wild beast, a demon of the air, a demon, an ocelot, a wolf -infamous, deserving of being left alone, avoided, detested as a respecter of nothing, savage, revolting. He terrifies with his gaze; he makes the earth rumble; he implants, he spreads fear. He is wished dead".

In case of accusations, a cacique had to be able to demonstrate that he was not like this.

For these reasons, the tribute reforms were usually not passed on to the macehuales, but rather on to those who had a few, recently acquired privileges. These were mainly the traders and artisans, who in prehispanic times had often been exempted from supplying products from their land as tribute, if they paid tribute with products from their trade. The cases of Indians with such moderate privileges caused many problems in the pueblos. At times, they did try to take advantage of the Spanish lack of knowledge of the Indian tribute system, by demanding the status of principal before the colonial courts. On the other hand, there were many macehuales who objected to the fact that large groups of macehuales were exempted from tributes and services. This can be illustrated by the example of the situation in Cholula, where there was a large and most complex conflict about these matters at the end of the sixteenth century.

As the sixteenth century passed, the position of Cholula declined, as a result of the loss of its status as a centre of trade and religion and of the growth of the 
nearby city of Puebla, which attracted much of Cholula's former trade. ${ }^{n}$ The loss of its old position was accelerated by the internal troubles of the pueblo. For the modem historian these troubles remain somewhat unclear. Few sources about Cholula's history exist. It is certain, however, that in the pueblo especially the macehuales objected to the exemption of the principales from the labour services of the repartimiento. Cholula was one of the provinces where the repartimiento de trabajo had been imposed most strictly; after all, it was situated between the valley of Atlixco and the city of Puebla, as a result of which it was liable to both the agrarian repartimiento and to the labour services in the construction of churches and monasteries in the new city. According to the sources, the Indians of what the Spaniards called the parcialidad del libro were opposed to those of the so-called parcialidad de los ejecutorios." It is not clear to what degree this was an expression of the divisions in cacique- factions, or if it reflected another division, possibly of prehispanic origin. However, it is certain that in the $1590 \mathrm{~s}$, all principales had to prove their rank as a noble before a committee of investigation of the Audiencia. In this investigation the repartimiento obligations of Cholula, from which all principales withdrew themselves were at stake."

A similar case occurred in Tecamachalco, where the leaders of the pueblo compelled the principales 'of lineage and blood' (de linage y sangre) to take part in the repartimiento in 'which the macehuales used to perform', even while they were part of the cabildo. In 1589, the principales asked the Audiencia to order the leaders to respect the 'privileges which were connected with their quality (calidad)'. Some years later, they also requested to exempt the artisans (carpenters, masons and other artisans) from the agrarian repartimiento, because they left 'other, more useful occupations' when they took part in it. This would be beneficial to the república, but also to the artisans, who used to 'make just four reales [in the agrarian repartimiento], while they could [make] this in their trade every day'."

The result of the conflicts of the sixteenth century, was a decline both in the number of principales and in the number of Indians of modest privilege. In general, only the caciques managed to maintain their positions, even if they lost many of their old privileges. Caciques who kept a legitimacy of power in this crisis where privileges disappeared and many nobles impoverished, stood a fair chance of securing the cacicazgos for their children, too. Notwithstanding all changes of the late sixteenth and the seventeenth centuries, the old social relations of Herrschaft of the Indian world did not give way that easily and the Spaniards took few actions to change this. To take one example, in the seventeenth and the eighteenth centuries many caciques still had terrazgueros, dependent Indians who gave rent and services. In one of the many lawsuits from the pueblo of Tecali around the middle of the eighteenth century, the attorney of the cacique Don Francisco Domingo declared that his family had not only had the cacicargo since 'the time of paganism', but also that in the entire period, the macehuales of the 
sujeto of Toxtepec -with which they had been litigating since the early sixteenth century- had been terrazgueros of the cacicazgo. Neither the Spanish judge nor the attorneys dismissed this claim as illegitimate, irrelevant, antiquated or even surprising, but considered it to be legal and to be taken seriously. In this, the valley of Puebla was no exception: during his research on the valley of Oaxaca, Taylor came across many caciques who held large cacicazgos with many terrazgueros."

The position of the caciques was chiefly stabilized with the recording of the rights to landownership in the 1590 s. With this, they received legal titles to land, but also to their cacicazgos as a whole. These were sufficient to substantiate their claims, and with it, indirectly, to tribute and services as well. Therefore, these titles should not just be seen as a definition of the caciques' rights to land in Spanish terms, but also as a incorporation of the caciques and the Indian system of rights to land into a Spanish colonial framework of institutions. However, this was by no means the end of the social development, which I have described as being the introduction to the relations of the Territorialverband.

The Indians had to keep on living within a system of Spanish rights and laws and, if necessary, they had to be able to word and defend their positions in Spanish legal terms. Therefore, in the course of time, the Spanish idea of landownership in the sense of Roman Law, penetrated ever further into the pueblos. The pieces of land that the caciques used themselves as farms or rented as such, were more often called haciendas or ranchos in the seventeenth century. The land serving for the subsistence of the macehuales of the pueblos was more often indicated as land of the comunidad. Thus, the old Indian structures of the Personenverband, in which the cacicazgos comprised influence over both categories of land, gradually gave way to the categories of landownership connected with the Territorialverband. Increasingly, the lands belonging to the cacicazgos were included in the composiciones, which took place in the late seventeenth and the eighteenth centuries. In this way, not just the division of landownership between Spaniards and Indians as corporative groups within the separate repuiblicas, but, in due course, also the division of landownership within the pueblos became increasingly clear to the authorities.

For the time being, however, the caciques retained authority over what the Spaniards used to call the tierras de comunidad (community lands). The relations which had come into being in the late sixteenth and the early seventeenth century remained intact, for as long as the caciques managed to keep their restored though reduced- legitimacy and as long as no new conflicts emerged. In general, though there were always many exceptions, the legitimate authority of the caciques depended on whether or not the inhabitants of a pueblo could subsist. In this respect, there were not many structural problems in the first part of the seventeenth century. As far as can be inferred from the literature, as the population started to grow during the second half of the century and the pressure on the land in the pueblos became higher, it became increasingly difficult for 
caciques to guarantee this, and new problems thus developed. As García Martínez, Dehouve, Ouweneel and Wood have shown, towards the end of the seventeenth century, these problems initiated a movement in which many sujetos separated from the cabeceras. The main cause for this was, that, in this way, they could obtain their own tierras de comunidad. This was often at the expense of the landownership of the caciques, of the tierras de comunidad of the cabecera, or of haciendas, and, quite often, applying for tierras de comunidad implied a revolt against a cacique. In these cases, discontented members of the local elite were usually the instigators and organizers of these revolts. These late seventeenth- and early eighteenth-century developments fall outside the scope of this study; nonetheless, they may serve as an indication that the period of relative stability which characterized the pueblos in the first part of the seventeenth century, was certainly not characteristic for the rest of the colonial period."

\section{Conclusion}

In the late sixteenth century, the pueblos de indios endured a period of crisis. Especially the position of the Indian leaders was under severe pressure. The reforms of the first phase of the colonial era touched upon all aspects of traditional indigenous leadership: political, economic and cultural. To a large degree, the cultural aspects have been treated in the previous chapter. In this respect, the caciques and principales mostly had to yield to the Spaniards, especially in more external aspects. Politically, they saw themselves forced to adapt to the institutional framework which the Spanish offered them within the pueblos de indios. During the colonial era, important factions remained under the leadership of the caciques in the pueblos. Principales were invariably dependent on the caciques and even derived their status from close links with them, whereas the caciques managed to control many of the new offices in pueblo administration through their factions. This made the new political situation largely instrumental to the Indian system of factions and pressure groups. As a result, these factions did change, but the changes were usually not so radical as to turn the entire power structure of the pueblos upside down.

In a socio-economic respect, the problems were far more fundamental. Incorporation of the new tribute system into the traditional indigenous situation was in fact impossible and the Spanish ideas about rights to land did not fit in the indigenous economic views, either. Forced by the combination of tribute reforms, the composicion of the $1590 \mathrm{~s}$ and the severe consequences of the depopulation of the pueblos, a rapid change of the social structure was set loose. The result was a general impoverishment of the indigenous population, the most important victims of which were those with moderate privileges: the principales of lower rank, the tradesmen and the artisans. In contrast to many of the caciques, they had no opportunity to keep up their old tribute rights in the new situation. These groups 
had derived from their former status or from the authority of the caciques in days gone by, but during the sixteenth century they lost all legitimacy. Spanish Law did not recognize traditional exemptions from tribute and these groups sank into the mass of macehuales, unless they were able to assume offices in the cabildos of the pueblos. These only gave power for a while, as the term of office was officially only for the duration of one year.

Generally the caciques were best able to retain their status. They had the support of the Spaniards and were usually able to record both their landownership and part of their rights to tribute under the conditions of Spanish Law. Still, the caciques were also fiercely attacked. The macehuales, confronted with a doubling of the customary tribute demands, challenged the position of the caciques with the help of Spanish attomeys; if their burden became too heavy, they emigrated from the pueblos to try their luck elsewhere. Others, like the cultivators and traders of cochineal, managed to make a fortune by making use of the opportunities which the colonial economy offered them and they gained a status which was based on money. The caciques resisted the loss of their power in all possible ways and protested against the destruction of the old standards and values. They had to defend their positions by constant adjustments or by regaining it from rivalling cacique-factions or, at times, from principales, who used the relations of colonial society to gain power with the support of a number of macehuales. Caciques who did not adapt, could be certain that they would either be oppressed or set aside after some time.

At the end of the sixteenth century, the worst crisis in the pueblos had passed. The recording of the rights to land and, with it, implicitly, of the rights to tribute, implied that the relations among the Indians took shape within the structure of the pueblos, which is to say within the framework of the institution of the pueblos de indios. For a long time, the caciques and their factions kept control of the pueblos. Their power had been reduced considerably and been put under formal Spanish control, but within the pueblos, the caciques had regained their legitimacy and for the time being, they continued to dominate social life. The old tribute rights had been reduced, but did not disappear, and for a long time, the caciques kept influence over the land which was known under the Spanish name of tierras de comunidad, but which in fact was land that the macehuales were entitled to cultivate in exchange for tribute payment, as in prehispanic times. After the turn of the century, the situation settled down, but it never became static. Caciques who lost their legitimacy, could count on resistance to their person from the pueblo, where there were always people ready to take the lead in the resistance, in order to take over their position. In the first half of the seventeenth century, these conflicts about legitimacy were not very pressing, but as authors like Garcfa Martínez, Dehouve, Haskett, Taylor, Wood and Ouweneel have shown, when in the second half of the seventeenth century, population started to grow again and the pressure on pueblo land rose, the caciques had increasingly trouble supplying macehuales with land for the tribute 
they had to pay. At that time, the pueblos became more restless and especially in the eighteenth century, the number of conflicts between the caciques and the pueblos rose rapidly." 


\section{Conclusion}

In the late sixteenth and early seventeenth centuries, Mexico underwent a social transformation. During the time of the conquest society -1521 to ca.1570-, Spanish and Indian elements in Mexican society were predominantly separated. In the period between 1570 and 1640 , a transformation took place these elements gradually merged, under the increasing influence of the conditions, that were to continue to be determining for many of the social relations of the following period. This transformation was induced by two developments with a fundamental influence on society. On the one hand, the entire society was affected by the dramatic epidemics that decimated the indigenous population, which predominantly lived in the countryside. The depopulation among the Indians bad severe economic effects, especially because the number of Spaniards was constantly growing. They mainly lived in urban centres, most of which they had founded themselves. On the other hand, the socio-political changes, initiated by the Spanish authorities from the 1540 s onwards, made themselves clearly felt during this period, affecting all parts of the population, Spaniards and Indians alike, and forcing everyone to reconsider his situation and to adapt to the new circumstances. In retrospect, it is important to distinguish between these two important trends, although in the period under study, they were always inextricably intertwined.

\section{The aftermath of conquest}

Necessarily, indigenous society was the point of departure for the social development of New Spain, because, at least partly, Indian society was the warp on which all elements introduced after the Conquest were the weft. However, this image is only appropriate to a certain extent, because not only were new elements introduced into the indigenous society, but in the course of the process, society as a whole was transformed, as well. The indigenous social structure existing at the time of the Spaniards' arrival was very different from that of colonial society. There were two fundamental differences. In the first place, Indian society before the coming of the Spaniards had been politically partitioned. Nearly all of an individual's life took place within the confinements of the political boundaries of the alrepetl.

This had important consequences for the economy, for the different indigenous people were usually living in discord or waging outright war, which was pernicious for trade. Therefore, prehispanic society had a rather limited system of trade, in which long-distance commercial contacts and local markets were of importance, but interregional trade was virtually absent. Yet, this was not solely the result of the division of the Mexican territories among the altepetl. Transpor- 
tation was rather hampered, because it depended entirely on human bearers, except on the lakes in the valley of Mexico where transportation was done by canoes. Still, the absence of interregional trade was no major obstacle for the functioning of the economy. In most cases, the altepetl could provide their own food. Only city of Tenochtitlan in particular, could not live from the supply of food from its direct surrounding areas alone. It was provisioned through the Axtec tribute system, in which the duties of supply of the allepetl subject to the empire were organized.

The idea that everyone had a place determined by the divine order was fundamental to indigenous society. Fulfilling one's task in life was vital to maintaining this order. There was a fundamental separation between those who were liable to pay tribute and those who had a right to tribute. The macehualtin generally peasants- were obliged to supply goods to and perform labour services for the nobility in recognition of their lordship. The nobles were to take upon themselves the responsibilities which were connected with their position: in exchange for tribute, they had to protect their subjects, to encourage their spiritual life and to administer justice. Therefore, the position of a tecuhtli or teuhctli (reucyotl) or tlahtoani (tlahtocayot), was conditional on these three duties, at least, in theory. In fact, there was a bond between lord and subject, which consisted of mutual duties and rights. Of course, this did not imply that injustice or the neglect of duties were precluded. From European history we are farniliar with similar mutual exchanges based on individual relations, which have been characterized as Herrschaft.

The principles of Herrschaft were not uniform nor were they confined to the relations between nobles and macehualtin. Traders and artisans were exempted from part of the tribute duties and labour services, and were allowed to supply products from their trade, instead. But there was also a relation of Herrschafi among nobles themselves, by which, for example, a tlahtoani received services from a tecuhtli, in exchange for his protection. Seen from this angle, the tecuhtli was a macehualli of the tlahtoani. Thus, the Aztec emperor demanded tribute from the altepetl which he had subjected, in recognition of their subordination. In the final analysis, the tlahtoque -including the emperor- were macehualtin of the gods. In this way, Indian society had many different tributary rights and herrschaftliche subordinations. Because these personalized relations were the foundation on which the entire social framework had been constructed, it would be useful to look upon Indian society as a Personenverband.

The Spanish Invasion initiated a transformation of this society, although this did not take place right after the conquest. In theory, the entire conquered territory was united under Spanish rule, but at first this mainly affected the upper strata of Indian society. The Aztec emperor was deposed and killed and the tlahtoque of the autonomous altepetl were subjected. However, for the time being, they retained their power within their own altepetl. Two Spanish groups dominated the conquest society which came into being during the first period after the Invasion. The first group were the conquistadores, who, as encomenderos, were placed above the Indians. The second group were the missionaries from the three mendicant orders, of whom the Franciscan order was the most important one in the valley of Puebla. 
These two groups fitted remarkably well into the socio-economic and mental framework of Indian society. The encomenderos, in fact, took over the place of the indigenous rulers as the King of Spain had taken the position of the Aztec emperor. They received tribute and services and with this, they fulfilled a role within the hierarchic system to which the Indians had been long accustomed. However, they remained outside the Indian world, as they usually lived in Mexico City and never exercised actual power within the altepetl.

The missionaries replaced the old priests, like churches replaced temples. Like their predecessors they enjoyed a large cultural influence. They always tried embrace the Indian way of living to be able to use their power most effectively. To make the conversion as effective as possible, they used the Indian nobles, whom they involved in upholding the new religion, in order to effectuate its consolidation. Many nobles realized that it would be to their advantage to cooperate in the conversion. The fate of the missionaries especially that of the Franciscans in the valley of Puebla- and of the Indian leaders came to be closely connected during the first period after the conquest.

The missionaries became doctrineros within the altepetl, which were tumed into parishes, called doctrinas in mendicant terminology. They organized these in accordance with a Spanish model of central subjected settlements, cabeceras and sujetos. At the same time, however, this was a logical adaptation of the prehispanic structure of the altepetl, in which there had been a main temple and subjected temples. As the new mediators between the Indians and the supernatural, the missionaries were the only Spaniards who officially held a position within the alseperl. As such, they fitted into the Indian tribute system and were the Spaniards most closely involved with the Indians.

Such were the social relations of the conquest society, but these did not remain intact for long. From the start, the two dominant groups, the encomenderos and missionaries, had not comprised all Spaniards. There had always been people without an encomienda of their own, who had been dependent on an encomendero, or who had to make a living in some other way. In the course of time, their number increased. In 1531, the city of Puebla de los Angeles was founded for Spaniards without an encomienda. They were given land, so that they could engage in agriculture. However, the foundation of Puebla did not have the desired effect, and in the middle of the sixteenth century, there was a widening gap between the Spaniards who enjoyed some power within the conquest society and those who did not. In the course of the sixteenth century, this last group was growing steadily. It could only benefit from a change in society.

Besides this growing group of Spaniards who, more or less, lived outside the conquest society, the Crown had also been very dissatisfied, from the start, with the power relations as they had developed in the colony. From their experiences with the early colonies of the Caribbean islands, the authorities in Spain had learned that it was very difficult to keep encomenderos on the other side of the ocean under control. Their encomienda provided them with a source of power and income which was independent of the Crown. The Crown held the view that too much tribute income only benefited the encomenderos and the indigenous nobility. From the very beginning, it had been intent on changing this situation. However, to effectuate this, the administration of the new overseas territories as 
a whole had to be changed. The Indian world had always been very heterogeneous and as such, it could hardly be incorporated into a centralized administration. There was no ready solution to this combination of problems. Therefore, the first measures by the Crown were of an experimental nature and often contradictory. In due course, however, policies were increasingly directed at a more centralized control of administration. In Spain, it was decided that only a uniform administrative system, based on a hierarchic subdivision of the territory and led by a newly created, centrally run machinery of civil servants would offer the best prospects for an effective governance. To this effect, the centralizing measures that had rather haphazardly been taken before, were codified into the Leyes Nuevas in 1542-43.

The Leyes were thus not so much the conclusion, as the crystallization point of earlier measures, from which further reforms could be initiated. They most directly hit the encomenderos, who lost nearly all of their influence after ca.1550. The Leyes reinforced the bureaucracy. The administration of the colony remained in the hands of a viceroy. With the administrative reforms the offices of alcalde mayor and corregidor had also been introduced at an earlier stage; these officials were formally put at the head of provinces. This was the Spanish part of the new administrative system, but the viceroy had also been given authority over the Indians. In the Leyes Nuevas, the principle became manifest, that the Spaniards and Indians were the two most important components of the colonial institutional order. Each group constituted a república of its own and accordingly, each had to have its own administration.

Therefore, the Leyes Nuevas were also directed at the administrative reorganization of the Indian world, which, from an organizational point of view, had been kept remarkably intact until then. The implementation of the reform was left to the authorities in New Spain; in the Leyes, the Crown confined itself to issuing basic laws, and, at times, by intervening when it feared that the situation was getting out of control. Even though there had been some wavering attempts at reforming some parts of the Indian social framework, the reforms never really started until after the Leyes Nuevas.

They consisted of a complex of measures, which were introduced over a longer period of time. The measures had two objectives, which the Spanish authorities tried to accomplish in one vast operation. The first objective was to simplify the Indian administration and to make it uniform. To this effect, the repüblica de indios was subdivided into pueblos de indios, which were placed under the leadership of Indian officials. The basis of these new administrative units consisted of the cabecera-sujeto organization of the missionaries, and with it, in most cases, of the structure of the former altepetl, as well.

The second important objective of the reforms was to simplify the complex indigenous tribute system, which was strongly based on personal ties, rights and duties. The Crown held the view that in the old system too much tribute income had been withheld from it and wanted to change this by establishing a capitation of tribute, and which, in addition, was to be equivalent to a specified sum in money, although it could be paid in kind. The subdivision into pueblos de indios also served this objective: the new administrative units which were based on territorial criteria were, consequently, also fiscal units. Of course, such radical 
changes could not be implemented without any major problems. Apart from this, they took up a lot of time, as well. However, the congregations of the 1550s were a decisive step in the direction of implementation. Their most important result was, that the indigenous population was classified by pueblos de indios. Meanwhile, they still belonged to cacicazgos, the indigenous lordships. The reform of the tribute system, however, was not accomplished until later; at about the middle of the 1570 s, the capitation tribute was established, though at that time, the conversion from tribute in kind to tribute in money had by no means been realized everywhere, yet. On the central highlands, the tributes in maize were continued for a long time.

The administrative and fiscal redivision had several important consequences. The official consequences were most obvious for the Indians. With the classification of all Indians by pueblos de indios, the status of an Indian had been legally defined. Notwithstanding all subsequent racial mixes and social changes, this legal definition would remain in force until the end of the colonial era. At a later stage, it would sometimes give rise to great confusion, but in these early colonial days, the separation between the repuiblicas of Indians and Spaniards was still clear. With the establishment and the demarcation of the territorial administrative units with on the one hand, the Spanish provinces and on the other hand, the pueblos de indios, a first milestone had been reached in the introduction of an administration on a territorial basis, a Territorialverband.

The administrative and fiscal reforms put a severe pressure on the social relations of the conquest society. Both Spaniards and Indians faced profound changes, which were reinforced by the demographic development and the economic developments connected to it. The demographic development had two contradictory sides. About the middle of the sixteenth century, the number of Spaniards which did not remain directly or indirectly dependent on the Indian economy, increased. In the valley of Puebla, the centre of the growing number of Spaniards was the city of Puebla de los Angeles, which had been attracting immigrants from the moment of its foundation.

The tremendous epidemics which time and again struck the Indians effected a drama without equal, in which the Indian population was decimated. Furthermore, a growing number of macehuales migrated from their pueblos de indios as a result of the tribute reforms and the increasing tribute burden. Many of them tried their luck in the urban areas, just like the Spaniards who had immigrated from the Iberian peninsula. Even though the epidemics did not miss out the Indians in the city, their number, there, decreased less than in the rural areas. On a smaller scale, effects similar to the ones in the city of Puebla will also have occurred in the centres of the pueblos de indios, the cabeceras.

The shift in relations between the number of people in the city and that in the rural areas, created a tension on the food market, as the urban demand was growing, while the rural supply decreased. This tension was reinforced further by the tribute reforms, which replaced the former supplies of goods and services with a capitation tax in money. Thus, the institutional reforms and the demographic and economic changes were not separated developments, but profoundly influenced each other. As these forces combined, the socio-economic system of the conquest society, largely based on the indigenous social structure, came under 
such severe pressure, that it rapidly began to give way in the second half of the sixteenth century. After about 1570, a process of transformation and, eventually, integration started, which was irreversible and soon uncontrollable. Then, the authorities in Spain and in Mexico City could do little more than making minor corrections, but by that time, the Crown no longer had administrative control or an initiating function like it had had in the middle of the sixteenth century. The social framework shook on its foundations.

\section{The real transformation: the genesis of the colony}

The rapidly changing relations of the society of New Spain made it necessary for everyone to adapt. If the period until 1570 had been characterized by a gradual undermining of the old social relations, the actual transformation of society took place between 1570 and 1640, in the valley of Puebla, as well as in many other parts of the colony. The transformation consisted of two intertwined elements. On the one hand, an economic region was formed with the city of Puebla as its centre. On the other hand, the administrative relations of the Territorialverband increasingly penetrated into the rural areas, while the influence of the ties of Herrschaft that had characterized the Indian Personenverband gradually decreased. The changes were especially caused by the increasing participation of Spaniards in New Spain's economy. They brought about many problems, connected with the introduction of Spanish elements into a society which had always been determined by strongly personalized and localized Indian social relations. The transformation of society really consisted of the intertwining and gradual integration of the old Indian, and new Spanish elements.

The process started off when the Spanish groups, which until then had not been able to play a significant part in society, seized the opportunities which the collapse of the conquest society offered them. In the valley of Puebla, they started trading companies and at the end of the sixteenth century, they were increasingly active in the agrarian sector, especially on haciendas, which in the terminology of the time were called labores to indicate wheat or maize farms and estancias when they were livestock farms. The labores were mainly founded in the fertile areas surrounding the city, making them important centres for food production, supplying of the city of Puebla, as transportation to Puebla was easy and inexpensive. Livestock breeding was especially carried out on remoter farms, where the land was less expensive and transportation less important. With this, agricultural production in the valley of Puebla focused on the city of Puebla, which, to a large extent, shaped the foundation of Spanish labores and estancias.

The introduction of the labores caused major problems, because of the differences between Spanish and Indian ideas about rights to land, rather than in the actual use of land for agriculture. The ecological circumstances needed for the wheat cultivation and the ploughing oxen of Spanish agriculture were quite different from those needed for the Indian milpa techniques. The Spanish system flourished best on the wet, flat and well irrigable plains on the banks of the rivers, whereas the Indian agriculture throve on the lower slopes of the hills and mountains. Before the conquest, the river banks, hardly suited for Indian 
agriculture, had been waste no-man's-lands between the different altepetl. There was therefore an ecological dichotomy between Spanish and Indian agriculture, which made it possible for them to coexist.

For the Spaniards, rights of ownership were of major importance and embedded in Spanish customary law. Anyone who started to cultivate waste land could make it his property. Yet, the Indians, most of all the nobles, did not have that sort of ownership rights, but were used to thinking in terms of spheres of influence, connected with the relations of Herrschaft, which made no distinction between economic and political rights. Therefore, what the Spaniards regarded as mere cultivation of waste land, the Indian nobility saw as an unlawful violation of their prerogatives, which were already under severe pressure as a result of the tribute reforms. The Spanish authorities were deeply concerned about the unrest, which these social and economic contradictions brought about. They were afraid that it would escalate and, on top of this, would harm the already precarious economic situation in New Spain. They realized that only a large-scale investigation on the spot, no matter how costly and time-consuming, and a recording of the claims of both Indians and Spaniards would be able to calm down emotions in the rural areas.

These considerations gave rise to the twofold measure of the composicion in the 1590s, in which the Spanish claims to land were recorded and inquiries were held both among the Indians and, of the congregations of the early seventeenth century, both baving the main objective to record landownership. This policy coincided with the Indian nobles' need to start selling useless parts of their land, which was bom from the impoverishment that had affected most of them in the late sixteenth century, due to their decreasing tribute income. As a result of this coincidence, many Spaniards bought land from the Indians in the 1590s. At first, a rather chaotic situation developed in which everyone was buying land at random. In the course of the first decades of the seventeenth century, the rather dispersed pieces of Spanish land crystallized into more viable labores. Not until ca. 1620 a situation of equilibrium had been reached.

The changes in landownership were a second crucial step in the direction of the transition into a Territorialverband. In the first period of congregations, the borders of the pueblos de indios had been demarcated, and now the landownership of the pueblos and the claims of the Spaniards were recorded. Part of the caciques' claims of Herrschaft were now expressed in Spanish legal terminology. This meant an important change to the Indians, but it gave the indigenous nobility a new grip on the situation. Seen in the light of the Territorialverband, the recording of the division of landownership meant an important change.

Within the pueblos de indios, however, the effects were rather different from those in society at large. Because the rights of the caciques were now reconded and, thus, also got official force of law for the Spaniards, it enabled the caciques to consolidate their position within the pueblos. For the time being, however, this did not imply that the new ownership relations also played a part in the pueblos. The Indian pueblos, being comunidades according to Spanish Law, also had a right to common landownership, but the caciques still managed to exert their rights of Herrschafi to these lands. However, the new landownership relations 
were the basis from which the rights to land in the pueblos would evolve and as such, the recording should be seen as a further implementation of the Spanish concept of the pueblo as a comunidad. A separation between cacigue land and pueblo land now slowly emerged.

The rapid growth of the Spanish labores was accompanied by a rise in the demand for labour. In prehispanic times, labour had been under the control of the nobility's Herrschaft and so there had never been even a need for a labour market. Even though the conquest society had brought about important changes in society, for the time being, the supply of labour could not keep pace with the growth in the demand. Reluctantly, the authorities agreed to establish the repartimiento de trabajo in order to satisfy this demand for labour. The repartimiento was an adaptation of the prehispanic labour services. According to the rules of the repartimiento, labradores got a fixed contingent of labourers from nearby pueblos de indios. However, formal regulations applied to certain areas and to a limited group of people only. Apart from the repartimiento, an informal system of labour services soon developed, organized by the caciques. Both the repartimiento de trabajo and the informal labour services particularly supplied seasonal labour, which was needed on the labores.

The repartimiento, which was administered by regional Spanish officials, only had a limited lifespan. As the labores consolidated towards 1620, the Spanish officials gradually withdrew from labour supply, something they had wanted to do for a long time. In 1633, the repartimiento de trabajo was formally abolished. This did not mean that the supply of seasonal labourers came to an end, but rather that it came to depend wholly on the connections between labradores and the caciques, who could dispose of the Indians in their pueblos.

In trade, developments were slightly different. The economy of New Spain had more need for interregional trade than Indian society had ever had. The old tribute system had disappeared, except within the pueblos themselves. Consequently, the system of provisioning the cities by means of the old tribute system failed. Spanish means of transportation -carts, mules- were more efficient than Indian bearers, but even more important was, that the Spaniards could start trading between the altepetl after the old borders had been removed. Many indigenous traders were forced to give up their privileged position and return to agriculture as a result of the tribute reforms and the depopulation of the pueblos. There always remained many people of Indian descent who were active in shortdistance trading, but the large-scale and long-distance trading was almost entirely in Spanish hands from the late sixteenth century onwards.

Local Spanish officials were also an important factor in trade, which mainly took place in the repartimiento de comercios. In the valley of Puebla, it predominantly involved the distribution of livestock, but elsewhere, it also comprised purchasing products from the pueblos. The repartimiento was a (non-official) prerogative of the alcaldes mayores, who were able to derive a considerable income from it. The actual organization in a particular area was nearly always in the hands of Spanish tradesmen or producers. The repartimiento provided a means for the buying or selling of goods, from or to the Indian population. As such, the repartimiento de comercios played an important part in regional and local economy. 
The wealthiest Spaniards lived in Mexico City and, to a lesser degree, in Puebla. They had considerable influence over affairs on the regional level, but by no means absolute control of life in the rural areas, which was largely hidden from their view. Trade in the countryside was conducted by often insignificant tradesmen or mule-train drivers. A similar situation was found in the realm of administration. The Crown in Spain received information from all possible parties in all possible ways, but gradually it perceived that, after all, it could get little grip on the situation in the overseas territories. It did interfere in basic political matters, but the execution of the administration was largely left to the authorities in New Spain. Even though the viceroy in Mexico City and the Audiencia had more and more direct means to exercise power, they, too, only had deficient lines of communication at their disposal. Furthermore, both the territory which they were supposed to be ruling and its population were huge and heterogeneous. Out of necessity, most direct political and legal authority was therefore left to the provincial officials, the alcaldes mayores and corregidores.

The provincial officials were more closely bound to local life and could react more directly to the local situation. But then again, their hands were tied by the situation. Not only did they have a limited term of office, but they also had to rely on powerful people in their provinces for an effective administration. Except for the urban areas, the Spaniards were an insignificant group among thousands of Indians. Colonial New Spain had neither a police force nor a standing army and rebellions had to be suppressed by a hastily gathered militia consisting of illtrained local Spaniards. Spaniards who traded in the countryside, or owned a Labor, were aware of being surrounded by an overwhelming majority of Indians. Some of them might even be in their service, though most Indians were not in a subordinate position vis $a$ vis the Spaniards, except in the strictly legal sense of the word, meaning that the Spaniards were thought to be superior to the Indians.

Most of the Indians with whom the Spaniards came into contact, were traders or local caciques, and in most cases it was beyond their power to force these people in any way. In this period -and long afterwards- many of the caciques were influential figures at a local level, and autonomous in most of their actions. All Indians living in a pueblo de indios, which was the most important labour reserve in rural areas, fell under their influence. The caciques usually controlled a considerable amount of land. Spaniards who wanted to keep their position within an area, and who wanted to buy products from the Indians or needed labourers on their labores, were well advised to maintain good relations with the caciques. This did not mean that there were no Spaniards who ill-treated their labourers or who abused the power they had as a Spaniard, but usually the power relations of rural society prevented them from conducting in this way.

Whatever had been left of the relations of the conquest society in 1570, received a final blow during this transformation. The most important result did not consist in a change of the Indian society itself, but rather in the altered relations between the pueblos de indios and the Spanish economy. The changes of the period of ca.1570 to 1640 affected all groups in society to a greater or a lesser degree. How much survival depended on the ability to adapt to the changing circumstances is exemplified by the different fates of the caciques and the Franciscans, the two groups, that were the link between the Indian and the 
Spanish worlds in the conquest society. The caciques were the most important link between the pueblos and society at large. They controlled an important part of both the production and labour force in the countryside, which made them important people in the areas surrounding their pueblos proper. The only measures which had radical consequences for the Indian social structure and in which the Spanish authorities were directly involved, were the introduction of a new tribute system and a uniform administration over the Indians, the two steps in the implementation of a Territorialverband, which had chiefly been shaped by the two periods of congregations. These brought about a severe crisis in the pueblos, which was even strengthened by the depopulation. In general, the complex of institutional and socio-conomic influences caused an impoverishment of the Indians in the pueblos, which especially affected the principales and the people with a few privileges, like the tradesmen: most of them lost their prerogatives.

The caciques also lost part of their income. Their position came under severe pressure and in many, if not all pueblos, sometimes fierce and long-standing conflicts developed. A number of the caciques lost their position during these conflicts, but many of them managed to regain at least part of their position by adapting to the new situation and seizing the opportunities which the changing society offered them. There was an important change in the political position of the caciques. As a consequence of the administrative reform, their former, usually hereditary, authority of the pueblos was replaced with a system in which officials annually rotated. By using their influence on the people in the pueblos, the caciques managed to bring this new administrative structure under the control of their factions. In the seventeenth century, the crisis caused by the changes of the sixteenth century, gradually passed and the situation stabilized. By this time, the pueblos had a completely different relation with the world around them. In the course of the process of transformation, the caciques had acquired a new legitimacy, which was now based on a strong position within the pueblos, as well as on a considerable influence on the world without. This did not mean that there were no more conflicts among caciques at a later stage, or that their legitimacy was now safe for ever. On the contrary, throughout the colonial period, the pueblos de indios would be characterized by great internal strife and by feuds among the cacique factions. However, the general upheaval which had struck the pueblos in the late sixteenth century, was not to return for quite some time.

The transformation proved fatal to the position of the Franciscans, who, in the valley of Puebla, remained as dependent on the pueblos as they had been from the early colonial period. As a result of the uncertain situation which had come to exist in the period after the conquest, initially the fate of the caciques and the Franciscans had been closely tied together, and even continued later on, due to the tribute reforms. The Franciscans pleaded with the colonial authorities to keep the Indian social structure intact. Support from the influential friars was also important for the caciques as a means to preserve their position.

On the other hand, the Franciscans depended on the pueblos, especially at an economic level, as they had been incorporated into the Indian tribute system. As the social transformation, and the erosion of the old tribute relations involved, proceeded, the Franciscans came to put increasing pressure on the economic base 
of the pueblos. In this respect, the Franciscans differed from the other missionaries, who, in the late sixteenth century, had found sources of income, particularly, in the exploitation of haciendas. The Franciscans, however, refused to give up their old way of living based on 'voluntary alms' from the pueblo, which meant that they were still dependent on the old tribute relations. Their refusal to adapt to the altered circumstances, alienated the friars from the caciques, who increasingly regarded them as a burden, rather than as an ally. Moreover, as the Church and Christian religion were incorporated into everyday life of the pueblos, the caciques came to depend less on the Franciscans. Due to these two developments, in the late sixteenth and early seventeenth centuries, the Franciscans lost much of the special position they had occupied in the middle of the sixteenth century. When in 1640, the bishop of Puebla, Don Juan de Palafox y Mendoza, ended the long-standing conflict about the doctrinas between the secular and regular branches of the Church, the pueblos hardly resisted his actions. Afterwards, the position of the Franciscans in New Spain was finished.

In the conquest society, the Franciscans had been the main link between two separate worlds, that of the Spaniards and that of the Indians. To defend their position, and their ideals, they had reacted most vehemently against the radical social changes of the late sixteenth century, which I have called social transformation. Their position was eroded and when it came to an end in 1640, it marked the stabilization of the altered social relations, in which there was no room left for positions based on the relations of the conquest society.

The introduction in the valley of Puebla of an administrative system based on territorial criteria, a Territorialverband, was to determine many of the social relations during the entire colonial era; increasingly it penetrated further into the institutional and juridical relations, even in the countryside. In the period under study, it particularly determined the relations between Indians and Spaniards. For the time being, the influence on the pueblos de indios was mainly of an external nature. The internal relations of the pueblos de indios were still characterized by the old relations of the indigenous social system of Herrschaft, which are to be characterized as a Personenverband.

The demographic developments caused a growing participation of Spaniards in the economic activities of the valley of Puebla. They especially took over those activities which transcended the regional level and which had been of little importance before. Therefore, they controlled the superregional sectors of the economy. This was far less the case in the local economy, in which the Indians, and especially the caciques, bad always played an important part and were able to continue to do so, because of their control of vital economic elements, such as the supply of labour.

The process of transformation also manifested itself in a social integration in the valley of Puebla, in which Spanish and Indian elements now became increasingly intertwined, especially in the rural areas. Yet, in the seventeenth century, Spanish and Indian elements could still be distinguished in this new society. However, at this time, there were no longer any real differences between Spanish and Indian society at a regional level. Of course, after the Conquest, the Spaniards had become the dominant party in New Spain as a whole and, naturally, 
they always remained the most powerful men in colonial society. At the regional and local level, however, Spaniards and Indians were less separated from one another than at the level of the colony as a whole. Though in the provinces the Spaniards officially were the most powerful group even in the provinces, but there, many of them were often too dependent on the cooperation of the Indian caciques to give this power more than a purely formal content.

The economic region which came into being in the valley of Puebla, and which was focused on the city of Puebla, was a region of the colonial society as a whole. The centre was situated in the city, from which a major part of the production and trade was controlled. In this way, the Spaniards certainly dominated society, and the regulations of what may be characterized as a Territorialverband were their standards. The Indians were part of the region, at least to the degree in which their life was dominated by the relations of the Territorialverband, which were in fact their relations with the Spaniards.

At a local level, however, the traditional indigenous way of exercising power according to the relations of Herrschaft prevailed and the Indian standards dominated. Spaniards who wanted to gain prestige in this socio-economic environment, which was so much dominated by Indians, had few other choices besides adapting their behaviour to these standards to the best of their ability. For most of them, this step was not very big, as Spanish society of the sixteenth and seventeenth centuries contained many elements that had been derived from comparable European values and standards of Herrschafi. I have argued that the social development of the late sixteenth and early seventeenth centuries was not characterized by a systematic marginalization of the Indians or by a polarization between a Spanish and an Indian world, but, on the contrary, by an entanglement of Spanish and Indian elements, in which both played an important part. This is in rather sharp contrast with the traditional view on this period, but it presents a picture of reality which seems to be a more plausible basis for the colonial relations of the eighteenth century as they have been presented in recent literature.

This study has predominantly been based on archival material on the valley of Puebla, even though I have attempted to make comparisons with other areas, whenever possible. Many of the social relations that came into existence, were basically the same everywhere, at least where there had been a sizeable prehispanic Indian agricultural population; in my view, the most important differences concern the period in which the process occurred. After all, in these areas, the same kind of influences interacted, which proved to be crucial for the social transformation in the valley of Puebla. Everywhere, the Spaniards realized that they had to participate more and more in the economy; thus, economic regions came into existence. The pueblos de indios were the necessary institutional and economic-administrative basis of all Mexican economic regions; even in places where there had been Xneithealtepetl nor a large Indian population in prehispanic times and which had been populated by Indians or people of mixed descent long after the Conquest, pueblos de indios came into being, which played a part similar to that of the pueblos de indios in the old centres of population.

The implementation of the Territorialverband first took place in the most densely populated areas, where a close contact between the two repuiblicas was 
inevitable and where the relations had to be settled first. In areas with fewer Spaniards, and where they were less engaged in agriculture, it was less important to record the division between Spanish and Indian landownership. In those places, it was sufficient to only classify the Indians by pueblos de indios, in order to effectuate the tribute reforms. Consequently, in remoter parts of New Spain, for a long time, only this first step was taken in the realization of the Territorialverband and a following step only became necessary with important socioeconomic changes, such as the growth of hacienda agriculture. In those areas, the caciques could long continue to operate more autonomously and consequently held an even more important position than on the central highlands, even though the inadequate infrastructural situation and the poor conditions made their position far less enviable. 



\title{
Notes
}

\author{
Introduction
}

Reviewe of the litereture on this decusion Mömer, "Spanish American Hactends", Van Young, "Mexucan Rurd Hutory sunce Chevalier", Phetechmann, "En torno", Cucllo, "Mro" Slucher ven Bath, Agransehe geschuedenus. "Inlendmg". PP 9 34. and pasom A summary of thes ducussion m Slicher van Bath, Mersch an land in de muddeleewwer. Vol I, pasam

Borh. "Spanuh and Indian Law" and "Some Problems of Sources", Dehouve, Quand les banquers Gament des saunis, Harvey, "Aspects of Land Tenure a Ancient Mexuco", Hasket, "Indan Communty Land", Hreks, "Tetzecos in the Earty 16th Century" Hockuln, "Dufferent Way of Thmkeng", also sce Chapter I below

Piebchmann, Estado, 13 and pasom An analysus of the hrotoncal development of the concept of 'atate' m Geschuchuche Grundbegrife, "Stat"

6 Braudel's statementus are moat clearly expressed in hu Medierraneo, Vol I

7 Borsh, Justace by Insurance, Stern, "Lotun Amencan'e Colonial Hutory", 12, also cited by Ouweneel, "Altepene and Pueblos de Indios", 4 More attenton to polituca than urual in general histones in Gerck Martínez, Histona de Menco, on polituca furthermore Sarbbia V, Velasco. Poole, Pedro Moya de Contreras For the the seventeenth century there in Inrael, Race Class and Poluacs A short untroduction of regional politics in Cobiemo provancial Important recent worke treatung eome aspects of insututional hustory Pietechmann. Esiado, Garefi Martinez. Pueblos de la Sierro, Bomh, Justace by Insurance Also wee Spalding's mtroduction to the vohme Essays in the Politucal Economic and Social History

Sabean, Property Production and Fawly, 27-28 In this andy the followms conventions regerdmg quotations ore used literal quotes from Englush" ", tranilated quotes " ", quotes within quotes " " or - All comments and addition on my part between equare brackets

Sabean, Power in the Blood and Properny Produchon and Fomily, Robisheaux, Rural Soczery and the Search for Order The notsons of Sabean and Robusheaux were first ducuseod in a Mexucan conlext by Ouweneel. "Alkepeme and Pueblos de Indiss" and Onderbroken groes

Average percentagea for the years 1570, 1600-1620 and 1640 calculated on basis of the date m Slecher ven Bath, Revolbing en economse oppendix I pp 215218

Gibson, Tharcala. Prem, Milpa y Hacienda, Ewald, Estudwas sobre lo hacienda colonial, Nickel, Sogale Morphologie, Trautmann, Wandel der Kulsurlandsehaf, Carrasco "Barnos antaguos". "Chrelly Housea" and "Lmajes noblea". Reyes Garcla, Cuaunnchan, Olivera, PIllis y macehuales

Wood, "Corporate Adjustments", Lockhart, "Spaniards between Indians", in Nahuas and Spaniands, 202. 242, Jarquin $O$. Melepec, Gibeon, Aztecs, some recent contributions about the early colonial wociety in the valley of Mexico Cline, Colonial Culhuacan. Hom "Pontconquest Coyoncan" On areas outsude the Central Highlands Haskett, Indigenous Rulers, Marun, Rural Soctery (bouh about the present atate of Morclos), García Martinea, Pueblos de la Sierra (about the Sierre Norte de Puebla), Dehouve, Quand les saunts dtauent des banquers (ebout Thape in the present state of Guerrero). Pastor, Campernos y reformas and Chnoce, Conquest of the Sierra (about the Murtea). Camagnan, El regreso de los dioses and Taylor, Landlord and Peasant (both about Oexaca) Farnes Maya Society, about Yucatin is perhapis the most influenimal sungle work about Indian rociety in colonid Mexico of the last decade Reviewa of the recent American research Taylor, "Between Global Process and Local Knowledge", Kıczo, "Social and Ethnic Hutorography" and for a sunmary of what in called the Nahuntl-school Lockhart. "A Vein of Ethno-Hestory" in Nahuas and Spaniards, 183-200

Hoberman Menco's Merchant Ehle, Lockhert, Nahuas and Spanuards

Van Oas and Slucher van Bath, "An Expernent", Van Oas, "Architectural Activity", Sheher van Bath, Spaans Amenka omstreets 1600, Bevolkng an economie, "Economic Diversification" and "Dos modelos" The regions as they were in the eighteenth century are also treated in Ouweneel, "The Economic Cycle" and Onderbroken groe, espectally 23-34

\section{Chapter 1}

Florentane Codex, Book XI, Chapter 12 p 247

The pyrarnid of Cholula was ectually colled "man mede mountain"

Van Zandwikk, Azlec Arrangement passum

Leon Portili, Tolsecoyou, 124

Forenture Codex. Book VI, p 87, bo wee below

Florentuse Codex. Book V. Chaptern 17 and 20

Florenture Coder, Book VI, Chapter 20

Reapectrveby Florentune Coder. Book VI. Chopter 43, p 252, Book X, Chapter 4, p 15, Book V. Chapter 43. P 525

Gibeon, Azlecs, 310, Slicher van Beth, Agrarische geschuedanls, 26, Orweneel, Onderbroken groe, 267

Relacion Geogrdfico de Tlarcala, 40 This Relacidn Geogrdfica wes writen by Muñoz Camngo

Relacion de Tepeaca, 15, abo Relacion Geagrdfiea de Thaxcala, 40

Knoblich, "Grundwaser", figure 1

Redacion Geografica de Thaxcala, 89 
14. About the climate abso Ounweneel, Onderbroken groti, Chapter III, 47-69.

15. Wilken, Goad Farmers, 27-28; Knoblich, "Grundwaser", figure 2; a map of the ground water level: Erffe, Whilges, Knoblich, Geologie des Hoctbecters, 107.

16. Gonzflez J., "Agroecologín", 211.

17. Wemer, "Consecuenciss"; Wilked, "Management of Productive Space".

18. Wilken, Good Famers, 99-101.

19. Sanders c.o., "Summary"; Gonzalez J., "Agroecolog th".

20. "Ast mismo, comen algunas perrillas, cuando son cachorras y estan gondas, porque dicen es buera came". Relacion de Cholula, 134.

21. Relación de Tepeaco, 232, 246-255; Relación Geogrofice de Taxcala, 95; description of Tecali in AGNTierna-Vol. 27-exp. 5.

22. On the role of maize-bortillas and their prepention in Mesoameriean culmire through the ages Bauer, "Miller and Grindere".

23. Reodon, "Mezaquiahuac", 104; Gibeon, Azrecs, 317-319.

24. Relación de Tepeaca, 245, 256; on indigenou tranoportation also Hassic, Trade, Tribute and Transortation, and more generally Cernesco, "Economin del Mexico prehiopinico".

25. Relacion Geogrdfica de Thaxcala, 42 and 39.

26. Relacion Geogrdfica de Tlaxcala, 42.

27. Relación del Conde de Moonterrey" in: Virreyes eppartoles, Vol. II, 159.

28. Letter of religious in AGI-Mexico-leg. 123-n $\mathrm{n}^{\circ}$ 68; description of Tecali AGN-Tierne-Vol. 27-exp. 5; Aguirr, Tacotepec, 93-94; Relacion de Tepeaca, 41.

29. Relacion de Tepeaca, 256.

30. Relacion Geografica de Thaxcala. 41.

31. On the geographical distribution of cuescomates and zencales Seele and Tyrakowsky, Cuescomate $y$ zercal.

32. Relación Geogrofica de Tlarcala, 78-79, also Florenine Codex. Book X, Chnpter 29 in which they are described as "untrnined, stupid, covelous, bazy and shifless" (translation by Devies, Aztec Empire, 21).

33. Reyes Garcín, Cwauhtinchan, passim; Olivern, Pillis y macehuales, 80-88.

34. In Nahuall the area was called Huebuequauhquechollan, liternlly 'Old Quauhquechollan'; a name atill uned for the area when the Spanish came. Motolinin, Menoriales, 325-326.

35. Motolinis, Menoriales, 327; quote taken from the tranolation of his Historia,

36. Calnck, "Patterns of Empire Formation".

37. Zoritn, Breve y sumaria relacion. This discussion of the allepet is based on the following liternture: Estratificacion social; Economlo politica e ideologia; Sociedad indigena en el Centro y Occidente de Mbrico; Carrasco, "Political Esonomy", "Social Organization of Ancient Mexico", "Amtrica indigenn" and "Loe mayeques"; Cline, "Land Tenure and Land Inheritance" and Colonial Culhuacan; Dyckerhoff, "Indian Corporate Landbolding"; Garcia Martinez, Pueblos de la Sierra, 65-105; Harvey, "Aspects of Land Tenure in Ancient Mexico": Hicks, "Tetzcoco in the Early 16th Century" and "Prehispanic Background of Coloninl Political and Economic Organization in Centrol Mexico"; Leon Portilla, "Mesoamerica before 1519"; Lockhart, Berdan, Anderson. "Preliminary Study"; Offner, Law and Politics; Menegus B., "La parcela de indios"; Olivern, Pillis y Macehuales; Reyes Gurch, Cwawhtinchan del Siglo XII al XVI; Spores, Mixtees in Ancient and Colonial Times. Also sce my "A Different Way of Thinking".

For a diecussion of the liternture and the sources see Borth. "Some Problems of Sources".

38. Hakket, "Indian Community Land", 133.

39. Borah, Justice by Insurance, 38, also wee hio "Spaniah and Indian Law", 270-272.

40. Hicks, "Tetzcoco in the Early 16th Century", 244; aleo Reyes, Cuawhtinchan, 115.

41. Zorith, Breve y sumaria relacion, 29, 30-32, 36.

42. Van Zantwijk, Azlec Amangentent, Chapters II and III, pp. 19-36; abo Davies, Toluec Resurgence and Aztee Empire, pasaim; summnrized in his Ancient Kingdoms, 164-191. Some additional information in Offner, Law and Politics, bout empire formation Calnek, "Patterns of Empire Formation": Rounds, "Dyonetic Succestion".

43. Gibson, "Structures of the Aztec Empire"; Davies, Ancient Kingdoms, 183.

44. Relación de Tepeaca, 226; about Tochimilco: Relacton de Ocopetlayuca, 256-257.

45. Hessig, Trade, Tribule and Transortation, 103-108; 145-150.

46. Relación de Cholula, 162.

47. About merchants Ven Zantwijk, Handel, 113-151; Hanig, Trade, Tribute and Tranportation, 113-126; Cerraco, Economba. About Choluth Relación de Cholula, 129-132; Carrasco, "Barrios entiguon".

48. Relacion de Tepeaca. 224 and passim.

49. DTSC, doc. 1, pp. 11-77; the historical treditions of Cunutinchan are eapecially well known beceuse of the ourvival of an elaborate hislorical manuscript from the colonial pueblo called Historia Tolkeco Chichineca, analysed by Reyea Garch in his monograph on Cuatinchan, in which he also used a 'Manuscrito de 1553' from the municipal archives, DTSC, doc. 4, pp. 8-100.

50. Relacion de Tepeace, 240.

51. "Documentos ... Nahums tramontanos", passim; Matricula, passim; Prem, "Entratificación", 176.

52. Relacion Geogrdfica de Thaxcala, 174-175.

53. Culnek, "Putterns of Empirc Formation", 59.

54. "Selores muy poderosos, Thaxcala no as debe vasallaje, $n$ il desde [los principion de au historia] jands reconocienon con tribulo il pecho a ninguin rey ni principal del mundo, porque siempre han conservado su Ilbertad. Y. como no acostumbrados a esto, no ke quertan abedecer, porque, antes morirdn, que tal casa como sta consentir. Antes entendemas que eso que les pedis, procurardn pediros, [v] sobre ello derramartn ands sangre que derranaron en la guerra de Poyauhilan. [...] con viestros ariepasadas, que fueron aquellos 


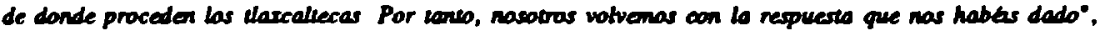
Relacion Geogrdfica de Tazcala, 178

-Cualquer vecuhlle que fundaba un veccall, que es ecasa de mogorosgos, o un pilcallh, que as acasa

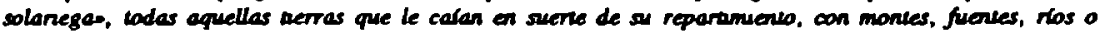
lagunas, somabase, para la casa prnopal, la mayor y mejor suerte o pagas de tierro, y lwego. las dends que quedaban, se repartan por sus soldedes, ongos y paneries, igualmente, y codos dros esto[ba]n abllgadas a reconocer la case major, y a acuder a ella con reconocumiento de aces y cezas y flores y remas

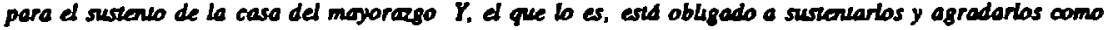
[e] anigas de aquella casa y panantes della $Y$ ans, se llanan ceirhuhuas, que quere decr alos nietass, de la casa de lal parte $U$, en estas repartunertas de herras, se reparmeron a verrazgueros e hachon poblazones en ellas, y detas eron vasallos que, como vales, les pagaban inbutos de las casas que criaban y cogtan, y por este orden, wueron a ser carques y sentores de muchas gantes y vasallas que los reconoctan y pagaban vasallaje, de los cuales vasallos findaran pueblas y ugares muy princtpales con que se sument-

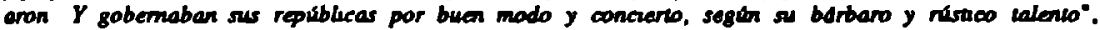
Relacion Geogrdfica de Tharcala, 174-175

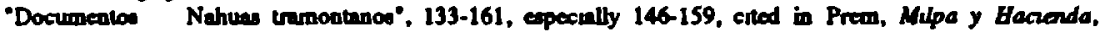
56-57

58 DTSC, doc 4, p 83

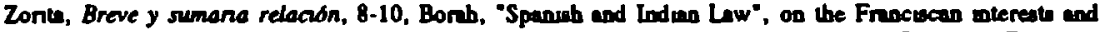
way of lookng at the Induas and the colony Phelan. The Francescan Mullerium. Breding. The First Amenco, passm

Zonth. Breve y sumaria relación, 113-114

This wes most clearly the case in Huejotango "Documenios

Nahuas tramontanos", 146-159

Zonta, Breve y sumana relacion, 31

See the Englieb edivon of Zonta, Breve y sumana relacion. edited by Keen, 93.94 (Spanob edition page 16) Also compare oole $10 \mathrm{~m}$ the English edition, 296-297 Zonta, Breve y sumana relacidn, 10 See as

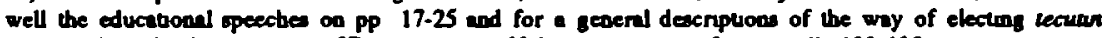
among others the description in "Documentos Nehuas tramontanos", especally 133-139. Compare Sulliven, "Thaboul and Thabcayol"

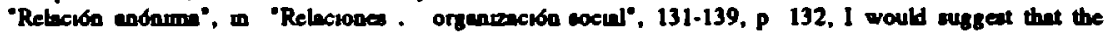
Nahuad equivaleat of suerke is mecate

"Trabajo tores an este su pueblo de dea, y de nache porque no tomas suelo con quetud, por ser labredor. y andar siviente. a aquel con que vives neves a punto mus sandalias, bordon, y azada, con lodo b dends, que pertenece a in ofico, que por ser labrador lo has menester, para ur a ut trabajo, an el cual los diases te pusieron slando esta us suerie y vestura, y no de mds aluve, y presumpadn naciendo para servir a otro. plsanda barro, y haciendo adoves, de mes de lo culura, que tienes en el campo ni desmates, que con esa vida, y ocupacion suves al pueblo. y al setor y con ese trabajo tendrds lo necesario para $h$, y paro th muger y hyos loma bo que pernenece a a ofico. trabaja y sembre y coge. y come de bo que rrabajares", Torquemedo, Monarqule Indiana, Vol II, 496

"Il fueres peraso al el pueblo, no podrds vivi y serds deshechado de lodos, y hards mucho mal, y dato a in muger, y hjos, y mi hallards casa, nu lugar donde queran acogerie, antes caeras an grande undignaabn. y aborrecumiento, y segurte ho mucha mala venturam no condrds hacienda, y esto serd por w culpa viverds an lacerio, y pobraza, por an desobedlencza [ ]'. Torquemeda, Monarquia Indiana, Vol II. 496

"Relación snónums". 133

69 In the tume the thibute abligatoune of table 1 I were recorded, the social relations of the Indian world had not yet broken down. the caciques uvolved even uned to retan their old nght by way of the laweut for which the documents on which this table based were compuled In this bght these documents may be regarded as indreatug at least part of the pro-conquest nght of adigenous nobles. For trentment aleo ree Reyes Gureh, Cuaunnchan

Hoektre, "A Duffereat Way of Thunkeng", Relanion andinma, 131, also see below

Rojes, "Coarequel", Gibeon, "Llanameanlo Gaveral"

Marriaula, if S0lv-S04v, e 8 the padron of Sen Junn Teqpan Huexozinco in the Martale, fecaumles of ff 482r-494r, Carneco, "Lmajes nobles", $19-20$

73 "Pudron de nobles de Ocoteloko", in Pedrones de Tarcala, 309-325, 67 of the pocheca were Ulechulitique, i c 'already counced', for other exemples CDCT. peem, epecially docs 170-186. pp 411-521, DTSC. passom, Coleccion Coyaacan, pasam

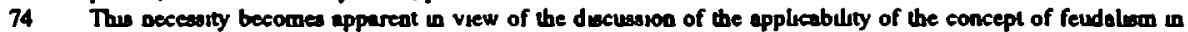
the case of the Maye berween FreideL "Lowhod Maye Polubeal Economy" and Adama and Smrh. "Feudal Modeb", both takmg Coubom, Feudakm un History (1956) a theur point of departure In 1960 Slicher van Bath hes critened Coulborn's ducusion of feudelism al limited, because it wes wo much focused on the

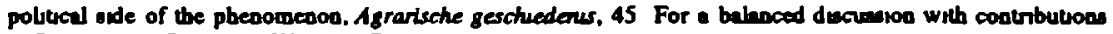
of Brunner and Bloch see Wunder, Feudahonus Slucher van Batb, "Hoven op de Veluwe" Wickham, Mountaiss and the Ciny, pasem

Davies, Small Worlds, 184-185

'Herrachaft', m Geschichlliche Gnundbegnffe, Brunner, 'Hermehnf'

Robuhcaux, Seanch for Order, 8.9

Meckey, Spain un the Muddle Ages, 105

'Hernchnf', 8, aleo Brunner, "Hemehnft'

Brunger, 'Feodalumus". 113 
83. Wunder, Bmertiche Gemeinde, Chapter 2. Pp. 12-25; Sprondel, Vefocsung und Gesellsehaft, Mitueis, Staat; Slicher, Agrarische geschiederis and Mersch an land; Blickle, Dentsche Untertanen.

84. Robishenux, Search for Order, 4.

85. Miteis, Stoar; Slicher, Agrarische geschiedenis, Measch an land; Sprandel. Verfassung; Blickle, Deusche Untertanen; Sabean, Power in the Blood and Property, Production and Family; Robisheaux, Search for Onder, Wunder, Bawerliche Geneinde; for Spain Altmin, Enigrants.

86. On the Spanish communities Vasaberg, Land and Society and also MecKny, Spain; Altman, Imnignants and Society etreases the importance of family and peronal ties in sixteenth-century Extremedure.

87. Bruaner, "Hernchaft", 74-75 and pasimin; Weber, Wirtschaft und Gesellschafi.

88. Brunner, "Hermehaft", 72.

89. Brunner, "Feodalismus, 113-114.

90. Brmner, "Hermechaft", 8.

91. Brunner, "Hermehaft", 75; also compare Breding, The First America, pasaim; Les Ceme, Apologetica, 212 and Torquemade, passim.

92. For example Dumbabin, "Government".

93. Dumbabin, "Government"; Quillet, "Community"; Southern, Mabing of the Middle Ages, $108-109$.

94. Bosay, Christianity in the West, passim, expecially Chapter 1, pp. 3-13 and 4, pp. 57-75.

95. Se provedan y gobemaban, o se hablan en el reginiento de st mimos, que se llama mondstica, cuasi gobemación de uno, y en la domestica o patemal o economica, an lo que concieme al entendiniento y uso de razbn, y [...] se hablan y sustentaban antes que vinitsemos los espatoles an la de la ciudad o políica". Lan Canas, Apologetica, 211 and passim; also nee Hanke, Siruggle for Justice.

96. As Appleby exposes, the separation of economics from political and moral theory only occurred in the eventeenth century, inspired by political motives, Appleby, Economic Thought; for some striking modem parallels, Gudeman and Rivern, Conversations.

97. Brunner, "Ganze Haus", 106-108.

98. Florentine Coder, Book VI, Chapter 15, p. 79.

99. Torquemada, Monarquia Indiana, Vol. II, pp. 497-499.

100. Sullivan, "Toloani and Tarocayotl".

101. To see the confliet of intereats of we only have to think of the dispute of the right of inveatiture. See for example Southern, Westem Society and the Church.

\section{Chapter 2}

1. For the Spanish context Elliot, "Mental World", in: Spain and its world, 27-42.

2. Simpoon, Encomienda, xiii.

3. Porque es cosa justa y razonable que los dichos indios naturales de la dicha tierra nos sinvan y den tributo en reconocintiento del senorb y servicio que como a nuestros súbditos y vasallos nos deben y somos informados que entre ellos antre st lentan costumbre de dar a sus tecles y setores principales cierto tributo", Miranda, Tributo, 53.

4. "Provincias o pueblos, los que paresciesen más provechosos y de más calidad", Mirande, Tributo, 54-5; cited from Gercla Icazbalteca, Coleccion de documentos, Vol. I, p. 470.

5. De esias partes son de mucha razon y orden, y acosumbrados a contribuir a Moctezuma y a sus sentores, como los labradores de Espana". Miranda, Tribulo, 55; cited from Gercla Icazbelleca Colección de documerios, Vol. I, p. 470.

6. Miranda, Tributo, 62.

7. Leyes Nuevas reproduced in Muro Orejon, "Las Leyes Nuevas, 1542-1543n"; Simpaon, Encomienda; Pietschmann, Estado; Garcla Gallo, "Origenes".

8. For example: "Don Hemando de Guondn, cacique del pueblo de Tamarulapa, y sefor natural de ello". LdA, 390 ; "Don Juan, hijo del senor narural del dicho pueblo [de Acatlan]", LAA, 430.

9. Simpson, Encomienda; the law prohibiting to use the tille of sefores for eacigues dates from 1538; in the ecventeenth century it wes incorporated inlo the Recopilacion, Libro VI, Titulo VI, Ley V, p. 220.

10. DTSC, doc. 28, p. 149.

11. Corte, Carras y documentos, 360-362.

12. Grent to Doña Isabel on 27 June 1526: Tacuba itself had 120 bouses; the estancias: Yetepec 40 houses, Escopuhuthongo 20 houses. Jilocingo 40 houses. The number of houses in Cectepec. Telasco, Guanuzeo and Tesula is not mentioned. Grent to Doña Marfa 14 March 1527. About Ecatepec no numbers of housea are mentioned. Corts, Cartas y documentos, 360-362.

13. Ricard, Conquista espirimal, passim.

14. Van Ona, "Mendicant expansion" and Catholic Colonialion for a comparative perspective on Guatemnla; Ricard, Conquista espiritual; Clendinnen, "Disciplining the Indians" and Ambivaleat Conquest; Brading. "Images and Profets".

15. Van Oas, "Mendicant Expansion", 42.

16. Breding, "Images and Profets", 186.

17. Especinlly see the works of Motolinin.

18. Van Oas, "Meadicant expansion"; Ricard, Conquista espiritual; Kubler, Arquitectura.

19. Van One, Cacholic Colonialim, 16.

20. Brading. "Images and Prophets", 187; Van Oss, Cacholic Colonialim, riii-xiv and the deseriptions of Motolinin and Mendieta.

21. Van Oss, Catholic Colonialism. 17. 
22. See Chapter 5 below.

23. Van Ons, Catholic Colinialion, 23; evventeenth-century Frenciscan chroniclen like Torquemede and Vetancur complained about the deteriorated monl etandard of the frine of their order.

24. Gibeon, Azten, 122-135; the bed treatment of the income of the parish clergy, albeit in Guatemala, in Ven Ons. Calholie Colonialison, Chapter 3, pp. 79-108. Aleo Cee Chapter 5 below.

25. This changed in Inter times. Garct Martinez describes how in the eventeenth-century Sierm Norte de Pueble the members of the encomendero family of Carvajal were patemalist protector of their encomienda Indian. Garcin Martinex. Pueblas de la Sierna, 233-235.

26. Van Oss, "Mendieant expansion"; Ricard, Conquista copiritual; Kubler, Anquitectura.

27. Mendieta, Hirsoria Eeleslartica Indiana, Libro III, Cepitulo XXII, "De dos cosas en que los conquintadores y los dems eapañoles de la Nueva España tienen gnade obligeción a los religionos de ha onden de San Francimco", pp. 140-141.

28. A number of these carby advicen is publinhed in Garem Icazbaheca, Coleccion de docwnentos and treated by Miranda, Tributo; Simpeon, Encomienda; Zuvala, Encomienda indiana; Pietschmenn, Estado.

29. Motolinth, History, 280.

30. G6ngore, "The Instibutions and Founding Idess of the Spanish State in the Indics", in: Snudies, pp. 67-126; Garcin Gallo, "Origines"; Simpson, Encomiende; Pietschmann, Erado.

31. Pietuchmann, Estado; Gercin Gallo, "Origines", Verlinden, "L'étht".

32. An exact datine in impossible and regionally different, Simpson, Encomienda, 112-113; Chamberhin, "Corregidor" an exhausting analyain in Gerhard, 1 Guide, passim; for come more specialized treatmenta: Valley of Merico: Gibwon, Aztecs, 86-91; Sierro Norte de Puebla: Gurefa Marlínez, Pueblos de La Slerra, 84-86; Mirtece Alta: Putor, Compesinas y reformas, pasim; the mber intricate and constantly changing ixteenth-century Spaniah edminintrative organization of Thaxcala: Gibeon, Thaxeala, 66-79 and appendix IV, 114-119.

33. AJP-1582, Sucecion de blenes de Don Diego Ptrez de Artiaga; the calary of the moyordomo of the hacieode AJP-1619, Sucecion de bienes, Hacienda San Bemardino, Larenzo Marth Cortd, f. 268r (hereafter: AJP1619-San Bemardino).

34. Recopilación, Libro V, Tf́tulo II, Ly III.

35. "[...] Conviene que los indias sean en tal manera regidos y gobemados, que ellos reciban algün contentonierto del tal goblemo, para que multipliquen y no se vayen acabando como hasta aquf, siendo regidos y sojuzgadas por personas que miraban mas su propio interts que la salud de los indias, ni su buen gobiemo; y por lanto parece que la juriedicción de toda lo tierra debe ser al presente colalnente de su Majestad, y que los que la ejercteren en lo civil y criminal, sean puestos por su mano o de su gobemador, y que esta jurisdieción se reparta por provincias [...]", CDHFSH, Vol. I, doc. 83, p. 151.

36. "Tem, parece que a los caciques por quian los indios se sollan gobemar, no se les debe quitar enteramente la superioridad que sobre ellas han tenido, antes se kes debe conceder que puedan compeler a los indias a que trabajen an sus haciendas y que no vivan ociosanente, y se les debe dar alguna manera de jurisdiccion y gobiemo sobre los dichos indios, porque si sus caciques, siando avisados e industriados de lo que han de hacer, acierian a regir bien, muy mejor y con mas grado de los indios se hard el gobiemo[...]", CDHFSH, Vol. I, doc. 83, p. 151.

37. Slicher ven Bath. "Spanje en de Peruanne Andes"; Pietschmann, Estado; Gach Gallo, "Orfgines", "Constitución", "Organización territorial"; G6ngora, "Institutions"; Hoekstra, "Different Way of Thinking" and "Changing Order". For Europe: Mitteis, Staat; Blickle, Deutsche Untertanen; Sprandel, Verfassung; Wunder, bauerliche Gemeinde; on the legal construction of the pueblos de indios, Gareln Martinez, Pueblas de la Sierra; Haskett, Indigenous Rulers, 27-29.

38. Prem, "Con mesa".

39. Motolinin, HLstory, 319-323; Hunke, First Social Experiments; Kubler, Merican Architecture; Chevelier, "Significancie rocial"; Hirsehberg. "Alternative to Encomienda"; Prem, "Allixco". The Franciscans abo had influeace on the developments within Huejotzingo (see above chapter 1 and "Documentos... Nahuse Inmontanos": Gerhard, A Guride, 56; AGI-Mexico-leg. 340; AAP-Suplemento del Libro I-f. 90v.

40. Huejotzingo-Tochimilco: LdA, 433-434, 12 February 1552; Calpan-Huejobingo: LdA, 400-401, 9 November 1551; Hugjobingo-Spaniards in Atlirco: LAA 59-60, 21 January 1551 and LdA 130, 30 April 1552.

41. AGI-México-leg. 340-pasim.

42. DTSC, doc. 1, pp. 11-78, especially 57-58 and 61-67. The Indian Murtin Suchi declared that they were -Indias pobres, macehuales rewoliosos e de poca verdad y los riene a vodos las del dicho pueblo por personas que prevenden juntarse con las del dicho pueblo de Guatinchan a $b$ menos la estancia de Yacacingo [=Acatzingo] y por ser de tal calidad cree y tiene por cierto que an las dichos que dijenon declararon el contrario de la verdad", p. 65; for a more profound treatment ace chapter 6 below.

43. Comenzesen a envender nuestra manera de vivir, as an al gobemación como la poliefa y casas de la repáblica", CDHFSH, Vol. I, doc. 67, p. 133.

44. Garch Mhrtinez, Pueblos de la Sierra; Haketl, Indigenous Rulers.

45. For the view of Carmagnani see his Regreso de las dioses.

46. Also extensively trealed in Hesketh, Indigenous Rulers; chapter 6 below. For the situntion in 1550/1551: "Relación de Antonio de Mendeza a Luiz de Velasco al término de au Gobierno. Sin fecha ca.1550 o 1551", in: Vireyes espatoles, Vol. I, pp. 38-56, pp. $49-50$ (hereafler cited we Relación de Mendoza).

47. Zorita, Breve y sunaria relacion, 166-167.

48. "Inatrucción a Antonio de Meodoza" in: Virreyes espanoles, Vol. I, pp. 22-25.

49. Relacion de Mendoza, 42; "C6subs parn que donde el tributo de los indios fuere reducido a dinero vuelva a low frutow (28-VII-1552)" in: CDHFSH, Vol. I, doc. 216, p. 308.

Mantles were part of the indigenow syatem of distinctiva, which dinappeared after the conqueat. With this 
mantlea had become partially superfluous.

50. $\quad[. .$.$] En verdad, que si hubiese de hacer lo que se aconseja, que ya la tierra estaviera trastomada de abqjo$ amiba veinte veces [...]. En bo de los indias son tantas las mudanzas, que algunas veces he dicho que bo hemas de volvertos locos con taveos ansayos. En diez y seis ahos anda que vine a esta tierta, y todos bs he gastado en mirar y procurar de entenderla, y podria jurar que me hallo mas nuevo y mas confuso an el gobiemo de ello que a principios, porque denuestran inconverientes que aries no vela ni artendia". Relación de Mendoza, 55.

51. Relación de Mendoza, 50.

52. Mirande, Tribub, 9, 140.

53. Relacion de Mendoza, parim. In 1554 there was a decree inotnting the cajas de comroridad, but legislation on thin in not clear, Gibson, Azees, 187, 213; Garcln Martfoez, Pueblo de la Sierra, 102-105. In the Siern Norte there in some pueblas there were cajas es earty at 1553, but eleewhere they were introduced hater on. Both the Historia Tolveca Chichimeca and the Codex Aubin mention the introduction of coins (lomines), which may be interpreted a designation of the introduction of alaries for the officials in the pueblos as an important episode in their history. In Tecali, Calpen and Tecamachaleo the caja was introduced in 1564, Libro de tasaciones, respectively 366-367, 131-132, 371-372. Apperanlly cajas were only introduced in the present stute of Morelos in the 1570- Hesketh, Indigenous Rulers, 62-63.

As antter of fact the trangition from personal to 'Aministrative' income did not only occur in mixteenth century Mexico, but abo in nineteenth-century Nigeria under English rule, where it caused jus w much problems of edaption. Peel, Jjeshas. Also Saltumen, "Feudal Relationships".

54. Libro de tasaciones, pasuim; Modo de tribusar, peasim; Mirande, Tributo; Cook and Bonh, "Stratification sociale"; Gibeon, Aztecs, 196-200; also Hockstre, "Different Woy of Thinking" and "Making of the Pueblo"; for the Andes arean Slicher van Bath, "Spanje en de Peruanse Andes".

55. "Instrucción a Luis de Velasco" in: Virreyes espanoles, Vol.II, Pp. 142-143.

56. Relación de Mendoza, 49; Gerhard, "Congregacionea"; Miranda, "Población ind lgena de Oaraca", 140-141; Debouve, Quand les banquiers diaiat des saints, passim; Garcla Martinez. Pueblos de la Sierra.

57. Gerhard, "Congregaciones", pp. 358-362; Thareala: Thaxeala was moved from 1530-1545/50, Gibson, Tlaxcala, 125-128; Huejotzingo: "Documentos... Nahuas tremontenos", 153-155; Prem, Milpa y Hacienda. paseim; Tepeaca: Relacion de Tepeaca, 232-237 and Anales de Tecamachalco, 20-24. Notwithstanding the counts of the 'macehualtin' of Quechula and Tecamachalco the alcalde mayor who wrote the relocion geografica in about 1580 renarted that only the Indians therneclves undentood which tributarias belonged to which pueblo, Relacion de Tepeaca, 240-241.

58. The social experiments of biahop Vasco de Quiroja can been seen in the light of the congregations. Gerhard, "Congregaciones", passim; Mirande, "Desplazamientos"; Gibeon, Azlecs, 47, 5456.

59. "Concierto pare la población y paz de los pueblos de Tepeace y Acacingo. Acatzingo, marzo 30 de 1558", CDCT, doc. 73, pp. 243-246; Gibson, Taxcala, 136-137; Actas de Tlarcala, 378-380 (Spanish translation of the original Nahuatl text, pp. 180-181, henceforth references to the Spanish text).

60. Gerhard, "Congregaciones", 352-353; Relacion de Mendoza, 45. Unfortunately Mendoza did not aubatantiate his warnings.

61. To my knowledge there are no equivalents in either Engligh or Spanioh for theae Geman concepts. Of course, they are dichotomy, devised for analytical purposes and in 'real life' things were urually more complicatod. The idea was first introduced into Latin American hirtory by the Slicher van Bath, in "Spanje en de Peruanse Andes". Also see my "Different Way of Thinking" and for an extension of the argument Ouweneel and Hoekstre, "Tierras concejiles".

62. The discussion on sixteenth-century demographic development bas not abatod altogether. A general critical evaluation of Cook and Borah's calculations is to be found in: Zambardino, "Mexico's Population in the Sixteenth Century". Despite all criticiam the the calculations of Cook and Borah have found their way to many generd worts, of which N.Sénchez Albornoz, "Population of Colonial Spanish America" in a recent example. A recent review of the literature and an attempt to build a quantitative model on basin of them Whitmore, "Sixteenth-Century Population Decline". A general treatment of the 'silent tragedy of the Indians' in: Slicher van Bath, "Stille drame van de Indinen". Studiea on the demogmahic development of seventeenth-century New Spain in genernl and the valley of Puebla in particular: Slicher van Bath, Bevalbing en economie; Miranda, "Población indigena", 182-189; Vollmer, "Evolución cuantitativa"; for New Spain in generd, but not very relevant for my purposes: Cook and Bornh, "Royal Revenues and Indian Population" in their Essays, Vol. III, pp. 1-128.

63. Cook and Borah, Essays; Slicher van Bath. "Calculation"; a recent criticiem by Kellogs, "Households", although perhaps she leans too heavily on urban evidence from Mexico-Tenochtitlin; The reliability of the tribute date for Peru are treated in: Cook, "Population Datn for Indian Peru".

64. An example of a tributeregister in the Indian trodition (with Spanish comments of an interpret with the glyphs): Matricula. A similar register, but in Nahuntl text written in the Latin alphabel: Padrones de Thaxcala and e.g. the lists in the documedt concerning the congregation of Tecali in AGN-Tierras-Vol. 2754, exp. 4.

The Franciscan sources:

-1570: "Relación particular y descripción de toda ha provincia del Sento Evangelio..." in: Nueva Coleccion, Vol. II, 1-28.

-1588: BNM-AF, Caja 89- exp. 1376-f. 1; and Scholes and Adams, Moderacion de doctrinas, passim.

-1623: The Franciscan count for the Moderacion de doctrinas of 1623 in: BNM-AF-Caje 89-exp. 1376. The frime report to have used the tribute registers of the pueblos; Scholea and Adams, Maderacion de doctrinas.

65. For example Martin, Vagabundos.

66. Hinchberg, "Alternative to Encomienda". 
67. $[$...] En esta ciudad de Mtrico hay muchas indias vaganumdas, as naturales de ella como de otras parkes gue acurren y vienen a esta ciudad, bs cuales sin trabajar ni querer senvir a nadie se andan holgazanes y cometiendo algunas acesas que la aciosidad da ocasibn a ellas; y porque al blen de la repablica conviene para que cese lo susedicho y otros inconvenientes que de ello podrtan suceder y que extos tales indias se pongan con anas y que haya padre de ellas que congan [aic] cuidado de las poner con amas". LdA, 14-15, repented on 16 November 15S1, LdA, 39.

Also compare the next decree: "[...] En exta ciudad de Mtrico y Mueva Espata hay muchas espatoles, mestizas e indias algunas que sabiendo oficias no quieron wabajar al asentarse con anos y ander ociasas y vagabundos, de que Dias y Su Majestad son desenvidos y La república dannificada. Por ande, queriendo obviar los inconvenientes que de ello se siguen y pueden seguir, mand[o] que dentro de veinte dlas prineros siguientes, los espatoles que saben oficios las usen y los que no las saben avientan con amos y tomen honerta manera de vivir, y las mestizos o indios lwego usen sus oficios los que los saben y los que no saben oficto of asientan con oficiales o con otras personas a quier sinvan. por mavera que no anden ociasas ni pendidos, so pena las apatoles que dentro del dicho termino na lo hicieren de caer en la pena de las vagabundos y que se mandardn echar de loda erta Nueva Espana, y a las mestizas e indlas de cada cien azotes y que el denunciador se sirve de ellos como de vagabundas y para que venga a noticia de lodas se pregone pablicaneste [on the central squnre of Mexieo]", LAA, 13.

68. Marricula, 49-50; Lopez de Velasco, Geografio, 107.

69. Indian migration inlo Thaxcaln: Matricula, 49-50 and passim on huidas; Indinn migration in general Miranda, "Poblacion indigene", 184; in the eighteenth century: Slicher van Bath, Bewolling en economie, 51; Ouweneel, Onderbroken groel, 77-91 and "Growth, Stagation and Migration".

70. Figure for Cholule and Huejotzingo:

\begin{tabular}{lcr}
\hline \hline Year & Choluh & Huejotzingo \\
\hline 1623 & 6496 & 4008 \\
1626 & 3644 & 2027 \\
\hline
\end{tabular}

Sourees: Scholes and Adams, Maderacion de doctrinas, 47-48; Gerhard, A Guide, 115, 142 and notes on p. 426 (Cholula) and 428 (Hucjotzingo).

Spanith vereion of the quotation: 'Que de mis de siele alos a esta parte se han ido a ella muchos indios huidos de otras partes que se ausentan de su naturataza solo por no pagar el tributo que deben a su magestad [...] [Atento a que ellos por] no estar expadronados ni estar de asiento en ninguna parte y me pidieron mandase fuesen conpelidos a pagar al tributo como los demas naturales de la dicha ciudad". AGN. Indios-Vol. 4-exp. 30-ff. 8v-9r.

71. '[...] Alguros indias de Thaxeala, Guaxoelngo, Teguantepec y otras partes se han venido cada dla poblar al dicho pueblo de Guajaca [Oereca] y tienen en al sur casas, mujeres, hijos y tierras, y [...] aknque gozan de ellas no quierer pagar tributos, siendo a ello abligados, de bo cual el pueblo recibe agravio". LdA, 357.

72. For Europe see among others Hochstedt, "Migration"; Chert, "Migration"; Clark and Slack, English Towns; Jones, Politics and Rural Socien: Lucansen, "Seizoensigebonden trekarbeid".

73. Whitmore presents a model in "Sixtcenth-Century Population decline", which is eapecially besed on the figures of Cook and Borah, in which be unfortunately complete neglegts migration.

74. On the distinction between migretion and congregation Gapcía Martínez, Pueblos de la Sierra, $156-163$.

75. AGN-Indios-Vol. 5-exps 267-268-f. 141r; exp. 271-f. 142r.

76. "Advertimientos de Antonio de Mendoza" in: Virreyes espastoles, Vol. I, p. 47.

77. Relacion de Tepeaca, passim; Anales de Tecamachalco, 36; On the internal colonization of Thexcala: Trutunann, Koloniakeidiche Wandel, 24-25 and 76; AJP-1605-Sarla Maria Nativilas contra Juar Jimenez de Riancho. Further proof of relative overpopulation in the penistent erosion of egrieultural land in Thexeala: Werner, "Verbreitung, Nützung und Zentōnung von Böden", apecially p. 16. Many mignnts went to Thaxcale because this province was exempt of tribute.

78. AGI-MExico-leg. 600, passim; Gerhard, A Guide, passim; Slicher van Bath, Bevolbing an economie, passim.

79. Simpson, Encomienda, 149, transtated from a letter of Velasco of 1553.

80. Relacion de Mendoza, 43.

81. Prem, "Atlixco".

82. Colección...tributos, 39.

83. LU, pasim, in hter times the pueblos de indios were also obliged to mainthin certain roeds. For an example from Cunuhtitun in the valley of Mexico which was ibuted on the road to the oilvermines in the North, AGN-Tiems-Vol. 2003-exp. 5 (1599); Vol. 2026-exp. 2 (1644).

84. LAA, 169.

85. Garclin Martinez, Pueblos de la Sierra, 137 and Map 5, p. 147.

86. Prem, Milpa y Hacienda; Trautmann, Koloniakeilliche Wandel; Garcin Martinez, Pueblos de la Sierra, 143; Simpeon, Exploitation of Land; Lewis, "Mexico City's Shadow"; Gibeon, Aztecs, 277-279; Konred, Santa Luclo.

87. Vasaberg, Land and Society. 
2. Gibeon, Aztecs, 282-299 and 403-409; the exmple on pp. 294-295. Prem abo contributes to this picture: Milpa y Hacienda, 164168 and pansim.

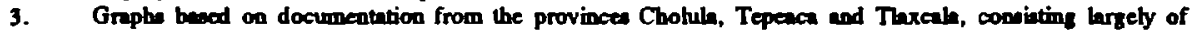
hndeale by Indians to Spaniards, provening from noterial archives, completed by other documents. Documentition on the mercedes comes from the AGN, in which I have used the cainlogue of the Rono de Meneedes. For the provinec of Huejotzingo I have used the dath as they are presented in Prem' a monograph Milpa y Haclenda, compleiod by information from the Registro de Intrumentas Publicas of the AGET. Not all province are equally documented. Most fully documented are Thaxalh and Huejotzingo. Although the number of badeales in these provinces is not complete, I wee no reaen to curme that the material would not be representativo. The dati for Thereal are the mont relieble; for the entire period of 1570 to 1608 they come from the noturiel erchives of Thexalh, which are mither complete. Nareala: AGET-RIP.Vol 1-20; Cholula: Protocolos de Cholula; Tepeaca: AGNot-Ventas de Tiertas de Indlas in varioun paqueten. Huejotzingo and Allixco: Prem, Milpa y Hacienda, and for Allixco only aleo Prem, "Atlixco", 205-228; AGET-RIP.

The cathogue of the Ramo de Mencedes ha not been checked for exectneas; for the genenl approach used bere it is aufficient

4. Datn on tithes in: Medina Rubio, La iglesia y la produccion agricola 118-124 and cuadro 2, p. 176; aleo Schwaller, Origins of Church Wealth.

5. Floreacano, "Abadto y legielacion"; Frank, Mecican Agriculoure, Wolf, Sons of the Shabing Earth.

Number of mercedes in graph 3.2; conflicts on tand between Indinas and Spaninds are treated in: Hocketre, "Different Way of Thinking".

6. On Indian landue see chipter 1 above.

7. Ouweneel. "Xaltipan"; Prem, "Alixeo", fig. 9.3: Hinchberg. "Alternative to Encomienda", 241-262, 258. Abo Ewald, Estudios sobre Ia hacienda colonial, on the Jesuit haciende Los Reyo and the eighteenthcentury map, which showe a marh on the haciende.

8. The background of Spanisb agriculure Vassberg. Land and Sociefy; for colonial agriculture Ouwencel, Onderbroken groai, pasaim and "Ejghteenth-Century Thaxcalan Agriculture".

9. Vasabere. Land and Saciety, 11 and pasim; MecKny, Spain in the Middle Ages, 41-44; also compare de Solano, "Tenencia de tierre".

10. Vasbers, Land and Society, 85-86.

11. Theac rights are extensively trated in Vanoberg. Land and Society, 7-8 and posim; there was no basic difference in the rights of different kinds of communities to hand, only the size of their entitlement differed.

12. For a case containing all these elementis see Protocolos de Cholulo, from p. 467-515; a juridical thudy of the colonial amparo, Nophal de Parr, "Amparo colonial".

13. Borah, "Spanish and Indian Law" and "Statur jurfdico"; Hoeksten, "Different Way of Thinking".

14. AGN-Tiema-Vol. 2003-exp. 5; Torquenada, Monarqula Indiana, Vol. II, Cap. XXX, p. 478.

15. "Releción del Marque de Monteschros", in: Virreyes espatoles, Vol.II, pp. 277-283, especially 283.

16. Onder of viceroy Conūn of 7 Jenuary, 1581, AGNot-Tepeaca-Paquete 40/I-exp. 69-ff. 7r-16r; published in $C D C T$, doc 182, pp. 489-495.

17. AGN-Tiems-Yol. 25-exp. 1-f. 40r. Excerpt from the onderanza: "[...]En acuendo de mi Consejo Real de las Indias as doy comision poder y facultad para que reservando anse todas coses lo que os pareciere necesario para plazes, ejidos, propios, pastos y baldios de los lugares y consejos que estan pobladas, arf por lo que toca al estado presente como al porvenir y al ammento y execiniento que puede tener cada uno y a los indios lo que hubieren menester paro hacer sus sementeras y labores y crianzes lado lo dands lo poddis conponer y sirvikndome les paseedores de las diches tierras, chacaras, estancias, cortijos y caballerias con lo que as pareciere justo y razonable según la calidad y cantidad de las tierras que tienen y paseen sin justo y leglino urulo se las padais confimar y darles nuewo ofulo de ellas y para que a les mismo y a extancias con buenas urulos quisieren nueba confimacion de ellas se las podais conceder con las clausulas y fimmezas que les conviniere sivandome por ello con lo que fuere justo y con ellos consendndose.

$E$ otra $S_{1}$, para que las tierras no an sido ocupadas ni repartidas reservando siempre las necesarias para los ugares y consejos poblados y que de nuewo conviniere que se puebla y para las indias las que hubieren menester y les fallare para sus sementeras y crianzas lodas las demas padais dar y conceder de nuevo por tierras, estancias, chacaras y estancias de molinas a quien los pidieren y querieren mediante la dicha compasicion", AGN-Tierme-Vol. 25-exp. 1-f. 40r, abo see Chevalier, Formacion, 326-328 and MecLachlen Spain's Empire.

18. Chevalier, Fomacion, 327-329.

19. ‘[...] No se aprovecha de ellas por estar eriasas y por romper y [tengo] otras muchas [tierma] an que [hago mio] milpas", e.g. Protocolos de Cholula, 468.

20. For example Protocolos de Cholula, doc. 1, p. 1: "De las quales [tierras] no se aprovectio por estar en la cienega a donde no se puede labrar por la mucha agua".

21. Excerpt: "La eperiercio b va mastrando que hoy muchas personas que tienen contidad de tiemas y estancias sin las dichas justificaciones sino solo cuando otras as pidan se les haga merced de algurins demastas en tierras semejantes y que se les han concedido mandaniantos acordados por al Virrey y echose diligencias sobre [ellhe] con costas y gastos quieren las que las poseen valerse de la Real Codula haciendoles contradiciones con ella y causandoles pleytas y pretiando haberles de preferir en la merced defraudando con esto el derecho del Real Fiscal", AGN-Tierras-Vol. 25-exp. 1-ff. 40v-41r.

22. Por el presente mando que dentro de seis meses primeros siguientes que corran desde el dia de la fecha de erta mandanionto tadas y qualesquier personas de qualquier calidad y condición que sean, que tuvieren y paseyen tierras y estancias sil justo y legtimo arulo acurren anke mi a conponerse con si magertad con bo que poreciere justo y llevar de ellas anilas [...] bastortes según por la dicha Real Catula se dipone," AGN-Tierns-Vol. 25-exp. 1-f. 41r; abo letter of Don Luia de Velaco in AGI-Mexico-leg. 23-co 16. 
AGET-RIP 13-ff 288-291, Prolocoles de Cholula, pasam, AGET-RIP 12-13, pasam, Trautmann,

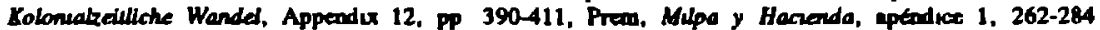

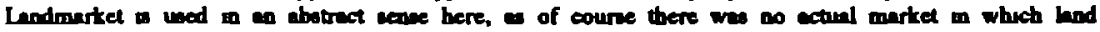
innesctrons took place on the spot

AGN-Tiern-Vol 74-exP 5, AGET-RIP 13-ff 3-6v

AGET-RIP 13-f 292-294v, AGET-RIP 13-ff 323-326v, AGET-RUP 13-fi 95-96v

AGET-RIP 21-ff 298-330v, AGET-RIP 21-fi 235-237v, AGET-RIP 20-ff 497-498v, Rendon,

"Mazzquaburec". 101

Protocolos de Cholula, 467-515

Cancen tiken from Torales, "A Nowe", respectuvely 95-98, 98-100. 100-102

AGN-Tiems-Vol 74-ex 4, 7 October 1605 The consultong of the Indians about whether or not the hand m queation were baldias is called "Ciecion de los indlos por esto partaculanded", if Ir

Nickel, Sozal Morphologue, 501

Prem, Mupa y Hacranda, panam, especally Apeadice 1

The two exemples taken from Ewald, Estudios, respectrvely 54-64, 45-48

Compare Niekel's map with the drvision of bodownerahup in the eighteenth and nineteenth centurnes on which many hackendas that were formed in the suxteenth century are recognizable, Nickel, Sozuale Mophologie, 204 and for the area of Tecamachako/Tecal Schnerder, Landwartschaft in Valsegullo

AGI-Mexico 340. Prem. Mipa y Hactendo, 156-169

Ordonnance of the Crown AGET-Caja 6 1590-exp 2, AGNot-Paquete 58/1-exp 108

Diego de Coca alleged that in the escritura de verta the truth is not declared "La verdad es que dio por las dichas trerras anquenta y ocho pesos que es contra la cedula de su Magestad y han de andar an almoneda tranta dias conforme a [lo que] su magertad manda A VM pido y suplico mande dar la escritura por nunguna porque la undia fue angahado en muchos pesos que valen mas las dichas nerras y anden en pregones trentia dias y pudo justacia Diego de Coca Rendon" After the 30 pregones due the land was eold for 160 pesos to Jumn Rodnguez Quntero, the higheat bidder, Prococolos de Cholula, 499

AGET-Caje 6 1592-exp 9

-Papel del Conde de Monterroy sobre la congregeciones" un Virreyer epanoles, Vol II, pp 156-174, especially pp 172-173, Cline, "Civi Congregetions", 354-355

"Conde de Monterrey sobre congregechones", 171, mtermediete reports on the congregetrons in AGIMéruco-leg 25- $\mathrm{n}^{\circ} 7$ (1602), n $\mathrm{n}^{\circ} 8$-480 (1594-1599), Méuco-leg 26- $\mathrm{n}^{\circ} 7$ (1604), $\mathrm{n}^{\circ} 18-19$ (1604), $\mathrm{n}^{\circ} 45$

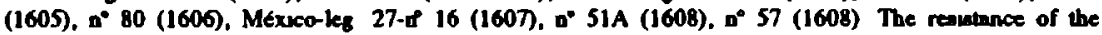
regular clergy to the congregstions documented an AGI-Mexuco-leg 123-nio 68 (1604) (all mendicant

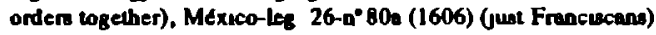

The general ducusion on the congregations are based upon the following hterature Clme, "Civil Congregutuons", Gerhard, A Gude, Dehouve, Quand les banquiers diavent des sants. Sumpeon, Congregaton, García Martinex, Pueblos de la Sierta, Gibeon, Marcala and Azsecs, Tmutmann.

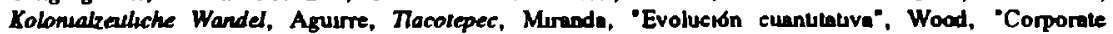
Adjustments" For Guatemma see Lovell. "Indien Migratuon" and Conquest and Surnval

Tochumiloo AGN-Tierres Vol 998 exp 6, Huaquechula AGN Congregeciones Vol 1-exp 83, Thaxcala Truutmann, Kolonualzeuliche Wandel, 24-27, 130-138, 115.129 Tlareala, Tepeaca and Tecall nee the documentation mentioned below On the carlem part of the temtones of Tecamachalco and Quechula, Lucate, Creation

Instructuon for jueces Tharcala AGN-Indios-Vol 6 (2n parte)-expo 745 and 1009, AGET-Caja 6 1592-exp 5, eurroundinge of the city of Puebla AGN-Indios- Vol 6 (2a parte)-exp 1021 and vol 6 (2a parte)-exp 979 (prolongation of the term of appointment) AGN-GdP-Vol 6 exp 705, AGNot- Paquete 40/1 exp 77

This could vary greally within a province as humidity and temperabure in this mountainous area depended on the eluturde

Santo Tomas AGN-Tierrw-Vol 2723-exp 7, publubed as doc 96 in CDCT, 290-302, Tecal AGNTierras-Vol 27-exp 5 (1599)

AGN-Tierras-Vol 2723-exp 7

The attributes explicitly mentioned "Homanuentos de casullas y frontales musales, mugcas de rompetes chunuas y flaulas y otros unstrumentos con que se sirve el cullo divno". AGN-Tierras-Vol 27-exp 5-f 10v

Data on the congregation of Tecalt are taken from AGN-Tnbulos-Vol 42 exp 2. AGN-Tierras Vot $27-$ exp 5 and Vol 2754-exp 4 Considerng the conlunumg folsation and subject these bat two files unitully were one

These are called tlanlacall in the Nahum tribute bots

AGN-Tributos-Vol 42-exp 2-f 53r

The deatruction of bouscs as affical arga of desertion wes rether usual in New Spam, and len a engral of desperale or tyrannical behnviour of the authontues then it would perhepe eppear to be

AGN Tributas-Vol 42-exp 2-f 47v

AGN-Tierres-Vol 2782-exp 33, AGN-GdP-Exp 705

AONot-PT-Paquete 49ח-exp without number (1607) Surteenth-century Amozoc and Cunubachan were in a state of contonuous turmoll See chapter 6 below

"Como s fueranos unfieles y Chuchumeces", AJP-1605.Santa Marta Nativias contra Juan Junena de Riancho Chichunecs (Nahuatl for barbanana) wes the geoerel designation of the lndians in the North of Mexuco with which the Spaniardl were waging wr

From everel expedientes it is clear that there were cacuques bebmd the congregations, for example AGNIndios-Vol 4-exp 960, publushed in CDCT, doc 264-265. AGNot-Pequete 41/11-exp wrthout number (1604). AGI-Mexuco-leg 340 and Marm, Colonual Morelos, 47.52 
55. Some of theac large-acale congregations: Tehwacan: AGN-Congregaciones-Vol. 1-expw 11, 34 and 40 (1603); Tierne-Vol. 2736-exp. 23 (1602); Siem Norte de Puebla: Garcin Murthez, Pueblos de la Sierra, 135-179.

56. Garcin Martine, Pueblos de La Sierro, Chopter 4.2 pp. 163-175.

57. AGN-Tieme-Vol. 1721-exp. 5; Lockhart, "Views of Corponte Self. Some examplen of the recording of landownership: Arochinp (Cuernavaca) AGN-Tierme-Vol. 1491-exp. 1 (1 thank Arij Ouweneel for bringing: this doecment under my attention and allowing me to use $\mathrm{it}$ ); Dennis, Intervillage Confict in Oaxaca, where it appear the congregntion documents are indeed ritl in use today a a means to show the hadrights of the villiges.

58. Citod by Chevalier from AGN-Mercedes Formacion, note 16, p. 469; Prem, Milpa y hacienda; Tonles, "A Note".

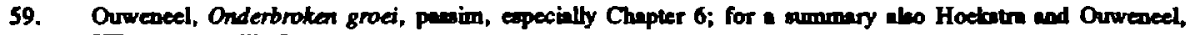
"Tierres concejilea".

\section{Chapter 4}

1. The officinl name of the regional officinl of Thaxcala changed frequently in the sixteenth century; from 1587 he was lastly called gobernador, here translated govemor in order to prevent confusion with gobemadores de indias. See Giben Tlaxcala, Appendix IV, 214-218.

2. Para conocer civil y criminalmante de todo la que ofreciere en sus distritos, ast antre Espatoles, como entre Espatoles, e Indios, e Indios con Indias", Recopilación, Libro V, Título II, Ley III, f. 146v.

3. Mandminas a los gobemadores, comegidores y sus tenientes que traigan en su mano la vara de nuestra Real Justicia, y no salgan en público sin ella, pues es la insignia por la qual son conocidos los Jueces, a quien han de acudir las portes a pedirla, para que se les administre igualmente, y olgan a todas con benignidad", Recopilacion, Libro V, Tftulo I, Ley XI, f. 127v; on the official term of office Recopilacidn, Libro V, Título II, Ley X, f. 147r. Aleo compare Gibeon, Tlaccalo, Appendix IV, 214-218.

4. Pietschmann, Estado, 162. He argues that at least in its intentions the Spanish wtate of the wixteenth century was a rational burenueratic Herrschaft in a Weberian eense, even if pnctice was more complex and lea nationalized, a indeed all contemponary European states. On this last point also: Blockman, "Bebeersen en overtuigen" and for a reeent long-term survey of strte-formation Tilly, Coercion.

5. Parry, Sale of Public Offices, Tomds y Valiente, La venta de oficias en hdias, panaim; Muro Romero, "E 'beneficio' de oficion vendibles".

6. Garefi Martinez, Pueblos de la Sierra, 243-244; Parry, Sale of Public Offices, passim. A number of higher official posts which were sold anyway: 55-57; Piebchmann, "Alcaldes Moyores, Corregidores und Subdelegados"; Romin, "Sobre alcaldias mayore y corregimientos en Indins"; Tomis y Valiente, La venta de oficias en Indias, passim, especially Apendice 11, pp. 173-177; Muro Romero, "Reforme del pacto colonial"; Navarro Garela, "Oficios vendibles". Eighleenth-century saleable and sold offices in the city of Puebla, Liehr, Stadtrat und stadtische Obersehich von Puebla, 49-64; 154. About the weal pawer of the itate in the late-beventeenth and early eighteenth centuries: Burkholder and Chandler, From Impotence bo Authority.

7. Gerein Gallo, "Origines"; Ots Capdequs, Hiseria del derecho espatol en America, 89-90, 128-138, 142143. How well this balance of power could work is made clear by the monographs of Isreel, Race, Class and Politics and Liehr, Stadtrat und stadtische Oberschicht von Puebla, 155-177, especially 155-156.

8. Garefe Martinez, Historia de Merico, 48-49; Scholes, Diego Ramlra Visila and for his actions in the Siem Norte de Puebla Garcin Martínez, Pueblos de la Sierra, 87-91; Sambia, Luis de Velasco; in general Pietschunann. Estado, 169.

9. "Real Instrucción sobre el trabajo de los indios" of 24 November 1601, point 6. CDHFSH, Vol. II, 71-85; reisoued in 1609: CDFSH, Vol. I, doc. 104, pp. 154-168 and 1624: FHT, pp. 393-394.

10. This is true for the entire colonial period. For example Lackhart, "Encomienda and Hecienda", "Spaniands among Indians", "Cepital and Province"; Lewis, "Mexico City's Shadow"; Altmen, Emigrants and Society; Butkholder and Chandler, From Impotence to Awhority.

11. Pietochmann, Estodo, pausin; MacLeod, 'Prinitive Nation-Stote" about Middle-America. In MiddleAmerike the control of the otate was les than in Central Mexico, but in my view Macleod stresees its 'primitive character' - little too much. More general considerntions about the nature of the colonial state Spalding, "Introduction" in her volume about the Polinical, Economic and Social Histon of Colonial Latin America.

12. Borah's articles in Gobiemo provincial.

13. Transition of repertimiento to gataria in: Zavaln. "Orfgenes coloniales", "La evolución del regimen de trabajo", Servicio personal, Vols II and III; Verlinden, "Regimen de trabajo en México"; Gibson, Aztees, 224-229; Riley, "Crown Lew and Rural Lebor". Colonial labour regimea are much diacused. Treditional views, dating from the 1550s: Chevalier, Fomacion; Borah, Century of Depression; Wolf, Sons of the Shaling Earh and also in Frank, Merican Agriculture. For a review of the literature Bauer, "Rurnl Workers". Some further recent literature: Florescano, "Formation and Economic Structure"; Dehouve, Quand les banquiers thaient des saints, 101-102; Gutitrrez Brockington, Leverage of Labor, Nickel, Relaciones de trabajo; Orweneel. Onderbroken graei, especially Chapters 5 and 6. "Eighteenth-Century Thexcalen Agriculture" and "Schedules"; Tutino, "Creale Mexico". "Heciende Social Rehelions", "Provincial Spaniards"; Zeitlin, "Ranchern and Indians"; MacLeod, "Aspects", 225-230; Cintron T., "Indien Labor Policy"; Hirachbers, "Alternative to Encomienda"; Sherman, Forced Native Labor, Lovell, Conquest and Survival. 
Lockhart and Schwartz, Earty Lahn America, 138-142

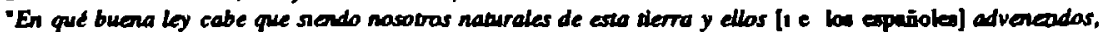

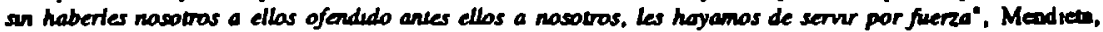
Histona Eelenderce Indiara, Vol II. Cap XXXVI, p 101, aleo csted in Zovabu, Servicio personel. Vol II, p 160

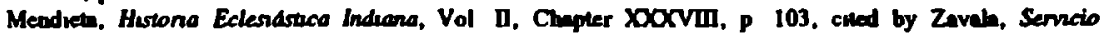
personal, Vol III, p 161

Zonte, Breve y sumana relacidn, 146

Gliaon, Azecs, 223

'I ] Porque las dichas undias de su natural unclunachon son ourgas de holgar, de que se les sgue harto

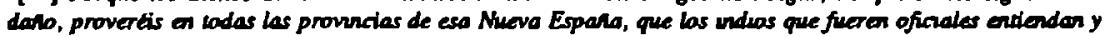
se acupen en sus ofinos, y los que ficeren labradores culbven y labren la nerra y hagen sementeras de mak

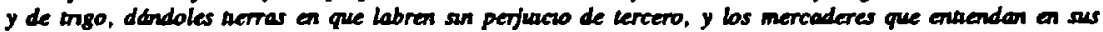
tralos y mercaderias y los indios que an nungure cosa de las mesodichas se ocupen, dartss ordar que se alqulan para trabajas an labores del canpo y obras de cuedad, por manera que no esten octosas porque la aczosidad es cause de muchos nocas, y aicargartis a los religiosos que les persuadan y and lo hagan, y wos por vuestra parte ovi b harts, y los oudores que visitares lendran el musma culdado, con que bo susoducho se haga y gevie por mano de la nuestra justria y que las espatoles no les pueden compeler a ello, anque sea a los indios de sus ercomiendas, y darts ordar edmo les paguen el pomal de su trabaja a las mumos udias que irabajaren y no a sus prneupales mi a otras persones algunas, y que el trabajo sea maderado, y que sepan las que excedieren an esto que han de ser gravamente castigados", Zavaln, Sernaro personal. Vol II, PP 1314

Husachberg. "Aternatrve to Encomuenda"

Huschbers. "Alernatuve lo Encomuenda", 241, Gibion, Aztecs, 224

Gibeon, Azlecs, 224-229 and "Llanamiento Generar", Roje," "Cootequil"

Zavaln, Serncio Personal, Vol II, p 177, Bakewell, Zacatecas, 122

AGN-Tierre-Vol 2754 and Tributos Vol 42, FHT, doc 540, pp 588-590, doc 529, Pp S47, doc 542. Pp 568569 , AGN-Indion-Vol 10 (32 parte)-exp 138-f 58 r (=f 558r, alterative folntoron), for a generi treatment of the desague Gibeon, Aztecs, 236-242

For example FHT, doc 8, p 30 (1606 4 Indian per week to the Auguitunes of Puebla), doc 9, p 31 (1606 4 Indian per week to the Carmelites of Pueble, for a period of four montha) On the construction wort on churches and monentenes, Kubler. Archutectura. Chapter IV, repnnted a "Mano de obn ondigene"

Zavah, Serviclo personal, Vol III, p 224

Zevalh, Servicio personal. Vol III, p 226

AGN Indroo-Vol 6 (2a parte) exp 1046-f 282r/v, Zevale, Servicwo personal, Vol III, pp 184-185, Aptudice B, pp 809-815, FHT, doc 307, Pp 29-30 For esumery ulso Verinden, "Trabajo", 229-230 CDCT, doc 108, pp 318-321

$C D C T$, doe 108, p 321, the obligation to vart the labores m order to see how many bbouren they needed Allexco AGN-GdP-Vol 3 exp 373-ff 175r/v, Sen Pablo AGN-GdP-Vol 3 exp 321 f 150v (both 1587)

- Se sirvan de ellos [1 e the Indiona] on muy diferentes efectos para solo su aprovechanuento pornculor y no del republica como debieran", CDCT, doc 134, pp 346-348, p 346

CDCT, doc 134, pp 346-348, apecially 348

"[ ] Prneapalmente porque sado labrador ere enteresado tomondo para sf mucho mas undwos de los que perienestian y a otros era fuerza dar mds y menos indias como le parenese", FHT, doc 30, pp $24-25$

For exemple Don lui de Velueco "Las dos republicas de que este raso consre, de epanoles e indias. venen entre st an 6 que es $s$ gobiemo awmento y estabulidad, gran repugnancia y dificultades, porque la conservacion de aquella sempre parece que es la oposiabn y destruccion de esta las haciendas de

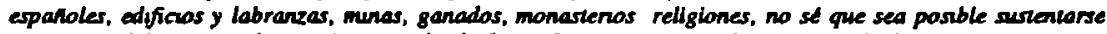
in pasar adelanie sin al sermato y ajuda de los undios, crya naturaleza y poca inclunacion a acuparse. rabajar y ganar es de varto unconveriene que ha obligado sempre a compelertas a que hagan aquello que

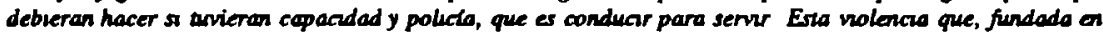
necerdad de esparioles, y a obligacibn siga, se les hace, pues no se les debe permiar la dejacion de sí mumas y octardad y vacos que de aqu se les sguen, les es tan pasosa que ha mondo a muchos religusas a procurar que estos reparturuentos y servicios se quitasen de lodo punto [ ] Yo a lo manas, s me hallara en los pnicipios con la inteligarcia que vengo, in me atrevera a fundar los repartinuentos que, in an el estado que hoy menen a quilarbs, porque augque he desecdo sumamente favorescer los naturales, veo la necerdad lan apretada que me ha obligado a hacer particulares socorros de gente y connumar otros que los

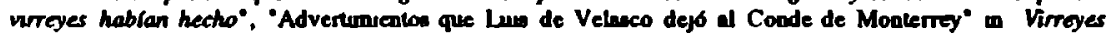
epanoles. Vol II. pp 101-102, also ented in Zavah, Servaco personal, Vol III, pp 63.65

- Nuevo y buar orden en el repartimeato de las undeos para las labradores", Zovab, Servicio personal, Vol II, p 211

"A las dichas heredades y estoncras d semaso que han menerter para su labor y bengficlo siso que tenterdo

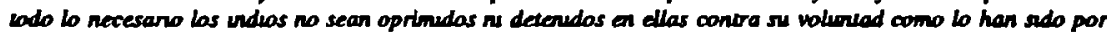
lo pasado I ] undias que hubueren de trabajar an las dichas heredades y estancas para el setricho que han menester se alquillen de las pueblos arcanvecusos a ellas I I", CDHFSH, Vol D, doc 48, pp 71-85. quote on Pp 76-77 For it hetory Zavala, Senvero personal, Vol III, pp 58-272, expecally 58-70, CDHFSH, Vol I. doc 22, pp 43-47, capecenlly 46 A summary m Verlmden. "Trabajo", 234

See above chnpter 3

AGN-GdP-Vol S-exp 1420-f 307 (1601), poutponement of the mandanuento GdP-Vol 6- exp 700-f 352v (1603), Vol 6- exp 856-f 403r (1603), Vol 6-exp 894-f 413r (1604), Vol 6-exp 904-f 416 
(1604), Vol 6-exp 926-f 422 (1604), Mandamento of 26 May, 1609 in CDHFSH, Vol II, doc 104, pp 154-168, copecully 155 Aleo Verimden, "Trabajo", 234

It not clear why the regudores were refused the nght to repartumiento, but suddenly they saw their supply of labourers diappear as a reauh of which their labores "Se estan perdiendo por falla de gente" They protested forcefulty and their nghts to labour were temponnty reatored FHT, doc 383, pp 394-397, doc S26, pp 540-541, doc 536, p 560, doc 541, p 567

Decree of 27 January 1631 reproduced in CDHFSH, Vol II, doc 219. pp 335-336 Abo see Znvaln. "Evolución", 30, Gibion, Aztecs, 229, Isreel, Race, Class and Polities, Verlmden "Trabajo", 243 AGN Indion-Vol 6 (2a parte)-exp 906-f 230r/v, exp 913-f 233r/v, exp 1046-f 182r/v, exp 1049-f 284r/v, exp 1050-ff 284v-285r, exp 1050 th 285r/v Publuhed in CDCT, docs 126-131, Pp 338-342 Aleo doc 112, pp 326-330

41 In non-ungated wheat culuvabon there also wos a peak in the opentions at the time of weedmg, but it was les acute than in the harvest wrth irngated cultrvation In Atlixco and Calpan and aloo in Sen Pablo irrigated whent cultuvation us mentroned FHT, p 595, doc 542 , PP 568569, "La cosecha [u Atlexeo] de ahoro este a nesgo de penterse [because many of the Induna have gone to the desagae worke] por ser an las meses de abril y mojo princupio de las aguas si no se alza con coda fuerza", m 1603 Alluco "Los labradores del dicho valle nenen muy protino el desyerto de sus sementeras de ogaho que por ser de thempo cuando mas tande se comensara a hazer entrante enero del ato". AGN GdP-Vol 6-exp 856-f 403r/v Conanderng the natural atumtion the labores (which after all were usually situated in the wetier parts of the valleys) were epecially suted for de tomporal cultuvation Ouweneel mentions that in the ejghteenth century there were hardly haciendas employmg de cemporal culuvaluon, Orwencel. "Schedules", 69 Accordmg to the accounts of the hacienda San Bernardino in seventicenth century Tepeace there was de iemporal cultivation In mandamuento of 13 Jenunn 1604 the authonties wrote about "sementeras de tenporal" of the plang of San Pablo However, in the eighteenth century the haciendas of San Pablo prodominantly produced maze In the eightcenth century haciendas using water from canals were usually deaignated as de nego, even if they only employed this imgation in summer (peroonal communication of Arj Ouweneel) On basis of the documentation I have seen, it cannot be decided whether thus was abo the case in the axteenth and early seventeenth centures

About the operation in wheat cultuvation and harvest. Ovweneel, "Schedules m hacienda agneulture", 6971 , Appendices 12, PP 9396 and figure 1, p 83, Onderbroken groa, 222 232, "Xaltupan", 174176, Gibaon, Aztecs, 329-334 About maize Ouweneel, Onderbroken groe, 19-196 (pueblos) and 232-237 (hacienda), "E1ghteenth-Century Tharcalen agnculture" and "Schedulea in Hacienda Agnculture", 72-78, "Xaltupan". 176-178, Wilken, "Management of productive rpace" and Good Famers, passm Other atudies on colonual hacienda-agnculture Ewald, Estudios, Konrad, Santa Lucza, Trautmann, Kolonsalzealuche Wandel, Wobeser, "Uno" and Formacion, Van der Meer, "Colegio de San Andres"

Verlinden, "Trabajo", 233, he also remarks that the documents do not mentuon this pling of work According to Zavaln Torquemadn was the only author complaining that the repartumiento kept the Indiana from their fields on the busjest moment Serncio personal, Vol II, p 233, Guterrez Brockington, Leverage of Labor

In 1580 the viceroy decreed conceraing Atzcapotzaleo "Por ahora cada undwo ha de venir al dicho repartmiento tres veces an un alo de cuatro en cuaro meses una semana y no mds excepto los mozos por casar que pasen de quince atos que dstos han de venur cuatro veces an cado ato como gente más desocupada y por andar holgazanes y desocupados se enuende ser perruczosos en los pueblos donde son". Aptndice B in Zavala, Senicho personal Vol III, pp 809815 , especially 812 For Thexcale also Actar de Tlaxeala, thems 157-158, p 265

Possibly there also was a difference in tuning in the operations of the mulpas of the pueblos and those of the haciendas Most dotw on both milpa and wheat cultuvation come from eighteenth century haciendas, where seasonal labour was costly and had to be used as efficiently as possible Posably the haciendas concentrated the operations on the mulpas and for the wheal harveat in one penod, while the binding of the sheaves on the mulpas of the pueblos took place somewhat carlier (abo see figures 13 and 14 in Ouweneel, Onderbroken groes, pp 205 and 224)

Latly we have to consider that the occurrence of ceasonal labour in Mexico was nothmg exceptonal in Europe this kind of labour was unual and dud not hamper agranan peasant production See Hochstadh, "Migration", Jones, Poltucs and Rural Society, Chet, "Migrntron", Chark and Stack, Englesh Towrs, Lucasen, "Sezoenagebonden trekarbend"

FHT, doc 29, Pp 23-24 (1606) Labradores who applied for edmusion to the repartumiento, or for indios de socomo (helpmg Indans) 1579 Pedro de Stm Cruz Polanco (At $1 \times 00$ ) AGN-GdP-Vol 2-exp 280, 1580 Podro Nuñez (Aluxco) AGN-GdP-Vol 2-exp 609, 1582 Meria del Hierro (Atlixco) AGN-Indios-Vol 2. exp 124, Antono Gozales (Puebla) AGN-Indioo-Vol 2-exp 222, 1583 Diego Barren (Aluxco) AGNIndios-Vol 2-exp 342, 1587 Menuel de Rodes (Alluxco) AGN-GdP-Vol 3-exp 430, I590 Compañin de Jenia (San Pablo) AGN-Indjos-Vol 4-exp 557, 1599. Fnncisca Gonzalea (San Pablo) AGN.GdP.Vol 5 . exp 616, 1602 Thome Muñoz Vellesteras (San Pablo) AGNot Paquete 40/-exp 52, 1603 Junn de Villabobos (Atlexco) AGN GdP-Vol 6-exp 833, 1604 Rufio Manuel (Atlexco) AGN-GdP-Vol 6-exp 896, Juan Dommguez (Atlexeo) AGN-GdP-Vol 6-exp 996, 1606 Augutunes of Texmelucan (grinted for one hervest as they were outonde the valley of Alluco) FHT, doc 75, pp 66-67, Blis Martin (Athxeo) FHT, doc 4, p 5, Son Chrotobal Puelle y Mendoza (Atlexco) FHT, doc 29, pp 23-24, Bartolome de Erven (Ormaba) FHT, doc 124, p 111, Doñe Agustuna de Carvajal, FHT, doc 85, p 79, 1607 Gercta de Artvalo (Atlixco) FHT, doc 221, pp 199-210, Francisco Holguin (Sen Pablo) FHT, doc 201, pp 177-178, 1632 Franciaco de Cabren (Calpan) AGN-GdP Vol 7-exp 311 
314r/v; bwnuit of Hunthethuce AGN-Civit-Vol. 75-exp. 1 (1601).

47. FHT, doc. 537, pp. 561-562.

48. AGN-Indios-Vol. 5-ex. 576-f. 160r/v.

49. AGN-Indiow-Vol. 7.exp. 151-ff. 72v-73r. Aleo in Simpson, Repartivitarlo, 98-99.

50. CDCT, doc. 114, p. 331; Tecanachaloo: AGN-Indiou-Vol. 4-exp. 470-f. $144 \mathrm{v}$.

51. FHT, doc. 537, pp. 561-562.

52. FHT, doc. S44. Pp. 570-571; doc. 546, Pp. 572-573; doc. 556, Pp. 585-586; AGN-Indioc-Vol. 12-ex, 60f. $35 v-36 r$.

53. Zaval. "Introducción al town VII": Riley. "Crown Law and Runl Lobour": Tutino. "Hecieade Social Relations" and "Proviocial Spaniards"; Gibeon, Azters, Orweneel, Onderbroken grod, Chapters 8-9.

54. Province of Tepeaca: AGNot-Paquele 40/I-exp. 45 (1600); 41/L-exp. 175 (1593); 42/1-exps 31, 34, 35. 39. 39 * (1640); Pequete 42/I-exp. 59 (1636); AGN-Indion-Vol, 11-ex. 39-f. 30r (1638); Chalula: AONIndios-Vol. 11-exp. 165-f. 136r (1639); Raxeala: AGI-Excribanfo de Clman-les. 221A-ff. 1121 and paesim and AGN-Tierre-Vol. 971-ff. 6-17 (1636-1641).

55. Dat then from: BNM-AF.Caje 89-exp. 1376-ff. 1-28; AGNot-Pequete 39/-exp. 89 (1602); Pequede 40/1exp. 124 (1614); Pequete 48-exp. 3 (1591); Pequet 4/-(no expl) ff. 27v-28r (1602); Pequete 4/II-f. 141t (1602); Pequete 5/1-extion Registo de escriburas (1608)-exp. 32 (Tepeace 1608); Paquete B/T-f. 61v; Paquete 8/1-f. 57r, AGET-RIP 13-ff. 159-175 (1602); AGET-Caje 1603-exp. 2-ff. 56r-67r. For Sar Bemandino: AP-1619-San Bemandino.

56. In a worting month of thirty days (which seems to have been uaul, but Sundays and bolidaye were abo counted) this meant that the Ulaquetuales got a elightly more than a half real per day.

57. Protocolos de Cholula, pasion.

58. AGNot-Pequete 42/I-exp. 83.

59. AJP-1619-San Bemardino-f. 232r.

60. Gibson, Azlecs, 252-256; Thompson, "Monl Economy" and Mating of the English Worting Class; Scot. Moral Economy; Orweneel. Onderbraken groei, 252-262, capecially 252-256; Riley, "Crown Law and Rural Labor", Bonb, Justice, paenim; Rendón, "Pulemaliam and Moral Economy"; Nickel, "Elenente der 'Monl Econorny"; Mecfarlane, "Civil Disorder" and MecFarlane, Culmre.

61. For example FHT, doc. 380 , p. 392.

62. AGNot-Pequete 42/I-exp. 107.

63. AGN-Indion-Vol. 3-exp. 911-f. 222r, FHT, doc. 198, pp. 175-176; for Huejotringo AGN-Indios-Vol. 6 (2e parte)-exp. 693-f. 160r.

64. AGN-Indios-Vol. 10 (2a pare)-exp. 135-f. 59v.

65. FHT, doc. 532, Pp. S49-552; doc. 561, pp. 590-592; BNM-AF-Cajo 89-exp. 1376-fT. 1-28; 20vah. "Origenes del peonaje", pasim; Riley "Crows Law and Rurl Labor", eepecially 262-267.

66. Porque aurque es deudo de inibues reales, por las cuales parece es jurto quedar obligados a pagar o senvir, por ser deudo etvil, st el indio quisiere pagar al dineros, se le ha de recibir", but the monsy could not be "recibido de prestado al dado de ovro epanol ni a fin de defraudar al dicto Juan Guerrero". to whom the decree wes directed FHT, doc. 532, p. 551. The conchusion in this decivion of the Audlencia makes w mupect that there wa another legal opponition at stake. In the cave of convicted in Cholula (end probably eloewhere) it was decreed that they had to werve in the closed division of one of the obrojes of the cown, intil the imposed fines were had been paid by the wages. This concerned deudas crininales, which could not be redeemed in money, but bed to be cerved completely. The conideration nther sesm to huve been that only in the case of daudos crininales forced labour could be imposed, but that in other cases this was not allowed.

67. The duties of both employer and employee are oflen expreased in the labour contracts, Protocolos de Cholula, passim. Employer :"[...] Le a de vestir y cakar y curar de sus enfermedades [...]". doc.950, p. 252; Employee: "Para senir [con le recul de arriero/como gañen] en lo que le mandare como es uso y costumbre [...]", doc. 1296, p. 351.

68. AGNot-Paquete 43/II-exp= 3 and 27.

69. Protocolos de Cholula, doc. 1578, p. 448.

70. AP-1619-San Bemandiva-f. 256r.

71. AGNot-Pequete 43/-ex. 89.

72. Riley. "Crown Law and Runl Labor", 264.

73. Satvueci. Teriles and Copicalien, 137; Bazant, "Textile Industry of Puebla"; eccording to a report of 10 Mny 1604 in AGL-México-leg. 26-n" 19B entitled "Relación de los obrajea de paños que hay en ente reino". Thaxcale hed 11 obrajes, Tepence 5 (with 50 b 70 Indian worten each), Pueble 35, Choluta 6 and hay muchas obrajes an las pueblos de Guauitlan, Queretaro, Tecanachalco, Guachindeo. ciudad de Valladolid, Villa de Carrion [ = Atlixco], y Cryuacar".

74. FHT, doc. 78, pp. 69-74; AGNot-Paquete 42/1-exp. 63 (1633).

75. For the period 1606-1631 FHT, doc. 71, p. 63; doc, 83, pp. 121-122; doc. 166, 147-148; doc. 223 , pp. 201-202; doc. 273, p. 272-274; doc. 329, p. 305; doc. 384, pp. 386-387; doc. 450, pp. 460-461; doc. 523, pp. 537-538; doc. 545, pp. 571-572; doc. 548, pp. 575-577; AGN-Indion-Vol. 12-exp. 246-fi. 154-157v.

76. FHT, doc. 510, p. 524 (31 Oetober 1631).

77. Baned on Prolocolos de Cholvla, panim.

78. Prolocolos de Cholula, peasim; for the decree of 1606 FHT, doc. 78, p. 72.

79. Giboon, duers, 9497; Pestor, "Repartimiento"; Teylor, "Cooflict and Balance", pasim; Geref Martine. Pueblos de la Siern, 243-247; Lovell, Conqued and Survival, peanim; Lockhast end Setwertz, Earty Latin America, 332 and $355-356$.

80. Ouweneel, Onderbroker grow, 123-147 and note 33. p. 326; Pietuchmann, "Comercio de repartimieatan". 
an abbrevialed venion of his German article "Repartimienio-Handel der Dirtritubeamten" , "DependencisTheorie und Kolonielgeachichte". "Agriculturn e induatra runl"; Dehouve, "El pueblo de indios y el mercodo"; Hemneth, Politics and Trade, pasoim; Pastor, "Repartimiento"; Ewald, Merican Salt Industry, 20, 209, note 25, p. 255, note 41, Pp. 356-357, and especially Chapter 5, pp. 39-57. The only studies for the ceventeenth century treating the reparimiento trede I know of are Gereh Martinez, Pueblas de la Sierra, 243-247, who pays come attention the tinde and eapecially Peotor, "Repartimiento", 204-206 and 208-211 and Campesinos y reformas, 153-159. Puntor beses himeelf on his own investigations for the Mixteca, but capecially on e number of umpublished atudies; Lockhnrt, "Spaniards Among Ind ians", 235-236.

B1. "[A los indios] venden lo que no an menester y se lo hacen lomar por fuerza llamado el Alealde Mayor a un Covernador de Indios para que reparta entre ellos de su divtrito vacas, mulas y otro ganado a veinte pesos cada cabara no costandoles de ellos más que a seis pesos; 10 mismo hacen an el who con que hacen gran dato a los indias y los acaban y an ladas las dencis mereaderias", AGI-Mérica-leg. 600-ff. 109r-111r (24 jumi 1641).

82. Gibeon, Aztecs, 96; Garcfin Mnrtinez, Pueblos de la Slerra, 245.

83. AGN-Indios-Vol. 4-exp. 944-ff. 242v-243r.

84. AGN-Indion-Vol. 4-exp. 898-f. 241v.

85. AGN-Indion-Vol. 4-exps 55-56-f. 16v. The supplies to the corregidor of Xattocan (valley of Mexico) were on an even larger seale, AGN-Indion-Vol. 3-exp. 468-f. 107v.

86. For example CDHFSH, Vol. I, doc. 79, Pp. 120-121; doc. 215, p. 332.

B7. AGN-Indios-Vol. 11-exp. 151-f. 124r/v.

88. AGN-Indion-Vol. 11-exp. 234-ff. 192v-193r.

89. AGN-Indios-Vol. 11-exp. 234-ff. 192v-193r.

90. AGN-Indios-Vol. 9-exp. 181-f, 85r/v. In cases in which an investigatory judge was suspected of partiality, he could be challenged. This happened for example in a question about land in Huejotzingo, September 1591, AGN-Iadion-Vol. 5-exp. 880-f. 227r/v.

91. Bornh, "Los auxiliares", 58-59.

92. AGN-Indios-Vol. 7-exp. 494-f. 237r/v; Vol. 7-exp. 180-fr. 89v-90r.

93. Protacolos de Cholula, doc. 929, p. 244 (1594). From 1590 to 1599 a lot of caceo was traded in Cholula Protocolos de Cholula, passim. Also the remarte of Juan de Piñeda in his "Carth al Rey", Pp. 180-181: "[...] [Los indioa de Cholula] ast ellos como sus mujeres y otros indios van hasta Guatemala y otras partes con sus caballas y mulas que tienen de arria para el dicho trato [de merceder]; a dande llevan muchas cosas a vender y traen cacao a trueco de lo que llevan como de vuelea en el cacao que treen"; in the Relación de Tepeaca. 41: "[Hey eapeñoles en la provincia de Tepeaca que] compran y venden cacao que es la bebida de los naturales que al presente se compra y vende y usa de ello como de moneda baja".

94. For example Geronimo Niño, labrador in San Felipe Ixtacuixtla, AGI-Eacribanín de Cúmara-leg. 221A-f. 530r. Payment in kind was common between traders, labradores and Indians alike.

95. AGI-Eacribanin de Cumare-leg. 221A-f. 134r.

96. AGI-Eacribanín de Comara-leg. 221A-f. 661r.

97. AGI-Eucribance de Cámara-leg. 221A-f. 382r.

98. AGI-Eacribanía de Cúmara-leg. 221A-ff. 411r-619r and f. 528v.

99. AGI-Eacribanía de Cámara-leg. 221A-f. 435r.

100. AGI-Eacribanía de Cómara-leg. 221A-f. 673r. Also compore Pastor, "Repartimiento", 203-206 and figure on 205.

101. Debouve, "Pucblos de indios y el mercado" and Quands les banquiers claient des saints, 101-102; Pastor, Campesinos y refomas, 153-159 and "Repartimients", 204-211.

102. AGN-Indios-Vol. 7-exp. 118-f. 58r/v.

103. Pestor, "Repartimiento"; storege in Tepeace AGN-Indios-exp. 888-f. 229r; AGN-Indios-Vol. 6 (In exp. 338-f. 90v; eccounts of Tepeace, CDCT, doc. 3, pp. 36-107.

104. AGN-Indioe-Vol. 6 (2a parte)-exp. 813-ff. 197v-198r. Refen w decree of 23 Mareh 1573; AGN-Indio-Vol. 6 (2a parte)-exp. 814-f. 198r.

105. For cochineal in general Lee, "Cochineal"; MecLeod, "Trabajo" and for eighteenth and nineteenth-century production Hemnett, Politics and Trade.

106. Frneisco Vello seems to have sold tribute maize from Huamantin (AGI-Eacribanin de Cumarn-leg. 221A-f. 689r) but this was no systemntic action; elso refer to the tribute books from Thexcali in AGI-Escribanin de Camare-leg. 221A-ff. 1080r-1154v, copecially 1134r-1142v. This ouggeats a difference between the central highlands and remoter areas, where the repartimiento of cochineal was carried out by the alcaldes moyores. Pietschmann's data for eighteenth-century Puebl also suggents that the purchase of producth remined confined to more marginal areas, while the sale of liventock was present in all areas of the intendancia of Puebla. Pietschmann, "Repartiniento-Handel der Diatrirtsbeamten", pasim, especially tablea 1 and 2 . In more periferous areas lite Thape or Oureca repartiniento trede we more elaborate. Debouve, Quand les basquiers tiaient des sairt, 97-102; and "Los pueblos de indios y el mercado"; Ouweneel, Onderbroken groei, 123-148; Hannett, Polities and trade, pansim.

107. AGN-Indion-Vol. 6 (2t parte)-exp. 747-f. 176v; Vol. 9-exp. 378-fr. 186r-187r.

108. AGN-GdP-Vol. 1-exp. 521-f, 110r: also publiahed in CDCT, doc. 48, p. 183.

109. AGET-Caja 4 1578-exp. 4.

110. AGET-Cuje 4-1581-exp. 6.

111. Converting colonial measures is risky buines, and so it in in this case. Acoording to the dhth of Carrere Stampa 9 arrobas $(\Theta)$ mode one carga of cochineal. With a carga-weight of $138 \mathrm{~kg}$ this amount to $15.3 \mathrm{~kg}$ per 9 . Then $2,000 \bigcirc$ in $30,600 \mathrm{ke}$. The 'normal' arroba, however, weighed $11.506 \mathrm{~kg}$, which would amount $1023,012 \mathrm{~kg}$. Carrere Stampe, "The Evolution of Weights and Mearures", 13.

112. Based on Protocolos de Cholula, pamim. 
113. According 10 the "Cart al Rey", p. 180, the price wee 40 peses per 9 . The avernge price is based on alea between Spaniarda as they have survived in the Prolocolos de Cholula, panim. Price of 1618 in AGI-

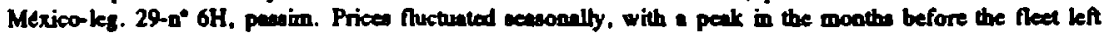
for Spain.

Protocolos de Cholula, doc. 10, p. 11 (1590); doc. 157, p. 45 (1591); "Carte al Rey". 180 and pamim; thi. leter wes writien in protea to the mesure.

114. In 1618 especially Frneinco Vitorie from Puebla bought much cochineal, but Antoaio Loper Gallego from

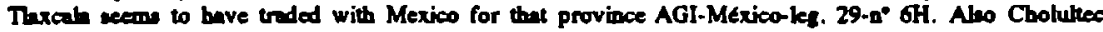
toders trided directly with Mexico City and even directly with Spain. For example Probcolos de Cholula, doc. 628 (16 March 1591).

\section{Chopter 5}

1. Vetancurt, Teatro Mericano, 31, 106.

2. For exemple the Fneciocans of the city of Pueble took care of the epiritual care of a number of hentets near Puebli, which were under Thaxcaltec edministration.

3. Ven Ow, "Mendicant expansion".

4. Phelen, Francicean Millenium, passim; Rieard, Conquiste espirimal; Bonh, "Status jurddico".

5. Ven Oas, "Mendicant Expansion"; Ricard, Conquisea epiritual; Kubler, Archilecaura; Velancurt, Teatro Merieano, 28.29.

6. This ongoing dispute wes treated by the eventeenth-century chronicler Veteneurt in hil Teatro Mericano. pasain; furthermore lonel, Race, Class and Polltics, passim; Pooke, Pedro de Moya y Contreras, pasaim; Cummins, "Afler the Spiritual Conquest".

7. Vetancurt, Teatro Mericano, 14-16; Imel, Roce, Class and Politics, 207. Canterle y Martín de Tovar, La iglesia de Oaraca; Breding. "Tridentine Catholicism"; for Guatemaln Van Ow, Cacholic Colonialism.

8. There heve been long-standing and lively debates about eeventeenth-ceatury Mexico and it alleged eriaib. Taken as whole the debnte is mher eluaive and only ceeras to concem the silverproduction and the part of the economy depending on it Anywny, too liuk research bes beeo conducted on seventeenth-century Mexico to dexide the question. Bormh, New Spain 's Centary of Depression; Iarael, Race, Class and Poliaics, pasim and expexially "Mexico and the General Crisis of the Seventeenth Century". Lenel refers to the debate about a geoend crisia in eeventecoth-ceatury Europe; for sumnary Parker and Smith, The General Crisis of the Seventeenth Century. The crisia-debate in reaction to Isnel's article in Past and Present 90 (1981) and 97 (1982) with contribution by TePakke, Kkin, Kamen and a reply by Isreel. Furthermore Bakewell, Silvermining and Society: Boyer, "Mexico in the Seventeenth Century": Hoberman, "Merchents in Seventeenth-Century Mexieo City" and Mexico's Merehart Elite; Cuello. "Snltillo in the Seventeenth Century"; Muro Romero, "Reforme del pacto colonial"; Slicher van Bath, Real hacienda, passim, especially 31-39.

9. For Pulafox y Mendoza's idean his, Trafados Mericanas, especially "Exhortaloria a los curas, y beneficiedos de ta Puebla de los Angeles". 72-124; his romintic views about the Indians in De la naturalaza del Indio. About Palafox: Iareel. Race, Class and Politics, 200-202; Simmon, "Palafox and hil Cribica"; Garela, "Don Jun de Palafox y Mendoza"; Piho, "Le seculariseción de las parroquias" and La secularisación en la Nueva EspaAa; Brading characterizes Palnfox as 'tridentine prelate'. The First America. 228-251.

10. Inmel, Race, Class and Politics, 201-203,

11. The background of seventeenth-century Spain Elliot, Spain and its World, passirn, especially Chapter VD, "Power and Propaganda in the Spain of Philip IV'.

12. See chepter 1; for Frnociecan reactions Mendieta, Hisloria Eclesidstica Indiano; Motolinin, Memoriales.

13. AGNot-Paquete 41/1-exp. without aumber Cuenlo de 1572-1573 de la cara de comuridad de Tecamachaloo.

14. AGNot-Paquete 41/1-exp. without number Cuenta de 1572-1573 de la cara de comunidad de Tecamachalco.

15. AGNol-Paquete 41/-exp. without number Cuenta de 1572-1573 de la cara de comunidad de Tecanechalco; CDCT, doc. 3, pp. 36-86.

16. Gibwon, Alsecs, 111: Vetuncur, Tearo Mericano, 142.

17. Zevala, Servicio personal, Vol. II, p. 532. Taylor about Oaxaca, Landlond and Peasant, pasoim.

For the development of landownership of the Chunch in genend Zevala, senvicio personal, Vol. III. pp. 527. 712; Prem. Milpa y Hacterda. Church finances of the virteenth ceatury ere trealed in Schwalker. Origins of Church Wealth. An overview of parrochin income in eighteenth-century Guntemals in Van Ows, Catholic Colonialion, 79-108.

18. For example AGNot-Pequete 4 / (no exp) f. 3r (Acaringo 1602).

19. AGNot-Puquete 41/11-exp. 179.

20. AGNot-Paquete 40/II-exp. 129. Thin we aloo the case with cofradias of the Spaninds. For example the charges the cofradla del Sandssino Sacromento of Acatzingo inued ageinat Diego de Thanes in AGNotPaquete 41/-exp. 64.

21. Ven Oas, Catholic Cathollicion, 21; Foter, Culture and Conquert.

22. Gibeoo. Azlecs, 132-133, wken from Torquemede. Monarquala Indiana, Vol. III. p. 220.

23. Motolinin, History; Burthnth Stippery Earth and "Doctrinal Aspects".

24. The Franciscand were not the only ones atso the Dominican Durin pointed out thin danger in him Fiestas y rilos, 71; Dibble. "Sahagin's Appendicen".

25. Baudot "Fray Rodrigo de Sequere".

26. For short background of aixteenth-century Spain Ellioth, The Old World and the New, "Spanieh Conqueat" and "Spain end it Empire" in: Spain and is World, 7-26. 
27. In the eventechth century, Torquemedn atill epent be bf effor in proving the degree of policta of the Indian, Monarqufa Indiana, Vol. II, pp. 309-349.

28. For exemple the respective Ordenarzas de Tepeaca: CDCT, doca 1-2, pp. 23-36; Ordenarzas de Cuautinchan: DTSC, doc. 40, pp. 180-215.

29. Vetencurt, Teatro Mericaso, 60 and passim.

30. AGN-Tierrer-Vol. 27-exp. 5-f. 102r and Vol. 2754-exp. 4-pantion.

31. AGN-Tiems-Vol. 27-exp. 5-f. 7v and f. 10v.

32. For example in Nopaluca AGI-MExico-les. 300, in which ato in opoken of the baptimal fonl; the criterium of the 'sonido de la campana' is mentioned by Garef Murtiner, Pueblas de la Sierra, 152, ccoording to whom it was a means to form congregations.

33. About the capillas abiertas, MecAndrew, Open Air Churches and Kublex, Arquitectura, $360-383$.

34. Vetnncur, Teatro Mericano, 87 (Calpan) and 57 (Huejozingo): "tiene los ewatro dngulos del patto cada parcialided su hemita donde se enterraban sus sepulturas de piedra y donde las Doningos cantaban sus feligreses"; also Kubler, Arquilectura, 384-386.

35. AGN-Tierne-Vol. 2754-exp. 4; about a eparnte cemethry for meveral sujesas of Tecamachaloo AGN-IndiosVol. S-exp. 881-f. 228r/v; exp. 987-f. 224r.

36. For example in San Vicente Xiloxochithan (Tlaxala) AGET-Caja 5 1582-exp. 5.

37. Van Oas, Invertory; Kubler, Arquitectura.

38. DTSC, doc. 5, p. 102. For a similar case in the valley of Mexico (San Jumn Ixhuntepec) Gibson, Aztecs. $120-121$.

39. Kubler, Arquitectura; AGN-Tierns-Vol. 2327-exp. 7; also CDCT, doc. 96, p. 295; Vetencurt, Teatro Mericano, 70.

40. Relación de Cholula, 144. The number of people in the ehapel wail probably a lot amaller.

41. FHT, doc. 336, pp. 400-401.

42. $C D C T$, doc. 203, p. 552.

43. $C D C T$, doc. 3, p. 47.

44. A royal cedula of 1565 , abo citod by Ven Ow, Catholic Colonialim. 20.

45. $C D C T$, doc. 3 , p. 59.

46. CDCT, doc. 3, pp. 83-86; doc. 4, pp. 87-107.

47. Esta proveido por cedula real el orden adificar iglesias y capillas y quien las edfificare sin licencia ha de ser cartigada can rigor". AGN-Indiog-Vol. 6 (1 le parte)-exp. 1013-ff. 272v-273r.

48. "Porque de estar [b capilla] descubierla se sigue que padezean dalo y peligro de las aguas, aires, sotes, y frias cuando se estan en misa y semon", AGN-Indios-Vol. 6 (1e parte)-exp. 1057-ff. 297v-298r.

49. AGN-Indios-Vol. 6 (1e parte)-exp 1010-1013-ff. 271r-273r.

50. AGN-Indios-Vol. 6 (1a parte)-exp. 1057-ff. 297v-298r, exp. 1063-f. 288v. About Censos Bauer, "Censeos and Depositos".

51. DTSC, doc. 40, pp. 180-215, p. 205.

52. AGNot-Pequete 41//-exp. without number Cuenta de 1572-1573 de la caja de comuridad de Tecanachalco.

53. AGI-Eacribanía de Comarn-leg. 221A-f. 1112r/v.

54. Gibeon, Azsees, 215; Ouweneel, Onderbroken groei, 184-191.

55. Recent litenture about the cofradtas: Van Ow, "Rural Brotherhoods" and Cacholic Colonialion; Gruzinuki, "Indian Confretemities": Lavrin, "Rural Confrnternities" and "Diversion and Disparity" (Spanish version "Mundow en controte"); Dehouve, "Money of the Saint" and Quand les banquiers deaient des saints, passim; Chance and Taylor, "Cofrad fas and Cargoe"; Gibeon, Aztecs, 127-133.

About Spain: Christian, Local Religion, passim; Gerbel, "Confreries religieuses 1 Cicerea".

56. This was less the case in Spain than in large parts of France, where in the rurd areas it lanted until well into the eighteenth century before the politica of the Church look effect. For a long time the local elergy there remined poorly educated and strongly bound to tocal traditions. Only in the eighteenth-century large-scale ecclesiantical programme of innovation the clergy in the rural parishes were recruted from elsewhere and better educated and adopted a more distant altitude vis d vis their parishionern. In hrge parts of Fnnce only in this time the local clergy began to take a more critical attitude towards the local veriante of Christinnity.

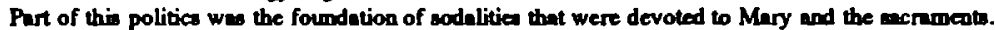

Gerbet, "Confreties religieuses \ Cáceres"; Guthon, "Confretemities"; Tackeft, Priest and Parish, passim, expecially 194-201; Jones, Politics and Rural Sociery; Bosey, Christianity in the West, panim and "Godparenthood"; Peters, "Religion and Culure"; Hoffmen, Chunch and Comnuariy.

57. Chance and Taylor, "Cofradlas and Cargas", 463-464, 467 and paetim.

58. In Tecamechalco the cofradia of Sen Francivoo wos founded in 1580, Arrales de Tecanachalco, 75; aleo Licate, Creation, 83; Chance and Taylor "Cofradias and Cargos", 402.

59. Para que an estas hospilales hubiese facultad para el servido de las affermas y gastos ordinarlas, dieron [los fniles onden abmo las dichos hospitales anviesen de srya algura estancia de ganado o semertera de mati. 6 otra manera de grangeria de que se pudienon susteriar", Nueva Coleccion, Vol. II, p. 65-66.

60. Fue esta istioucion de las hospitales muy acepta a los principales y mandones de las pueblos, como lo son ladas aquellos an que interviene casa de recogerse algo de las macehuales, por la esperanza que tienen de lo que alli se les ha de pagar, como de necesidad lodas estas cosas se hoyan de administrar y regir por su mano. Y cierto no es de maravillar que desto y de todo lo denas que los labradores se recogiere dejen aprovecharse b que pudieran, pues que se van desposeidos y privados del absoluso mando y aprovechamiento que antiguenante tentan, que era vado aquello que a ellas les parescia pedir, siendo su boce medida, y no les quedado otro majorazgo at otra via por donde se puedan sustentar". Nueva Coleccion. Vol. II, p. 65.

61. AI no han servido ni sirven los dichas hapluales, sino para das 8 tres mancos o parelficas, cuardo 
mucho, y a veces solo wo, que sive alle de cabeza de bbo para que los pranclpales hagan sus mangas". Nueva Coleccion, Vol I. p 66 Mendieta dds that the wa more the case in Central Mexuco then in

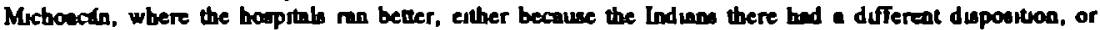
beceuse there were leas Indian, and the Franciscano could keep a closer control

Nueva Coleccion, Vol II, p 67

Mueva Coleccion. Vol II, p 68

Nueva Colecenon. Vol II, P 67

DTSC, doc 133, p 159

DTSC, doc 12, p 110

CDCT, doc 206, pp 558.569

DTSC, doc 5, pp 102.103 Some care of caczques who bequenthed hind Don Pedro de Lum, DTSC doe 27, p 149 (1589), Dotan Ana Velízquex, DTSC, doc 35, p 170 (1628), on the valley of Toluce also Wood, "Adopted Sants"

For the valley of Mexuco abo mee Gibeon, Aztecs, 116 This was not juot the cane $\mathrm{m}$ Mexuco, but aloo in unny parts of ancien regune Europe, wee for example Tackett, Prest and Pansh, 214-215

The derranas abour which the Spaniarda oflen complamod $m$ the documents usually were levies by mdividual caciques, without interference of the cabuldos CDCT, doc 27, p 145, doc 29, p 159, doc 33, p 165

- Onere y es su boluntad que se den de sus bienes a la cofradia del Sactamento de los espatoles de esta culdad ireario pesas de oro comur", CDCT, doc 203, p 552, Anales de Tecamachalco, 91 Aleo Leate, Creation, 83

Anales de Tecanachalco, Lavrin, "Mundos en Contraste", Gibson, Aztees, 127 In 1551 the Indans were stall excluded from the the cofradia of Nuestra Sestora de Guadelupe in Span, while the Spaniards in the Indies could become members CDHFSH, Vol I, doc 192, pp 185-186 For an analyaw of the finances of the prestugious cofradia of the Santisamo Sacramento in the seventicenth-century city of Mexuco Ruelbergen "Kolonual cartas" It hed wealth of af least 260,000 pesas For the expenditures of Lorenzo Mertin Cortes, AJP 1619-San Bemardino-257v

Debouve, Quand les sants thaiert des banquiers, pasam, espectally 152-157 Actas de Tlaxcala, 286 also Anales de Tecmachalos, passm For a dufferent vew Chance and Taylor, "Cofradlas and Cargos", paem Chance and Taylor, "Cofradias and Cargas", 463-464

Ingham, Mory. Michael and Luafer, 78-102

Confesionario Mayor, passum, the most eloborate treatment of compadrazgo in twentieth-century Thaxcale in Nulun, Rumal Xunshup For the European beckground Bossy, "Godparenthood" and Chrstuanty in the West. peasm, especully 14-19, about Tarcaln Acias de Tharcala, 233

CDCT, doc 3, pasem, AGI-Eacribanfin de Cómara-leg 221A-f $1112 \mathrm{r} / \mathrm{v}$, for a comparroon with the Valley of Mexuco. Viewe of Corporate Self and about the unportance of meals in Europe Gutuon. "Confritemites" and Sobean, Power in the Blood

Taylor, Drintrig, Homicude and Rebellon, 28-71, especully 28-34

Tacket, Presi and Parsh, 204

Torquemads Monarqula Indiana, Vol I, Pp 224-225

AGET-Caja 4 1576-exp 3

Torquemeda, Monarquio Indiana, Vol II, p 224

Anales de Tecamachalco, 66-67 On sumilar practaces in Span Chritian, Local Religion, 92

Tacket. Priest and Parsh. 205 This was also the case in the Spanish part of society about which the Counel of the Indies on 1600 bad to wosue decree to decide a conflict between the viceroy and the archbushop about their respectuve pleces in the processions in Mexuco Crty CDHFSH, Vol II, part 1 , doc 45, p 67

Torquemeda cited by Brading, The First Amenea, 287, Actas de Thaxcala, 260

AGN-Inquusion-Vol 255-exp 8 -ff 189r-200v

AGN-Indios-Vol 5-exp 1084-f 345r

Torquemeds, Monarquila Indiana, Vol II, p 225

AGN Indios-Vol 6 (le parte) exp 336-f 90r/v

Here we should mention the names of Pedro Ponce and Rukz de Alareon The results of theur unvesugetons have got uncreasing atiention bicly The exemples of the seventeenth century mvesugators seern to remain confined to magre and only seldom they found barger forms of 'idolatry', which could be conadered to be more than superitution The results of Rune de Aleresn and De la Serme are respectuveby publuhed un Tratado de supersticanes, and La alma encantada Tacket. Priest and Ponsh, 214

I ] Consuderamas que an Espala hay otra gante lan reda y basta como ellos [1 e loe mdioe], o poco menos, como es la gente que an muchas partes de Casulla hay. conviene a saber, hacta Sayago, las Batuecas y en otros muchos nncones de provincias, donde son las hombres de juczos estrahamente loscas y groseras y sobre lodo fallos de doctinna. mucho más estas naturales, pues a ertos cada domingo y fiesta se les assata la doctrusa y se les predica la Lay Evangelica y a aquellos aconiece no ou un solo sermon an la vida, an muchas partes, y con lodo eso vertus un hombre de aquellos, harto de andar an el canpo, que

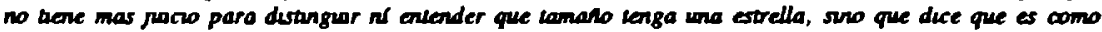
wha nue y que la luna es como un queso, y con loda $s$ rudala se dejard hacer pedezos pronero que dudar

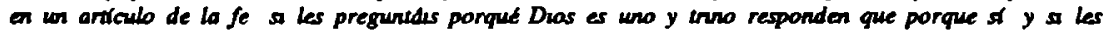
pregunials porqué no son quatro personas sino tres, responden que porque no, y con estas dos razones, porque sf y porque no, respondar a codas las dudas y pregunias de la ft, creyendo firmenence aquello que les enseltaron sus padres y bo que tene y cree la Sania Madre Iglesia", Durín, Rubs y Fiestas (onginal 
adition 1576-1578), p. 69.

94. Durdin, Ribos y Fiertas, 69.70.

95. Salas C., Iglesia, 122 and figure on p. 129.

96. CDCT, doc. 3, peasim.

97. CDCT, doc. 4, p. 101 and pasaim. DTSC. doc. 20, p. 143. Testament of Juan de Mosooso, 1590, who decheres to possess some objects mede of featherwork.

98. Dentefano, Miractes and Monarticim.

99. AGN-Inquinicion-Vol. 342-exp. 3-ff. 282r-299v. Quole of Francioce de be Nieven on f. 286r. Actually peyole we unully catton.

100. Relacion de Cholula, 143.

101. Cleodingen, Ambivalent Conguerts.

102. Gruzinski, Poder sin Ilnites, Chapter 2, pp. 45-76.

\section{Chapter 6}

1. AGN-Indioo-Vol. 13-exp. 67-f. 60r; Vol. 18-exp. 237-ff. 171v-172v.

2. AGN-Tierra-Vol. 2723-exp. 23-f. 250v aod panim.

3. The propoal in AGN-Indion-Vol. 4-exp. 255-f. 77v; the anower of the alcalde mayor in AGNot-Pequete 49/-exp. 2-f. 3v.

4. Henketh, Indigenous Rulers, pasgim, and for opecific offices Chapter 4, pp. 95-123.

5. $C D C T$, doc. 2, p. 32; DTSC, doc. 40, p. 194; Actar de Tharcala, 297. To my knowledge veny few of thease residencias have survived. The Indien quite oflen comphined about gobemadores or cacigues before the Juzgado General de Indios of the Audiencia. A detniled example is the complaint againta the gobemador of Huejotzingo of 1593 AGN-Indios-Vol. 6 (2a parte)-exps 834-835. For an example of a residencia ageinst a Spanisb teniente from Quechuln AGNot-Paquete 40/L-exp. 102 (1610).

6. Ordenanzas. Tepeaca (1552): CDCT, doc. 2, pp. 28-36, compleiely different from the ordenarza y aranzel of 1539 CDCT, doc. 1, pp. 23-27; Cuautinchan (1559): DTSC, doc. 40, pp. 190-215. Scettered ondenanzas for Thaxcala (1550) in the Actas de Thatcala, passim. A much later (1580) and ahorter ondenarza for Quechula: AGN-GdP-Vol. 2-exp. 962-ff. 227r-228r. The ordenanzas of Cunutinchen are obviousty a Nahuall tranilation of a decree isued by the Audiencia, which se presently kept in the archives of the municipio. The Tepeacan ordenarzas are the Spanish original, which aecording to the accompanying text were aleo trinslated inlo Nahurt. For a part of the ordenanzas of Thexala both the Spanish and the Nahunall decrees have survived.

7. Para las negocios y casos que se ofresctan bocantes a la ejecucion de la justicia y administracion de ella muchas y diversas veces se hablan jurlado an su cabildo y oyuntaniento, hablan platicado y tratado de dar alguna orden conveniente al bien de la república, y habiendola vivisoy mirada habian hecho ciertos captulas de las cuales hactan presentacion ante mí y me pidieron que porque bo que en ellos contenido era útil y provechoso al buen gobiemo del pueblo los mandase aprobar y confimar". CDCT, doc. 2, p. 28.

8. The relation with the orderanzes of Cuautinchen ere leas obvious. Future reacarch has to ahed light on the origins of the decrees.

9. Hakken, Indigenour Rulers.

10. Actas de Thaxcala, 274.

11. Haketh, Indigenous Rulers; Gibson, Aztecs, Chapter 7, especially table 13, p. 185; Carmagnani, 'Local Governments" and Regreso de los dioses; Chance, Conquest of the Sierra.

12. CDCT, doc. 2, p. 29; Actas de Tlaxeala, 275.

13. Actas de Thaxcala, p. 28.

14. Ackas de Thaxcala, p. 28.

15. Actas de Thaxcala, p. 31.

16. Documertos tlaxealsecos, doc. 8, pp. 308-315. We may infer the boy'd rank from his fither's name, Tezin ending in -tzin, which indicates that be wes a principal. The father of the girl funt tried to make it up with the boy, but efter all the boy would not 'confess', p. 309. There only wes one witnesa, which did not suffice to condemn the boy. Second case thken from AGNot-Paquete 40/-exp. 17.

17. Reyes Garcin, Cuauhsinchan; Lewis, "Indian Political Activities'; Gibeon, Tharcala and Azsecs, passim; Locthnrr, "Complex Municipalitien: Thaxala and Tulencingo in the Sixteenlh Ceatury", in Nahuas and Spariands, 23-38; Cammagnani, Regreso de las dioses.

18. Comenzando desde el pueblo de Cacazongo [ = Acatzingo] voya por su rueda par los dends pueblos sujesos a la dicho provincia de Tepeaca", CDCT, doc. 2, p. 29.

19. $C D C T$, doc. 2 , p. 29.

20. De aqui adelante an las elecciones que se hizieren salgan electos los alcaldes regidores mayordomas y otros oficiales de tadas las parialidades para cada un ato al el dicho para escussar las divinciones y dfferencias que es de salir lodos los oficiales de una parcialidad y quando hublere de hacer eleccion de gobemador tambien salgo de una de las parcialidades andando por sn mima. Y no pueda salle de una parcialidad gobemador y alcalde, sino de adonde saliere gabemador no ha de salir alcaldes, y de esta manera y orden los demas oficiales para la elección de cada un alo dends del gobemador y alcaldes y regidores entre los electores que tienen de commbre de elegir los tales oficias como personas que saben de sus vidas y los conocen y que sean buenos Christionos y erto se guande con la pera que Vuestra Exelencia mandare", AGN-GdP.Vol. 2-exp. 962-f. 227v.

21. Actas de Thascala, 279. 


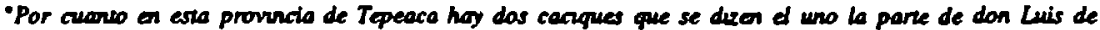
Gronm, y at otro la parte de don Hemordo [de b Cnu] que son las das cabezas ded ducho pueblo y hombres paderasos, mando que por evitor molertas y vejaciones que se pueden hocer a las namrales que al presente son y las que fueren, no se elijan y no las pueden elegir por gobemador at alcaldes, porque can las cargas y siendo las cabeceras que son no les atrebuten a nadie ni a poner alborolas an el pueblo". CDCT. doc 2. P 31. "Y porque [ece pro para que] no se quejen no wenen an algunas partes on lo

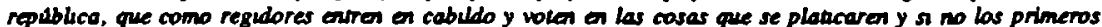

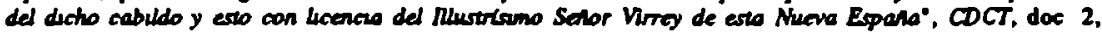
p 29

- Porque el govemador y regudor son huticuas de su mogestad y es radon que sean honrados y acacadas. que auando el governador fuere por la calle y $b$ encontraren las alcaldes y alguaciles lo acomperen hasto donde fivere; y lo momo hogan el gobemador, alealdes y regidores al corregudor que fuere an di dicho pueblo por su mogertad, y 6 mismo hogan las alguactes cuando encontraren a las alcaldes de las del dicho pueblo". CDCT doc 2, 34

- Por haber en el dicho pueblo muchos indias unguletas y revoliosas estan divididos an bandos y

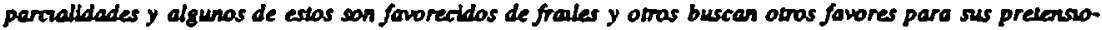
nes y que suempre prevalesce la parte que alcuiza al oficio de gobemador que dando las de la parte contrano abasidas y persegundos lodo lo cual resulua an dano wuversal de los macehuales y el pueblo y los unburas reales neres an mucha dunumabn". AGN-Indrou-Vol 4-exp 254-f 77v AGET-Caje 6 1591-expe 5/6 AT-1605-Sania Marla Nabutas contra Juan Junkne de Rlancho, AGET-Caje 3 1571-ex 2

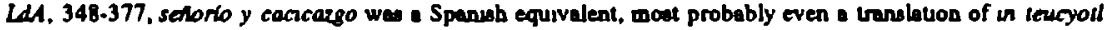
in Uahbcayoll, see Chnpter 1 above These terms are used in the tnalation of the mierpreter m AGNTherres-Vol 2723-exp 23-f 241v, which concerns the bwout of Don Francisco de Mendoza (Tecomschaleo) An example of a references to the tmea before the coming of the Spaniard "[ai] conforme a las

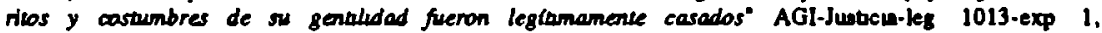

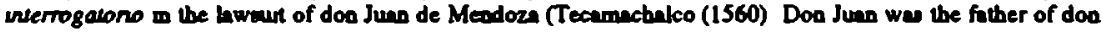
Franceco)

Actes de Thaxcale, 269 (18 November, 1549), 312 (17 October, 1550), 381 (16 February, 1560) mterprethon taken from Tharcalan Actes, 43, 60, LAA, 237 (16 September, 1551) AGN-GdP.Vol 6 - exp 399

31 Cwe tiken from Relaczón Geogrdfica de Thaxcala, 85-86 Muñoz Camargo in not quite clear about the chronology of the case According to the account of the caja de comunudad of Tepeace it wes in conflict abour Nopaluce from at leat 1555-1560, CDCT, doc 3. paum, only in 1563 Tepeace alked for a re. usacabn of the tribute "por haberse muerio y ausentado muchas indios dapucs de la uluma tasacion [1556] y haberse adjuducado at pueblo de Nopaluco tres estancias que andaban con la dicto provicia y sus sujetos", Libro de Tasaciones, 399

AGNot-Pequete 41/1-Caje 81-exp 28

Cartas de cabildas, $n^{*}$ 622. PP 357.358 Gnntung of the utle of audad to Tepeaca mentioned in Cartas de Cabildos, $0^{\circ} 619$ An eighteenth-century transcripuon of the ongmal ulle of audad in possension of the comuuded of Tepeace, AGN-Tierres-Vol 2730-exp 1 AGNot-Pequele 41/1-exp 41 publibbed in CDCT, doc 77

AGN-Indroo-Vol 9-exp 382-f 188r/v

AGNot-Puquete 42/1-exp 87

Gertard, A Gude, 280, for the proces of bie-eventeenth and elghteenth-century fragmentation of the pucblos de undlos Gurch Martinez, Pueblas de la Sterra, pasim, Ouwencel and Hocketre. "Tierms concejules" About the sujetos of Acabingo AGN-Indioa-Vol 12 (2a parte)-exp 145 f 237r/v

"Temen que alguonas personas se las guerean lomar [la tuerra] de que les verdrd gran daso y pegucao". AGN-Tierma-Vol 27-exp 6-f 36r Cue takea from AGN-Tierras-Vol 27-exp 2 (no folmution)

AGN-Tierme-Vol 27-exp 2 (oo foliation)

AGN-Tierme Vol 27-exp 6-f 38r

- Don Jusepe de Celss por jue nombrado paro lo meduda de terras de esa dicho jundianon, excediendo de su comerón, a tratado de unquietartes y quilartes las dichas aerras asf a ese puebla de Sanio Clara como a los dends de eso dicha cabecero 560 a fin de vendertas a algunos de las canques de ese pueblo de Tecali dando color para ello de que no henen ufulos particulores cada uno cosa que jands ha sido costumbre $Y$ como son pobres y no soben de plealos se han dejado despojar de rus berras crnos propnos duetos como muserables e undefersas les han causado volento despojo de ellas respecto de no verer quan los ampare y para que asto lengo el remedio debido y se guorde y cumpla lo cddula de Su Mogestad contradiando como contradiean la posesion que dichos caciques han comado de dicho nerro", AGN-Tierrs-Vol 27-exp 6-f 38 r

AGN-Tiems-Vol 25-exp 1-ff $23 \mathrm{r}-24 \mathrm{v}$ The axteenth-century document are all contumed in the three volume AGN-Tierme-Vols 25-27, but these volummous vohmes are just a emall part of the documentuvoa abour Tecall in the eaghteenth and nineteenth centures, which a cattered about the AGN-Tiems and the AGI in Seville, and mout probably abo in AGNoh in Puebla Aloo nee Tuylor. "Coaflict and Balnice" for a firt treatroet of the problem A treatmeat of the problemates of the repartmuerto de comernas in the enghteenth century in Ouweneel, Ondertroken groes and "Cobemador de undwos" 
to wear a word, nde a horse and put on Spanmh clothes, AGN-Tiernu-Vol 2723-exp 23

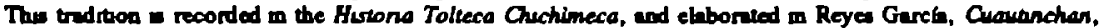
and Olvere, Pulls y macehuales The vanous alleped were melmed to streas theur own mportance m their historical writunge and chroncles and to dom the hustoncal events with ther own colourng Aleo cee Lockhart, "Views of Corporite Self" and Bornh. "Some Problems of Sources" Oflen the partucularity of

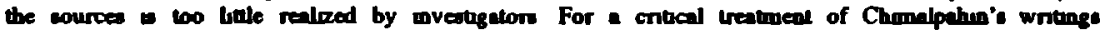
Schrooder, "Chmalpahm" and "Chnlco"

AGN-Indion-Vol 4exp 49-fi 14v-15r

AGN-Indroe-Vol 2-ex S26-f 121v

AGN Indioe-Vol 4-exp So-f $15 r / v$

AGN-Indroo-Vol 4-exp 254 f $77 v$ and pasem

AGN-Indos-Vol 4-exp 261-f 79v, exp 259-f 76v, exp 253-f 77r, exp 252-ff 76v-77r, exp 287-ff 86V-87t

AGNot-Paquete 49/-exp 4 (though this case we nomewhat bier, m 1621)

AGN-Indios-Vol 4-exp 252-ff 76v-77t

AGN-Indioo-Vol 4ex 277-f 84r

DTSC, doc 32, Pp 163-165

AGN-Indiog-Vol 4-exp 429-f 125v, exp 566-f 155v, exp 188-f 206r/v, Vol 11-exp 159-f 129r, Vol

12-exp 160-f 269r

Taxealan Aclas, B1

Tharcalan Actas, 81

Tharcalan Actas, 81.82

Thacalan Actas. 80-82

Tharealan Actas, 85

"Los descrandentes de los [teccall y pilalli] son estumados por hombres calyficadas Porque, aunque sean pobrisunos no usan oficios mecanicos, tralos bajos, w viles, on jands de permuten cargar at cavar con coas nt azedes, diciendo que son hudalgos, y que no han de aplucarse a estas casas soeces, $\pi$ no es servir an guerras y fronteras, como hudalgos, y monr como hombres peleando la cual locura nrasosa dura y permanece hasta ahoro [1 e eurca 1580], diciendo que son hudalgas y caballeros desede ab mito, y que ahora Lo son mejor, porque se convinteron al veriladero Dus y se han tomado cristhanos, dando la obediencia al Emperdor Don Certos, Rey de Cartille. Dends, y alleade de esto. Le ayudaron a ganar y congastar lado lo

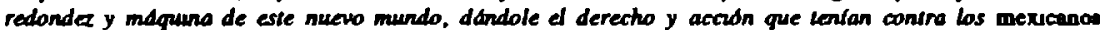
porque fuese universal rey y sehor de ellos, y que, por esto, son hudalgos y caballeros Estos, y otras fanfamas y Locuras dicen, gue jands acaban de blasonar del amds", Relacion Geografica de Tlaxeale, 174 "Docuruedion Nehusetranontanos", 133-161, especially 146-159

"Cuardo se coned y lass ulumamenie al dicho pueblo (de Teperf, la persona que lo conls y lass mando que no se le acudiese con I I cosa alguna de cuya causa estaba pobre y necestiado $Y$ me [1 e be viceroy] pidu mandarsele ocudiese con el terrazgo que sollan dar e le diesen de las sobras de inbulos lo que obmadamente hubiese menester para su sustentacion". AGN-Tieme-Vol 9 (la parte) exp 1-f 12r AGNot Pequete 40/7-fojas sueliar, CDCT, docs 176-179, pp 447-479

AGET-Ceja 3 1571-exp 4, aleo compare the order agangt the 'rebelloun mestrzo' Diego Lopez Ayale in AGET-Caja 3-1570-exp 2

- Se obligaban y obligaron de dar y pagar y daron y pagaron cada uno de ellos de terrazo por razon de las dichas merras en que viven y labran y labraren que son de los dichos princupales", AGET-Ceje 3 1570-exp 2-f $5 r$ AGET-Caja 3 1570-exp 2-ff 17v 27v, Caja 3 1572-expo 5/6

AGET-Caje 3-exp 4

"[ ] Porque presupuesta el derecho de las gentes que permutra y admitia las guerras lfertas como hablo sido la que en esia nerro an Nuestro real nombre [1 e of the king in whose name the allegaluons ure summanzed]

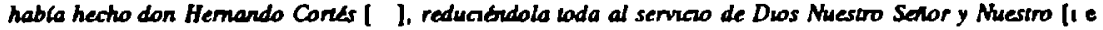
the kung's], entonces los dichos naturales hablan quedado sujetas y por nuestros vasallos como bo eran y cin sin distucuon que fuesen princepales o no lo fuesen, y consecueniamenue por la dicha razon y derechos sus mertas sguendo las personas hablan quedado y eran nuestras, y sendo as la razon alegada de contrana. por la cual se quere decar que por via de kemazgo hablan llevado los dichos mbulas y los padian llevar de sus partes como de renteres, cesaba en el presente caso pues lada la therra habla quedado y era nuestro, y la parte contrana no venla nu podla dar lo que no ero suya mi masos atrendarto y las dichas uetras eran de si pare" The procurador went on "Y porgue edemás de lo amba dicho y an confimacion de ello, el damuno que de contrano se decta la parte contrana no leala nu podla aver tenudo an hampo de su unfideludad conforme a derecho lo habla perdedo y an nuguna cosa habia conanuado nu conanuabo respecto de las dichas aerras la posesidn que de contrano se alegaba, mayomente que este presuponia propiedad, la cual habla quedado esagueda y sin renta por el derecho de las gentes que lo habla admindo y permuda la decto guerro I ]". CDCT, doc 177. p 458

Zorts, Breve y sumana relacion, 129, quoted from the Englush tnaslation

AGN-Indico-Vol 3-exp 407-f 94r

AGN Indroo-Vol 6 (20 parte)-exp 945-f 143y

Athough the ancient umagery soon fell into duswe, these prehsopanic norms were influenlual for a long ume Florertere Coder, Book 10, Chapier N. P 15

77 Many Spanardo compented on the hrge number of Cholulan Indians employed m tride For exemple Juan de Pinede un bu "Carta al Rey", pp 18-181 "[ne indios de Cholula] ar ellos como sus mugeres y otros undias van hasea Guatemalo y otras partes con sus caballas y mulas que tienen de ormo pare el dicto trato 
[de merader]; a donde llevan muchas casas a verder y traen caceo a trueco do lo que llovan como de veles an el cacao que traen".

78. Thus they are called in AGN-Indion-Vol. 4-exp. 536-f. 149r/v.

79. Zavale, Servicio personal, Vol. III, pp. 776-782. Thi it mumary of AGN-Civit-Vol. 645-ff. 2182-2573, which I have not been able to andy myself. Additional archival material: AGN-Indian-Vol. 3-exp. 984-f. 237v; Vol. 4-exp. 478-f. 136r/v; exp. 900-f. 232r.

80. AGN-Indios-Vol. 4-exp. 15-f. 4r/v.

81. AGN-Indion-Vol. 4 erp. 384f. 114r/v.

82. Taybor, Landlord and Peasart, 33-66; for en exemple from the eventecenth century AGNot-Pequete 43/Iexp. 89 (1638).

83. For the argument see Ouweneel and Hoeknth, "Tierme concejiles"; Wood, "Lands Por Racon de Pueblo";

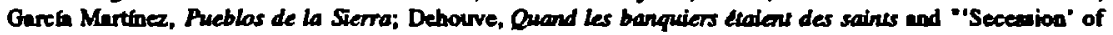
villegen".

84. In addition to the litenture mentionad in the previous note Ouweneel, Onderbroten groe; Gurel Martinez, "Pueblos de Indias, Pueblos de Castas": Hacket, Indian Community Land" and Indigenous Rulers, Taylor, Ladlord and Peasant and "Indian Pueblos"; Wood, "Corporte Adjutments"; Oaborn, "Indian Lned Relention". 


\section{Abbreviations}

AAP - Archivo del Ayuntamiento de Puebia (Puebla)

AdE1 - Anales de Estudios Americanos

AGET - Archivo General del Estado de Tlaxcala (Tlaxcala)

AGI - Archivo General de Indias (Sevilla)

AGN - Archivo General de la Nación (Mexico City)

AGNot - Archivo Generol de Notarías (Puebla)

AJP - Archivo Judicial de Puebla

Annales, ESC - Anrales, Economies, Societés, Civilisabions

BNM-AF - Biblioteca Nacional de México (Mexico City)- Archivo Franciscano

Boletin ELC - Boletín de Estudios Latinoamericanos y del Caribe

Bulletin SLAS - Bulledin of the Society of Latin American Srudies

CDCT - Colección de documentas coloniales de Tepeaca

CDHFSH - Colección de Documentos para la Historia de la Formactón Social de Hispanoamérica

CHLA - The Cambridge History of Latin America

CSSH - Comparitive Studies in Society and History

DTSC - Documentos sobre tierras y sefiorto en Cuautinchan

ERLACS - European Review of Latin American and Carlbbean Studies

ESHJ - Economisch- en sociaal-historisch jaarboek

exp. - expediente

f.- foja

FHT- Fuentes para la historia del trabajo

GdP - General de Parte

HAHR - Fispanic American Historical Review

HMex - Historia Mexicana

LA - Ibero Amerikanisches Archiv

JbLA - Jahrbuch fur Geschichue von Staat, Wirschaft und Gesellschaft Laseinamerikas

JLAS - Joumal of Lasin American Studies

LAP - Latin American Perspecrives

LARR - Latin American Research Review

LdA- Libro de Asientos

leg. - legajo

MNAH-AH - Museo Nacional de Antropología e Historia-Archivo Historico

p.- page

PaP - Past and Present

$R d I$ - Revista de Indias

RIP - Registro de Instrumentos Públicos

Suplemento de AdEA - Suplemento al Anuario de Estudios Americanos

TAm - The Americas

TVG - Tijdschrift voor Geschiedenis

TvSG - Tijdschrift voor Sociale Geschiedenis

Vol. - Volume

VSWG - Vieneljahreszeitschrift fur Sozial- und Wirschaftsgeschichte 


\section{Bibliography}

\section{Unpablined Soareas}

Archiven (abbreviations ued in noces between brackets)

Spoin:

Archivo General de Indlas (AGI), Seville.

- Audienda de Mérico (Mérico)

- Justicla

- Eseribanla de Camara

Mnterial orgenized in legajos (leg.)

\section{Mexico:}

Archivo General de la Nación (AGN), Mexico City.

- Civll

- Crininal

- General de Parte (GdP)

- Indias

- Mercedes

- Tierras

- Tributos

Material organized in Volumes (Vol.), and expedientes (exp.)

Biblioteca Nacional de México (BNM), Mexico City

- Archivo Franciscano (AF)

Archivo Histórico, Museo Nacional de Antropologla e Historia, Mexico City (MNAH-AH)

- Fondo Francisedio

Archivo General de Notarias (AGNot), Puebla

- Prolocolos de Tepeaca

Material organized in expedientes in paquetes, each paquete divided over two cajos (e.g. Paquele 40/l and 40/II)

Archivo del Ayuntamiento de Puebla, Puebla (AAP)

Suplemento al tibro primeno

Archivo Judicial de Puebla (Puebla) (AJP)

Material orgenized in bundles on year

Archivo General del Estado de Tlaxcala (Tlaxcala) (AGET)

- Fondo hiskrico

- Registro de instumentos públicos (RIP)

Malerial organized in on year in cajas (Fondo historico) and libros (RIP)

\section{Published Sources:}

Actas de cabildo de Thaxcala, 1547-1567 E.Celealino Sols, A. Valencin R., C.Medina Lima, eds (Thaxcaln, 1985) Beyond the Codices. The Nahua View of Colonial Merico A.J.O.Anderson, F.Berdan and J.Lockhart, eds (Berkeley and Los Angeles, 1976)

Carrasco, P., "La casa y la hacienda de un señor thalhuica", Estudios de Cultura Náhuotl 10 (1972), 225-244

"Carth al Rey sobre la ciudad de Cholul en 1593", P.Carraco, ed., Thabcan 6 (1970), 177-191

"Cartes privadas de Pueble del aiglo XVI". E.Oute, ed., JbLA 3 (1966), 10-87

Cartas de cabildos hispanoanericanas. Audiencia de Mérico (siglos XVI y XVII) E.Vila Vilar Ma.J.Serabin Viejo, ade (Seville, 1985)

Colección de documenios coloniales de Tepeaca H.Martinea M. (Mexico, 1984) 
Colecelbn de Documantas para la Historia de La Formación Soctal de Hispanoamerica 1493-1810 4 Vole (M-drid, 1953)]

Coleccion de documeneos para la historia de Merico 2 Vol, J.Gerch Icarbalteca, ed. (Mexico City, 1858-1866) [face. Mexico City, 1971]

Coleccion de documentos sobre Coyoacdn Vol. I, P.Camsco and J.Monjarn-Ruiz, eds (Mexico City, 1970)

Corté, Hernin, Cartas de relacion de las conquista de Mtaico (Madrid, 1945)

- Cartas yydacumantas (Mexico City, 1963)

Documentas intilies para la hisoria de Merico Genaro Gareh, ed. (Mexico City, 1905-1911) [fica. Mexico City, 1974]

"Documentos sobre el rengo de tecuhtli entre los Nahues tramontanos". P.Carnseo, ed., Thalocar 5 (1960), 133-161

Documentos sobre therras y setiorto en Cuauhtinchan L.Reyea Garein, ed. (Mexico City, 1978)

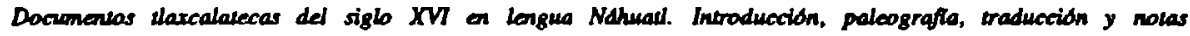
T.D.Sulliven, ed. (Mexico City, 1987)

Puettes para la historia del trabajo an Nueva Espata S.Zaval and M.Cestelo, eds (Mexico, 1939-1946) [face. Vol. VI Ann Arbar, 1989]

Indice y etractas de las provocolas de la novoria de Chalwla (1590-1600), C. Reyee Garele, ed. (Mexico City, 1973) Historia de la nación mericano (Codex Aubin), Ch.E.Dibble, ad. (Mexico City, 1963)

Historia lolveca-chichineca P.Kirchhoff, LOdena Güemea and LReyes Gerch, do (Menico City, 1976)

Keiko Yoneda, Los mapas de Cuautinchan y la historia cartogrdfiea prehispdnica (Avchivo Genenl de beción, Mexico City, n.d. [1981])

Frny Bartolome de les Casas, Apologetica hiseoria sumaria 2 Vols, E.O'Gorman, ed. (Mexico City, 1967)

- Las Lajes Nuevas, 1542-1543. Reproducción de los ejemplare existentes en la seceión del Arehivo General de Indias", Muro Obrejon, A., ed, , AdEA 2 (1985), 811 1-835

El bibro de las lasaciones de pueblos de la Mueva EpaAa, Siglo XVI F.Gonzalo de Cossfo, ed. (Mexico City, 1952)

Lbros de asientos de la gobemación de la Nueva Espana S.Zuvala, ed. (Mexico City, 1982)

Lopez de Velnsco, J., Geografia y descripcion uriversal de las indias Bibliotece de Autores españoles CCCLVII (Modrid, 1971)

Marricula de Huctotzinco Ms.Mer.387 der Bibliothaque Notionale de Paris). Edition-KommentarHierogbyhenglossar (Gnz, 1974)

Mendieta, Fr.Gerdnimo de, Hislorla eclesidutica indiana (ed. Mexico City, 1971)

Moderación de doctrinas de la Real Conona, administradas por las órdenes mendicantes (1623) F.V.Scholes and E.B.Adams, edn (Mexico City, 1959)

Molin, Fr.Alonso de. Confesionario mayor, en la lengua mertcana y castellana E.O'Gorman, ed. (Mexico City, 1984) [facs. of original edition 1569]

Mote y Eacobar, Fr.A.de le, "Memoriales del obispo de Thexcala, Fray Alonoo de la Mota y Eacober", Anales del Institulo Nacional de Antropologla e Historio 1 (1939-'40) (Mexico City, 1945), 192-304

Mololinin. Fr.Toribjo, OFM, Memoriales o libro de las cosas de la Nueva Espana y de las cosas de ella (Madrid, 1970)

- Mololinia's History of the Indians of New Spain, F.Borgia Steck, ed. and trans. (Wahington D.C., 1951)

Muñoz Camargo, Hirzoria de Taxcala. Crónica del siglo XV] (Mexico City, 1892) [reprint Mexico City, 1978)

Nuevo Colección de documentos pare la historia de Merico 5 Vols, J.Gareln Icazballeca, od. (Mexico City, 18861892) [facs. 3 Vol Mexico City, 1941]

Pabafox y Mendoza, J., Tratados Merieanos F.Sanchez Castañer, 2 Volo (Medrid, 1968)

- "De la naturaleza del Indio", in: Junn de Palafox y Mendoza, Manual de ertados y profesiones; De la naturaleza del Indio facs. (Mexico City, 1986), 45-110

Padrones de Thaxcala del Siglo XVY y padrón de nobles de Ocoteluloo T.Rojas R., ed. (Mexico City, 1987)

Ponce, Pedro e.a., El alma encantada. Anales del Museo Nacional de Merico F.Bentez, ed. (Mexico City, 1987) [fics of edition 1892]

Prem, H.J., "Zwei alle Mapas au der Region von Huejotaingo", Actas du XIJle Congres Intemational des Ameficanistes Vol. VI (Paris, 1979), 39-50

Recopilación de leyes de los reynos de las Indias 3 Vols (Medrid, 1791) [fact.Medrid 1943]

Relaciones geogrdficas del Siglo XV: Thaxcala, 2 Vob, Rene Acuñe, od. (Mexico City, 1984-1985)

Relaciones geogrdficas de Mérico F.del Paso y Troncoso (Mexico City, 1890) [facs. ed. Mexico City, 1979]

"Relecionca sobre la organización social indigen en el siglo XVI', P.Carrasco, ed., Errudios de Culaura Nahuaul 7 (1967), 119-154

"Rebeión de Tepeaca y su partido", in: Relaciones geograficas del siglo XV: Tharcala Vol. II. pp. 217-262

"Releción de Cholula", in: Relaciones geagraficas del siglo XVI: Thaxcala Vol. II, Pp. 123-148

'Relación de Ocopethyuca, por Juan de ln Vega, 6 Octubre 1580', in: Relaciones geogrbfucas de Mérico 251-262

Ruiz de Alarcon, Treatise on the Heathen Superstitions that Taday Live among the Indiars Native to this New Spain 1629, RJ.Andrewa and R.Hansig, da (Nomnan 1984)

Sahngin, Fr.Bernardino de, Florentine Coder: General History of the Things of New Spain A.J.O.Anderson and Ch.E.Dibble, trang. and eds, 13 Vols (Sult Leke City, 1950-1982)

- Coloquios y dactrina Christiana M.Leon Portilla, d. (Mexico City, 1986) 
The Tharcalon A etas J Lockhart, F Berdan, A J O Anderson, tran and eds (Salt Lake Crty, 1980)

Torquearede, Frny Juan de. Monarquifa Indiana 3 Vob. M Leon Portllh, ed (Meruco, 1969)

-A Tranalaton and Crrtical Edition of Gonzalo Gomer de Cerventes La Vida coonomica y soclal de Nueva Epano al finaizar del siglo XVT, W LGnu, of , Ph D Dec Unrvernity of New Mexwo 1984 (Ann Arbor, 1987)

Verquez de Epmoza, P Antonso, Compendio y decrpenon de las indras ocendertales (Mednd, 1969)

Vetancurth Frny Aputin de. Teatro Mencano Daxcripcudn breve de las sucems cremplores, hurbincos, y religiasos del Nuewo Mundo de las Indias Crónca de la provincia del Sareo Evangelio de Menoo Marelogeo Francuscano (Mexuco Crty 1697 1698) [foco Mexuco City, 1971]

Las vimgyes eppaloles an Amtrica durante el gabiemo de la Casa de Austria, Menco, Vola I-D, L.Hanke, ad (Mindrd, 1976-1977)

Zortm. Alonso de. Breve y swmatia relactón de las selores de la Nueva Epposa Ed UNAM (Mexuco City, 1963) [Engluh editon Abreo de Zorita Lye and Labor in Anelent Menco The Bnef and Swonnary Relatwon of the Londs of New Span B Keen, ed (New Bnmowick, 1971)]

\section{Smoondary Sources}

Actes du XUle Congrts Internanonal des Amencanstes (Purs, 1977-1979)

Aquirre B , H J, La congregación avil de Tlacotepec (1604-1606). Cuademos de la Casa Chase Vol 98 (Mexuco Crty, 1984)

Aberro, S Behocarny, "Inquisiton et eccéte nvalites de pourvore t Tepeece (1656-1660)", Annales, ESC 36 (1981), 758-784

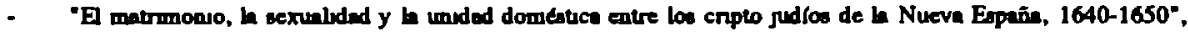
m 1 placer de pecar y el afdn de nomar, 103-145

Atman, I A Farnily and Region an the Northern Frmge Lands The Marqueses de Agunyo of Nuevo Ledn an Coahuile", on Provnces of Earty Manco, 253272

- Eugranis and Socieny Extremadura ald Amenco in the Sureenth Century (Berteley and Los Angeles, 1989)

- "Spaneh Socrety a Mexico Cety after the Conquest", HAFR 71 (1991), 413-445

Andrien, K J. "The Sale of Ficeal Offices and the Declune of Royal Authonty in the Vuceroyalty of Peru, 16331700*, HAHR 62 (1982), 49-71

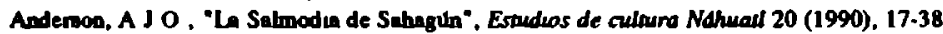

Appleby, J O Economuc Thought and Ideology in Seventecuth Century England (Proncelon, 1978)

Bakewell, PJ , Muners of the Red Mowrtaln, Indian Labor in Polost IS45-1650 (Albuquerque, 1984)

- Selvermuning and Sociery in Colonual Merco Zacavecas /S46-1700 (Cambondge, 1971)

- 'Zeatecas An Economic and Social Outlune of a Sulver Mining Distnet, 1547-1700*, in Provinces of Earty Menco, 190-230

Barren, EM, "Encomendas, Mercedes and Haciendes in the werra calierte of Michoacin", JbLA 10 (1973), 71.112

"Indinn Communty Lends in the therra calienie of Micboacin", JbLA 11 (1974), 78-120

Barrett, W J , The Sugar Haczendas of the Marqueses del Valle (Mmneapolw, 1970) (London, 1983)

Bartholomew Warld Travel Map, Menco (London, 1983)

Baudot G. "Fray Radngo de Sequern Devl's Advocate for Sahagin's Forbudden Hutory", an The Work of Sahagin, 119-134

- "Un señorio guntemalteco según aus caciques indigena, a fines del siglo XVI". AdEA 29 (1972), 103-120

- "Vanuded y ambición en el Tratado de los pecados moriales en leogun Nhunul de fray Andrts de Olmos", Estudias de culura Nahual 20 (1990), 39-63

Bawer, A J ."The Church and Spanish Amerncan Agraran Structure 1765-1865", TAm 28 (1971), 7898

- The Church in the Economy of Spanmb Amence Corsos and Depositas in the Eaghteenth and Nmeteenth Centurea". HAHR 63 (1983), 707-733

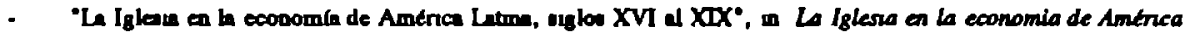
Lawna, 13-57

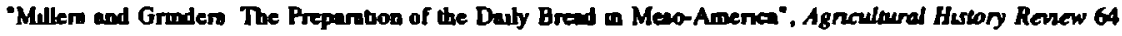
(1990). 127

- 'Purl Worters an Spanah Amence Probleme of Peonage and Oppreanon", HAFR 59 (1979), $34-63$

Buyon, D. "The Archrlecture and Art of Colonal Spanoh Amena", CHILA Vol II, 709-746

Berant, J. Cinco hacrendas meneanas tres rglas de vida rural an San Lus Polas (Mexuco City. 1975)

- Evolumon of the Textle Industry of Puebla, 1544-1845", CSSH 7 (1964-1965), 56-69

Berden, F F , The Aztecs of Contral Mercos An Impenal Soctaty (New Yort, 1982)

- "Replicación de prmcipios de mtercambio en le socieded mexucane de h cconomb a la religuda". m Economía polfuca e udeología en al MLaco prehuspanco (Mexuco City, 1978)

Buthen-Sumons, B , "The City of Cholula and its Ancient Bamos", in Verhandlungen des XOOVIII Interationalen Amertanuster Kongresses (1968) Vol D, 139-150

Bletkle, P Deutsche Untertanen - En Widerspruch (Mumich, 1981) 
Blockmam. W. "Beheerned en overtirgen Reflectes bu areuwe visies op etantsvormmg", TvSG 16 (1990), 18.30

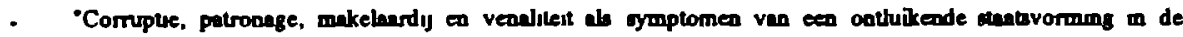
Bourgond usch-Habsburges Nederlandeo". TvSG 11 (1985). 231 -247

Blood, R, "A Hutoncal Geography of the Economic Actuvite of the Jerut Colegio Mrimo de Sen Pedro y Sen Pablo in Colonal Mextco, 1572-1767'. Ph D das , Unversity of Mmnesote, 1972

Borh. W W . "Loe euxuliares del gobernedor provmenl", m El gablemo provinaal, 51-64

'E gobernedor como edmmustredor civi", on El gobuemo pronncal, 65-74

"El gobernedor novohispano (elcalde myyor/corregudor) eqpectos economicon de h consecución del pucato". m El gobiemo provnacial, 37.50

- Jusuce by Insurance The Gereral Indian Coun of Colonal Menco and the Legal Alds of the Half Real (Berkeley and Los Angeles, 1983)

New Span's Century of Deprestron Ibero Amencane 35 (Berkeley and Lo Angeles. 1951)

"Some Problems of Sources", in Explorahons in Ehnohurtory, 23-39

"The Spanub and Indun Law New Spam". in The Inca and Azree Seates, 265-285

"El stanus jurdico de los andros en Nueve Eopaña". Amenca Indigena 45 (1985), 257-276

Bornh, W W and S F Cook, "A Case Hutory of the Tnnertion from Precolonul to the Colonul Penod a Mexuco Seougo Tejupen", un Social Fabnc and Spatial Sirucaure, 409-432

Bowy, J . Chnstanily in the Wer, J400-1700 (Oxford, 1985)

- Godparenthood the Fortunes of a Social Insumution in Early Modern Chratianity". in Religlon and Socieny in Earty Modem Europe, 194-200

Boyer, RE , La gran unudacadn Vida y sociedad en la ciudad de MEnco (1629-1638) (Mexuco City. 1975)

"Mexuca in the Seventeenth Century Transition of a Colonial Society', HAHR 57 (1977), 457-465

Breding, DA The First America The Spanish Monarchy Creole Paunots, and the Lberal State, 1492-1867 (Cumbindge, 1991)

Hoctendas and Ranchos in the Mencan Bajlo Ladn 1700-1860 (Cambrige, 1978)

"The Histoncal Demognaphy of Eughtecenthentury Mexico a Review", un Bulletun SLAS 25 (1976), 3-17

"Images and Prophes Indian Religion and the Spanish Conquest", in The Indian Communuy of Colonial Menco. 184-203

"Govemuent and elite in late colonual Mexico", HAHR S3 (1973), 389-414

Los origeres del nacionaluma mencaro (Mexuco City, 1973)

Prophecy and Myth in Mencan History (Cembndge. 1985)

"Tndentune Catholucum and Enlightened Despotum un Bourbon Mexues". JLAS 15 (1983), 1-22

Braudel, F, El mediterraneo y el mundo meterraneo en la tpoca de Felpe II 2 Vols (Mexico Crty, 1987) [Ongunal Freach editoon 1949]

- Civilzation and Capitalusm, 15th-18th Cerisury 3 Vob (London, 1984-1985) [ongunal Freach edition 1979]

Brenner, R, 'Agrenan Clases Struggle and Economic Development in Pre-Industral Europe". PoP 70 (1976), $30-75$

- Agranan Clase Struggle and Economic Development in Pre-Induatral Europe the Agranan Roots of European Cepraliem: . PaP 97 (1982), 16-112

Breuer. S "Impeneo der Neuen Welt" Zur Klasafikauon des Inke und Aztekenstantes", Soeculum Jahrouch for Unuversalgeschichte 39 (1988), 35-62

Broda, J . Algunas notns sobre crfuce de fuentes del Mexico antiguo Relaciones entre las crónicas de Otmos. Motolnha, La Caan, Meadrela y Torqquenade', RdI 3334 (1973.'74). 123-165

- "Templo Mayor as Rubual Space", an The Great Tenple of Tenochatlan. 61-123

Brunner, $O$. Neue Wege der Vefassongs- und Sozalgeschuchse (Gōtungen, 1968)

"Feudalsmus Ein Beitrog zur Begriffageachichte", in Feudaluonus, 87.125

Burke. "How to be a Counter Reformetion Saunt", in Religion and Sonery in Earty Modem Eunope, $45-64$ Volkscultuur in Europa, 1500-1800 (Amaterdam 1990) [Ongunal Engluah editron London 1978]

Burtharh LM . "Doctrmal Aspects of Sahagin's Coloquros", in The Work of Bemardino de Sahogin, 65.82 The Stppery Earth Nahwa-Chrstian Moral Dialogue in Sutcenth-Century Meaco (Tucsoo, 1989)

Burtholder, M A and DS Chandler, From Impolence to Authony The Spansh Crown and the American Audlencias, I787-1808 (Columbis and Loodon, 1977)

Burns SJ, RI, "Relic Vendors. Barefoot Frars, and Spansh Musims Reflectoon on Medieval Economie and Religious Hutory", CSSH 24 (1982), 153-163

Buve, RTh. "Cloo en de campesinos in de Mexucangace revolute De lange oagepleverde weg nanr bet dorp". Oration Lexdeo Unversity, 1986

- Peanantry and the Stric in Colonal Mexuco A Teatauve Compareon with Wertero Europe", Ianerano 15 (1991), 97111

Calnek, E E , The Interal Structure of Tenocbbtha", un The Valley of Menoo, 287.302

- "Patrerns of Empure Formaton in the Valley of Mexuco, Late Poutelasic Penod. 1200-1521", in The Inca and Azsec Slates, $43-62$

Calvo. T , Acazango Demografia de una parroqua mericana (Mexico City, 1973)

The Combrige Husery of Medeval Polucal Thought, c 350-c 1450J H Burns, ed (Cambrndge, 1988)

Canterle y Martin de Tovar, F , La iglesia de Oarace en el Siglo XVIII (Seville, 1982) 
Cambridge HLrory of Latin America Vols I-II, L.Bethell, ed. (Cambridge, 1984)

Carmagnani, M., "The inertin of Clio: The Social Hibory of Colonial Mexico", LARR 20 (1985), $149-166$

"Local Governmente and Ethnic Govemment in Oaxeca", im: Essays in the Potitical, Economic and Social History of Colonial Latin America 107-124

- E regreso de los dioses: el proceso de reconstincion de la idensidad enica en Oaxaca. Siglos XVI y XVIII (Mexico City, 1988)

Camseo, P., "América ind f́gena", in: Historia de America Latina, 11-122

- "Ln bases socinles del politeismo mexicano: los dioses tibulares", in: Actes de XIIle Congres Intemational des Americanistes Vol, VI, Pp. 11-17

- "La Barrion Antiguos de Chohuln", in: Estudios y docwnerios de la region de Puebla-Tharcala Vol. III (Puebla, 1971), 9-88

- "The Chiefly Houses (Tecolli) of Ancient Mexico", in: Actes de XIIIe Congris International des Amdricanistes Vol. DXb, Pp. 177-186

- The Civil-Religiow Hienerchy in Mesoamerican Communities: Pre-Hipanic Background and Colonial Development", American Anthropologist 63 (1961), 483-497

- "La conomín del México prehispanico", in: Economia polltica e idealogía

- "Los límajea nobles del Mérico nntiguo", in: Estrabificacion social en la Mesoamérica prehiopdnica

- "Los myeques", HMex 39 (1989), 123-166

- "The Political Economy of the Aztec and Ince States", in: The Inca and Aztec States, 23-40

- "Social Organization of Ancient Merico", in: Handbook of Middle American Indians, Vol. X: Archacology of Northem Mesoamerica, Vol. I, Eckholm and Bernal, eds (Austin, 1971), 347-375

"La transformación de la culture ind figena durante la colonia', HMex 25 (1975), 175-203

Carren Stamps, M., "The evolution of Weights and Measures in New Spoin", HAHR 29 (1949), 2-24

"Las ferias novohispanse", HMex 2 (1953), 319-342

Chambertain, "The Corregidor in Castile in the Sixteenth Century and the Residencia as applied to the Corregidor". HAHR 23 (1943), 222-257

Chance, J.K., Conquest of the Sierro. Spariands and Indians in Colonial Oaxaca (Norman, 1989)

- Race and Class in Colonial Oaxaca (Stanford, 1978)

Chance, J.K., and W.B.Taylor, "Cofradtas and Cargos: an Historical Peropective on the Meanamerican CivilReligious Hierarchy", American Ethrologist 12 (1985), 1-26

Chartion, T.H., "Uman Rural Relations in the Basin of Mexico", Supplement to the Handbook of Middle American Indians Vol. IV, R.Spore, ed., 122-133

Chevalier, F., La formation des grands domaines a Merique. Terte et socialt aux XVe-XVIle sizcles (Parit, 1952) reference to Spanioh translation: La formacion de los latifundios en Mérico. Tierra y sociedad an los siglas XVI y XVII (Mexico City, 1976)

- 'La gran propieded en México deado el niglo XVI hasta comienzos del aiglo XIX'. in: Fonnación, 499-508

Christian, W.A.Jr., Local Religion in Sirteenth-Century Spain (Princeton, 1981)

Clark, P., "Migration in England during the Late Seventeenth and Early Eighteenth Centuries", PaP 83 (1979), $57-90$

Chrk, P., and P.Slack, English Towns in Transition, 1500-1700 (Oxford, 1976)

Clendinnen, I., Ambivalent Conquests. Maya and Spaniard in Yucatan, 1517-1570(Cambridge 1987)

"Disciplining the Indians: Franciscan Ideology and Missionary Violence in Sixteenth-Century Yucatin", PaP 94 (1984), 27-48

- "Landecape and World View: The Survival of Yucatec Maya Culare Under Spanish Conqueat", CSSH 22 (1980), 374-393

Cline, H.F., "Civil Congregations of the Indiano in New Spain, 1598-1606", HAHR 29 (1949), 349-369

Cline, S.L., Colonial Culhuacan 1580-1600. A Social Hirtory of an Aztec Town (Albuquerque, 1986)

- "Land Tenure and Land Inherilance in Late Sixteenth Century Culhuncan", in: Explorations in Ethrohistory, 277-309

- "Revisionist Conquest History: Sahngun's Revised Book XII", in: The Work of Bemardino de Sahaguin, 93-106

Coleman, J., "Property and Poverty", in: Cambridge History of Medieval Political Though, 607-648

Collomp, A., "Alliance et filiation en haute provence au XVIlle sitele", Annales ESC 27 (1972), $445-477$

- La Maison du Pere. Fanille et village en Haute-Provence aur XVIle et XVIlle siecles (Paris, 1983)

- From Stem Farnily to Nuclear Fumily: Changes in the Coresident Dorneatic Group in Haute Provence Between the End of the Eighteenth and the middle of the Nineteenth Century", Continuty and Change 1 (1988), 65-81

Cook, N.D., "Population Data for Indian Peru: Sixteenth and Seventeenth Centuries", HAHR 68 (1982), 73-120

Cook, S.F., The Historical Demography and Ecology of the Teotlalpan Ibero Americana: 33 (Berkeley and Los Angele, 1949) [facs. Ann Arbor, 1987]

Cook, S.F. and W.W.Borah, Essays in Population History: Merico ard Calfomia 3 Vob (Berteley etc., 1971 1979)

- The Indian Population of Central Merico, 1531-1610 Jbero Americans: 44 (Berkeley and Lot Angeles, 1960) 
- Quelle fut he itratification sociale au Centre du Mexique durant la premitre moitie du XVIe sitcle". Annales, ESC 18 (1963), 226-258

- The Population of Contral Merico in 1548 Ibero Americans; 43 [facs. UMO, Ann Arbor, 1987]

- 'Royal Revenues and Indian Population in New Spain, ca. 1620-1646', in: Essays Vol. III, 1-128

in Cook and Borah, Essays in Population History Vol. II, 1-128.

Couturiex, E.B., La Hacienda de Hucyapan, 1550-1936 (Mexico City, 1976)

Cuello, J., "El mito de la haciende colonial en el norte de Mérico", in: Empresarias, indias y estado, 186-205

"Sultillo in the Seventeenth Century: Local Society on the North Mexican Frontier", Fh.D.dien. Univenity of Califomin (Bertreky 1981)

- 'Socioeconomic Involution in Colonial Saltillo, 1577-1821", ERLACS 49 (1990), 55-78

Cummins, V.H., "After the Spiritual Conquest: Patrimonialin and Politics in the Mexican Church, 1573-1586", Ph.D.Dies Tulane University, 1979 [fecs. Ann Abor, 1987]

Davies, N., The Ancient Kingdoms of Herica (Hamondoworth, 1982)

- The Aztec Empire (Normen, 1987)

- The Toltee Heritage: From the Fall of Tula to the Rise of Tenochtitlan (Nomen, 1980)

Devies, W., Small Worlds. The Village Comnunity in Earty Medieval Brinary (Berteley and Los Angeles, 1988)

Davies, W. and P.Fouracre, "Conclusion", in: Settlement of Disputes in Earty Medieval Europe, 207-240

Dehouve, D., "The 'Mosey of the Saint'. Ceremonial Organization and Monethry Capital in Thapa, Guerrero, Mexico", in: Manipulating the Saints, 149-174

- "El pueblo de indios y el mercado: Thap (Guerrero) en el siglo XVII", in: Empresarios, indios e estado, 86-102

- Quand les banquiers deaient des saints. 450 ans de l'histoire Economique et sociale d'une province indieane du Merique (Paris, 1990)

- The 'Secession' of Villages in the Juriadiction of Thap (Eighleenth Century)", in: The Indlan Comnuniry of Colonial Merico, 162-182

Destefano, M.T., "Miracles and Monestician in Mid-Colonial Pueble, 1600-1750: Chariamntic Religion in a Conaervative Society", Ph. D. Dins University of Floride, 1977 [facs. Ann Arbor, 1986]

Dibble, Ch.E., "Sahagún's Appendices: There in No Reason to Be Surpicious of the Ancient Practicese", in: The Work of Sahogun, 107-118

Duby, G., Guerriess et paysans. Vle-XIle sidele. Prenier essor de l'coonomie curoptenue (Parin, 1973)

Dumont, D.E., "An Outline of the Demognphic History of Tlaxcab", in: The Maxcallecars, 13-23

Dumbebin, J., "Government', in: Canbridge History of Medieval Political Though, 477-519

Dyckerhoff, U., "La extratificación social en Huexotzingo", in: Estrafificacion social, 157-177

"Forged Viligge Documents from Huejotzingo and Calpan". Actes de XIIle congrts Intemational des Americanistes Vol. VI (Paris, 1979), 51-64

- Indian Corporte Landholding during Colonial Tunes. A Glimpse from the Valley of Puebla", in: The Indian Community of Colonial Merico, 40-59

Elliot, J.H., Spain and Americe in the Sirteenth and Seventeenth Centuries", in: CHLA Vol. I, pp. 287.339

- Spain and iss World, 1500-1700. Selected Essays (New Haven and London, 1989)

- "The Spanish Conqueat and Setulemeat of America", in: CHIA Vol. I, Pp. 149-206

Empresarios, indios y estado. Perfil de lo economia mericana (Siglo XVIII) A.Ouwencel y Ch.Tonles Pacheco, compa (Amotendam, 1988)

Enciso Rojas, D., "La legislación sobre el delito de bigamia y au apliceción en Nueva Eapaña", in: El placer de pecar y el afdn de normar, 249-293

Enge, K.T., and S. Whiteford, The Keepers of Water and Earth. Meriean Rural Social Irrigation and Imigation (Austin, 1989)

von Erffe, A., e.o., Geologie des Hochbectens won Puebla-Tlaceala wod seiner Umgebung. Eriduferungen ze einer geologischen Karke (Wienbeden, 1977)

Essays in the Political, Economic and Social History of Colonial Latin America K.Spalding, ed. (Newark, 1982)

Etratificacion sacial en la Mesoanérica prehiparica P.Cermeco and J.Brode, eds (Mexico City 1976)

Estudias sobre polltica indigarista espaftala an América. Actas del simposio commemorativo del V. centenario del Padre Las Casas. Teneeras jomadas anericanistas de la wiversidad de Valladolid 3 Vols (Valledolid, 19T7)

Ewald, U., Estudias sobre la hacienda colonial an MErico. Las propiedades rurales del Colegio Espiriou Santo a Puebla (Wieabuden, 1976)

The Merican Sall Industry, 1560-1980. A Suefy is Change (Stuttgert, 1985)

Fanily and Inherilance. Rural Sociany in Westem Europe, 1200-1800 J.Goody, J.Thirak, E.P.Thompaon, eds (Cumbridge, 1976)

Ferrias, N.M., Maya Society under Colonial Rule. The Collective Enterprise of Survival (Princeton, 1984)

- "Indians in Colonial Yucaten: Three Perepectives", in: Spantands and Indlans in Southem Mesoamerica, 1-39

Feudalionus. Zehn Ayfseze H. Wunder, ed. (Munich, 1974)

Five Cenmries of Low and Politics in Central Merico R.Spores and R.Hessig, eds (Nabuille, 1984)

Floreacano, E., "El abusto y b legisleción de tranow en el siglo XV1", HMax 14 (1965), 567-630

"The Formation and the Economic Structure of the Heciende in New Spain", in: CHLA Vol. II, pp. 153-188 
Precias de mate y crisis agricolas an Mérico, 1708-1810 (Mexico, 1969)

Frnok, A.G., Merican Agriculture, 1521-1630. Tranformation of the Mode of Production (Cambridge 1979)

Freedman, P.. "Military Orden and Peasant Servitude in Catwlonia: Twelfh and Thirteenth Centuries", HARR 65 (1985). 91-109

Freidel, "Lowhand Maye Political Economy: Hitorical and Archeological Penpectives in Lifht of Inteneive Asriculture", in: Sparlands and Indiars in Southem Mespanerica, 40-63

Gentes Trellez, M., 'Aspetos eocio-ecooomicos de Puebla de los Angeles (1624-1650)", AdEA 40 (1983). $497-613$

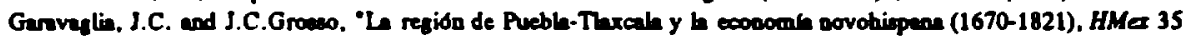
(1980), 549-600

- 'Mexican Eliles of a Provincial Town: The Landownen of Tepeaca (1700-1870)", $R$ AFR 70 (1990), $255-293$

Gareh, G., 'Don Juen de Palafox y Meodoza", in: Dacumertos insdicos para la hisworia de Merico

Gerch Cook, A.. "The Historical Importance of Therale in the Cuturn Developoneat of the Central Highlands". in: Supplenent 1 to the Handbook of Middle American Indians, 244-276

Geref Gallo, A., "Alaldes mayores y corregidores en Indias". in: Menorias del primer congreso Venezolano de hirtorio, Vol. I (Cancas, 1972), 299-315

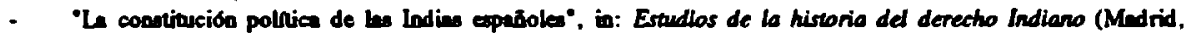
1972), 11-32

"Los orffinea de le adminisución territorial de las Indies', Anuario del Derecho Espanol 15 (1944). 16-106

Garce Martines, B., Historie de Mérico (Mexico City, 1985)

- El Marquesado del Valle. Tres siglos de reginen setarial an Nueva Espana (Mexica City, 1969)

- Los pueblos de la sierro. El pader y el epacio arre los indios del norre de Puebla hasra 1700 (Mexico City. 19877

- Pueblas de Indios, Pueblos de Castas: New Setulenents und Treditional Corporate Orjanizntiona in Eighteenth Ceatury New Spain", in: The Indian Community in New Spain, 103-116

Geroer, R L. "Price Tronds in Eightecenth Century Mexico", HAHR 6S (1985), 279-326

The General Crisis of the Seventeench Cenary O.Parker and LM.Smith, ads (Loodon, 1978)

Gerbat M-C. 'Le confréries religieune a Ctceres de 1467 1523". Mellanges de la Caso Velazque 7 (1971), 75-113

Gerbi, A.. The Dipule of the New World (Pituburgh, 1973)

Gerhard, P., "Un Ceneo de la didcesia de Puebla en 1681", HMer 30 (1981). 53 1.560

- Congregaciones de indioa en la Nueva Eapania antes de 1570". HMe 26 (1977), 347.395

- 'La evolución del pueblo rural Mexicano: 1519-1975", HMer 30 (1981), 566-578

- A Guide to the Historical Geography of New Spain (Cambridge, 1972)

Geschichuliche Gnoubegriffe. Historischer Letcon zur politisch-sociale Spreche in Dauschland, O.Brunner, W. Conze, R.Koselleck, de, 6 Vols (Stuttgart, 1984-1992)

Gibson, Ch., The Aztecs under Spanish Rule. A Bistory of the Indiars of the Valley of Merico, ISIR/810(Sinnford, 1964)

- IIndian Societiea under Spanish Rule", in: CHLA Vol. I, pp. $381-419$

- 'Lamamiento Generd, Repartimiento, and the Empire of Acolhuscan', HAFR 36 (1956), 1-27

- Rotation of Alcaldes in the Indien Cabilda of Mexico City", HAHR 33 (1953), 212-223

- Raxcala in the Sirteath Centwry (New Heven. 1952) (repriat Sianford, 1967]

- 'Structure of the Aztec Empire", in: Hordbook of Middle American Indlars Vol. X, Pp. 376-394

E goblemo provincial an la Nueva Epata. 1570-1787 W. W.Bonh. ad. (Mexico City. 1985)

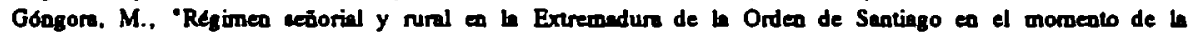
enigneióa Indie", JbLA 2 (1965).

- Soudies in the Colonial History of Spanish America (Cambridge, 1975)

Gonatea Marmolejo, J.R. "Confeares y mujeres en el obispado de Pueble, aiglo XVII", in: El placer de pecar y el afdu de nomar, 147-165

Gonzalo de Sen Segundo, M.A. 'Pervivencie de b organización ecīorial aborigen (contribución al esandio del cacionzo y ut ordennción por el derecho indiano)". AdEA 39 (1982), 47.92

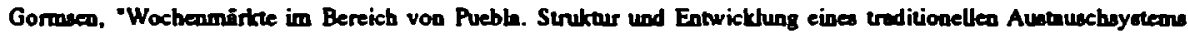
in Meriko", JbLA 8 (1971). 366-400

Gosoer, K., "Las elites indígens en los altos de Chimpas (1524-1714)". HMer 33 (1984), 405-423

The Great Tenple of Tenochitilan. Conter and Perifery in the Azlec World J.Brode. D.Carmeco, E.Mnion Mocteama, ds (Berkeley and Los Angelea. 1987)

Greyerz, K. von. "Iotroduction", in: Religion and Sociery in Earty Modem Europe, 1-10

Gries. D., Population Growth and Agrarian Change. An Histarical Perspective (Carabridge, 1980)

- The Dynanics of Agrarian Change. The Historical Epperience (London, 1982)

Gnzzinaki, S.. "Confesión, alinnza y sexualided eatre los indios de Nueva Españe (introducción al estandio de los confesionsrios en leoguns ind(genes)", in: El placer de pecar y el aften de nomar, 169.215

- La colonisadon de l'imagiraire. Socilts indigenes es oceldentalisation dars le Merique eqpognol. XVe-XVIIJe silecle (Paris, 1988)

- Indinn Coofnternities. Brotherhoods and Mayordomiss in Central New Spain. A Lit of Queatioas for the 
Hutorien and the Anthropologut", in The Indean Communuty of New Spain, 205-223

- El poder sn lfmules Cuatro respuestes undigenas a la domunacion expanola (Mexuco City, 1988)

Gudeman, S, and A Ruern. Conversations in Colombia The Domesnc Economy in Lufe and Tert (Cembndge. 1990)

Gutherrea Brockington, E. The Leverage of Labor Managing the Cortes Haciendas in Tehuantepec (1588-1688) (Durham, 1989)

Gution, I P . "Confraternties, Curés and Communites in Runal Arcas of the Drocese of Lyon under the Ancien Regame", in Religion and Soctety in Earty Modem Europe, 202-211

Hactendas and Plantations in in Latn Amencan HLstory R G Kerth, ed (New York, 1977)

Hactendas in Central Menco from Late Colonsal Tines to the Revolution R.Th J Buve, ed (Amsterdam, 1984)

Hactendas, laffundias y plantaczoner en Amernea Latura, E Florescano, coord (Mexico City, 1975)

Hemnett, B R. Poluncs and Trade in Soushem Menco (I750-1821) (Cambndge, 1971)

"Dye Production, Food Supply and the Leborng People of Oexaca, 1750-1820", HAHR 51 (1971), 51-78

Houdbook of Muddle Amencan Induars R Wuchope, ed , 12 Vots (Auston, 1971)

Henke, The Spanish Struggle for Jusnce in the Conquest of America (Baston, 1949)

Harvey, H R. "Aspects of Land Tenure in Ancient Mexuco", Explorations in Ethnohurery, 83-102

- "Techualoyan Codicea Seventeenth Century Indian Land Tilles in Central Mexico", m Supplemert to the Handbook of Muddle Amencan Indians, Vol IV, R.Spores, ad , 153-164

Hekett, R.S. "Indan Town Government in Colonial Cuernaveca Perastance, Adaption and Change", HAHR 67 $(1987), 203231$

- Indian Community Land and Munecipal Income in Colonial Cuemavace An Investugation through Nehuntl Documents", in The Indian Commerity of Colonsal Mesca, 130-141

- Indigenous Rulers An Ethnohustory of Town Govemment in Cobnual Cuemavaca (Albuquerque, 1991)

- "Our Sufferng with the Taxco Tnbule" Involuniary Mina Labor and Indigenous Society in Central New Span", HAHR 71 (1991), 447-475

"A Social Hustory of Indian Town Government in the Colonial Cuernaveca Juradiction", Mexuco, Ph D Duss , Univereity of Californis, Los Angeles (Ann Arbor, 1985)

Hassig. R.Trade. Trbute and Transortation The Suleenth-Cannry Polincal Economy of the Valley of Meaco (Norman, 1985)

Heme, K , "Oullme of Man's Impact on the Natural Environment in Central Mexico", JbLA 20 (1973), $121-132$

Heredia H A de, and J J Real P, "Las cartas de los virreyes de Nueva España a la corona española en el siglo $\mathrm{XVI}^{*}$, AdEA 31 (1974), 441596

Hıcks, F, "Mayeque y calpuleque en el autemn de clases del Méxıco antuguo", un Estratuficacudn soctal, 6787

- "Prchupanic Background of Colonjal Politucal and Economic Organization in Central Mexico", m Supplement to the Handbook of Middle Amencan Indians, Vol IV, R Spores, ed (Austun 1986). 3554

'Tetzcoco in the Early 16th Century the State, the City and the Celpoll". Amencan Ethnologist 9 (1982), 230-249

Hurschberg, J , "An Altemative to Encomuenda Pueble's Indios de Servicio, 1531-45", JLAS 11 (1979), 241262

'Transienta in Early Colonial Society Puebla de los Angeles, 1531-1560", in Ibenan Colonies, New World Societres, 21-35

Histona de Amenca Latura, N Stnchez Albornoz, ed (Madnd 1985)

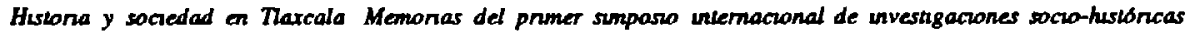
sobre Tlaxcala Octubre 1985 (Thaxcale, 1986)

Hoberman, LS, "Merchanto in Seventeenth-Century Mexuco City A Prelumunary Portrait", HAHR 57 (1977), 467-494

- Menco's Merchant Elite, 1590-1660 Stiver State, and Soctety (Durham and London, 1991)

Hochstedt, S , "Migration in prendustral Gemminy", Ceniral European History 16 (1983), 195-224

Hoekstra, F G , "A Changung Order Congregation poliuca in Mexico (1550-1605)", (in preas)

- A Different Way of Thukung Contrasung Spanush and Indian Social and Economic Views in Central Mexico (1550-1600') in The Indian Community of Colonsol Menco, 60-86

- The Making of the Pueblo de Indios A Suxteenth-Century Dualectre between State and Cacaque". Paper Wortchop CEDLA 1990 (un press)

"Profit from the Wastelands Social Change and the Formation of Haciendas in the Valley of Puebla, 15701640", ERLACS 52 (1992), 91-124

Hoffinan, Fh T, Church and Communty in the Diocese of Lyon 1500-1789 (New Haven and London, 1984)

Hom, R, Postconquest Coyoactin Aspects of Indigenous Sockopolitical and Economic Organizetion in Ceatral Mexuco, 1550-1650*. Ph D Duss, Unuversity of Calufomin (Ann Abor, 1989)

Ibenan Colones, New World Socnetaes Essays in Memory of Charkes Gibson R LGarner and W B Taylor, ede (private edition, 1986)

La Iglesia en la economfa de Aménca Latuna, siglas XVI al XIX A J Bauer, ed (Mexuco, 1986)

The Ince and Azsec Slates 1400-1800 G A Colluer, R.I Rosaldo and J D Wurth, eds (New Yort, 1982)

Indian-Religuous Relations in Colonal Spanush Amenca S E Ramirex, ed (Syncuse. 1989)

Ingham, J M , Mary, Miehael, and Luczfer Folk Catholocken in Central Menco (Austun, 1986)

Ingham. M Religion, Communities, and Moral Decpline in late Sixteenth-Century England Case Studres". in 
Religion and Society in Earty Modem Europe, 177-190

Inel, J.I., "Mexico and the 'Generd Crisis' of the Sevententh Century', PaP 63 (1974)

- Race, Class and Politics in Colonial Merico. 1610-1670 (Oxford, 1975)

Jarquen O., M.T., Fornación y desarrollo de un pueblo nowohiparo: Metepec en ed Valle de Toluce (Toluca, 1990) Jooen, P.M., Polities and Rural Sociesy. The Southem Masif Central (I750-1890) (Cembridge, 198S)

Jone, L de, "Community Diecoune: A Family Confliet in Eighteentb-Ceaniry Coyotepec, Oaxece". in: The Indian Communily of Colonial Merico, 250-269

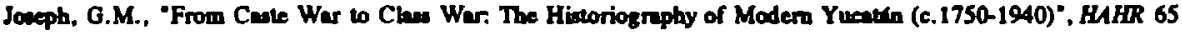
(1985), 111-133

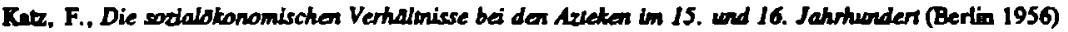

Keen, B., "Mnin Currente in Uniled Stater Writings on Colonial Spaniah America, 1884-1984", HAHR 65 (1985), 657-682

Keith, R.G., "Encomienda, Hacienda and Corregimiento in Spanish America: A Structurl Analyois", HAHR 51 (1971), $431-46$

Kelloge, S. "Housebolds in Late Prehimpanic and Earty Colonial Mexico City: Their Structure and its Implications for the Sudy of Hittorical Demography", TAm 44 (1987), 483-494

- La upervivencia culural de lo indfenas en el Mérico Cenlral deade 1521 hrita 1600: una nueve interpretacion", Mesoantrica 8 (1984), 304-320

The Indian Communiny of New Spain. Fifleen Essays on Land Tenure, Corporase Organizations, Ideology and Village Politios A.Orweneel and S.Miller, eds (Amsterdam, 1990)

Kiern, J.E., "The Social and Ethnic Historiography of Colonial Inlin America: The Lat Twealy Yeari", Willan and Mary Qwarkenty 45 (1988). $453-488$

Khaw, D., Niederschlogsgenese und Miederschlogsverteilung in Hochbecken won Puebla-Tlarcalo (Bonn, 1975)

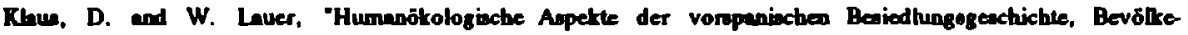
nungeentwictlung und Gesellachaftertruktur in Mexikniachen Hochland". JbLA 20 (1983), 85-120

Rbveran, J. van, "Fintelimum-Mestantilianua-Komption", VSWG 64 (1960), 333-353

Klein, H.S., "The State and the Labor Marted in Rural Bolivin in the Colonid and Early Republican Periods", in: Essays in the Political, Economic and Social History of Colonial Latin America, 95-106

Klor de Ave, J.J., "Spiritul Conflict and Accomodation in New Spain: Toward a Typology of Aztec Responses to Chritianity", in: The Inca and Aztec States, 345-366

Knoblich, K., "Grundwaserneubildung und Grundwnuerenchliebungemöglichkeiten im Raum Puebla-Thexcaln". JbLA 20 (1983), 133-150

Konnd, H.W., A Jesuil Hacienda is Colonial Merico. Santa Lucla, 1S76-1676 (Sunford, 1980)

Kubler, G., Arehirectura mexicana del siglo XV (Mexico City, 1984) [original Engliah edition 1948]

- "Mano de obre ind fgena en la construcción eclesiratica", in: La lglesia a la economia de America Larina. 279-313

"La traza colonial de Cholula", Estudias de Historia Navohispana 2 (1968), 111-128

Laron, B., Colonialion and Agrarian Tranformation in Bolivia, Cochabamba, 1550-1900 (Princeton, New Jersey, 1988)

Levren, A., 'Diverity and Disperity. Rural and Urban Confraleraitice in Eighteenth Century Mexico", in: Manipulating the Saints, 67-100

- "Mundoa en contraste: cofredía rurale y urbanes en Mexjeo a finea del siglo XVII", in: La Iglesia an la conomila de America Latina, 235-276

- Rurl Confrnternities in the Local Economies of New Spain. The Bishopric of Oncaca in the Context of Colonial Mexico*, in: The Indian Comnerity of Mexico, 224-249

Lee, RC., "Cochineal Production and Trude in New Spain to 1600", TAm 4 (1948), 449-473

"Grin Legialation in Colonial Mexico (1575-1585)", HAFR 27 (1947). 649-660

Lehmenn, "Two Pathe of Agrainn Cepitaliam, or a Critique of Chayanovian Marxinn". CSSH 28 (1980), 601-627

Leda Portilh, M., Azlee Though and Culare. A Study of the Ancien Nahuall Mind (Noman, 1963)

"Mesoamerica before 1519", in: CHIA Vol. I, Pp. 3-36

Tolvectyoul. Aspectos de la cultura nathaul (Mexico City, 1980)

Levine, D., Reproducing Fanilies. The Political Economy of Englinh Population Hivtory (Cambridge, 1987)

Lewis, L, "Indian Political Activitics in Spanish Texcoco, 1570-1630", in: Five Centuries of Low and Polides, 55-60 "In Mexico City's Shadow: Some Appects of Economic Activity and Social Procenes in Terocen, 15701620", in: Provinces of Earty Mesico, 125-136

Liente, J.A., Crearton of a Merican Landecpe. Territorial Organization and Sedlenat in the Eartem Puebla Basin. IS20-1605 (Chicago, 1981)

Lichr, R., "Die Grundhermechaft der Herzōge von Alixco im koloninlen Mexico", JbLA 9 (1972), 137-172 Stadtrat und stadtische Oberschlcht uon Puebla an Ende der Kolonialzeil (1787-1810) (Wiesbiden, 1971)

Lipeen-River, S. "Puebla's Eighteenth Century Agrainn Decline: A New Perspective", HAHR 70 (1990), $463-481$

Lockher, J., "Cepital and Province, Spanind and Indian: The Erample of Late Sixteenth-Century Toluca", in: Provinces of Earty Merico, 99-124

"Charles Gibaon and the Elhnohirtory of Poatconqueat Cantral Mexios". LaTrabe Univenity of Latin American Studies, Occasional Paper, 9, n.d. [1978] 
- "Encomiende and Heciende: The Evolution of the Great Eatule in the Spaniah Indien", BAHR 49 (1969), 411 429

"Eppefioles entre indion: Tohuca a funes del aiglo XVI", RdI 33-34 (1973-74), 435-491

"Introduction", in: Provinces of Early Merico, 3-28

"Podcongued Nehun Society and Concepto Viewed through N(huntl Writingo", Estudlas de Culaura Naluad 20 (1990), $91-116$

"The Socill HEtory of Colonial Spenith America", in: LARR 1 (1972), 6-45

"Social Orgeniration and Social Chenge in Colonil Spaniah America". in: CHIA Vol. II, pp. 265-320

"Viere of Corponle Self and Hitory in Some Valley of Mexico Town: Lete Seventeenth and Eighteanth Centurice", in: The lice and Avter States, 367-393

Locibart, J., F.Berden, A.J.O. Andernon, 'Preliminary Study: Some Themes in the Acts', in: The Tharcalan Actas, 1-34

Locthart, J. and S.B.Schwert, Earty Latin America. A Blstory of Colonial Sparish America ad Braedl (Cembridge, 1983)

Loten, M.H. and W.T.Sanders, "The Madel", in: The Valley of Merico, $31-58$

Lovell. W.G., Conquest and Survival in Colonial Guatemala. A Historical Geognaphy of the Cuchumaten Hightands, 1500-1821 (Kinguton aod Monireal, 1985)

- Indian Migration and Commenity Formation: an Antyain of Congregacion in Colonial Guntemale", in: Migration in Colonial Spanish Ameriea, 18-40

Lynch, J., Spain under the Hapsburgs. Spain and America, 1598-1700 (Oxford, 1969)

MecAodrew, The Open Air Churehes of Sirteerth-Century Merico (Harvard, 1965)

MacCormack, S., "The Heart Hes It Ressons': Prodicament of Minionary Chriatianity in Earty Colocial Peru", HAFR 65 (1985), 443-466

MecFurlane, Alan, The Culure of Capitalion (New Yort, Oxford. 1987)

MacFurbene, Antbony, "Civil Dieorden and Popular Proteat in Lele Colonial New Granda". HAFR 64 (1984), $17-54$

Mackey, A., Spain in the Middle Ages. From Frontier to Empire, 1000-1500 (London, 1977)

Maclechlno, C.M., Spain's Empire in the New World. The Role of Ideas in Instimutional and Social Change (Berkeley and Lo Angeles, 1981)

MacLeod, M.J., 'Appect of the Internal Economy of Colonial Spanich America: Labour, Taxation, Dintributrion and Exchange", in: CHLA Vol. I. pp. 219-264

- 'Dominican Explanation for Revolte and Their Suppreaion in Colonial Chinpes, 1545-1715', in: IndianReligious Relations in Colonial Spanich America, 39-53

- Ethnic Relations and Indiap Socien in the Province of Guntemnh, an. 1620-ca.1800", in: Spariands and Indians in Southem Mesoanerica, 189-214

-The Primitive Nation State, Delegation of Functions, and Resulu: Some Eromple From Early Colonial Centril Americe", in: Essays in the Political, Economic and Soctal History of Colonial Latin Ameriea, 53-68

Spanish Ceatral America. A Socioeconomic History, IS20-1720 (Berkeley, 1973)

MacNeish, R.S., "A Summary of the Subaintence", in: Prehistory of the Tehuacan Valley Vol. 1, 290-310

Manipulating the Saints. Religious Brotherhoads and Soclal Integration in Pastconquest Latin Americo A. Meyers and D. E.Hopkins, eds (Hamburg, 1988)

Matvido, E., "Factore de despoblación y de repasición de la población de Cholula (1641-1810)', HMex 23 (1973/89), 52-110

Martin, Ch.E., Rural Sociery in Colonial Morelas (Albuquerque, 1985)

- The Dynamics of Clio: Periodization in the Social Hivtory of Colonial Mexico", LARR 20 (1985), 171-175

- "Hocieoder and Villages in Lete Coloninl Morelos". HAFR 62 (1982), 417-427

Martin, N.F., Los vagabundas on la Nueva Epala. Siglo XVI (Mexico City, 1957)

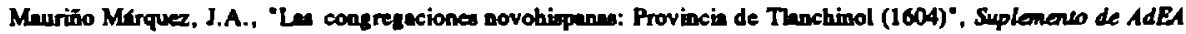
XLVI. Historla y Bibliografia 2 (1990), 27-59

Medina Rubio, A., La iglesia y la produccion agrtcola an Puebla (1540-1795) (Mexico City, 1983)

Meer, P.LG. ven der, "Jesuitenheciendes in kolonienl Mexico", Laidsethift 8 (1987), $35-50$

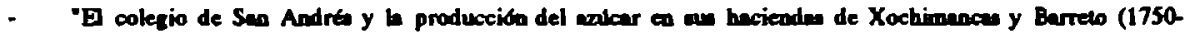
1767). in: Indios, empresarias y estado. 138-164

Meged, A., "Acoomodation and Resintance of Elites in Tranition: The Cane of Chinge in Enrly Colonial Mesonmerice", HAHR 71 (1991), 477-500

Menegus B., M., "L parcete de indias", in: Sociodad indigena en el Centro y Occidente de Merion, 103-128

Michoacen en el siglo XVI, Pardea M.. C.S. a.al., odo (Morelis, 1984)

Migration in Colonial Sparish America D.J.Robinaon, od. (Cembridge, 1990)

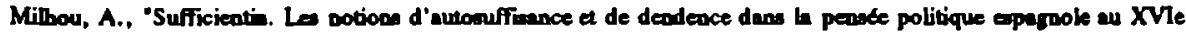
a.: de la Cortille de comeneros an Perou colonial", Melanges de la Casa de Velazqua 17 (1981), 105-145

Millon, "Social Rebsione in Ancient Teotihuecte", in: The Valloy of Merioo, 205-248

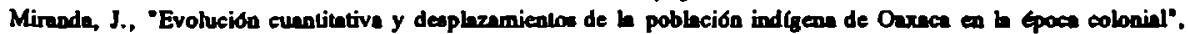
Esudlas de Historio Novahispara 2 (1967). 129-148 
- 'La pobleción indigena de Mérico en el siglo XVI', FMer 12 (1962-63), 182-189

- Le Pax hippaica y lo deplazamientos de bo pueblos indigene", in: J. Minode, Vida colonial y albores de la isdependencio (Mexico City, 1972), 7479

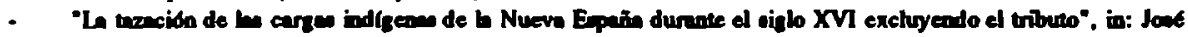
Mirada, Vido colonial y albores de la independencia (Mexico City, 1972). 129.152

- D triburo indigesa al la Nueva Espala dunarte el siglo XV (Mexico, 1952)

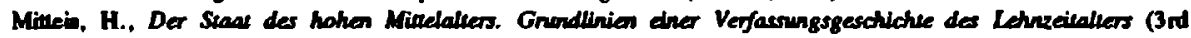
edition Weimer, 1948)

Molim Argitello, C.. "Gobernaciones, alcaldes myore y corregimientos en el reino de Guntemala", AdEA 17 (1960), 105-132

Monle OFM, F., Ethic and Social Background of the Pranciscan Friars in Seventeenth Century Merico (Washington D.C., 1973)

Moreno Toscano, A., "Trea probleme en la geognfita del mate, 1600-1624", HMer 14 (1965), $631-55$

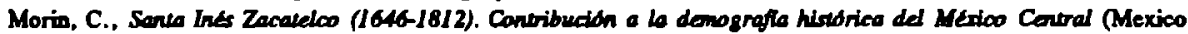
City, 1973)

Mourzeli, N.P., Organization and Bureaucracy. An Anabysis of Modem Theorles (Loadon, 1967)

Muro Romero, F., "La reforme del pacto colonial en Indix. Nots sobre Intitucionea de gobierno y sacieded en el niflo XVI", JbLA 19 (1982)

- "El 'beneficio' de oficion publicon con juriediccion en Indies. Notus sobre au origines", AdEA 35 (1978), 1-67

Mörner, M., 'Economic Factor and Stratification in Colonial Spanish America with Special Regard to Elites", HAHR 63 (1983), 335-369

- "Indiens abjects and Actors in the Hirtory of Latin Americe". in: Approaches 10 Latin American HLstory, $1-10$

- Race Mirture in the History of Lath America (Baston, 1967)

- The Spaninh American Hecienda: A Survey of Recent Recarch and Debate", HAHR 53 (1973), 183-216

Mömer, M, B.H. Slicher ven Beth, H.Hoetint, Approaches so Latin American Hirrory edition Department of Latin American Studiea (Leiden, 1990)

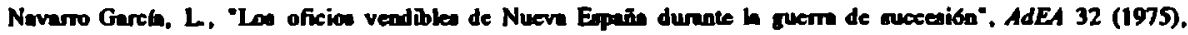
133-153

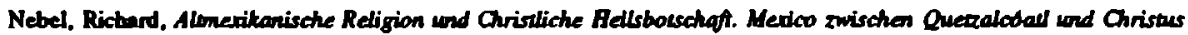
(Immenee, 1983)

Neweon, LA., "Indian Populntion Putterns in Colonial Spnish Americe", LARR 20 (1985), $41-74$

Nickel, H.J., Relaciones de trabaja en las haciendas de Puebla y Tlareala (1740-1940). Cuarro ansayas sobre reclutanianto, peonaje, y ranureracion (Mexico City, 1987)

- Sociale Morpholgy der Merikarischen Hacienda (Wiesbaden, 1978)

Nicolson, H.B., "Recent Sahaguntioe Sudies: A Review", in: The Wort of Bemandino de Sahagun, 13-30

Nutini, H.G., "An Outline of Thexcalecan Culare, Hirrory, Ehnolory and Demography", in: The Tharcalkecars 24-35

- Rimal Kirship. Vol. I The Structure and Historical Development of the Compadrazgo System in Rural Taxcala; Vol. II Ideological and Structural Integration of the Compadnargo System in Rural Thaxcala (Princeton, 1980-1984)

Offoer, J.A., Low and Politics in Azsec Texcoco (Cembridge 1983)

Oliver, M., "El despotimo tributirio en he region de Cunutinchne-Tepeace", in: Estratificación social en la Mesoamerica prehipónica, 181-205

- "Pepel de los pillin de Teceli en le eatructure cocio-ecoodmien del aiglo XVI prehiopúnica". Actes de XVIle Congres Intemational des Americanistes Vol. VI. pp. 199-215

- Pillis y Macehuales. Las fomaciones sociales y los mados de produccion de Tecali del Siglo XII al XVI (Mexico City, 1978)

Ouborn, W.S., "A Community Study of Metail/n, New Spein, 1520-1810. Ph.D.dies., University of Jown, 1970

- Indian Land Resention in Colonial Mectithe", HAHR S3 (1973), 217-38, reprimied in The Indian Comunnigy of New Spain, 142-161

Ow. A.C. ven, Architectural Activity, Demognphy and Ecooonic Divenification: Regional Economies of Colonial Mexico". JbLA 16 (1979), 97-145

- Catholie Colonialion: A Parish Histary of Guatenala, 1524-1821 Ph.D.Dim. Univenity of Texea (Auntin, 1982; and revined edition Cembridge, 1986)

- "The Excleainatical Colonization of Central America", Itinerario 8 (1983), 46-56

- A Far Kingdom: Central American Autarky at the end of the Eighteenth Century", [mo. Augtin 1979]

- Invertory of 86I Monwments of Mexicon Colonial Archilechure (Amsterdam, 1978)

- Mendicant Expanion in New Spain and the Extent of Colony (aixleenth eentury)", Boling ELC 11 (1976), 32-56

- Printad Culture in Centrl America, 1660-1821", JbLA 21 (1984), 77-107

- "Runal Brothertoods in Colonial Guntemnln", in: Manipulating the Salnts, 35-49

Ove, A.C. ven, and B.H.Slicher ven Bath, "An Experiment in the Hitory of Economy and Culbure", Joumal of European Economic HLstory 7 (1978), 407-427 
Ouweded, A., "The Agnrian Cycle a a Catalyat of Economic Development in Eighteenth-Ceanury Central-Mexico. The Arable Eatate. Indian Villages and Proto-Industrialization in the Central Hightand Vallay". WA 15 (1989). 399-417

- Altepene and Pueblas de Indios. Some Comparative Tbeordial Perpectives on the Anolyois of the Colonial Indian Communition", in: The Indten Comnuotiny of Colonial Merleo, 1-37

- The Economic Cycle in Bourten Centrl Mexico: A Critique of the Recaudecida del diezmo llquido en pease", RAFR 69 (1989), $487-491$ and following comments and rejoinder, pp.531-557

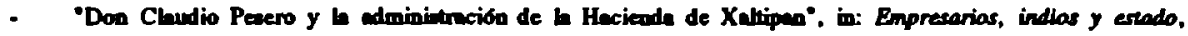
176-177

- Ejghloenth-Century Thexcalen Agrieuburc: Diery 9 of the Heciende Sen Anlonio Pahula, 1765-1766", in: Hactendas in Central Medico, 21-83

- 'De gobemador de indios en de gealoten boerengemeenechap in Central-Mexico in de achutiende ceurw', ESH $S 3$ (1990), 253-304

- Growth, Stngnation, and Migntion: An Explontive Analyois of the Tribusarto Seriea of Anchuac (1720. 1800)', HAFR 71 (1991), 531-577

- Onderbroten groel in Andhuac. De ecologische achtergrond van onnvitteling an amoede op hes plateland ven Cortraal-Merico (1730-1810) (Amoterdum, 1989)

- Schedules in hacienda agriculture: the casea of Sante Ane Aragon (1765-1768) and San Nicolas de lon Pihrea (1793-1795), Valley of Mexico", Boleten ELC 40 (1986), $63-98$

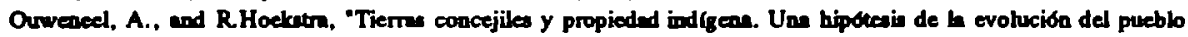
mexicano (1520-1920)", ms. Amsterdam, 1991

Orweneel, A., and W.Pansters. "Capitaliot Development and Politieal Ceatralization Before and After the Revolution: An Intraduction", in: Region, Srate and Capitaliom in Merico. 1-25

Paroos, J.R. "Setteonent and Population History of the Basin of Mexico", in: The Valley of Merico, 69-100

Pastor, R. Camperinas y reformas: La Minteca, 1700-1856 (Mexico City, 1987)

'E repartimicato de mercanctay y los alcaldes myores novobiapanos. Une aideme de explatacion de nu orfgenea a ta crisis de 1810", in: El gabiemo provincial, 201-236

Patch, RW., 'Agrarien Change in Eighteenth-Century Yucatin", HAFR 65 (1985), $21-49$

Peel, J.D.Y, Jjeshas and Ngeriars. The Incorporation of a Yoruba Kingdom, 1890's-1970's (Cambridge, 1983)

"Undentanding Alien Belief Syotem", British Joumal of Sociology 20 (1969)

de b Peía, J.F., Oliganquia y propiedad an Nueva Esalo, I550-1620 (Mexico City, 1983)

Páre Prende, J.M., La monorqula indiana y el estado de derecto (Medrid, 1989)

Ptrez Zevallow, J.M., "El gobiemo ind ('enen coloninl en Xochimileo (viglo XVT), HMex 33 (1984), 445-462

Pelers, E.M., "Religion and Culture. Popular and Unpopular, 1500-1800', Joumal of Modem Hision 59 (1987), 317-330

Pietschmann, H., "Agriculture e industria nural indígen en el México de la segunda mitad del siglo XVII", in: Indios, empresarios y estado, 71-85

- 'E comercio de repartimientos de los alcaldes mayorea y corregidores en la región de Puebla-Thexcala en el siglo XVI", in: Estudios sobre polfáca indigenista espatiola an Americe Vol. II, pp. 147-153

- El estado y su evolución al principio de la colonización espalola de Amética (Mexico City, 1989) [Spanish edition of Steat und Staaliche Entwicklung an Beginn der spanische Xolonisation Amerikas (Mumater Weatfalen, 1980)]

- 'Der Repartimiento-Handel der Distriktsbeamien im Raum Puebla im 18. Jahrundert', JbLA 10 (1973), 236-250

- En torno - In historia del agro hispanoamericano colonial. Inveatigaciones recientes y perspectivan de interpratacion", in: La Hacienda en America Latina. Su impornancia hirdrica para la econonta y la saciedad O.Siebbenmmnned. (St Gellen, 1979), $37-50$

Pho, V., 'La secularieción de las parroquins y la economin eclesiratica en ta Nueva España', Joumal de la Sociese des Ambricanires 64 (1977), $81-88$

- La secularisación de las parroquias an la Nueva Epana y su repercusion an San Andrds Calpan (Mexico City, 1981)

E placer de pecar y el afdn de nomar atition Seminario de historia de la mentalidedes (Mexico City, 1988)

Poole CM. S.M., "The Dexlining Imege of the Indian among Churehmen in Sirteenth-Centhry New Spain". in: Indian-Religious Relations in Colonial Sparish Americo, 11-19

- Pedro Moya de Conureras. Catholle Reform and Royal Power in New Spain, IS7I-159I (Berkeley, 1987)

Prehisory of the Tehuacan Valley Vol. I. Environnent and Subsitence D.S.Byer, ed. (Aurim, 1967); Vol. IV Cronology and Imigotion. F.Johnson, ed. (Austin, 1972)

Pren, H.J., "Con mean, agujón y tríngulo filar. Die Koloninbeillich Grenze zwiechen Huejotzingo und Thexcaln". LM 7 (1981), $111-136$

"Early Spaniah Colonization and Indians in the Valley of Atlixco, Puebla", in: Eqplorations in Eshahistory. 205-228

- Mipa y Hacienda. Tenercia de la tierra indlgena y epalola en la Cuanea del Allo Atoyac, Puebla, Mbrico (JS20-J650) (Wieabeden, 1978)

Provinces of Earty Merico: Varianks of Spanich American Regional Ewolution. I.Almen and J.Lockhert, ede (Lon 
Angeles, 1976)

Quillet, J, "Community", in: Cambrige History of Medieval Political Though, 607-648

Quimoos Keber, E., "The Sahaguntine Corpus: A Bibliographic Index of Extant Documeata", in: The Wort of Sahogen. 341.346

Ramire, S.E. "The "Duelo de Indias": Thought on the Conequences of the Shifting Buen of Power of the - Curnea de los Vejos Ansiguas under the Spaniah in Sixteenth Century Peru", RAHR 67 (1987), 575-610

Ramos, L.J. and M.C. Blanco, "En tomo al origen del tributo indigeon en h Nueva Espafia y an evolución en be primer mith del aiglo XVI segin el vatimonio del "Codice de Coyonein", de Simmen", in: Entudias sobre polvica indigenista Vol. II, pp. 357-391

Refugio Gonzales, M. del, and T. Lozeno, 'Le eiministración de juticie", in: El goblemo proviscial, 75-105

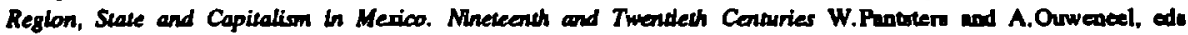
(Amoterdam, 1989)

Rellgion and Sacien in Earty Modem Europe, I500-1800 G. von Greyerz, od. (Loodon, 1984)

Reliving the Past O.Zunz, ed. (Chapel Hill and Loodon, 1985)

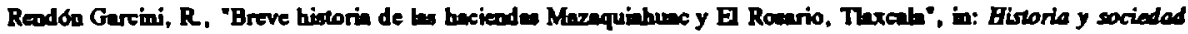
in Thareala (Mexico Ciny, 1986). 101-107

- Das haciendas pulqueras an Thacala, 1857-1884 (Thacal, 1990)

- "Phternalian and Morl Economy on Two Throlan Hacterdas in the Llanas de Apan (1857-1884)", in: Region. Stake and Capicalion in Merico, 37-46

Reye Garcin. L. Cuawhinchan del Siglo XII al XVI. Fommacion sactal y desarrollo historico de un selorio prehipdrico (Wresbeden, 1977)

Reynolds, S., Kingdoms and Communities in Westem Europe, 900-1300 (London, 1983)

Ricard, R, La conquista epirimal de Merico. Ersoyo sobre el apastolado y los melodos mirioneros de las drdenes mendicantes an la Nueva Espana de 1523-1524 a 1572 (Mexico City, 1986) [original Freach dition 1947]

Riley, Michnel G., "Land in the Spanith Enterprise. Colonial Morelon. 1522-1547". TAm 27 (1971), 233-251

Riley, Jame D., "Crown Law and Rural Lebor in New Spain: The Stntur of Garanes during the Eighteenth Century". HAHR 259-285

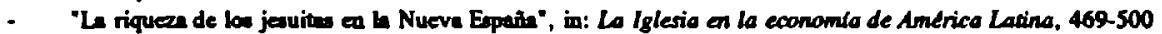

Robimen, D.J., "Introduction: Towards a Typology of Migntion in Colonial Spanish America", in: Migration in Colonial Spanish America, 1-17

Rojes Rabiele. T., "Ln organización del trabajo para la obres purblicas: el contsquill y les cundrilla de tubajedores". El trabajo y las trabajadores, 41-66

Romin R., A.Y., "Sobre alcaldín mayores y corregimientos en lndies", JbLA 9 (1972), 1-39

Round, J., "Dymatic Suceesion and the Centralization of Power in Tenochtithn", in: The Inca and Azsec Staves, 63-89

Rude, G., 'The 'Pro-Industrial' Crowd", in: Van oproeren en statingen, H.A.Diederiks, ed. (The Hague, 1981)

Ruvalabe M., J., "Agriculturn coloniel temprane y tranformeción cocial en Tepeapulco y Tulencingo (15211610)', HMex 33 (1984), 424-444

Sabean D.W., "Aspects of Kinhip Bebnviour and Property in Rurl Wealern Europe before 1800", in: Fanily and Inheritance, $96-111$

- Power in the Blood: Popular Culture and Village Discourse in Earty Modem Gemmany (Cambridge, 1984)

- Property, Production, and Family in Nectartausen, $1700-1870$ (Cumbridge, 1990)

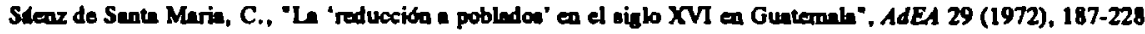

Saln Cuenta, M., La iglesia y el convento de Huejotringo (Mexico City, 1982)

Satvucei, RJ., Tertiles and Capirallon in Merico. An Economic History of the Obrajes, 1539-1840 (Princelon, 1987

Sinctre Abornox. N., "The Population of Colonial Spaniab America". CHIA Vol. I, pp. 3-36

Salcedo Lzu, J., "Inotrueciones pare los virnyes de Mexico, bajo lon Austrins (1535-1701)", in: Estructuras, gobiemo y agenies de le administracion an la América espakola (stglas XVI,XVII Y XVIII) (Valledolid, 1984), 291-340

Saltman, M., "Feudal Relationahipe and the Law: A Compantive Enquiry", CSSH 29 (1987), 514532

Sandere, W.T., "The Agricultural History of the Basin of Mexico", in: The Valley of Merico, 101-160

"The Naturl Environment of the Basin of Mexico", in: The Valley of Merien, 59-68

- "Seulement Parnerm in Certral Mexico", in: Handbook of Middle Americen Indiars, Vol. X Anchaeobgy of Northern Mesodmerica, Vol. I, 3-44

Sanden, W.T., J.R.Parmon, M.H. Logan, "Summary and Conchusions", in: The Valley of Mexico, $161-178$

Sarabia Viejo, M.J., Don Luis Velasco, virrey de la Mueva Espana (IS5a-1S64) (Seville, 1978)

Schell Jr., W., Medieval berian Tradition ald the Development of the Merican Hacienda (Syracue, 1986)

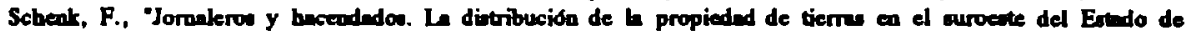
México haci 1900", wi.1989

Scbole, W.V., The Diego Romire Visita Univentity of Mi-eouri Studien, Vol. XX (Cohumbia 1940)

Schneider, H., Die Landwirtochaft in Valsequllo. Eine Untersuchurg des agroren Wandels in Hachland won Mentoo

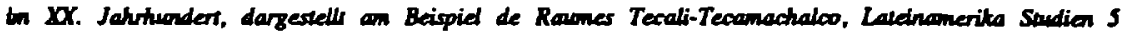


(Mumich, 1979)

Schroeder, S., "Chalco and Sociopolitical Concepta in Chimalpahin", Ph.D. Dissertation UCLA (Los Angelea, 1984)

"Chimalpahin'a View of Spanish Eccleaintics in Colonial Mexico". in: Indian-Religlous Relations in Colonial Spanish America, 21-38

Schryer, F.J., 'Chas Conflict and the Corponte Peasant Community: Disputea over had in Nahuntl Villagen". Jounal of Anthropological Research 43 (1987), 99-120

- 'A Renchero Elite in the Region of Huejuth (The Career of Generd Juvencio Nochebuena of Athpereo)". Region, State and Copilallon, 158-174

- The Ranchenas of the Pisafiores. The History of a Peasant Bourgeolsie in Twentiath-Century Merico (Toronto, 1981)

Schwaller, J.F., The Churet and CJergy in Sirteenth-Century Merieo (Albuquerque, 1987)

- Origins of Church Wealh in Merico. Ecclesiastical Revenues and Church Funances 1523-1600 (Albuquerque, 1985)

Scoth, J., The Moral Economy of the Peasant. Rebellion and Subsintance in Sowh East Aria (New Heven, 1976)

Scribner, R. "Cowmic Order and Deily Life: Secred and Secular in Pre-Induatrial Germen Society". in: Religion and Socieny in Earty Modem Europe, 17-27

Seed, P., To Love Honor and Obey in Colonial Merico. Conflicts over Marriage Choice, 1574-1821 (Stunford, 1988)

The Seqlemert of Disutes in Earty Medieval Europe W.Davie and P.Fourncre, edo (Cumbridge, 1980)

Seek, E. and Tyrakowki, Cuescomase y tencal an lo región Puebla-Tlatcala. Mérico, Suplemento to Comuricaciones (Mexico City, 1985)

Sherman, W.L., Forced Native Labor in Sirteath-Century Central America (Lincoln and London, 1979)

- Some Apects of Chnge in Guntemnina Society, 1470-1620", in: Spaniards ard Indians in Southem Mesoanerica, 169-188

Simmonw, Ch.E.P., "Palafox and hin Critica: Reappraising an Cootroveroy", HABR 46 (1966), 394408

Simpson, LB., The Encomienda in New Spair. The Beginnings of Spanish Merico Berkeley and Los Angeles, 1950)

- Eploitation of Land in Central Merico in the Sirteenth Century Ibero Americans: 36 (Berkeley, 1952)

- Studies in the Administration of the Indians of New Spain, Vol. II, The Givil Congregation, Ibero americann: 7 (Bertreley and Low Angeles, 1934)

- Studies in the Administration of the Indians of new Spain, Vol. II, The Repartimianto System of Native Labor in New Spain and Guatemala, Ibero Americama: 13 (Berkeley and Loe Angeks, 1938)

Skipp, V., Crisis and Development. An Ecological Case Study of the Forest of Arden. 1570-1674 (Cambridge, 1978)

Slicher van Bath, B.H., "The Absence of White Contract Labour in Spaniah America during the Colonial Period", in: Colonialion and Migration: Indentured Labour before and after Slavery (Dord recht, Boston, Lancanter, 1986), 19-31

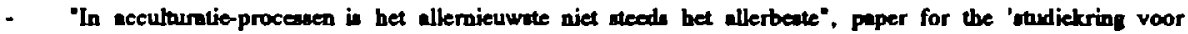
ontwikkelingevrangstukken', Wageningen, November 23, 1985

- De agrarische geschiedenis van West Europa (Utrecht, 1964; 6th reprint 1987) [Englieh edition The Agrarian Hiriory of Westem Europe )London, 1963)]

- 'Agriculbure in the Vilal Revolution", in: Cambridge Economic History of Europe 5 (1977), 42-132

- Bowolking en economie in Nieww-Spanje (ca.1570-1800) (Amsterdam, 1981)

- "Bevolkingeconcentratie en economixche differentintie in Peru gedurende do koloninle tijd", in: Arbeid in vedroud E. Witte and J.Hannes, ato (Brumel, 1988), 76-90

Bijdragen tot de agrarische geschiedenis (Utrecht, 1978)

- The Calculation of the Population of New Span, especinlly for the Period before 1570", Boletin ELC 24 (1978), 67-96

- Dos modelos referidos a le relación entre población y economin en Nueve Espain y Peni duranie le Epoce coloninl", in: Empresarios, indias y ertado, 15-44

"Economic Divernification in Spanish America around 1600: Centen, Intermediate Zones and Periferien". JbLA XVI (1979), 53-95

- "Feodaliteit en kapitalisme in Latijn-Amerike", in: Geschledenis van maaschappij en cultuwr, 118-139

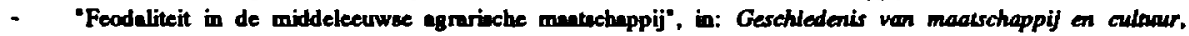
56-70

- Geschiedenis: theorie en prakrijk (Utrecht, 1978)

- "De hintoriache demognafie van Latijns Amerik. Problemen en realtaten van onderzock", TvG 92 (1979), $527-556$

- "Hoven op de Veluwe", in: Sticher ven Bath, Bijdragen lot de agrarkche geschitederis, 268-303

- Indianer a Spanjaarden. Eer onbueting aussen twee werelden. Latijis Amerika 1500-1800 (Amoterdem, 1989)

- Mens en milien in de pre-historische tijd", in: Geschiodenis van maasechappij en culaw, $30-55$

- Mosch an land in de middeleauwer Een bijdnage lot cen geschiederis der noderzettingen in Oastelijk Nederland 2 Vola (Aven, 1945 [reprint Amhem, 19T7) 


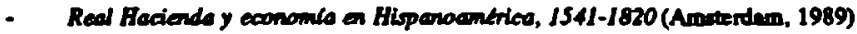

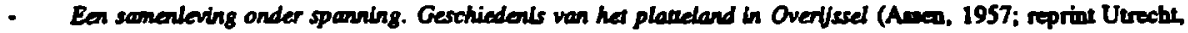
$1977)$

- Spaoss Amerita omstreets 1600 (Utrecht, 1979)

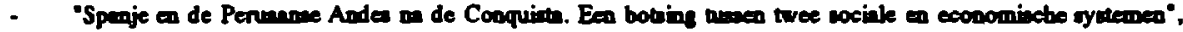
in: Bewoger an bewegan W.Th.M.Frijhoff. ed. (Tilburg. 1980).134-151 [roprinted in Indlaner an Spajiaanden]

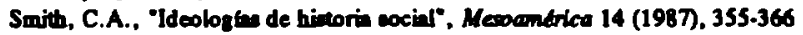

Snow, D.R. "Prehirery of the Valley of Thaxcale". in: The Tlaxcalecens, $9-12$

Sadal Pabric and Spatial Sinucture in Colonial Lacin America D.J.Robinion, ed. (fecs. Ann Abor, 1979)

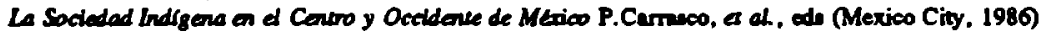

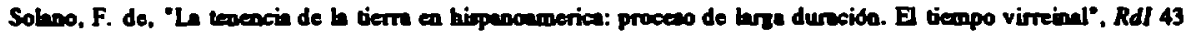
(1983), 9-26

Southern. RW. The Maling of the Maddle Ages (London, 1953)

- Westem Sociaty and the Church in the Middle Ages (Hamondworth, 1979)

Spalding, K., "Exploitution a an Ecosomic Syutem: the Stute and the Extrection of Surpha in Colonial Peru", The bues and Arvee States, 321-342

- Ruarochir, An Andean Soclen weder Ince and Sporioh Rule (Sunford, 1984)

- "Introduction", in: Escogs in the Polldical, Economle and Social History of Colonial Ladin Anerica, vii-xx

- Social Climbers: Changine Patieres of Mobility among the Indians of Colonial Perr", HAKR 50 (1970), 645. 664

Spariands and Indians in Southem Mesoanerico M.J.Meleod and R.F.Wusernorom, eds (Lincoln. 1983)

Social Fabric and Spadal Soncture in Colonial Latin America (Symewae, 1979)

Spiegel, "Hitory, Hitocion, and the Social Logic of the Text in the Middle Agea", Speculwon 65 (1990), 59.86

Spore, R. The Mlrecs in Ancieat and Colonial Times Norman, 1984)

Spnondel, Veffacsung wad Gerellschant in Micelalier (Pederborm, 1975)

Stavin, "Ethnic Cooflict Mornl Economy, and Population in Rurel Curoo on the Eve of the Thupe Amaro II Rebellios:, HAHR 68 (1988), 737-770

Stein, S.J., and B.H.Stein, The Colonial Berieoge of Laih America. Essoys an Economic Dependence in Perspecdve (New Yort. 1970)

Stere, S.J., Peru's Indlan Peoples and the Challenge of Spanish Conquest. Huananga to 1640 (Medieon, 1982)

"Lntin America', Colonial Hintory. Invitution to en Agende", LAP 12 (1989), 3-16

Steveroon, R. "The Muic of Colonial Spanith Ameriea". CHIL Vol. II. pp. 771-778

Stooe, L The Revival of the Nermetive: Reflection of a New OLd Hirtory". PaP 85 (1979), 3.24

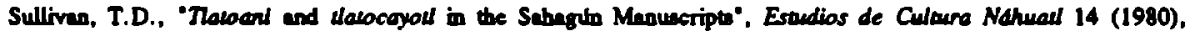
225-238

Super, J.C., The Agricultund Near North: Querturo in the Seveoteconth Century". in: Provinces of Earty Merico. 231-252

- Pood, Conquast and Colonization in Siveenth-Cormery Spanish America (Abuquerque, 1988)

Sipplemer to the Hendbook of Mlddle American Indlars: Archoology, U.K.Brieber, J.A.Sabloft, ede (Austin, 1981)

Supplenert to the Blodbook of Middle American Indiars Vol. N. RSpores, ed. (Awetin 1986)

Swan, S.L, "Climate, Crope and Livestock: Some Apects of Colonial Mexican Agriculhure'. Ph.D.dies. Wahinglon State Uaivenity, 1977

Szewezy, "New Elements in the Society of Thexala, 1519-1618", in: Provinces of Earty Medico, 137-154

Tacken, T., Pries and Parish in Elgheenth-Canary Frence. A Social and Pollited Santy of che Ourds in a Diacese of Dasphine, 1750-1791 (Princeton, 1977)

Taylor, W.B., "Between Global Procens and Local Koowledge: An Inquiry into Earty Lntin Ameriean Social Hitory, 1500-1900', in: Rellving the Parr. 115-190

- "Conflict and Balance in Dirtrict Politics: Tecali and the Slerra Norre de Puebla in the Eighleenth Cenbury". in: The Indian Commurity of Colonial Merico, 270-294

- Dribing, Honicide and Rebellion in Colonlal Merican Villoges (Stanford, 1979)

- Indino Pueblas of Central Jalieco on the Eve of Independence", in: Berian Colonier, New World Societies. 161-184

- 'Lended Society in New Spain: A View froon the South", BABR S4 (1974), 387-413

- Landlord and Peasent in Colonial Oeraca (Sunford, 1972)

Thome, X., Man and the Nanenal World. A Hisong of the Modem Secribilly. Sandies in Popular Beligfs in Sirteath and Severteerth-Conery England (London, 1983)

Rellgion and the Dectine of Magic (Hermondrworth, 1971)

Thompeno. E.P., "The Grid of Inberitance: A Comment". in: Fonily ard Inheritance

- The Mabing of the Englleh Worting Caes (Harmondrworth, 1963)

- "The Morl Economy of the Englieh Crowd in the Eighteenih Century", PaP SO (1971), 76-136

- Trme, Wort-Diecipline, and Indutrial Cepioliem", PaP 38 (1961). 56-97

Thompan, G.P.C., Pueble de los Angeles. Indurary and Socies in a Merican Cing, 1700-1850 (Boulder, San 
Frencieco, Londen, 1999)

Tily, Ch., Coercion, Capilal, and European Stakes, AD 990-1990 (Cumbridge, 1990)

"Retrieving European Lives", in: Reliving the Part, 11-52

The Thaxcallecars: Prehireary, Demography, Morphology and Genetics Cruwford, M.H. (Lawrence, 1976)

Tornler Pacbeco, Chr.. 'A Note on the Composiciones de Therro in the Juridjetion of Cholula, Pueble (15911757', in: The Indian Community of New Spain, 87-102

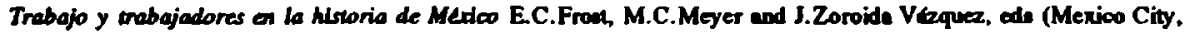
1979)

Trautmann. W., "Formen der Ladnutzang in pritrolonialeo Mexizo", JbLA 10 (1973), 1-15

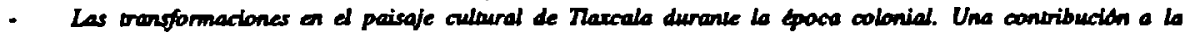
historla de Mbrico bajo epecial consideracion de aspectos geogrdfico-economicos y sociales (Wiesbeden, 1981) [reference b the Genman edition: Der Koloniakeillehe Wandel der Xulourlandschafi in Thaxcala. Ein

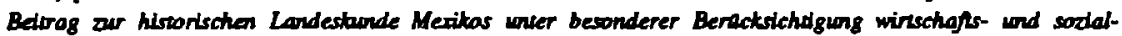
seographischer Aspetse (Puderborn, 1983)]

"Der Wandel de Zentrabortlichen Syntems in Thuxala mach der Conquirto", LA 7 (1981). 137-149

Trexler, RC., "Revercace and Profunity in the Study of Euty Modem Religion", in: Religion and Socieny in Earty Modem Europe, 245-264

Tutino, J.M., "Creole Mexico: Spaniah Elice, Haciendas and Indian Town, 1750-1810", Ph.D.Dies. Univenity of Texes at Austin 1976

- "Hecienda Social Relntiont in Mexico: The Chaleo Region in the Ere of Independence", HAHR 55 (1975), 496-528

'Provincial Spaniards, Indien Towns and Haciendas: Interrelated Sectors of Agrarian Society in the Valleys of Mexico and Tolwa, 1750-1810", in: Provinces of Earty Merico, 177-194

The Valley of Merico. Sudies in Pre-Hisparic Ecology and Society E.R. Wolf, d. (Albuquerque, 1976)

Ven Engen, "The Chrigtian Middle Ages as an Historiographical Problem", American Historical Review 91 (1986). 519.548

Van Young, E., "Conchuion", in: Indian-Religious Relations in Colonial Spanish America, 87-102

- "Conflict and Solidarity in Indian Villoge Life: The Gundajare Region in the Late Colonial Period", HAHR 64 (1984), 55-80

- Hacienda and Marter in Eighteenth Cenury Merico: The Rural Enonomy of the Guadalajara Region, 16751820 (Berkeley, 1981).

"Mexican Rural Hixtory eince Chevalier", LARR 18 (1983/3), 5-62

- Millenimm on the Northern Marchen: The Mad Measiah of Dunngo and Populn Rebellion in Mexico, 1800 1815", CSSH 28 (1986), 385-413

- The Raw and the Cooked: Popuhs and Elite Ideoloty in Mexico, 1800-1821", in: The Indian Comnurity of New Spain, 295-321

- 'Recent Anglophone Scholarhip on Mexico and Centnl America in the Age of Revolution (1750-1850)", HAHR 65 (1985), 725-743

Veaberg. D.E., Land and Society in Colden Age Cartile (Cambridge, 1984)

Verhandlungen des XOXVIII. Intemationalen Amerikanisten Kongresses (1958) (Munich, 1970)

Verlinden, Ch., "L'étal et l'edministration des communauts indigtnes d'Amérique. Quelquas reflexions", AdEA 34 $(1977), 695.705$

- "El Regimen de trabajo en México. Aumento y alcance de h gafianín, sitlo XVI". in: Historia y saciedad an a musdo de hable eppabla. Homenaje a Jose Miranda B.Garcf Martinez, ed. (Mexico City, 1970), $225-246$

Verrips, En bovan de polder de hanel. Een auropologische snudie van een Nederlands dorp, 1850-1971 Dimsertion Amterdam, 1977

Vilhoueve, M.A., 'From Calpixqui to Corregidor. Approprietion of Women's Cotoon Textile Production in Early Colonial Mexico", LAP 12 (1985), 17-40

Vollmer, G., 'L evolución cunntitutiva de bableción indigene en la región de Puebla (1570-1800)", HMex 23 (1973) 43-51

Wewertiom, RF., Class and Saciesy in Cautral Chiopas (Bertreley. 1983)

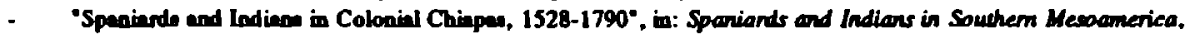
92-126

Wetson, R, "Informal Senlement and fugitive migntion emongat the Indiane of hie-colonial Chinpas, Mexico", in: Migration in Colonial Sparich America, 238-278

Wectomnnn, L. "The Middle Ages in the Conqued of Americe", Speculuon 26 (1951). 130-141

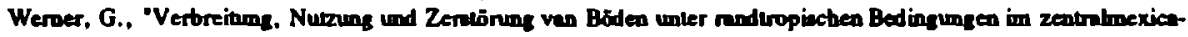
niacheo Hochland*, LA 7 (1981) 3-23

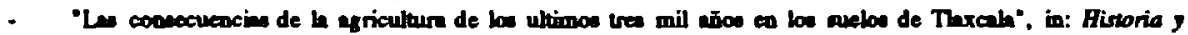
saciedad an Tharcala. 221-230

Wet RC.. "Population Demities and Agriculumel Precticen in Pre-Cohumbien Mexico, with Emphenin on SemiTerncing". in: Vethandluugen des XXXVII. Intemationalen Ameritaniter Longresea (I968). Vol. II, Pp. $361-370$

Whimore, T.M., "Sirteenth-Century Populntion Decline in the Bain of Merico: A Syademe Simulation", Latin 
Americar Population Flstory Bulletin 20 (1991), 2-18.

Wistham, C.. The Mountains and the Giy. The Tuscan Appenivis in the Earty Middle Ages (Avford, 1988)

Williams, B.J., "Mexico: Aztoc Soil Clawification and Land Tenure", Actes du IIIle Congrds bremationale des Americanister Vol. DXb (Pari., 1979). 165-176

When, O.C., Good Famers. Traditional Agriculture and Resource Management in Merioo and Cantral America (Bertrel-y, 1987)

- "Menegement of Productive Spece in Treditional Farming". Actes du Xalle Congris Intemational des Anericaristes (Perie, 1977), Vol. II, Pp. 409420

Wiufogel, The Hydraulic Approsch to Pro-Spanish Mesommerica", in: The Prehtrory of the Tohuacan Valley, Vol. TV, pp, $59-80$

Whituler. "Axtec Dialectology and the Nabunt of the Frian", in: The Wonk of Sahagin, 321-340

von Wobener, G., La formacibn de la hacienda en la tpoca colonial. El uo de la tierra y d agua (Mexico City. 1983)

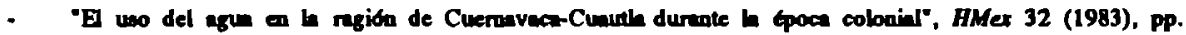
467-497

Wolf, E.R. "Closed Corponte Peanent Communitier in Mesomerica and Central Jave", Southwertem Joumal of Anthropologg 13 (1957), 1-18

Europe and the People without History (Berkeley and Los Angeles, 1982)

- Sons of the Shatding Earth (Chicago, 1959)

- Types of Letin American Peasantry: - Preliminny Discusojon", American Anehropologls 57 (1959), $467-497$

- The Vicisitudes of the Closed Corporate Peasant Community", American Ethrologirt 13 (1980), 325.329

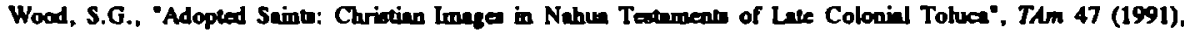
259-294

- Corporate Adjustments in Coloaial Mexican Indien Towns: Toluce Region, 1550-1810". Ph.D.Diss., University of Californis, Lou Angeles, 1984

- The Fundo Legal or Land Por Razon de Pueblo: New Evidence from Central New Spain", in: The Indian Commonity in Colonial Merico, 117-129

The Wonk of Bemardino de Sahagun. Pioneer Ehhographer of Sirteenth-Century Azlec Merico J.J.Klor de Alva, H.B.Nicbolaon, E.Quiñonea Keber, eds (New Yort, 1988)

Wuder. H., Die bduertiche Gemeinde in Deutschland (Götingen, 1986)

- "Einkeitumg: Der Feudalimus-Begriff. Uberlegungen zu Moglichkeiten der historiachen Begriffibildung", in: Foudalionus, 10-78

Yuste, C., "Las aubridedes lovales como egentes del fieco on b Nueve Españe", in: El goblemo provincial, 107-123

Zentwijk. The Aztec Arrangement. The Social Hirtory of Pre-Sparlsh Merico (Norman, 1985) (translation and deption of Handel en wandel van de Azleten. De sociale geschiederis van worr-Spaans Merioo (Aveen, $1977)]$

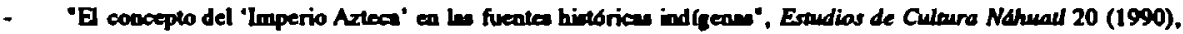
201-211

Zambardino, RA., "Mexico'. Population in the Sixteenth Ceatury: Demographic Anomaly or Mnthematical Itheion", Joumal of Intendisciplinary History 11 (1980-81)

Zovala, S., La encomienda indiana (Mexico City, 1973)

- Esadias acerca de la historia del trabajo en Merico (Mexico Ciny, 1988)

- El servicio personal de los indios de la Nueva Esparla 3 Vols (Mexico City, 1984-1987)

Zeilim, J.F., "Renchers and Indians on the Southern Ithmus of Tehuantepec: Eoonomic Change and Indigenons Survival in Colonill Mexico", HAHR 69 (1989), 23-60 


\section{Glossary}

Alepped. Lordahip. Basic socinl economic and political unit of the Nahunt-epeaking peoples of Centrat-Mexico.

Aleabala. Salea tax.

Alcalde. Important member of a cablldo. Also judge of fint intance.

Alcalde Mayor. Provincial Spaniah official with edministrative and judicial powers, after the implementation of the Leyes Nuevas equivalent to corregidor. Supreme official of an alcaldia mayor.

Alcaldla Mojor. Spaniah province, couprising one or more pueblas de indias and eometimea a Spanish city (ciuded) or town (villo). After the implementition of the Leyes Nueves equivalent to correginiento.

Alguacil. Leser member of a cabildo. Conotable. Uaully under the leadernhip of an alguacil major (chief constuble).

Amparo. Legal protection of a upecifie right, urully to bad.

Audlencia. Supreme Court, bere of New Spain. The Audlencia also had many administrative prowers. Presided by viceroy; members were called oidores.

Baldias. Uneultivated and unused land. In Spanish hw considered to be property of the Crown (realengas). Atwo deaignated as tiema baldfa, or tierra realenga.

Barrio. Constituent territorial unit of a pueblo de indias. In a (Spaniah) city the Indian wands.

Cabecera. Centre and main town of the juriedictional area of a pueblo de indias. As cabecera de doctrina abo centre of Indian parish.

Caballerla. Land grant of a.43 ha. intended for agriculturl use.

Cablldo. Municipal cotmeil, governing a comunidad, both Spenish and Indian.

Cacigue (feminine: cacica). Important Indian noble afler the conquest. Originnlly acesuor of high prehippenic nobility. Leter also used to indicate those who were newcomen in Indinn power.

Cacicazgo. Hereditary entailed juriadictions and rights of a cacique, modelled after mayorago.

Caja de comunidad. Treacury of a puebla de indias.

Calpulll. Aleo calpolli. Orgenizational unit of indigenou wociety, part of en alkepell with regionally widely diverging meaning.

Cantor. Indien choir singer.

Centecpanpirqui (pl.centecpanpirque). Leader of 20 macehualtin.

Cedula. Official decree.

Cienega. Manh.

Congregacion. Revettlement to schieve greater nucleation.

Chirampa. Artificial raised plot for intensive agriculture built up in ahallow water (Valley of Mexico). In postconquest times similer plots were usually called camellon in Spanish.

Coa. Digging ntick (Nahustl huicti).

Cofrade. Member of a cofradia.

Cofradio. Sodality.

Compadrazgo. Compaternity. Spiritual affiliation between a gadfather and the parenta of a child.

Composicion. Legalization of de facto bodownenhip.

Comenidad. Legally defined public body and administrative unit in Spanish Law. Entilled to upecified rights, among which tand was one of the mont importank

Consejo de Indias. Council of the Indies. Supreme governmental body of the king of Spain, with juriadiction of the Spanish Amerian territories.

Corregidor. Provincial Spanish official with adminintrative and judicial power, after the implementation of the Lyes Nuevas equivalent to alcalde mayor. Supreme official of an correginiento.

Cuescamate. Adobe trough.

Doctrina. Pariah under jurisdiction of regular clergy.

Don, dofla. Spaniah title, wed for any noble. In the Indian workd used for a cacique.

Encomendero. Holder of an ercomienda, a granl of the tribute (and initinlly bbour) of the Indian in a epecified territory, coublly an alseped or part of ih.

Escribano. Scribe.

Ertancia. Spanish livontock farm. Also used for outlying barrio of a pueblo de indias.

Fonega. Unit of dry mearure, uxully 55.5 litres.

Fuscal. Most important Indien church-official. (Alo very importunt member of the Audiencia).

Gandn. Paid, resident, permanent Indien employee, in the service of Spaniards.

Cobemador. Govemor. Presideat of the cabildo of a pueblo de indias (gobemador de indias). Official tille of the

Thexalan equivalent of the (Spaniah) alcalde mayor.

Coblemo. Rule.

Bacendado. Owner of a brge ente. Seldom uned in sixteenth and seventeenth-century dacumenth.

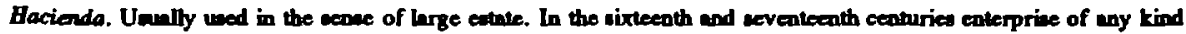


and size, in this sense also the word grangerta in used. Thus: Real Hacienda (royal tressury); hactenda delabor (wheat farm); hacienda de minas (mining enterprise).

Bermita. Chepel, urually without a formal parrochil function.

Indto. Genenl Spanish term for all indigenous people. Later. those belonging to the repablica de indlos.

Jacal. Indian house.

Juez. Judge, any commissioned official with authority in a specific field (hence jwer repartidor, jua congregador)

Labor. Spaniah wheat-farm.

Labrador. Farmer.

Legua. Spanish mile, ca.4.2 km.

Layes Nuevas. 'New Laws', promulgated in 1542-1543. Fint codification of the bwe concerning the Spaniah American territories.

Macehwalli (pl. macehwaltin). In prehispenic times vessal in a browd sense, but abo commoner in general. In postconqueat times only this last meaning was rethined. After the conqueat hispenized to macehwal.

Macullsecpanpirqui (pl. macuiltecpanpirque). Leader of 100 Indiana.

Mandon. Indien leader, usually low-ranked.

Maguey. Large agave (Nahuatl metl).

Merced. Grant (often of land).

Milpa. Indien agricultural plot.

Monte. Uncultivate tand, used for other purposes (pastures, firewood etcetere).

Nahuatl. Language of the Uto-Aztec family, apoken by the majority of the indigenous people of Centril Mexico (now often called Nahun) at the time of the Conqueat and long after. Lingue frnece of Mexico already before the coming of the Spaniands.

New Spain. The large juriadiction centred on Mexico City, embracing the largest part of present-dey Mexico.

Nopal. Kind of cenctus.

Oidor. Judge of the Audiencia.

Ordenarza. Ordinance

Parcialidad. Subdivision of a pueblo de indios, unually the domain of a former Matoani.

Pilli (pl. pipiltin). Nahuatl term for noble.

Pueblo de indios. The banie territorial unit of the república de indias under Spanish rule. Initially nearly always successor of an allepell. Pueblo was aloo used for any Indian settlemenh.

Peso. Basic unit of money in larger transactions, consisting of eight reales. Usually peso de oro, although other types of pesos were sometimes used.

Principal. Indien noble in general; ubually lower nobility.

Pulque. Alcobolic beverege obtrined from magueyes.

Rancho. Farm. Uounlly smeller than a hacienda. Often used for the handed private property of a cacigue.

Real. A silver coin, worth one eighth of a peso.

Regidor. Member of cabildo with execulive takk.

Rentero. Tenant, aleo used in the sense of a macehual.

Repartimiento. Prerogative of monopoly of certain items that were considered to be too crucial to be left to the free market. Hence for example repartimiento de comercios (privilege to buy and sell specific kinds of goods, e.g. live-stock or tribute-goods); repartimiento de trabajo (privilege to thare out babour services).

Repabllea. Commonwealth of a calegory of people in genernl. In the Spaniah-American territorie the basic eatalea of wociety were the repuiblica de Espatoles and the repuiblica de Indios.

Residencia. Court or trial held at the end of a term of office.

Sestoria. Lordship.

Sendico. Agent in financial affeirs of a mendicant monantery.

Slito. Grant of land intended for pastoral use. Sivio de ganado mayor. ca.1756 ha; sitio de ganado menor: ca.780 ha.

Solar. House lot

Sujeto. (abbrevintion of pueblo sujeto) Constituent part of a pueblo de indias, subject to a cabecera. More generally any kind of subject.

Tecululi (plural (ue)tecuhtin). Lord.

Teocalli. Temple. After the conquest also used for church.

Teopirqui. Prieat

Twotl. (Indigenow) god. Not used for the God of Christianity.

Teccalli. Lordty house.

Tecpar. Palace.

Teperate. A kind of white boulder chy.

Tequillato. Low-ranked indigenous leader.

Terrazguero. Spanish word for berf used for the Indians residing on the bands of a cacique and paying terrazgo (rent in kind, in services, or in money) for it; equivalent with rentero.

Tianguds (abo: tianquiz or biangwez). Indian market

Thaheoani. Prehispanic indigenous ruler. Unofficially the title was abo used after the conquest.

Thaheocayoul. Rulerehip, the rights and duties of a llaheoand often used together with laucyoul (lordahip). In this study 
trenelated as Herschaf.

Thaquehual. Seanonl Indien labourer, tributario of a pueblo de indios.

Tequill. Task.

Marilacalli. Constitueat part of the altepedl. Organizntion of group of mecehuales, unually within a opecific territory. Tributario. Indian paying tribute to a pueblo de irdias.

Vara. Unit of meaurement, equivalent to $c 4.84 \mathrm{~cm}$.

Visite. (Official) Viat or abbordinnte church, viaitad from the min church.

Zacate. Kind of rough gram.

Zeneal. Trough. 


\section{Samenvatting}

\section{Twee samenvloeiende werelden. De transformatie van de samenleving in de vallei van Puebla, 1570-1640.}

De late zestiende en de vroege zeventiende eeuw kenmerkten zich in Mexico door een maatschappelijke transformatie. De maatschappelijke ontwikkeling transformeerde de conquest sociery van de eerste decennia na de Spaanse Invasie tot cen samenleving waarvan de verhoudingen bepalend zouden zijn voor de rest van de koloniale periode in Mexico. In die zin kan zij een koloniale samenleving worden genoemd. In de tijd van de conquest sociery, de tijd direct na de verovering door de Spanjasrden, waren de Spaanse en de Indiaanse elementen in de Nieuw-Spaanse maatschappij grotendeels gescheiden. In de periode van ongeveer 1570 tot 1640 veranderde dat. De koloniale maatschappij kwam niet ineens tot stand manr evolueerde uit de conquest society. Uitgangssituatie voor de magtschappelijke ontwikkeling in Nieuw-Spanje was de inheemse samenleving.

De Indiaanse maatschappij voor de komst van de Spanjaarden verschilde sterk van de koloniale samenleving. Twee wezenlijke punten waren van groot belang. Ten eerste was de inheemse maatschappij politiek en militair sterk verdeeld. Vrijwel het gehele leven speelde zich af binnen de beperkingen van de politieke begrenzingen van de altepetl, de inheemse koninkrijken van veelal beperkte geografische omvang. Dit had belangrijke consequenties voor het economisch leven. De verschillende inheemse volken verkeerden met elkaar in onmin of in regelrechte oorlog, wat funest was voor de handel. Ten tweede was de inheemse samenleving sterk gestructureerd volgens een stelsel van verticale persoonlijke bindingen, waarin er een fundamentele scheiding bestond tussen tribuutplichtigen en tribuutgerechtigden.

De gewone Indianen (macehualtin) -veelal boeren- waren verplicht tribuut in goederen te leveren en arbeidsdiensten te verrichten voor de adel als erkenning van hun ondergeschiktheid. De edelen moesten de verantwoordelijkheden op zich nemen die aan hun positie waren verbonden: het was hun taak in ruil voor het tribuut hun onderdanen te beschermen, geestelijk leven mogelijk te maken en recht te spreken. Uitoefening van cen functie was daarom -althans in theorie- gebonden aan het vervullen van deze drie plichten. Er bestond dus in feite een verbinding tussen een heer en een onderdaan, waarbij er cen wederzijdse ruilverhouding was, warin plicht tegenover recht stond. Ten overvloede zij overigens opgemerkt dat dit niet betekende dat onrecht of verzaking van plichten en rechten uitgesloten was. Uit de Europese geschiedenis zijn dit soort op individuele relaties gebaseerde wederzijdse ruilverhoudingen bekend geworden als Herrschaft, en het stelsel van een maatschappij die wordt gekarakteriseerd door deze verbindingen van Herrschaft wordt Personenverband genoemd.

De Spaanse Invasie (in Mexico voltooid in 1521) bracht grote veranderingen in dit inheernse maatschappelijke stelsel, al kwamen die niet meteen met de verovering. Direct na de verovering werden vooral de hogere lagen van de inheemse samenleving getroffen. De hoogste maatschappelijke posities werden overgenomen door Spanjaarden. De posities van de inheemse koningen werden overgenomen door de veroverasrs en hun nazaten, de religieuze posities door Spaanse geestelijken. Door de vrijwel directe overname van de leidende posities pasten deze twee groepen wonderwel binnen het kader van het Indiaanse maatschappelijk systeem. $\mathrm{Zij}$ opereerden voor het grootste deel aan de marge van de inheemse sameleving; het directst bij de Indianen betrokken waren de geestelijken die in de eerste tijd na de verovering een bemiddelende rol speelden tussen Spanjaarden en Indianen. De conguest sociery die hiermee ontstond was geen lang leven beschoren. Tegen 
het midden van de zestiende eeuw begon zij asn alle zijden barsten te vertonen.

Aan de basis van de afbraak van de verhoudingen van de conquest society lagen twee ontwikkelingen die fundamentele invloed hadden op de samenleving. Enerzijds werd de gehele mantschappij beinvloed door de dramatische sterfte onder de inheemse bevolking, waarvan de economische effecten diep ingrijpend waren. Daartegenover stond cen voortdurende groei van het aantal Spanjaarden, die vooral in steden woonden. Door deze tweeledige demografische ontwikkeling steeg de vrang naar voedsel in de steden met rasse schreden, terwijl het aanbod daalde. Dit werd nog versterkt doordat in deze zelfde tijd een aantal sociasl-politieke en bestuurlijke veranderingen hun beslag kregen. Deze veranderingen waren gericht op een uniformering en centralisatie van het bestuur en op een hervorming van het fiscale stelsel, die het beter an het nieuwe bestuur moest asnpassen. Evenals de demografische ontwikkelingen raakten ook zij alle lagen van de bevolking en noodzaakten een ieder zich te bezinnen op zijn situatie en zich aan te passen aan de nieuwe omstandigheden.

De invloed van de demografische ontwikkelingen deed zich sterk gelden op het gebied van cen sterk toegenomen deelname van Spanjaarden in de economische activiteiten van de vallei van Puebla. Een deel van de op de steden gerichte landbouwproduktie en economische activiteiten die boven het lokale niveau uitgingen en die voor de verovering van weinig belang waren geweest, werden door Spanjasrden overgenomen. Deze sectoren van de economie werden dan ook door hen beheerst. Veel minder gold dit voor de lokale cconomie, wasrin de Indianen, en vooral de edelen (na de verovering caciques genasmd), van oudsher een belangrijke rol hadden gespeeld, en door de controle over vitale economische elementen, wasronder een groot deel van de arbeidskrachten, de lokale nijverheidsproduktie en ook een groot deel van het landeigendom en konden blijven spelen.

De doorvoering van de bestuurlijke en sociaal-politieke hervormingen leidde tot een ernstige crisis binnen de Indiaanse maatschappij. De inheemse altepell werden vervangen door pueblos de indios wasin voortaan alle Indianen administratief waren ondergebracht. Een van de belangrijkste onderdelen van deze verandering was dat zij allen geacht werden cen hoofdelijke belasting (tribuut) te betalen aan de Spaanse staat, via de pueblo. Doordat dit stelsel sterk bouwde op verdeling van het bestuurde gebied in territoriale cenheden, wordt het wel een Territorialverband genoemd. Dit doorkruiste de inheemse banden van afhankelijkheid die voor een belangrijk deel waren gebaseerd op persoonlijke tribuutgerechtigdheid. Met de verplichting tribuut te betalen aan de Spaanse staat verviel een groot deel van deze tribuutgerechtigdheden. De inheemse edelen lieten dat niet zomaar gebeuren en trachtten hun oude rechten te handhaven; aan de andere kant voelden de macehwales er weinig voor dubbele belastingen te betalen zonder dat ze er meer voor terugkregen. Dit leidde tot grote interne tegenstellingen binnen de pueblos de indios die nog werden versterkt door de afname van het bevolkingsaantal en daarmee van het aantal tribuutbetalende macehuales. Het duurde geruime tijd voor de conflicten binnen de pueblos luwden; de Spaanse rechtspraak speelde daarbij vaak een doorslaggevende rol doordat de rechters als arbiters optraden in de conflicten.

De gelederen van het inheemse adeldom werden in de loop van dit proces aanmerkelijk uitgedund. Hoewel er door de sterk teruggelopen persoonlijke tribuutinkomsten en de daarmee gepaard gaande groei van de gemiddelde lastendruk voor de macehuales en van inkomen voor de edelen over de gehele linie een verarming van de Indianse bevolking optrad, betekende dit niet dat de pueblos veranderden in een grauwe, ongedifferentieerde massa van armen. Over het algemeen konden de caciques, dat wil zeggen de hoogste edelen, zich ook binnen de pueblos een rol van betekenis toemeten. De macehuales aan de andere kant, konden niet onder te extreme economische druk worden gezet, want dan onttrokken zij zich aan de invloed van hun pueblo en gingen wonen en werken in de stad of op nabijgelegen Spaanse landbouwbedrijven die voortdurend verlegen zaten om arbeiders. Aan het eind van de zestiende eeew kwam dit veel voor. De Indianen die het 
hardst werden getroffen door de veranderingen waren de lagere edelen en anderen met een van oudsher licht gepriviligieerde positie, bijvoorbeeld de handelaren. $\mathrm{Zij}$ konden in rechtszaken hun privileges niet aantonen en bezaten de macht niet om privileges af te dwingen. Als het gevolg van deze processen stabiliseerden zich in de eerste decennia van de zeventiende ceuw de pueblos de indios, met daarin de caciques als leidende figuren.

Met de transformatie was in de vallei van Puebla cen nieuw maatschappelijk geheel ontstaan waarin Spaanse en Indiaanse elementen zich vooral op het platteland vervlochten hadden. In de zeventiende ceuw waren hierin zeker nog Spaanse en Indiaanse elementen te onderscheiden. Ben echte tegenstelling tussen Spanjaarden en Indianen bestond er echter op het regionale niveau niet meer. Natuurlijk waren na de verovering de Spanjaarden de dominante partij in Nieuw-Spanje als geheel en de machtigste lieden in de koloniale samenleving waren uit de aard der zaak altijd Spanjaarden. Regionaal en lokaal gezien waren Spaans en Indiaans echter minder gescheiden dan op landelijk niveau. Formeel waren daar de Spanjasrden nog altijd het machtigst, maar juist op het lokale niveau waren ze te vaak en in te sterke mate afhankelijk van de Indiaanse caciques, om die macht meer dan formele inhoud te geven.

De economische regio die in de vallei van Puebla ontstond en die vooral gericht was op de stad Puebla, was een regio binnen de koloniale samenleving als geheel. Het centrum was de stad, en cen groot deel van de produktie en de handel verliep over de stad. In die zin waren de Spanjaarden ook ontegenzeggelijk toonaangevend, en waren de door de Spanjaarden geintroduceerde bepalingen van wat als een Terriorialverband kan worden gekarakteriseerd, normgevend. De Indianen maakten hiervan ook deel uit, althans voor het gedeelte dat hun leven beheerst werd door het Territorialverband, en dat was juist in de verhouding met de Spanjaarden. Op het lokale niveau echter werden de economische verhoudingen slechts zeer ten dele bepaald door zulke Spaanse normen. Daar bleef vooralsnog de wijze van machtsuitoefening door persoonsgebonden machtuitoefening, gevangen onder de term Herrschaff, prevaleren en voerden de Indiaanse normen de boventoon. Spanjaarden die zich in die in overweldigende mate door Indianen beheerste sociaal-economische omgeving prestige wilden verwerven, hadden weinig andere keus dan zich in hun gedrag aan die normen aan te passen.

De maatschappelijke ontwikkeling van de late zestiende en de vroege zeventiende eeuw in de vallei van Puebla kenmerkte zich niet door een systematische marginalisering van de Indianen of door een polarisatie tussen een Spaanse en een Indiaanse wereld, maar in tegendeel door cen samengaan van Spaanse en Indiaanse elementen, waarbij voor beide een belangrijke rol was weggelegd. 


\section{Curriculum Vitae}

Frederik Galenus (Rik) Hoekstra werd geboren op 28 januari 1961 te Delft. Hij doorliep de lagere school in Voorburg en Voorschoten en het ongedeeld VWO in Leiden. Van 1979 tot 1985 studeerde hij geschiedenis aan de Rijks Universiteit Leiden. Daar werd zijn belangstelling gewekt voor Latijns Amerika. Na de vervulling van zijn dienstplicht bij de luchtmacht vertrok hij in 1987 voor acht masnden archiefonderzoek naar Mexico. Na terugkomst in 1988 werden in het kader van het onderzoek nog onderzoeksreizen gemaakt naar Spanje (1989) en andermaal Mexico (1990-1991). In het kader van het promotieonderzoek publiceerde hij een anntal artikelen. Vanaf 1989 kwam ook een verbinding met het CEDLA tot stand. Momenteel woont hij in Leiden waar hij als beleidsmedewerker werkzaam is aan de faculteit der Wis- en Natuurkunde van de Rijks Universiteit Leiden.

CIP-GEGEVENS KONINKLIJE BIBLIOTHEEK, DEN HAAG

Hoekstra, Rik

Two worlds merging : the transformation of society in the valley of Puebla, 1570 . 1640 / Rik Hoekstra. - Amsterdam: Centrum voor Studie en Documentatie van Latijns Amerika, CEDLA. - Ill.- (CEDLA Latin America studies ; 69)

Ook verschenen in handelseditie: Amsterdam : Centrum voor Studie en Documentatie van Latijns Amerika, CEDLA, 1993. - (CEDLA Latin America studies ; 69). Proefschrift Nijmegen. - Met lit. opg.

ISBN 90-70280-35-3

NUGI 649

Trefw.: Indianen ; Mexico ; geschiedenis ; 1570-1640 / Mexico ; sociale geschiedenis ; 1570-1640. 

The late sixteenth and seventeenth centuries were crucial for the formation of Mexican society, both in the colonial period and thereafter. Nevertheless, they remain a neglected period in historical writing concerning Mexico. The author criticizes the traditional picture of early colonial society, in which the Indians are depicted simply as victims of the formation of colonization. In joining recent historiography on the late-colonial period, this study means to give a new perspective on the transformation of society between 1570 and 1640 in the valley of Puebla, one of the three main valleys of the Central Mexican highlands.

The year 1570 found the rural society of the valley of Puebla in a crisis which would not be resolved for another half century, leaving it transformed. Many Indians, especially the Indian nobility (the caciques), proved remarkably adept at using the institutions and opportunities of the evolving colonial society, thereby gaining new positions. At the same time, Spaniards who needed to involve themselves in agriculture in an overwhelmingly Indian rural environment had to adapt to many indigenous social relations to be able to function adequately. The author argues that to an important extent the formation of colonial society was determined by the ongoing interaction of Spanish and Indian elements, resulting in the merger of two previously separate worlds.

The Centre for Latin American Research and Documentation (CEDLA) conducts and coordinates social science research on Latin America, publishes and distributes the results of such research, and assembles and makes accessible documentary and scholarly materials for the study of the region. The Centre also offers an academic teaching programme on the societies and cultures of Latin America.

Rik Hoekstra is a historian and affiliated with CEDLA. He has published several articles on the sixteenth and seventeenth-century social and economic history of Mexico. 